\title{
OD PRAXE K TEORII A ZPĚT VE VYUČOVÁNÍ ČEŠTINĚ II
}

MARIE ČECHOVÁ

MARTINA SPĚVÁČKOVÁ (EDS.) 


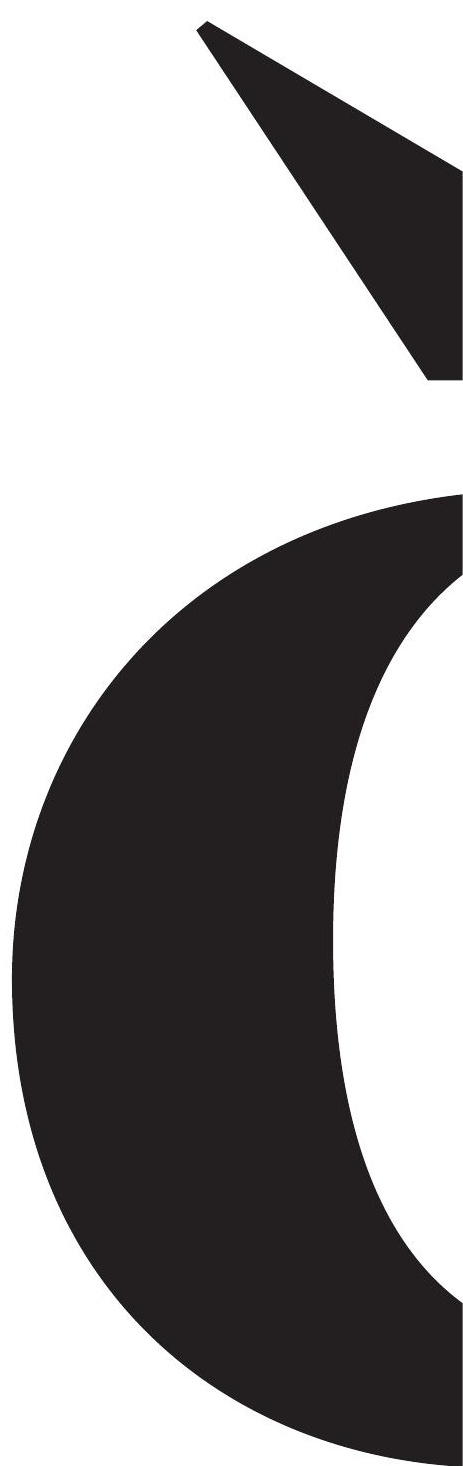




\section{OD PRAXE K TEORII A ZPĚT VE VYUČOVÁNÍ ČEŠTINĚ II}

MARIE ČECHOVÁ

MARTINA SPĚVÁČKOVÁ (EDS.)

DOI https://doi.org/10.24132/ZCU.2021.10118 


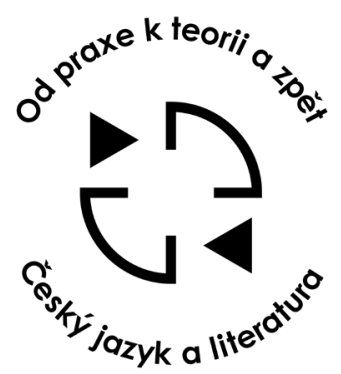

Od praxe k teorii a zpět ve vyučování češtině II

Editorky:

Marie Čechová, Martina Spěváčková

Autorský kolektiv:

Marie Čechová, David Franta, Milan Hrdlička, Helena Chýlová, Dominic Jačka, Ladislava Lederbuchová, Jitka Málková, Jaroslava Nováková, Jiří Novotný, Petr Pánek, Vladimíra Pánková, Růžena Písková, Martina Spěváčková, Stanislav Štěpáník, Jana Vaňková, Jana Vejvodová, Viktor Viktora, Věra Zelenková

Recenzenti:

doc. PhDr. Ondřej Hník, Ph.D., doc. Mgr. Patrik Mitter, Ph.D.

Vydání publikace bylo schváleno Vědeckou redakcí Západočeské univerzity v Plzni.

ISBN 978-80-261-1011-8

ISBN 978-80-261-0982-2 (brožovaná vazba)

(C) Západočeská univerzita v Plzni, 2021 autoři, 2021 


\section{Obsah}

Preambule (Marie Čechová) .................................................... 1

\section{PEDAGOGICKÁ PRAXE A STUDIUM} UČITELSTVÍ ČEŠTINY

Reflexe výuky jako prostředek propojení pedagogické praxe studentů s jejich teoretickou přípravou (Jana Vejvodová) .... 20

K průběhu blokové výstupové praxe v době výuky na dálku (Růžena Písková)

Kvalifikační práce a jejich provázanost s výukovou praxí (Dominic Jačka, Petr Pánek)

Obsah vs. forma: jak forma ovlivňuje učitelovo hodnocení žákovských textů? (Stanislav Štěpáník)

\section{POSTUPNÉ ZVLÁDÁNÍ UČIVA SMĚREM}

Zralá grafomotorika jako předpoklad pro rozvoj myšlení

a (tvůrčího) psaní (Jaroslava Nováková)

Znalosti vybraných jevů kodifikace studentů bohemistiky a jejich postoje k ní (Helena Chýlová) ………..................... 151

O spisovné češtině, chybě a chybování (Milan Hrdlička) .. 181

Využití metody komplexních jazykových rozborů ve výuce českého jazyka (Jana Vaňková, Martina Spěváčková) ....... 198

Učitel jako vzor i arbitr kultivovanosti mluveného projevu ve výukové komunikaci (Jitka Málková) 
Literárněhistorické poznatky v literární výchově na 2. stupni ZŠ a v odpovídajících ročnících víceletých gymnázií (Ladislava Lederbuchová)

Současná česká próza ve vyučování: ukázky práce se studenty (Věra Zelenková) 258

Arbesův Svatý Xaverius: Praktické uplatnění interpretace literárního díla (Viktor Viktora)

Model integrované výuky předmětu český jazyk a literatura: Praxe z klatovského gymnázia (David Franta) 296

Motivace nemotivovaných a česká středověká literatura (Jiří Novotný)

Kam směřuje dnešní výuka literární výchovy?

(Vladimíra Pánková)

Resumé 363

Summary 368

Použitá literatura 374

Věcný rejstř́ik 393

Výběrový jmenný rejstřík 402 


\title{
Preambule
}

\author{
Marie Čechová
}

\section{A) Výzkumné metody a postupy}

Už i v nedávné historii se uplatňovaly v oborové didaktice dva protikladné přístupy, které, máme-li dojít $\mathrm{k}$ lepším vyučovacím výsledkům než dosud, by však měly jít ruku v ruce a vzájemně se korigovat: na jedné straně př́ístup praktický (někdy až prakticistický), mající na zřeteli prováděcí procesy bez ohledu na podstatu věci, na druhé straně teoretický (či spíše teoretizující), dbající na oborové obsahy, ale nikoli na jejich realizovatelnost v praxi.

Při bádání se dosud uplatňoval postup směřující bud' od žáka k materii, tedy k jazyku a řeči, nebo naopak od materie k žákovi. Dokladem toho jsou postoje Jaroslava Jelínka (pro postup první), realizovaný jím u mladších žáků, a Karla Svobody (pro postup druhý), aplikovaný u žáků starších. Na těchto př́islušných stupních také každý z nich předtím učitelsky působil.

Oba přistupy mohou být úspěšné, jsou-li dobře promýšleny. To je do jisté míry ambicí předkládané monografie. Představuje 2. díl k publikaci Od praxe k teorii a zpět ve vyučování češtině. 1. díl postihl některé aktuální problémy učitelského studia bohemistiky, předložil didaktické problémy a navrhl některá řešení. Vyšel od místa pedagogické praxe ve vzdělávání učitelů, dotkl se systému spisovného jazyka z pohledu studia bohemistiky, jazykových rovin ve výuce, problematiky spisovnosti v mluveném projevu ve škole, integrované a specializované orientace výuky češtiny. 
Také 2. díl vychází z praxe škol, podrobuje ji kritické analýze a na základě výzkumných sond dospívá $\mathbf{k}$ návrhům na dosažení předpokládaných pozitivních změn. Máme-li v úmyslu podpořit učitele a studenty učitelství v jejich působení, musíme si uvědomit některé základní skutečnosti, proto cíleně volíme následující př́istup a metodologii:

Nutno poznat praxi, a to nejlépe $z$ autopsie, nejen jako experimentátor, který navštíví školu a provede jednorázový výzkum, ale jako učitel, který s žáky absolvoval několikaletý ucelený výchovně-vzdělávací proces, alespoň po jeden celý školský stupeň (podle toho, kterému stupni se chce/bude výzkumně věnovat), tj. od 1. do 5. ročníku, od 6. do 9. ročníku či od 1. do 4. ročníku střední školy - ideálně všem. Tak pozná praxi - školní programy, učebnice, školní prostředí, žáky a celou učební situaci, do níž jeho působení spadá. Jen takovéto komplexní poznání by mělo být východiskem analýzy (spolu s tím vyhledávání kritických míst ve výuce) a účinné kritiky současného stavu výuky s následným podáním návrhů na změnu koncepce zaměřené na zlepšení, zdokonalení budoucího stavu výuky a jejích výsledků. Podmínkou však je vypracovaná koncepce nejen na základě poznané praxe, ale současně i nejnovějších vědeckých poznatků základních disciplín, bohemistiky jazykovědné i literární a výsledků věd pedagogických. Ale tím se stává výzkum v oborových didaktikách obtížný, ve hře je totiž vždy mnoho proměnných (různá úroveň žáků, učitelů, různost sociálního prostředí, jazyková a komunikační situace $\mathrm{v}$ něm...), které mohou výsledky výzkumů omezovat. Platnost výzkumných teorií bývá nesnadno prokazatelná, a tak dává oponentům př́ležitost až $\mathrm{k}$ zpochybňování výsledků bádání.

Připomeňme alespoň jeden faktor ztěžující pedagogický výzkum, a to časový. Má-li mít výzkum výsledky všeobecněji platné, je 
časově náročný, rozprostraněný na léta. Výzkumy, s nimiž v této monografii operujeme, mohou být proto pouze sondy do vybraných oblastí vyučování češtině. $Z$ udaných důvodů monografie tudíž využije jen omezený počet výzkumných metod, především metody dotazníkové, dále metod analytických, konfrontačních, dílčích experimentálních, vše s následnou syntézou, především s orientací na zjištování problémů, pozitiv a nedostatků, např. vypozorovávaných při kontrole pedagogické praxe i se zaměřením na vysledování současných trendů ve výuce. Proto si nevytyčujeme př́liš vysoké mety, ale i tak jsem přesvědčena, že monografie může studentům a učitelům nabídnout ledacos $\mathrm{k}$ úvaze a přispět $\mathrm{k}$ řešení vybraných problémů ve vyučovací praxi, protože poznání syntetizuje.

Zkušenosti z výzkumu: ne vždy do výzkumu přicházejí lidé $s$ předpoklady k této činnosti. Někdy za sebou nemají potřebnou praxi, takže jejich poznání je dané jen teoretickým studiem, což není ideální, avšak ještě horší situace nastává, uplatňuje-li se ve výzkumu učitel, který v praxi neobstál (asi bychom každý někoho takového mohli jmenovat). Jde-li o některou z popsaných situací, výzkum nemůže splnit očekávání. Bud’ je navržen obsah, postup a metody od „zeleného stolu“, nebo „posvěcen“ stávající stav, výsledek je v obou případech nevalný. Často se běžně užívané a zažité metody jen označují novými názvy, především anglickými (brainstorming pro volnou diskusní metodu) nebo se jinak metody grupují, takže se např. pro metody najde nadřazený cizojazyčný název (viz scaffolding, souhrnný název pro podpůrné strategie, opory „lešení"). Nic proti tomu, ale každý uživatel těchto a dalších metod by si měl ujasnit, v čem spočívá jejich novátorsví a nedomnívat se, že přímo objevil nový svět. Připomínáme to proto, aby studenti, kteří mají ambice výzkumné, si toho byli vědomi a nepídili se za pofiderními „objevy“ a inovacemi za každou cenu, aby respektovali kontinuitu vývoje. 
Jedním z módních trendů dnešní výuky je tzv. strategie líného učitele, který přesouvá aktivity v hodině na žáka - a to je pozitivní, ale tu může s úspěchem volit jen na výuku dobře připravený učitel, tedy nikoli líný, jinak půjde o plevelné mluvení.

Po předložení návrhu koncepce by měla následovat její oponentura odborníky ze školské praxe, teoretiky oborové didaktiky, bohemistiky a pedagogiky, aby se neopakoval postup „pokus omyl“, kdy dobře míněná, ale neprověřená navržená změna vede $\mathrm{k}$ neúspěchu, jak se opakovaně ve školství děje, viz dlouholeté pokusy o zavádění státních maturit, postup „odezdikezdismus“, kdy se odmítne cosi a nahradí pravým opakem, viz zcela protikladná (v krátké době) rozhodování o tom, zda maturitní práce mají opravovat a klasifikovat učitelé prríslušných škol, nebo učitelé vybraní ze škol jiných, nebo zda matematika bude, či nebude povinným maturitním předmětem (viz zdůvodňování odkladu: až se zlepší stav výuky!). Zdůrazňujeme to proto, že mezi současnými učiteli a studenty mohou být i budoucí činitelé, kteří budou rozhodovat o prŕštím osudu školství, a přáli bychom sobě i jim, aby staré chyby neopakovali.

Základní výzkum předpokládá experimentální výuku konfrontovanou s výukou tradiční, srovnávání výsledků experimentálních a kontrolních tříd a škol. Takovýto výzkum by měl obsáhnout celý vzdělávací cyklus (tj. 13letý), aby byl průkazný, ale $\mathrm{k}$ tomu v současnosti není trpělivost ani vůle. Bez nich však je všechno úsilí velmi nejisté, založené jen na teoretických úvahách, či naopak jen na intuici (přitom obojí je potřebné). Nutné je zajistit pro výzkumné školy přípravu učitelů vedenou navrhovateli koncepce, zpracování pokusných učebních a metodických materiálů, upravovaných postupně podle zkušeností vyučujících zúčastněných na experimentální výuce. I proto se předkládaná monografie může soustřed'ovat jen na dílčí 
problémy, k vypracování celkové koncepce nemáme „power“, moc, čas ani sílu.

Celková změna koncepce, zavádění výsledků celoplošného výzkumu do praxe, by měly probíhat promyšleně, nejprve na vybraných školách a teprve po ověření přijít do všech škol. Jak už jsme podotkli, podmínkou úspěchu jsou i učebnice a instruktivní metodické příručky, ale nikoli vydávané kdejakým nakladatelstvím a napsané jakýmikoli autory, jak se děje, ale autorů vybraných na základě konkursů, které povedou nejvzdělanější a nejzkušenější odborníci, bohemisté, pedagogové, učitelé, kteří se na projekci podíleli, aby učebnice se schvalovacími doložkami MŠMT neobsahovaly chybné informace a nezaváděly žáky mylnými instrukcemi (o tom viz naposledy Robert Adam in ČJL č. 5 20019/2020, dříve už např. Milan Hrdlička (2009) o učebnicích češtiny pro cizince). Učitelé by pak měli být $s$ to, pokud k takovým chybám dojde, je odhalit, ale k tomu nedochází, protože ti nejsou mnohdy dobře odborně vybaveni nebo si netroufají "autority" kritizovat. Viz zde ve stati Jany Vejvodové výrok studentky po absolvování souvislé praxe (s. 52).

Všichni učitelé by měli před zavedením změn do praxe projít soustavnou př́pravou na realizovanou změnu, s možností vyjadřovat se $\mathrm{k}$ celkové koncepci, $\mathrm{k}$ obsahu i metodám práce, a autoři (po zvážení závažnosti připomínek) odpovědně přistupovat k úpravám programů i př́ruček.

\section{B) Výzkumné sondy realizující metody uvedené v části A}

Už v předchozím díle jsme představovali pedagogickou praxi, $\mathrm{v}$ tomto díle na to navazujeme, protože tato praxe má uvádět studenty učitelství do jejich budoucího povolání. Pedagogické 
praxe jsou trvalou součástí učitelské prrípravy. Zpravidla ji zahajují úvodní náslechové hodiny s rozbory, pak výstupy vybraných částí vyučovacích hodin $\mathrm{v}$ seminářích didaktiky češtiny, kdy studenti simulují reakce žáků př́slušných tříd, následují souvislé praxe přímo na příslušných stupních škol za vedení učitelů fakulty a osvědčených učitelů $\mathrm{z}$ terénu. Ti poskytují studentům učitelství rady a instrukce $\mathrm{k}$ vedení hodin a poté realizované hodiny s nimi rozebírají a hodnotí. Publikace postihuje realitu s jejími pozitivy i negativy s cílem pozitiva zobecnit a negativa eliminovat.

Po obecných výkladech v úvodní studii následují kapitoly sedmnácti spoluautorů, rozčleněné do tří oddílů. I. oddíl vychází z postavení pedagogické praxe ve studiu učitelství, II. oddíl přechází k vybraným stránkám zvládání jazykového učiva od nejnižších úrovní a jazykových rovin směrem ke komplexnímu pohledu na jazyk a řeč. V návaznosti na předchozí oddíly III. oddíl představuje práci učitele a žáků s autorskými texty ve smyslu možných interpretací.

\section{I. oddíl}

Experimentátorka-didaktička Jana Vejvodová charakterizuje model propojení pedagogické praxe s předměty vybavujícími studenty reflektivními kompetencemi na základě výzkumných sond. V první části jejího výkladu je předmětem úzká vazba jednotlivých typů praxí na základy reflexe a hodnocení výuky v bakalářském studiu a reflexe a hodnocení výuky v navazujícím magisterském studiu (seznamuje s jejich cíli a s obsahovou náplní). Uvádí příklady využití simulačních metod, mikrovyučování a virtuální třídy ve výuce didaktiky českého jazyka, což je zvláště, ale nejen v současnosti potřeba př́mo aktuální. Aby totiž studenti před vlastními vystoupeními ve třídách měli možnost vystoupit „nanečisto“: 
Simulují se výukové situace na vybraných, problémových místech učební látky. V druhé části studie autorka interpretuje výsledky dotazníkového šetření, jehož cílem bylo zjistit, jak studenti hodnotí efektivitu náslechové praxe navazující a souvislé výstupové pedagogické praxe. Výsledky průzkumu jsou mimořádně pozitivní: naprostá většina praktikantů se vyjádřila s uspokojením o prínosu praxe.

Protože členkou autorského týmu je zkušená učitelka Růžena Písková, která vede na plzeňské katedře českého jazyka a literatury pedagogické praxe, svou kapitolou přispívá k diskusi o pojetí a realizaci praxe i o jejím vnímání všemi zúčastněnými, žáky, studenty učitelství, učiteli, jak se to projevilo v jejich výpovědích. Uvádí přehled prostředků elektronické komunikace využívaných ke komunikaci studentů učitelství se žáky a učiteli. Přináší názory studentů na online webináře, jejich zkušenosti a zamyšlení nad přínosem absolvovaných kursů. Představuje výhody i úskalí elektronického kontaktu na základě zkušeností v letním semestru r. 2020, v době epidemie covid-19, shrnuje poznatky všech zúčastněných a objasňuje obsah a průběh elektronické online praxe, která by se mohla stát stálou součástí portfolia modulů pedagogické praxe i v dalších letech.

Třebaže pedagogická praxe tvoří neodmyslitelnou součást učitelské přípravy, probíhající na všech fakultách vychovávajících učitele, nikoli však všude se jí přikládá stejná váha. Podrobnější, kritický rozbor stavu nalezne zájemce ve studii Profesní príprava učitelů češtiny (viz Čechová, ČJL 2014/15, s. 125-133, upravenou in Život s češtinou, s. 253-261), založené na analýze provedené na všech katedrách bohemistiky v Česku. V ní byla značná pozornost uprena i na roli pedagogické praxe ve vzdělávání učitelů. I na těch fakultách, kde praxe není podceňována, lze působení praxe posílit. Vzorem by mohly být kdysi zřizované 
cvičné/fakultní školy (i dnes v omezené podobě leckde fungující). Pro ně bývali vybíráni nejlepší učitelé, takže studenti měli před svými zraky skutečné mistry oboru. Sama jsem takové zažila už na pedagogickém gymnáziu / škole pro učitele národních škol v Praze v 50. letech minulého století, později na fakultě, pak i jako vedoucí praxí na FF UK jsem je nejen sledovala, ale i mnohé obdivovala, např. Václava Kučeru, Vladimíra Nezkusila nebo svého bývalého studenta Jiřího Kostečku (ti se osvědčili i jako autoři článků v časopise ČJL, autoři a posuzovatelé učebnic). Přeji takové vedoucí praxe současným a budoucím studentům učitelství.

O zkvalitnění pedagogické praxe s cílem využít ji v přípravě na učitelské povolání usilují nedávní absolventi fakulty, doktorandi Petr Pánek a Dominic Jačka. Nejen na základě svých studentských zkušeností, ale i na základě provedené výzkumné sondy do kvalifikačních prací na Fakultě pedagogické Západočeské univerzity se pokusili zpracovat návrh systému pedagogické praxe a v této souvislosti si všímali i témat a vedení závěrečných prací studentů učitelství v jejich pregraduální přípravě. Dospěli k systému vycházejícímu z konsenzu katedry o její vědecko-výzkumné činnosti a představili náměty diplomových prací orientovaných na pedagogickou praxi. Od propojení teorie s praxí v pregraduální př́ípravě učitelů si slibují její zdokonalení.

Zkušený učitel i didaktik-výzkumník Stanislav Štěpáník se věnuje produkci žákovských prací. Analyzuje př́ípravu slohových prací, jejich tvorbu a jejich hodnocení učitele. Uvažuje nad možnostmi zlepšení, nad tím, jakou by mělo mít povahu, zvažuje úlohu složky formativní v něm; případná klasifikace by měla toto hodnocení odrážet a měla by být zdůvodněná. Zamýšlí se nad motivováním žáků k psaní, nad zasazováním tvůrčích aktivit do určitého komunikačního kontextu a nad účelností celého 
procesu. Po diskusi, jež následuje po seznámení s výsledky sond, autor vyvozuje závěry pro změnu praxe.

\section{II. oddíl}

Monografie využívá přednosti pracoviště, totiž jeho komplexního zaměření na celý cyklus vzdělávání, od nižšího stupně přes vyšší stupeň základní školy až po maturitu na škole střední a vysokoškolské studium učitelství, může tedy postihnout i kontinuitu vzdělávání, která je nezbytná pro to, aby se žáci ve škole nenudili nežádoucím opakováním činností, ani aby nebyli frustrováni skoky ve výuce bez potřebné návaznosti.

V tomto smyslu je základem kapitola Jaroslavy Novákové, která studuje předpoklady a raný vývoj psaní u žáků počátečních ročníků, nutný pro úspěch v další etapě vzdělávání. Její zkoumání dospěla $\mathrm{k}$ př̀esvědčení, že nedostatečný rozvoj dětí v oblasti hrubé a jemné motoriky vede $\mathrm{k}$ pomalému a disharmonickému vývoji grafomotoriky. Grafomotoriku učitelé mateřských škol a počátečních ročníků základních škol sice cvičí, ale bez patřičného výsledku či jen s malým úspěchem, a to pro jejich neznalost psychomotorického vývoje dětí, popř. jeho nerespektování. Studie postihuje průběh rozvoje grafomotoriky zařazováním promyšleného systému cviků. S těmi se čtenáři, studenti i učitelé mohou nejen seznámit, ale podle jejich popisu je mohou využívat ve své praxi. Zvládnutí techniky psaní a chápání psaného textu je důležitým východiskem i pro osvojení si principů českého pravopisu.

Ukazuje se stále a opakovaně, že pravopis je slabou stránkou v systému osvojování češtiny, a to i budoucích učitelů češtiny. Na tento stav poukazuje svým výzkumem Helena Chýlová. Její studie vychází z dotazníkové sondy zjištující znalost pravopisné 
kodifikace, zvláště pravopisu morfologického, a jejích změn u vysokoškolských studentů češtiny v roce $2020 \mathrm{v}$ komparaci s rokem 1995. Sonda je zaměřena na posun ve znalostech Pravidel českého pravopisu vydaných v roce 1993 v období posledních dvaceti pěti let. Autorka současně seznamuje čtenáře s postoji budoucích učitelů českého jazyka $\mathbf{k}$ podobě ortografické kodifikace a k jejím př́ípadným změnám.

Část studií v tomto spise je zaměřena jak na práci s texty hotovými, zkušených autorů, tak i žákovských včetně těch s nedostatky, nebở ty při náležitém diagnostikování, tj. detekování chyby, výkladu její podstaty a zdůvodněné rektifikaci jsou výborným pramenem poučení pro vlastní další tvorbu žáků. To ukazuje ve své studii Milan Hrdlička. Inspirací pro práci se stylizačními nedostatky mohou být skripta Karla Svobody nebo cvičení Marie Čechové v Mluvnických a slohových cvičeních ke Stručné mluvnici české, obojí už ze 70. let 20. století.

Jana Vaňková a Martina Spěváčková se v této monografii, navazujíce přirozeně na svou studii $\mathrm{v}$ předchozím díle, zaměřují na určitou složku odborné připravenosti učitelů českého jazyka, totiž na schopnost rozlišovat jazykové prostředky různých jazykových rovin a jejich stylovou přináležitost. Tato schopnost je důležitá v procesu chápání jazyka jako systému. Na základě výsledků dotazníkového šetření zkoumají tyto otázky v souvislosti s komplexními jazykovými rozbory, jejich postavením, využitím a efektivitou v současné výuce českému jazyku.

Spolu s projevy psanými, jimž se zatím věnuje ve výuce větší pozornost, nelze přehlížet mluvenou formu řeči. Jí jsou určena na všech stupních mluvní cvičení, na střední škole by to měla být i cvičení řečnická, tj. projevy vyššího stylu i s využitím prvků stylu uměleckého. Pro učitele je pak schopnost souvislého 
kultivovaného spisovného projevu mluveného podmínkou úspěšného učitelství, proto se na něj soustředuje i tato monografie. Studie Jitky Málkové pojednávající o vzoru a arbitru je postavena na sebereflexi studentů učitelství a učitelů. Analyzuje výsledky výzkumné sondy orientované na mluvený projev učitelů ZŠ a na jejich vliv na rozvoj mluveného projevu žáků. Zjištuje na základě rozboru zvukových nahrávek výukového dialogu a následné sebeevaluace, jak učitelé hodnotí svůj mluvený projev ve vyučování z hlediska kultivovanosti a jak posuzují užité jazykové prostředky z hlediska jejich adekvátnosti. Dotazníkovým šetřením ověřuje, které metody a formy práce učitelé používají ke zlepšení úrovně mluveného projevu žáků, pozornost soustředuje na mluvní cvičení na různých stupních školy, včetně jejich vyhodnocování.

Právě sebereflexe je vůbec významným diagnostickým prostředkem při úsilí o zdokonalení pedagogického působení, nejen tedy při kritickém posuzování vlastní řeči (o tom viz M. Čechová in Mužská a ženská specifika školní komunikace, 1996 a 2012). Srozumitelnost a kultivovanost učitelovy řeči je do značné míry podmínkou jeho úspěchu, a proto by měla být součástí veškeré profesní učitelské přípravy také cvičení v kultuře projevu, což bývalo kdysi praktikováno.

V posledních letech se odborná lingvistická literatura právem zaměřuje na mluvené projevy a je to pochopitelné, protože starší stav techniky neumožňoval jejich bezprostřední zachycení. Klasická bohemistika, za niž považujeme i lingvistiku Pražské školy, byla sice orientována více na řeč psanou než na řeč mluvenou, ale už zakladatel Pražského lingvistického kroužku a její předseda, Vilém Mathesius, dávno před jeho založením, ve studii O potencinálnosti jevů jazykových (r. 1911, přetištěno 1970) si byl vědom jejích odlišností od řeči psané, postihl kolísání nejen mezi řečí jednotlivců, ale i uvnitř řeči jednotlivce. Soustavně se českou 
fonologií a fonetikou, rozdílem mezi psaným a mluveným projevem zabýval přímý Mathesiův žák a jeho pomocník Josef Vachek. Následovníci Milan Romportl, Jiřina Novotná Hůrková, Zdena Palková se mj. soustředili na zjištování a popis normy spisovné výslovnosti. Oni i další měli na mysli spisovný kultivovaný mluvený projev, šlo jim o normu a kodifikaci takovéhoto projevu.

V této souvislosti lze konstatovat, že současná lingvistika se soustředuje na popis stavu řeči, odlišování normy a úzu ponechává stranou, popř. je zaměňuje, nebo některé rozdíly mezi nimi opomíjí. Např. Mluvnice současné češtiny I Václava Cvrčka a kol. (2010) je vybudována na úzu zachyceném Českým národním korpusem, V. Cvrček nepracuje s pojmem norma, vystačí s územ. Zpochybňuje platnost teorie jazykové kultury, jeden ze základních sloupů české klasické lingvistiky a základního principu řečové výchovy, viz např. V. Cvrček in Teorie jazykové kultury po r. 1945, z r. 2006, nebo Regulace jazyka a Koncept minimální intervence z r. 2008 (o tom Čechová in Život s češtinou, 2017).

Všimněme si nejnovější literatury, ocitujme ze Syntaxe mluvené češtiny Janu Hoffmannovou (2019), která právem předpokládá (na základě rozboru názorů různých lingvistů) určité obecné, univerzální rysy syntaxe běžně mluvené češtiny: „je ona „chaotická“, „pokleslá“, „vágní“ syntax přirozenou součástí normy těchto neformálních soukromých projevü“ (s. 12). V daném př́padě však nejde o normu, ale o úzus nekultivovaných projevi̊ (o tom viz v recenzi M. Čechové Mluvená syntax (Nová čeština doma a ve světě, 2020). Rozhodně nemůže být v knize objektivně popsaný stav řeči vzat za základ syntaktické normy mluvené ve škole, nebot knihou zachycené projevy jsou nekultivované, někdy i vulgární, leckdy i nesrozumitelné. $\mathrm{V}$ pedagogické praxi a práci učitele lze s takovými projevy zacházet jen kriticky. 


\section{III. oddíl}

Základním materiálem ve vyučování češtině v obou jejích (zdi̊razněme) nedělitelných složkách (jazykové a literární) by měl být text/jazykový projev (pro tuto př́ležitost termínů užíváme bez jejich odlišení) a základní metodou práce s ním, a to jak jeho produkce, tak př́jem $s$ interpretací, přičemž postup by měl být obousměrný, nejen od interpretování k produkování, ale i od produkování k interpretování. Odmítnout a odstranit je nutno výuku pojatou jen jako naplňování pouček na cvičeních v jazykové složce a popis literární historie s pouhou demonstrací na ukázkách ve složce literární. A právě proto se naše publikace mj. zaměřuje na př́ijem uměleckých textů učiteli a žáky.

Jak už je patrno z výše charakterizovaných studií, k vědeckým metodám náleží vedle metody dotazníkové a jiných sond zvláště metody experimentální. Neméně významná je vědecká analýza stávajících koncepcí a jejich obsahů i s návrhy na jejich změny, jak se to promítá i do této publikace.

Ladislava Lederbuchová se zamýšlí nad místem a funkcí literárněhistorických poznatků ve struktuře učiva literární výchovy na 2. stupni ZŠ a v odpovídajících ročnících víceletých gymnázií, jež mají oprávnění i v komunikační koncepci literární výchovy. Utváření žákových představ o literatuře souvisí nejen s vlastní čtenářskou kreativitou a s poznáváním kontextů vymezených literárněteoreticky (poznávání literárních druhů a žánrů, uměleckého jazyka), ale také literárněhistoricky. Vybranými texty klasické literatury (především české) žák vstupuje do kontextu díla konkrétních autorských osobností. Studie demonstruje metodu didaktické interpretace textu jako učitelovu platformu pro transformaci literárněhistorických poznatků do role účinných komunikantů v procesu žákovy četby. 
Následující kapitoly navazují na tuto obecně pojatou studii interpretací textů; postupuje se od nejnovějších, nejbližších dobou vzniku současnému čtenáři, $\mathrm{k}$ nejstarším. Oddíl ukončuje stat’ o směřování literární výchovy, která tak uzavírá rámec otevřený Ladislavou Lederbuchovou.

Věra Zelenková literárněvědných poznatků využívá při analýze vybraných textů současné literatury, textů - pro žáky i učitele nejobtížnějších. Současné texty, často postmoderního charakteru, jsou totiž zpravidla naplněny náznaky, aluzemi, symboly, které čtenáři ztěžují četbu s porozuměním. A právě na tom ztroskotává interpretace těchto textů, nebot' ta vyžaduje, aby ji vedl učitel nejen sečtělý, ale i poučený. Proto studie Věry Zelenkové může být vítaným vodítkem pro jeho didaktické záměry se současnými texty.

Využívání literárněvědných poznatků představuje Viktor Viktora na textu klasické literatury, rozborem Arbesova Svatého Xaveria. Poukazuje na to, že při interpretaci literárního díla je nutno respektovat jeho sémantickou víceznačnost, neexistuje univerzální analytická metoda. Nesporným východiskem má být sociální, umělecký a literární kontext, ovšem dílo není jen kritickým svědectvím o době, v níž vznikalo, má nadčasovou platnost. Podle V. Viktory Arbesovo dílo tvoří spojující oblouk mezi romantismem a realismem, $\mathrm{v}$ něm se prolíná sakrální s profánním.

Autorský tým monografie má tu výhodu, že je složený z pracovníků katedry českého jazyka a literatury plzeňské univerzity, a proto je nasnadě, že má na mysli integrovaný pohled na vyučovací předmět, intencionálně se to promítne zřetelně ve studii Davida Franty, věnované modelu integrované výuky, jak ji realizuje na klatovském gymnáziu. Hledá nápravu snižující se čtenářské schopnosti (gramotnosti), kritizuje nedostatky ve 
vyučovací praxi i teorii. Hledá je v neporozumění gramatice a lexiku staršího textu (brání čtenáři otevřít „svět vytvořený ze slov“). Řešení nachází ve vhodně zvoleném jazykově-slohovém detailu, aby „se zvýraznil a zjitřil jeho smysl pro to, jak estetické i myšlenkové poselství vychází z jazykového formováni““ (cituje A. Sticha). Uvádí, v souladu s tím, že jazykový znak, včetně morfologických jevů, může pomoci ozřejmit smysl díla; na překladu Goethova Fausta předvádí na výuce v 2. ročníku gymnázia, že gramatické kategorie způsobu a času prostupují tematickou i kompoziční rovinou díla.

Jiří Novotný uvažuje o tom, jak motivovat nemotivované, a to na př́kladu středověké literatury. Vychází z rešerše dat portálu hodnocení kvality výuky. Uvažuje nad prř́činami, které stojí za neochotou studentů češtiny zabývat se národní historií a starší literaturou. Předkládá své dlouholeté zkušenosti s motivací a aktivizací studentů k poznávání starší české literatury a historie raného středověku a vyžaduje interdisciplinární př́stup učitelů na všech stupních škol.

V závěrečné studii Vladimíry Pánkové se rozvíjí úvaha o směřování literární výchovy. Jde o to, aby se žáci podíleli na objevování smyslu textu, ve spolupráci s učitelem aktivně poznávali hodnotovou orientaci textu a utvářeli svůj čtenářský postoj, aby se stali spolutvưrci obsahu vnímaných textů včetně obsahu estetického. Proto se studie zabývá rozmanitými metodami tvořivého a kritického myšlení, analyzuje na konkrétních textech krásné literatury užívání podvojného deníku, brainstormingu, pětilístku, domýšlení př́iběhu a dalších zajímavých metod, jejichž mechanické zavádění do výuky však nevede k četbě s porozuměním, ale naopak může žáky od smyslu díla i vzdalovat, výuka pak směřuje k samoúčelné hře a zábavnosti. Autorka dovozuje, že tvořivý interpretační př́stup (poznávání díla) je třeba kombinovat s reflexí 
produkovaných výstupů a s př́stupem informačním (poznávání o díle).

\section{Dovětek}

To, co kdysi bývalo běžné, by bylo záhodno obnovit a místy se tak děje: studenti učitelství od samého počátku studia, a pokud to jde, už před tím, mají mít možnost, snad by se dalo uvažovat i o povinnosti, zúčastňovat se života škol nižších stupňů a žákovských aktivit v nich nebo i mimo ně provozovaných, např. jako vedoucí zájmových kroužků nebo oddílů dětských/mládežnických organizací, průvodců žáků do různých institucí (muzeí, galerií...), působit jako pomocníci učitelů. Tím by se studenti přesvědčili, zda se k práci ve škole hodí, zda je těší a zda jsou odhodláni zasvětit jí svůj profesní život. Podotýkám to proto, že značná část studentů učitelství se vystudované profesi nevěnuje. Nevedou je $\mathrm{k}$ tomu jen finanční důvody (výhrady $\mathrm{k}$ výši platu dnes už vlastně neobstojí), ale náročnost pedagogické činnosti, ta vyžaduje celou osobnost, oddanost mládeži, ale i notnou dávku psychické odolnosti, trpělivosti až andělské, schopnosti řešit nekonfliktně problémové situace, a to i s rodiči, s nadřízenými i s kolegy, kteří někdy nemají pro mladé, nadšené iniciativní učitele pochopení, protože starší se zaběhli v jistém systému a ten nehodlají opustit, mladým házejí klacky pod nohy, usilují-li o změny. Toto píšu s plnou odpovědností, protože několik mých takových nadaných studentů-diplomantů opustilo po čase školu a uplatňují se jako úspěšní pracovníci v jiných profesích, jako redaktoři nebo i bankéři ... Škola tak přišla o zapálené, ale zklamané učitele (vesměs šlo o chlapce). Na druhé straně ve škole někdy zůstávají neschopní nebo psychicky neotužilí jedinci, jimž škola působí utrpení, ale oni v ní přesto zůstávají ( $\mathrm{z}$ různých důvodů), vedení školy a kolegové němě přihlížejí. 
I této problematice by bylo záhodno věnovat větší pozornost, něco už naznačila ve své studii Jana Vejvodová, více snad v některé z příštích publikací.

Předložená kniha představuje vybraná významná témata, zpracovaná výzkumnými metodami, které jsme uvedli výše. Na některých výzkumech se přitom podíleli současní studenti a spolupracující mimofakultní učitelé, někteří alespoň jako respondenti. Učitelé katedry českého jazyka a literatury plzeňské univerzity tak ukázali, čím mohou přispívat k zdokonalování přípravy svých svěřenců, budoucích češtinářů, ale i praktiků v činné službě, těch, kteří se dále chtějí vzdělávat. Přitom si neděláme iluze o všemocnosti působivosti našeho „slova“.

\section{Použitá literatura}

CVRČEK, Václav. Teorie jazykové kultury po r. 1945. Praha: Karolinum, 2006. $123 \mathrm{~s}$.

CVRČEK, Václav. Regulace jazyka a Koncept minimální intervence. Praha: Karolinum, 2008. 232 s.

CVRČEK, Václav; aj. Mluvnice současné češtiny 1. Jak se píše a jak se mluví. Praha: Karolinum, 2010. 354 s.

ČECHOVÁ, Marie; aj. Komplexní jazykové rozbory. Praha: SPN - pedagogické nakladatelství, 1996 (2. upravené vydání). 263 s.

ČECHOVÁ, Marie. Mužská a ženská specifika školní komunikace. In Řeč o řeči. Praha: Academia, 2012, s. 212-219.

ČECHOVÁ, Marie. Profesní prŕíprava učitelů češtiny. Český jazyk a literatura 65, 2014/15, s. 125-133, upraveno in Život s češtinou. Praha: Academia, 2017, s. 253-261.

ČECHOVÁ, Marie; SPĚVÁČKOVÁ, Martina (eds.). Od praxe $k$ teorii a zpět ve vyučování češtině. Plzeň: Západočeská univerzita, 2019, $220 \mathrm{~s}$. 
HOFFMANNOVÁ, Jana a kol. Syntax mluvené češtiny. Praha: Academia 2019, $392 \mathrm{~s}$.

HRDLIČKA, Milan. Gramatika a výuka češtiny jako cizího jazyka. Praha: Karolinum 2009. 158 s.

JELÍNEK, Jaroslav. Úvod do vyučování českému jazyku. Praha: SPN 1980. $275 \mathrm{~s}$.

MATHESIUS, Vilém. O potencionálnosti jevů jazykových. In VACHEK, Josef (ed.). U základi̊ pražské jazykovědné školy. Praha: Academia, 1970. $81 \mathrm{~s}$.

STYBLÍK, Vlastimil, ČECHOVÁ, Marie. Mluvnická a slohová cvičení ke Stručné mluvnici české. Praha: SPN 1976 (1. vydání), Fortuna 2007 (8. vydání).

SVOBODA, Karel. Stylizační výcvik ve spisovné češtině a rozvoj myšlení. Praha: FF UK, 1. díl 1975, 2. díl 1976.

SVOBODA, Karel. Didaktika českého jazyka a slohu. Praha: SPN, 1977. $307 \mathrm{~s}$.

ŠTĚPÁNÍK, Stanislav. Vztah jazyka a komunikace v česko - slovensko - polské didaktické reflexi. Praha: Karolinum 2019, 226 s. ŠTĚPÁNÍK, Stanislav. Výuka češtiny mezi tradicí a inovací. Praha: Academia 2020. $328 \mathrm{~s}$. 


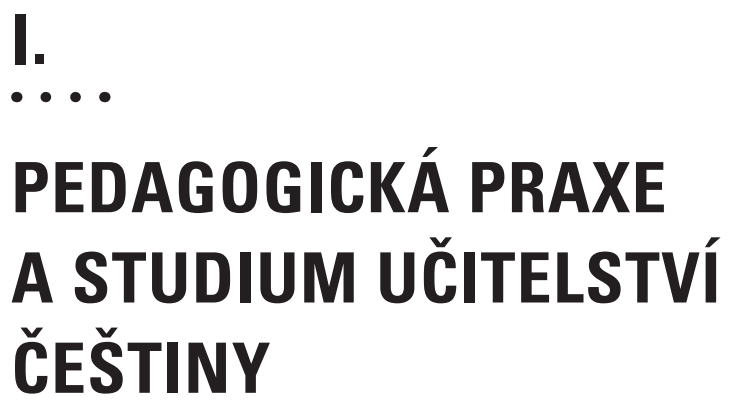




\title{
Reflexe výuky jako prostředek propojení pedagogické praxe studentů s jejich teoretickou prípravou
}

\author{
Jana Vejvodová
}

Studenti učitelství by měli v průběhu své vysokoškolské přípravy získat co nejvíce prŕležitostí k profesionálně efektivnímu propojování vzdělávací teorie s praxí. Možnosti takového propojování však narážejí na své limity a často selhávají (Korthagen 2011). Diskutuje se o „propasti” mezi teorií a praxí ve vzdělávání. „Propast“ oddělující vzdělávací teorii od praxe snižuje kvalitu odborné komunikace $\mathrm{v}$ rámci učitelské profese, oslabuje autoritu učitelství $\mathrm{v}$ akademické sfére a má nepříznivé dopady na přípravu učitelů k jejich povolání” (Slavík aj. 2017, s. 25). Příčiny tohoto stavu mohou být rozmanité, nezáleží však na kontextu konkrétního vzdělávacího systému. „Jsou zřejmě společné všem způsobům učitelského vzdělávání spadajícím do tzv. modelu technické racionality, který spočívá v tom, že se nejdříve vyučují základy oborů, pak se přednášejí metody didaktické aplikace a nakonec následuje praxe“ (Argyris a Schön 1992, s. 18).

K překonávání této „propasti“ lze přispět užším propojováním mezi reflexí výuky ve vzdělávací praxi a uplatněním teoretických znalostí. Teorie má pomoci učiteli zkvalitnit pedagogický výkon v duchu myšlenky „teorie pro praxi“ (Schön 1983, s. 21; Korthagen 2011, s. 19). 
V této studii se pokusíme ukázat, jak jsou studenti v průběhu bakalářského i magisterského studijního programu na FPE ZČU v konkrétních studijních disciplínách vedeni k uplatňování teoreticky podložené reflexe výuky a jak jsou tyto disciplíny propojeny s pedagogickou praxí. Výrazně ovlivnit kvalitu profesní přípravy budoucích učitelů může pedagogická praxe totiž jen tehdy, pokud nebude izolovaným konceptem $\mathrm{v}$ pedagogické přípravě budoucích učitelů, ale stane se funkční součástí celkového pojetí pedagogicko-psychologické prrípravy.

Disciplíny Základy reflexe a hodnocení výuky v bakalářském studiu a Reflexe a hodnocení výuky v navazujícím magisterském studiu vedou studenty i vyučující k transdisciplinární didaktické součinnosti (Slavík aj. 2017), k součinnosti mezi oborovými didaktikami a obecnou didaktikou nebo pedagogikou. Studenti by se díky těmto disciplínám měli naučit nepřistupovat $\mathrm{k}$ výuce intuitivně, především jen jako její tvưrci, ale také jako její zodpovědní hodnotitelé, schopní své soudy o výuce zdůvodňovat a obhajovat.

\section{Cíle a funkce pedagogické praxe}

„Pedagogická praxe vychází z pedagogické teorie a je jí rozvíjena, ale na druhé straně konfrontuje informace teoretického poznání a umožňuje konkretizaci a syntézu vědomostí a poskytuje studentům základní pedagogické způsobilosti potřebné pro výkon jejich budoucího učitelského povolání" (Porubská 2001, s. 43).

Systém pedagogických praxí by měl studenty vybavit souhrnem kompetencí, které jsou nezbytné k tvořivému pojetí učitelské profese. 
V Pedagogickém slovníku jsou stanoveny tři cíle pedagogické praxe:

1. Spojovat teorii a praxi všech složek vysokoškolské přípravy.

2. Uvést studenta (budoucího učitele) do podmínek reálného školního prostředí.

3. Zacvičit studenta (budoucího učitele) v činnostech učitelské profese.

(Průcha, Walterová a Mareš 2009, s. 92)

„Pedagogické praxe plní následující funkce:

- motivační,

- postojově-transformační (měnit postoj studenta v postoj učitele; během praxe probíhá proces formování základních profesních dovedností a návyků),

- reflektivní (cílem je vést studenty k sebereflexi a sebehodnocení),

- $\quad$ syntetickou (praxe umožňuje syntézu znalostí získaných v ostatních studijních předmětech),

- orientační (orientovat se ve školním životě, v pedagogických situacích, seznámit se s chodem školy, s organizací výuky, se školskou legislativou, vzdělávacími programy prrímo $\mathrm{v}$ praxi),

- integrační (spojování teorie a praxe složek vysokoškolské př́ípravy),

- aplikační (pedagogická praxe jako aplikace pedagogické teorie; student má možnost využít a ověřit si své teoretické poznatky, vědomosti a dovednosti získané při studiu na vysoké škole; praxe poskytuje možnost $\mathrm{k}$ upevnění získaných vědomostí),

- diagnostickou (student diagnostikuje sám sebe, své silné a slabé stránky, plus „ukazuje” fakultním učitelům i učitelům z fakulty, jak je na tom v určitých oblastech), 
- poznávací (poznání věkových zvláštností žáků, odhalení problémů, které na žáky doléhají aj.)"

(Bendl aj. 2011, s. 48).

\section{Systém pedagogické praxe studentů na FPE ZČU a její propojenost s jinými disciplínami}

Náslechová praxe bakalářská

K profesionálnímu propojování teorie s praxí jsou na Fakultě pedagogické ZČU vedeni již studenti bakalářského studijního programu Český jazyk se zaměřením na vzdělávání. Předmět Základy reflexe a hodnocení výuky (ZRHV) je zařazen do letního semestru druhého ročníku bakalářského studia a je velmi těsně propojen s Náslechovou praxí bakalářskou (NAPX). Pojetí předmětu je založeno na využití Schönova konceptu reflektivního praktika a v metodologické oblasti se opírá zejména o Korthagenovo pojetí reflektivní praxe a metodiku $3 \mathbf{A}$ založenou na konceptové analýze učiva (Korthagen 2012). Předmět ZRHV má dílčí návaznost na předměty Úvod do pedagogiky a Obecná teorie výchovy a vzdělávání a na oborovou propedeutiku. Předmět vyučují oboroví didaktici. Vzhledem $\mathrm{k}$ tomu, že $\mathrm{v}$ bakalářském studijním programu na FPE ZČU nejsou v současnosti zařazeny žádné jiné předměty obecně či didakticky zaměřené, tvoří ZRHV $\mathrm{v}$ tomto stupni studia ve vazbě na náslechové praxe důležitý prvek spojování vzdělávací teorie s praxí.

Předmět ZRHV je zaměřen především na rozvoj profesního vidění (Janík a kol. 2014) a na rozvoj reflektivních kompetencí. V přednáškách a seminárích se studenti seznamují s aspekty podmiňujícími kvalitu výuky, analyzují videoukázky vybraných výukových situací, hodnotí integritu výuky s ohledem na 
návaznost jejích jednotlivých částí, učí se identifikovat formalismy ve výuce, tzv. odcizené a utajené poznání, získávají vhled do metodiky 3A (anotace, analýza, alterace), jsou vedeni k tomu, aby alteraci vnímali jako reflektivní východisko profesního rozvoje.

Poznatky a základní dovednosti získané v předmětu ZRHV pak studenti aplikují při blokové náslechové praxi bakalářské. V průběhu jednoho týdne hospitují v pěti vyučovacích hodinách českého jazyka na různých typech škol.

Úkoly pro analýzu výuky v předmětu ZRHV př́mo využívají zkušeností studentů z náslechové praxe. Seminární práci, především její analytickou a alterační část, studenti veřejně prezentují a obhajují v kolokviu. Dochází k podnětným diskusím, ukazuje se, jak různorodé může být jejich „vidění“, výběr, analýza a návrhy alterací vybraných situací. Společná diskuse slouží k upevnění schopnosti studentů identifikovat podmínky a př́íciny, za kterých vznikají, a umožňuje navrhovat zlepšující alterace (Chocholoušková, Slavík a Soukupová 2019).

\section{Náslechová praxe navazující}

Náslechová praxe je zařazena i do studijních plánů navazujícího studia, především proto, že do tohoto studia jsou přijímáni i absolventi jiných bakalářských oborů, kteří se s danou problematikou v průběhu předchozího studia dosud nesetkali.

Náslechová praxe je bloková, probíhá v zimním semestru 1. ročníku. V učitelství pro střední školy jsou do rozvrhu souběžně zařazeny didaktické disciplíny: Didaktika literatury (DIDSŠ), Moderní metody a formy práce (MONA) a Informační a komunikační technologie ve výuce (ICT). Ve všech těchto disciplínách 
jsou rozvíjeny reflektivní kompetence studentů. V disciplíně MONA jsou studenti vedeni $\mathrm{k}$ tomu, aby dokázali identifikovat silná a slabá místa demonstrovaných metod a aby zdůvodnili vlastní návrhy moderních výukových metod vzhledem ke stanoveným výukovým cílům a $\mathrm{k}$ požadavkům RVP. V předmětu ICT studenti posuzují a hodnotí efektivitu počítačových programů a aplikací určených k výuce českého jazyka. Analyzují videoukázky vyučovacích hodin slohové a komunikační výchovy, v nichž dochází k rozvoji digitálních kompetencí žáků, např. na téma Komunikace na sociálních sítích a veřejných fórech, Netiketa napříc internetem aj. Stejné disciplíny absolvují i studenti učitelství pro 2. stupeň základní školy, jejich výhodou oproti studujícím pro střední školy je to, že ve stejném semestru, v němž probíhá náslechová praxe, je již zařazena i disciplína Didaktika českého jazyka (DIJZ).

Studenti vykonávají náslechovou blokovou praxi podle studovaného programu, tedy bud' na 2. stupni základní školy, nebo na střední škole. Hospitují v průběhu jednoho týdne v pěti vyučovacích hodinách $\mathrm{z}$ každého aprobačního předmětu u vybraných učitelů. Průběh náslechových hodin a závěry z rozborů hodin si zapisují do záznamových archů.

\section{Bloková výstupová praxe}

Na sérii náslechových hodin navazuje předmět Výstupová praxe (PEZŠ a PSŠ). V průběhu jednoho týdne si studenti vyzkoušejí $5+5$ vyučovacích hodin $\mathrm{z}$ každého aprobačního předmětu.

Rovněž na tuto praxi jsou studenti připravováni v didaktických disciplínách. Jako součást seminářủ disciplíny Didaktika českého jazyka pro stř̌ední školy (DIJS) jsme zavedli mikrovyučování, 
tj. simulované školní situace, v nichž studenti zaujímají roli učitele a učí své spolužáky v semináři. Analýzy mikrovyučování jsou pak př́ležitostí k rozvoji schopnosti studentů analyzovat vlastní činnost a prezentovat své pojetí práce. Studenti si připravují tandemové mikrovýstupy $\mathrm{v}$ rozsahu 15 minut, jsou pořizovány jejich videozáznamy a na základě následné analýzy videozáznamů pak probíhá velmi důkladná sebereflexe a reflexe (Čechová 1998, s. 39, 40, 41; Vejvodová 2019, s. 16). Ta je prováděna z několika hledisek, a to z hlediska odborné správnosti, z hlediska psychodidaktického, $\mathrm{z}$ hlediska komunikačního a $\mathrm{z}$ hlediska řídicího/ organizačního.

Ve školním roce 2019/2020 jsme vyzkoušeli novou simulační metodu, tzv. virtuální třídu. Je to trenažér ve virtuální realitě, který umožňuje simulovat situace, $\mathrm{k}$ nimž dochází při výuce ve škole. Student v roli vyučujícího si nasadí 3D brýle, vezme si do ruky speciální ovladače a ocitne se ve virtuálním modelu školní třídy, v jejíchž lavicích sedí několik žáků. S nimi učitel vede dialog, žáci na něj reagují - hlásí se, povídají si mezi sebou. Ve trrídě je také virtuální tabule a mapa světa. Student s 3D brýlemi stojí za projekčním plátnem, v druhé části třídy sledují jeho výkon spolužáci a vyučující. Učitel ovládá chování žáků ve virtuální tř́dě pomocí počítače, může hrát roli jednotlivých žáků sám nebo mohou v roli žáků vystupovat i ostatní studenti (Duffek aj. 2019).

Bezprostředně po každém výstupu následuje sebereflexe studenta v roli vyučujícího i reflexe ostatních studentů a oborového didaktika.

V letošním roce se bloková výstupová praxe v důsledku uzavření škol v souvislosti s onemocněním covid-19 neuskutečnila ve formě, v jaké běžně probíhá. Studenti absolvovali blokovou praxi (Výstupová praxe - PEZŠ a PSŠ) formou distanční výuky (viz zde Písková, s. 64). 


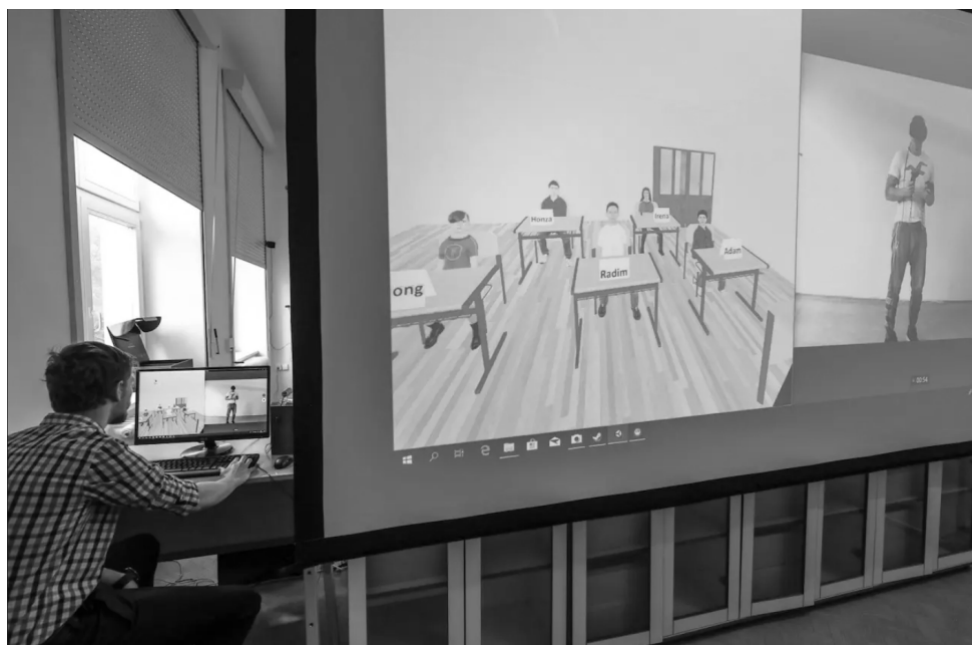

Foto: ZČU

\section{Souvislá pedagogická praxe}

Souvislé pedagogické praxi, která je ve studijním plánu zařazena $\mathrm{v}$ letním semestru 2. ročníku, předchází předmět Reflexe a hodnocení výuky (RHV). V navazujících magisterských programech učitelství pro základní školy a učitelství českého jazyka pro střední školy je tento předmět systematickým pokračováním předmětu ZRHV vyučovaného $v$ bakalářském studiu. Je zařazen do zimního semestru druhého ročníku. V předchozích semestrech již studenti učitelství českého jazyka pro základní školy absolvovali obecnou didaktiku i většinu oborových didaktik, studenti učitelství pro střední školy ještě v tomto semestru současně absolvují disciplínu Didaktika slohové a komunikační výchovy (DISS). Obsahová východiska předmětů ZRHV a RHV jsou stejná, v předmětu RHV dochází k rozširrení a prohloubení učiva. Při analýzách videozáznamů výukových situací se již studenti mohou opírat o znalosti 
a dovednosti získané v oborových didaktikách i v obecné didaktice. Předmět dále rozvíjí profesní vidění a reflektivní kompetence studentů. Studenti si osvojují model hloubkové struktury výuky, posuzují kvalitu výukových situací s oporou v konceptové analýze, s ohledem na vztah mezi obsahem, žákovskou činností, cílovými požadavky a požadavky na hodnocení ve výuce. Reflektují transformaci vzdělávacího obsahu prostřednictvím výukových/učebních úloh, identifikují důkazy o kvalitě učení žáků. Výstupem předmětu je seminární práce $s$ názvem Reflexe hospitované výuky metodikou 3A. Stejně jako v předmětu ZRHV veřejně prezentují a obhajují seminární práci v kolokviu.

Při souvislé výstupové praxi vyučuje student 20 hodin každého aprobačního předmětu podle studovaného programu bud' na 2. stupni základní školy, nebo na střední škole.

\section{Výzkum}

\section{Cíle, popis a metody výzkumu}

Cílem výzkumu provedeného ve školním roce 2019/2020 bylo zjistit, jak studenti reflektují efektivitu náslechové praxe navazující a souvislé výstupové pedagogické praxe, které považujeme v magisterském navazujícím studiu za stěžejní. Zajímalo nás zejména to, do jaké míry dochází při pedagogické praxi studentů k propojení mezi teoretickými poznatky a dovednostmi získanými ve studijních disciplínách a jejich praktickou aplikací ve výuce a do jaké míry si studenti toto propojení uvědomují.

Po skončení náslechové praxe navazující a souvislé výstupové praxe jsme studentům zadali dotazníky s uzavřenými otázkami i otázkami otevřenými, zdůvodňujícími odpovědi na otázky uzavřené. 
K pedagogické praxi náslechové jsme vyhodnotili celkem 22 odevzdaných dotazníků, z toho 16 dotazníků studentů učitelství pro 2. stupeň základních škol a 6 dotazníků studentů učitelství pro střední školy. Rozdíly v počtu odevzdaných dotazníků jsou dány jednak nižším počtem studentů učitelství pro střední školy, jednak tím, že někteří z těchto studentů jsou již zaměstnáni jako učitelé, proto jim byla praxe uznána.

K souvislé výstupové pedagogické praxi jsme vyhodnotili celkem 14 odevzdaných dotazníků, z toho 5 dotazníků studentů učitelství pro střední školy a 9 dotazníků studentů učitelství pro 2. stupeň základní školy.

Interpretace výsledků dotazníkového šetření k náslechové navazující praxi

Otázka č. 1.

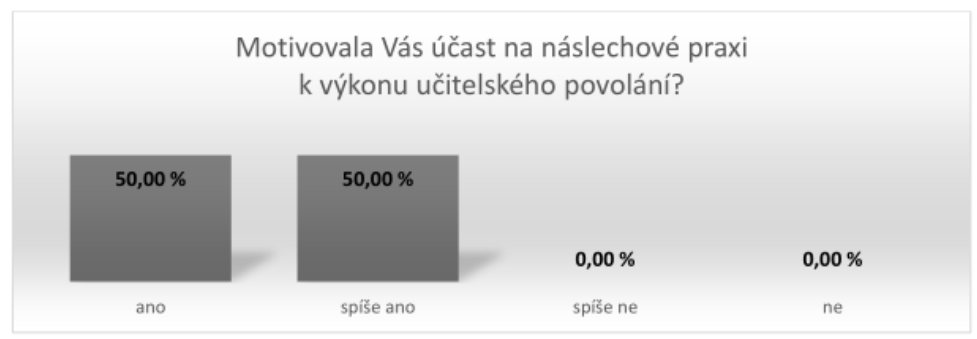

Graf č. 1

Motivační funkci náslechová praxe zcela naplnila. Je velmi potěšující, že 50 \% studentů odpovědělo ano a 50 \% studentů spiše ano. 
Svou odpověd' zdůvodnilo několik studentů tím, že náslechová praxe předčila jejich očekávání.

\begin{abstract}
„Na praxi jsme měli povětšinou štěstí setkat se sinspirujícími a motivujícími lidmi, kteři vypadají ve svém povolání štastně a naplněně. Vètšina $z$ nich dokázala ve tř́dě udělat velmi př́ijemnou a př́telskou atmosféru. Stejně však nevím, jestli bych něco takového dokázala já sama."
\end{abstract}

Někteří studenti uváděli, že byli pro učitelské povolání motivováni již před praxí, ale praxe je jejich rozhodnutí posílila.

Vyjadřovali i spokojenost s volbou stupně školy, který pro své studium zvolili.

„Utvrdila jsem se v tom, že volba učitelství pro SŠ byla správná. Po náslechových praxích mám motivaci stát se dobrým učitelem a pristupovat $k$ žákưm se stejnou úctou, se kterou chci, aby oni přistupovali ke mně.”

„Praxe mě utvrdila $v$ tom, že chci učit. Dokonce mi ukázala, jak učit - jak své povolání konat správně a být pro žáky prínosem."

Jedna ze studentek, které na otázku odpověděly „spíše ano”, vyjádřila názor, že ke konečnému rozhodnutí, zda se stane učitelkou, přispějí až její zkušenosti z výstupových praxí.

„Vzhledem $k$ tomu, že jsem zatím neabsolvovala výstupové praxe, nejsem zcela presvědčena, že budu učit. Pokud bych zjistila, že to nejde, raději zvolím jiné povolání, než být celý život špatným učitelem.” 
Potěšující je rovněž výborná zkušenost studentů s učiteli, kteří dokáží skvěle motivovat.

„Skoro všichni učitelé mi ukázali, že čeština se dá vyučovat tak, aby dèti bavila."

\section{Otázka č. 2}

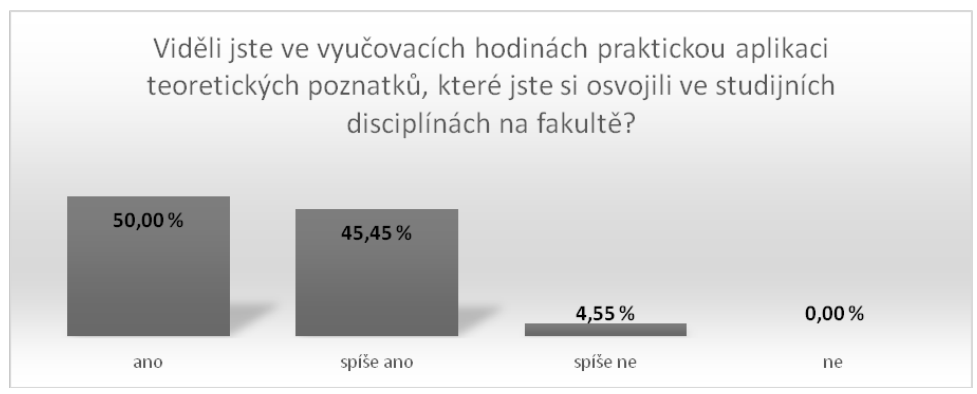

\section{Graf č. 2}

Jediný student odpověděl na otázku spíše ne. Vzhledem k tomu, že byl při náslechové praxi ve skupině se studenty, kteři odpověděli ano či spiše ano, je zřejmé, že nedokázal konkrétní příklady vzájemně propojit.

Studenti učitelství pro střední školy uváděli jako př́klad vyučovací hodinu jazykové složky předmětu, ve které se žáci seznamovali s přechodníky a jejich funkcí na literárním textu Vladislava Vančury. $\mathrm{V}$ bakalářském studiu $\mathrm{v}$ disciplíně morfologie rovněž analyzovali přechodníky v ukázkách z Vančurových textů. V dotaznících jsme se setkali i s dalšími príklady témat $\mathrm{z}$ morfologie, syntaxe a tvoření slov. 
Jeden z uvedených prŕkladi̊ se týkal propojení složky slohové a komunikační výchovy a složky literární; žáci psali charakteristiku postavy na základě četby povídky Oty Pavla. Funkční propojování jednotlivých složek předmětu je jedním z pilíruu disciplíny Moderní metody a formy výuky. I další studenti uváděli příklady zasazování tématu výuky do širších souvislostí, propojování s jinými obory.

Studenti učitelství pro 2. stupeň ZŠ uváděli prŕiklady využití metod kritického myšlení, se kterými se seznámili v disciplíně Didaktika literatury, či prríklady využití elektronických testů a kvízů, které vytvářejí v předmětu Informační a komunikační technologie ve výuce českého jazyka.

Jeden ze studentů uvedl i př́klad autoevaluace žáků a jejich vzájemného hodnocení.

\section{Otázka č. 3}

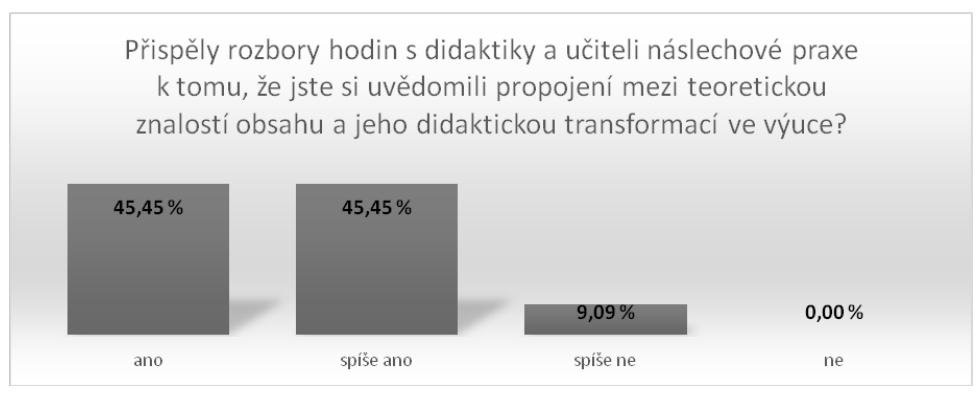

Graf č. 3 
Převažovaly odpovědi ano (45,45 \%) a spíše ano (45,45\%). Byly zdůvodněny následujícími vyjádřeními:

„Didaktikové nám velmi často odůvodnili jednání učitelů. Podali nám vysvětlení ze zkušenějšího pohledu, který my ještě nemáme."

"Rozbory hodin s didaktiky mi velmi vyhovovaly. Pomohly mi všimnout si věcí a důležitých detailù ve výuce, které bych jinak přehlédla."

„Rozbory byly velmi př́jemné a prospěšné. Došlo k pojmenování a zduraznèní toho, co bylo dobré, co bylo nutné a co je v praxi funkční."

Za pozitivní považujeme to, že v odpovědi na tuto otázku studenti funkčně používali pojmy, které si osvojili v disciplíně Základy reflexe a hodnocení výuky.

„Při rozborech jsem si uvědomila, že pro učitele coby odborníka může být při didaktické transformaci obsahu problém volit pojmový aparát, který bude žákưm srozumitelný."

„Líbil se mi rozbor hodiny, jejímž tématem byly větné členy. Byla zdi̛razněna potřeba presnosti vyjadřování (věta jednoduchá obsahuje jediný určitý slovesný tvar, nikoli jediné sloveso) (viz též zde J. Vaňková a M. Spěváčková, s. 198). Diskutovali jsme o tom, jak nejlépe vysvětlit rozdíl mezi přivlastkem několikanásobným a postupně rozvíjejícím, jak dưležitá je závislost rozvijejícího větného členu na slovním druhu (četba knihy x čte knihu). Tématem diskuse bylo $i$ to, zda je ve školní praxi účelné rozlišovat všechny druhy př́slovečných určení." 
Otázka č. 4

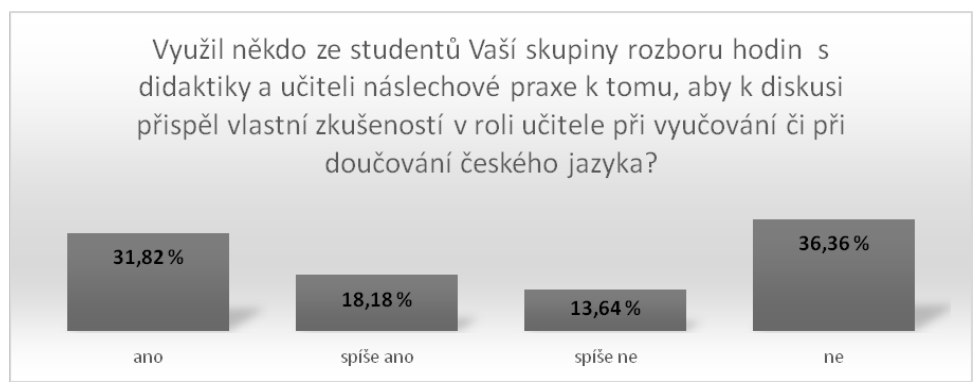

Graf č. 4

Někteří ze studentů již vyučují český jazyk v průběhu studia nebo doučují žáky či je připravují k přijímacím zkouškám na stř̌ední školy. Př́ispěvky těchto studentů považujeme při rozborech zhlédnutých hodin s učiteli náslechové praxe za podnětné.

„Většina z naši skupiny někde učí/doučuje, takže jsme diskutovali o tom, jak to děláme my, co jiného bychom využili apod."

Abychom se vyhnuli šírení nevhodných „praktik“, je velmi důležité, aby didaktikové i cviční učitelé při diskusi vedli studenty $\mathrm{k}$ profesně podloženým soudům o výuce.

Na otázku odpovědělo $31,82 \%$ studentů ano.

V odpovědích na doplňující otázku, kterého problému se diskusní příspěvek týkal, uváděli studenti učitelství pro střední školy funkčnost a atraktivnost zhlédnuté hodiny jazykové složky předmětu na gymnáziu, jejímž tématem byly přechodníky. Studenti, kteř́ již učí, uváděli, že přechodníky dosud nepovažovali za téma, 
které by mělo být v současné době ve výuce zařazeno, hodina však pro ně byla natolik inspirující, že svůj postoj přehodnotili.

Ve skupině studentů učitelství pro 2. stupeň škol se jako př́́klad diskusního tématu objevila kromě témat didaktických (shoda přísudku s podmětem, př́ibuznost jazyků) i témata $\mathrm{z}$ oblasti pedagogicko-psychologické - inkluze, dítě s autismem ve třídě, oslovování žáků.

\section{Otázka č. 5}

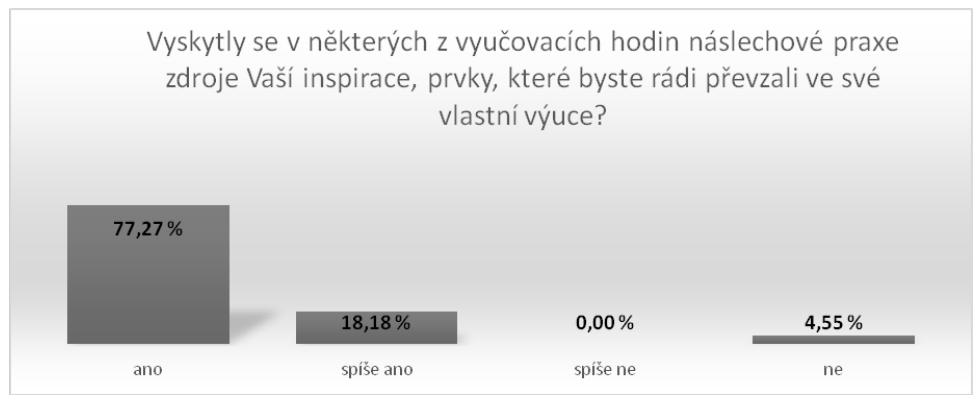

\section{Graf č. 5}

$77,27 \%$ studentů odpovědělo na otázku ano, 18,18 \% spiše ano. V bližším zdůvodnění se objevily př́klady inspirace týkající se jak didaktických aspektů výuky, tak aspektů souvisejících s osobností učitele.

Z didaktických aspektů studenti uváděli jako inspirativní dovednost učitele aktivně zapojovat žáky, rozvíjet jejich schopnost spolupracovat a diskutovat, rozvíjet tvořivost žáků, učit zajímavě a smysluplně i látku na první pohled nudnou, využívat funkčně metody kritického myšlení, model učení E-U-R (evokace 
- uvědomění - reflexe), výborně vést žáky při práci s textem, vhodně využívat audioukázky i videoukázky, funkčně zapojovat do výuky technologie, vést žáky k sebehodnocení i vzájemnému hodnocení, hodně chválit. Za inspirativní označili netradiční tandemové vyučování učitel - žák.

Studenti vyzdvihovali takové rysy osobnosti učitele, jako jsou vřelost, usměvavost, přátelskost, zápal, porozumění žákům a vřelý vztah k nim (viz i Čechová 2012, s. 212-219). Jedna z vyučujících studentce připomněla učitelku, která ovlivnila její volbu studijního zaměření.

Otázka č. 6

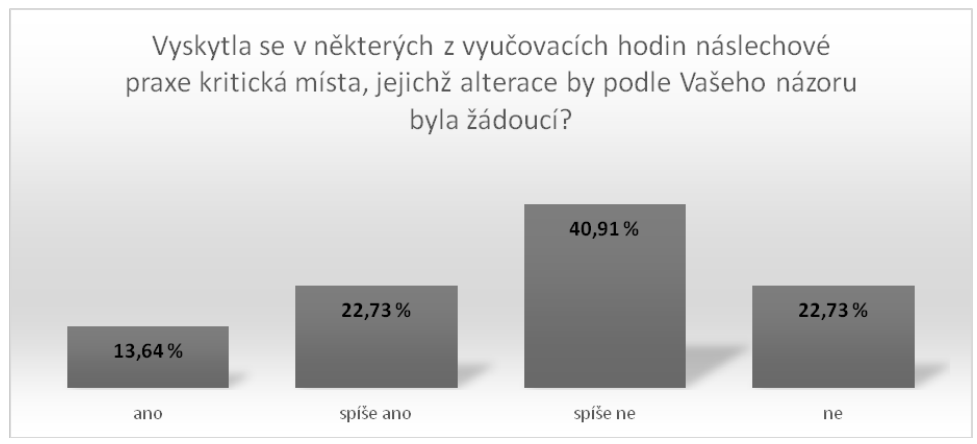

Graf č. 6

Domníváme se, že v odpovědích na tuto otázku se již projevila postojově-transformační funkce praxe. Studenti se vžívají do rolí učitelů, jsou s nimi solidární, vidí se na jejich místě a nepovažují za vhodné hledat $\mathrm{v}$ jejich hodinách kritická místa, ani se $\mathrm{k}$ tomu dosud necítí být oprávněni. $Z$ tohoto hlediska považujeme za důležité v duchu konstruktivistické pedagogiky v seminářích 
studentům zdůrazňovat, že identifikace kritických míst je důležitá. Metodika 3A, kterou při př́ipravě studentů využíváme, si totiž neklade za cíl soudit učitele, ale hledat možnosti pro zvyšování kvality tvorby učebního prostředí pro žáky. Proto vyhledává kritická místa výuky. „V tom navazuje na metodiku tzv. analýzy kritických událostí převzatou do oborově didaktického diskursu z metodiky „critical incident technique“(CIT) J. C. Flanagana, která je nesena cílem dosáhnout co nejhlubšího porozumění podstatným složkám situací rozhodujících o úspěšnosti výsledku.“ (Rusek, Slavík a Najvar 2016, s. 161)

Studenti se nejvíce shodli na tom, že ve zhlédnutých hodinách se kritická místa spíše nevyskytovala (40,91\%) nebo nevyskytovala (22,73\%).

„Vètšina náslechových praxí byla bezproblémová.“

Ti, kteří odpověděli ano nebo spiše ano, se vyjadřovali obecně $\mathrm{k}$ méně vhodně užité metodě či organizační formě.

„Pokud se něco takového stalo, jednalo se především o nevhodně zvolenou formu práce, napríklad $v$ jedné $z$ hodin využití pracovního listu do skupin. Tato aktivita následně žáki̊m zabrala celou hodinu, na nic jiného nezbyl již čas a žáci z hodiny odcházeli bez jakéhokoli výstupu."

„Práce ve čtyřclenných skupinách. Ve třídě nastal rozruch, který vyučující nedokázal dostatečně korigovat, a práce jednotlivých členů skupiny nebyla dostatečně efektivní."

Pojem kritické místo je jedním z klíčových pojmů disciplín Základy reflexe a hodnocení výuky a Reflexe a hodnocení výuky. Pro studenty má zřejmě př́liš negativní konotaci. Je třeba vysvětlovat, 
že identifikace kritických míst nemá být v žádném př́padě spojována $s$ negativními soudy o těch, $v$ jejichž výuce se taková místa objeví. Na druhé straně však je zřejmé, že cvičnými učiteli jsou především výborní zkušení učitelé a lze předpokládat, že se v jejich výuce taková místa skutečně většinou nevyskytla.

\section{Otázka č. 7}

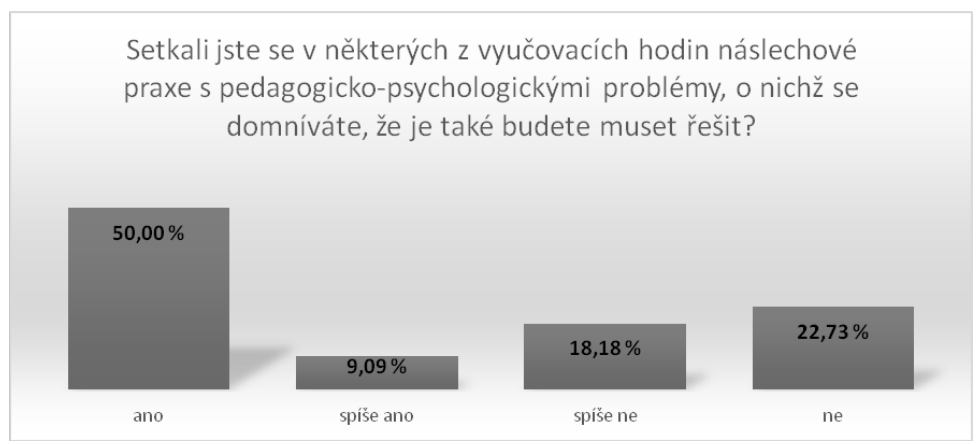

\section{Graf č. 7}

$50 \%$ studentů zvolilo odpověd' ano, 9,09 \% studentů odpověd' spíše ano.

Jako př́iklady uváděli studenti učitelství pro 2. stupeň ZŠ práci s žáky s IVP bez účasti asistenta, práci s žáky, které rodina nepodporuje ve vzdělávání, řešení kázeňských problémů, šikanu, problém nespolupracujících žáků, jako potenciální problém uvedli i žáky s domácím vzděláváním. 


\section{Otázka č. 8}

Co Vás na náslechové pedagogické praxi nejvíce překvapilo?

Studenti učitelství pro střední školy se shodovali na tom, že aktivní př́stup žáků $\mathrm{v}$ hodinách náslechové praxe předčil jejich očekávání. Dodávali ovšem, že šlo o žáky gymnázií a chybí jim srovnání s žáky jiných typů středních škol. Aktivita žáků překvapila i studenty učitelství pro 2 . stupeň ZŠ.

„Po mé špatné zkušenosti z let, kdy jsem byl žákem základní školy, to bylo př́iemné zjištění.

Porovnání se svou rolí žáka uplatnil v odpovědi na tuto otázku i další student.

„Překvapila mě vy̌šsi úroveň výuky, pestrost a různorodost didaktických metod, než jaké jsem zažil, když jsem navštěvoval základní školu já."

Pozitivním překvapením byl i přístup učitelů.

„Největším a nejpříemnějším překvapením byl elán a zápal učitelů."

„Vstřícnost učitelů a chut’s námi diskutovat.“

Překvapující byla i variabilita hodin se stejným tématem.

„Každý z učitelư, kteří vyučovali stejnou látku, pojal hodinu úplně rozdílně; hodiny se v ničem nepodobaly."

V odpovědích se objevilo jen jedno negativní překvapení, tím bylo pomalé tempo žáků, zejména při čtení. 


\section{Otázka č. 9}

Chcete $\mathrm{k}$ náslechovým pedagogickým praxím přidat ještě nějaký postřeh?

Studenti se kriticky vyjádřili k tomu, že byli součástí příliš početných skupin.

„Byla to přijemná zkušenost, ale bylo by lepší chodit do tříd $v$ menších skupinách. Bylo nás 7 a občas jsme se nevešli do učebny."

Vyjádřili rovněž prání vidět i „problémové“ vyučovací hodiny.

„Rádi bychom viděli také nějaké problémové třídy, zkušeného učitele, který zvládá kázeňské problémy během hodiny."

Jedna ze studentek ocenila prrítomnost vyučujících katedry českého jazyka na náslechových praxích.

„Velmi si cením toho, že s námi chodil vždy nějaký vyučující $z$ katedry a hodiny jsme rozebírali společně. V mém druhém aprobačním předmětu tomu tak nebylo."

Naplnění motivační funkce náslechové praxe je nejvíce patrné z následujícího komentáře.

„Určitě jsem za tuto zkušenost ráda. Osobně to beru jako jakési místo bodu zlomu, které mi ukázalo, zda chci opravdu jednou učit, nebo se vydat jinou cestou. Jsem ráda, že u mě zvítězila první možnost." 


\section{Interpretace výsledků dotazníkového šetření k souvislé výstupové praxi}

\section{Otázka č. 1}

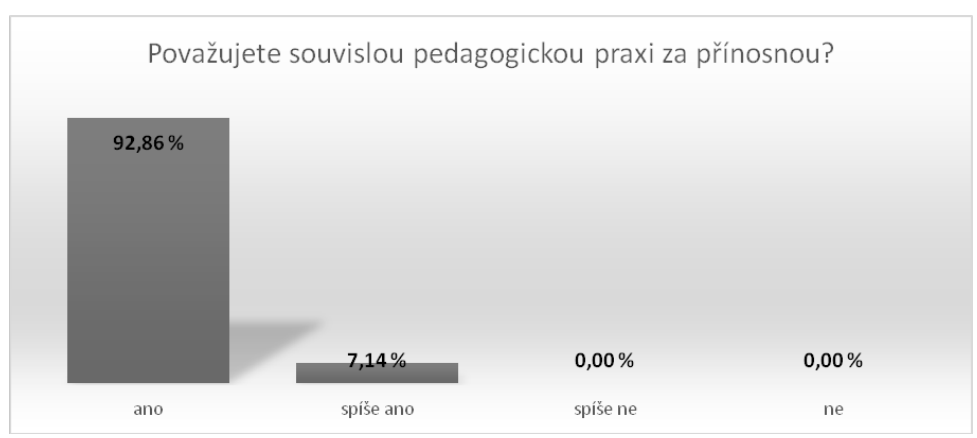

\section{Graf č. 8}

Studenti odpovídali jednoznačně kladně (ano - 92, 86 \%, spíše ano $-7,14 \%)$. Souhlasné odpovědi studenti zdůvodňovali zejména tím, že jim praxe přinesla ujištění, že učitelskou profesi opravdu chtějí vykonávat a že se pro ni hodí. $Z$ rozhovorů se studenty vyplývá, že by však takové ujištění potřebovali již v dřívějších fázích studia.

„Studenti pedagogické fakulty si konečně (!) vyzkouší profesi pedagoga na vlastní kưži."

„Vyzkoušela jsem si, jaké je to pracovat s různými skupinami žákư, byla jsem zasvěcena do každodenního chodu školy. Praxi hodnotím jako prínosnou nejen z profesního hlediska, ale i z hlediska osobnostního rozvoje. Díky ní jsem se seznámila s reálnou podobou výuky, poznatky, které jsem získala na FPE, jsem měla možnost využit v praxi." 
K přínosu souvislé praxe podle studentů velmi přispívá vstřícný postoj cvičných učitelů.

„Všichni se mi ve škole věnovali, konzultovali se mnou, co bylo třeba. Cítila jsem ze strany vyučujících obrovskou podporu a naučila jsem se díky tomu spoustu věcí."

$\mathrm{Z}$ odpovědí studentů je patrné, že dochází k naplnění transformační funkce pedagogické praxe, že se mění postoj studenta v postoj učitele. Někteří respondenti se už nenazývají studenty, ale učiteli.

"Měsíční praxe nám hlavně pomůže "přehoupnout se“ na stranu učitele a školu vnímat $z$ jeho perspektivy. V př́padě, že je učitel praxe vstřícný (v mém prípadě šlo o více než vstřícnost), může studenta $v$ jeho schopnostech výrazně posunout. Měli jsme možnost vyzkoušet si metody výuky, které nás zaujaly, experimentovat."

„Pedagogická praxe je velmi přinosná. Učitel zjistí své nedostatky a objeví, $v$ čem se může více zdokonalovat.

\section{Otázka č. 2}

Co vás při souvislé pedagogické praxi nejvíce překvapilo?

Z odpovědí vyplynulo, že jedním z největších překvapení pro studenty bylo zjištění, že učitelské povolání je náročné jak po stránce psychické, tak fyzické. V několika dotaznících byla zmíněna náročnost prŕíprav na vyučovací hodiny.

Mezi kladná překvapení studenti řadí aktivitu, vstřícnost, otevřenost a celkově neočekávaně dobré chování žáků. 
„V̌sechny děti věděly, kde jsou nastavené hranice. Letos už jsem měla srovnání ( $v$ loňském roce jsem konala praxi na jiné škole) a velmi mě prekvapilo, jak rozdílné mohou být školy v rámci jednoho města. Jsem vděčná, že jsem mohla učit právě na 15. ZŠ. “

Studenty učitelství pro střední školy překvapila míra tvořivosti žáků.

„Při slohové etudě vytvořili texty, které mě vyloženě ohromily. Nečekala jsem u nich takovou mentální vyspělost a dospělý pohled na svět."

V některých dotaznících však studenti vyjadřovali podiv nad nízkou úrovní znalostí a laxním př́istupem žáků, zejména v 9. ročníku.

Studenti neočekávali tak vysoké množství žáků s IVP, přítomnost asistenta téměř $\mathrm{v}$ každé třídě ZŠ a množství administrativy třídních učitelů.

Negativním překvapením bylo pro jednu studentku opisování žáků při testu a to, že tuto situaci musela následně řešit.

V průběhu souvislé praxe se studenti setkali u některých vyučujících s převahou frontální výuky bez jakéhokoli zapojování žáků. „Doufala jsem, že tento př́stup k výuce už na školách vymizel.“ Ne vždy je frontální výuka zavrženíhodná. Pokud však při ní nedochází k aktivizaci žáků, nelze ji považovat za efektivní.

Jednu ze studentek překvapila mimořádná situace, která nastala při výpadku proudu zpo̊sobeném hurikánem Sabina. 
„Nečekala jsem, že zažiji situaci, kdy byla většina žáku poslána domů a výuka byla zrušena a presunuta."

Ještě netušila, $\mathrm{k}$ jak mimořádné situaci dojde o několik týdnů později v důsledku koronavirové krize.

\section{Otázka č. 3}

$\mathrm{V}$ čem vidíte zásadní rozdíl $\mathrm{v}$ přínosu souvislé výstupové praxe oproti blokové výstupové praxi?

Studenti uváděli, že díky většímu časovému rozsahu měli možnost lépe a intenzivněji proniknout do běžného chodu školy, seznámit se se školní dokumentací a lépe navázat kontakt s žáky v hodinách. Rovněž vyjádřili uspokojení, že měli více prostoru pro vyzkoušení různých postupů a aktivit, se kterými se seznámili $\mathrm{v}$ přednáškách a v seminářích.

Pro genezi př́íprav na vyučovací hodiny studenti kladně hodnotili návaznost vyučovacích hodin $\mathrm{v}$ daných třídách během delšího časového období.

Jako výhodu uváděli i možnost zvolit si školu, na které budou souvislou výstupovou praxi vykonávat.

„Souvislá praxe je dvakrát delší, proto je sice náročnějǔí, ale zároveň se student opravdu vžije do role učitele, sžije se s chodem školy. Pokud má štěstí na učitele praxe, může navíc získat kontakty $k$ nezaplacení, at už se jedná o možnost konzultovat různé jevy či podání referencí u prijímacího pohovoru." 
Otázka č. 4

Kolik hodin jednotlivých složek předmětu český jazyk a literatura jste vyučovali?

\section{Studenti učitelství pro SŠ}

\begin{tabular}{|l|c|c|c|} 
& Jazyková výchova & Slohová a komunikační výchova & Literární výchova \\
\hline Student 1 & 5 & 1 & 14 \\
\hline Student 2 & 8 & 2 & 12 \\
\hline Student 3 & 0 & 0 & 20 \\
\hline Student 4 & 5 & 3 & 12 \\
\hline Student 5 & 4 & 4 & 12 \\
\hline
\end{tabular}

Tabulka č. 1

\section{Studenti učitelství pro 2. stupeň ZŠ}

\begin{tabular}{|l|c|c|c|}
\hline & Jazyková výchova & Slohová a komunikační výchova & Literární výchova \\
\hline Student 1 & 13 & 3 & 4 \\
\hline Student 2 & 9 & 4 & 7 \\
\hline Student 3 & 8 & 5 & 6 \\
\hline Student 4 & 8 & 3 & 9 \\
\hline Student 5 & 9 & 3 & 8 \\
\hline Student 6 & 8 & 8 & 4 \\
\hline Student 7 & 8 & 4 & 8 \\
\hline Student 8 & 10 & 4 & 6 \\
\hline Student 9 & 8 & 2 & 10 \\
\hline
\end{tabular}

Tabulka č. 2

Ze zjištěných údajů vyplývá nevyrovnanost v možnostech vyzkoušet si jednotlivé složky předmětu český jazyk a literatura. Za naprosto nevyhovující považujeme to, že jeden ze studentů si vyzkoušel 20 hodin literární výchovy a žádnou hodinu jazykovou ani hodinu slohové a komunikační výchovy. Za ideální 
považujeme to, aby počet hodin jednotlivých složek předmětu, které si student při souvislé praxi může vyzkoušet, byl co nejvyrovnanější.

\section{Otázka č. 5}

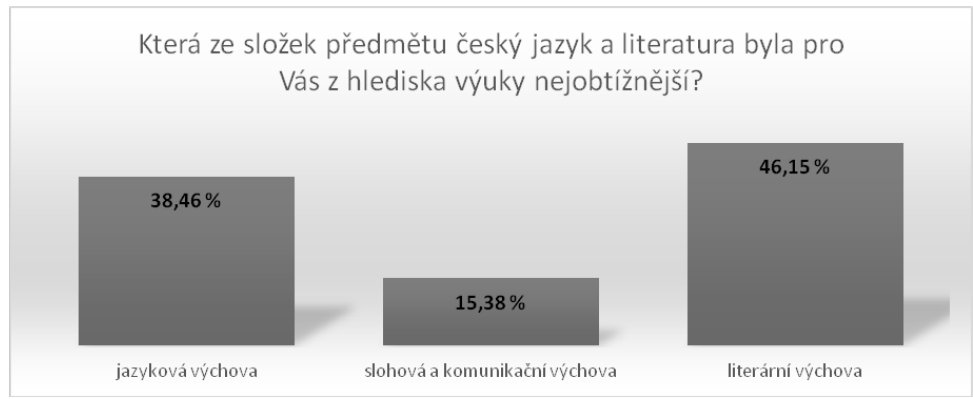

Graf č. 9

V odpovědích na tuto otázku se vyskytly výrazné rozdíly mezi studenty učitelství pro střední školy a studenty učitelství pro 2. stupeň základní školy, proto uvádíme přehled jejich odpovědí ještě zvlášṫ v jednotlivých tabulkách.

\section{Studenti učitelství pro SŠ}

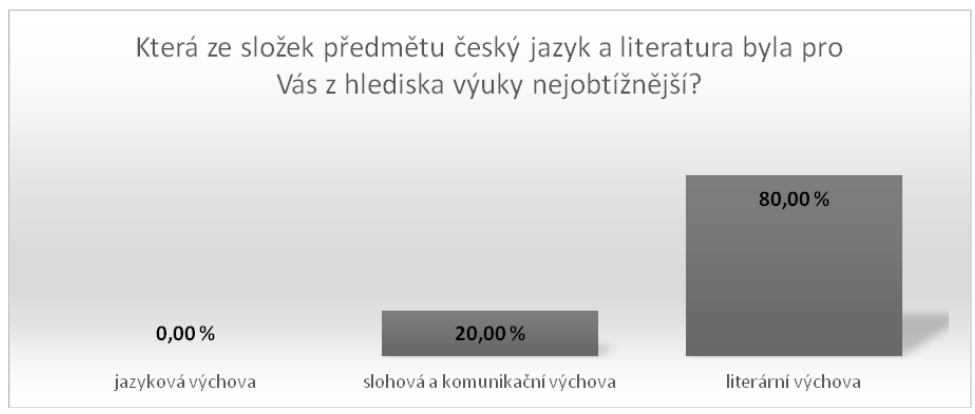

Graf č. 10 
80 \% studentů učitelství pro střední školy uvedlo jako nejobtížnější literární výchovu, z dotazníků však vyplývá, že obtížnost se netýká př́mo výuky, ale prŕípravy na ni.

Argumentují časovou náročností příprav na hodiny literární výchovy, v nichž je základní metodou didaktická interpretace literárního textu. Uvádějí, že bylo obtížné vybrat vhodné úryvky textů pro interpretaci, zatímco promyšlení metod a forem výuky již takový problém nepředstavoval.

Jedna ze studentek vyjádřila názor, že jazyková výchova pro ni nepředstavuje problém, protože látku jazykových disciplín ovládá na dobré úrovni.

Studentka, která považuje za nejnáročnější slohovou a komunikační výchovu, zdo̊vodnila svou odpověd’ takto: „Tato složka je největši měrou postavena na schopnosti naučit žáky tvořit. Klade také dle mého názoru největší požadavky na kreativitu učitele."

Studenti učitelství pro 2. stupeň ZŠ

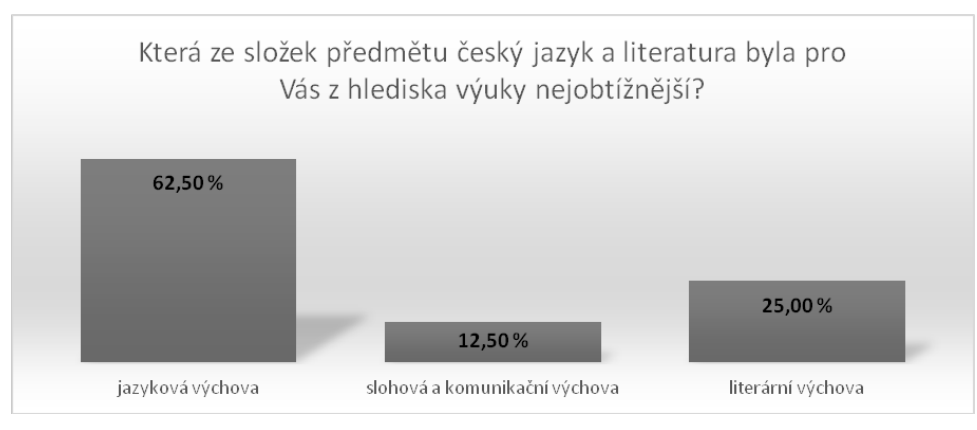

Graf č. 11 
Studenti učitelství pro 2. stupeň ZŠ uváděli jako nejobtížnější jazykovou výchovu (62,50\%). Zásadní problém spatřují v motivaci, ve schopnosti učitele získat zájem žáků.

„Jazyková výchova je pro žáky velice náročná a mnohdy je opravdu nebaví. Stále zápasím s tím, jak jazykovou výchovu vyučovat jinou formou - aktivně, zábavně."

„Několikrát jsem narazila na problém, že jsem se vyjadrovala $v$ termínech, které žáci neznali (např. modální slovesa...), př́padně jsem zabrousila do určitého jazykového jevu více, než byli žáci schopni pochopit."

Podle názorů studentů mají žáci ve slohové a komunikační výchově i v literární výchově více možností prosadit svou individualitu, vyjádřit své názory, postoje.

Studentka, která označila jako nejnáročnější slohovou a komunikační výchovu, uvedla, že jí nejdéle trvalo vymyslet aktivity, které by žáky bavily a byly př́nosné. Zároveň jí však výuka této složky předmětu přinesla spoustu nových zkušeností.

Stejně jako u studentů učitelství pro střední školy byla pro dvě studentky učitelství pro 2. stupeň základní školy literární výchova obtížná nikoli z hlediska výuky, ale z hlediska příprav.

Jedna ze studentek neoznačila žádnou z možností s následujícím vysvětlením: „Nemohu označit ani jednu z možností, protože pro mě byly všechny tyto složky stejně náročné. Nebo lépe řečeno stejně nenáročné. Nutno ale dodat, že s výukou českého jazyka už mám větši zkušenosti. V loňském roce jsem zhruba dva měsíce zastupovala vyučující českého jazyka na základní škole." 


\section{Otázka č. 6}

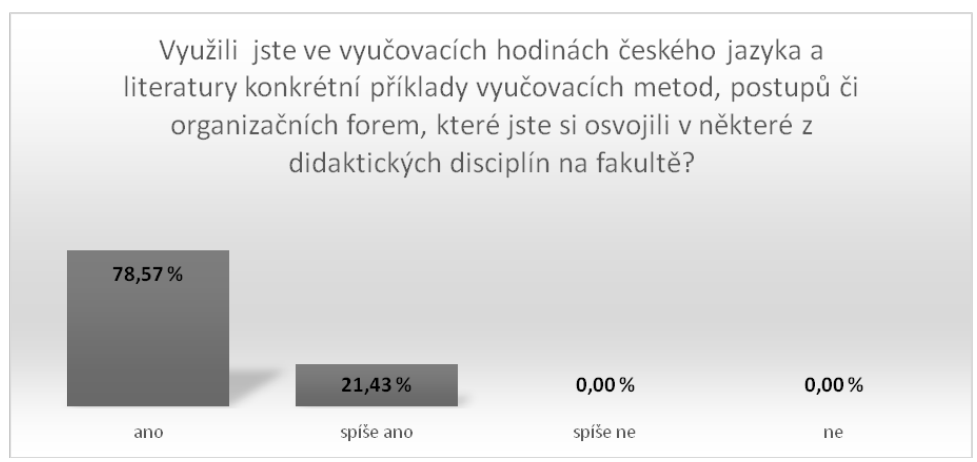

\section{Graf č. 12}

Za velmi potěšující považujeme pouze kladné odpovědi na tuto otázku (78,57 \% ano, 21,43\% spiše ano). Studenti učitelství pro střední školy uváděli příklady slohových etud rozvíjejících tvořivost žáků, texty založené na makrozáběrech i mikrozáběrech okolní skutečnosti, na modelaci průběhu textu. Uplatňovali komunikační pojetí literární výchovy, využívali metody RWCT (pětilístek, vnitřní monolog, akrostich, dokončení příběhu, autorské psaní), model E-U-R, různé typy vstupní motivace, propojování jazykového, literárního i slohového učiva s hudebním i výtvarným uměním.

Jedna ze studentek uvedla, že si vyzkoušela v kvartě víceletého gymnázia interpretaci básnické skladby Františka Halase Staré ženy, kterou si osvojila v semináři didaktiky literatury. 


\section{Otázka č. 7}

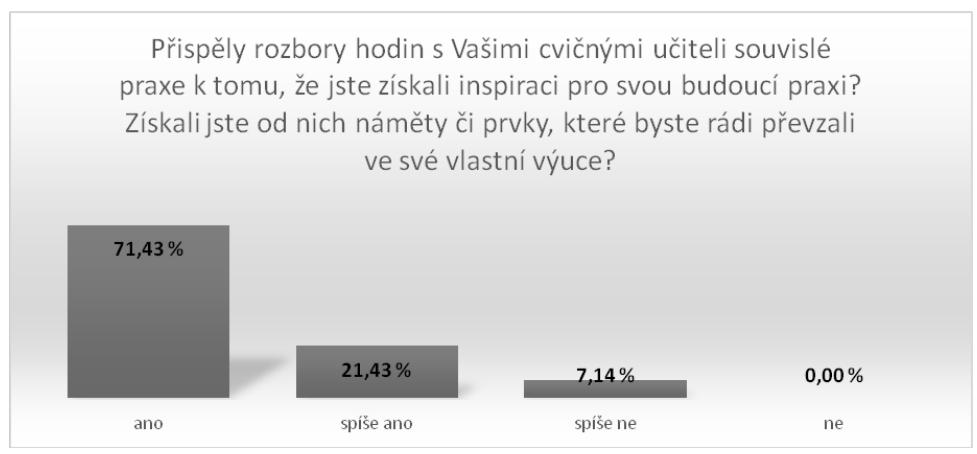

\section{Graf č. 13}

Pouze 7,14 \% studentů odpovědělo spíšse ne, ostatní odpověděli kladně (ano - 71,43\%, spíše ano - 21,43\%).

Jedna ze studentek získala od cvičného učitele námět na projekt.

I další uvedené zdroje inspirace jsou zajímavé.

„Dostala jsem k nahlédnutí celé portfolio námětů do výuky, ve kterém jsem se pro svou budoucí praxi inspirovala."

„Inspirací se mi stal slovníček, do něhož si žáci lepí pravidla pro jednotlivé jazykové jevy. Zakládaji si ho $v$ 6. ročníku a mají jej po celé 4 roky. Používají ho každou hodinu, v případě pochybností v něm mohou vyhledávat." 
Otázka č. 8

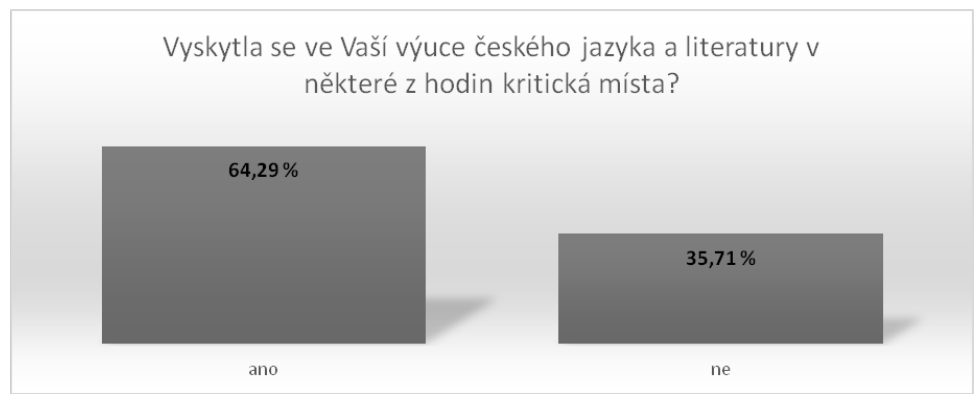

\section{Graf č. 14}

V odpovědi na tuto otázku se opět projevily rozdíly mezi studenty učitelství pro střední školy a studenty učitelství pro 2. stupeň ZŠ, proto uvádíme oba dílčí grafy.

\section{Studenti učitelství pro SŠ}

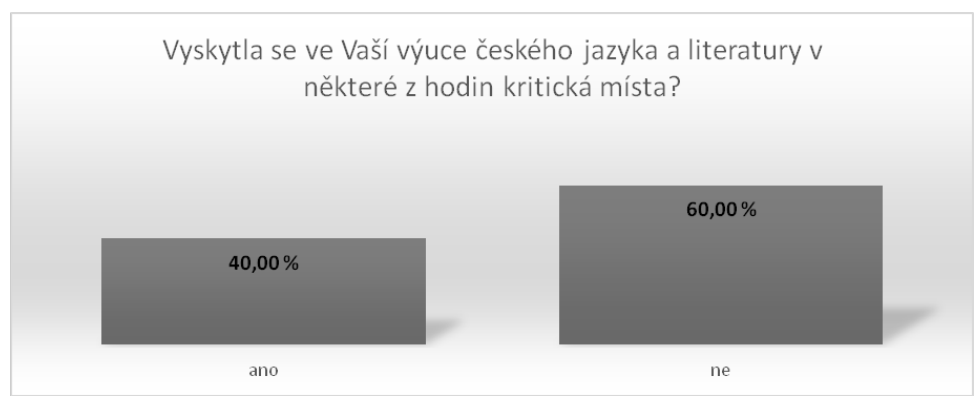

Graf č. 15 
Studenti učitelství pro 2. stupeň ZŠ

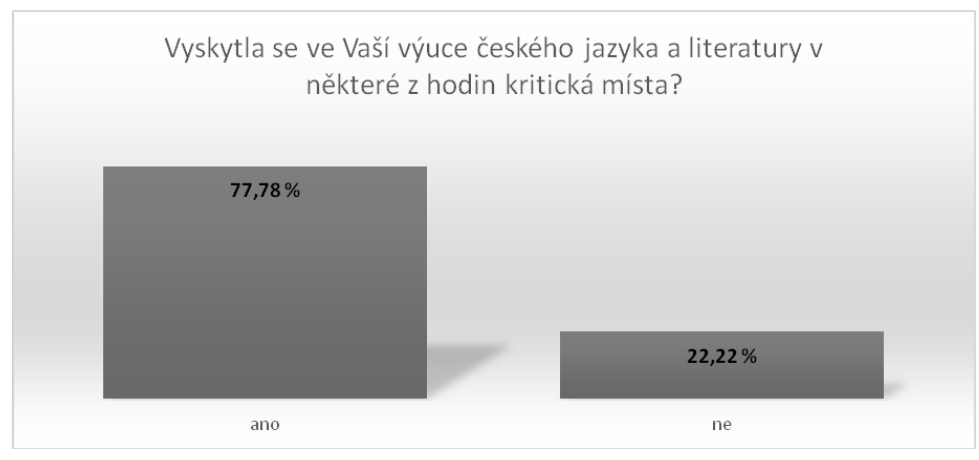

\section{Graf č. 16}

Zatímco studenti učitelství pro střední školy ve většině případů (60 \%) uváděli, že se v jejich hodinách na souvislé praxi kritická místa nevyskytovala, 77,78 \% studentů učitelství pro 2. stupeň základní školy je ve své výuce identifikovalo.

Jedna ze studentek učitelství pro střední školy označila jako kritické místo situaci, v níž žák položil k vyučovanému tématu otázku, na kterou neznala odpověd. (Proč byl uvězněn F. M. Dostojevskij?)

Studentka učitelství pro 2. stupeň základní školy odpověd' rozvedla takto:

„Někteři žáci výklad nové látky zcela nepochopili, bylo tedy třeba zvolit jiný postup."

Problémem bylo porovnání vedlejší věty přísudkové a vedlejší věty doplňkové. Cílem profesionálně vedené reflexe pak je identifikovat prŕičiny a zdůvodnit vhodnější alteraci. 
Jeden ze studentů si nevěděl rady s vhodnou didaktickou transformací obsahu tematického celku pravopis.

„Já sám vím, proč a jak se co píše, ale nedokážu občas "polopaticky" dětem vysvětlit, proč to tak je."

Další studentka podle svého názoru nerespektovala přiměřenou náročnost učiva a žákům zadala $\mathrm{k}$ doplnění interpunkce příliš složité souvětí.

V jednom př́padě se studentka nevyjádřila ke kritickému místu ve výuce přímo, ale ke zpětné vazbě, kterou získala $\mathrm{z}$ testu zadaného žákům.

„Na konci své praxe jsem zadala žákưm 9. ročníku test. Přestože se mi s touto konkrétní třídou velmi dobře pracovalo a žáci byli v hodinách aktivní, test, který byl zaměren převážně na to, co jsem s žáky probírala a opakovala já, dopadl naprosto katastrofálně."

Někteří ze studentů se místo kritického místa zaměřili při sebereflexi na organizační a řídicí aspekty vyučovacích hodin.

„Problém mi dělalo časové rozvržení hodiny, především abych stihla množství naplánovaných aktivit. Bud' byly mé hodiny predimenzované, nebo mi do konce scházelo několik prázdných minut. Ačkoli nikdy nenastalo úplné ticho a byla jsem schopná obě situace vyřešit improvizací, ráda bych se v organizaci času zlepšila. Obvykle se jednalo o 5-10 minut, proto si myslím, že jde pouze o záležitost praxe." 


\section{Otázka č. 9}

Co se Vám v některé z Vašich hodin českého jazyka a literatury hodně povedlo?

Studenti učitelství SŠ uváděli prríklady tvůrčích úkolů ze slohové a komunikační výchovy, někdy propojených i s literární výchovou.

„Při výuce slohu jsme psali recenzi na trailer $k$ filmu. Recenze jsme pak společně četli a hodnotili. Žáky tato hodina hodně bavila."

„Žáci měli během interpretace Máchova Máje napsat z pozice Viléma krátký text určený Jarmile. Vznikly opravdu zajímavé texty. $V$ jiné hodině měli žáci parafrázovat staročeského Tkadlečka a tuto parafrázi pojmout jako slohovou práci, a to lamentaci - co mě trápí. Ačkoli se jedná o velmi obtižné téma, vznikly skvělé práce."

„Při hodině věnované životu a dílu Arnošta Lustiga bylo ve fázi hodiny, kdy jsem studentům vyprávěla o židovských pogromech, Norimberských zákonech a celkově dobovém kontextu, hrobové ticho."

Jedna ze studentek vyjádřila radost z toho, že se jí některé žáky podařilo motivovat vlastními čtenářskými zkušenostmi i vhodně vybranými literárními ukázkami.

Za úspěch považovali studenti to, že dokázali vytvořit ve třídě př́jemnou atmosféru a že předešli takovému chování žáků, které by výuku narušilo.

Další ze studentek hodnotila kladně to, že se v jejích hodinách podařilo rozvíjet komunikační kompetence žáků, byla spokojena 
s jejich reakcemi na otázky a s jejich schopností rozvinout diskusi a reagovat nejen na vyučující, ale především také reagovat vzájemně na sebe. Tuto sebereflexi považujeme za obzvlášt důležitou, protože v předmětu Reflexe a hodnocení výuky se studenti seznamují s indikátory dialogického vyučování, kterými jsou autentické otázky, tzv. uptake, tj. situace, kdy mluvčí dále rozvíjí to, co bylo řečeno předchozím řečníkem, evaluace vyššího řádu, tedy taková forma učitelské zpětné vazby, kdy replika žáka není označena pouze za správnou, či nesprávnou, nýbrž je rozvitěji komentována a doplněna, a otevřená diskuse, při které žáci na sebe vzájemně reagují, volně se navzájem dotazují a komentují své výpovědi.

Rovněž studenti učitelství pro 2. stupeň ZŠ považovali za nejzdařilejší hodiny slohové a komunikační výchovy, ve kterých uplatnili aktuální a atraktivní témata, či hodiny literární výchovy se zařazením aktivit tvůrčího psaní.

Jako př́klad úspěšné hodiny literární výchovy uvedla jedna studentka didaktickou interpretaci bajek s následnou dramatizací a čtením v roli. Podařilo se jí aktivizovat žáky, kteří běžně o výuku zájem neprojevují.

Další studentka byla velmi spokojená s motivačními aspekty práce s iPohádkou Karla Kováře.

V didaktických disciplínách klademe důraz na funkční uplatnění mezipředmětových i mezisložkových vztahů. Proto považujeme za potěšující i následující sebereflexi studentky:

„Jsem sice velmi sebekritická, ale mám pocit, že jsem několikrát využila velmi zajímavých aktivit pro žáky. Např. $k$ novému tématu číslovky $v$ šestém ročníku jsem zapojila 
i dějiny umèní (datum vzniku obrazu Mona Lisa), v sedmém ročníku Eysenckovo dělení osobnosti, $k$ tématu řeckých báji poznatky z občanské výchovy a z biologie)."

Za zdařilou označila táž studentka rovněž skupinovou práci, kterou při praxi často využívala a kterou žáci pozitivně přijali.

Tu uvedla i další studentka.

„Největši radost jsem měla ve slohové a komunikační výchově z reflexe skupinové práce $v$ sedmém ročníku na téma Jaký by měl být můj nejlepši parták do života."

\section{Otázka č. 10}

Kterých akcí života školy jste se v průběhu pedagogické praxe zúčastnili?

Studenti v odpovědích uvedli pedagogické porady, návštěvu generální zkoušky Plzeňské filharmonie, výstavu v galerii, přednášku $\mathrm{v}$ knihovně, promítání dokumentárního filmu v kině.

\section{Otázka č. 11}

Které aspekty souvislé pedagogické praxe nejvíce oceňujete?

Za nejzávažnější považujeme následující odpověd:

„Oceňuji prístup vedoucích praxe a vlídné prostředí školy. Všichni, včetně samotných žáků, se ke mně chovali hezky, s úctou. Myslím, že jsem si s žáky vypěstovala pěkný vztah, po absolvování praxe mně bylo nabídnuto na škole místo učitelky na částečný úvazek." 
Studenti dále oceňovali reflexi výuky od zkušených učitelů či odborného didaktika, vstřícnost pedagogů, jejich rady a pomoc, přátelské prostředí školy, seznámení se školskými dokumenty.

Za velmi motivující považují možnost vidět progres žáků za pouhý měsíc.

Je potěšující, že se v odpovědi na tuto otázku projevilo, že si studenti uvědomují důležitost reflektivních dovedností: „Možnost začít a dokončit téma a poté zapřemýšlet, zda žáci již probrané učivo zvládli, a pokud ne, kde nastal problém, a přesně ho pojmenovat."

Jedna ze studentek uvedla výraznou aktivitu žáků, která předčila její očekávání. Jiná ocenila možnost nahlédnout do každodenního života učitele - řešení nenadálých situací, komunikace s rodiči, řešení problémů s dětmi.

Otázka č. 12

Postrádali jste při souvislé pedagogické praxi něco?

Většina odpovědí byla záporných, pouze dva studenti odpověděli ano.

Jedna studentka postrádala kontakt s vyučujícími z katedry:

„V prvních hodinách jsem byla ráda, že jsem neměla hospitace, ale u těch dalšich už bych ocenila podnětnou zpětnou vazbu."

Přestože patři kontrola pedagogické praxe mezi priority na katedře českého jazyka a literatury, zajistit kontakt vyučujících se všemi studenty na souvislé pedagogické praxi je problematické, 
zejména i proto, že řada studentů praxi vykonává ve vzdálených městech. Přesto je velmi žádoucí umožnit co největšímu počtu studentů kontakt s učiteli z katedry.

Další student uvedl, že postrádal možnost tandemové výuky.

„Mohlo by to ze začátku pomoci s trémou, nebot bychom tam byli dva. Nebyl by to takový šok. Navíc bychom se od sebe mohli navzájem učit, chodit na hospitace a podporovat se. Nebyl by takový stres, že na to jsem sám."

S tímto názorem se ztotožňujeme. Tandemovou výuku volíme při mikrovýstupech v seminářích didaktiky českého jazyka pro střední školy, stává se i velmi oceňovanou výukovou formou současnosti. Jak vyplynulo $\mathrm{z}$ dotazníků, studentům tato forma skutečně pomáhá př̀konat počáteční nejistotu.

\section{Otázka č. 13}

Chcete k souvislé pedagogické praxi přidat ještě nějaký jiný postřeh?

V odpovědi studenti uváděli maximální spokojenost s průběhem praxe, vyjadřovali politování, že je stále praxe vzhledem k ostatním disciplínám velmi málo.

V jednom z dotazníků se objevil názor, že by studenti přivítali, kdyby byla souvislá praxe zařazena do zimního semestru, v letním semestru by tak získali více prostoru pro prrípravu na státní závěrečné zkoušky a dopisování diplomové práce.

Takovou změnu však vzhledem $\mathrm{k}$ rozprostření kreditů v průběhu studia $\mathrm{v}$ současnosti provést nelze. 


\section{Shrnutí}

Propojení předmětu Základy reflexe a hodnocení výuky v bakalářském studiu s náslechovou praxí bakalářskou považujeme za velmi důležité. Studenti poprvé získávají dovednost profesního vidění, poprvé pozorují výuku nikoli již očima studenta, ale očima budoucího učitele. K tomu je nezbytný teoretický pojmový aparát, který si v disciplíně osvojují. K formování reflektivních kompetencí přispívají i simulační metody, jako jsou mikrovyučování a virtuální třída, aplikované v didaktických disciplínách v magisterském navazujícím studiu.

Z dotazníků zadaných studentům po skončení náslechové praxe navazující vyplývá, že praxe přispěla $\mathrm{k}$ motivovanosti studentů pro budoucí povolání učitelů českého jazyka. V rozhodnutí, zda skutečně budou chtít povolání vykonávat, však hrají nejdůležitější roli praxe výstupové. Na náslechových praxích studenti vidí transformaci didaktického obsahu, který si osvojili v lingvistických či literárněvědných disciplínách studijního programu. Pro uvědomění si vzájemných souvislostí mají velký význam rozbory hodin s cvičnými učiteli a oborovými didaktiky. Ti by měli vést studenty $\mathrm{k}$ profesně přesnému zdo̊vodňování soudů o výuce. 77,27 \% studentů odpovědělo ano a 18,18 \% spiše ano na otázku, zda se v některých $\mathrm{z}$ vyučovacích hodin náslechové praxe vyskytly zdroje jejich inspirace, prvky, které by rádi převzali ve své vlastní výuce. Studenti se shodli na tom, že ve zhlédnutých hodinách se spíše nevyskytovala (40,91\%) nebo nevyskytovala (22,73\%) kritická místa. Velmi kladně oceňovali přítomnost vyučujících katedry českého jazyka při náslechové praxi a možnost analyzovat zhlédnuté hodiny i s nimi. Kriticky hodnotili poměrně vysoký počet studentů ve skupinách vytvořených pro náslechovou praxi. Vyjádřili prání vidět i „problémové“ vyučovací hodiny. 
Rovněž prŕípravu studentů na souvislou pedagogickou praxi $\mathrm{v}$ předmětu Reflexe a hodnocení výuky považujeme za velmi užitečnou. Studenti si v něm hlouběji osvojují dovednost reflektovat výuku, identifikovat $\mathrm{v}$ ní didakticky důležité jevy a funkčně ji analyzovat s cílem jejího zlepšování.

Z dotazníkového šetření vyplynulo, že 92,86 \% studentů souhlasí a 7,14 \% studentů spíše souhlasí s tvrzením, že souvislá výstupová praxe je přínosná. Oproti blokové výstupové praxi považují studenti za výhodu možnost učit $\mathrm{v}$ jedné třídě celý tematický celek a v závěru si ověřit efektivitu své výuky. Z dotazníků vyplynulo, že př́ležitost vyzkoušet si při praxi jednotlivé složky předmětu český jazyk a literatura, byla u jednotlivých studentů nevyrovnaná. Je třeba, aby byl tento problém řešen $\mathrm{v}$ součinnosti cvičných učitelů a oborových didaktiků katedry. Zatímco studenti učitelství pro střední školy uváděli jako nejobtížnější složku předmětu literární výchovu (nikoli však z hlediska výuky, ale z hlediska přípravy na ni), pro studenty 2. stupně základní školy byla nejobtížnější jazyková výchova, především z hlediska motivace žáků.

Rozbory hodin s cvičnými učiteli považují studenti za inspirativní (ano - 71,43\%, spiše ano - 21,43\%). Ukázalo se, že v disciplínách zaměřených na rozvoj reflektivních kompetencí je třeba vést studenty $\mathrm{k}$ tomu, že identifikace míst vhodných pro zlepšující alteraci, tzv. kritických míst, je velmi důležitá pro zlepšení kvality výuky a rozhodně nevede $\mathrm{k}$ negativním soudům o vyučujícím. Z př́kladů zdařilých prvků výuky studentů při souvislé pedagogické praxi je patrná inspirace didaktickými předměty vyučovanými na katedře českého jazyka a literatury.

Studenti velmi oceňují možnost zvolit si školu i cvičného učitele pro souvislou pedagogickou praxi. Za důležité považují, aby svou výuku zhodnotili nejen v diskusi s cvičným učitelem, ale 
i s vyučujícími z katedry. Uvítali by také možnost vyzkoušet si při praxi výuku $\mathrm{v}$ tandemu.

Propojení předmětů ZRHV a RHV s pedagogickou praxí se ukázalo jako velmi efektivní. „Snaha do hloubky didakticky rozumět procesu vzdělávací praxe, tj. nahlížet do „černé skřriňky“ výuky klade velké nároky na teoretické myšlení s ohledem na jeho provázání s reálnou praxí. Má-li být teorie pro praxi opravdu funkční, nemůže být mělká, proto je náročná." (Chocholoušková, Slavík a Soukupová 2019, s. 24).

\section{Použitá literatura}

ARGYRIS, Chris; SCHÖN, Donald A. The theory of practice. Increasing professional effectiveness. Reprint. San Francisco: Wiley \& Sons, Incorporated, John, 1992. $264 \mathrm{s.}$

BENDL, Stanislav; aj. Klinická škola: místo pro výzkum a praktickou př́pravu budoucích učiteli̊. Praha: Univerzita Karlova v Praze, Pedagogická fakulta, 2011. 554 s.

ČECHOVÁ, Marie; STYBLÍK, Vlastimil. Čeština a její vyučování. Didaktika českého jazyka pro učitele základních a středních škol a pro studenty učitelství. Praha: SPN, 1998. $264 \mathrm{s.}$

ČECHOVÁ, Marie. Řeč o ř reči. Praha: Academia, 2012. $311 \mathrm{~s}$.

DUFFEK, Václav; aj. Pre-service teacher training in the virtual classroom: pilot study. In: BESEDA, Jan; ROHLÍKOVÁ, Lucie (ed.) DisCo 6 2019: E-learning - Unlocking the Gate to Education around the Globe - 14th conference reader. Prague: Center for Higher Education Studies, 2019, s. 201-210.

CHOCHOLOUŠKOVÁ, Zdeňka; SLAVÍK, Jan; SOUKUPOVÁ, Pavla. Nové poznatky z transdisciplinární didaktiky. In SANDANUSOVÁ Anna (ed.). Educo. Príprava učitelov prírodovedných, 
polnohospodárskych a príbuzných odborov vmeniacich sa požadavkách. Nitra: FPV UKF v Nitre, 2019, s. 5-29.

JANÍK, Tomáš. Didaktické znalosti obsahu a jejich význam pro oborové didaktiky, tvorbu kurikula a učitelské vzdělávání. Brno: Paido, 2009. 120 s.

JANÍK, Tomáš a kol. Kvalita (ve) vzdělávání: obsahově zaměřený přistup ke zkoumání a zlepšování výuky. Brno: Masarykova univerzita, 2016. $434 \mathrm{~s}$.

KOLÁ̌̌, Zdeněk a kol. Výkladový slovník z pedagogiky. Praha: GRADA, 2012. $192 \mathrm{~s}$.

KORTHAGEN, Fred; aj. Jak spojit praxi s teorií: didaktika realistického vzděláváni učitelu․ Brno: PAIDO, 2011. 293 s.

PORUBSKÁ, Gabriela. Vzṫah všeobecnej didaktiky a pedagogickej praxe. In Význam pedagogickej praxe $v$ profesijnom raste učitel'ov, Zborník príspevkov z vedeckej konferencie s medzinárodnou účastou. Nitra: Pedagogická fakulta UKF v Nitre, 2001, s. $43-48$.

PRŮCHA, Jan; WALTEROVÁ, Eliška; MAREŠ, Jiří. Pedagogický slovník. Praha: Portál, 2009 (6. vydání). 384 s.

RUSEK, Martin; SLAVÍK, Jan; NAJVAR, Petr. Vyjádření autorů. ORBIS SCHOLAE, 2016, roč. 10, č. 2, s. 161-171.

SLAVÍK, Jan; aj. Transdisciplinární didaktika. Brno: Masarykova univerzita, 2017. $457 \mathrm{~s}$.

SCHÖN, Donald A. The reflective practitioner, how practitionals think in action. New York: Basic Books 1983. $384 \mathrm{~s}$.

SPILKOVÁ, Vladimíra. Gradace praktické přípravy, „reflektivní praxe" v novém modelu prípravy na PedF UK. In JŮVA, Vladimír (ed.). Teorie v pedagogické praxi, praxe v pedagogické teorii $v$ učitelském studiu. Sborník príspèvků z celostátního semináře, Šlapanice u Brna, 7. a 8. února 1995. Brno: Paido, 1995, s. 62-65. URBÁNEK, Petr. Vybrané problémy učitelské profese. Aktuální analýza. Liberec: TU, 2005. 229 s. 
VEJVODOVÁ, Jana. Konstruktivistické přístupy v prrípravě studentů na pedagogickou praxi. In ČECHOVÁ, Marie; SPĚVÁČKOVÁ, Martina (eds.). Od praxe $k$ teorii a zpět ve vyučování češtině. Plzeň: Západočeská univerzita v Plzni, 2019, s. 16-31.

\section{Internetové zdroje}

LOUDOVÁ, Irena; SIMONOVÁ, Carmen; TříSKALOVÁ, Libuše. Rukovět $k$ pedagogické praxi. [online] [cit. 28. 7. 2020] Dostupné na: http://inpdf.uhk.cz/wp-content/uploads/2014/03/Skripta _Rukovet_k_pedagogicke_praxi.pdfu

SLAVÍK, Jan; aj. Profesní soud o kvalitě výuky: předem a následně strukturovaná reflexe. In Pedagogika, 65(1), s. 5-33. Dostupné na: <http://pages.pedf.cuni.cz/pedagogika/?p=11138\&lang=cs $>$ 


\title{
K průběhu blokové výstupové praxe v době výuky na dálku
}

\author{
Růžena Písková
}

Bloková výstupová praxe tvoří významnou součást navazujícího magisterského studia učitelství pro ZŠ a SŠ. Studenti se při ní seznamují s prostředím škol, vyučovacím procesem, používanou školskou dokumentací a legislativou i s pracovními podmínkami v praxi. ${ }^{1}$

Situace, jež vznikla na Fakultě pedagogické ZČU po uzavření škol v březnu 2020, ukázala další možný způsob, jak realizovat pedagogickou praxi. O něm pojednáme v této kapitole. Studenti dostali možnost absolvovat praxi s využitím nástrojů komunikace online. Jejich spolupráci se žáky i učiteli na základních a středních školách považujeme za velmi podnětnou. Jak dokládáme níže, elektronický kontakt se žáky poskytl studentům cenné praktické zkušenosti a poznatky.

Proto se domníváme, že jistá část praxe by formou elektronické komunikace online měla probíhat i do budoucna a doplnit portfolio činností, které mají za cíl připravit studenty učitelství na výkon povolání. Dle našeho názoru by tímto způsobem bylo možné rozšírit objem praxe při minimálním zatížení prezenční výuky žáků přítomností praktikantů v hodinách na ZŠ a SŠ. Poznatky získané během letního semestru 2020 by se dle našeho názoru

\footnotetext{
${ }^{1}$ Studenti učitelství dlouhodobě žádají navýšení časové dotace a rozsahu praxe a vedení Fakulty pedagogické ZČU se jim snaží vycházet vstříc např. spoluprací s tzv. fakultními školami a dalšími aktivitami (webové stránky s nabídkou volných pracovních míst ve školách apod.).
} 
měly stát základem př̀i plánování a realizaci pedagogické praxe $\mathrm{v}$ dalších letech.

Zákaz fyzické přítomnosti žáků a studentů ve školách, vyhlášený vládou ČR dne 11. března 2020 jako preventivní opatření proti šírení nemoci covid-19, znamenal pro učitele, žáky i studenty zásadní změnu ve způsobu výuky (u učitelů) a v př́ístupu k učení (u žáků a studentů). Učitelé základních a středních škol (dále jen ZŠ a SŠ) začali prakticky okamžitě hledat způsob, jak zůstat se svými žáky a studenty v kontaktu, aby mohli pokračovat ve výuce a zajistit naplnění učebních plánů daného školního roku.

Po počátečních zhruba třech týdnech ověřování možností se spolupráce se žáky a studenty ustálila. ${ }^{2}$ Mezi školami i jednotlivými učiteli a jejich žáky a studenty však existovaly významné rozdíly v kvantitě i kvalitě spolupráce. Na tyto rozdíly upozornila mimo jiné zpráva $\mathrm{z}$ tematického šetření České školní inspekce vydaná v květnu 2020.

Výše popsaná situace se podobně projevila i na vysokých školách (dále jen VŠ). Již započatá výuka byla uzavřením škol přerušena zhruba ve třetině probíhajícího letního semestru 2020. Jedním $\mathrm{z}$ důsledků bylo mimo jiné i to, že studenti prvního ročníku navazujícího magisterského studia FPE ZČU nemohli absolvovat blokovou výstupovou praxi.

Stejně jako učitelé na ZŠ a SŠ, hledali i vysokoškolští pedagogové způsoby, jak pokud možno minimalizovat dopad této

\footnotetext{
${ }^{2}$ Viz tematická zpráva ČŠI, str. 3: „V prvních dvou týdnech dotčeného období mnoho škol hledalo způsoby, jak vše nejlépe zajistit, rozhodovaly se, které komunikační platformy využít apod. Zároveň se snažily zjistit podmínky v rodinách jednotlivých žáků, aby na ně mohly během př́ípravy vzdělávání $i$ jeho vlastního průběhu zareagovat. Po tř̌ech týdnech od zákazu fyzické prrítomnosti žáků ve vzdělávání byla již na většině škol situace určitým způsobem stabilizovaná.“
} 
situace na výuku a zajistit adekvátní způsob vzdělávání studentů na dálku.

Západočeská univerzita vyšla svým studentům a zaměstnancům vstříc tím, že integrovala do vzdělávacího portálu nástroje distančního vzdělávání a zpřístupnila je učitelům i studentům. Kromě již existujícího prostředí Moodle byly nově zpřístupněny nástroje firmy Google, jmenovitě Google Classroom (dále jen Učebna) a Google Meet. Díky těmto nástrojům bylo možné začít $s$ vedením výuky na dálku ${ }^{3}$ Zavedení nástrojů Google zároveň umožnilo realizovat blokovou výstupovou praxi studentů.

Výstupy všech předmětů byly na počátku období výuky na dálku upraveny s ohledem na stávající situaci. Po dohodě didaktiků na katedře českého jazyka a literatury (J. Vejvodová, Z. Suda a R. Písková) došlo $\mathrm{k}$ úpravě obsahu blokové výstupové praxe tak, aby odrážel soudobou situaci (podrobně viz níže). Studenti dostali možnost rozhodnout se, zda za současných změněných podmínek chtějí praxi absolvovat, či zda odloží plnění praxe na další školní rok.

Blokovou výstupovou praxi mělo $\mathrm{v}$ daném semestru absolvovat 15 studentů učitelství pro ZŠ a šest studentů učitelství pro SŠ, celkem tedy 21 studentů. $Z$ této skupiny se 18 studentů rozhodlo změnu podmínek přijmout a praxe „na dálku“ absolvovat.

\footnotetext{
${ }^{3}$ Rozlišujeme formu vzdělávání „na dálku“, jehož vzdělávací obsah je primárně určen pro prezenční výuku, od vzdělávání „distančního“, jehož obsah reflektuje fyzickou neprrítomnost studentů ve výuce po většinu akademického roku.
} 


\section{Podmínky absolvování blokové výstupové praxe na dálku}

Cílem blokové výstupové praxe je: „Studentům poskytnout zkušenosti (formou jejich samostatných výstupů a analýzy odučených vyučovacích hodin) ze školní praxe." (Courseware ZČU, sylabus předmětu). Tento cíl jsme chtěli zachovat. Současně jsme chtěli studentům poskytnout př́ležitost, aby se seznámili s aktuální situací na ZŠ a SŠ, aby zjistili, jakým zpo̊sobem probíhá výuka na dálku a aby získali praktické dovednosti z tohoto způsobu vedení výuky.

S ohledem na výše uvedené cíle dostali studenti následující úkoly:

1. Prostudovat obsah webových stránek ZŠ nebo Š́, kterou sami navštěvovali jako žáci (podle toho, zda patřili mezi studující učitelství pro ZŠ nebo pro SŠ), a zjistit:

a) jakým způsobem daná škola komunikuje se svými žáky a jejich zákonnými zástupci,

b) jak je zadáváno učivo (frekvence, množství úkolů, způsob prezentace žákům),

c) které další informace škola na svých stránkách prezentuje (odkazy na další možnosti vzdělávání, spolupráce s neziskovými organizacemi, podpora žáků bez technického zázemí apod.).

2. Kontaktovat vyučující českého jazyka a literatury na zvolené ZŠ nebo SŠ a vést s nimi polostrukturovaný rozhovor či dotazníkové šetření na téma současného stavu a způsobů výuky na dálku.

Informace získané kontaktem s učiteli a poznatky o stavu a obsahu webových stránek vybrané školy měli za úkol zpracovat do podoby souhrnné zprávy. 
3. Zorientovat se $\mathbf{v}$ aktuální nabídce webinářủ a videokonferencí pro učitele ZŠ a SŠ, vybrat si téma, které je zajímá, a daného webináře se zúčastnit bud' aktivně online, nebo ze záznamu. Cílem zde bylo, aby se studenti seznámili s možnostmi a aktuálním obsahem dalšího vzdělávání pedagogických pracovníků (DVPP). Chtěli jsme, aby si uvědomili rozsah a obsah vzdělávacích aktivit pro učitele ZŠ a SŠ, aby pochopili, že rovněž jejich vzdělávání coby učitelů bude mít charakter celoživotního procesu a že se mohou dostat do situace, $\mathrm{v}$ níž budou postaveni před nové technologie, metody a způsoby výuky, stejně jako se to stalo v době výuky na dálku učitelům. Své poznatky z absolvovaného vzdělávání měli za úkol reflektovat písemnou formou.

4. Prostudovat obsah testů jednotné přijímací zkoušky (dále jen JPZ) z českého jazyka a literatury společnosti Cermat a vytvořit didaktický materiál, který:

a) bude obsahovat výchozí text a 5-7 návazných úkolů různých typů, ale typově shodných s JPZ,

b) bude možné zpracovat do záznamového archu typově shodného s JPZ,

c) bude možné zkontrolovat pomocí klíče správných odpovědí.

Studenti následně odevzdali takto vytvořený didaktický materiál do Google učebny, v níž probíhal na ZČU jejich kurs blokové výstupové praxe pro ZŠ i SŠ. Materiál byl tedy odevzdán do Učebny v elektronické podobě a ve formátu vhodném pro sdílení se žáky ZŠ/Š̌.

Následně jsme tyto materiály pomocí Učebny zpřístupnili 80 žákům 9. ročníku na 28. základní škole v Plzni. ${ }^{4}$ Materiál jednoho

${ }^{4}$ Ředitelce 28. základní školy P. Jedličkové patří poděkování za to, že schválila spolupráci školy se ZČU při zajištění blokové výstupové praxe. Tato spolupráce jen 
studenta byl zpř́stupněn vždy 4-6 žákům, kteří nevěděli, kdo další zpracovává tentýž materiál. Tím bylo zajištěno, že žáci zpracovávali materiály samostatně a nesdíleli odpovědi mezi sebou. Skupiny byly sestaveny jako heterogenní, s různou úrovní pokročilosti žáků, která se při zpracování výsledků jasně projevila. Jejich odpovědi se často výrazně lišily. Studenti tak měli k dispozici široké spektrum výsledků a možností pro následnou diskusi i práci s chybou. Současně se projevila různá míra technické zdatnosti žáků (i studentů) při práci s elektronickými materiály. Studenti tak dostali př́ležitost uvědomit si hlavní úskalí výuky na dálku - omezené možnosti a dovednosti, na jejichž úroveň nelze u žáků vždy spoléhat.

Vypracované materiály (záznamové archy) odevzdávali žáci prostřednictvím Učebny, kterou 28. základní škola disponuje. Z Učebny jsme záznamové archy opět zpř́stupnili studentům, kteří provedli důslednou opravu a hodnocení, včetně okomentování chyb.

Opravené záznamové archy jsme následně opět pomocí Učebny předali žákům, aby se mohli seznámit s výsledky své práce. Zároveň jsme žákům prozradili, s kým pracovali ve skupině, a požádali jsme je, aby spolu prodiskutovali výsledky a promysleli dotazy, které by mohli položit studentovi-autorovi jejich materiálu. Tímto krokem jsme zajistili, aby o materiálech přemýšleli i žáci, kteř́i obvykle se zpětnou vazbou prŕliš nepracují, nebo ti žáci, kteří by měli potíže při hovoru se studentem online položit vlastní dotaz. Spolupráce žáků v tomto kroku odpovídala skupinové práci ve třídě.

5. Zúčastnit se setkání online, při němž probíhal rozhovor skupiny 4-6 žáků, kteří zpracovávali tentýž materiál, se studentem-autorem materiálu a s oborovým didaktikem. Studenti měli za

podtrhuje důležitost flexibility při rozhodování ve školství. 
úkol zhodnotit práci žáků, podrobně rozebrat všechny problematické jevy a nejasná místa $\mathrm{v}$ materiálech a ujistit se, že žáci porozuměli jejich zadání i řešení. Dále měli od žáků zjistit informace o způsobech a metodách jejich přípravy na přijímací zkoušky (které následně proběhly $\mathrm{v}$ dalším týdnu) a společně diskutovat o situaci v době výuky na dálku, o jejích kladech a záporech. Cílem bylo, aby se studenti zevrubně seznámili s aktuální situací žáků a dokázali ji porovnat s obrazem výuky na dálku, jenž byl $\mathrm{v}$ té době prezentován $\mathrm{v}$ médiích. Zjistili některé výrazné rozdíly, o kterých dříve neuvažovali (např. že s výukou na dálku nemají potíže pouze sociálně vyloučení a technicky nezdatní žáci, ale že tato výuka může činit potíže i žákům, kteří ve škole patří mezi výborné, nemuseli se nikdy učit doma a stačilo jim poslouchat ve škole. Při výuce na dálku si však neuměli naplánovat čas na domácí př́pravu nebo byli natolik ochromeni obavami z vývoje situace, že se nedokázali sami doma soustředit na práci).

Žáci dostali za úkol aktivně se zúčastnit setkání online, zeptat se studentů na to, čemu nerozuměli, zhodnotit zadaný materiál z hlediska jeho obsahu i formy zadání a přispět do diskuse o výuce na dálku.

\section{Průběh a výsledky blokové výstupové praxe}

Takto pojatá bloková výstupová praxe trvala přibližně dva měsíce - od počátku dubna do prvního týdne v červnu 2020. Během té doby studenti většinou nejprve kontaktovali své bývalé učitele českého jazyka a literatury a zjištovali stav výuky na dálku na ZŠ a SŠ. Výsledky jejich šetření (ve formě souhrnných zpráv) lze tedy porovnat s výsledky tematické zprávy České školní inspekce, jejíž šetření probíhalo v tutéž dobu. Uvědomujeme si, že sledovaný vzorek škol není dost rozsáhlý na to, abychom mohli dojít 
k obecně platným závěrům, přesto informace obsažené v souhrnných zprávách studentů představují zajímavou sondu do situace na ZŠŠŠ v dubnu 2020.

\section{K šetření studentů o stavu výuky na dálku na ZŠ a SŠ5}

Studenti zjištovali informace o stavu výuky na dálku na následujících školách:

- 26. ZŠ Plzeň

- ZŽ Kralovice

- $\quad Z S ̌$ a MŠ generála Pattona Dýšina

- ZŠ Domažlice

- ZŠ Staňkov

- 13. ZŠ Plzeň

- ZŠ Chrást

- Masarykova ZŠ Janovice nad Úhlavou

- ZŠ Plasy

- Z ZŠ Ohradní, Praha 4-Michle

- Z ZŠ a MŠ Křivoklát

- Gymnázium Cheb

- Gymnázium Zikmunda Wintra Rakovník

- Gymnázium Aš

- Gymnázium Př́bram

- Střední pedagogická škola Prachatice

- Gymnázium Český Krumlov

K získání informací použili metodu polostrukturovaného rozhovoru, dotazníkové šetření a ve dvou případech přímé pozorování (sledovali komunikaci školy s jejich mladšími sourozenci, kteří

${ }^{5}$ Pasáže ze zpráv a prací, které studenti v průběhu praxe odevzdali, jsou citovány doslovně, nejsou stylizačně upraveny a $\mathrm{v}$ textu jsou psány kurzivou. 
se na zvolených školách právě vzdělávají). Především se měli zaměřit na následující témata:

a) jak zvolená škola přistupuje k výuce na dálku (komunikace se žáky a jejich zákonnými zástupci, dostupnost, přehlednost a obsah informací na webových stránkách školy);

b) jakou formou komunikují učitelé se žáky a v jaké frekvenci (používané komunikační nástroje, průměrná četnost kontaktů);

c) jaké úkoly učitelé zadávají žákům na 2. stupni / na střední škole (typy úkolů, používané metody a formy práce),

d) jak tyto úkoly učitelé nyní hodnotí (systém hodnocení, zpětné vazby, př́ípadně klasifikace),

e) co je při zajištění výuky na dálku nejobtížnější, nejproblematičtější.

Ad a) Po počátečním zahlcení žáků i rodičů komunikací a učivem se situace většinou ustálila. Studenti vyzdvihovali především přehlednost informací na webových stránkách škol:

„Na stránkách školy je přehledně vysvětleno, jak používat virtuální učebnu Google Classroom, kterou celá škola využivá jako prostředek pro komunikaci a vzdělávání svých žáků. Oceňuji predevším fakt, že jsou na úvodní stránce školy přehledně vystaveny informace o samostudiu, takže rodič či žák tyto informace nemusí složitě hledat ve skrytých záložkách a jedním kliknutím se přenese do virtuální třídy." ${ }^{\text {"6 }}$

„Na stránkách školy je velmi přehledně umístěn odkaz, prostřednictvím kterého se žák snadno dostane k zadaným materiálìm. Ty jsou rozděleny podle tříd a následně podle

${ }^{6}$ Ze zprávy K. Skuhrovcové o Gymnáziu Př́bram. 
týdnu․ Na každý týden můžeme najit zip soubor obsahující materiály ke v̌̌em předmětưm. "

Dále studenti velmi oceňovali empatický prrístup učitelů a ředitelů škol k situaci žáků i rodičů a snahu učitelů o zpř́ijemnění stávající situace.

„Posledním příspěvkem na webu je poděkování pana ředitele žákưm i rodičưm za jejich práci $v$ uplynulých týdnech, které jistě nebyly pro nikoho jednoduché. Tohle gesto mi přijde moc pěkné."

„Na samotné stránce školy pod odkazem 'Náhradní výuka' se ještě kromě výuky a učiva samotného nachází několik užitečných informací a zajímavých nápadů (video s rozhovorem s ministrem školství v průběhu výuky na 1. stupních po otevření škol; odkaz na článek s inspirací na využití internetu; odkaz na Google Drive s velkým množstvím inspirace na výrobky, recepty, zábavné tvoření, pohybové aktivity, omalovánky a mnoho dalšího - tyto materiály jsou výtvorem samotných učitelů a učitelek, asistentek pedagogů, či vychovatelek). "9

Fakt, že studenti empatický př́stup učitelů ve svých zprávách oceňovali a vyzdvihovali, ukazuje, dle našeho názoru, na to, jak vysoko v žebřičku hodnot stojí empatie a snaha spolupracovat u nich, i u učitelů a ředitelů jednotlivých škol, kteří tyto zprávy na webové stránky umistují. Někteří ze studentů při následných diskusích online vyjádřili překvapení a znepokojení nad rozdílem, který vnímali, když porovnávali skutečnou práci a komunikaci

\footnotetext{
${ }^{7}$ Ze zprávy E. Šafaříkové o ZŠ Plasy.

${ }^{8}$ Ze zprávy K. Princové o ZŠ Chrást.

${ }^{9}$ Ze zprávy T. Karlovcové o ZŠ Staňkov.
} 
učitelů na konkrétních školách s mediálním obrazem „učitelů na prázdninách v době karantény“, který existoval ve stejném období $\mathrm{v}$ internetových diskusích a veřejném prostoru. Uvědomovali si, že je to poprvé, kdy se dostávají do situace, v níž se někdy v životě ocitl téměř každý učitel - že totiž veřejnost práci učitelů hodnotí pouze ve vztahu $\mathrm{k}$ délce a četnosti prázdnin, nikoli ve vztahu k výkonům podávaným při vzdělávání žáků a studentů.

Ad b) Přístup k výuce na dálku se u jednotlivých škol lišil. Většina škol v období prvních 2-3 týdnů zkoušela zavést jednotný systém zadávání úkolů. Volily si ovšem různá technická řešení (Škola online, Bakaláři, Dm software, Google Classroom, Office 365, Skype, přehled učiva na webových stránkách školy nebo na samostatné webové stránce, využití e-mailové komunikace atd.). Teprve v dalším období vznikaly jednotné rozvrhy a žáci i učitelé začali využívat časová okna pro zadávání úkolů, pořádání videokonferencí, diskusí online či streamování videa $\mathrm{z}$ hodin, ve kterých učitelé před prázdnou třídou vykládali učivo a nahrávali své výstupy pro žáky u počítačů.

Učitelé si taktéž začali uvědomovat, že ve svých tř́idách mají žáky, kteří s nimi nijak nekomunikují, a začali hledat možnosti, jak se s nimi spojit, pokud tito žáci nemají potřebné technické vybavení nebo pokud výuku ignorují. Jak se ukázalo, tito žáci se vyskytují ve většině škol ${ }^{10}$.

„Pro žáky bez možnosti pripojení k internetu, kterých se na základní škole v Janovicích nachází velké množství, jsou veškeré úkoly vyvěšeny na fyzické nástěnce před školou každé pondělí ve 12:00, žák nebo jeho zákonný zástupce

${ }^{10}$ ČŠI uvádí v tematické zprávě z května 2020 až $10 \%$ žáků ve školách jen s 1 . stupněm a zhruba 16 \% žáků v úplných základních školách, kteří během výuky na dálku vůbec nekomunikovali se svými učiteli. 
si je má dle informací opsat, př́ipadně vyfotit a následně odevzdat vypracované řešení označené jménem a třídou do poštovni schránky na vratech školy. Otázkou ovšem je, jakým způsobem se o této možnosti studia žáci a jejich zákonní zástupci dozvědí, dle informací ze školy se s tímto zpusobem práce vyskytují značné problémy, úkoly nejsou doručovány včas a ve vhodné formě. "11

Ad c) Studenti zaznamenali množství různých metod a forem práce. Ve svých zprávách konstatovali, že učitelé se snaží ovládnout komunikační technologie, aby mohli zatraktivnit výuku. V začátku výuky na dálku žáci dostávali např. úkoly: zpracovat do sešitu výpisky, vypracovat cvičení v učebnici nebo v pracovním sešitě a odeslat vyfotografované stránky apod. Tato praxe se však po prvních týdnech změnila. Učitelé začali natáčet výuková videa, namlouvat podcasty, vést videokonference, využívali aplikace jako Skype, Google Meet, Microsoft Teams nebo Zoom, aby učinili výuku co nejpraktičtější a nejzáživnější.

„K výuce slohu [paní učitelka] využívá instruktivní videa. Pomocí nich chce žákưm vysvětlit, jaká je charakteristika jednotlivých slohových postupi̊ a útvarů. Na videa pak žáci reagují svou slohovou prací. Pro príklad jsou jim také společně s videoukázkou zasilány vzorové práce a to takové, které jim například u vypravováni jasně napoví, že musí vystavět nějaký oblouk vypravování - nezapomenout na úvod, zápletku, nebo rozuzlení..."12

„Bavil jsem se hlavně s paní učitelkou (...), která má na starosti devátáky, kteři mají pred prijímačkami, a bavili jsme se o tom, že úkoly mají být ze všeho. Takže pokud mají český

\footnotetext{
${ }^{11}$ Ze zprávy L. Smolarové o ZŠ Janovice nad Úhlavou.

${ }^{12}$ Ze zprávy M. Štěchové o Stř̌ední pedagogické škole Prachatice.
} 
jazyk a literaturu, tak je dobré do nich prolínat dalši predměty. Ideálně spojovat s občankou, s němčinou či dalšimi předměty, nebo pokud píšou slohová cvičení. (...) Úkoly jsou u mluvnice typu doplňovačky, vytváření, stažení souborů, odkazy na portály, kde se dá procvičovat. U slohu a literatury je to vlastní slohová tvorba na daná témata. Někteři učitelé, například češtináři, tak poskytují vysvětlující videa $k$ daným problematikám. Např́ílad video, jak vystavět príběh atd. "13

Ad d) Většina studentů se shodovala, že hodnocení hraje v celém systému výuky na dálku důležitou motivační roli. Jeho funkce klasifikační byla potlačena nebo alespoň zmírněna ve prospěch formativního hodnocení a motivace pochvalou. Někteří studenti uváděli ve svých zprávách také časovou náročnost poskytování zpětné vazby a hodnocení prací. V mnoha zprávách se opakovala informace o tom, že je obtížné hodnotit práci žáků, protože učitel nikdy nemá jistotu, zda žák pracoval sám či s dopomocí.

„Žáci jsou hodnoceni na základě formativního hodnocení, při kterém jsou informováni, zda látku pochopili, $v$ čem mají určité problémy a mèli by se na to více zaměřit. "14

„Myslím si, že v této situaci je velmi obtižné hodnotit žáky formou známek, což mi potvrdila i paní učitelka, kterou jsem kontaktovala. Žáci totiž mohou při online testech "podvádět" a vyhledávat správné odpovědi v učebnici, či spolupracovat se spolužáky, což jim však nelze mít za zlé. Zároveň je zajištování výuky na dálku časově náročné, učitelé stráví mnohem více času u počitače, snaží se včas reagovat na maily a zároveň odpovídají každému zvlášte“."15

\footnotetext{
${ }^{13}$ Ze zprávy T. Glazera o ZŠ a MŠ generála Pattona Dýšina.

${ }^{14}$ Ze zprávy J. Kabourka o ZŠ Domažlice.

${ }^{15}$ Ze zprávy B. Tvarohové o Gymnáziu Český Krumlov
} 
„Hodnocení zadávaných úkolu je obtížné, nebot učitel si nemůže být jistý, zda úkol, který zadal, vypracoval samotný žák nebo s nějakou dopomocí. Převažuje formativní hodnocení, při kterém jsou žáci informováni, zda látku pochopili, nebo naopak, co jim dělá problémy a na co by se méli více zaměřit. "16

Ad e) Za nejobtížnější úkol považovali učitelé v prvních týdnech výuky především to, aby správně odhadli množství zadávaného učiva a aby své žáky (a často i jejich rodiče) nepřetěžovali.

„Úskalí spatřuji v rozdilném pohledu učitele a rodičů a žáků, protože je mi jasné, že se může stát, že si učitel myslí, že práce pro žáky nezadal príliš, ale když pak žáci dostanou práci ze všech předmětů najednou, může to vypadat úplně jinak. Tohle mi vždy vrtá hlavou, když úkoly jako učitel zadávám. "17

V pozdějším období se pak nejobtížnějším úkolem stalo trvalé udržení kontaktu i se špatně spolupracujícími žáky a dále motivace všech žáků $\mathrm{k}$ pokračování v práci. Zvláštní skupinou se stali žáci 9. ročníků, kteří dlouhou dobu neznali termíny přijímacích zkoušek. Žák 9. třídy z 28. ZŠ v Plzni to při diskusích se studenty vyjádřil výstižně slovy:

„Je to jako když běžím závod úplně naplno, ale nemám tušení, jestli běžím šedesátku nebo maratón. Snažím se nepolevit, ale bojím se, že mi pred cílem dojdou síly a já u prijímaček zpanikařim."

\footnotetext{
${ }^{16}$ Ze zprávy K. Ledvinové o ZŠ Domažlice.

${ }^{17}$ Ze zprávy A. Fojtíkové o ZŠ Kralovice.
} 
Za zajímavé považujeme i to, co se mezi obtížnými úkoly v odpovědích učitelů neobjevilo: Učitelé neviděli ani v jednom případě jako největší problém práci s novými technologiemi. Uváděli však, že jim chybí osobní kontakt se žáky i rodiči a za velmi obtížné považovali vedení videokonferencí při vypnutých kamerách, kdy namísto žáků viděli jen jejich zástupné ikony.

„Chybí mi osobní komunikace učitel - žák - rodič. Bohužel většina rodičů s učitelem nekomunikuje, a když je problém neúnosný, nekontaktuje přimo jeho, aby se mohli vše pokusit společně vyřšit, ale ř reši to stížností u vedení školy. Což je škoda, protože by se jednoduše stačilo ozvat a problém vyřrešit společně. " 18

\section{K účasti studentů na webinářích}

Během dubna a května se studenti účastnili webinářů pro pedagogické pracovníky. Je zajímavé sledovat jejich výběr, který nebyl ze strany fakulty nijak omezen a řídil se pouze jejich vlastními zájmy, potřebami a preferencemi. $\mathrm{V}$ přehledu uvádíme názvy, organizátory a lektory webinářů, které studenti absolvovali:

\begin{tabular}{|l|l|l|}
\hline Název webináře & Organizátor & Lektor \\
\hline $\begin{array}{l}\text { Aplikace Kahoot: Herní kvízy pro děti } \\
\text { i dospělé }\end{array}$ & NPI ČR & Jana Šperlová \\
\hline Škola v době koronakrize a po ní & Inspiromat & Michaela Veselá \\
\hline Největší přání - Ř́zené čtení II. & Člověk v tísni & Petra Skalická \\
\hline $\begin{array}{l}\text { Gramar.in, matika.in, geograf.in a zlatka.in: } \\
\text { Interaktivní výukové materiály v češtině }\end{array}$ & Projekt SYPO & Jana Šperlová \\
\hline $\begin{array}{l}\text { Jak na hodnocení v Google učebně, písemky } \\
\text { a kontrolní testy v Google formuláŕích }\end{array}$ & Projekt SYPO & Jitka Rambousková \\
\hline
\end{tabular}

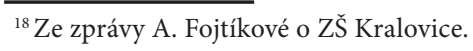




\begin{tabular}{|l|l|l|}
\hline $\begin{array}{l}\text { Online vzdělávání v době uzavřených škol } \\
\text { z pohledů učitelů }\end{array}$ & Projekt SYPO & Bohuslav Hora \\
\hline $\begin{array}{l}\text { Slovo v kostce a další volně dostupné nástroje } \\
\text { pro výuku češtiny }\end{array}$ & Projekt SYPO & Lucie Lukešová \\
\hline $\begin{array}{l}\text { Akviziční korpusy a jejich využití pro jazykové } \\
\text { vyučování }\end{array}$ & Projekt SYPO & Svatava Škodová \\
\hline Proč a jak vytvářet podcasty pro žáky & Projekt SYPO & Čeněk Rosecký \\
\hline $\begin{array}{l}\text { Formativní hodnocení: Úvod a praktické } \\
\text { ukázky }\end{array}$ & Projekt SYPO & Zdeněk Dlabola \\
\hline GDPR ve výuce v době nouzového stavu & Projekt SYPO & Milan Štoček \\
\hline $\begin{array}{l}\text { Komunikace na internetu v rámci rozvoje } \\
\text { digitální gramotnosti v českém jazyce }\end{array}$ & KVD PFE ZČU & Jana Vejvodová \\
\hline $\begin{array}{l}\text { Jak zavést online výuku a nezbláznit se? Jak } \\
\text { pracovat s žáky a rodiči? }\end{array}$ & Projekt SYPO & Václav Maněna \\
\hline $\begin{array}{l}\text { Jak zajistit plnohodnotnou výuku na } \\
\text { dálku díky technologí́m MS Teams a Google } \\
\text { Classroom }\end{array}$ & K-Net & Petr Nepustil \\
\hline $\begin{array}{l}\text { Jak na téma autorská práva a licence v hodi- } \\
\text { nách českého jazyka na 2. stupni ZŠ }\end{array}$ & Projekt SYPO & Jana Vejvodová \\
\hline Netiketa, kulatý stůl & KVD FPE ZČU & Jana Vejvodová \\
\hline Podpora digitální gramotnosti, kulatý stůl & KVD FPE ZČU & Jana Vejvodová19 \\
\hline
\end{tabular}

\section{K reflexím navštívených webinářů}

V reflexích webinářů se studenti soustředili na několik základních tematických oblastí:

\section{a) Nástroje a technické možnosti zajištění výuky na dálku a jejich dostupnost}

Většina studentů uváděla, že se během webináře poučili o využívání nástrojů, které dřive neznali nebo neovládali.

\footnotetext{
${ }^{19}$ Viz zde s. 20.
} 
„Bylo hezké vidět Google učebnu i z pohledu učitele. Učebna mi ze strany žáka přšla poměrně prehledná a jednoduchá. A prekvapilo mě, že i právě pro učitele je tato aplikace ohromně prehledná, jednoduchá a podle mého názoru ideální pro učitele, kteři se učí použivat technologie a aplikace $k$ výuce. Velice se mi líbí provázanost s Google dokumenty, která nabízí užitečné možnosti (otevření i neodevzdaných úkolů, přidávání komentářu uvnitř dokumentů, importování bodování z testu do učebny, ...). " ${ }^{20}$

Studenti taktéž oceňovali, že webináře vedou lidé z praxe, kteří sami vyučují, a nástroje, o nichž hovoří, sami aktivně používají ve výuce.

„Tento webinář považuji za velice přinosný, jelikož se ho zúčastnil člověk, který se aktivně podílí na vytvárení obsahu nejen na svých webových stránkách. Dodal také celou řadu dalších zajímavých zdrojů, které se za současné situace hodí využivat, ale stejně tak budou platné i v budoucnu. Zajímavé je, že se tento člověk, přestože nemá vystudovanou informatikou, stal jednim $z$ prednich odborníkư na používání moderních technologii v rámci výuky. (...) Právě uvedené weby a facebookové stránky pro mě byly nejdůležitějšími výstupy v rámci webináre, protože mi přinesly nové zdroje pro mou učitelskou kariéru, které jsem dosud neznal. Stejně tak jako postřehy ohledně autorského práva a problematiky, jak zapojit do výuky i dèti a rodiče ze sociálně znevýhodněných skupin, které nemají k dispozici moderní technologie. Překvapilo mě třeba, že některé školy $v$ těchto časech zapůjčují svá zařizení žákưm domů. To považuji za velice vstřícný krok. "21

\footnotetext{
${ }^{20}$ T. Karlovcová.
}

${ }^{21}$ L. Kohoutek. 
Studenti často uvažovali o využitelnosti obsahu webinářů pro jejich vlastní potenciální výuku a oceňovali propojení vědeckých a technických řešení s praxí ve výuce.

„Během webináře byli účastníci seznámení s korpusovým portálem www.korpus.cz a s jeho dostupnými aplikacemi. Tento webinár byl zaměren predevším na dva nástroje. Prvním z nich byla aplikace WaG, neboli Slovo $v$ kostce. Díky této aplikaci můžeme získat rychlý přehled o nějakém hledaném slově z psaných i mluvených korpusů. Druhou predstavenou aplikací byla aplikace SyD, která slouží k porovnávání dvou a více slov v současném jazyce, ale i v průběhu jeho vývoje. ... Český národní korpus věnuje pozornost i školnímu prostředí. Součástí korpusu jsou vytvořené pracovní listy pro školy, které se zaměřuji na práci s tímto webovým nástrojem.

Myslím si, že tento nástroj by mohl být velkým př́nosem do hodin českého jazyka především na střední škole, ale své uplatnění by měl i ve výuce českého jazyka na druhém stupni základní školy ve chvíli, kdy bychom se věnovali např́klad vývoji českého jazyka nebo rozvrstvení jazyka. $V$ současné situaci, $k d y$ se žáci vzdělávaji distančně, tak mají větši prostor seznámit se s těmito webovými aplikacemi. Pokud vytvořime vyhovující pracovní list, myslím si, že by je tato problematika, predevším díky již zmiňovanému grafickému zpracování, mohla zaujmout. “22

\section{b) Obousměrná komunikace mezi učitelem a žákem}

Studenti si ve svých reflexích všímali nejen technických prostředků pro zajištění výuky na dálku, ale především toho, jakou kvalitu

\footnotetext{
${ }^{22} \mathrm{~K}$. Ledvinová.
} 
tyto prostředky nabízejí v souvislosti s komunikací a kontaktem se žáky. Pro studenty bylo důležité, zda prostřednictvím zvoleného nástroje mohou nejen jednostranně zadávat úkoly, ale především opravdu komunikovat se žáky, poskytovat jim a získávat od nich zpětnou vazbu apod.

„Za jednu z nejdůležitějších částí kvízů na Kahootu považuji možnost feedbacku. Žáci ve zpětné vazbě hodnotí, jak moc se z testu naučili, jaké z nèj mají pocity, jestli by ho doporučili ostatním, a nakonec jeho kvalitu hodnotí počtem hvězdiček. Po dokončení kvízu maji žáci také možnost zahrát si ho znovu. V tomto př́padě jim na obrazce vyskočí obrázky duchů, které představují je samotné s předešlými výsledky. Žáci tak následně soutěží proti nim - sami proti sobě, což je velice motivující. (...) vytvoření podcastu je nesmírně jednoduché. Podcast (hlas učitele) je osobnějǔí než psaný text, proto si myslím, že podcast $v$ budoucnu použiji např. pro zadávání úkolů nebo hodnocení. “23

„Učitel a žák mohou diskutovat o daném úkolu a o splnění zadaných kritérií. Výhodou také je, že učitel vidí průběh práce - na které části úkolu žák právě pracuje, které úkoly už splnil a kolik získal bodu․ Učitel může také stanovit, že určité obrázky/symboly něco znamenají, např. obrázek berušky = zmenši velikost pisma. Takové funkce urychlují a usnadňují zpětnou vazbu. Žák si v aplikaci také může zažádat o pomoc od učitele nebo si žáci mohou pomáhat navzájem. Tyto aplikace by se podle mého názoru daly využit kdykoliv, nejen pro výuku na dálku. "24

\footnotetext{
${ }^{23}$ T. Doubková.
}

${ }^{24}$ M. Mondeková. 


\section{c) Hodnocení práce žáků}

Studenti uvažovali o možných úskalích hodnocení a známkování a uvědomovali si problematičnost hodnocení při výuce na dálku. Zjištovali, že postupy známkování a hodnocení zažité z kontaktní výuky nejsou v době výuky na dálku validní. „...známkování domácí práce by mělo být potlačeno a žáci by měli být hodnoceni slovnè. S tím souhlasím, slovní hodnocení v tomto období poskytne žákưm větší oporu a zpětnou vazbu. "25

„Považuji za zajímavé tvrzení, že slovní hodnocení není zcela totéž co formativní. Jako príklad zde [lektor] uváděl čtvrtletni slovni hodnoceni, které je sumativní, za podmínky, pokud mu nic nepredcházelo a nic po něm následovat nebude. ${ }^{" 26}$

„Velice zajímavá je funkce moje tř́da. Zde má učitel možnost vidět úspěšnost řešení jednotlivých úloh, jaké úkoly jsou pro žáky problematické. “27

„Líbí se mi, že v aplikaci učitel může žákưm zadat práci/ úkol, stanovit kritéria hodnocení a poskytnout žákưm zpètnou vazbu. " 28

\section{d) Právní a etické zajištění výuky na dálku}

Pro studenty bylo zajímavé zjištění, že výuka na dálku je potenciálně problematická z hlediska dodržování autorského zákona a zákona o práci s osobními údaji (GDPR). Uvědomovali si, že

\footnotetext{
${ }^{25}$ A. Fojtíková.

${ }^{26}$ Y. Zikmundová.

${ }^{27}$ J. Kabourek.

${ }^{28} \mathrm{M}$. Mondeková.
} 
procesy, které jsou nastavené v běžné škole při kontaktní výuce, nemusí při výuce na dálku vyhovovat nebo je nutné jim věnovat zvláštní pozornost.

„Webinářr, který jsem si vybrala, je zaměřený na GDPR, tedy na ochranu osobních údajů, a to predevším v aktuální situaci, kdy výuka i predávání materiáli probíhá dálkově. (...) Škola má, stejně jako mnoho dalších institucí, př́stup k velkému množství osobních údajů nejen o žácích, ale také o učitelích a rodičích. Překvapilo mè, že se opravdu mnoho dokumentů ve škole musí archivovat $i$ několik desitek let. (...) V době, kdy výuka probíhá pouze dálkově, vyvstává mnoho otázek týkajících se bezpečnosti při komunikaci a predávání informací. “29

„Velmi mě překvapil názor experta na problematiku komunikace s žáky a rodiči pomocí soukromého e-mailu, nebot' jsem si nikdy neuvědomila, $k$ jak velkému přehlcení učitele tato metoda může vést, nicméně je jasné, že se nejedná o metodu vhodnou k zadávání úkolì ani hromadnému odpovídání žákưm. Tato metoda není vhodná ani sohledem na GDPR. “30

„Hlavním tématem byla tzv. netiketa. (...) Velmi mě např́klad zaujala aktivita s QR kódy, kde si žáci pomocí čtečky $v$ mobilním telefonu načetli jednotlivá pravidla etikety na sociálních sítích, které posléze prépsali na papír a dále rozmistovali podle důležitosti do svých záznamů. (...) Dále mě velmi zaujala a zároveň pobavila skutečnost, že se dá virtuální výukové prostředí vytvořit i ve světě počitačových her, které žáci tolik milují. Problematiku netikety tak můžeme

\footnotetext{
${ }^{29}$ K. Princová.
}

${ }^{30}$ L. Smolarová. 
například studovat ve virtuální učebně hry Minecraft. Toto zjištění mě inspirovalo a podnítilo mou zvědavost $k$ tomu, abych si o tomto zajímavém a neobvyklém způsobu vykládání učiva zjistila něco více. "31

\section{e) Formální zpracování webináře a prezentační dovednosti lektorů}

Studenti si všímali i toho, jakým způsobem jsou jednotlivé webináře vedené. Reagovali na dovednosti lektorů a uváděli postřehy $\mathrm{k}$ průběhu webinářů. Oceňovali především možnost zapojit se aktivně do průběhu webináře, diskutovat a získávat okamžitou zpětnou vazbu od lektora i ostatních účastníků. Jejich schopnost všímat si nedostatků či předností v mluveném projevu lektorů považujeme za cennou především ve vztahu $\mathrm{k}$ jejich vlastním výkonům ve tř́dách i k výkonům jejich žáků v budoucnosti.

„Během celého videa jsem si dělala podrobné poznámky na papír, protože mě dané téma velice zaujalo. Tempo videa, prednesu, a i predkládání jednotlivých informací bylo ideální, (...) přišlo mi velmi vhodné, že po každém celku přišla rekapitulace jednotlivých kroků postupu, možností využití atd. Celkově se mi webinář opravdu moc líbil, mám $v$ plánu se postupně podívat i na některé další. Myslím, že by mohly být prínosné pro mě jako studentku, ale také pro mou budoucí pedagogickou praxi. “"

\footnotetext{
${ }^{31} \mathrm{~K}$. Skuhrovcová.

${ }^{32} \mathrm{~T}$. Karlovcová.
} 


\section{K tvorbě vlastních didaktických materiálů}

V dubnu se studenti seznámili s obsahem a formou JPZ, zvolili si výchozí texty a vytvořili didaktické materiály pro žáky. Následovalo období, v němž žáci materiály vypracovali, studenti je ohodnotili a okomentovali, žáci se s výsledky seznámili a prodiskutovali je ve skupinách a konečně se setkali online se studenty při společných diskusích. Materiály hodnotila při setkáních online také R. Písková a poskytovala studentům zpětnou vazbu k obsahu a kvalitě zpracování materiálů. Závěry tohoto společného hodnocení lze shrnout takto:

Studenti vybírali texty přiměřené věku a pokročilosti žáků. Jednalo se o texty vhodné ke komplexnímu jazykovému rozboru ${ }^{33}$, především o ukázky z prozaických děl české literatury (Němá barikáda J. Drdy, Bylo nás pět K. Poláčka, Zbabělci J. Škvoreckého, Léto s kovbojem J. Kolárové, Pověst o kouzelníku Žitovi T. Bednaříka, Báječná léta pod psa M. Viewegha, Fialový poustevník O. Pavla, Nové povídky Z. Svěráka), světové literatury (Farma zvírat a 1984 G. Orwella, Hobit J. R. R. Tolkiena), ale mezi texty se objevila i česká poezie (báseň Maminka J. Seiferta, Svatební košile K. J. Erbena, Toman a lesní panna F. L. Čelakovského), texty publicistické (článek o tapírovi z časopisu 21. století) a populárně-naučné (článek o černé smrti z Encyklopedie historie světa, článek o Janu Husovi z knihy Dějiny českých zemí P. Čorného).

Vznikl tak rozmanitý soubor výchozích textů, s jejichž využitím bylo možné procvičovat a testovat znalosti žáků ze všech jazykových plánů a stejně tak znalosti z oblastí literární, slohové a komunikační výchovy.

\footnotetext{
${ }^{33} \mathrm{~K}$ problematice komplexních jazykových rozborů viz zde J. Vaňková a M. Spěváčková (s. 198).
} 
$\mathrm{V}$ návazných úkolech se studenti zaměřovali na porozumění čtenému textu (otázky typu: Které tvrzení jednoznačně vyplývá $\mathrm{z}$ textu? Která informace není v textu uvedena? Jak by se dal jednou větou shrnout obsah sdělení? apod.), na zařazení ukázek k funkčním stylům či slohovým postupům (úkoly typu: Ke kterému funkčnímu stylu lze nejspíše zařadit výchozí text?), na vyhledání stylově příznakových slov (úkoly typu: V kterém z úseků výchozího textu se vyskytuje slovo knižní?). Další oblastí přítomnou prakticky ve všech materiálech byl pravopis (úkoly typu: Vyhledej v textu 4 chybně napsaná slova a napiš je pravopisně správně.). Často se objevovaly úkoly $\mathrm{z}$ lexikologie a slovotvorby (úkoly typu: Najdi spisovné podstatné jméno, které je v prvním pádě dvojslabičné, skloňuje se podle vzoru růže a je př́buzné se slovem zakoupit.) a také úkoly ze syntaxe (úkoly typu: Vypiš z textu prrísudek slovesný složený. Vyjádři obsah podtrženého souvětí větou jednoduchou. apod.). Často se objevovaly úkoly spojující práci s výchozím textem A s prací se sekundárním textem $B$, obsahujícím definici jevu, jehož příklad měli žáci ve výchozím textu A vyhledat.

Postrádali jsme úkoly zaměřené na textovou kohezi (řazení částí textu do vhodného pořadí s ohledem na textovou návaznost) i na rovinu foneticko-fonologickou (spisovná výslovnost ${ }^{34}$, přepis výslovnosti, zvuková shoda apod.), pouze u básnických textů pracovali někteři studenti s definicemi básnických figur (např. definice epizeuxis) a vyhledáváním dokladů těchto figur v textech. Tento fakt byl překvapivý, studenti při diskusích online na př́mý dotaz, proč rovinu foneticko-fonologickou opomněli, většinou uváděli, že „považovali jiné úkoly za důležitější / problematičtější / zajímavějšíc.

\footnotetext{
${ }^{34} \mathrm{~K}$ tématu spisovné výslovnosti viz zde J. Málková (s. 217).
} 
Celkově se v didaktických materiálech objevila široká škála typů úkolů postihujících mnoho jazykových, literárních, slohových a komunikačních jevů. Celý soubor použitých didaktických materiálů byl po korektuře a vyhodnocení poskytnut studentům ve formě materiálové banky. Studenti se sdílením materiálů nejen souhlasili, ale často vyjadřovali souhlasné stanovisko $\mathrm{k}$ tomu, že mohou své didaktické materiály sdílet $\mathrm{s}$ ostatními a přispět $\mathrm{k}$ vytvoření uceleného souboru, který jim v budoucnosti jistě poslouží při jejich vlastní výuce.

\section{Shrnutí}

Průběh blokové výstupové praxe v letním semestru roku 2020 považujeme za specifický, odrážející naprosto přesně soudobou situaci na ZŠ a SŠ. Z tohoto hlediska byl dle našeho názoru cíl blokové výstupové praxe beze zbytku naplněn. Studenti se seznámili se situací ve školách, komunikovali s učiteli, zapojili se do probíhající výuky, zažili interakci se žáky online, vytvářeli vlastní výukové materiály, hodnotili práci žáků a získávali zpětnou vazbu na svůj výkon.

Další přínos takto realizované blokové výukové praxe spatřujeme zejména $\mathrm{v}$ tom, že se studenti podrobně seznámili se systémem DVPP, s aktuální nabídkou webinářů a dalších podpůrných akcí pro učitele a uvědomili si, že významnou roli hraje v učitelské profesi celoživotní vzdělávání. K tomuto poznání, dle našeho názoru, většinou nemívají během běžné blokové výstupové praxe mnoho př́ležitostí.

Studenti museli zpracovávat didaktické materiály v elektronické podobě a následně je v této podobě rovněž sdíleli se žáky. Viděli tak naprosto jasně, v čem spočívají úskalí výuky na dálku - řešili 
technické problémy, jako je napřr. nemožnost zápisu do souborů určitého formátu, neviditelnost komentářů u jednotlivých odpovědí, nefunkčnost kamer a mikrofonů při setkáních online, hledání průsečíku volných termínů pro uskutečnění videokonference a další. Měli př́ležitost uvědomit si, že výuka na dálku realizovaná prostředky elektronické komunikace má své výrazné limit. Komunikační obtíže vyvstávaly jak na straně žáků, tak na straně studentů v roli vyučujících a občas znesnadňovaly vzdělávací proces.

Domníváme se, že studenti získali mnohem přesnější představu, v jaké situaci se žáci nacházejí, když mají denně vypracovávat úkoly při výuce na dálku a komunikovat se svými učiteli, ale přitom nemají odpovídající vybavení nebo dovednosti, aby mohli sami vyřešit př́ípadné potíže.

Mnozí studenti komentovali toto zjištění a docházeli k tomu, že budou např́ště mnohem více „empatičtí a pokornějšsi při zadávání úkoli̊ na dálku“ (citace jedné ze studentek). Začali si uvědomovat, že podmínky žáků $\mathrm{k}$ učení při výuce na dálku jsou rozmanité, mnohdy velmi obtížné a že nelze posuzovat jen výsledky, ale je nutné mnohem více brát v úvahu snahu o komunikaci, úsilí při vypracovávání úkolů a celkový př́stup jednotlivých žáků k práci. S tím pro ně vyvstaly otázky týkající se formativního hodnocení a poskytování kvalitní zpětné vazby v míře a intenzitě, kterou považujeme za mnohem vyšší, než s jakou by se setkali při běžné kontaktní výuce, kde stačí gesto, úsměv, souhlasné přikývnutí či změna postoje nebo tónu hlasu, aby žák věděl, zda pracuje správně či nikoli.

V těchto zjištěních a změně přístupu u studentů spatřujeme nejvýznamnější přínos blokové výstupové praxe realizované v roce 2020 a domníváme se, že právě proto by i do budoucna jistá část 
praxe měla probíhat $\mathrm{v}$ elektronickém komunikačním prostředí, např. formou spolupráce online $s$ fakultními školami. Vzhledem k současnému trendu využívání digitálních technologií na ZŠ a SŠ lze předpokládat, že i do budoucna budou chtít školy být připraveny na situaci, $\mathrm{k}$ níž došlo v roce 2020. Domníváme se, že stejně připraveni by měli být i studenti ZČU. Měli by chápat a oceňovat kvalitu přímé, osobní komunikace mezi učitelem a žákem a uvědomovat si, že vedení výuky online se od přímé výuky v mnohém liší. Na jedné straně může využívat možností digitálních technologií, na straně druhé je však tento zpơsob výuky ztížen mnoha překážkami a omezeními různého druhu a nemůže plně nahradit prezenční výuku ve školách.

\section{Použité zdroje}

Vzdèlávání na dálku v základních a středních školách: Tematická zpráva. Česká školní inspekce [online]. 2020, 7. 5. 2020 [cit. 5.6.2020]. Dostupné z: https://www.csicr.cz/Csicr/media/Prilohy/ PDF_el._publikace/Tematick \%c3 \%a9 \%20zpr \%c3 \%a1vy/ Vzdelavani-na-dalku-v-ZS-a-SS-Tematicka-zprava.pdf

Zprávy o stavu výuky na dálku na ZŠ/SŠ, reflexe navštívených webinářů a didaktické materiály pro žáky ZŠ vytvořili v průběhu praxe studenti a studentky KČJ FPE ZČU: Alena Bezchlebová, Tereza Doubková, Adéla Fojtíková, Tomáš Glazer, Jakub Kabourek, Tereza Karlovcová, Lukáš Kohoutek, Kateřina Ledvinová, Michaela Mondeková, Kateřina Princová, Karolína Skuhrovcová, Lucie Smolarová, Eliška Šafaříková, Lucie Šourová, Michaela Štěchová, Barbora Tvarohová, Lucie Zikmundová, Yvette Zikmundová. 
Od praxe k teorii a zpět ve vyučování češtině II

Všem studentům a studentkám děkujeme za spolupráci, za udělení souhlasu s publikací úryvků z jejich prací a za flexibilní př́stup k realizaci blokové výstupové praxe v letním semestru 2020. 


\title{
Kvalifikační práce a jejich provázanost s výukovou praxí
}

\author{
Dominic Jačka, Petr Pánek
}

V této kapitole pojednáváme o systému zadávání a tvorby kvalifikačních prací během pregraduální přípravy učitelů. Naším cílem je poukázat na potenciál, který tato nedílná složka vysokoškolského studia učitelství má, a navrhnout způsob, jakým by mohla být pojata, aby právě kvalifikační práce sloužily jako prostředek propojování praxe a teorie v profesním rozvoji budoucích učitelů češtiny.

Navrhujeme systém zadávání a tvorby kvalifikačních prací, který by mohl být využit na katedře českého jazyka a literatury na Fakultě pedagogické ZČU (eventuálně i jinde). Jeho zavedením by bylo možno prohlubovat kontakt studentů učitelství s edukační realitou $^{35}$, a tím jim poskytnout další př́ležitost $\mathrm{k}$ získání pedagogické praxe (tedy k nabytí zkušeností, rozvoji dovedností, upevnění postojů a hodnot, přispívajících celkově $\mathrm{k}$ formování učitelské osobnosti). Jedná se o reciproční systém, v němž kooperují jak studenti učitelství a akademici pedagogické fakulty, tak i školy a školská zařízení a $\mathrm{z}$ něhož může profitovat každá ze zúčastněných stran, jak vysvětlíme níže.

\footnotetext{
${ }^{35}$ Edukační realita je podle Průchy $(2009$, s. 64) „základní pojem pedagogické vědy nahrazující dosud uplatňovaný, avšak vágní pojem ,pedagogická praxe‘. Edukační realita je jakýkoli úsek objektivní skutečnosti, v níž probíhají nějaké edukační procesy”. V našem pojetí se jedná o stav výuky na školách, který by měl student učitelství aktivně poznávat, v ideálním prŕípadě ho pozitivně ovlivňovat.
} 


\section{Kvalifikační práce a pedagogická praxe v systému pregraduální př́ípravy učitelů}

Považujeme za důležité představit systém pregraduální přípravy učitelů, abychom mohli poukázat na stav, který bude východiskem pro naše další tvrzení v této stati. Podle novely vysokoškolského zákona z roku 2001, která navazuje na Boloňskou deklaraci ${ }^{36}$, je současná podoba učitelské př́ípravy strukturována na tříleté bakalářské a dvouleté navazující magisterské studium (s výjimkou nestrukturovaného pětiletého programu Učitelství pro 1. stupeň ZŠ). Jedním z pozitivních důsledků je, že se učitelská příprava $\mathrm{v}$ případě mnohých učitelských oborů pro ZŠ prodloužila ze čtyř na pět let, čehož lze „využít k posílení pedagogické praxe nebo k rozvoji osobnostních kompetencí studentů”, jak vzpomíná J. Mareš ve své Osobní reflexi událostí při zavádění strukturovaného studia učitelství (2013, s. 476).

Nabízí se otázka, zda je v pregraduální přípravě učitelů tento potenciál skutečně naplno využíván. Jaký je podíl pedagogické praxe ve strukturovaném studiu učitelství, je možné zjistit $\mathrm{z}$ níže uvedené tabulky představující Rámcové požadavky, které vyjadřují poměry mezi základními složkami odborné přípravy. „Spodní hranice rozpětí těchto složek určuje nepodkročitelné minimum; horní hranice rozpětí je doporučená, a lze ji tedy překročit" (MŠMT 2017, s. 2), a to v př́padě, že chce vysoká škola posílit určitou složku př́pravy, např. formou (povinně) volitelných předmětů.

\footnotetext{
${ }^{36}$ Cílem Boloňského procesu, který v roce 1999 vyústil v přijetí Boloňské deklarace, bylo sjednotit terciární vzdělávání na evropské úrovni (nastavit tř́istupňové vzdělávání, zavést rovnocennost akademických titulů, vytvořit společný kreditový systém, budovat studentské a učitelské mobility).
} 


\section{Učitelstvi pro Zš (Učitelstvi pro 2. st. Ž̌)}

23. V žádosti předkládá VŠ studijni plán Bc. studijního programu nebo varianty Bc. studijních programú, na něž bude NMgr. navazovat, a studijní plán NMgr. programu. Následující složky a jejich podily jsou vyjádřeny za Bc. s NMgr. v celostním poměru.

\begin{tabular}{|c|c|c|c|}
\hline Složka & $\%$ & Kredity & Hodiny \\
\hline \multicolumn{4}{|l|}{ učitelská propedeutika: } \\
\hline \multicolumn{4}{|l|}{ pedagogicko-psychologická príprava } \\
\hline \multicolumn{4}{|l|}{ a speciálněpedagogická připrava, } \\
\hline $\begin{array}{l}\text { např. obecná pedagogika, psychologie a didaktika, } \\
\text { školní pedagogika, pedagogická psychologie. }\end{array}$ & $20-25$ & $60-75$ & $1800-2250$ \\
\hline \multicolumn{4}{|l|}{ vývojová psychologie, inkluzivní didaktika, } \\
\hline \multicolumn{4}{|l|}{ metodologie, ICT, cizi jazyk se zaměřením na } \\
\hline \multicolumn{4}{|l|}{ vzděláváni, popř. univerzitní základ } \\
\hline první obor & $25-30$ & $75-90$ & $2250-2700$ \\
\hline druhý obor & $25-30$ & $75-90$ & $2250-2700$ \\
\hline oborové didaktiky & $10-15$ & $30-45$ & $900-1350$ \\
\hline \multicolumn{4}{|l|}{ praxe } \\
\hline ř́zená a reflektovaná praxe & $8-10$ & $24-30$ & $720-900$ \\
\hline \multicolumn{4}{|l|}{ (náslechová, prüběžná a souvislá) } \\
\hline príprava závěrečné práce & $5-10$ & $15-30$ & $450-900$ \\
\hline
\end{tabular}

\section{Tabulka č. 1: Rámcové požadavky - metodický materiál MŠMT k posuzování studijních programů}

Požadavky na zastoupení praxe (v součtu všech jejích druhů) $\mathrm{v}$ učitelské prrípravě se pohybují v rozmezí 8 až $10 \% \mathrm{z}$ celkového objemu studia. Z tabulky je patrné, že jsou to nároky relativně nízké vzhledem k zastoupení dalších složek. Lze též zjistit, že pedagogická praxe zastupuje téměř stejný podíl jako příprava závěrečné práce (5-10\%). Z těchto poznatků bude vyplývat náš návrh, který dále představíme.

Nejprve je však na místě položit si otázku, jak jsou požadavky týkající se těchto dvou složek vysokoškolského studia učitelství naplňovány na Fakultě pedagogické Západočeské univerzity v Plzni. Podíváme-li se na nově akreditované studijní programy platné od akademického roku 2020/21, zjistíme podle oficiálních studijních plánů, že v povinném bloku má pedagogická praxe podíl čtyř kreditů v bakalářském a 18 kreditů v navazujícím magisterském stupni. 
Připočteme-li $\mathrm{k}$ tomu ještě dva dvoukreditové předměty zaměřené na reflexi a hodnocení kvality výuky, dostaneme celkem 26 kreditů. Tato hodnota vyhovuje výše uvedeným Rámcovým požadavkům, které pro pedagogickou praxi vyhrazují minimálně $8 \%$ (resp. 24 kreditů) z celkového objemu studia (300 kreditů). Složka přípravy závěrečné práce představuje ve stejném pětiletém (strukturovaném) období celkem 25 kreditů. ${ }^{37}$

Pokud mají zmíněné dvě složky v pregraduální přípravě učitelů téměř identické zastoupení, pak by měl být oběma přisuzován stejný význam. Uvědomujeme si, že zvýšit podíl pedagogické praxe v pregraduální př́ípravě učitelů prostřednictvím systémové změny je snaha administrativně, časově a intelektuálně náročná. Proto chceme navrhnout operativní řešení uvnitř současného systému učitelské prrípravy, a tak naplno využívat potenciálu, který v jednotlivých složkách studia učitelství je. Těžištěm tohoto potenciálu jsou možnosti propojení teorie a praxe, které by mohly přinést užitek nejen pregraduální př́ípravě učitelů, ale i vzdělávání v širším smyslu slova.

\section{Výzkumná sonda do kvalifikačních prací}

\section{Analýza bakalářských prací}

Obsahové analýze jsme podrobili celkem 40 prací obhájených v letech 2018 a 2019 na katedře českého jazyka a literatury FPE (dále KČJ). Zároveň jsme zkoumali př́slušný počet posudků vedoucích i oponentů. Zaměřili jsme se na veškeré nedostatky,

\footnotetext{
${ }^{37} \mathrm{Na}$ FPE díky nově akreditovaným studijním programům vzroste ve strukturované i nestrukturované učitelské př́ipravě zastoupení pedagogické praxe, která je pro studenty bakalářských programů dokonce povinná. V této skutečnosti spatřujeme krok správným směrem na cestě za kontinuálním zkvalitňováním pregraduální př́ípravy učitelů.
} 
které se podle posudků v těchto pracích vyskytovaly, a po jejich identifikaci jsme je klasifikovali do tří skupin:

1. obecné,

2. formální,

3. jazykové a slohové.

Za obecné nedostatky jsme považovali nesprávně stanovený výzkumný cíl, nedostatečnou analýzu problému, vágní formulování hypotéz, slabou orientaci v sekundární literatuře, nevhodný výběr metod a postupů práce a také odborné nedostatky, jako je nedbalé citování jak v textu práce, tak v seznamu použité literatury. Formální nedostatky se projevovaly zejména v rozkolísanosti užité typografie. Znepokojivé bylo zjištění, že vedoucí i oponenti soustavně upozorňovali na množství drobných i závažných pravopisných chyb, především interpunkčních. Překvapilo nás, že studenti bezpečně neovládají základy lexikálního, morfologického a syntaktického pravopisu (zdůrazněme, že se jedná o studenty českého jazyka a literatury na pedagogické fakultě).

Někteří vedoucí a oponenti také považovali za problematické, že se studenti v teoretických kapitolách upínají k nadměrnému parafrázování literatury. Můžeme konstatovat, že ve snaze o přejímání teoretických poznatků tak studenti činí mechanicky, neobratně, a pravděpodobně proto se často dopouštějí syntakticko-stylizačních nedostatků. $Z$ výzkumného vzorku prací a posudků především vyplývá, že studentům činí potíže zaujmout k tvorbě práce badatelský př́stup a řešit zkoumaný problém analyticky a kriticky, a to s patřičným zřetelem $\mathrm{k}$ náležitostem odborného funkčního stylu.

Při interpretaci těchto dat jsme se snažili odhalit společného jmenovatele těchto nedostatků a dospěli jsme k následujícímu 
závěru: Domníváme se, že jazykové nedostatky, které studenti v bakalářských pracích vykazují, pramení z nedostatečné přípravy na základní a střední škole a nepodařilo se je eliminovat ani na vysoké škole. Zároveň považujeme za problematické, že vysokoškolská prríprava studentů učitelství na tvorbu závěrečné práce není soustavná a systematická, ale spíše nahodilá.

Abychom toto tvrzení podpořili faktickým argumentem, nahlédněme opět do oficiálního studijního plánu (platného od roku 2020/21) bakalářského programu Český jazyk se zaměřením na vzdělávání. Z něj vyplývá, že studenti nemají povinný předmět, který by se komplexně věnoval praktické přípravě na tvorbu kvalifikační práce. Dlužno podotknout, že si mohou zapsat výběrové předměty ${ }^{38}$ zaměřené na problematiku odborného funkčního stylu, asistenci při výzkumných metodách, nebo dokonce na zpracování kvalifikační práce. Pro představu uved’me, že v uplynulých dvou letech (tedy v době, do které spadají námi zkoumané bakalářské práce) byl ze strany studentů zájem o tyto předměty mizivý, zapsaly si je přibližně dvě desítky studentů všech oborů. Vzhledem k tomu, že na FPE studuje téměř dva tisíce studentů, nabýváme znepokojivého přesvědčení, že tvorba bakalářské práce je pro studenty spíše formálním prostředkem k dosažení titulu, tedy je ohrožena samoúčelností.

Při výzkumu bakalářských prací jsme odhalili ještě jeden fakt, který považujeme za problematický. V nabídce témat závěrečných prací téměř chyběla taková, jež by vycházela $\mathrm{z}$ kontaktu s edukační realitou a jež by prohloubila vhled do pedagogické praxe a připravila data pro pedagogický výzkum. To je důvodem, proč jsme se zabývali též magisterskými pracemi.

\footnotetext{
${ }^{38} \mathrm{Tj}$. předměty typu $\mathrm{C}$ podle normy Západočeské univerzity, které nejsou povinné ani povinně volitelné.
} 


\section{Analýza magisterských prací}

Při analýze magisterských prací jsme sledovali především tematické oblasti (lingvistickou, literární a oborovědidaktickou), ze kterých mohou studenti vybírat konkrétní téma pro svou kvalifikační práci. Hlavním kritériem zkoumání byl charakter nabízených témat a jejich potenciál pro kontakt s edukační realitou.

\begin{tabular}{|l|c|c|c|c|}
\hline & 2019 & 2018 & 2017 & 2016 \\
\hline $\begin{array}{l}\text { Celkový počet prací ukončených úspěšnou } \\
\text { obhajobou }\end{array}$ & 14 & 24 & 20 & 33 \\
\hline $\begin{array}{l}\text { Počet prací s potenciálem kontaktu studenta } \\
\text { s edukační realitou }\end{array}$ & 10 & 12 & 8 & 13 \\
\hline $\begin{array}{l}\text { Z toho vzniklých v programu Učitelství pro 1. } \\
\text { stupeň ZŠ }\end{array}$ & 8 & 7 & 6 & 11 \\
\hline
\end{tabular}

\section{Tabulka č. 2: Magisterské práce vzniklé na KČJ FPE}

Z tabulky lze vyčíst dvě zajímavé skutečnosti. Zaprvé vidíme podíl těch prací, při jejichž tvorbě měli studenti v relativní míře možnost setkat se s edukační realitou. Zadruhé můžeme konstatovat, že ve většině prrípadů byly tyto kvalifikační práce zpracovány studenty programu Učitelství pro 1. stupeň ZŠ (tedy nestrukturovaného studijního programu), a to opakovaně v různých letech. Na základě analýzy témat jsme zjistili, že v nestrukturovaném studiu programu Učitelství pro 1 . stupeň ZŠ jsou v hojnějším počtu zadávána témata, která z edukační reality čerpají už z podstaty svého názvu a směřují $\mathrm{k}$ využití výsledků výzkumu v praxi. Oproti tomu témata nabízená studentům strukturovaného studia učitelství jsou z odborného hlediska spíše bohemistické nežli pedagogicko-didaktické povahy - orientují se převážně na lingvistickou a literární oblast, méně pak na oborovědidaktickou. 


\section{Tvorba kvalifikačních prací jako prostředek kontaktu mezi praxí a teorií}

Vycházíme ze zjištění, že studentům nestrukturovaného programu Učitelství pro 1. stupeň ZŠ byla oproti studentům strukturovaných typů studia opakovaně s několikaletou periodicitou nabízena témata, při jejichž zpracování měli možnost kontaktu s edukační realitou. Jak docílit toho, aby i studentům strukturovaného studia učitelství bylo nabízeno více témat $s$ přesahem do edukační reality, ve které mohou nabývat pedagogickou praxi a získávat data pro pedagogický výzkum? A jak těchto dat nadále využívat? Náš návrh řešení se týká (především) magisterských prací, protože studenti magisterského stupně studia by měli být již vybaveni potřebnými pedagogicko-didaktickými znalostmi a měli by být schopni erudovaně provádět pedagogický výzkum. Naše perspektiva směřuje $\mathrm{k}$ postupné aplikaci níže popsaného návrhu do procesu zadávání a tvorby také bakalářských prací.

Navrhujeme zavést promyšlený systém zadávání a tvorby kvalifikačních prací, který bude vycházet $\mathrm{z}$ konsenzu katedry o její vědecko-výzkumné činnosti. Jeho nedílnou součástí bude revidovaná nabídka témat kvalifikačních prací, jejichž zpracováním se studenti budou podílet na strategickém rozvoji výzkumné činnosti katedry, a to prostřednictvím pedagogického výzkumu v edukační realitě.

Jsme toho názoru, že právě tímto systematickým krokem lze kontinuálně rozvíjet vědu a výzkum na katedře a zároveň zvyšovat podíl praxe v pregraduální př́ípravě učitelů. Uvědomujeme si, že nalezení konsenzu katedry o vědecko-výzkumné činnosti, z něj plynoucí realizace naplánovaných kroků, jejich následná evaluace a výsledná inovace jsou obtížné, byt základní části celého procesu. Proto nejprve usilujeme o otevření diskuse, jak při budování 
popsaného systému začít. Navrhujeme tyto dílčí kroky, jejichž pořadí je orientační, nikoliv určující:

1. Uspořádat kulatý stůl katedry a diskutovat o možnostech a limitech předloženého návrhu na vytvoření promyšleného systému zadávání a tvorby kvalifikačních prací a v souvislosti s tím hledat konsenzus o vědecko-výzkumné činnosti.

2. Zjistit postoj škol $k$ tomuto záměru takto prohlubovat vzájemné vztahy propr (propojovat teorii s praxí).

3. Zadávat studentům strukturovaného studia učitelství ve vyváženém poměru témata kvalifikačních prací, která se už z podstaty svého názvu dotýkají edukační reality na různém stupni vzdělávání nebo v různých institucích zajištujících výchovu a vzdělávání, jako například ${ }^{39}$ :

- jazyková specifika různých komunikátů ve školním prostředí,

- kontaktové prostředky v pedagogické komunikaci,

- mluvený projev žáka ve vybraném ročníku,

- využití vybraných vyučovacích metod a jejich funkce ve vybraném ročníku,

- $\quad$ specifika (např. defekty) v písemných pracích žáků ve vybraném ročníku,

- zprostředkování učiva ve vybraném ročníku,

- didaktická interpretace zvolených uměleckých textů,

- zájmová a povinná četba dětí, pubescentů, adolescentů,

- návaznost vybraných řad učebnic českého jazyka a literatury,

- $\quad$ interdisciplinární vztahy v českém jazyce a literatuře.

4. Propojit nabízená témata a využít jejich zpracování k získávání dat o edukační realitě, která využije jak student pro tvorbu své kvalifikační práce, tak katedra pro rozvoj své výzkumné a publikační činnosti.

\footnotetext{
${ }^{39}$ Vycházíme z témat nabízených v uplynulých letech na KČJ, jejichž znění zobecňujeme.
} 
5. Vypracovat systém prrípravy studentů na tvorbu kvalifikační práce a provádění pedagogického výzkumu.

Konkrétní nabídka témat (bod č. 3) a způsob jejich provázání (bod č. 4) budou vycházet ze zmiňovaného konsenzu katedry o její vědecko-výzkumné činnosti (bod č. 1). Povede-li se katedře realizovat tyto cíle a na jejich základě nastavit promyšlený systém zadávání kvalifikačních prací (bod č. 1), můžeme se dále zabývat zpơsoby, jak by mohl sběr dat v edukační realitě probíhat (bod č. 2). Aby mohli studenti přispívat $\mathrm{k}$ naplňování vědecko-výzkumné činnosti katedry, je samozřejmě zapotřebí vybavit je základy provádění pedagogického výzkumu (bod č. 5 - viz zde M. Čechová, s. 1).

Z našeho výzkumu vyplývá, že na katedře českého jazyka a literatury FPE vzniká sice nezanedbatelné procento kvalifikačních prací, jež se věnují současnému stavu výuky na českých školách, avšak proces jejich zadávání není systematický a z větší části tvoří tyto práce studenti jednoho studijního programu (nestrukturovaného programu Učitelství pro 1. stupeň ZŠ). Proto usilujeme o cílené zpestřrení nabídky témat magisterských prací pro studenty strukturovaných programů učitelství, a to v závislosti na definování představy o vědecko-výzkumné činnosti katedry. Budováním sofistikovaného systému zadávání a tvorby kvalifikačních prací se chceme podílet na posílení složky pedagogické praxe ve strukturované pregraduální prrípravě učitelů.

\section{Shrnutí}

Data získaná díky kontaktům studentů a jejich učitelů s praxí mohou být využita při dosahování vědecko-výzkumných cílů katedry. Tvorba kvalifikační práce by tak byla přínosná nejen pro studenta, 
ale i pro katedru. Student se díky zpracování kvalifikační práce setká s edukační realitou, v níž si prohloubí vhled do p pedagogické praxe a může sbírat data pro pedagogický výzkum. Člen katedry může sebraná data využít k vlastním tvůrčím účelům, které korespondují se sjednocenou vizí katedry o její vědecko-výzkumné činnosti. V neposlední řadě může mít $\mathrm{z}$ tvorby takových kvalifikačních prací užitek i edukační realita, která bude přinejmenším ujištěna o tom, že o ni instituce vzdělávající učitele jeví zájem. Výzkumem nabyté poznatky pak může zúročit v kritické reflexi vlastního edukačního prostředí a $\mathrm{z}$ aspektu pregraduální přípravy učitelů lze předpokládat, že takové poznatky ji pozitivně ovlivní.

Ne všechny práce však musí být nutně výzkumné. Užitečné mohou být také práce popisující současný stav výuky, završené úvahou či rozvahou o prrípadných jejích změnách.

Od těsnějšího propojení praxe s teorií v pregraduální přípravě učitelů si slibujeme utváření osobnosti ideálního učitele češtiny. ${ }^{40}$ Podle Šmilauera (1969, s. 241) je dokonalý češtinář „spojením trojí dokonalosti: je znamenitým odborníkem, vynikajícím učitelem a charakterním člověkem“. S tímto tvrzením se plně ztotožňujeme. $\mathrm{V}$ našem pojetí se jedná o inspirativního učitele, který spoluvytváří ve školním prostředí takové podmínky, v nichž se všechny děti učí naplno, s radostí a rovnými šancemi.

Představený návrh zavedení promyšleného systému zadávání a tvorby kvalifikačních prací považujeme za jednu z možností, jak v pregraduální přípravě učitelů na FPE ZČU v Plzni posílit složku pedagogické praxe a jak trvale udržovat a rozvíjet těsný vztah mezi praxí a teorií.

\footnotetext{
${ }^{40} \mathrm{Na}$ osobnost ideálního učitele je třeba nazírat nejen pohledem odborníků, ale především studentů. Podle nich u takového učitele vynikají jeho „psychické a sociální kompetence“, je citlivý a trpělivý, důsledný, ale nekonfliktní, náročný a spravedlivý, schopný sebereflexe a má smysl pro humor (in Čechová 2017, s. 209).
} 


\section{Použitá literatura}

ČECHOVÁ, Marie. Život s češtinou: Nomen omen: Češka - češtinářka - Čechová. Praha: Academia, 2017. 391 s.

MAREŠ, Jiří. Osobní reflexe událostí při zavádění strukturovaného studia učitelství. Pedagogika, 2013, roč. 4, s. 460-484.

PRŮCHA, Jan; WALTEROVÁ, Eliška; MAREŠ, Jiří. Pedagogický slovník. Praha: Portál, 2009 (6. vydání). 395 s.

STROUHAL, Martin; ŠTECH, Stanislav (eds.). Vzdělání a dnešek: pedagogické, filosofické, historické a sociální perspektivy. Univerzita Karlova: Karolinum, 2016. 226 s.

ŠMILAUER, Vladimír. Profil češtináře. Český jazyk a literatura, 1969, roč. 19, s. 241.

ŠTĚPÁNÍK, Stanislav. Konstruktivistické a kognitivně-komunikační paradigma jako východisko koncepce výuky českého jazyka. Pedagogika, 2020, roč. 70, č. 1, s. 5-28.

\section{Internetové zdroje}

Rámcové požadavky na studijní programy, jejichž absolvováním se získává odborná kvalifikace k výkonu regulovaných povolání pedagogických pracovníků. [online]: MŠMT, 2017. [cit. 24.9.2020] Dostupné z: https://www.msmt.cz/vzdelavani/dalsi-vzdelavani/ ramcove-pozadavky-na-studijni-programy-jejichz-absolvovanim 


\section{Obsah vs. forma: jak forma ovlivňuje učitelovo hodnocení žákovských textů?}

Stanislav Štěpáník

Učitelé českého jazyka na 2. stupni ZŠ a na SŠ se často ve vztahu k psaní1 ${ }^{41}$ (mj. slohových prací) setkávají s nezájmem, obavami, někdy dokonce až s odporem žáků. Zatímco na 1. stupni ZŠ či $\mathrm{v}$ nižších ročnících 2 . stupně ZŠ tento problém není zásadně významný, s postupujícími ročníky nabývá na intenzitě. Na základě analýzy pedagogické praxe v české základní škole (Štěpáník 2020) lze souhlasit s Boscolem (2009, s. 300), jenž pro to uvádí dva důvody:

1. Zatímco zpočátku žáci využívají psaní přirozeně jako způsob sebevyjádření, ve škole se proces psaní značně formalizuje, vyžaduje se dodržování přesně stanovených pravidel a schémat, což u žáků posiluje pocit, že psaní představuje rutinní aktivitu s omezeným účelem (k tomu srov. též Čechová 2017, s. 223-225; Štěpáník 2018; Wiśniewska, Karwatowska 1998, či Nocoń 2010).

2. Pisatelské úlohy se postupně stávají složitější a jejich hodnocení se zpřísňuje, nároky na kvalitu textů se zvyšují. To ovšem u žáků také podněcuje pocit ohrožení a strachu z neúspěchu.

Vnímání psaní jako náročné, či dokonce nezvládnutelné aktivity je o to silnější u těch žáků, kteří se pro psaní necítí dostatečně

\footnotetext{
${ }^{41}$ Máme zde na mysli pokročilé psaní, tj. psaní jako součást funkční gramotnosti.
} 
nadaní. To mohou být žáci ze sociálně znevýhodněného prostředí, žáci se speciálními vzdělávacími potřebami, žáci s odlišným mateřským jazykem, ale stejně tak žáci intaktní. Motivace k psaní, ale i mluvení, resp. jakémukoliv způsobu sebevyjádření, je přitom $\mathrm{z}$ hlediska rozvoje osobnosti, ale také naplnění cílů výuky českého jazyka zcela klíčová (srov. Čáp 1993, s. 84-85; Čechová 1985, 1998; Skalková 1999), stejně jako potřeba úspěchu, jejíž dlouhodobé nenaplnění vede $\mathrm{k}$ frustraci, úzkosti, strachu, nezájmu atd. (srov. Hrabal, Man, Pavelková 1984). Otázky motivace k psaní ve škole přitom doposud stojí na okraji zájmu didaktiků i učitelů češtiny.

Psaní patří ke kognitivně nejnáročnějším aktivitám, které ve výuce mateřštiny žáci vykonávají1 ${ }^{42}$. Všestrannost textotvorného procesu má významný potenciál nejen vzhledem k naplňování komunikačních cílů, ale tím, že vyžaduje zapojení složitých a rozmanitých kognitivních procesů a rovněž využití sociálních a jazykových dovedností a znalostí (např. Flower, Hayes 1981; Myhill aj. 2011, 2012, v didaktice slovenštiny Klimovič 2016), vede také k rozvoji myšlení žáka, tedy naplňování cílů kognitivních. Kellogg (1999) kognitivní náročnost procesu psaní přirovnává k aktivitám vyžadujícím nejvyšší hladinu koncentrace (např. k profesionální hře $\mathrm{v}$ šachy). Slohová práce tak představuje artefakt značně komplexní, který v sobě zahrnuje nejen míru zvládání komunikační kompetence (či snad velmi úzce školního jazykového učiva), ale celou osobnost žáka - jeho motivaci, vlastnosti, názory, postoje, city, zájmy, kognitivní úsilí atd.

Samo psaní je ale pochopitelně také způsobem poznávání, nebot' proces tvorby textu je ve svém průběhu doprovázen také učením (Slavík, Chrz, Štech aj. 2013, s. 12). „Žák musí obsah uchopit sobě vlastním způsobem, aby jej mohl zvládnout, a musí se o něm

\footnotetext{
${ }^{42} \mathrm{~K}$ tématu grafomotoriky viz zde J. Nováková, s. 130).
} 
dorozumět, aby mu mohl porozumět. Tím jej zasazuje do aktuálního kontextu a připisuje mu vlastní rozvrh vnitřních strukturních vztahů nebo vnějších souvislostí. V tomto smyslu jej vždy znovu tvoří, aby jej mohl poznávat" (ibid., s. 16).

\section{Hodnocení slohových prací}

Z uvedeného vyplývá, že se učitel českého jazyka při hodnocení slohových prací ocitá uprostřed činnosti značně složité a náročné. Ne nadarmo právě proto hodnocení žákovských textů tvoří nedílnou součást vzdělávání učitelů, a to nejen v pregraduální, ale také postgraduální etapě.

I když češtinář vnímá text jako celek, při hodnocení slohové práce se zaměřuje na tři hlavní oblasti:

a) oblast tematickoobsahovou (obsah práce vzhledem k tématu; rozpracování tématu, myšlenky, argumentace, projevené názory a postoje atd.),

b) oblast slohovou (zpo̊sob zpracování tematickoobsahové stránky projevu, kompozice, soudržnost, vhodnost užitých jazykových prostředků atd.),

c) oblast jazykovou v užším slova smyslu (lexikální, gramatická a pravopisná kvalita slohové práce; Čechová 1998, s. 174-176).

Ve vztahu k hodnocení slohových prací za tř̌i klíčové teze považujeme:

1. potřebu funkčnosti a komunikační autenticity projevu,

2. chápání stylu jako kvalitativního fenoménu,

3. mj. z toho vyplývající hierarchizaci kritérií hodnocení s preferencí tematickoobsahové a slohové oblasti před oblastí úžeji jazykovou. 
Ad 1. V přirozených podmínkách každý komunikát plní určitou funkci. Vzniká za nějakým účelem, nikoliv jen sám o sobě a pro sebe. Výjimkou jsou v tomto ohledu školní texty, které vznikají $\mathrm{s}$ didaktickým účelem. Cílem výuky by však mělo být, aby umělých komunikátů („psaní pro psaní) bylo co nejméně. Výuka by měla usilovat o odstranění neautentičnosti, resp. nepřirozenosti textů vytvářených žáky a v co největší možné míre by měla simulovat přirozený komunikační proces ilokuce - lokuce - perlokuce $\mathrm{v}$ dané komunikační situaci, a to nejlépe vzbuzením přirozené potřeby žáka se ( $\mathrm{k}$ danému tématu) vyjádřit.

Ad 2. Podstatné je vnímat komunikát jako entitu dynamickou a styl pak jako jeho specifický kvalitativní rys, jenž dává prohlédnout, jakým způsobem se realizují různé komunikační funkce a záměry, jak se výběr jazykových prostředků přizpůsobuje komunikační situaci atd. (srov. Nocoń, rukopis); obecně řečeno jak jazyk utváří realitu. „Styl jako způsob verbální interakce, který je dán výběrem a uspořádáním tematických, jazykových a mimojazykových prostředků; styl jako konfigurace výrazových kvalit textu; styl jako soubor individualizovaných zvláštností textu; styl jako odraz identity autora; styl jako sémiotická entita" (Slančová 2003, s. 214).

Ad 3. Proto by při hodnocení žákovského textu měl převažovat zřetel k jeho obsahu a slohovému zpracování, tzn. k rozpracování tématu, funkčnosti komunikátu vzhledem ke komunikační situaci a komunikačnímu záměru, $\mathrm{k}$ vyspělosti argumentace atd.

\section{Sonda}

Předmětem této kapitoly je prošetřit, do jaké míry forma ovlivňuje učitelovu recepci žákovských textů, a tedy jejich hodnocení, 
mj. vyjádřené klasifikací. Na jedné straně jsou teoretická východiska opravování slohových prací, která jsou dlouhodobě známá (srov. již Čechová 1985), na druhé straně je však praxe, do níž významně vstupuje učitel se svými subjektivními teoriemi, preferencemi, přesvědčeními, se svou osobností. Pouze vysoká erudice oborová i didaktická, ale také jeho osobnost respektující žáka jako lidskou bytost a zachovávající důstojnost každé osoby jako základní hodnoty veškerého bytí učiteli zaručuje, že je schopen slohovou práci adekvátně posoudit, byt’ vždy bude hodnocení slohové práce - stejně jako kteréhokoliv jiného tvořivého díla - do jisté míry subjektivní.

K prozkoumání daného problému jsme vybrali soubor 27 slohových prací 7. třídy jedné z pražských základních škol. Žáci slohovou práci psali ve škole, jejich úkolem bylo napsat vypravování na jedno ze tří nabídnutých témat: (1) Historická událost, (2) Můj dobrodružný zážitek, (3) Příběh z budoucnosti. Pracovali na dvojlist řádkovaného papíru, psali rukou. Čelní strana sloužila jako úvodní, kam žáci zaznamenali mj. nadpis, téma a osnovu práce, text pak psali na stránky uvnitř dvojlistu, kam si před psaním nalinkovali okraje.

Český jazyk a literaturu ve třídě vyučovala kvalifikovaná zkušená učitelka s více než sedmi lety praxe. Slohové práce opravila a ohodnotila dle svých zvyklostí, nepoužívala žádná standardizovaná kritéria. Opravy zanesla přímo do textu, celkové hodnocení a klasifikační stupeň zaznamenala pod žákovský text.

Ze souboru jsme vybrali slohovou práci žáka V. K., který si z nabídky zvolil téma Můj dobrodružný zážitek. Tuto slohovou práci jsme zvolili proto, že pro rozvoj didaktických kompetencí (budoucích) učitelů právě tento žákovský text skýtá značný potenciál. Z hlediska výše uvedených tří hlavních oblastí hodnocení totiž 
poskytuje prostor $\mathrm{k}$ dialogu hodnotitele jednak sama se sebou, jednak s ostatními hodnotiteli. Možnosti hodnocení a následné klasifikace ukazují pravděpodobnost pochybností, nejistoty, rozporuplnosti, ba dokonce protichůdnosti. Spor v uvažování nad touto prací je dán jednak objektivním faktorem, totiž rozporem tematickoobsahové a slohové složky se složkou jazykovou, jednak subjektivním faktorem, totiž osobním vnímáním, které do hodnocení každý vyučující nutně projektuje v tom, které $\mathrm{z}$ hodnocených oblastí přiřazuje jakou váhu.

Zamyslíme-li se nad dvěma základními póly, pak lze uvažovat, zda v myšlení učitele převládá obsah, nebo forma; na základě dlouhodobé práce $s$ učiteli i vlastní pedagogické praxe se nedomníváme, že by vzhledem k subjektivnosti hodnocení slohové práce jako tvořivého díla bylo možné dosáhnout úplné vyváženosti - tuto možnost proto vylučujeme. Základním kritériem pro posouzení textu by ale $\mathrm{v}$ každém případě měla být vnímána ústrojnost žákovského textu vzhledem $\mathrm{k}$ jeho funkci.

Slohová práce žáka V. K. splňuje základní požadavky kladené na vypravování: obsahuje dobrou zápletku, poměrně vylíčení plastické postav, stupňuje napětí, sleduje vhodnou linii vypravování i s funkčním zapojením nespisovnosti (o tom však též dále).

Výzkumný vzorek pro účely této studie tvořily dvě skupiny studentů učitelství českého jazyka a literatury pro 2. stupeň ZŠ a pro SŠ na Pedagogické fakultě Univerzity Karlovy studující druhý semestr didaktiky českého jazyka (tj. 1. ročník navazujícího magisterského studijního programu), každá skupina čítala 14 subjektů. Jako kontrolní subjekt jsme vybrali jednu odbornou asistentku z katedry českého jazyka Pedagogické fakulty UK a jednu velmi zkušenou středoškolskou učitelku (t. č. s 16letou pedagogickou praxí), mj. též certifikovanou hodnotitelku 
maturitních slohových prací, která vyučuje na střední odborné škole v Praze.

Se studenty jsme pracovali metodou společné diskuse, učitelek jsme se dotazovali individuálně. Skupinové diskuse trvaly cca 35 minut, individuální cca 25 minut. V průběhu diskuse jsme pořizovali zápis, $\mathrm{z}$ něhož jsme při psaní této studie vycházeli.

Postupovali jsme v následujících krocích:

1. Zkoumaným subjektům jsme předložili vybranou slohovou práci, v níž jsme však předem opravili pravopisné chyby, včetně interpunkčních (všechno ostatní jsme ponechali v původní podobě; ukázka 1). Respondentům jsme poskytli čas na prostudování práce.

2. Poté jsme zkoumaným subjektům položili širokou otázku, jak by danou práci zhodnotili. Studenti uváděli vše, co je napadlo, vzájemně diskutovali. Mnohdy jsme je žádali o rozvedení či zpřesnění odpovědi, popř́íp. jsme jejich pozornost zaměřovali na specifické jevy, které byly předmětem zkoumání (napr. Jak hodnotíte nespisovné tvary $v$ textu? apod.).

3. Následně jsme zkoumaným subjektům předložili vybranou slohovou práci v původní podobě (ukázka 2) a poskytli jim čas na její prostudování.

4. Poté jsme zkoumaným subjektům opět položili širokou otázku, jak by danou práci zhodnotili v tomto př́padě, a následně jsme je požádali o reflexi toho, jak se jejich uvažování o práci změnilo oproti předchozí podobě textu, v němž byly opraveny ortografické jevy, včetně interpunkčních.

5. Na závěr jsme je požádali o volnou reflexi celého postupu. 
Zkoumané subjekty nevěděly, že jim bude tentýž text předložen dvakrát, pokaždé v jiné formě. Byly informovány pouze o tom, že předmětem našeho rozhovoru bude hodnocení slohové práce. $\mathrm{Na}$ závěr pak došlo ke společné reflexi, $\mathrm{v}$ níž respondenti měli vyjádřit, jak vnímají výsledek sondy.

\section{První fáze sondy: upravený žákův text}

Nejprve jsme zkoumaným subjektům předložili text slohové práce, v němž jsme opravili pravopis, včetně interpunkce (ukázka 1).

\section{Ukázka 1.}

Žákovský text s opraveným pravopisem, včetně interpunkce.

Můj dobrodružný zážitek

V̌̌e se stalo před rokem, když jsme se s klukama vsadili, jestli existuje ufo, nebo ne, já jsem byl pro, že existuje. A chtěli jsme si to ověrit. Tak jsme řekli rodičưm, že budeme spát ve stanu na konci lesa u Zelené pláně. Rodiče to nechtěli dovolit, a po dlouhém premlouvání svolili. Šel jsem za klukama se stanem a spacákem, že můžu jít. Ostatní mohli taky. Všichni jsme se vypakovali a šli jsme na velmi dobrodružnou noc. Došli jsme na místo asi za pưl hodiny. Pavel se celou cestu vytahoval, že se ničeho nebojí. Tak jsme mu řekli, když je tak nebojácnej, at postaví stan. Za chvíli ho postavil. Petr, já, Pavel a Čenda jsme šli prozkoumat okolí. Jak jsme šli lesem, najednou jsme viděli, jak po modré obloze něco strašně rychle letělo. Všichni jsme si řkli, že to byla nějaká hvězda. Najednou se začalo stmívat a všichni jsme šli pomalu ke stanu rozdělat oheň. Čenda rozdělal oheň a my jsme vytáhli buřty a napíchli jsme je na klacky a začali jsme je opékat, jak jsme se najedli sytosti, 
řekli jsme, že pưjdeme spát, a najednou slyšime, jak zase něco letí, a vidime to všichni rychle, zalezem do stanu a jsme pořádně vystrašení. Všichni se šileně klepali, ale nejvíc se klepal Pavel, který se predtím vychloubal, že se ničeho nebojí. A najednou to přistálo, já jsem se podíval ven a viděl jsem, jak se otevírá poklop, a co jsem neviděl, zelený ufony, byli tak odporný, mèli čtyř̀ ruce a dvě nohy, $z$ kterých trčely dva prsty, dvě uši, prostě martani. Ted’se bližili ke stanu, všichni jsme vzali nohy na ramena a utíkali jsme do lesa co nejrychleji. Zastavili jsme a viděli jsme, že ufoni za náma neběží. Hodně jsme byli rádi, že jsme jim utekli. Pavel vytáhl mobilní telefon a volal rodičưm, ti se okamžitě sebrali a jeli sem. A najednou vidíme ufony, jak vytáhnou laserové pistole a začnou po nás stř́let, my utíkáme $k$ vodě, skočíme do vody a préplaveme na druhý břeh. Ale ufoni se ani neprribližili $k$ vodè. To mně hrklo v hlavě, že ufoni nesnáší vodu, tak jsme vzali igelitové pytlíky a naplnili vodou. Přeplavali jsme zase zpátky a s pytlikama jsme běželi za nimi a oni utíkali do lodi a uletěli. My jsme začali slavit. Najednou prrijeli rodiče s palicí a ptali se nás, co se tu stalo. My jsme jim říkali, že tu byla ufa, samozřejmě že nám nikdo nevěril. Já jsem vyhrál sázku a dostal jsem od klukư veliký pohár. A v duchu jsem si říkal, že ve stanu spát už nebudu. A naštěstí to dopadlo dobře.

Jak studenti učitelství, tak i obě zkoumané učitelky se k předloženému textu vyjadřovali pozitivně. Vyprávění hodnotili jako koherentní, funkční, s dobrou zápletkou i gradací, zřetelně tedy propracované s osobním zaujetím autora („vcítil se do toho, bavilo ho to“). Oceňovali dobré propracování tématu, nápaditost textu a originalitu některých motivů (např. motiv ufonů, kteří se bojí vody). 
Všímali si prvků mluvenosti, které reflektovali tak, jako by autor skutečně vyprávěl. Zpracování textu pojímali jako autorský styl (ten dokonce někteří studenti přirovnali $\mathrm{k}$ profesionálním spisovatelům - např. J. Škvoreckému). Nespisovnost jim nijak nevadila, naopak její užití hodnotili jako funkční, příhodné, autentické, a to především ve spojení s tím, že žák vypráví svůj zážitek ich-formou, že se tak vyjadřují i ostatní hrdinové vyprávění a že jde o umělecký styl ${ }^{43}$. Zkušené učitelky si povšimly určité nekonzistentnosti stylu: na jedné straně se objevují tvary stylově nízké (nespisovné a hovorové), na druhou stranu tvary stylově vyšší (za ně však považovaly i: že tu byla ufa, igelitové pytlíky), což hodnotily jako zřetelnou snahu o dodržení školského požadavku užívat spisovnou češtinu, jenž bývá mnohdy pokládán za absolutní (srov. Čechová 1995; Svobodová 2003; Štěpáník 2020).

Na druhou stranu ale respondenti také vnímali vadný slovosled a slabou návaznost některých větných celků. I to však v kontextu celé práce posuzovali jako př́padné, $\mathrm{z}$ hlediska tematickoobsahového odůvodnitelné a zajímavé.

Zkoumané subjekty také poměrně zjevně uvažovaly nad tím, zda jde o žákův (umělecký, resp. estetický) záměr, anebo o žákovu neznalost daných jazykových jevů. Už tady někteří usuzovali na žáka se specifickou poruchou učení (dysgrafie, dysortografie, dyslexie), nebot hodnotili žákův myšlenkový proces jako př́liš uvolněný a nesourodý, zvláště v postupu práce - „začátek dobrý, ale postupně ztrácí pozornost“.

Na závěr byly zkoumané subjekty dotázány na hodnocení vyjádřené klasifikačním stupněm, ten studenti i učitelky vyjádřili $\mathrm{v}$ intencích stupně výborně či chvalitebně. Při klasifikaci do hry

\footnotetext{
${ }^{43}$ Raději než o uměleckém stylu bychom hovořili o esteticky zaměřeném komunikátu nebo o komunikátu s estetickou funkcí.
} 
vstoupila nejen celková kvalita textu, ale také přihlédnutí k vývojovým dispozicím žáka 7. ročníku ZŠ.

\section{Druhá fáze sondy: původní žákův text}

Ve druhé fázi sondy jsme zkoumaným subjektům předložili původní text (ukázka 2).

\section{Ukázka 2.}

Původní verze žákovského textu.

Můj dobrodružný zážitek

V̌̌e se stalo před rokem když jsme se s klukama vsadili jestli existuje ufo nebo ne já jsem byl pro že existuje. A chtěli jsme si to ověrit. Tak jsme rekli rodičưm že budeme spát ve stanu na konci lesa u zelené pláň. Rodiče to nechtěli dovoli a po dlouhém přmlouvání svolili. Šel jsem za klukama ze stanem a spacákem, že mužu jít. Ostatní mohli taky. Všichni jsme se vypakovali a šli jsme na velmi dobrodružnou noc. Došli jsme na misto asi za pưl hodiny. Pavel se celou cestu vytahoval, že se ničeho nebojí. Tak jsme mu řekli když je tak nebojácnej at postaví stan. Zachvíli ho postavil. Petr, já, Pavel a Čenda jsme šli prozkoumat okolí. Jak jsme šli lesem najednou jsme viděli jak po modré obloze něco strašne rychle letělo. Všichni jsme si řekli že to byla nějaká hvězda. Najednou se začalo stmívat a všichni jsme šli pomalu ke stanu rozdelat oheň. Čenda rozdělal oheň a my jsme vytahly buřty a napichli jsme je na klacky a začali jsme je opekat jak jsme se najedli sytosti řekli jsme, že pudeme spát a najednou slyšíme jak zase něco letí a vidíme to všichni rychle zalezem do stanu a sme pořadně vystrašeni. V̌̌ichni se šileně klepali, ale nejvíc se klepal Pavel, který se pretim 
vychloubal, že se ničeho nebojí. A najednou to přistálo já jsem se podíval ven a viděl jsem jak se otevírá poklop a co jsem nevidel zelený ufony byli tak odporný mèli čtyři ruce a dvě nohy z kterých trčely dva prsty dvě uši prostě mart’ani. Tet' se blyžili ke stanu všichni jsme vzali nohy na rame a utikali jsme do lesa co nejrychleji. Zastavili jsme a vidèli jsme, že ufoni za náma neběží. Hodně sme byli rádi že jsme jim utekli. Pavel vytahl mobilní telefon a volal rodičum ty se okamžite sebrali a jeli sem. A najednou vidíme ufony jak vytáhnou lejzrové pistole a začnou po nás stř́let my utíkame $k$ vodě skočíme do vody a preplaveme na druhý břeh. Ale ufoni se ani nepřibližili k vodě. To mě hrklo v hlave že ufoni nesnaší vodu tak sme vzali igelitové pitlíky a naplnili vodou. Přeplavali jsme zase spátky a s pitlíkma sme běželi za nimi a oni utikali do lodi a uletěli. My jsme začali slavit. Najednou prijieli rodiče s palicí a ptali se nas co se tu stalo. My jsme jim říkali, že tu byla ufa samozřejmě, že nám nikdo nevěril. Já jsem vyhrál sázku a dostal jsem od kluků veliký pohár. A vduchu sem si říkal, že ve stanu spád už nebudu. A na stesti to dopadlo dobře.

Po předložení druhé ukázky se hodnocení práce u respondentů zřetelně proměnilo, především u studentů bylo znát určité rozpaky. Přiznali, že způsob čtení a vnímání textu se změnil, že text na ně působí jinak než v první fázi, což se následně promítlo také do jejich hodnocení.

Zkoumané subjekty jednoznačně usoudily, že byl text napsán žákem s poruchou učení. V té souvislosti se objevily úvahy nad tím, jak žákovi pomoci lépe větné celky navazovat, rozdělit do odstavců a komponovat text a jak žáka dovést ke zvládnutí interpunkce. Dělení větných celků totiž shledávaly jako nefunkční, chybnou interpunkci pak jako poměrně zásadní překážku čtenářského 
komfortu, která nejenže „rozmazává“ význam, ale zároveň činí čtení a porozumění textu namáhavé - „text se rozpadá“.

Otázku, zda jde o záměr, či žákovu neznalost, respondenti posoudili jako zodpovězenou, a to ve prospěch druhé varianty. Jazykovou stránku kritizovali jako zřetelně nezvládnutou.

Bylo patrno, že zvláště u studentů došlo k určitému vnitřnímu konfliktu: na jednu stranu si uvědomovali velmi nízkou jazykovou úroveň práce, na druhou stranu - protože již s prací měli zkušenost z první fáze sondy - si byli vědomi toho, že tematickoobsahová stránka se nezměnila - že se stále jedná o kvalitní vypravování. Z tohoto hlediska i napodruhé hodnotili text jako zvládnutý, a to mj. stále v souvislosti s možnostmi žáka 7. ročníku.

Důležitou otázku představoval fakt, jakým způsobem se postavit $\mathrm{k}$ hodnocení slohové složky, a to především při vědomí toho, že nespisovnost představuje prvek ze strany žáka nezáměrný, avšak ze strany požadavků kladených na dobré vypravování někdy funkční. V podstatě se jedná o rozpor mezi výsledkem (hodnocení práce jako hotového produktu bez zvažování osoby autora) a mezi procesem psaní (hodnocení práce s ohledem na to, kdo je jeho autorem, a s vědomím toho, že daný žák jazykovou složku ovládá nedokonale). Ve výsledku nespisovnost zkoumaným subjektům ale ani tady nevadila, byt ji vnímaly méně („víc se ztrácí).

Studenti reflektovali, že jsou ovlivněni podvědomě, že se hůře soustředí na obsah („působí zmateněji“), hưř̀e se v textu orientují („sdělení zaniká“). Jazykové chyby vnímali jako závažný faktor při vnímání textu. Studenti způsob zpracování textu přestali vnímat jako autorský styl, namísto toho text vyhodnotili jako odbytý proud vědomí („neprečetl si to po sobě“). 
V závěru také této fáze byli respondenti dotázáni na hodnocení vyjádřené klasifikačním stupněm. Studenti se pohybovali v intencích stupňů chvalitebně a dobře (s různými modifikacemi „horší dvojka“, „lepší trojka“, „dva mínus“). Učitelky se shodly na stupni dobře.

\section{Oprava práce učitelkou}

Pro zajímavost předkládáme též práci opravenou učitelkou, zkušenou praktičkou. (Práci jsme přepsali a do přepisu jsme přenesli opravy učitelky.)

\section{Mưj dobrodružný zážitek}

Vše se stalo před rokem,když jsme se s klukama vsadilijestli existuje ufo, nebo nejá jsem by! pro-že existuje. A Chtěli jsme si to ověrit. Taḱ jsme řekli rodičům ǰe budeme spát ve stanu na konci lesa u zelené pláñéRodiče to nechtěli dovolija po dlouhém premlouváni svoliti. Šel jsem za klukama ze stanem a spacákem, že mužu jít. Óstatni

merpio.
mohli taky. Všichni jsme se vypakovali a šli jsme na velmi dobrodružnou noc. Došli

jsme na fínisto asi za pưl hơdiny. Pavel se celou cestu vytahoval, že se ničeho nebojí.

jsme na misto asi za pul hodiny. Pavel se celou cestu vytahoval, že se niceho neboj!.

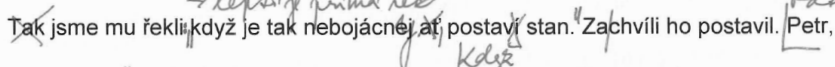

já, Pavel a Čenda jsme šli prozkoumat okoli. Jakjjsme šli lesern, najednou jsme viděli jak po modré obloze něco strašne rychle letělo. Všichni jsme si řekli,že to byla nějaká hvězda. Najednou se začalo stmivat a všichni jsme šli pomalu ke stanu rozdělat oplistavec

oheň. Čenda/rozdělal oheň a my jsme vytahly burty a napichli jsme je na klacky. ’’ Začali jsme je opekat.jak jsme se najedli sytost rekli jsme, že püdeme spátą Aajednou slyšime jak zase něco letí a vidime to.všichni rychle zalezemedo stanu a neyio. gpahovalú

jsme pořadně yystrašeni. Všlchni se šilenè klepali, ale nejvíc se klepal Pavel, který se d odce.

prettim vychloubal, že se ničeho neboji. A najednou to přistálojá jsem se podival ven

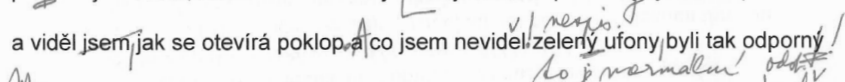
A hèli čtyři ruce a dvě nohy z'kterých trčely dva prsty。 dvě uši prostě mart'ani. Tet se 


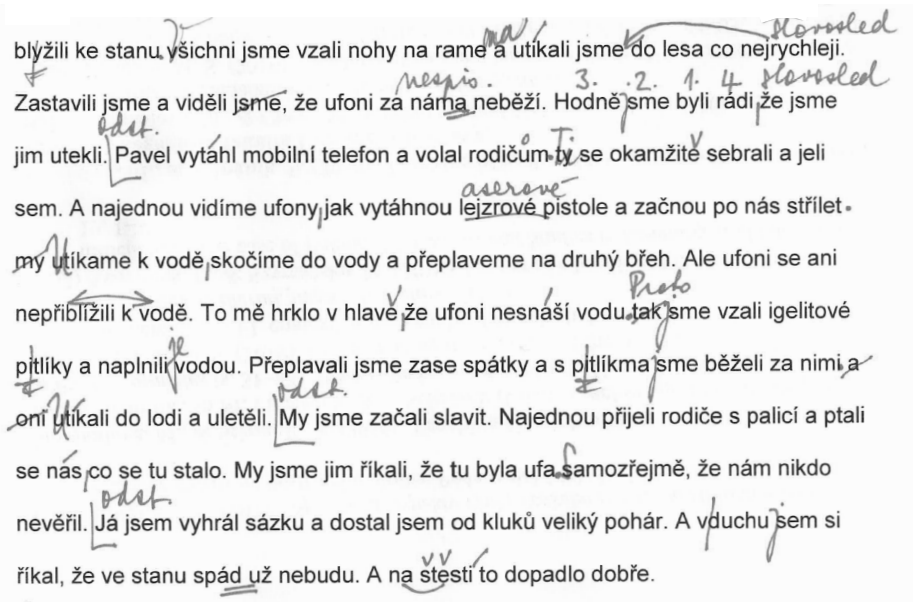

Komentář učitelky:

Napínavý a hezký příběh. Chybí odstavce, přímá řeč. Používáš nespisovné tvary. Máš mnoho pravopisných chyb.

Sloh: dobře

Pravopis: nedostatečně

Hodnocení učitelky lze v kontextu české školy považovat za prototypické. Učitelka se soustředí především na formu - na jazykovou složku v užším smyslu, a to nejen v poznámkách, které přičinila do textu, ale také v odůvodnění hodnocení a v celkové klasifikaci práce. Opravy se zaměřují na pravopis, včetně interpunkce, členění textu do odstavců, vybrané jevy větné skladby a spisovnost, resp. nespisovnost.

V závěrečném komentáři oceňuje tematickoobsahovou kvalitu textu („napínavý a hezký př́běh“), v textu samém však tyto kvality nijak nekomentuje. Ke slohovým kvalitám poznamenává pouze to, že žák používá „nespisovné tvary“ (v práci některé výrazy označuje jako nespisovné a některé jako hovorové). Celkově tyto 
aspekty klasifikuje dobře, aniž by udělenou známku dostatečně zdůvodnila.

Ačkoliv hodnocení jazykové složky nabízí celou řadu skutečností, k nimž by se měl učitel vyjádřit, $\mathrm{z}$ označení této položky („pravopis“) je zřejmé, na co se učitelka soustředuje nejvíce. To však představuje podstatnou redukci hodnocení kvalit žákovského textu a především přeceňuje jev, který z hlediska hodnocení kvality textotvorného procesu i výsledného komunikátu, tedy obecně míry zvládání komunikačních dovedností a ostatních složek jazykové kultury nepředstavuje jev nejdůležitější (srov. Čechová 1998, s. 177; Čechová, Styblík 1998, s. 171; Styblík 1966, s. 52). Jak M. Čechová (1998, s. 171) upozorňuje, ve slohových pracích je třeba odchylky od kodifikace posuzovat shovívavěji než $\mathrm{v}$ pracích jednostranně zaměřených na ověření znalostí kodifikace, a to proto, že je tvorba textu značně složitá a chyby v jevech eventuálně dosud neprobíraných a neprocvičených nelze penalizovat snížením klasifikace. Zásadní je hodnocení slohové práce jako celku (ibid.).

Množství oprav je značné a je nepochybné, že jejich forma i množství (zásahy do textu červenou barvou, škrtání a přepisování) ovlivňují žákovu motivaci k psaní negativně. Důsledkem toho je efekt, jejž jsme popsali v úvodu. Na místě je také konstatování, že takové opravy jsou neefektivní, zvláště nejsou-li doprovázeny dalším komentářem a/nebo prací s žákem, díky níž by si uvědomil, v čem jsou řešení navrhovaná učitelkou lepší než původní řešení žákova. Kdyby žák uměl text rozčlenit do odstavců a používat přímou řeč, jistě by to udělal. Konstatování, že tyto prvky v práci chybí, mu nijak v dovednosti členit text do odstavců a užívat přímou řeč nepomůže. Stejné je to i v otázce spisovnosti a obecně v otázce stylu. 
„Nejdůležitější je vytvořit pro žáky př́ležitost reagovat na zpětnou vazbu ke konkrétnímu úkolu, než jen zpětnou vazbu poskytnout" (Hendrick, Macpherson 2019, s. 28). Prakticky je tedy třeba žákům předvést konkrétní dobré řešení a především žáky jejich tvorbou provádět a nechat žáky o nich uvažovat. Žáci by měli mít možnost na zpětnou vazbu reagovat, tzn. měli by mít možnost práci upravit a následně ji s učitelem konzultovat atd. Hodnocení by mělo představovat př́íležitost $\mathrm{k}$ reakci a zlepšení, nikoliv konečný rozsudek (ibid., s. 23).

\section{Diskuse výsledků}

Formální jazykové nedostatky, nejčastěji pravopisné chyby jako to nejviditelnější pro nejširší škálu uživatelů jazyka, až př́liš často vystupují jako kritéria stupně ovládání češtiny, ale také vzdělanosti, a dokonce i inteligence člověka (o tom už Styblík 1966, s. 52). Mohou tak zcela zastínit obsah sdělení, ba dokonce se stát argumentem pro posouzení daného sdělení jako irelevantního. $\mathrm{S}$ tím se lze setkat nejen $\mathrm{v}$ běžných každodenních situacích (srov. např. diskusní příspěvky na různých elektronických platformách), ale také při hodnocení školních písemných projevů žáků. Disproporce mezi tematickoobsahovou, slohovou a jazykovou složkou a hodnocením učitelky u zkoumaných slohových prací nás přiměla podívat se na problém v kontextu školy hlouběji. Slohová práce zvolená pro tyto účely je tematickoobsahově na poměrně vysoké úrovni a slohově funkční (zvláště v kontextu dispozic žáka 7. ročníku ZŠ), z úžeji jazykového hlediska však podprůměrná.

Konstituujícím faktorem vypravování, jako útvaru projevu s estetickým zaměřením, je právě funkce estetická (Čechová, Krčmová, Minářová 2008, s. 296) - tomu je podřízena volba výrazových prostředků (ibid.). Na rozdíl od některých jiných stylů je u projevů se 
subjektivním estetickým zaměřením stěžejní role autora. V tomto směru by tedy žák měl mít nárok na celé spektrum ztvárnění projevu dle vlastního uvážení. Zdá se, že k tomuto požadavku jsou zkoumaní studenti učitelství vnímaví, což je pozitivní zjištění.

Rozpor učitele - stejně jako našich respondentů - zde však nastává v tom, že „snaha autora vytvořit aktivní prací s jazykovými (i tematickými) prvky dílo esteticky účinné“ má být vědomá (Čechová, Krčmová, Minářová 2008, s. 300). To v tomto př́ípadě splněno není. Na druhou stranu ale způsob estetizace sdělení musí být v souladu se zaměřením komunikátu (ibid., s. 298). To $\mathrm{v}$ tomto případě splněno je. Tyto skutečnosti zkoumané subjekty také adekvátně posoudily.

Předpoklad, že v ukázce $1, \mathrm{v}$ níž byly opraveny formální nedostatky, respondenti budou více vnímat tematickoobsahové a slohové kvality žákova textu, se naplnil. V konfrontaci s ukázkou 2, tedy originálním zněním práce, zkoumané subjekty přiznaly, že se jejich vnímání textu mění. Ačkoliv kvalita sdělení byla stále táž, proměnil se způsob recepce textu, obsah sdělení byl zastřen formálními nedostatky žákova výkonu. To z didaktického hlediska představuje závažné zjištění.

Obecně však je zajímavé, že studenti učitelství tematickoobsahovou a slohovou složku předloženého textu reflektovali více než učitelka, která danou práci hodnotila (kap. 3.3). Více zohledňovali funkci textu, resp. základní charakteristiky jeho povahy, a tedy též užívaných jazykových prostředků. To se odrazilo také v navržené klasifikaci - práci studenti hodnotili nejhůře známkou dobře, $\mathrm{v}$ čemž se shodovali také se dvěma učitelkami vybranými jako respondentky sondy. Je pozoruhodné, že klasifikace originální verze práce (druhá fáze sondy) se oproti upravené verzi (první fáze sondy) zhoršila jen o jeden stupeň. To napovídá, že by 
budoucí učitelé - jsou-li k tomu náležitě ve svém vysokoškolském studiu vedeni - mohli být k tematickoobsahové i slohové složce žákovských textů vnímavější než někteří jejich starší kolegové. Stejně tak se ukazuje, že ohodnocení slohové práce známkou pro studenty učitelství představuje problematickou redukci pisatelského výkonu žáka - o tom svědčí tápání mezi jednotlivými klasifikačními stupni (1-, 2+, 2- atd.).

V obou fázích sondy se projevil předpoklad, že by se mohlo jednat o žáka se specifickou poruchou učení - žák byl skutečně diagnostikován s lehkou formou dyslexie a dysgrafie. Vzhledem $\mathrm{k}$ diagnostikované poruše $\mathrm{v}$ oblasti psaní a čtení textu žák má problém již se samou technikou grafického záznamu. To pak ovlivňuje kvalitu jeho výsledného textu (což je též výzkumně ověřeno - srov. Gregg aj. 2007). I toto je třeba vzít při hodnocení slohových prací do úvahy.

Tradiční formy opravy, které demonstruje oprava učitelky v kap. 3.3, tak mohou vést $\mathrm{k}$ zlepšení žákovy dovednosti psaní velmi omezeně, resp. k němu nepovedou vůbec. Nejenže se jako dyslektik v opravách těžko orientuje, ale zároveň mu nedostatečná funkcionalizace oprav neumožňuje jim skutečně porozumět. To je ostatně náročné i pro žáka intaktního. Nezanedbatelné jsou také aspekty motivace, na něž má zpơsob hodnocení práce značný vliv. Opravy v této podobě, tradiční v naší škole, vykazují rysy didaktického formalismu zvaného odcizené poznávání (Janík aj. 2013; Slavík aj. 2017): poznávací aktivitu žáků - v tomto případě bytostně interní (psaní jako vrchol vlastní kognitivní i afektivní aktivity jedince) - totiž vyučující nahrazuje, resp. překrývá vlastní verzí textu, vlastním uvažováním o textovém řešení, vlastním hodnocením činnosti žáka. Je pozitivní, že zkoumaní studenti učitelství potřebu motivace žáka vnímají jako podstatnou. 
Při hodnocení slohové práce učitel zohledňuje nejen kvality textu jako hotového díla, tj. výsledku žákovy činnosti, ale také objektivní faktory ovlivňující žákův výkon (např. přítomnost SVP), ale i subjektivní úsudky (byt’ nevědomě) o žákovi a jeho osobních dispozicích. Klíčová je v tomto ohledu teze, že by hodnocení mělo vycházet od toho, co se žákovi podařilo (Čechová 1998, s. 175). U slohové práce, která je předmětem našeho zájmu, může být zmíněný konflikt vyřešen pouze za předpokladu, že učitel podstatně více vyzdvihne a ve svém hodnocení zohlední pozitivní kvality práce (zde především v oblasti tematickoobsahové i do jisté míry slohové - nápadité vyprávění, velmi dobrá kompozice textu, funkčnost zvolených jazykových prvků atd.) a upozadí nízkou kvalitu jazykovou (zvláště pravopisnou, včetně interpunkční), a to především proto, že vezme v úvahu individuální dispozice žáka s ohledem na jeho diagnostikovanou dyslexii a dysgrafii (porucha se projevovala jako lehká). Klíčová je následná práce $s$ textem, v němž učitel vyznačí vybrané nedostatky, tj. fáze, kdy je žák nucen nad nedostatky a chybami uvažovat a následně je opravit.

Výsledky sondy jsou podstatné především pro vzdělávání studentů učitelství i zkušených praktiků: vhodná práce s žákovskými texty, které budoucí i stávající učitele staví do podobných dilematických situací, mohou být vhodným nástrojem $\mathrm{k}$ tomu, aby sami hodnotitelé zjistili, v čem skutečně tkví podstatné kvality žákova pisatelského výkonu. I svým adekvátním hodnocením pak následně vedou žáky $\mathrm{k}$ tomu, aby pravopis nebyl vnímán jako stěžejní kritérium míry jazykové a komunikační kompetence. 


\section{Shrnutí}

Ověřili jsme, že učitelovo hodnocení žákovských textů může být výrazně ovlivněno formou, aniž by učitel vnímal kvalitu obsahu daného textu. Netýká se to jen komunikátů psaných, ale rovněž mluvených. Je třeba, aby si tohoto učitel byl vědom a nedopustil situaci, kdy jeho hodnocení žákova textu a uvažování o něm bylo výrazně ovlivněno, ne snad dokonce určeno pouze formou. Při hodnocení tak komplexního jevu, jako je žákovské psaní, je nezbytné upřednostnit kvality tematickoobsahové a slohové, před kvalitami úžeji jazykovými. Hlavním cílem výuky češtiny totiž není jazyková správnost (tento pojem je zpochybňován jak v didaktice, tak v lingvistice), ale rozvinutá komunikační kompetence podpořená funkčními znalostmi jazykovými, tedy znalostmi o fungování jazykového systému a jeho možnostít ${ }^{4}$. Z toho důvodu výuka nemá být pouze preskriptivní, jak se to demonstruje v opravě slohové práce užité v této kapitole jako prríkladu, ale primárně deskriptivní a funkcionalizační (Štěpáník 2020) - má vést $\mathrm{k}$ tomu, aby byl žák schopen využívat možností jazykového systému k efektivnímu vyjadřování.

S tím souvisí také způsob oprav slohových prací a zdůvodňování hodnocení. Žák by měl opravám porozumět, měl by mít možnost ověřovat různou funkčnost jazykového ztvárnění skutečnosti a působení jazykového vyjádření na př́ijemce. Opravy, v nichž učitel pouze přepisuje žákovo řešení, aniž by je jakkoliv zdůvodnil, vykazují rysy formalismu. Z hlediska efektivity výuky je klíčová funkcionalizace opravy a zdůvodnění hodnocení. Rovněž je vhodné ponechat žákovi prostor k uvědomění si nedostatků, vlastnímu zlepšení konkrétního řešení ve formě opravy apod. To lze dělat např. označováním nedostatků ustálenou formou značek, kdy učitel upozorňuje na chyby a nedostatky, ale nepřepisuje

\footnotetext{
${ }^{44}$ Srov. např. Spěváčková, Vaňková (2019).
} 
je vlastními variantami - k úpravám se vrací při kontrole opravy slohových prací. I opravě je tak třeba věnovat dostatečný prostor. Učitelovo hodnocení by mělo mít povahu formativní - vyzdvižení kvalit práce a doporučení možností zlepšení, případná klasifikace by měla toto hodnocení odrážet a měla by být zdůvodněná. Ne všechny slohové výkony je však třeba klasifikovat.

Podstatná je motivace k psaní, zasazování pisatelských aktivit do určitého komunikačního kontextu a tím zdůraznění účelnosti procesu psaní - píšeme proto, že chceme něco vyjádřit, něco sdělit, něco oznámit, něco si zaznamenat atd. (Liptáková aj. 2011, s. 291). Cílem je, aby se žák naučil rozlišovat jazykové prostředky dle jejich funkce v interakci. Snahou češtinářủ by tedy mělo být odstranit schematismus a šablonovitost textotvorného procesu ve škole a pisatelské aktivity co nejvíce kontextualizovat a tím rozvoj komunikačních (i úžeji jazykových) dovedností funkcionalizovat (srov. Štěpáník aj. 2020).

\section{Použitá literatura}

BOSCOLO, Pietro. Engaging and motivating children to write. In BEARD, Roger; MYHILL, Debra; RILEY, Jeni; NYSTRAND, Martin (eds.). The SAGE handbook of writing development. London: SAGE, 2009, s. 300-312.

ČÁP, Jan. Psychologie výchovy a vyučování. Praha: Univerzita Karlova, 1993. 415 s.

ČECHOVÁ, Marie. Vyučování slohu. Praha: SPN, 1985. 260 s. ČECHOVÁ, Marie. Vztah spisovnosti a nespisovnosti v pedagogické komunikaci. Pedagogika, 1995, roč. 45, č. 1, s. 38-42.

ČECHOVÁ, Marie. Komunikační a slohová výchova. Praha: ISV nakladatelství, 1998. $226 \mathrm{~s}$. 
ČECHOVÁ, Marie; KRČMOVÁ, Marie; MINÁŘOVÁ, Eva. Současná stylistika. Praha: NLN, 2008. $381 \mathrm{~s}$.

ČECHOVÁ, Marie. Život s češtinou: Nomen omen: Češka - češtinářka - Čechová. Praha: Academia, 2017. 391 s.

ČECHOVÁ, Marie; STYBLÍK, Vlastimil. Čeština a její vyučování. Didaktika českého jazyka pro učitele základních středních škol a pro studenty učitelství. Praha: SPN, 1998 (2., upravené vydání). $264 \mathrm{~s}$.

FLOWER, Linda; HAYES, John. A cognitive proces theory of writing. College Composition and Communication, 1981, roč. 32, č. 4, s. 365-387.

GREGG, Noel; COLEMAN, Chris; DAVIS, Mark; CHALK, J. C. Times essay writing: Implications for high-stakes tests. Journal of Learning Disabilities, 2007, roč. 40, č. 4, s. 306-318.

HENDRICK, Carl; MACPHERSON, Robin. Co funguje ve třídě? Most mezi výzkumem a praxí. Praha: Euromedia Group, 2019. $230 \mathrm{~s}$.

HRABAL, Vladimír; PAVELKOVÁ, Isabella; MAN, František. Psychologické otázky motivace ve škole. Praha: SPN, 1984. $254 \mathrm{~s}$.

JANÍK, Tomáš. Kvalita (ve) vzdělávání: obsahově zaměřný př́stup ke zkoumání a zlepšování výuky. Brno: Masarykova univerzita, 2013. $434 \mathrm{~s}$.

KELLOGG, Ronald T. (1999). The psychology of writing. Oxford: Oxford University Press.

KLIMOVIČ, Martin. Detský pisatel'v procese tvorby textu. Prešov: Prešovská univerzita v Prešově, 2016. 434 s.

LIPTÁKOVÁ, L’udmila; aj. Integrovaná didaktika slovenského jazyka a literatúry pre primárne vzdelávanie. Prešov: Pedagogická fakulta Prešovské univerzity, 2011. 579 s.

MYHILL, Debra, aj. Re-thinking grammar: The impact of embedded grammar teaching on students' writing and students' metalinguistic understanding. Research Papers in Education, 2012, roč. 27, č. 2, s. 1-28. 
NOCOŃ, Jolanta. Kształcenie umiejętności pisania w języku ojczystym w perspektywie lingwistycznej i lingwodydaktycznej. Didaktické studie, rukopis.

NOCOŃ, Jolanta. Styl(e) wypowiedzi pisemnej licealistów. Studia Pragmalingwistyczne, 2010, roč. 2, s. 66-78.

SKALKOVÁ, Jarmila. Obecná didaktika. Praha: ISV nakladatelství, 1999. $292 \mathrm{~s}$.

SLANČOVÁ, Daniela. Východiská interaktívnej štylistiky (Od eklektizmu k integrácii). Slovenská reč, 2003, roč. 68, č. 4, s. 207-223.

SLAVÍK, Jan; CHRZ, Vladimír; ŠTECH, Stanislav; aj. Tvorba jako zpưsob poznávání. Praha: Karolinum, 2013. 538 s.

SLAVÍK, Jan; JANÍK, Tomáš; NAJVAR, Petr; KNECHT, Petr. Transdisciplinární didaktika: o učitelském sdílení znalostí a zvyšování kvality výuky např́ič obory. Brno: Masarykova univerzita, 2017. $455 \mathrm{~s}$.

SPĚVÁČKOVÁ, Martina; VAŇKOVÁ, Jana. Dokáží studenti českého jazyka rozlišovat jazykové roviny a jim odpovídající jazykové prostředky? In ČECHOVÁ, Marie; SPĚVÁČKOVÁ, Martina (eds.). Od praxe $k$ teorii a zpět ve vyučování češtině. Plzeň: ZČU, 2019. s. 84-93.

STYBLÍK, Vlastimil. Problém reformy českého pravopisu $z$ hlediska školy. Praha: SPN, 1966. 98 s.

SVOBODOVÁ, Jana. Jazyková specifika školské komunikace a výuka mateřštiny. Ostrava: Ostravská univerzita, 2003. $148 \mathrm{~s}$.

ŠTĚPÁNÍK, Stanislav. Vliv nové podoby maturitní zkoušky z českého jazyka a literatury na vyučování ve výpovědích učitelů. Pedagogická orientace, 2018, roč. 28, č. 3, s. 435-471.

ŠTĚPÁNÍK, Stanislav. Výuka češtiny mezi tradicí a inovací. Praha: Academia, 2020. $328 \mathrm{~s}$.

ŠTĚPÁNÍK, Stanislav; HÁJKOVÁ, Eva; ELIÁŠKOVÁ, Klára; LIPTÁKOVÁ, Ludmila; SZYMAŃSKA, Marta. Školní výpravy do krajiny češtiny: didaktika českého jazyka pro ZŠ a VG. Plzeň: Fraus, 2020. 312 s. 
WIŚNIEWSKA, Halina; KARWATOWSKA, Małgorzata. O typowości tekstów uczniowskich. In BARTMIŃSKI, Jerzy; BONIECKA, Barbara (eds.). Tekst: analizy i interpretacje. Lublin: Wydawnictwo UMCS, 1998, s. 255-266.

\section{Internetové zdroje}

MYHILL, Debra, aj. Grammar for writing? The impact of contextualised grammar teaching on pupil's writing and pupils' metalinguistic understanding: ESRC End of Award report, RES-062-23-0775. Swindon: ESRC, 2011. Dostupné z: https:// www.researchcatalogue.esrc.ac.uk/grants/RES-062-23-0775/ outputs/read/c5bff83b-28d3-4945-8b8c-eb4b4c8406ae. 


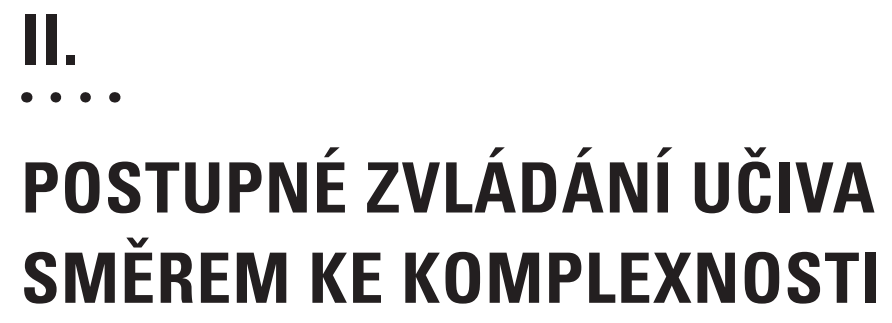




\section{Zralá grafomotorika}

\section{jako předpoklad pro rozvoj myšlení a (tvưrčího) psaní}

Jaroslava Nováková

Chceme-li mít společnost gramotnou, pak musíme zajistit, aby se člověk ve škole naučil číst a psát, a to nejen po stránce technické, nýbrž postupem doby i s porozuměním. Veškerý proces učení závisí na psychomotorickém vývoji, v němž motorika hraje primární roli. Bez propriorecepce potřebný rozvoj myšlení nenastane. Budeme-li hledat počátky motorického vývoje, pak se dostaneme až do prenatálního období. Už zde se nutně musí odehrávat procesy, které souvisejí s rozvojem motorických oblastí v mozku, mimo jiné i s oromotorickou oblastí, která je významně zodpovědná za rozvoj řeči (Solms, Turnbull 2014, s. 233n). Správný a včasný řečový rozvoj je dalším předpokladem pro následující proces učení, úroveň učebních procesů, mluvené i psané vyjadřování. Veškeré pedagogické metody, byt' sebelepší, nepadnou na úrodnou půdu, pokud nebude vývoj dítěte v normě, pokud bude mít opožděný či jakkoliv omezený, popř̀ odlišný vývoj řeči, přičemž i řeč je primárně závislá na celkové úrovni motorického vývoje (Kejklíčková 2018, s. 47-90).

Žák je živý organismus, který prochází vývojem, a proto nastavujeme-li libovolnou výukovou metodu, měli bychom bezpodmínečně znát úroveň rozvoje centrální nervové soustavy (CNS) pro určitou oblast učení, protože v opačném prrípadě navrhujeme metody jen na základě pokusu a omylu. Současný učitel už se neobejde bez neurovědeckých poznatků, které posouvají pedagogickou oblast na úroveň vědy, nikoliv jen pouhých návrhů. 
Právě neznalost psychomotorického vývoje dětí, neznalost vývoje myšlení, motorických a smyslových schopností a dovedností a rovněž neznalost vývoje řečových schopností jsou v současnosti největší deficity českého školství. Od pedagoga se na jednu stranu žádá, aby byl schopen pedagogické diagnostiky, tj. dokázal určit stav schopností, dovedností a znalostí žáka v konkrétním učebním procesu, dokázal určit prŕíčiny tohoto stavu a navrhnout další postup, který povede k rozvoji; na druhou stranu ale takový pedagog často nezná vývoj centrální nervové soustavy dítěte. $\mathrm{V}$ takovém př́padě se jeho diagnostika nezakládá na žádném hmatatelném základě, nýbrž na dojmech, které vedou k úspěchu jen náhodně.

Učební procesy a užití rozmanitých výukových metod se v zahraničí stále významněji opírají o výzkumy v oblasti neurověd a také do českého prostředí pronikají tyto trendy, byt zatím jen velmi omezeně. To je způsobeno zejména tím, že v českém prostředí se medicína tradičně odděluje od oblasti školství. Péče o dítě je tak bud' vedena lékařem, anebo učitelem. Oba si vymezují svou oblast působení s tím, že jeden nezná cíle a metody druhého. To je do značné míry absurdní stav vzhledem k tomu, že dítě je jeden organismus, a usilujeme-li o jeho komplexní rozvoj, pak nutně musíme mít poznatky také o jeho vývoji. Nedocházelo by pak k situacím, jež jsou zcela běžné, že se dítě v učebním procesu nezlepšuje a pedagog to řeší hledáním „vhodnějších“ učebních materiálů ( $v$ tom lepším př́ípadě), anebo nadměrným množstvím dalších a dalších úloh téhož typu, které by údajně měly pomoci problém vyřešit ( $\mathrm{v}$ tom horším případě). Automatizace, která se tímto zpơsobem uplatňuje celkem často, však není vhodným prostředkem ve chvíli, kdy byla zvolena nevhodná metoda $\mathrm{v}$ nevhodný okamžik, a to proto, že pedagog vůbec nezjistil, že v daném okamžiku vývoje dítěte nelze dané metody použít, nebot’ se minou účinkem. 
Velmi stručně řečeno - je důležité si uvědomit, že nervová soustava člověka je plastická jen po určitou dobu. Tato plasticita nervové soustavy zajištuje, že si určité dovednosti a znalosti můžeme vštípit v určitém období celkem snadno a rychle. Mimo toto kritické období však bude učební proces probíhat velmi pomalu, těžkopádně, popřípadě vůbec. Plasticita nervové soustavy pro každou oblast totiž v určitém období mizí, a tak nastává moment, kdy už se žák danou věc nenaučí, popř́ípadě se ji naučí jen s krátkodobým efektem (ve velmi krátké době dojde k naprosté ztrátě znalostí v rámci procesu zapomínání). Velice dobře můžeme sledovat tento proces $\mathrm{v}$ oblasti pravopisu.

Veřejnost stále intenzivněji uplatňuje vůči škole výhrady, které pramení jednak z neznalosti, jednak z nedostatečné komunikace školy s rodiči žáků. Výsledkem toho jsou dva trendy - nepřetěžovat žáky a vyřadit učivo pro život „nepotřebné“. Veřejnost a bohužel i mnozí pedagogové si neuvědomují, že omezení aktivit nervové soustavy vede $\mathrm{k}$ jejímu nedostatečnému rozvoji. Mozek potřebuje být po celý život zatěžován - jednak proto, aby se v rámci svých možností rozvíjel, jednak proto, aby ztráta mentálních schopností nastávala postupně a trvala co nejdéle.

Nedostatečná zátěž na jednotlivá centra mozku omezuje rozvoj dítěte, ale také jeho celkovou odolnost (snižuje frustrační toleranci). V životě, kromě toho že je pak dítě znalostně omezené, je i méně adaptabilní a snese menší psychickou zátěž, propadá rychleji do depresí (stav narůstajících psychických onemocnění $\mathrm{v}$ důsledku snižující se frustrační tolerance ve společnosti je evidentní).

Vrat'me se k pravopisu, ten trpí druhým ze jmenovaných trendi̊, a to snahou zapovědět ho jako nepotřebný. Není to jen široká veřejnost, nýbrž i „odborníci“, kteří se snaží najít nové způsoby, 
jak tuto učební oblast „inovovat“, ale právě jejich neznalost v oblasti psychomotorického vývoje dítěte vede $\mathrm{k}$ tomu, že v podstatě znalost pravopisu u široké populace likvidují. Přitom je patrné, že pozdní učení pravopisným jevům nevede $\mathrm{k}$ jejich trvalému osvojení. Pro pravopisnou stránku písemného projevu je důležitých několik oblastí mozku; jednou z nejdůležitějších je oblast zrakové paměti. $\mathrm{V}$ dospělé populaci je běžné, že se setkáme s tím, že dotyčná osoba už nezná žádné pravopisné poučky (pravidla), ale přesto píše bezchybně. Na druhou stranu vidíme neblahý trend u osob, které absolvovaly základní školu v posledních deseti, patnácti letech: autor textu se úporně snaží napsat text bezchybně, ale přestože si připomíná různé poučky, vyskytnou se v jeho textu mnohé naprosto základní chyby. ${ }^{45}$ Důvodem jistě není hloupnutí mladé generace, nýbrž nedůslednost pedagogů při nácviku pravopisu, nerespektování kritických období při jeho osvojování, a zejména uplatňování chaotických, někdy rádoby moderních metod, které nerespektují vývoj mozku v oblasti zrakové paměti, mechanické paměti, v oblasti řečového vývoje včetně rozvoje jazykového citu a potřeby mozku ukládat si informace ve struktuře.

Moderní, takzvaná „provázanost informací za každou cenu“ nevychází z neurovědeckých poznatků a nerespektuje potřeby mozku při tvorbě synapsí mezi nervovými buňkami. Výsledkem jsou teorie o potřebě provázanosti učiva „všeho se vším“, přičemž žádný výzkum neprokazuje, že by se všeobecné znalosti tímto způsobem zlepšily. Právě naopak. Mozek dítěte primárně potřebuje informace strukturovat (škoda, že se struktura prosazuje jen u dětí s autismem, kde mimochodem není prokazatelným pomocníkem, ale pouze berličkou k tomu, aby se dalo s takovými žáky vůbec pracovat) a teprve poté je možné dávat je do souvislostí - i tento proces musí být ale postupný, smysluplný, a nikoliv

\footnotetext{
${ }^{45}$ Viz zde dotazníkové šetření $\mathrm{H}$. Chýlové zaměřené na postoje studentů bohemistiky k vybraným jevům kodifikace, s. 151.
} 
náhodný, jak se to běžně děje. Také zmíněné souvislosti by měly být strukturované, měli bychom v nich nacházet logiku, rovněž veškerá aplikace poznatků by měla být systémová (viz Friederici 2017). Toto však současnému školství chybí a mnohé „moderní, „nové“ přístupy to nejen nerespektují, nýbrž to i výslovně zavrhují (znovu lze jen podotknout, že to je pouze známka naprosté neznalosti vývoje CNS).

\section{Grafomotorika}

Předešlý výklad nám připravil půdu pro to, abychom mohli konstatovat, že současný trend omezit rukou psaný projev, je pro vývoj dítěte nevýhodný. Veškeré motorické procesy souvisejí s rozvojem myšlení a řeči. Žádné tukání do klávesnice nemůže vynahradit plnohodnotný pohyb ruky s psacím náčiním. Rovněž tolerance psaní písmem „tiskacím“ rozvoji mozku neprospívá. Princip syntézy, který se postupně rozvíjí ve všech dílčích oblastech (od oblasti zrakové přes sluchovou až po syntézu v logickém a abstraktním myšlení), se uplatňuje rovněž v grafomotorice a při psaní vázaným písmem. Psaní pomocí nespojených písmen nepodporuje rozvoj syntézy v mozku. Tyto deficity se pak projevují v dalších oblastech myšlení, kde je potřeba principy syntézy aplikovat.

Základem psaní je grafomotorický vývoj (srov. Nováková 2019), který je přímo úměrný kvalitě a rychlosti vývoje hrubé a jemné motoriky. Sám o sobě pak podporuje dokončení vývoje jemné motoriky, čímž se stává podpůrným prostředkem pro rozvoj oromotoriky - tedy motoriky mluvidel (blíže viz Kejklíčková 2018 s. 30-38; Šimíčková Čížková 2005). Včasný a kvalitní vývoj oromotoriky pak souvisí s celkovým rozvojem řeči. To ale neznamená, že jedinec s dobře rozvinutou oromotorikou má zajištěn 
správný vývoj řeči. Vztah je přesně opačný - dítě s nedostatečným vývojem oromotoriky vykazuje opožděný vývoj řeči. Řeč je úzce provázaná s rozvojem myšlení (Morales 2006; Gangale 2004). Naším cílem však není zkoumat, zda je ve vývoji primární myšlení, nebo řeč. Bereme jako fakt, že jsou dané oblasti provázané a jedna bez druhé se nemůže plnohodnotně rozvíjet.

U opožděného vývoje řeči se $\mathrm{v}$ jeho prvopočátcích zpravidla neuvažuje o opožděném vývoji myšlení. Děti obvykle vykazují standardní výkony v neverbálních činnostech a předpokládá se, že se vývoj rozběhne a normy bude nakonec dosaženo. Sledovat úroveň rozvoje myšlení je navíc velmi obtížné u dětí s opožděným vývojem řeči. Přestože se však jeho opoždění nedá prokázat, či se o to diagnostika obvykle nesnaží (není-li podezření na mentální retardaci, není důvod taková vyšetření provádět), lze předpokládat, že k těmto opožděním dochází, jen se v této fázi nezjištují. Norma je navíc poměrně široká a nezohledňuje individuální vývoj dítěte. Celkově však můžeme přistoupit k problému tak, že k opožděním v myšlení dochází (to, že se nesledují, neznamená, že neexistují).

Pokud se dítě opožduje $\mathrm{v}$ řeči a myšlení, nacházíme takřka vždy opoždění ve sluchové oblasti - konkrétně ve sluchové analýze a syntéze a rovněž ve sluchové diferenciaci. Tyto dílčí oblasti sluchového vnímání jsou však nezbytné pro nácvik techniky psaní, nebơ fonému musí být přiřazen grafém. Pokud ho dítě nedokáže přesně diferencovat a identifikovat, nemá „zvuk“, který by si mohl $s$ grafémem spojit. Učí se pak mechanicky psát celá slova, píše vlastně pamětově, aniž by se řídilo tím, co slyší.

To, co dítě sluchem analyzuje, opět při psaní syntetizuje - tedy $\mathrm{v}$ př́padě, že píše vázaným písmem. Napsaný celek mu musí dávat smysl, a to na úrovni slabiky (máme na mysli jednoslabičná slova, 
popř. počátky slov), slov i vět - hovoříme o primárním psaní s porozuměním. Pokud budeme žádat v pozdějším věku samostatné psané projevy, pak již ve fázi nácviku techniky psaní je nutné akcentovat význam opisovaných či přepisovaných jednotek.

V souhrnu můžeme říci, že pro pozdější rozvoj tvưrčího psaní je důležitý vývoj v takových oblastech, které na první pohled mohou působit vzdáleně. Související je jednak vývoj hrubé a jemné motoriky, které podporují rozvoj grafomotoriky i rozvoj motoriky mluvidel; dále rozvoj grafomotoriky a kresby ${ }^{46}$ (která stimuluje rozvoj grafomotoriky), jež podporují rozvoj mluvidel a tím i řečových dovedností; a dále pak úroveň rozvoje řečových schopností a myšlení (Fábianová 2014). K tomu všemu se pak připojuje nácvik techniky psaní, jenž v sobě zahrnuje jednak primární vývoj psaní s porozuměním, jednak podporu rozvoje myšlení, přičemž sekundárně se tím podporuje i vývoj řečových schopností ${ }^{47}$.

\section{Výzkumné šetření}

Protože jsme si vědomi důležitosti grafomotorického vývoje pro pozdější dovednost samostatného psaní, věnujeme se sledování grafomotoriky u dětí před vstupem do 1. ročníku základní školy a v 1. ročníku základní školy již řadu let. Kromě toho nás zajímá také způsob, jakým učitelé rozvíjejí grafomotorické schopnosti dětí v průběhu 1. ročníku základní školy. Veškerá cílená pozorování byla provedena $\mathrm{v}$ mateřských a základních školách Plzeňského

\footnotetext{
${ }^{46}$ Počáteční vývoj kresby a vývoj grafomotorických schopností se překrývají. I v předškolním věku ještě platí, že kresba podporuje rozvoj grafomotoriky a nácvik grafomotoriky podporuje rozvoj kresby. Kresba patř́ také mezi aktivity, jež rozvíjejí jemnou motoriku, čímž se podílí i na rozvoji oromotoriky. Vliv na rozvoj řeči má i v jiném ohledu - o svém obrázku děti rády hovoří, často i ty málomluvné.

${ }^{47} \mathrm{U}$ některých druhů narušené komunikační schopnosti se řečový vývoj významně posune dokonce až v souvislosti s nácvikem čtení a psaní.
} 
kraje v průběhu posledních sedmi let. Sledovat práci učitelů je časově náročné, avšak je to objektivnější než využití dotazníku, $\mathrm{v}$ němž mají učitelé tendenci uvádět to, jak by se měla činnost provádět, než to, jak ji skutečně realizují. Vyloučit nelze ani možnost, že někdo nemusí otázkám v dotazníku rozumět a jeho odpovědi jsou pak výrazně zkreslené.

Pro potřeby naší stati jsme využili data zjištěná při vyšetření grafomotoriky u 250 intaktních dětí (které skutečně nastoupily $\mathrm{v}$ daném kalendářním roce do 1 . ročníku ZŠ) a při pozorování 40 pedagogů základních škol.

Při (speciálně)pedagogickém vyšetření byly u dětí sledovány následující projevy:

a) pohyb v ramenním kloubu,

b) pohyb v zápěstí (pomocí teček),

c) čára vertikální a horizontální,

d) kruhový pohyb (kružnice, směr vlevo i vpravo),

e) ovál (směr vlevo i vpravo),

f) kličky (horní i dolní),

g) kresba (omalovánka). (srov. Bednářová, Šmardová 2015;

Dvořák 2003, s. 110-114)

\section{Diagnostika dětí}

a) Rozsah pohybu v ramenním kloubu vypovídá o úrovni rozvoje hrubé motoriky. Nedostatečný vývoj v oblasti hrubé motoriky vždy vykazuje odlišnosti v pohybech velkých kloubů. Jak psaní, tak i kresba vycházejí právě z ramenního kloubu. 
Sledované děti nejevily na první pohled žádné nedostatky v pohybu - hodily míčkem, přelezly překážku, přešly po obrácené lavičce (ač některé s obtížemi, udržet rovnováhu bylo pro mnohé náročné), poskočily na jedné noze atd. Při provádění zadaného cviku však měla většina $\mathrm{z}$ nich potíže. Úkolem bylo točit ramenem na jednu stranu, pak na druhou a poté provést cvik druhým ramenem. Pohyb měl být zcela minimální, k čemuž posloužila představa mince - ramenem měly být prováděny kroužky o velikosti desetikoruny. Cvičící ruka měla viset volně, bez jakéhokoliv napětí. Děti cvičily bez zrakové opory (zrcadlo nebylo povoleno). Provést cvik správně a bez dopomoci svedlo pouhých $10 \%$ dětí. Nejčastěji se objevovaly trhavé pohyby ramenem, zapojení druhého ramene, neschopnost udržet směr, neschopnost provést krouživý pohyb (prováděny byly pouze libovolné pohyby všemi směry), zvedání či pokrčení ruky, zapojení celého trupu (kroucení), poskakování na místě. Při dopomoci (užití zrcadla, pohybu ramene s vedením - $\mathrm{k}$ rameni položil pedagog ruku, pokrčení ruky v lokti - hra na mašinku, rytmizaci) se výsledky u většiny zlepšily.

Výsledky zjištěné při sledování uvolňování ramenního kloubu a rozsahu jeho pohybu souvisely nejen s nedostatečným rozvojem hrubé motoriky, ale také s nedostatečným rozvíjením kresby, a to zejména $\mathrm{v}$ počátečních obdobích jejího vývoje. Pravděpodobně totiž v období mezi dvanáctým až osmnáctým měsícem věku nedostávaly tyto děti dostatečné množství podnětů k rozvoji počátečních kresebných schopností. V tomto období může být kresba realizována vsedě u stolku, na čtvrtku (u papíru často dochází k protržení) pomocí pastelky, voskovky, štětcem apod. Může ale probíhat i na zemi, úspěšně lze využít prstové barvy. Nanášení libovolné barvy v libovolném množství bez potřeby něco kresbou vyjádřit je důležitý mezník ve vývoji kresby. $Z$ reakcí rodičů obvykle vyplývá, že v tak raném období dítě nemělo o kresbu zájem. 
Faktem ale je, že dítě nemůže mít zájem, pokud mu ji nenabídneme. Rané seznámení s kresbou se častěji objevuje u dětí, které navštěvují libovolnou dětskou skupinu (tam se totiž zabavení dětí pomocí kresby objevuje častěji než v domácím prostředí).

Ramenní kloub potřebuje být poměrně dlouho stimulován pouhým čmáráním na velký formát papíru (min. o velikosti A3); jedná se o diagonální pohyb, obvykle „půlkruhový“, popřípadě rovný. Ruka dítěte intenzivně čmárá nahoru a dolů, a rozvíjí tak jednak pohyb pro pozdější vertikální čáru (mnohem později i čáru horizontální), jednak pohyb pro pozdější kruh. V mateřských i základních školách jsme sledovali, že děti už nedostávají př́ležitost tento pohyb provádět - není totiž považován za kresbu a je zavrhován jako zbytečné počmárání papíru. Rovněž kresba na malé formáty papíru nevede k rozvoji potřebného pohybu. Nedostatečná stimulace $\mathrm{v}$ raném období a nedostatek př́ležitostí provádět pohyb později se neblaze projeví v předškolním věku, kdy se dítě nedokáže z grafomotorického prvku kruhu posunout k oválu (jeho nezbytnost pro nácvik psaní písmen je přiblížena níže).

b) Pohyb zápěstí jsme sledovali na jednoduchém cviku - psaní teček. Formát papíru nemusí být velký, pohyb totiž vychází ze zápěstí, přičemž ruka by měla být po celou dobu podložena (předloktí položeno na desce stolu). Tento cvik běžně provádějí žáci 1. ročníku základní školy při výuce psaní. Při grafomotorickém vývoji dochází samozřejmě v prvních fázích $\mathrm{k}$ tomu, že i tento pohyb vychází z ramenního a loketního kloubu, avšak v období 1. ročníku už se jedná o cílený nácvik pohybu vycházející z kloubu v zápěstí. Při diagnostice tohoto pohybu se potvrdil předpoklad, že žáci nebudou vědět, jak pohyb provádět. Přestože i předškoláci by již měli mít ruku podloženou a provádět cvik jen v rozsahu pohybu zápěstí, ani předškolní ani školní děti neprováděly při našich dlouhodobých sledováních cvik správně. Hospitace ve 
třídách prokázaly známou skutečnost, že pokud není v pracovním listě vymezen malý prostor na tvorbu teček, píši žáci tečky na celý list (obvykle o velikosti A4). V podstatě se jedná o jakési bodání do celé plochy papíru (v extrémním př́ípadě i se změnou úchopu na pěstový).

Při předvedení správného postavení ruky došlo u všech sledovaných dětí $\mathrm{k}$ pozitivní změně pohybu, přičemž už žádné $\mathrm{z}$ dětí nemělo potřebu měnit svůj zažitý úchop psacího náčiní (nehodnotíme, že se často jednalo o nekorektní či neustálený úchop). Avšak ani s touto dopomocí nebyly děti schopny provádět pohyb skutečně správně - provedení odpovídalo bud' jen pohybu ruky nahoru dolů, anebo s přidáním malého posunu do stran (tukání do kroužku). Plný rozsah pohybu v kloubu nevyužilo ani jedno $z$ dětí. Pokud se však děti nebudou namáhat zvětšit rozsah pohybu, nijak se ve vývoji neposunou - budou opakovat jen to, co už dávno umějí. Nedostatečně rozvinutý pohyb v zápěstí komplikuje psaní složitějších písmen (např. $f$ ), vázání písmen do slov, doplňování diakritických znamének nad písmena i tah ruky po papíre.

c) Při prováděné diagnostice děti považovaly psaní vertikální a horizontální čáry za nejjednodušší prvek. Vertikální čáru zvládly všechny děti, rozdíly byly v jejím provedení. Nejjednodušší byla volná tvorba čáry shora dolů, obtížnější už přerušovaná čára ( $v$ takovém okamžiku se mění i přítlak - ruka se nadzvedne a znovu přitlačí, což už je samo o sobě náročnější; děti neumějí př́liš pracovat $s$ př́itlakem na psací náčiní a často ho nemají vůbec pod kontrolou).

Horizontální čáru na velký formát papíru zvládla zhruba polovina dětí. Pokud bychom vyžadovali bezvadné a opakované provedení (tvorba dlouhých vodorovných čar bez zakřivení s posunem ruky po papíře směrem dolů, tj. psaní čar pod sebe), pak bychom se 
v podstatě žádného kladného výsledku nedobrali. Děti, jejichž výkon byl hodnocen negativně, obvykle významně zakřivily čáru, nedopsaly čáru do konce listu, měly nápadný rozdíl v přítlaku v jednotlivých částech čáry, popř. byla čára sotva viditelná, anebo vůbec nedokázaly čáru nakreslit (otočily si papír, vytvořily vertikální čáru a pak otočily papír nazpět).

Neschopnost tvorby horizontální čáry komplikuje při pozdějším psaní do písanek tah ruky po papíře, žáci mohou mít písmo deformované, ovšem vždy je psaní zhuštěné. Pozorování ve školách prokázalo nedostatečný nácvik tohoto pohybu, cvik byl navíc prováděn na malé formáty (max. A4, ale ani ne přes celou stranu) a měl obvykle formu volné vlnovky, popř. vlnovky v podobě slalomu. Vlnovka sama o sobě není problém, problematické je nedostatečné cílené procvičování po dobu celého 1. ročníku v ZŠ a cvičení na malý formát papíru.

d), e) Psaní kruhu a oválu (tzv. šišky) spolu úzce souvisí. Vývojově vychází ovál z kruhu. Krouživý pohyb je možné dělat po obvodu - tedy kružnici (takové bylo zadání při diagnostice), anebo v celém kruhu (vznikne tzv. klubíčko).

Krouživý pohyb musí být plynulý, rytmický, dostatečně rychlý (ale nikoliv překotný), přičemž se provádí kroužením na obě strany (po určitém časovém úseku se změní směr). Kruh musí zabrat co největší plochu papíru, ale nesmí se přetahovat mimo list papíru. Všechny sledované děti prováděly krouživý pohyb; rozdíly byly v umístění na listu, velikosti tvaru, a zejména $\mathrm{v}$ pečlivosti provedení tvaru - v některých případech byla dráha kružnice natolik široká a nejistá, že se dalo o kružnici těžko hovořit (provedení se blížilo klubíčku). Některé děti nedokázaly zrychlit pohyb, poprrípadě nebyl pravidelný, jiné naopak postupně zrychlovaly a odbývaly provádění cviku. 
Celkově lze ale konstatovat, že všechny děti prováděly krouživý pohyb, byt' v rozdílné a někdy nedostatečné kvalitě.

Provedení oválu je obdobné jako u kruhu, náročnější je však umístění na listu. Často dochází k přetahování přes okraj papíru v horní či dolní části oválu. Velikost a umístění oválu jsou velmi důležité, lze z toho diagnostikovat zorné pole dítěte a úroveň jeho vizuomotoriky (tj. koordinace ruky a oka při psaní).

Přestože je pohyb po oválu obdobný pohybu po kruhu, nedozraje-li primární krouživý pohyb, nedokáže dítě ovál vytvořit. Ovál v patřičné kvalitě - tedy přes celou stranu A5 (používá se formát A4 na šířku), bez přetahování, prováděný adekvátně rychle a pravidelně (rytmicky), s plynulým obratem při změně směru - jsme nenalezli u žádného dítěte. $U$ třetiny $\mathrm{z}$ nich bylo evidentní, že potřebují ještě docvičit kruh (k oválu u nich vývoj ještě nedospěl) u dalších dvou třetin byl ovál teprve ve vývoji, tj. vyzrával.

Kruh i ovál se musí cvičit po delší čas na větším formátu papíru, a protože $\mathrm{k}$ tomu nemají děti dostatek příležitostí, nedochází k potřebnému včasnému vyzrávání těchto grafomotorických schopností. Z oválu se však vyvíjejí další grafomotorické prvky - kličky a vratné oblouky, z nichž jsou tvořena písmena. Zpomalení vývoje grafomotoriky $\mathrm{v}$ předškolním období vede ke komplikovanějšímu nácviku písmen, jež jsou tvořena právě těmito prvky.

f) Psaní kliček se obvykle testuje při zápisu do 1. ročníku základní školy. Pokud se tak skutečně děje, nemělo by to být samoúčelné. Sledovat by se mělo jednak provedení kliček a rovněž to, zda dítě píše oba druhy - tj. kličky horní i dolní. 
Při našem sledování psaly kličky všechny děti, převážná většina dokonce zvládla napodobit oba typy kliček. Při spontánním projevu, kdy bylo možno umístit kličky do kresby (v podobě kouře z komína), však využilo kličky jen cca 60 \% dětí. Tento rozdílný výsledek je vcelku zarážející. Všeobecně se předpokládá, že pokud dítě zvládne kličku napsat, pak ji spontánně využívá, nebot' je na daném vývojovém stupni a neuplatňuje jednodušší grafomotorický projev, totiž vlnovku.

Chceme-li zjistit, v čem tkví tento rozdíl, musíme se zaměřit na provedení kliček napsaných podle vzoru. U dětí, které spontánně nepsaly kličky (a to ani jeden typ), se ukázalo, že jejich kličky tvořené nápodobou vykazují specifické rysy - kromě těžkopádného a nepřesného provedení či překrývání jednotlivých kliček vedlejšími (což svědčí o nedostatečném tahu ruky po papíře) se kličky podobaly spíše spojeným šiškám či kruhům. Zejména v horních kličkách se zobrazovalo překřížení takřka na (pomyslné) dolní lince, což naznačovalo nezralost tvaru oválu. U dolních kliček, které celkově vykazovaly horší provedení (u všech dětí), se pak opakovalo překřížení na (pomyslné) horní lince a tvary podobné kruhům, což ukazovalo jednak na nezralost tvaru oválu, jednak na ještě probíhající zrání kruhu.

Vzhledem k tomu, že pozdějším umístěním kliček do liniatury, čímž je stanovena přesná velikost a přesný tvar, se dospěje až ke konkrétním písmenům, je potřeba, aby nácvik kliček proběhl intenzivně, nebot to $\mathrm{v}$ dalším období ovlivní tvary mnoha písmen. Pokud však nedozrála úroveň oválu, či dokonce ani kruhu, nemůžeme pouhým nácvikem kliček získat kýžený výsledek, tj. rychlé zlepšení daného grafomotorického projevu. Navíc vyzrávání grafomotoriky u psaní kliček vede ke zrychlení daného pohybu a k rozvoji dalšího vývojového stadia - $\mathrm{k}$ rozvoji vratných oblouků (dolního a horního). Vazba kruh - ovál - klička - oblouk 
je tak významná pro celý proces psaní písmen. Z daných prvků se př́mo utvářejí písmena: $l, e, i, u$ (pro horní kličku a dolní oblouk); $m, n$ (pro dolní kličku a horní oblouk).

Nejčastější chybou, jíž jsme byli svědky při nácviku kliček v 1. ročníku základní školy, bylo nedostatečné cvičení obou kliček (upřednostňována byla jen horní klička, dolní byla cvičena minimálně, či vůbec), cvičení kliček ve velmi krátkém období a chápání kličky pouze jako prvku písma, z něhož se vytvářejí písmena $l$ a $e$ (v takových případech byla cvičena horní klička jen před nácvikem psaní těchto písmen). Ani jeden z pedagogů si neuvědomoval vztah mezi oválem, kličkou, obloukem a utvořenými písmeny (viz výše) z těchto tvarů. Bez pochopení patřičných souvislostí však nemůže pedagog nabídnout dítěti adekvátní postup nácviku a rovněž nemůže být schopen provést diagnostiku psaného projevu dítěte, natož nastavit další postup, jenž by vedl $\mathrm{k}$ posunu žáka $\mathrm{v}$ jeho grafomotorickém vývoji.

g) Poslední část diagnostiky tvořila kresba. Jednalo se o omalovánku s drobnými prvky. Zvolili jsme ji proto, že jsme jednak chtěli zakončit práci s dítětem pozitivně, děti to bavilo a braly to většinou ${ }^{48}$ jako odměnu (spontánní kresbu některé děti nerady provádějí), a jednak jsme chtěli zjistit alespoň orientačně, jaká je úroveň vizuomotoriky u těchto dětí (spontánní kresba nemusí vizuomotoriku zobrazit).

Výsledky nepřekvapily - úroveň celkově nebyla nijak vysoká, všechny děti by měly mít $\mathrm{v}$ daném období vizuomotoriku mnohem zralejší. Nakonec učitelé se stále potýkají s tím, že musí při psaní děti upozorňovat, aby nepřetahovaly, aby nepsaly pod linku, aby „neskákaly“ nad linku atd. Jednoznačně se ukázalo, že

\footnotetext{
${ }^{48}$ Pokud některé z dětí nerado vybarvovalo, nemuselo činnost dokončit. Stačilo vybarvit několik málo prvků, za což byly tyto děti očividně vděčné.
} 
pečlivější (ale i pomalejší) v provádění tohoto úkoly byly dívky, zatímco chlapci měli velké problémy při vybarvování nejen velmi drobných, ale i větších úseků.

Je však potřeba zdůraznit, že nácviku vizuomotoriky se nevěnoval žádný z učitelů. Problém neřešili, protože byli přesvědčeni, že se všechny děti nakonec naučí „nějak“ psát do liniatury a že se to časem zlepšuje. Samozřejmě že psaním do liniatury se také současně cvičí i vizuomotorika, ale kvalitní a dlouhodobý nácvik vizuomotoriky na cvičných materiálech jednak její vývoj uspíší, jednak se vývoj dostane v mnohých př́padech mnohem dál (i zde platí, že nervová soustava je plastická jen po určitou dobu, a tak pozdní nácvik vizuomotoriky už nenese valné výsledky).

\section{Pozorování výuky, rozhovor s pedagogy}

Další část výzkumu byla zaměřena na pedagogy. Při cíleném sledování pedagogů základních škol bylo využito nejen metody pozorování, ale také rozhovoru. Ten měl dle potřeb volnou či řízenou podobu. $\mathrm{V}$ jeho průběhu padla řada otázek, mimo jiné i otázky cíleně se zaměřující na grafomotoriku. Pedagog, alespoň se tak domníváme, nemohl vědět, že jsou některé otázky cílené, odpovědi zaznamenány, a tak neměl důvod údaje měnit.

Pozorování jsme prováděli při rozmanitých př́ležitostech. Bud' si nás pedagog pozval sám - nejčastějším důvodem byl vstup nového žáka s podpůrnými opatřeními do 1 . ročníku ZŠ, kde se stal pedagog třídním učitelem (a žádal rady, jak s ním pracovat). Nebo proběhla standardní kontrola uplatňování podpůrných opatření u žáků přímo $\mathrm{v}$ konkrétní škole. $\mathrm{V}$ obou případech probíhají hospitace ve třídě po libovolně dlouhou dobu a rozhovory s pedagogy tak, aby došlo k uspokojení jejich požadavků či 
k možnému zhodnocení zjištovaných dat při prováděné kontrole. Toho jsme využili $\mathrm{k}$ našemu cílenému pozorování a př́ípadným rozhovorům.

Všech 40 pedagogů mělo minimálně pětiletou praxi, dokonce tři čtvrtiny učitelů praxi delší než deset let. Nebylo zjištováno, zda jsou všichni kvalifikovaní (pravděpodobně nikoliv), ale rozhodně patřili ke zkušenějším - v prvních třech ročnících základní školy totiž ředitel obvykle ponechává pedagogy s delší praxí.

Všech 40 pedagog ${ }^{49}$ se shodlo na tom, že připravenost dětí z hlediska grafomotoriky klesá. Jednak upozorňovali na časté nekorektní úchopy (to však není obsahem naší stati, a tak se zjištěným datům nebudeme věnovat), jednak, a to především, na nevýkonnost a neobratnost při provádění grafomotorických cvičení v průběhu prvního ročníku. Pod nevýkonností si představovali neschopnost provádět grafomotorické cviky po delší dobu (vinou narůstající nepozornosti), roztržitost, zpomalování tempa, nedokončování úkolu atd. Jako neobratnost pak popisovali nekvalitně prováděné grafomotorické cviky, s chybami a rozličnými nedostatky (bud'v zadaném tvaru, nebo v jeho velikosti, popř. v obojím).

Při pozorování výuky (nakonec to vyplynulo i z vyšetření dětí) se potvrdila zkušenost učitelů, že úroveň grafomotorických schopností a dovedností u dětí celkově klesá. Nedostatky popisované učiteli se skutečně vyskytují v hojné či převážné míře, dospěli jsme však ještě k dalším postřehům. Řada grafomotorických cviků není prováděna $\mathrm{v} 1$. ročníku správně a dostatečně intenzivně. Pedagog zpravidla vůbec neví, proč cvik provádí a na co daný

\footnotetext{
${ }^{49}$ Zajímavé je, že zhoršení stavu popisují také učitelé s kratší praxí. Bud' vycházeli z porovnání vlastních dětí (což zaručovalo delší časový úsek), anebo z tvrzení starších kolegů.
} 
cvik cílí (obvyklá odpověd’ byla, že „uvolňuje ruku“, což je zcela nedostačující a nevypovídá to o potřebné odbornosti učitelů). Z toho pak ale také plyne tak časté chybné provádění cviků. Rovněž období, kdy se grafomotorické cviky provádějí, bylo ve všech př́padech příliš krátké. $V$ neposlední řadě jsme dospěli ke zjištění, že učitelé se spoléhají na grafomotorické cviky v písankách ${ }^{50}$ a nekontrolují, zda sešit od daného nakladatelství obsahuje vše, co se má s žáky procvičit. A už vưbec nesledují individuální vývoj dítěte, přičemž je evidentní, že se nejedná o výkon, nýbrž o vývoj (a tak diagnostika a v př́padě potřeby nastavení vhodného individuálního postupu je na místě).

Nelze pominout ani fakt, že grafomotorické cviky učitelé běžně klasifikují, což je svým zpo̊sobem absurdní situace. Adekvátní hodnocení je tak vyřešeno známkou (samozřejmě jedničkou) a tím se pro žáka i učitele, ale i rodiče celá věc uzavírá ke všeobecné spokojenosti - to, že zůstala grafomotorika nedostatečně rozvinutá, si v tomto okamžiku nikdo z nich neuvědomuje. Problémy nastanou až při psaní písmen, při jejich navázání do slabik a slov, ${ }^{51}$ popř. při snaze zrychlit psaní. Zajímavé je, že ani v této chvíli učitelé obvykle nezařazují grafomotorické cviky, nýbrž cvičí stále dokola jen psaní písmen (slov či slabik); a pokud se rozhodnou grafomotorické cviky zařadit, považují to za návrat „ke staršímu učivu“ - což je chybný výklad daného problému (který ovšem nebyl správně diagnostikován).

Příčinu nepochopení funkce grafomotoriky, neznalost jejího rozvoje a neschopnost její úroveň u žáka diagnostikovat spatřujeme už v nedostatečné př́pravě budoucích pedagogů na vysoké škole a dále pak v nedostačujícím dalším vzdělávání učitelů či

\footnotetext{
${ }^{50}$ První sešit (někdy neoznačený číslem, pouze většího formátu) je obvykle určen $\mathrm{k}$ rozvoji grafomotoriky.

${ }^{51}$ Zpravidla vázne tah ruky po papíre.
} 
v minimální možnosti poskytnout jim adekvátní supervizi. $\mathrm{Na}$ základních školách mohou učit a opravdu vyučují lidé nekvalifikovaní (kteří si vzdělání teprve doplňují), což je (nejen) pro žáky 1. až 3. ročníku ZŠ zcela nevhodné. Škody napáchané neznalostmi tohoto „učitele“ jsou trvalé a pro další učební proces fatální. Problematické také je, že se pedagogické diagnostice v oblasti čtení a psaní věnuje při přípravě pedagogů málo času, pokud vůbec. Diagnostiku v této oblasti by měl vyučovat zkušený diagnostik, nikoliv pouhý teoretik, a to v semestru, který následuje po období, kdy posluchači úspěšně absolvovali didaktiku čtení a psaní. Zajištěn by měl být přístup do škol (nejlépe fakultních), a to v malých skupinách ( 3 až 5 studentů). V podstatě individuální prríprava budoucích pedagogů se vyplatí, nebot' to je jediný způsob, jak lze studenta kvalitně připravit na učitelskou profesi.

Studium oboru učitelství by nemělo být jen pouhým studiem na vysoké škole, nýbrž by mělo být skutečnou prrípravou na povolání, které je nesmírně náročné a vyžaduje hluboké znalosti a rozbory sledované praxe ještě před tím, než bude učitel sám vyučovat. Jinak jsme stále na úrovni výuky pokus omyl. Nestačí v učebnách vysoké školy popisovat situace, které nastávají na škole základní (pro niž je student připravován), posluchač je musí vidět, zažít, analyzovat a kriticky hodnotit. K tomu nejsou dostačující souvislé praxe, alespoň u nácviku čtení a psaní je potřeba systematické docházky do základní školy v průběhu jednoho roku v doprovodu odborníka-diagnostika, a to s individuálním přístupem popsaným výše.

Nakonec je vhodné ještě doplnit, že žádný z pedagogů ZŠ nesdílel názor, že by děti byly z hlediska grafomotoriky málo připravované $\mathrm{v}$ mateřských školách či rodinách. To můžeme jen potvrdit $-\mathrm{z}$ jiných dílčích pozorování vyšlo najevo, že grafomotorika je u př̀edškoláků jedna $\mathrm{z}$ nejčastěji stimulovaných oblastí (at’ už 
formou kresby či cílených grafomotorických cviků). Položit před dítě papír a nechat ho kreslit či mu zadat na pracovním listu grafomotorické cvičení je totiž pro pedagoga MŠ i pro rodiče nejjednodušší, není tedy divu, že jsou tyto typy úkolů tak časté, a to nejen $\mathrm{v}$ předškolním věku (myšleno $\mathrm{v}$ posledním roce mateřské školy). Co už však běžné není, je systematická, cílená a smysluplná př́prava dětí v oblasti grafomotoriky - také u pedagogů MŠ shledáváme chaotičnost a nevývojovost při rozvoji grafomotoriky. $\mathrm{V}$ tomto ohledu postupují podobně neodborně jako učitelé na ZŠ.

\section{Shrnutí}

Nedostatečný rozvoj dětí v oblasti hrubé a jemné motoriky vede $\mathrm{k}$ pomalému, těžkopádnému a někdy i disharmonickému vývoji $\mathrm{v}$ oblasti grafomotoriky. Př́čcinu vidíme v jednoznačně nedostatečném pohybu, primárně v oblasti velkých kloubů. Neobeznámenost pedagogů (v mateřských i základních školách) s psychomotorickým vývojem dětí (či jeho nerespektování) pak situaci nijak významně nezlepšuje - grafomotorika se intenzivně cvičí, ale bez patřičného výsledku či jen s malým úspěchem a pomalým průběhem při jejím rozvoji. Jednoznačně je potřeba zlepšit př́ípravu budoucích pedagogů, a to zejména v oblasti diagnostiky (při níž se rovněž aplikují získané odborné poznatky, které si tak posluchač i lépe vštípí a jejichž smysluplnost má možnost si ověřit), přičemž podmínkou by mělo být, že vyučovat v 1 . až 3. ročníku základní školy by měl pouze pedagog s adekvátní kvalifikací (úspěšně absolvovaným magisterským studiem v oboru učitelství pro 1. stupeň základní školy). 


\section{Použitá literatura}

BEDNÁŘOVÁ, Jiřina; ŠMARDOVÁ, Vlasta. Diagnostika dítěte předškolního věku. Brno: Edika, 2015 (2. vydání). 217 s.

DVOŘÁK, Josef. Vývojová verbální dyspraxie. Ždár nad Sázavou: Logopedické centrum, 2003. $144 \mathrm{~s}$.

DYLEVSKÝ, Ivan. Anatomie dítěte. Nipioanatomie. 2. díl. Praha: ČVUT, 2017. $646 \mathrm{~s}$.

FÁBIANOVÁ, Adelaida. Orofaciálna a bazálna stimulácia u detí $s$ psychomotorickým oneskorením $v$ ranom veku. Havlíčkův Brod: Tobiáš, 2014. $160 \mathrm{~s}$.

FRIEDERICI, Angela D. Language in Our Brain : The Origins of a Uniquely Human Capacity. Cambridge, Massachusetts: The MIT Press, 2017. $284 \mathrm{~s}$.

GANGALE, Debra C. Rehabilitace orofaciální oblasti. Praha: Grada, 2004. 232 s.

KEJKLÍČKOVÁ, Ilona. Vady řeči u dětí. Praha: Grada, 2018. 224 s. MORALES, Rodolfo Castillo. Orofaciální regulační terapie. Praha: Portál, 2006. $184 \mathrm{~s}$.

NOVÁKOVÁ, Jaroslava. Prvopočáteční čtení a psaní u žáka se speciálními vzdělávacími potřebami. In ČECHOVÁ, Marie; SPĚVÁČKOVÁ, Martina (eds.). Od praxe $k$ teorii a zpět ve vyučování češtině. ZČU v Plzni: Plzeň, 2019, s. 169-177.

SOLMS, Mark; TURNBULL, Oliver. Mozek a vnitřní svět. Praha: Portál, 2014. $309 \mathrm{~s}$.

ŠIMÍČKOVÁ ČÍŽKOVÁ, Jitka; aj. Přehled vývojové psychologie. Olomouc: UPOL, 2005. $176 \mathrm{~s}$.

VÁGNEROVÁ, Marie. Vývojová psychologie I. Praha: Karolinum, 2005. $468 \mathrm{~s}$. 


\title{
Znalosti vybraných jevů kodifikace studentů bohemistiky a jejich postoje k ní
}

\author{
Helena Chýlová
}

Kapitola vychází z několika podnětů, hlavním byl stav po vydání Pravidel českého pravopisu v roce 1993. V souvislosti s prezentací nové ortografické kodifikace vydané v podobě pravidel pravopisu v politicky rozjitřené době, se otevřely mnohé otázky souvisící s pravopisnou reformou samou nebo s tradičně se opakujícími snahami o zjednodušení jednotlivých jevů českého pravopisu. Nechceme na tomto místě připomínat všeobecně známé skutečnosti spojené s vydáním nových pravidel pravopisu z roku 1993, ale i poměrně dlouho po vydání pravidel pravopisu jsme se s kolegy setkávali s opakovanými dotazy studentů, které byly většinou motivovány nejčastěji určitou kritickou reakcí na novou podobu pravopisné kodifikace, ovšem většinou se týkající jednotlivých slov či jednotlivých jevů. Jedním z nejčastějších byl dotaz na zápis př́pony -ismus/-izmus a na výklad konkurence v užití obou variant.

Zároveň s vydáním pravidel pravopisu (dále PČP) v roce 1993 znovu ožily určité mýty souvisící s pravopisem zejména u laické veřejnosti, ale přežívající také ve školním prostředí, které si studenti ze střední školy přenášeli do vysokoškolského studia. Z reakcí na nová pravopisná pravidla bylo patrné, že je stále živá mylná představa o neustálých pravopisných změnách ${ }^{52}$, které

\footnotetext{
${ }^{52}$ Podrobněji např. ČECHOVÁ, Marie. Řád a chaos v myslích uživatelů češtiny in Život s češtinou: Nomen omen: Češka - češtinářka - Čechová. Praha: Academia, 2017. s. $36-45$
} 
podle názoru pisatelů proběhly $\mathrm{v}$ době, kdy už uživatel jazyka nechodil do školy a nebyl s nimi tedy patřičně seznámen. Znovu se potvrdilo, že znalost a náležitou aplikaci pravopisných pravidel považují uživatelé za prestižní a významnou součást (nejen) jazykové kultury a že pisatelé jsou při hodnocení pravopisných jevů a jejich užívání motivováni často emocionálně (což dodnes silně rezonuje např. $\mathrm{v}$ internetových diskusích a v komentárích jednotlivých jazykových projevů u mnoha mluvčích-pisatelů na sociálních sítích). Opakovaně byl laickými uživateli vznášen požadavek, aby pravopisná úprava směřovala ke zjednodušení a k jednoznačnosti, k existenci jednoduchého a jednoho správného řešení, a z tohoto hlediska byly také mnohdy laickou veřejností kriticky hodnoceny soudobé pravopisné úpravy. Ne ovšem z pohledu uplatňování a př́padné revize pravopisných principů, ale obvykle podle jednotlivých případů zápisu konkrétních slov. Negativně se v názorech laiků projevovala také značná mediální politizace tématu, v níž byla proti sobě stavěna demokratizace společnosti na straně jedné a vnímání kodifikace a ortografické preskripce jako svazování jazyka na straně druhé.

Další dobově zakotvený argument představovalo volání po nutnosti provedení demokratizace jazyka v souladu s postupující demokratizací společnosti; mnohdy tak byly vnímány i pravopisné inovace směřující $\mathrm{k}$ fonetizaci, např. zápis slov kurz nebo diskuze. Antonymní argumentace odmítající uplatňování fonologického principu českého pravopisu naopak chápala zápis cizích slov ve shodě s výslovností jako návaznost na předválečný i poválečný stav nedbalé výslovnosti, např. Vilém Mathesius píše o výslovnosti žrejmě vulgární (1947, s. 115), např. u slov [demogracije] nebo [režizér]. Některé $\mathrm{z}$ těchto mediálně užívaných argumentů se objevily i v názorech našich respondentů. 


\section{Výzkumná sonda}

Cílem dotazníkového šetření v roce 1995, jehož podoba vznikla a realizace proběhla ve spolupráci s kolegyní Ivankou Macháčkovou, bylo zjistit, jaké jsou základní znalosti vybraných jevů kodifikace a postoje studentů bohemistiky $\mathbf{k}$ pravopisu a do jaké míry v průběhu dvou let od vydání nové pravopisné kodifikace studenti ovládli její podobu. Soustředili jsme se na to, jaké znalosti pravopisu si studenti přinášejí ze střední školy (pravopisná úprava z roku 1957 platila s drobnými úpravami 35 let) a zda se v krátkém čase seznámili s podobou nové ortografické kodifikace: to jsme ověřovali formou testových otázek, které obsahovaly i to, zda studenti vědí, že u daného pravopisného jevu došlo podle nových pravidel pravopisu $\mathrm{k}$ inovaci ve srovnání s předchozím stavem.

Jako autoři otázek jsme si uvědomovali, že budeme zjištovat nejen znalosti jednotlivých studentů, ale do značné míry i úspěšnost výuky a přístup $\mathrm{k}$ pravopisnému učivu na středních školách. Předpokládali jsme, že výsledky naší analýzy bude možné využít přímo v přípravě budoucích učitelů českého jazyka a literatury a samozřejmě také pro praxi na nižších stupních škol, nebot’ pravopisné učivo je ve značném rozsahu součástí výuky českého jazyka na všech stupních a typech škol.

Dotazníky jsme zadávali v jednotlivých skupinách osobně, respondenti byli vybráni tak, aby dotazník vyplnili ještě před absolvováním výuky pravopisu na vysoké škole, šetření probíhalo v průběhu zimního semestru v roce 1995. Tento rok byl vybrán záměrně, nebot pravidla pravopisu již byla dva roky po vydání a rok předtím vyšel ve druhém vydání Slovník spisovné češtiny pro školu a veřejnost, do něhož byly nové pravopisné zásady implementovány. Zároveň bylo ministerstvem školství 
zavedení pravidel do školní praxe pozastaveno a došlo k němu až ve školním roce 1994/1995. V roce 1994 byl publikován tzv. Dodatek, který je v akademickém vydání PČP nazván Pravopisná poznámka, jímž se zpřesňují zásady psaní přejatých slov zejména řecko-latinského původu a který přináší značné množství variant. Rok 1994 je tedy možno považovat za významný z hlediska doplňujících pravopisných inovací, s nimiž se studenti stojící před maturitní nebo prrijímací zkouškou na vysokou školu museli seznámit.

Celkem se ankety v roce 1995 zúčastnilo 100 studentů prvního ročníku, z toho 37 studentů studujících Učitelství pro 1. stupeň ZŠ, 33 studentů studujících obor Učitelství českého jazyka $\mathrm{v}$ kombinaci s jiným oborem pro 2. stupeň ZŠ a 30 studentů studujících obor Učitelství českého jazyka v kombinaci s jiným oborem pro střední školu ${ }^{53}$. Bylo zadáno celkem devět otázek.

Inspirací pro zopakování dotazníkového šetření po 25 letech byly vlastní zkušenosti, především z výuky: již více než 12 let vyučuji na Fakultě pedagogické ZČU předmět nazvaný Pravopisný proseminář nejen u rodilých mluvčích, ale koncipovaný také pro mluvčí nerodilé, a pravidelně se také setkávám s učiteli základních i středních škol při různých školeních věnovaných pravopisné problematice. Inspirativní jsou pro mne také dotazy posluchačů v jazykových koutcích Českého rozhlasu Plzeň, v nichž dominuje pravopisná problematika. Dalším inspiračním zdrojem byl pro mne článek Marie Čechové nazvaný Srovnání nesrovnatelného? Znalosti funkční morfologie u žáků před 50 lety a dnešních bohemistů (2018, s. 24an), v němž autorka zjistila, že „současní adepti bohemistiky nejsou uspokojivě připraveni na vysokoškolské studium a ani současní studující

\footnotetext{
${ }^{53}$ Názvy studijních oborů ponecháváme $\mathrm{v}$ původní, dobové formě, proto u sondy z roku 2020 uvádíme názvy studijních programů.
} 
uspokojivě nezvládají morfologickou problematiku“ (tamtéž, s. 32$)^{54}$.

Uvědomujeme si, že článek Marie Čechové přináší poznatky z výuky morfologie češtiny a autorčina zjištění jsou založena na analýze vzorku neporovnatelně většího, než je naše sonda, ale příspěvek prezentoval pro nás základní otázku, zda zopakování naší dotazníkové sondy bude svědčit o zlepšení stavu znalostí pravopisu u vysokoškolských studentů bohemistiky s ohledem na to, že poslední pravidla pravopisu fungují již 27 let. Styčné body můžeme nalézt i v tom, že morfologické i pravopisné problematice byla a je věnována ve výuce jazykové složky mateřského jazyka značná pozornost a obě složky měly a mají (v osnovách a i v platném kurikulu) také značnou časovou dotaci.

Zároveň je třeba konstatovat, že s ohledem na současnou situaci nebylo možno dodržet stejné podmínky zadání dotazníků jako při prvním šetření. Kvůli opatřením zaměřeným proti šíření koronaviru neprobíhala běžná výuka, nebylo tedy možné zadat dotazníky osobně, ale byly zadány bud' prostřednictvím e-mailů v období od března do června 2020 (79 exemplářů), nebo v červnu osobně (21 exemplářů) k vyplnění. Dotazníky byly odeslány ve dvou vlnách tak, aby bylo dosaženo počtu respondentů srovnatelného s předchozí sondou. Výsledky obou šetření uvádíme pro přehlednost u daného dotazu na jednom místě, nejprve zjištění z roku 1995, poté zjištění z roku 2020.

Celkem se ankety v roce 2020 opět zúčastnilo 100 studentů, ale složení vzorku studentů mělo jinou vnitřní strukturu než v 90. letech minulého století: s ohledem na výše zmiňovanou situaci nebylo možné dodržet naprosto shodné podmínky opakování

\footnotetext{
${ }^{54}$ Podobný stav zjistila Marie Čechová i v komparativně pojatém výzkumu zaměřeném na úroveň znalostí frazeologie u mládeže (2012, s. 114-118).
} 
výzkumné sondy. Zcela převažovali studenti studijního programu Učitelství pro 1. stupeň ZŠ: 40 studentů studujících v prvním ročníku, 46 studentů studujících stejný studijní program, ale již v druhém ročníku, 6 studentů studujících program Učitelství českého jazyka pro základní školy a 8 studentů studujících program Učitelství českého jazyka pro střední školy. Povedlo se zopakovat to, aby se dotazníkového šetření zúčastnili studenti před zahájením studia vysokoškolského předmětu zaměřeného na pravopisnou problematiku; pouze u studentů 2. ročníku studujících učitelství 1. stupně ZŠ proběhla před zadáním dotazníku dvakrát kontaktní výuka, od března do června 2020 byl pak předmět vyučován online.

Podoba dotazníku byla shodná, všichni respondenti v šetřeních z roku 1995 i 2020 byli rodilými mluvčími. Studenti v řadě případů přidávali $\mathrm{k}$ jednotlivým odpovědím na dotazy také vlastní hodnocení či komentáře pravopisných jevů, které jsme také využili. Často se jednalo nejen o hodnocení, ale také o jejich osobní postoje.

Vycházeli jsme z předpokladu, že právě učitel by měl dobře vyložit postavení pravopisu ve výuce jazykové složky českého jazyka a literatury a měl by nejen sám ovládat podobu současné ortografické kodifikace, ale měl by umět jednotlivé jevy klasifikovat, zdůvodnit a objasnit. Významným faktorem ve výuce je podle našeho názoru a praktických zkušeností také schopnost a dovednost učitele objasnit funkce pravopisu nejen v jazyce, ale i ve společnosti a vyložit východiska a filozofii současné pravopisné kodifikace.

Ve výběru otázek jsme se soustředili na otázky uzavřené, ověřující znalost jednotlivých pravopisných jevů, a na otázky otevřené, zjištující postoje respondentů $\mathrm{k}$ pravopisu. U uzavřených 
dotazníkových otázek jsme se orientovali na ověřování jevů vývojově progresivních, které byly objektem změn v pravidlech po celé 20 . století: na morfologické varianty substantiv, číslovek a verbálních forem a rod substantiv, na kodifikaci zápisu přejatých slov a jeho varianty, na zápis $s$ a $z$ a délky $\mathrm{v}$ přejatých slovech.

Záměrně jsme kombinovali oba typy otázek a ponechali jsme stranou ověřování znalosti psaní velkých písmen; předpokládali jsme, že tato problematika se projeví v otevřených otázkách. Pozornost jsme nevěnovali také otázkám syntaktického pravopisu, a to zejména ze dvou důvodů: došlo zde k minimu inovací, především pravopisná úprava z roku 1993 posílila kongruenci podle smyslu, a také v této oblasti nemůžeme uvažovat o pravidlech př́mo pravopisných, ale o pravidlech morfosyntaktických a syntaktických, vycházejících z konstruování a spojování syntaktických jednotek.

Změny $\mathrm{v}$ rovině morfologické nejsou $\mathrm{v}$ pravidlech pravopisu komentovány ve výkladové části, nejsou uváděny v souhrnném přehledu (to je předmětem gramatických příruček), uživatel se s nimi seznamuje postupně v pravopisném slovníku. Z vlastní praxe můžeme doložit, že právě na výklad morfologických inovací uvedených v pravopisném slovníku bývají studenti i učitelé nejméně připraveni, nebot' kromě pravidel pravopisu musejí pracovat i se současnou mluvnicí češtiny.

Zařazení morfologických údajů do pravopisného slovníku školního vydání pravidel pravopisu vyplývá podle našeho názoru především z několika aspektů. Ve flektivním jazyce, jako je čeština, není možné oddělit podobu zápisu formy slova od morfosyntaktické funkce v textu, dále morfologický princip českého pravopisu má velmi silnou pozici - již např. Baudouin de Courtenay (Vachek 1933, s. 309) uvažoval o tom, že v češtině je základním pravopisným principem právě princip morfologický místo většinově 
uváděného principu fonologického. A v neposlední řadě může být východiskem také tradiční pojetí pravidel pravopisu, která již od vydání roku 1902 jako Pravidla hledící k českému pravopisu a tvarosloví obsahují s ohledem na název údaje morfologické. ${ }^{55}$ Od začátku 20. století také byla morfologie součástí oddílu pravidel pravopisu s názvem Pravopisná pravidla, dokonce byla zařazena celá kapitola nazvaná $\mathrm{Z}$ tvarosloví. Je třeba dodat, že morfologické údaje byly v pravopisném slovníku postupně, ale značně omezovány, až téměř minimalizovány - od pravopisné reformy v roce 1957 jsou jen ve školním vydání. Toto postupné omezování morfologických informací v pravopisném slovníku souvisí také částečně se skutečností, že na konci 20. století a v současnosti existuje množství gramatických příruček, které se morfologií zabývají, a stávají se tak kromě pravidel pravopisu dalšími možnými zdroji poučení.

Zároveň o frekvenci dotazů z oblasti morfologického pravopisu a o propojení pravopisné a morfologické problematiky v češtině vypovídá také množství dotazů adresovaných jazykové poradně ÚJČ a množství popularizačních příruček, které vyšly na přelomu posledních dvou století a které právě z obou oblastí mívají nejrozsáhlejší kapitoly. Nechceme a ani nemůžeme na tomto místě vypočítávat autory a tituly publikací. V této souvislosti bychom odkázali na Databázi popularizačních knih o češtině56 a také na

\footnotetext{
${ }^{55}$ Pro rodilého mluvčího je uvádění morfologických informací o slově v souvislosti $s$ jeho pravopisem očekávané $s$ ohledem na flektivní charakter češtiny, při výuce zahraničních bohemistů, zejména Neslovanů, se však již více než dvacet let setkávám pravidelně s jejich úžasem nad tím, že ve školní verzi pravidel pravopisu nacházejí údaje morfologické. Pozastavují se nad určitým paradoxem mezi názvem př́ručky a jejím obsahem a dotazují se, zda pravidla pravopisu představují v češtině kombinaci $s$ príručkou mluvnickou.

${ }^{56}$ [cit. 2020-07-02] Dostupné z: https://ucjtk.ff.cuni.cz/veda-a-vyzkum/databazepopularizacnich-knih-o-cestine/. Databáze popularizačních knih o češtině je v elektronické formě umístěna na stránkách Ústavu českého jazyka a teorie komunikace FF UK. Supervizorem databáze je Robert Adam a databáze v současnosti obsahuje 69 titulů.
} 
publikaci Zdroje a cíle jazykové popularizace ${ }^{57}$. Významným zdrojem poučení o podrobněji zaměřených pravopisných otázkách je také rubrika Jazyková poradna v časopise Český jazyk a literatura, jejíž dlouholetou autorkou je pracovnice Ústavu pro jazyk český Ivana Svobodová.

Fakta zjištěná výzkumnou sondou jsme pro lepší praktické využití doplnili v naší studii ještě porovnáním se současným stavem kodifikace a také základními údaji vycházejícími z korpusových dat. Domníváme se, že tak bude možné lépe sledovat nejen vývojové inovace pravopisné kodifikace, ale zároveň i stále se opakující pravopisné nedostatky, kterým je nutné věnovat systémovou pozornost.

Zjištění vycházející z komparativně pojaté dotazníkové sondy jsou následující.

První otázka dotazníku byla nejrozsáhlejší a byla rozdělena do tří podotázek:

a) Který z tvarů uvedeného slova uživáte?

b) Vite, zda jsou podle Pravidel pravopisu považovány oba tvary či více tvarů za správné, nebo zda v něm najdete pouze jeden tvar?

c) Došlo ke změně oproti minulým pravidli̊m?

Použity byly následující prŕíklady ${ }^{58}$ zastupující určitý typ a záměrně neuváděné vždy podle pořadí publikovaného v Pravidlech českého pravopisu. V sondě z roku 2020 jsme vynechali dotaz z původního bodu c), který již neměl význam. Odpovědi u sondy z roku 2020 uvádíme spojitě v bodech a) a b).

${ }^{57}$ SVOBODOVÁ, Jana; SVOBODOVÁ, Diana; GEJGUŠOVÁ, Ivana. Zdroje a cíle jazykové popularizace. Ostrava: Ostravská univerzita, 2010. 143 s.

${ }^{58}$ Odpovědi uvádíme v autentické podobě. Údaje v procentech zaokrouhlujeme. 
Dotazovali jsme se na kodifikované morfologické varianty u konkrétních tvarů záměrně zvolených slov, nejprve na substantiva a číslovky, poté na slovesa.

Všimněme si nejprve substantiv. U nich jsme se nejprve zaměřili na znalost forem frekventovaného typu reprezentujícího kolísání mezi vzory kost a píseň zastoupený slovy pravomoci/pravomoce a velmoci/velmoce (1., 4. a 5. pád pl.). V obou př́ípadech se $83 \%$ studentů shoduje v preferenci tvaru pravomoci a velmoci, $64 \%$ respondentů z celkového počtu uvádí, že „v nových pravidlech pravopisu je uvedena $i$ druhá varianta a pořadí je shodné se zadáním otázky ${ }^{\text {“59. }} 26 \%$ respondentů uvádí, že právě kolísání mezi vzory kost a píseň pro ně představuje obtížnější jev současné pravopisné kodifikace. Tato odpověd' svědčí o nepochopení vztahu mezi morfologií a pravopisem, o špatném zařazení jazykového jevu k dané jazykové rovině, ${ }^{60}$ do jisté míry může být ovlivněna tím, že studenti jsou zvyklí vyhledávat formy ohebných slov také v pravopisném slovníku.

V komparativním srovnání se ukazuje, že pro všechny respondenty $\mathrm{z}$ ankety $\mathrm{v}$ roce 2020 jsou již běžné obě formy, u obou píší, že jsou uvedeny v pravidlech pravopisu, 72 \% respondentů užívá jako neutrální tvar velmoci, pravomoci, 28 \% preferuje druhý tvar v pořadí. O rozkolísanosti jevu a o vývojovém pohybu vypovídají také nejednotně uváděné informace na různých místech $\mathrm{v}$ Internetové jazykové př́ručce (dále IJP), která je pro současné studenty hlavním zdrojem informací o pravopisné a tvarové podobě slov (uvádí to $98 \%$ respondentů v anketě z roku 2020). Např. na prvním místě u vyhledávání jednotlivých slov je uveden jako první

\footnotetext{
${ }^{59}$ Internetová jazyková príručka uvádí, že podle ČNK je stále frekventovanější podoba pravomoci, velmoci. [cit. 2020-07-10] Dostupné z: https://prirucka.ujc.cas.cz/ ?slovo=pravomoci\#bref2.

${ }^{60}$ Srov. M. Spěváčková a J. Vaňková (2019, s. 84-93).
} 
tabulkový tvar pravomoce, velmoce, ale v obecném poučení ${ }^{61}$ se $\mathrm{v}$ přehledové tabulce uvádí pouze koncovka - $i$, avšak u konkrétních slov jsou v kapitole $2 \mathrm{v}$ bodě 2.1. u slova pravomoc již koncovky obě, ale $\mathrm{v}$ obráceném pořadí, tedy pravomoci, pravomoce, u slova velmoc je pouze $-i$ (velmoci).

Koncovky -i/-e u slova pravomoc uvádí také Marie Čechová (2011, s. 206 $)^{62}$ a stejně i Akademická príručka českého jazyka (dále APČJ), u slova velmoc je v APČJ uvedena pouze koncovka - $i$ (s. 355). Studenti v odpovědi na dotaz, které pravopisné jevy považují za obtížné, uvádějí ve výčtu „kolísání mezi vzory píseň a kost", a to ve $13 \%$.

Jako základní hodnotí dokonce 100 \% respondentů v roce 1995 první variantu také u př́kladu husité/husiti. Zároveň $54 \%$ studentů odpovídá, že v pravidlech je uvedena i druhá varianta a že nedošlo ke změně. Toto zjištění je pro nás poměrně překvapivé, domníváme se, že přesvědčení nadpoloviční většiny studentů o tom, že forma husiti již byla součástí kodifikace od roku 1957, svědčí sice o její značné frekvenci, ale zároveň o neznalosti studentů, nebot̉ v předchozí pravopisné úpravě byla kodifikována jen forma husité.

V odpovědích z roku 2020 označuje většina (81 \%) již obě formy jako rovnocenné, $21 \%$ respondentů vnímá formu husiti jako hovorovou, $16 \%$ respondentů píše, že jim dokonce „vadí uživání této koncovky moderátory ve vysílání veřejnoprávní televize“. Koncovku -i jako hovorovou uvádí i Slovník spisovné češtiny pro školu a veřejnost (dále SSČ) a APČJ. Také v korpusu syn2015 je vyšší frekvence formy husité (67) než formy husiti (8).

\footnotetext{
${ }^{61}$ [cit. 2020-07-10] Dostupné z: https://prirucka.ujc.cas.cz/?slovo=pravomoci\#bref2

${ }^{62}$ Tuto publikaci vybíráme jako jeden ze zdrojů s ohledem na to, že se jedná o př́ručku vydanou ve sledovaném období vícekrát a velmi oblíbenou mezi studenty.
} 
Podotázka věnovaná konkurenci tvarů lokálu pl. o ořeších / o ořechách přináší jednoznačně zjištění, že studenty preferovaná varianta z roku 1995 je o ořechách, užívá ji 89 \% respondentů, zároveň se ve většině př́ípadů (v 69 \%) respondenti domnívají, že je daná forma po změně pravidel pravopisu př́pustná. Ve značné míře se setkáváme s neznalostí kodifikace, ale můžeme sledovat i výrazně se prosazující vývojovou tendenci.

Formu o ořeších uvádí IJP i SSČ jako jedinou, koncovku -ách u daného typu jmen IJP hodnotí jako hovorovou až nespisovnou: „U některých slov se koncovka -ách dosud hodnotí jako hovorová, až nespisovná, ale stanovit pro jednotlivá slova přesnou hranici mezi jejich tvary slohově neutrálními a slohově příznakovými nelze; může se lišit u jednotlivých mluvčích nebo teritoriálně a ani výklad v českých mluvnicích a ve slovnících nemůže být striktní, protože jde o živou tvaroslovnou proměnu. " ${ }^{63}$ Stejně tak se vyjadřuje i Marie Čechová aj.: „do spisovné formy proniká ještě variantní podoba -ách původem od ženského rodu... Hodnotí se často jako příznaková, ale toto hodnocení se stále více stírá, a naopak koncovka -ích se cítí jako knižní..." (2011, s. 197).

S tímto hodnocením se shodují i naše zjištění z roku 2020. Dotazovaní studenti v nadpoloviční většině (v 58 \%) preferují užívání koncovky -ách, ale $45 \%$ z nich uvádí, že v pravidlech je asi koncovka -ích, kterou hodnotí jako knižní (ve $27 \%$ uvádějí hodnocení archaická $)^{64}$. Roli v tomto př́ípadě může hrát i fakt, že v našem vzorku je převaha studujících učitelství pro 1. stupeň ZŠ, kteří mají morfologii již v prvním ročníku studia - tedy studenti

\footnotetext{
${ }^{63}$ [cit. 2020-07-10] Dostupné z: https://prirucka.ujc.cas.cz/?slovo=o \%C5 \%99ech\#bref4 ${ }^{64}$ Mylná záměna termínů archaický a knižní při hodnocení příznaku podle vrstvy slovní zásoby je tradičně a opakovaně jedním z častých nedostatků u vysokoškolských studentů při studiu lexikologie, uvědomujeme si, že se jedná o pojmy, které se mohou kř́žit a jejich zařazení nemusí být jednoznačné. K jejich stabilizaci dochází u studentů obvykle až po absolvování stylistického semináře.
} 
2. ročníku již kursem morfologie prošli a studenti 1. ročníku jej měli souběžně s dobou, v níž vyplňovali dotazníky. Korpusová data uvádějí jako frekventovanější u daného slova koncovku -ích. V korpusu syn2015 je doložena varianta (o) ořeších v 18 výskytech, varianta (o) ořechách má 12 výskytů. Druhá varianta je doložena jen v textech publicistických. APČJ (s. 340) dokládá značnou rozkolísanost daného jevu.

Vedle substantiv jsme věnovali pozornost i číslovkám, nejprve tvarům základní číslovky třech/tři (G. pl.). V odpovědích z roku 1995 jsme zjistili mírnou převahu varianty tř́, 56 \% dotazovaných píše, že ji užívají častěji. O tvaru třech se většina (91\%) domnívá, že je v pravidlech také uvedena, z toho 61 \% neví, zda došlo ke změně.

Jiná situace je však v roce 2020, 86 \% dotazovaných preferuje ve svém projevu variantu třech a také téměř všichni, kteří takto odpovídali (79\%), se domnívají, že tato varianta je stylově bezpříznaková. 11 \% respondentů uvádí, že ,formu třech bychom neměli napsat / je vhodná jen do mluveného projevu“. Ve srovnání s údaji $\mathrm{z}$ předchozího šetření je patrné, že u mladé generace bez ohledu na znalost kodifikace převažuje v současnosti užívání formy třech. IJP označuje tvar třech jako hovorový, SSČ jej nehodnotí, Marie Čechová uvádí, že „z hlediska stylového se varianta třech běžně pokládá za hovorovou“ a pokračuje: „Nelze však automaticky přisoudit hovorovost prostředku jen proto, že byl dříve považován za nespisovný, tvary třech, čtyřech v 2. p. (analogické k tvarům 6. p.) jsou užívány sice řidčeji, ale v různých stylech.“ (2008, s. 14965), v korpusu syn 2015 převažuje stále varianta tř́.

\footnotetext{
${ }^{65} \mathrm{~K}$ stylovému rozlišení není možné použít mluvnici, nebot mluvnice obvykle stylový příznak neuvádějí, citujeme proto v těchto př́ípadech z monografie stylistické.
} 
PČP z roku 1993 přicházejí s výraznou změnou u verbálních tvarů, jsou kodifikovány mnohé frekventovaně užívané tvary variantní. Znalost kodifikace jsme zjištovali především u forem prézentních (1. os. sg. a 3. os. pl. ind. préz. aktiva) a u forem participiálních.

U forem 1. os. sg. ind. préz. aktiva kryju/kryji dokládáme zjištění, že 61 \% respondentů již v roce 1995 se domnívá, že častější je tvar kryju. Domnívají se, že v pravidlech je povolen i tvar kryji, který však označují za knižní, př́padně opět za archaický.

V šetření z roku 2020 je znalost kodifikace v této položce lepší, v $68 \%$ odpovědí je za neutrální tvar uvedený v PČP považováno kryji, za druhý tvar $\mathrm{v}$ pořadí kryju. $31 \%$ respondentů zařazuje formu kryju mezi tvary hovorové. IJP i SSČ kategorizují tvar kryju jako hovorový, Marie Čechová (2008, s. 149) uvádí, že u sloves třetí třídy jsou tvary na - $u$ hodnoceny jako hovorové a jejich postupná stylová neutralizace probíhá rychleji v 1. os. sg. než v 3. os. pl. Korpusová data u tohoto slovesa jsou neprůkazná: kryju (4 výskyty v syn2015) a kryji (3 výskyty v syn2015). Podle našeho názoru jsou výsledky sondy $\mathrm{v}$ tomto bodě výrazně ovlivněny regionálním původem a příslušností pisatelů.

U prézentních variant formy 3. os. pl. ind. prézenta aktiva slovesa souvisejí/souvisí v roce $199588 \%$ respondentů užívá častěji tvar souvisí ${ }^{66}$, ale dotazovaní vědí, že je kodifikovaný i tvar souvisejí. Domnívají se, že nedošlo k žádné změně v kodifikaci. Konkrétně u tohoto slovesa PČP z roku 1958 uvádějí již oba tvary.

${ }^{66}$ Nezjištovali jsme teritoriální původ či prúslušnost respondentů, ale z osobních rozhovorů víme, že kolem 90 \% respondentů pocházelo v obou šetřeních z území historických Čech, kde trvale žili. Tato skutečnost se také projevuje v jejich preferencích. 
V roce 2020 se $91 \%$ respondentů shoduje, že kodifikovány jsou oba tvary bez rozdílu, jen ve $12 \%$ odpovědí je považován tvar souvisejí za stylově vyšší, tedy „vhodný do psaného jazyka, užívaný v odborném stylu, užívaný v rozhlase“. SSČ a také IJP citují jako první v pořadí formu souvisejí, APČJ (s. 465) chápe koncovky -ejí a -í jako stylově rovnocenné. Můžeme tak usuzovat na stabilizované prolínání tvarů, které již v současnosti žádný problém nepřinášejí. Z korpusových dat vyplývá, že frekventovanější je forma souvisí (4645 výskytů v syn2015), souvisejí (694 výskytů tamtéž). Doklady jsou však většinou $\mathrm{z}$ beletrie a publicistických textů.

Konkurence tvarů pišípišou vychází u obou šetření naší sondy velmi podobně jako u předchozího dotazu na prézentní tvar 1. os. sg. Je patrné, jak spolu prézentní formy 1. os. sg. a 3. os. stále úzce souvisejí. 58 \% respondentů v roce 1995 se domnívá, že v PČP je tvar píšou, který také nejfrekventovaněji sami užívají. Druhý tvar pravopisný slovník podle nich obsahuje, „ke změně $v$ tomto př́padě došlo“.

V odpovědích z roku 2020 je poměrně překvapivě u $67 \%$ respondentů za neutrální označen tvar piší, za další / druhý tvar v PČP píšou. $28 \%$ respondentů vnímá formu píši jako „starší; archaičtější; dobově starší; velmi starou; spisovnější; více spisovnou" (ani $\mathrm{v}$ jedné odpovědi není řečeno, s čím autor srovnává). IJP uvádí oba tvary bez rozlišení, v tabulkových tvarech je první píší, opačné pořadí nacházíme v SSČ, v němž je zároveň tvar píši označen za knižní. V korpusových datech je frekventovanější piší (695 výskytů v syn2015), forma pišou vykazuje frekvenci nižší (533 výskyty v syn2015).

PČP v roce 1993 přinášejí také úpravu forem prŕíčestí, vývojový pohyb vykazují především slovesa 2 . třídy typu tisknout a začít. U typu vyňal/vyjmul panuje značná nejistota. Studenti (91\%) 
v roce 1995 odpovídají, že užívají tvar vyjmul, ale nevědí, zda je tvar kodifikovaný, „asi spíše ne“, a nevědí, zda došlo k inovaci v PČP. Tvar označují jako „mluvený, uživaný v řeči, říkám, nevím, jestli to mužu napsat".

V roce 2020 studenti odpovídají, že je možné užít oba tvary (87\%), 96 \% respondentů užívá tvar vyjmul. Tvar vyňal je vnímán jako knižní. Můžeme tak sledovat dobový posun v hodnocení obou tvarů.

IJP uvádí: „Za základní se nadále považují tvary s - $a$-, novotvary $\mathrm{s}$ - $m u$ - pronikají $\mathrm{k}$ jednotlivým slovesům $\mathrm{v}$ různé míře a jejich vžitost je třeba u konkrétních sloves ověřovat ve slovnících. Oba typy tvarů, pokud $\mathrm{k}$ danému slovesu pronikly $\mathrm{v}$ dostatečné míře, jsou dnes považovány za plně spisovné. “67 V korpusu je vyjmul $61 \mathrm{x}$, vyňal $125 \mathrm{x}$.

U variant $t v r d l / t v r d n u l$ z odpovědí v roce 1995 vyplývá, že $76 \%$ respondentů užívá tvar tvrdnul. Zároveň studenti vědí o tom, že kodifikovaný je tvar tvrdl (v 89 \%). Domnívají se, že k žádné změně nedošlo.

V roce 2020 se zvětšuje počet odpovídajících užívajících formu tvrdnul na $88 \%$. O formě $t v r d l$ se $29 \%$ respondentů vyjadřuje jako o „knižní, staré“. V tomto případě se všechny námi sledované př́ručky shodují na pořadí forem $t v r d l$, tvrdnul. Shodují se s tím i korpusová data, ale s malou vypovídací hodnotou, $t v r d l$ se vyskytuje 9x, tvrdnul 6x. Přestože kodifikace stále udržuje ve vztahu ke slovesům typu tisknout stejný přístup, opírající se o historický vývoj češtiny, respondenti vnímají tento stav jako rozkolísaný a preferují tvary ahistorické, analogické.

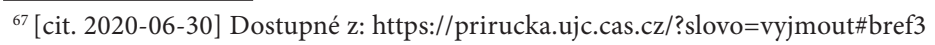


V odpovědích týkajících se ověřování znalosti kodifikace verbálních forem se často objevují vyjádření „nevím, nejsem si jistý; je to velmi rozkolísané; každý tvar musím hledat "68 Výsledky naší sondy prokazují, že studenti ovládají ve větší míře pravopisnou kodifikaci jmen, ale zvládnutí kodifikace variant u slovesných forem může být i pro vysokoškolské studenty, kteří neznají v odpovídající míře vývoj jazyka, složitější. Hlavním problémem není (ne)znalost variant, ale spíše jejich hodnocení.

Dalším jevem, kterému jsme věnovali pozornost, bylo ověření znalostí zápisu přejatých slov. Nejprve jsme se dotazovali na psaní $s$ a $z$ ve frekventovaných slovech přejatých: v sondě z roku 1995 u varianty kurs/kurz byla v 90 \% odpovědí preferována varianta kurs, projevuje se $\mathrm{v}$ tom podle našeho názoru silná návaznost na předchozí stav, $\mathrm{v}$ němž byla kodifikována pouze tato podoba. $73 \%$ respondentů mělo povědomí o změně v PČP, o možnosti užívat také novější variantu.

V roce 2020 je pro respondenty běžnější varianta kurz (86 \% odpovědí), studenti také většinou náležitě považují obě varianty za stylově rovnocenné, téměř třetina (27\%) však uvádí, že kurs je podle nich variantou stylově vyšší. APČJ uvádí kurz/kurs mezi dubletami stylově rovnocennými (s. 107). Korpusová data vypovídají takto: v syn2015 má kurs 6981 výskytů, kurz 1904 výskytů (srov. např. Bermel 2008).

Pro zjištění znalosti zápisu sufixu -ismus/-izmus, jsme zvolili příkladové slovo realismus/realizmus. V tomto prrípadě $97 \%$ respondentů v roce 1995 uvádí jako jimi užívanou variantu realismus, druhou variantu respondenti znají, změnu zápisu si uvědomují, ale neužili by ji, označují ji jako „stylově nižší, mluvenou, hovorovou“. V $10 \%$ případů byla varianta realizmus označena jako

\footnotetext{
${ }^{68}$ Podobně formulované komentáře přidávají respondenti ve $48 \%$ prŕípadů.
} 
„slovakismus“, v 15 \% jako „přizpiosobení se nespisovné výslovnos-

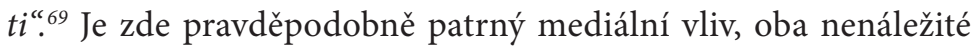
výklady se objevovaly v dobových médiích. ${ }^{70}$

Také v roce 2020 můžeme doložit v naší sondě podobný výsledek, 89 \% studentů preferuje variantu realismus.

V současnosti se v korpusu syn2015 objevuje podoba realismus v 971 výskytech, především v odborných textech; realizmus je doložen čtyřmi výskyty. Obecně př́pona -ismus vykazuje 14892 výskytů, podoba -izmus pouze 375 výskytů. Podle našeho názoru to dokumentuje zřejmou převahu tradičního způsobu zápisu dané prrípony.

Další problémový okruh zápisu přejatých slov tradičně představuje zápis délky samohlásek. V roce 1995 jsme ještě zjištovali u příkladového slova téma i možnost zápisu skupiny th. U slova téma/thema všichni respondenti v roce 1995 uvedli, že užívají pouze podobu téma, jiný možný zápis neznají. Pouze dva respondenti se vyjádřili k podobě thema, hodnotili ji jako ,formu odbornou“ (snad mínili termín), osm respondentů uvedlo jako variantu formu tema bez bližší specifikace. V roce 2020 už $100 \%$ respondentů píše jako jedinou variantu téma.

U konkurence variant tematický/tématický naprostá většina respondentů v roce 1995 konstatovala, že nedošlo k žádné pravopisné úpravě, ale $34 \%$ studentů se domnívalo, že jediná možná podoba slova uvedená v pravidlech pravopisu je tématický.

\footnotetext{
${ }^{69}$ Obě tyto odpovědi vypovídají o neznalosti podstaty daného jevu.

${ }^{70}$ Šlo o dobu zvýšeného nacionalismu, nebot v roce vydání pravidel pravopisu došlo $\mathrm{k}$ rozdělení republiky.
} 
Také v roce 2020 se objevuje ve $41 \%$ (tedy více než v roce 1995) jako jediná varianta tématický. S ohledem na to, že dané slovo je velmi frekventované právě ve školské komunikaci, je užívané např. ve spojení časově-tematický plán nebo tematické kapitoly či tematický celek, bylo toto zjištění poměrně překvapivé. ${ }^{71}$

U zápisu délky $\mathrm{v}$ přejatých slovech reprezentovaného slovem balon/balón uvedlo $81 \%$ respondentů v roce 1995 jako základní podobu balón a $37 \%$ studentů se domnívalo, že nedošlo ke změně. Pouze $19 \%$ respondentů uvedlo jako základní podobu balon, všichni s touto odpovědí pak uvedli i další variantu balón. Můžeme sledovat značnou závislost na předchozích pravidlech, podle nichž byl náležitý pouze zápis balón, a jistou roli zde určitě hraje i fakt, že původní pravopisná inovace připustila pouze zápis s krátkou samohláskou, varianta byla upravena Dodatkem, který navrhovanou jednoznačnou zvyklost do jisté míry rozkolísal. Sedm respondentů doplnilo komentář, že variantu balon chápou „jako slovo cizi“ (4) nebo „přejaté“ (3 respondenti), balón je podle nich "podobou počeštěnou“.

V roce 2020 respondenti vědí, že je možné použít obě varianty. To uvádí $37 \%$ respondentů, 43 \% zároveň preferuje variantu balón, 20 \% balon. Domníváme se, že se tak v odpovědích projevuje nedostatečně objasněný princip uplatněný v pravidlech pravopisu: přejaté slovo se zapisuje bez délky, i v př́ípadě, že je vyslovována, druhá možnost zápisu je s délkou. O uplatňování tohoto kodifikačního principu vypovídají i korpusová data: v syn2015 se balon vyskytuje 1347x, balón 348x.

U slova konstruktívní/konstruktivní všichni respondenti v roce 1995 uvedli pouze variantu s krátkým $i$, nikdo neuváděl existenci druhé varianty ani změnu. $V$ roce 2020 studenti píší, že nevědí

\footnotetext{
${ }^{71}$ Bohužel se mnohdy s tímto zápisem setkáváme také u řady učitelů.
} 
(45\%), konstruktivní preferuje $28 \%$, konstruktívní $27 \%$ dotázaných. IJP uvádí pouze konstruktivní, totéž SSČ, varianta konstruktívní je součástí Dodatku k pravidlům pravopisu, APČJ pak chápe jako rovnocenné obě varianty (s. 110).

V první testové otázce u položky zaměřené na znalost zápisu délky v cizích slovech je možné sledovat poměrně značnou znalost kodifikace i jejích inovací ve zjištění z roku 1995, v 2020 je patrné, že pravopisná kodifikace je ve sledovaných př́ikladech pro uživatele poměrně stabilizovaná, ale že zpětné změny zápisu délky je možné považovat do jisté míry za diskusní, způsobující u uživatelů nejistotu.

Následující otázka sondy byla také zaměřena na morfologické inovace uváděné v PČP - na znalost gramatického rodu některých slov a jeho prrípadných změn: Uved'te rod u těchto substantiv: esej, káně, displej a čepel. b) Došlo k nějaké změně?

Tato položka byla zařazena v návaznosti na položku předchozí, uvědomovali jsme si, že položka nezkoumá přímo znalost ortografické kodifikace, ale pouze morfologické údaje uváděné v PČP, které využívají především učitelé na nižších stupních škol. $Z$ tohoto důvodu byla položka součástí šetření, ověřovali jsme, zda si budoucí češtináři uvědomují změny, $\mathrm{k}$ nimž v rovině morfologické došlo a které pravidla pravopisu pouze zachycují.

V roce 1995 u slova esej v 46 \% uváděli respondenti rod mužský $^{72}$ a ženský, u slova káně $69 \%$ střední ${ }^{73}$, u slova displej mužský, u slova čepel 36 \% mužský i ženský. Jen 12 \% respondentů uvedlo, že došlo ke změně u slova esej. Pravopisná úprava z roku 1957

\footnotetext{
${ }^{72}$ Bohužel respondenti většinou neuvedli životnost, udali ji jen asi v $10 \%$ př́padů.

${ }^{73}$ Bez rozdílu významu - podle SSČ: střední rod pouze s významem mládě káněte, oba rody u obecného označení dravého ptáka, také v souvislosti s deklinačními formami.
} 
kodifikovala u slova esej pouze rod mužský, téměř polovina studentů předjímala budoucí stav, u slova káně naopak uváděli jen rod střední, přestože kodifikovány byly oba rody.

Slovo displej není v pravopisném slovníku z roku 1957 vůbec uvedeno, studenti vycházeli pouze z úzu. O postupné stabilizaci slova $\mathrm{v}$ češtině $\mathrm{v}$ dané době může svědčit i zjištění $\mathrm{z}$ naší sondy, $\mathrm{v}$ němž $18 \%$ odpovědí přináší variantní podoby: jednak podobu $d y$ splay (5 \% studentů z celkových $18 \%$ ) nebo display (13\% respondentů z $18 \%$ ). Slovo čepel mělo již v předchozí kodifikaci uvedeno dva rody, znalost prokazuje pouze třetina respondentů (32\%), $47 \%$ studentů se domnívá, že čepel je rodu ženského, $21 \%$ studentů řadí čepel k rodu mužskému; všichni se domnívají, že ke změně nedošlo. Obecně se v dané položce projevuje malá znalost kodifikace rodu či rodových inovací u sledovaných slov.

V roce 2020 u slova esej rod mužský i ženský určuje $71 \%$ respondentů, nesledovali jsme, jak se diference rodová projevuje v deklinačním paradigmatu, ale je zde patrný výrazný posun ve znalosti kodifikace, pravděpodobně to také souvisí s rychlým zdomácněním slova esej právě v oblasti školní výuky. U slova káně $42 \%$ dotazovaných preferuje rod střední ${ }^{74}$, 58 \% rod ženský. $\mathrm{Z}$ celkového počtu pouze $15 \%$ studentů zná obě varianty. U slova displej všichni uvádějí rod mužský, 12 \% respondentů zná i rod ženský, hodnotí jej ale jako nespisovný, projevuje se tak neznalost kodifikace. Čepel je pro $68 \%$ studentů jen rodu ženského, oba rody udává třetina respondentů $(32 \%)$. V posledních PČP je u slova čepel kodifikován pouze rod ženský, třetina respondentů tento fakt nezná. V korpusu nebylo možné s ohledem na charakter dokladi̊ preference rodu u dané položky ověřit.

\footnotetext{
${ }^{74}$ Přestože ve středoškolských učebnicích biologie je uváděn v popularizačněodborném textu převážně rod ženský.
} 
Další otázka sondy sledovala vývoj kodifikovaných tvarových variant substantiv: Uvedte spisovný tvar / spisovné tvary slov ve 2. pádě sg. slov kámen, ječmen a ve 2. pádě pl. slova ruka. V roce 1995 se projevuje neznalost morfologických inovací, objevují se pouze tvary kodifikované dříve: kámen - kamene, ječmen - ječmene, ruka - rukou.

V roce 2020 jsou již odpovědi i s variantami: kámen - kamene, kamenu (88 \%), ječmen - ječmenu, ječmene (92\%), ruka - rukou, ruk (96\%). U slova ječmen pouze $8 \%$ studentů zapsalo variantu ječmena. V IJP i SSČ je kamene, kamenu; v IJP ječmena, ječmenu, v SSČ ječmene, ječmenu, v IJP rukou, ruk, v SSČ jen rukou. Znalost variant je ve srovnání s odpověd’mi z roku 1995 vyšší, ale je patrná nejistota respondentů.

V odpovědích na otázku Napište dubletní tvary, pokud existují, těchto slov uvedené $v$ pravidlech pravopisu: polévka, roláda, omeleta, dvacetikoruna, pedikúra, kolébat, dolétnout. se v roce 1995 projevila silná závislost na stavu $\mathrm{v}$ předchozích pravidlech pravopisu, varianty mají v odpovědích pouze slova polívka, kolíbat, dolítnout. Respondenti se ve většině (v $84 \%$ ) domnívají, že kromě uvedených variant změna nenastala a že se jedná „o varianty nespisovné", pouze $8 \%$ respondentů je považuje „za hovorové, $\mathrm{z}$ toho $4 \%$ odpovědí znějí tak, že v nich není možné odlišit spisovnost a nespisovnost, nebot' studenti uvádějí, že „tyto dubletní tvary jsou nespisovné, hovorovéc.

V roce 2020 již studenti zachytili varianty u všech zmiňovaných slov. Všichni respondenti uvedli formy polévka i polívka, z toho 29 \% dotázaných považuje tvar polívka za nespisovný, u forem roláda a ruláda variantu ruláda znalo $41 \%$ respondentů a hodnotilo ji jako „nespisovný tvar, archaický tvar“, stejní respondenti uvádějí, že není uveden v PČP. U variant omeleta a amoleta převažuje 
znalost varianty amoleta - uvádí ji $61 \%$ odpovědí, z toho $15 \%$ odpovídajících se podle našeho názoru překvapivě domnívá, že omeleta je slaná a amoleta je sladká. U podob dvacetikorunal dvacítikoruna připomíná druhou variantu jen $34 \%$ respondentů, z toho $11 \%$ ji hodnotí jako nespisovnou. U slova pedikúra/pedikůra/pedykýra je varianta pedikưra u studentů stále považována za náležitou, spisovnou, uvádí ji $42 \%$ respondentů. Svědčí to o nepochopení podstaty označování délky $\mathrm{v}$ přejatých slovech. Podobu pedykýra zná jen 7 \% studentů a považují ji za „starou, archaickou“. U forem kolébat/kolíbat a dolétnout/dolítnout znají obě varianty všichni, nejsou si jisti, „jestli jsou druhé varianty spisovné, jsou nespisovné, hovorové “ uvažuje tak 35 \% respondentů. Opět z takto formulované poslední odpovědi není možné zjistit, jak studenti chápou hovorovou češtinu. PČP uvádějí u všech vybraných slov dvě varianty, stejně IJP, SSČ má hovorový prríznak u slov dolítnout a kolíbat.

Korpusová data preferují polévku (3446 výskytů) před polívkou (768 výskytů), přihlédnout je třeba k charakteru zdrojů, v syn 2015 jde převážně o psané texty publicistické. Roláda má 233 výskytů, ruláda $2^{75}$, omeleta je v korpusu syn 2015 obsažena $243 \mathrm{x}$, amoleta pouze $3 \mathrm{x}$, dvacetikoruna vykazuje 55 výskytů, dvacítikoruna není doložena. Pedikúra má doloženo 73 výskytů, pedikůra jen 2, pedikýra se nevyskytuje. Kolébat je ve 428 výskytech, kolíbat má 58 výskytů, dolétnout 77 výskytů, dolítnout pouze tři doklady.

Po ověřování znalostí podob u jednotlivých slov jsme pokračovali otevřenými otázkami. První z nich byla formulována takto: Který pravopisný jev je podle vašeho názoru nejobtižnější a proč? Odpovědi z roku 1995 jsou následující: "psaní velkých písmen" (32\% studentů); "psaní čárky mezi větnými celky, psaní čárek

\footnotetext{
${ }^{75}$ Překvapivé může být zjištění, že v SSČ je uvedena varianta ruláda jako první v pořadí, domníváme se, že se jedná o návaznost na SSJČ.
} 
(musím k tomu znát češtinu)“ (31\% respondentů); "pravopis cizích slov, neustále se měni“ (15\% odpovědí); „kolísání mezi píseň a kost“ (13\% studentů $)^{76}$; „nové změny v kodifikaci prípon u sloves, psaní obou tvarů - kde to je a kde není kodifikované" (9 \%). Vymezují se především dva základní problémové okruhy - psaní velkých písmen a zápis interpunkčních znamének.

V roce 2020 tyto dva základní okruhy zůstávají, přidává se však i okruh třetí a jednotlivé jevy i ve slovech domácích. „Psaní velkých písmen ve víceslovných pojmenováních, především názvi̊ institucí " považuje za obtížné $29 \%$ studentů, „interpunkci“ $27 \%$ respondentů, "psaní prejatých slov“ - $18 \%$ odpovědí, psaní predpon s-/z-ve slovech domácích - $12 \%$, psaní spojovníku a pomlčky - $8 \%$, psaní slova výjimka a psaní délek ve slovech domácích - $4 \%$, psaní príslovečných spřežek - $4 \%$.

Pro srovnání uvádíme výsledky staršího rozsáhlého výzkumu veřejného mínění ve vztahu $\mathrm{k}$ pravidlům pravopisu, provedeného v závěru 60. let minulého století (Tejnor 1969). Respondenti zhodnotili obtížnost pravopisných jevů v odpovědi na otázku Co pokládáte $v$ dnešním českém pravopisu za zvlášt obtižné? Uvedte dva nejobtížnější jevy. v tomto pořadí: 1. Psaní $i$ a $y-38 \%, 2$. Kladení čárek ve větě a v souvětí - $34 \%$, 3. Předložky $s$ a $z-30 \%$, 4. Psaní -mě- a - mně- - $28 \%$, 5. Psaní velkých písmen - $25 \%$.

Uvědomujeme si velkou relativitu srovnání výzkumu ze 60 . let minulého století a naší sondy, ve starším výzkumu byl užitou metodou řízený rozhovor, nikoli dotazník, respondenty nebyli studenti učitelství, ale dospělí občané a v druhé části skupina aktivních uživatelů psané podoby spisovného jazyka a výzkumný

\footnotetext{
${ }^{76}$ Uvědomujeme si, že se jedná o jev morfologický, totéž platí i pro kodifikaci verbálních tvarů, ale uvádíme na tomto místě doslovné odpovědi studentů, které daný jev radí $\mathrm{k}$ pravopisu.
} 
vzorek čítal 1960 jedinců. Porovnáme-li přesto naše zjištění v této otázce s výsledky získanými před více než 50 lety, je patrné, že na prvních místech u veřejnosti i studentů bohemistiky zůstávají tyto okruhy vnímané jako problematické: psaní velkých písmen a zápis interpunkčních znamének. V současnosti nepůsobí studentům tolik problémů psaní $i / y$, ale naopak zápis prejejatých a cizích slov. Můžeme sledovat, že se v popředí pravopisných problémů udržují především dva okruhy, u nichž se předpokládá přesné vyjádření nebo znalost jiných skutečností než pouze pravidel pravopisných. U zápisu velkých písmen zvláště v názvech institucí je nutná, jak uvádí např. Marie Čechová (2017, s. 40), „znalost věcných údajů včetně přesných pojmenování jednotlivých institucí“ a problémy interpunkční jsou „výsledkem nedostatečné školní výchovy, protože interpunkce $\mathrm{v}$ češtině má řád daný syntaktickou stavbou věty..."(tamtéž).

Názorům na psaní velkých písmen byla také v roce 2012 věnována rozsáhlá anketa ÚJČ, z níž vyplynulo, že „pravidla pro psaní velkých písmen zná $59 \%$ z celkového počtu respondentů (...) $\mathrm{Z}$ takového výsledku nelze soudit, že by byl stav znalostí této pravopisné problematiky uspokojivý." (Svobodová 2015, s. 28).

V další otázce jsme zjištovali názory na postavení pravopisu v jazykovém systému. Otázka zněla: Považujete pravopis za jazykovou rovinu? Proč ano, proč ne? V roce $199554 \%$ respondentů odpovídalo, že ano, stejně odpovídalo v roce 2020 dokonce $62 \%$ respondentů. Studenti vynechávali druhou část otázky, nezdo̊vodnili svou odpověd'. U nadpoloviční většiny se v obou sondách projevuje neznalost postavení pravopisu v jazykovém systému, je to další důležitý moment, jemuž je třeba $\mathrm{v}$ přípravě budoucích učitelů češtiny věnovat pozornost. 
S předchozím dotazem úzce souvisí i následující otázka orientovaná na vymezení pravopisu. Na otázku Jak byste definovali pravopis? odpovídali respondenti v roce 1995 takto: „psaný jazyk, jak se píše“ (48\%), „spisovný jazyk, psaní spisovné“ (27\%), „pravidla pro psani“ (10\%), „součást gramatiky češtiny“ (8\%), 7 \% respondentů neodpovědělo.

V roce 2020 byly odpovědi obdobné, „psaný jazyk, písmo“ (43\%), „spisovný jazyk“ (21\%), "pravidla pro psani“ (17\%), „mluvnice češtiny“ (10\%), $9 \%$ neodpovědělo.

Z odpovědí vyplývají dvě tradiční negativní zjištění: část respondentů ztotožňuje pravopis s gramatikou, část se spisovností. Oba názory svědčí o nepochopení podstaty pravopisu, zároveň ale představují mylné opakované jevy objevující se ve výuce češtiny.

Další otázka zněla: Je podle vašeho názoru český pravopis těžký, nebo lehký, středně těžký, nebo středně lehký? V obou sondách se kolem 90 \% (1995 - 89 \%, 2020 - 91 \%) respondentů shoduje, že český pravopis je těžký, jen přibližně $10 \%$ respondentů se domnívá, že je středně těžký. Zejména $\mathrm{v}$ současnosti, $\mathrm{v}$ době větší znalosti cizích jazyků a jejich pravopisných systémů, můžeme toto zjištění považovat za překvapivé, předpokládali bychom, že pravopisný systém češtiny bude studentům připadat jednodušší než např. pravopisný systém dnes tak rozšiřrené angličtiny. Je také možné, že studenti odpovídali mechanicky nebo že jejich odpovědi mohly být ovlivněny i vztahem jejich školní výuky $\mathrm{k}$ pravopisným otázkám.

Na poslední otázku dotazníkové sondy Které znáte zdroje informací o pravopisu a jaká je jejich výhoda před zdroji jinými? odpovídají v roce 1995 studenti v naprosté většině, že zdrojem informací o pravopise jsou Pravidla českého pravopisu, pouze $10 \%$ 
respondentů připomíná také Slovník spisovného jazyka českého pro školu a veřejnost.

$\mathrm{V}$ roce 2020 je na prvním místě citována IJP (71\%), studenti oceňují „aktuálnost, jiné a další př́iklady než v PČP“ (stranou pozornosti u respondentů zůstávají odkazy do slovníků a ČNK), na druhém místě PČP $(22 \%)$ a pouze $7 \%$ respondentů užívá SSČ. V citovaných zdrojích je patrný dobový stav a možnosti, podle našeho názoru je ale velmi překvapivé zjištění, jak málo studentů užívá výkladový slovník a také fakt, že studenti neuvádějí jako zdroj také APČJ, která má doložku MŠMT, a je tedy př́ručkou kodifikační. Kromě IJP v sondě z roku 2020 studenti žádnou z prř́ruček nehodnotí, neuvádějí odpověd’ na druhou část otázky.

\section{Shrnutí}

Podle našeho názoru komparačně pojatá sonda přinesla zjištění, která je možno přímo užít v praxi, a to jak ve vysokoškolské přípravě budoucích učitelů češtiny, tak i ve školách nižších stupňů. Z našich zjištění vyplývá, že znalost současné pravopisné kodifikace nedosahuje očekávané úrovně a že $\mathrm{v}$ př́pravě budoucích učitelů je třeba věnovat pozornost nejen jednotlivým pravopisným jevům, ale ve větši míre výkladům teoretickým souvisícím s pravopisným učivem a dbát také na neustálé propojování pravopisných vědomostí a dovedností s jednotlivými jazykovými rovinami a také s mimoškolní praxí.

Z ověřování znalosti kodifikace $\mathrm{v}$ oblasti morfologického pravopisu vyplynulo, že problémem zůstává hodnocení variant, především stylové, které není v pravopisné příručce uváděno, a také využívání variant v kultivovaném jazykovém projevu, přetrvává zde značná nejistota. Zdánlivou rozkolísaností je pro vysokoškolské 
studenty poznamenáno především tvoření slovesných tvarů, zejména participiálních. Jako problematickou můžeme také hodnotit znalost gramatického rodu u analyzovaných příkladových substantiv.

Ukazuje se větší znalost variant $\mathrm{v}$ zápisu psaní $s$ a $z \mathrm{v}$ přejatých slovech, za rozkolísaný je uživateli považován v naší sondě zápis délky v přejatých slovech.

Dalším důležitým aspektem výuky pravopisu je odstraňování různých mylných výkladů a vysvětlení, které si studenti přinášejí z nižších stupňủ škol a také z mediálního prostoru, např. záměna psané podoby jazyka a spisovnosti, záměna pravopisu a gramatiky. V pravopisné oblasti se projevuje frekventovaně záměna jevů z jednotlivých jazykových rovin. Znovu se potvrdilo, že i v současnosti v návaznosti na předchozí stav existují pro studenty bohemistiky dva základní okruhy pravopisných jevů vnímané jako problematické: užívání velkých písmen a užívání interpunkčních znamének, $\mathrm{k}$ nimž se přidává i zápis přejatých slov.

Respondenti nejsou podle našeho názoru dobře seznámeni s možnostmi, které jim nabízejí současné příručky v oblasti pravopisu. Sledujeme sice na jedné straně preferenci IJP jako zdroje informací o pravopisných jevech, ale nemůžeme potvrdit využívání jejích funkcí, studenti také minimálně využívají SSČ a podle našich zjištění vůbec nepracují s APČJ.

Výsledky naší sondy potvrdily, že všem výše jmenovaným aspektům je nutné věnovat systematickou pozornost právě ve výuce budoucích učitelů češtiny, nebot význam znalosti pravopisné kodifikace se ani v dnešní době ve škole nesnižuje, ale tvoří stále jeden $\mathrm{z}$ předpokladi̊ pro tvorbu kultivovaného jazykového projevu. 


\section{Použitá literatura}

BENEŠ, Martin; aj. Studie k Moderní mluvnici češtiny 5. K české fonetice a pravopisu. Olomouc: FF UPOL, 2013. 208 s.

BERMEL, Neil. Pravidla jako cukr a bič? Pravopis v českém národním korpusu (1. část). Naše ř reč, 2008, ročník 91, č. 1, s. 1-12. ČECHOVÁ, Marie; aj. Současná stylistika. Praha: NLN, 2008. 354 s. ČECHOVÁ, Marie; aj. Čeština - ř č a jazyk. Praha: Státní pedagogické nakladatelství, 2011 (3. upravené, rozšířené vydání). $442 \mathrm{~s}$. ČECHOVÁ, Marie. Život s češtinou. Češka - češtinářka - Čechová. Praha: Academia, 2017. 391 s.

ČECHOVÁ, Marie. Srovnání nesrovnatelného? Znalosti funkční morfologie u žáků před 50 lety a dnešních bohemistů. Český jazyk a literatura, 2018-2019, ročník 69, č. 1, s. 24-32.

MARTINCOVÁ, Olga (ed.). Co přinášejí nová Pravidla českého pravopisu? Praha: Ústav pro jazyk český, 1991. 51 s.

MATHESIUS, Vilém. K výslovnosti cizích slov v češtině. In Čeština a obecný jazykozpyt. Praha: Melantrich, 1947, s. 110-129.

PRAVDOVÁ, Markéta; SVOBODOVÁ, Ivana (eds.). Akademická příručka českého jazyka. Praha: Academia, 2014. 536 s.

Pravidla českého pravopisu (S Dodatkem Ministerstva školství, mládeže a tělovýchovy). Praha: Academia, 1993. 389 s.

Pravidla českého pravopisu. Praha: SPN, 1958. 391 s.

SPĚVÁČKOVÁ, Martina; VAŇKOVÁ, Jana. Dokáží studenti českého jazyka rozlišovat jazykové roviny a jim odpovídající jazykové prostředky? In ČECHOVÁ, Marie; SPĚVÁČKOVÁ, Martina. (eds.) Od praxe $k$ teorii a zpět ve vyučování češtině. Plzeň, ZČU, 2019, s. 84-93.

SVOBODOVÁ, Ivana; aj. Psaní velkých písmen v češtině. Praha: Academia, 2015. $350 \mathrm{~s}$.

ŠIMANDL, Josef. Jaké úpravy pravopisu a kdy? (Na okraj Pravidel českého pravopisu 1993). Čeština doma a ve světě, 1993, ročník 1, č. 2, s. 62-73. 
TEJNOR, Antonín. Český pravopis a veřejné mínění. Naše řeč, 1969, ročník 52, č. 5, s. 265-285.

VACHEK, Josef. Český pravopis a struktura češtiny. Listy filologické, 1933, ročník 60, č. neuvedeno, s. 278-319. 


\title{
O spisovné češtině, chybě a chybování
}

\author{
Milan Hrdlička
}

Pedagogická praxe představuje cennou a nezastupitelnou součást odborné průpravy budoucích učitelů nejen českého jazyka a literatury. Posluchači učitelského studia bohemistiky během působení na základní či střední škole načerpají nové poznatky, získají neocenitelné zkušenosti, seznámí se s relevantními skutečnostmi jak z vyučovacího procesu, tak i z každodenního chodu př́ílušného školského zařízení.

Budoucím vyučujícím je na pedagogické praxi poskytována př́ležitost vyzkoušet si $\mathrm{v}$ reálných podmínkách a $\mathrm{v}$ autentickém prostředí různé vyučovací postupy a metody, uplatnit nabyté vědomosti a dovednosti. Praktikanti však vedle pozitiv nepochybně narazí i na jevy povahy negativní. Ponecháme stranou pestré spektrum problémových momentů (kázeň žáků, jejich motivace ke studiu, šikana, vztah škola - rodina aj.) a zastavíme se u problému obecného dosahu, u mnohdy nedostatečné úrovně komunikační kompetence studentů bohemistiky (a potažmo i žáků) s důrazem na neznalost, resp. na porušování kodifikace normy spisovné češtiny. Zaměříme se na oblast formálního i funkčního tvarosloví, kde chybují jak rodilí mluvčí češtiny (čeští žáci a studenti), tak i mluvčí jinojazyční, žáci a studenti češtiny s odlišným mateřským jazykem. Těch v posledních desetiletích soustavně přibývá, jejich počty se v současnosti uvádějí v řádech desetitisíců. ${ }^{77}$

\footnotetext{
${ }^{77}$ Statistická ročenka MŠMT ČR uvádí, že se na základních školách učilo ve školním roce 2018/2019 celkem 940928 žáků. České občanství z nich mělo 916902 žáků, slovenské 5181, občany dalších států Evropské unie bylo 2622, z ostatních evropských
} 
Dřive než přejdeme $\mathrm{k}$ chybování, $\mathrm{k}$ druhům chyby a $\mathrm{k}$ jejím příčinám, zastavíme se u role a postavení spisovné češtiny v české jazykové situaci a v soudobé řečové komunikaci. ${ }^{78}$ Tyto otázky pokládáme za klíčové, představují stěžejní východisko zkoumané problematiky.

\section{Spisovná čeština v řečové komunikaci - názory, postoje, realita}

Vycházíme-li z teorie jazykové kultury propracované předními představiteli Pražského lingvistického kroužku (Havránek 1932; Mathesius 1932 aj.), dalo by se oprávněně usuzovat, že stále převažuje názor, který ve spisovné češtině spatřuje prestižní strukturní útvar naší mateřštiny a který uznává její roli národně reprezentativní a sjednocující. Spisovný jazyk - v psané i v mluvené podobě - by se proto měl užívat (je tomu tak i v dalších vyspělých jazykových společenstvích) v široce chápané oficiální komunikaci. Uplatnění standardu ${ }^{79}$ by mělo být běžné ve státní správě a v administrativě, ve státních hromadných sdělovacích prostředních, ve vzdělávací soustavě na všech stupních škol, v odborné literatuře, ve vědecké sféře i v prestižním hovoru apod.

Naznačená prestižní pozice spisovné češtiny v řečové praxi není samozřejmostí, nejedná se o názor jediný ani jednotný. U některých korpusových lingvistů a bohemistů (především pražských) se setkáváme i s tvrzeními a postoji protichůdnými: zpochybňují významnou roli spisovné češtiny, ${ }^{80}$ šírí iracionální tezi o celonárodní

států pocházelo 9290 žáků a z ostatních států světa (včetně nezjištěných) 6933 žáků (www.msmt.cz).

${ }^{78} \mathrm{~K}$ postojům studentů učitelství 1 . stupně základní školy a studentů bakalářského studia (nečeštinářů) ke spisovnému jazyku a jeho užívání viz zde J. Málková (s. 217).

${ }^{79}$ Termíny spisovná čeština a standard užíváme jako synonymní.

${ }^{80}$ Odlišné postoje k péči o standard jsme vystihli metaforou: „Předně se naskýtá 
platnosti obecné češtiny, ${ }^{81}$ nekriticky prosazují rozhodující, resp. výlučnou roli úzu při kodifikaci standardu (kolik bychom ovšem potom měli prestižních variet naší mateřštiny?), ${ }^{82}$ popírají existenci hovorové vrstvy spisovné češtiny, nesouhlasí s teorií jazykové normy (Daneš 1997; Cvrček 2006; 2008; Čechová 2012/2013; Svobodová 2014; Hrdlička 2015; 2017 aj., tam další literatura). Češtináři, kteří se o tyto otázky zajímají (což by mělo být samozřejmostí), jsou obeznámeni s již chronickým celonárodním nesouladem, jsou jim známy rozdílné názory a nesmiřitelné postoje předních odborníků $\mathrm{k}$ řadě zásadních problémů (srov. výše).

Jaký je stávající reálný stav? Jak vypadá současná jazyková situace? Zůstává spisovná čeština i nadále prestižním útvarem našeho národního jazyka? Anebo už došlo k zásadnímu obratu a k podstatným změnám? Pro přiblížení aktuálního obrazu stručně připomeneme vybrané výstupy a údaje z rozsáhlého reprezentativního výzkumu uskutečněného kolektivem bohemistů pod vedením J.Svobodové (2011, s. 115n.). ${ }^{83}$

připodobnění francouzskému parku s jeho ostrými konturami a neúprosně souměrnými liniemi, s jeho působivou, i když poněkud upjatou klasicistní krásou, s jeho prrirozeností spoutanou v duchu určitého vyššího principu. Dále je možné uvažovat o paralele s př́irozeným parkem anglickým, vyznačujícím se naturelem poněkud rozvolněným, který je nicméně predmětem soustavné a cílené péče. Podstata problému spočívá v její povaze, rozsahu, kvalitě. A konečně při četbě Sgallova výroku „já považuju Čechy jako nositele jazyka českého za svéprávné a nějaké pečování tady nevidím jako potřebné" [...] se nabízí i prirovnání $k$ deštnému pralesu, $k$ neprostupné tropické džungli, $k$ bezprizorní vegetaci ponechané velkoryse svému osudu." (Hrdlička 2017, s. 86)

${ }^{81}$ Uličný (1996, s. 61) uvádí: „Především se tzv. obecná čeština nešírí na východ Moravy; nemá tu dostatečné psychosociální podmínky, protože vždy byla vnímána jako cizí a neprestižní jev. Tato situace se dnes díky televizi poněkud změnila, avšak ve východomoravských interdialektech se to projevilo jen velmi málo."

${ }^{82}$ Nepokládáme za štastné, že se do složité, ba pro mnohé mluvčí nepřehledné situace pokoušejí někteří lingvisté (např. Cvrček 2008) vnášet kontroverzní př́istupy (podle našeho soudu programovou anarchii) a vytvářet koncepce iluzorních pluralitních kodifikací (Čechová 2012/2013; Hrdlička 2017; 2018).

${ }^{83}$ Sběr dat probíhal formou dotazníkového šetření na jaře 2010. Výzkumu se zúčastnilo 3269 respondentů, rodilých mluvčích češtiny, paritně zastoupených ze všech krajů ČR. Byli rozděleni do tř́i skupin. První skupinu tvořili dospělí mluvčí v počtu 
Znění první otázky bylo následující: Který z nabízených výroků nejlépe charakterizuje Váš pohled na spisovnou češtinu?

Má se používat: a) Vždy v jakékoliv oficiální komunikaci, a to jak v psané, tak mluvené formè. // b) Vždy v oficiálních psaných textech, které jsou určeny pro širši veřejnost. V mluvené formě vždy za určitých okolností, pokud vystupujeme na veřejnosti, hovořime s osobou, kterou bliže neznáme, s někým, koho si vážime apod. // c) Hlavně v oficiálních psaných textech. V mluvené formě záleží jen na každém osobně, zda někdy chce a bude spisovně také mluvit. // d) Jen $v$ psaných textech. Do mluvené komunikace vỉbec nepatři, pưsobí tam neprirozeně až směšně. // e) Nemá se používat ani $v$ psaných textech, ani v mluvené komunikaci.

Výrazně převážila odpověd' b), a to $44,1 \%$ u dospělých účastníků, 59,9 \% u mladých lidí a 63,7 \% u odborníků. Na druhém místě následovala odpověd' c) (dospělí 28,7\%, mládež 21,6\%), odborná veřejnost volila jako druhou odpověd' a) $27,4 \%$. Odpověd' a) byla u dospělých zastoupena 24,5 \%, u mládeže 15,5\%. Z údajů vyplývá, že reakce a) až c), získaly u dospělých 97,3\%, u mládeže $97 \%$ a u odborné veřejnosti $100 \%$ hlasů.

Relativní shoda názorů se projevila i v odpovědích na druhou otázku: Který z následujících výroki̊ nejlépe odpovídá Vašemu názoru na dưležitost spisovné češtiny?

a) Spisovná čeština má velký význam. Je živá a naprosto vhodná v psané i mluvené podobě. Spojuje všechny občany

1511 (byly zastoupeny všechny věkové kategorie), druhou mladí lidé ve věku 12-18 let (1422 účastníků ankety) a třetí skupina sestávala z 336 odborníků, tedy bohemisticky vzdělaných mluvčích, kteří ve své profesi pracují s jazykem. Pro dotázané bylo připraveno 17 otázek, 3 dotazy byly určeny pouze zástupcům odborné veřejnosti (Svobodová a kol. 2011, s. 107). 
České republiky, starši i mladší. Měla by se využivat co nejvíc. // b) Spisovná čeština má stále svi̊j význam. Potřebujeme ji, proto by ji každý měl znát. Nejlépe by ji měli ovládat ti, kdo vystupují veřejně. Vedle toho je třeba odlišit takové situace, ve kterých postačí nespisovné vyjadřování, a to hlavně mluvené. // c) Spisovná čeština už částečně ztrácí význam. Je poněkud zastaralá, pưsobí nepřirozeně. Hodí se pro písemné dokumenty a oficiální projevy, ale mluvit spisovně se běžně nedá. I přes tyto pripomínky bychom si jí měli vážit a podle potřeby jí používat. // d) Spisovná čeština rychle ztrácí význam. Patři už jen do učebnic, slovniků, mluvnic a pravidel pravopisu. Je to teorie a s tím, jak se běžně píše a mluví, má málo společného. Přesto se občas může hodit, a to př̀ psaní. // e) Spisovná čeština úplně ztratila význam. Jazyková pravidla nejsou důležitá, je zbytečné je od lidí vyžadovat. At každý mluví i píše, jak chce.

$S$ velkou převahou byla preferována varianta $b$ ). Výsledky byly následující: dospělí a) 18,3\%, b) 55,6\%, c) 22,6\%; mládež a) $9,6 \%$, b) $62,3 \%$, c) $24 \%$; odborníci a) $16,3 \%$, b) 76,7 \%, c) 7,1\%.

Na základě uvedených statistik lze konstatovat, že se všechny skupiny respondentů většinou vyslovily pro důležitou roli a pro výsadní postavení spisovné češtiny v oficiální řečové komunikaci. Mohlo by se tudíž zdát, že se přesvědčivým způsobem naplňuje, resp. potvrzuje koncept jazykové kultury vypracovaný představiteli Pražské školy, oficiálně prosazovaný i v druhé polovině minulého století (bliže Cvrček 2006) a uznávaný výraznou většinou bohemistické obce. Ukazuje se ovšem, že je naznačený deklarovaný postoj respondentů ke spisovné češtině nezřídka $\mathrm{v}$ nesouladu $\mathrm{s}$ reálnou skutečností, s empirickými poznatky z každodenní řečové praxe. ${ }^{84}$

\footnotetext{
${ }^{84}$ Zarážející jsou data ze třetí otázky (s. 122): Ve kterém prostředí se podle Vás skutečně setkáváme s mluvenou spisovnou češtinou? Můžete označit víc možnost. Dotázaní měli
} 
Prestižní povaha spisovné češtiny je sice přesvědčivým procentem dotázaných vnímána a uznávána, zaznamenáváme však nemalé potíže a rezervy v jejím uplatňování ve zmíněných oficiálních (prestižních) komunikačních sférách.

Situaci pokládáme za znepokojivou. Domníváme se, že získané poznatky jen umocňují potřebu zkvalitnit jazykovou a odbornou př́pravu budoucích vyučujících předmětu český jazyk a literatura. Máme na mysli posílení a prohloubení aktivní znalosti spisovné češtiny, cílenější pěstování schopnosti rozlišovat a funkčně využívat stylovou platnost jazykového výraziva (odlišování prostředků knižních, neutrálních, hovorových, kolokviálních) i orientovat se ve stratifikaci českého národního jazyka. Jsme však svědky četných potíží a nemalých rezerv.

\section{Sonda do povědomí studentů bohemistiky o strukturních varietách českého jazyka}

Na počátku zimního semestru akademického roku 2014/2015 a 2019/2020 jsme provedli na dvou vysokoškolských pracovištích mezi oborovými posluchači bohemistiky průzkumnou sondu, jejímž cílem bylo orientační zmapování přehledu budoucích češtinářů o stratifikaci češtiny. Šlo o zařazení syntagmat mezi náma dvěmi, ${ }^{85}$ mezi náma dvěma, mezi náma dvouma a mezi

na výběr 14 možností ( $v$ kostele, na církevních obřadech, na úřadech aj.), mohli dopsat i další reakce. Také zde panovala shoda. Nejvíce procent získala odpověd’ $v$ televizi jen v některých pořadech (hlavně ve zprávách): u dospělých 57 \%, u mládeže 72,1\%, u odborníků $75,9 \%$. Až čtvrtá v pořadí byla u dospělých odpověd’ ve škole, alespoň $v$ hodinách češtiny (40,2\%), tatáž reakce obsadila třetí pozici u odborníků (44\%), u mládeže figurovala na pátém místě $(47,4 \%)$, přičemž varianta ve škole ve většině předmětů se v téže skupině dotázaných umístila až jako šestá: $29,5 \%$.

${ }^{85} \mathrm{~V}$ písňovém textu J. Suchého z počátku šedesátých let minulého století bylo toto spojení zdrojem jazykové komiky. Dnes má $\mathrm{k}$ autorem zamýšlenému komunikačnímu účinku na hony daleko... 
námi dvěma ke strukturním útvarům naší mateřštiny. Průzkumu se zúčastnilo 41 respondentů (skupina A), posluchačů bakalářského studia (čerstvých absolventů SŠ), a 31 studentů 1. ročníku navazujícího magisterského studia (skupina B). Jednalo se o kvantitativně omezený vzorek dotázaných, získané závěry proto nepřeceňujeme. Jsme však přesvědčeni, že relevantní výpovědní hodnotu mají.

Ve skupině A bylo syntagma mezi náma dvěmi ${ }^{86}$ třiadvacetkrát explicitně interpretováno jako nespisovná čeština, někdy s dodatkem, že se jedná o nespisovnou koncovku osobního zájmena. Nespisovnost se vyrozumívá i z dalších čtyř odpovědí (nespisovný pokus o spisovnou češtinu aj.). Pouze čtyři bohemisté nadto okomentovali (avšak neadekvátně) hyperkorektní koncovku číslovky základní (český jazyk neobsahuje toto slovo). Podle čtyř respondentů jde o češtinu obecnou, dvakrát je spojení nazíráno jako chybné a jako nonsens, šest dotázaných bylo bezradných: bud' nevyplnili nic, nebo svi̊j postoj verbalizovali (nevím).

Spojení mezi náma dvěma bylo v sedmnácti př́ípadech označeno jako hovorová čeština (tento pojem však v lingvistické bohemistice označuje vrstvu spisovné češtiny, jde zde nejspíše o záměnu hovorový za kolokviální, běžně mluvený). Pět účastníků je hodnotí jako obecnou češtinu, dva si nevěděli rady, osm uvedlo nespisovnou češtinu. Devět dotázaných se domnívá, že jde o vyjádření spisovné...

Mezi náma dvouma bylo dvanáctkrát posouzeno jako nespisovné, jedenáctkrát jako hovorové (evidentně je ovšem myšleno kolokviální), jednou je nazíráno jako stará čeština, po jednom jako nářečí středomoravské a západočeské, jednou jako nespecifikovaný

${ }^{86}$ Zarážející je skutečnost, že ve třech př́ípadech napsali studenti ve tvaru číslovky ypsilon (dvěmy). 
dialekt, třikrát jako obecná čeština. Ve třech př́ípadech zůstalo bez jakékoliv odezvy.

Náležitý tvar mezi námi dvěma je jako spisovný označen dvaatřicetkrát. Pozoruhodná je reakce „opět nevhodné, nedávajicí mi smysl“. Podle mínění dvou dotázaných jde o obecnou češtinu, pro šest oslovených je spojení nespisovné.

Ve skupině B jsou výsledky uspokojivější, avšak nikoliv bez výhrad. Spojení mezi náma dvěmi vyvolalo pestrou směsici reakcí. Šestnáctkrát je správně poukazováno na hyperkorektní neduálovou koncovku ( $d v e ̌ m i)$, ve třech dotaznících je uvedeno „chybné, nesmysl“, resp. „nespisovné, hovorové", po jednom jsou zastoupeny následující názory: „nespisovné; snaha o korektní tvar, byt dvěmi neexistuje; pseudočeština; obecná čeština; dialekt". Jednou zůstalo bez odpovědi.

Spojení mezi náma dvěma je dvacetkrát interpretováno jako obecněčeské, čtyřikrát jako hovorové / obecněčeské (oba termíny jsou užity jako synonymní), pětkrát jako hovorové. Ve dvou případech se pisatel domnívá, že jde o vyjádření spisovné...

Mezi náma dvouma je vyhodnoceno osmnáctkrát jako obecněčeské, sedmkrát jako nespisovné (někdy s dodatkem hovorové), v jednom dotazníku s dovětkem „naštěstí méně časté, nespisovné, velmi nepríjemné na poslech", třikrát jako hovorové a jako dialekt.

Syntagma mezi námi dvěma je pojímáno jako spisovné v sedmadvaceti př́padech. Ve třech dotaznících je uvedeno, že se jedná o „korektní tvar“, v jednom stojí „asi bych to považovala za nespisovné“ (blíže Hrdlička 2015). 
Pozornost ve výuce je třeba obrátit i na případy tzv. hyperkorektnosti, tedy přehnané snahy o užití prestižní variety češtiny bez patřičné znalosti standardu: Stalo se to před dvěmi lety.

Výsledky ankety nejsou pozitivní. I s přihlédnutím $\mathrm{k}$ nim, ale především na základě dlouholetých zkušeností z vyučovací praxe konstatujeme, že budoucí češtináři by měli být schopni plynulé, soustavné komunikace ve spisovné češtině, a to nejen v hodinách mateřského jazyka. Měli by být rovněž náležitým zpơsobem argumentačně vybaveni pro přesvědčivou obhajobu role standardu $\mathrm{v}$ řečové komunikaci. Měli by si být vědomi skutečnosti, že jde o varietu prestižní, o jediný celonárodní strukturní útvar (což pokládáme za klíčové), o jedinou kodifikovanou varietu českého národního jazyka. ${ }^{87}$

\section{Jazyková (řečová) chyba - její druhy a příčiny}

Jen málokterý druh lidské činnosti je tak úzce a nerozlučně spjat s chybováním jako učení se jazyku, a to jak cizímu (ev. druhému), tak i mateřskému. Je proto možné konstatovat, že chybovat je lidské, resp. že chybami se člověk učí.

\footnotetext{
${ }^{87}$ Jsou lingvisté, kteří namítají, že spisovná čeština není mateřštinou nikoho: „Osobní zkušenost, která zdaleka není jen moje, mi říká, že jsem se narodil do obecné češtiny a že ta je mou mateřstinou a že škola se s lepším či horším úsilím až od šesti let snaži věci hodnotově obrátit [...]. Není proto divu, že většina Čechů vnímá pak spisovnou češtinu jako cosi umělého, naučeného, popř. vnuceného." (Čermák 1996, s. 14) Mají pravdu. Mateřským jazykem ovšem není ani prestižní podoba angličtiny, francouzštiny, španělštiny... V těchto jazykových společenstvích je rozdíl mezi varietou prestižní a útvary kolokviálními běžný, v komunikaci funkčně využívaný. Situace u nás není výjimkou (Hrdlička 2017). Kdyby byla mluvčím otázka jazykové správnosti lhostejná, jak někteři lingvisté prohlašují, tvůrci a provozovatelé Internetové jazykové příručky by patrně neregistrovali ve všedních dnech přes 30000 př́stupů (Svobodová 2014).
} 
V kapitole užíváme pojem chyba ${ }^{88}$ ve smyslu nežádoucího tvaroslovného odklonu od jazykové normy. V tuzemské lingvisticko-bohemistické tradici se $\mathrm{v}$ pojetí jazykové chyby vyčleňují dva základní př́istupy: rozlišuje se totiž chyba v širším a chyba $\mathrm{v}$ užším smyslu (Jelínek 2001 aj.).

Problematiku chyby v širším smyslu, tedy prrípadů defektní odchylky od všech rovin národního jazyka, včetně roviny mluvnické, jichž se dopouštějí kvůli nedostatečné úrovni komunikační kompetence $\mathrm{v}$ češtině pouze její nerodilí mluvčí (mluvčí rodilý by se podobného porušení normy nedopustil), ponecháme z prostorových důvodů stranou (viz Hendrich a kol. 1988; Korčáková 2004 aj.).

Zastavíme se blíže u chyby v užším chápání. Dostáváme se $\mathrm{k}$ velkoryse pojímané a $\mathrm{k}$ bohatě strukturované problematice nerespektování standardu, k odchylce od normy prestižní variety českého národního jazyka. V této souvislosti se nabízejí úvahy o nejčastějších příčinách a provenienci chyb. V kapitole se zaměříme především na formální tvarosloví, ${ }^{89}$ připomeneme ale také vybrané problémy morfologie funkční.

Nejčastějším a nejvýraznějším případem nerespektování kodifikace spisovné normy je bezesporu významné pronikání obecněčeských,

\footnotetext{
${ }^{88}$ Hausenblas, Kuchař a kol. (1979, s. 169) poukazují na poznatek z psychologie: u člověka vyvolávají větší pozornost jevy negativní než pozitivní: „Veřejnost, běžní uživatelé jazyka mívají vyhraněnějši prédstavy o jazykových chybách než o jazykové správnosti, existují také jednoznačnéjší názory na to, co je chyba, než na to, co je správné." Rodilí mluvčí jsou citlivější na chybování ve výslovnosti (nedbalá, nesrozumitelná artikulace, př́liš rychlé tempo řeči) než na chyby mluvnické. Různé národy projevují k chybám jinojazyčných mluvčích nestejnou míru tolerance. Češi, zejména starší generace, jsou (na rozdíl od anglicky hovořících mluvčích) dosti nároční a přísní (Hrdlička 2012).

${ }^{89}$ Vedle potíží se spisovnou flexí mají studenti problémy s popisem tvoření tvarů: mnozí oboroví studenti bohemistiky nedokážou popsat tvoření př́íčestí trpného či tvarů imperativu, dále př́ípady, kdy se nemohou tvořit posesivní adjektiva atd.
} 
popř. nářečních prvků ${ }^{90}$ do spisovné češtiny. Př́ikladů nejen $\mathrm{z}$ vyučovací praxe by bylo možné uvádět bezpočet. Zmíněný trend ostatně dokládá zřetelná převaha kolokviálních (zejména obecněčeských) forem nad tvary kodifikovanými, a to zejména v komunikaci mluvené, v poněkud menší míře i v projevech psaných. Ve Cvrčkově deskriptivně pojaté mluvnici češtiny se kupř. uvádí, že v instrumentálu plurálu tvrdých adjektiv se v mluvené češtině vy-

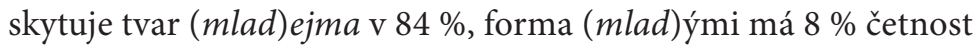
výskytu, podoba (mlad)ýma $8 \%$ frekvenci (Cvrček a kol. 2010, s. 200). Obdobně je tomu v řadě jiných případů..$^{91}$

K naznačenému průniku spisovného výraziva s kolokviálním dochází v důsledku neznalosti, resp. nedostatečné znalosti (nejen) tvarosloví prestižní variety naší mateřštiny. ${ }^{92}$ Mnozí rodilí mluvčí češtiny se náležitě neorientují v mluvnické rovině spisovné češtiny, bezpečně neovládají kodifikované tvary, místo záměrného diglosního střídání kódů (kupř. češtiny spisovné a obecné) jednotlivé útvary nesystémově mísí, jejich řečový projev je nestrukturní, hybridní, oscilující mezi různými varietami, což je z komunikačního hlediska nežádoucí.

Negativní roli sehrává rovněž rozkolísanost řečové distribuce mluvnických forem pramenící z nejistoty mluvčích, dále problémová nepřehlednost spisovných variantních tvarů (jejich nesnadná osvojitelnost) i nejednota názorů na podobu spisovné kodifikace. Nestejně je kupř. hodnocen tvar genitivu číslovek tři

\footnotetext{
${ }^{90}$ Pro ilustraci poslouží západočeské nářeční užívání posesivních adjektiv Viděl tam $i$ tatínkovo dceru, hojně zastoupené $\mathrm{v}$ písemných projevech plzeňských studentů bohemistiky.

${ }^{91}$ Poznamenáváme (Svobodová a kol. 2011; Svobodová 2014), že v odborné literatuře panují vážně výhrady k nevyváženému poměru textů, resp. analyzovaného korpusového materiálu. Řečové projevy moravských a slezských mluvčích jsou zastoupeny minimálně, tím se validita údajů velmi problematizuje.

${ }^{92}$ Samostatnou kapitolu představuje vliv nesprávných analogií, srov. chybné TolstojTolstoje (jako muž - muže), nikoliv náležité Tolstoj - Tolstého (jako dobrého) aj.
} 
a čtyři v renomovaných českých mluvnicích posledních desetiletí. Ve Šmilauerově Nauce o českém jazyku (1972, s. 197) se jako spisovná uvádí pouze forma tří, resp. čtyřr. V akademické Mluvnici češtiny 2 (1986, s. 405) se prezentují jak tvary spisovné neutrální (tří, čtyřr), tak také (explicitně pojmenované) dublety spisovné hovorové (třech, čtyřech). V pražské gramatice M. Čechové a kol. Čeština - řeč a jazyk (2011, s. 234) figurují všechny zmíněné tvary jako spisovné, bez odlišení. Rozlišení daných tvarů lze ovšem nalézt v pozdější publikaci Současná stylistika (Čechová a kol. 2008, s. 148-149). V brněnské Příruční mluvnici češtiny $(1995$, s. 307) se připouštějí formy tří, třech, ale paradoxně pouze čtyř - varianta čtyřech je pokládána za substandardní (Hrdlička 2019).

Jako další z relevantních faktorů lze zmínit problémové pospisovnění (zhovornění) některých frekventovaných, původně kolokviálních morfologických tvarů. Výmluvným dokladem je komparativ adverbií málo a dlouho. Vedle tvaru spisovného, původně neutrálního méně je spisovná hovorová rovněž konkurenční, původně kolokviální (obecněčeská) podoba míň, kdežto ke knižnímu tvaru déle má mluvčí k dispozici dubletu dýl, která nadále zůstává nespisovná.

K chybování mohou menší měrou přispívat některé kontaminační procesy, např. v oblasti českých předložek nebo spojek. U prepozic připomínáme zeugma, tedy případy souřadného užití dvou, popř. několika předložek (Sejdeme se před, nebo po obědě?), ${ }^{93}$ ale také stále četnější výskyt koexistence dvou prepozic (Její vztah s o dvacet let starším partnerem skončil rozchodem). $\mathrm{V}$ obou prrípadech se tak nepochybně děje $\mathrm{z}$ důvodu jazykové ekonomie, snahy o stručnost vyjádření, o kondenzaci sdělení. Nenoremní je i užívání prepozice mimo s genitivem Vjezd zakázán

\footnotetext{
${ }^{93}$ Náležité řešení zní: Sejdeme se před obědem, nebo až po něm?
} 
mimo dopravní obsluhy (pod vlivem významově blízké předložky kromě+G), nikoliv náležitě s akuzativem.

V souvislosti s nerespektováním kodifikace spisovné češtiny nelze opomíjet ani obecnou neznalost náležitého užívání knižního výraziva (srov. časté potíže s deklinací zájmen jenž, týž).

S vědomím těchto skutečností jistě není třeba př́liš zdůrazňovat potřebu pěstování schopnosti vyučujícího náležitě detekovat chybu, spolehlivě odhalit tvar, který není v souladu s kodifikovanou normou. Dobrý češtinář tvaroslovnou chybu nejen identifikuje, ale také dokáže srozumitelným způsobem žákům či studentům vyložit, jak se př́slušný korektní tvar tvoří, jakou funkci v komunikaci plní. Je proto nezbytné, aby bohemisté sledovali relevantní změny a vývoj v oboru, aby se průběžně seznamovali (nejen) s inovovanými podobami kodifikace standardu.

Mnohé je třeba napravovat i v oblasti morfologie funkční. ${ }^{94}$ Ocitujeme výrok, který neutěšenou situaci na základě rozsáhlého šetření vystihuje: „Zjištěné výsledky vyjevily v plné nahotě, že dosavadní výuka v sledované oblasti neplní stanovené cíle, stav se rozhodně proti situaci před 50 lety nezlepšil, ba naopak, ještě se zhoršil. Učitelé nedovedli k chápání podstaty mluvnických kategorií nejen většinu absolventů středních škol, ale ani ty, již projevili zájem a byli prìiati ke studiu bohemistiky. “ (Čechová 2018/2019, s. 32$)^{95}$

\footnotetext{
${ }^{94}$ Znalosti studentů-bohemistů jsou mnohdy sotva průměrné. V naprosté většině nejsou schopni rozlišit generalizující posesivní genitiv od individualizujícího posesivního adjektiva (dům otce $\mathrm{x}$ otcuv di̊m), číslovku souborovou označující počet týchž entit od druhové, která vyjadřuje počet druhů (dvoje brýle x dvojí brýle), nedokáží uspokojivě popsat řečové užití sloves dokonavých a nedokonavých, trpného rodu opisného a zvratného, reflexivního posesivního zájmena svůj apod.

${ }^{95}$ K problematice blíže Adam 2010/2011; 2017/2018; 2018 aj.
} 


\section{Shrnutí}

Jednou z důležitých kvalit oborového studenta bohemistiky a budoucího vyučujícího - češtináře je náležité zvládání spisovné češtiny, prestižní variety českého národního jazyka, její pokročilá, komplexní, aktivní odborná znalost: stratifikací češtiny a jednotlivými varietami počínaje a stylovou platností jazykového výraziva konče. Samozřejmostí by mělo být rovněž noremní užívání mluvnické roviny standardu, plánu morfologického (tvarosloví formálního i funkčního) i syntaktického.

Nezrrídka se jedná o nedostižný ideál. Uchazeči o studium bohemistiky často přicházejí na univerzitu s nízkou vstupní úrovní znalostí češtiny, mnohé je proto třeba v prvních semestrech vysokoškolského učitelského studia dohánět a napravovat. Mělo by se tak dít kvalifikovaným způsobem, soustavně, systémově, důsledně, před potížemi by se rozhodně nemělo ustupovat a spokojovat se s šedým průměrem. Tvarosloví je třeba pojímat komunikativně a kognitivně, výuka by měla být náročná, zajímavá, kreativní, interaktivní, užitečná, účelná (nikoliv samoúčelná). Její podstatnou část by měl tvořit rozbor a řešení praktických jazykových, resp. řečových problémů. Měla by podněcovat k zájmu o obor a posluchačovo zaujetí dále podporovat a rozvíjet.

V takovém prŕistupu spatřujeme jednu z účinných cest, jak zamezovat nežádoucímu chybování oborových studentů v průběhu jejich odborné bohemistické průpravy a následně předcházet chybám žáků a studentů základních a středních škol ve vyučovací praxi, potažmo v každodenním životě. 


\section{Použitá literatura}

ADAM, Robert. Co neumějí studenti bohemistiky. Český jazyk a literatura, 2010-2011, roč. 61, č. 1, s. 8-14.

ADAM, Robert. Postup při morfologickém rozboru jmenných tvarů. Český jazyk a literatura, 2017-2018, roč. 68, č. 5, s. 222-229.

ADAM, Robert. Určování morfologických kategorií jmen: sonda do praktik začínajících studentů bohemistiky. Didaktické studie, 2018, roč. 10, č. 1, s. 13-30.

CVRČEK, Václav. Teorie jazykové kultury po roce 1945. Praha: Karolinum, 2006. $123 \mathrm{~s}$.

CVRČEK, Václav. Regulace jazyka a Koncept minimální intervence. Praha: Karolinum, 2008. 232 s.

CVRČEK, Václav; aj. Mluvnice současné češtiny 1. Jak se píše a jak se mluví. Praha: Karolinum, 2010. 354 s.

ČECHOVÁ, Marie. Mluvnické kategorie podstatných jmen ve vyučování českému jazyku. Praha: Státní pedagogické nakladatelství, 1976. $154 \mathrm{~s}$.

ČECHOVÁ, Marie; aj. Současná stylistika. Praha: Nakladatelství Lidové noviny, 2008. $381 \mathrm{~s}$.

ČECHOVÁ, Marie; aj. Čeština - řeč a jazyk. Praha: Státní pedagogické nakladatelství, 2011 (3. upravené, rozšířené vydání). $442 \mathrm{~s}$.

ČECHOVÁ, Marie. Variantní kodifikace, nebo kodifikace variet? Český jazyk a literatura, 2012-2013, roč. 63, č. 1, s. 19-25.

ČECHOVÁ, Marie. Srovnání nesrovnatelného? Znalosti funkční morfologie u žáků před 50 lety a dnešních bohemistů. Český jazyk a literatura, 2018-2019, roč. 69, č. 1, s. 24-32.

ČERMÁK, František. Obecná a spisovná čeština: poměr, funkce a metodologie. In ŠRÁMEK, Rudolf (ed.). Spisovnost a nespisovnost dnes. Brno: Pedagogická fakulta Masarykovy univerzity, 1996, s. 14-18. 
DANEŠ, František. Situace a celkový stav češtiny. In DANEŠ František; aj. (eds.). Český jazyk na přelomu tisíciletí. Praha: Academia, 1997, s. 12-24.

HAUSENBLAS, Karel; KUCHǍ̌, Jaroslav; aj. Čeština za školou. Praha: Orbis, 1974. 486 s.

HAVRÁNEK, Bohuslav. Úkoly spisovného jazyka a jeho kultura. In HAVRÁNEK, Bohuslav; WEINGART, Miloš (eds.). Spisovná čeština a jazyková kultura. Praha: Melantrich, 1932, s. 32-84.

HENDRICH, Josef; aj. Didaktika cizich jazyků. Praha: Státní pedagogické nakladatelství, 1988. 498 s.

HRDLIČKA, Milan. Jazyková chyba a práce s ní v jazykovém vyučování. In ŠEBESTA, Karel; ŠKODOVÁ, Svatava (eds.). Čeština - cílový jazyk a korpusy. Liberec: Technická univerzita v Liberci, 2012, s. 89-108.

HRDLIČKA, Milan. Vo vobecný češtině a jiné př́běhy. Praha: Karolinum, 2015. 266 s.

HRDLIČKA, Milan. Spisovná a obecná čeština ve výuce cizinců. In NEKULA, Marek; ŠICHOVÁ, Kateřina (eds.). Variety češtiny a čeština jako cizí jazyk. Praha: Akropolis, 2017, s. 85-106.

HRDLIČKA, Milan. Variantností k chaosu? Český jazyk a literatura, 2017-2018, roč. 68, č. 4, s. 174-180.

HRDLIČKA, Milan. Kapitoly o češtině jako jazyku nemateřském. Praha: Karolinum, 2019. 166 s.

JELÍNEK, Milan. Co je to jazyková chyba? In KNESSELOVÁ, Helena; KLÍMOVÁ, Květoslava; HAUSER, Přemysl (eds.). Profesor Hauser jubilující. Brno: Pedagogická fakulta Masarykovy univerzity, 2001, s. 75-85.

KORČÁKOVÁ, Jana. Chyba a učení cizím jazykưm. Hradec Králové: Gaudeamus, 2004. 134 s.

MATHESIUS, Vilém. O požadavku stability ve spisovném jazyce. In HAVRÁNEK, Bohuslav; WEINGART, Miloš (eds.). Spisovná čeština a jazyková kultura. Praha: Melantrich, 1932, s. 14-31.

Mluvnice češtiny 2. Tvarosloví. Praha: Academia, 1986. $536 \mathrm{s.}$ 
Příruční mluvnice češtiny. Praha: Nakladatelství Lidové noviny, 1995. $800 \mathrm{~s}$.

SVOBODOVÁ, Jana; aj. Fenomén spisovnosti v současné české jazykové situaci. Ostrava: Ostravská univerzita, 2011. 233 s.

SVOBODOVÁ, Jana. Čeština na rozcestí. Ostrava: Ostravská univerzita, 2014. $136 \mathrm{~s}$.

ŠMILAUER, Vladimír. Nauka o českém jazyku. Praha: Státní pedagogické nakladatelství, 1972 (3. vydání) 334 s.

ULIČNÝ, Oldřich. Čeština devadesátých let dvacátého století. In ŠRÁMEK, Rudolf (ed.). Spisovnost a nespisovnost dnes. Brno: Pedagogická fakulta Masarykovy univerzity, 1996, s. 59-63. 


\section{Využití metody komplexních jazykových rozborů ve výuce českého jazyka}

Jana Vaňková, Martina Spěváčková

Kapitola volně navazuje na problematiku zpracovávanou v textu Dokáží studenti českého jazyka rozlišovat jazykové roviny a jim odpovídající jazykové prostředky? publikovaném v monografii Od praxe $k$ teorii a zpět ve vyučování češtině (2019). Zatímco $\mathrm{v}$ uvedené stati jsme se zabývaly analýzou toho, jak jsou studenti 1. a 3. ročníku bakalářského studijního oboru Český jazyk se zaměřením na vzdělávání schopni rozlišovat jazykové prostř̌edky náležející $\mathrm{k}$ různým jazykovým rovinám (Nekula in Karlík aj. 2002, s. $380^{96}$ ) a zda jsou schopni chápat jejich stylovou hodnotu, $\mathrm{v}$ předkládaném textu se zaměříme na tyto otázky šíře a $\mathrm{z}$ jiného úhlu pohledu. Náš výzkum se nyní orientuje na učitele českého jazyka působící na základní škole a v nižších ročnících gymnázií, zjištujeme, jak učitelé vnímají otázky vymezení spektra jazykových prostředků (náležejících $\mathrm{k}$ různým jazykovým rovinám) a jejich funkčněstylové rozlišení (jejich stylovou hodnotu) jako jevy důležité pro školní výuku českého jazyka. Zároveň hledáme odpovědi na otázky zaměřené především na míru a efektivitu využívání metody komplexních jazykových rozborů (KJR) v předmětu český jazyk a literatura, na současný prŕístup učitelů $\mathrm{k}$ této metodě a na její funkční pochopení.

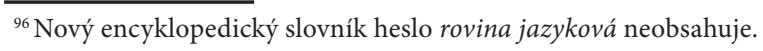


Zde je samozřejmě nutno připomenout, že problematika komplexních jazykových rozborů byla a je v české didaktické tradici dlouhodobě sledována, vymezována a vykládána a byla jí vždy věnována systematická pozornost. $\mathrm{V}$ posledním vydání publikace Komplexní jazykové rozbory (Čechová M. a kol. 1996) v kapitole Pojem komplexní jazykový rozbor stojí: „Jazykový rozbor je starý, známý pojem. Jednou jeho složkou, větným rozborem, se zabýval už J. Gebauer (1891), vypracoval schémata a grafy pro znázornění stavby věty a souvětí.“ (s. 7). Připomínána jsou zde i jména dalších lingvistů, kteří vnímali komplexnost přístupu k jazykovým problémům jako nezbytné východisko správného pochopení jazykového učiva. Jmenujme namátkou V. Šmilauera, K. Hausenblase, M. Dokulila, J. Jelínka, V. Styblíka, J. Hrbáčka, z mladších autorů pak např. R. Adama (2018) aj. Zásadní význam pro školní výuku a pro uvedení této metody do moderního školního vyučování českému jazyku a pro její didaktickou aplikaci však měly studie a práce M. Čechové (1998). V celé naší stati vycházíme ze zásadního stanoviska, že: „Rozbory, ovšem právě jen komplexní, umožňují odstranit izolaci poznatků získávaných v různých jazykových hodinách orientovaných na jednotlivé jazykové plány. “ (Čechová 1996, s. 10).

Ve svém zkoumání se zároveň zabýváme problémem vnímání stylové hodnoty jazykových prostředků (a to jazykových prostředků všech rovin) jako učiva, jako didaktického problému. Ve výkladech o stratifikaci národního jazyka se žáci seznamují s termíny stylový příznak hovorovosti, neutrální jazykový prostředek (prostřredek bezpř́íznakový), stylový př́íznak knižnosti a s vymezením těchto jevů. ${ }^{97}$ Pochopení této problematiky a její následná didaktická transformace jsou však složitější. Ve školní praxi se mnohdy nesprávně zužuje pouze na otázku spisovnosti

\footnotetext{
${ }^{97} \mathrm{~K}$ přehledu budoucích češtinářro o stratifikaci češtiny viz zde studie M. Hrdličky
} (s. 181). 
a nespisovnosti (a to zvláště v rovině lexikální), stranou pozornosti (a často nevymezeny) zůstávají otázky rozvrstvení jazykových prostředků $\mathrm{v}$ rámci spisovného jazyka (právě problém spojený s výkladem pojmu hovorová čeština to ukazuje). Mnohdy se setkáváme $s$ tím, že jsou v zadáních úkolů žáci přímo vybízeni $\mathrm{k}$ tomu, aby našli hovorové prostředky, ale v nabízeném jazykovém materiálu jsou zahrnuty pouze prostředky nekodifikované.

Otázky stylového prŕźzaku, a to i v jeho didaktické aplikaci, je žádoucí vnímat spíše jako hodnotu jazykového prostředku, který je součástí vyššího celku (tedy promluvy), nikoli jako danou hodnotu výrazu mimo řečový kontext. Je třeba soustavně vést žáky k chápání adekvátnosti výběru jazykového prostředku a ke schopnosti jeho náležité volby ze synonymních prostředků (ale nezúžených jen na rovinu lexikální, příp. hláskovou), a to vždy ve vztahu $\mathrm{k}$ vyššímu celku ( $\mathrm{k}$ textu, příp. ke komunikační situaci u textů mluvených), vnímat hodnotu jazykového prostředku jako situačně-kontextovou (Čechová 2008). Pěstuje se tím žákova schopnost citlivé volby, pochopení a vnímání odlišností stylové hodnoty.

Problematika stylového př́iznaku jazykových prostředků se ve školní praxi promítá do výuky předmětu český jazyk a literatura různými způsoby, různými formami a hlavně v různé intenzitě a frekvenci.

Základní metodou našeho výzkumu bylo dotazníkové šetření zaměřené na učitele základních škol a nižších ročníků gymnázií. Byla provedena výzkumná sonda orientovaná na dva základní okruhy problémů, jež jsou však vnitřně provázány, a sice na problematiku komplexních jazykových rozborů a na to, jakým způsobem se v hodinách českého jazyka a literatury pracuje se stylově př́znakovými (zabarvenými) jazykovými prostředky. Zajímalo 
nás, co učitelé českého jazyka a literatury rozumějí pod pojmem komplexní jazykový rozbor, ve kterých ročnících a jak často tento rozbor provádějí a které zdroje využívají jako podklady ke KJR. Rovněž nás zajímalo, která jazyková rovina se respondentům jeví z pohledu KJR jako nejobtížnější a nejproblémovější a zda v hodinách českého jazyka a literatury do komplexních jazykových rozborů zařazují také učivo o stylové hodnotě jazykových prostředků. S tím souvisely otázky, do kterých jednotlivých složek předmětu je učivo o stylové hodnotě jazykových prostředků zařazováno, zda je zařazováno systematicky, či nahodile, které aktivity jsou k tomu využívány a které jazykové roviny jsou $\mathrm{k}$ tomu podle respondentů nejvhodnější. V poslední části dotazníku měli respondenti rozhodnout o vhodnosti konkrétního jazykového materiálu, který by mohl být východiskem výkladu o stylové hodnotě jazykových prostředků, a komentovat některá nesprávná tvrzení, s nimiž se mohou ve výuce setkat.

Na základě zkušeností s výukou studentů bohemistiky v disciplínách zařazovaných do úvodních fází studia, do předmětů Úvod do lingvistické terminologie, Základy jazykovědy, Úvod do studia českého jazyka, opakovaně zjištujeme, že poznatky o této problematice nemají studenti upevněny a mnohdy ani ujasněny.

Cílem naší výzkumné sondy je hledat odpovědi na řadu otázek: Jsou všestranné jazykové rozbory, pochopení a poznání jednotlivých jazykových rovin a jejich ústrojné propojování dostatečně akcentovány ve školní výuce? Zabývají se jimi učitelé pravidelně? Jsou přesvědčeni o jejich důležitosti $\mathrm{v}$ celém komplexu výuky předmětu český jazyk a literatura ve škole? Vnímají otázku užitečnosti (či dokonce nezbytnosti) zařazení komplexních jazykových rozborů do výuky českého jazyka? Zařazují do komplexních jazykových rozborů také učivo o stylové hodnotě jazykových prostředků? 
Zde je však na místě si uvědomit, co vše je učiteli vnímáno jako komplexní jazykový rozbor. Podle některých zjištění je často za komplexní jazykový rozbor považován jakýkoli rozbor textu, mnohdy jen prosté nahromadění úkolů bez logické struktury, bez vnitřní propojenosti, bez systematického postupného řazení úkolů.

Ve své výzkumné sondě se pokusíme aktuálně ověřit, nakolik je problematika KJR skutečně plně pochopena a osvojena, jaké má místo ve výuce českému jazyku.

Internetový odkaz na elektronický dotazník ${ }^{98}$ byl rozeslán ředitelům a učitelům vybraných základních škol a gymnázií v Plzeňském kraji a zároveň byl sdílen na sociální síti facebook, např. ve skupině Učitelé $+{ }^{99}$.

V období od 10. 3. do 20. 4. 2020 se nám podařilo získat celkem 75 odpovědí, sondy se zúčastnilo 64 učitelů základní školy a 13 učitelů působících na nižším stupni gymnázia, dva z nich uvedli, že vyučují zároveň na ZŠ i na gymnáziu. ${ }^{100}$ Délka praxe respondentů byla v rozmezí od jednoho roku do 37 let. ${ }^{101}$

\footnotetext{
${ }^{98}$ survio.com [cit. 1. 9. 2020]. Dostupné z: https://www.survio.com/survey/d/O2R 6E7J5G0C6I3C3M

${ }^{99}$ Jedná se o skupinu určenou pro učitele, učitelské profese a studenty učitelských fakult. Cílem této skupiny je předávání informací a diskuse mezi učiteli.

${ }^{100}$ Vzhledem k tomu, že počet respondentů působících na ZŠ a na gymnáziu je nevyrovnaný (84,9\% a 17,8 \%), nevyhodnocujeme rozdíly mezi jednotlivými stupni školy, ale získaná data sumarizujeme.

${ }^{101}$ Průměrná doba praxe byla 15 let (při vyhodnocování výsledků nebyla doba praxe zohledněna).
} 


\section{Výsledky získané dotazníkovým šetřením}

Jedna $\mathrm{z}$ výchozích otázek zadaného dotazníku je zaměřena na vnímání komplexních jazykových rozborů jako jedné ze základních vyučovacích metod. Na otázku Co rozumite pod pojmem komplexní jazykový rozbor? se nejčastěji vyskytovaly odpovědi dokládající v zásadě náležité pochopení této metody a jejího správného užívání. Respondenti např. odpovídali:

„Základní poznávací metoda pro systém jazyka, $k$ němuž se dostáváme analýzou komunikační situace. Slouží k uvědomění souvztažnosti mezi funkcí projevu a $k$ tomu uzpi̊sobeným výběrem korespondujících jazykových prostředků. Vhodné je pracovat is defektními komunikáty, kde je tato korespondence mezi funkcí a prostředky oslabena."

„V̌̌estranný jazykový rozbor, zaměrený na rozbor komunikační situace, rozbor syntaktický, lexikální a slovotvorný, slovnědruhový a tvarotvorný, rozbor zvukové a grafické stránky a rozbor stylistický. “

Někdy učitelé uvažovali o rozboru pouze v rozmezí věty:

„Rozbor větného celku ve všech rovinách - stavba slova, určování gramatických kategorií, určování větných členů, stavba souvětí, druhy vedlejších vět a vztahy mezi nimi..."

Nezanedbatelná část učitelů pak ve svých odpovědích zužuje KJR pouze na rozbor syntaktický a morfologický. Odpovídají např.:

„Určení slovních druhư, větných členů, druh souvětí, všechno, co se dá určit." 
„Syntax, morfologie, někdy i lexikologie."

Zajímavá byla jedna odpověd, odkazující přímo ke konkrétnímu titulu:

„To, co obsahuje klasická publikace Vèry Hartmannové Jazykové rozbory."

Lze tedy říci, že $\mathrm{v}$ teoretické rovině a $\mathrm{v}$ charakteristice pojmu většina respondentů vymezuje komplexní jazykové rozbory relativně správně, chápe je v celé jejich komplexnosti, uvědomuje si jejich smysl a cíle v jazykovém vyučování. Z části odpovědí však vyplývá, že se problém komplexních jazykových rozborů spojuje pouze s některými jazykovými rovinami, a to nejčastěji s morfologickou, syntaktickou, př́p. lexikální.

Výsledky naší sondy dále ukazují, že komplexní jazykové rozbory jsou do výuky zařazovány především ve vyšších ročnících. $\mathrm{Na}$ otázku Ve kterých ročnících provádíte se svými žáky komplexní jazykové rozbory ${ }^{102}$ odpovědělo 54 dotázaných (celkem $74 \%$ ) v 8 . ročníku, 53 dotázaných $(72,6 \%)$ v 9. ročníku, 43 respondentů $(58,9 \%)$ provádí komplexní jazykové rozbory v 7 . ročníku a 41 respondentů (56,2 \%) v 6. ročníku. Tři dotazovaní uvedli, že komplexní jazykové rozbory v hodinách českého jazyka neprovádějí vůbec.

Celkem 28 respondentů (38,4 \%) zařazuje komplexní jazykové rozbory do výuky jednou týdně, jeden dotazovaný uvedl, že je provádí s žáky každou hodinu. Někteří dotazovaní u otázky zaměřené na frekvenci rozborů $\mathrm{v}$ hodinách českého jazyka uvedli, že je provádějí nepravidelně, protože jde o časově velmi náročnou práci, př́ípadně že komplexní jazykové rozbory nechávají až

${ }^{102}$ Respondenti mohli označit více odpovědí. 
na konec školního roku, tedy na dobu, kdy je již všechno učivo probráno. Mnohé odpovědi korespondovaly s výsledky získanými v předchozí otázce, totiž že frekvence zadávání komplexních jazykových rozborů je vyšší ve vyšších ročnících.

Jako podklady ke komplexním jazykovým rozborům jsou nejčastěji využívány vlastní zdroje ${ }^{103}$ pedagogů (86,6 \% dotazovaných), učebnice (75,3 \% dotazovaných) a internet (57,5 \% dotazovaných), 6,8 \% dotazovaných pracuje i s jinými zdroji (vedle výše uvedených), napr. s úryvky žákovských prací. Dva respondenti uvedli, že v hodinách využívají podklady získané v různých facebookových skupinách, jejichž členy učitelé českého jazyka jsou.

Zajímavé zjištění přninášejí odpovědi na otázku Která jazyková rovina (roviny) se Vám jeví z pohledu komplexních rozborů jako nejobtižnější a nejproblémovější 44 dotazovaných (60,3%) uvedlo rovinu syntaktickou, 20 respondentů $(27,4 \%)$ uvádí rovinu stylistickou, 19 respondentů (26\%) rovinu morfologickou a 14 respondentů $(19,2 \%)$ rovinu foneticko-fonologickou. Pouze 9 respondentů $(12,3 \%)$ se domnívá, že obtížná a problémová je rovina lexikální. V komentářích byly uváděny např. následující důvody:

„Děti obtižně chápou větné členy, druhy vedlejších vět atd. Neumí se správně na problematiku zeptat, pletou se jim pojmy."

„Tvarosloví je pro žáky obecně obtižné, nevidí v něm logický systém, ale spís spoustu výjimek. Skladba, slovní zásoba i stylistika jsou pro ně prehlednější."

\footnotetext{
${ }^{103}$ Pod pojmem vlastní zdroje rozumíme portfolio materiálů, které učitelé shromaždují během své učitelské praxe.
} 
„Práce s psaným textem príliš nepodporuje sluchové vnímání textu a mnozi žáci mají potíže rozpoznat jevy ze zvukové roviny v psaném textu."

„Neznají význam slov či slovních spojení, nečtou."

Z odpovědí dále vyplynulo, že při práci s textem se učitelé vedle vlastních komplexních jazykových rozborů zaměřují především na porozumění textu, pochopení smyslu sdělení, chápání významu neznámých slov a na sledování pravopisné správnosti.

Na naši předchozí stat' (2019) asi nejvíce navazuje obsah úkolu zaměřeného na jevy, které se ve školní praxi opakovaně ukazují jako problémy, a to zejména proto, že žáci nemají dostatečně upevněno učivo o jednotlivých jazykových rovinách. Zajímalo nás, zda se učitelé setkávají ve své výuce se zavádějícími, mylnými tvrzeními, která se však objevují znovu a znovu a představují zásadní didaktické problémy, a jak s nimi didakticky pracují.

Respondenti pracovali s tímto konstatováním: V následující větě je slovo červená př́vlastkem, protože je to př́davné jméno. $\mathrm{Na}$ stole ležela červená jablka.

18 respondentů $(24,7 \%)$ uvedlo, že se s tímto problémem ve výuce setkává. $\mathrm{Na}$ otázku, jak s tímto nepřesným tvrzením didakticky pracují, např. odpovídají:

„Opravuji, že prívlastek sice často bývá vyjádřen př́ídavným jménem, ale může být vyjádřen také jiným slovním druhem (čtyři jablka), pojí se k substantivu."

„Žáci si skutečně často pletou větněčlenskou a slovnědruhovou platnost. Tento způsob zdìvodnění bych netolerovala, 
je zavádějící a matoucí."

„Velmi často, snažím se vysvětlit, aby „nemíchali“ do sebe jazykové vědy. Srov. větu Na semaforu svítila červená."

Opakovaně se v odpovědích setkáváme se záměnou pojmů jazyková věda a jazyková rovina. Sám pojem jazyková věda je značně problematický, i když chápeme, co mají respondenti na mysli.

Z odpovědí je zřejmé, že si učitelé tento problém většinou uvědomují a že ho ve výuce procvičují.

Dále učitelé měli posoudit vztah mezi vymezením přísudku (jako učiva roviny syntaktické) a vymezením slovesa (jako učiva roviny morfologické). Ukázalo se, že tento problém vnímají jako mnohem závažnější. 41 respondentů (56,2\%) odpovědělo, že se ve výuce setkalo s tvrzením: Počet vět v souvětí určujeme podle počtu sloves.

Respondenti např. uvádějí:

„Je to nepresné. V nižších ročnících to ale toleruji, pokud žák upřesní, že se jedná o počet časovaných sloves (ne infinitivy).“

„Obvykle pak nechám určit počet vět $v$ souvětí s několika infinitivy a pracujeme s rozdílem mezi pojmy prísudek a sloveso."

„S tímto tvrzením pracuji, protože je to nejjednodušši způsob, jak pomoci žákưm vưbec začít vnímat strukturu věty."

„Vysvětlím, že počet vět poznám podle sloves v určitém tvaru - vyjadřují osobu, a dám nový úkol na dané téma." 
„Ano, dál se ptám na doplnění tohoto sdělení, dohledáváme podměty, počitáme základní skladebné dvojice."

„Vedu žáky k rozlišení pojmu sloveso, činný tvar slovesa a infinitiv s použitím príkladù."

„Ano, nechávám, u většich doplňujeme určitým slovesným tvarem/prísudkem."

„Ano. Vysvětluji možnost několikanásobný větný člen."

„Upozorním na infinitivy a prechodníky.“

Z mnoha doložených odpovědí (formulací odpovědí) vyplývá problematičnost a obtížnost vysvětlování těchto otázek. Je to zřejmé mj. ze záměny $\mathrm{v}$ užívání základních odborných termínů ve výkladu jevu (Např. počet časovaných sloves - zde měla respondentka zcela jistě na mysli počet určitých slovesných tvarů. Podobně problematické je užití termínu činný tvar slovesa.) či z toho, že do výkladu daného jevu jsou zahrnovány problémy jiné („Vysvětluji možnost několikanásobný větný člen.“).

Učitelé se s výše naznačenými problémy setkávají, věnují jim pozornost, ale ne vždy dokážou vést žáky $\mathrm{k}$ důslednému pochopení faktu, že systémovým základem věty může být jedině určitý slovesný tvar, a to jednoduchý nebo složený. I když z odpovědí vyplývá, že vedou žáky k rozlišování termínů přísudek a sloveso, není vždy vytvořen jasný algoritmus vedoucí žáky k pochopení rozdílů mezi složeným slovesným tvarem (přísudkem slovesným jednoduchým - budeme pracovat) a predikátem slovesným složeným tvořeným různými tvary více sloves (začali jsme pracovat). 
Ukazuje se tak, že směšování roviny morfologické a syntaktické je ve výuce českého jazyka zásadním a stále se opakujícím problémem - viz výsledky sondy zaměřené na znalosti vysokoškolských studentů (2019).

Další konstatování v dotazníku bylo zaměřeno na problematiku slovotvorby: Slovo rybár je odvozeno od slova ryba, protože mají stejný kořen slova.

13 respondentů (17,8 \%) uvádí, že se s tímto tvrzením setkává. Ukazuje se, že učivo o slovotvorbě patří k problémovým pasážím výuky českého jazyka. Většina respondentů ve svých odpovědích prvoplánově uvádí, že je důležitá znalost a vymezení základních pojmů, jako jsou pojmy slovo základové, slovotvorný základ, slovo odvozené, kořen slova. Zamyslíme-li se však podrobněji nad skutečným obsahem jednotlivých odpovědí, vidíme, že odborné i didaktické zvládnutí problému, náležité užívání algoritmických postupů a skutečně důsledné užívání základních termínů tomu neodpovídá. Povšimněme si např. odpovědi:

„Nesetkávám se, žáci odpovídají na otázku: Kdo je to rybářr? Odpovědí je: Rybář je člověk, který chytá ryby - zákl. tvar $=R Y B A .{ }^{“}$

Žáci správně hledají vztah motivace, ale zároveň se nesprávně pracuje s pojmem základní tvar (nikoli s pojmem slovo základové).

Respondenti dále uvádějí:

„Kořen je stejný, to je pravda. A co slovo rybaření? Z jakého slova bylo utvářeno. $Z$ rybařit, správně. Ale vždyt ryba a rybaření má stejný kořen." 
„Kořen patř́ do morfologie, naopak odvozování do lexikologie, nelze kombinovat tyto dvě vědy ve zkoumání."

„Toto nechám většinou bez poznámky. Pokud jsem si ale danou třídu učila já sama, zmíním slovo základové."

"Ano, setkávám. Vyhledáváme slova príbuzná, odvozená. Nebo naopak: Které slovo nepatři do rady slov."

„Slovotvorba je problém, sama ji učím velmi nerada." „Ano, stačilo by mi.“

Z některých odpovědí vyplývá, jak problematickým učivem je slovotvorba. $\mathrm{Z}$ pohledu učitelů mnohdy patří $\mathrm{k}$ neoblíbenému učivu, je odsouvána nebo probírána povrchně. Velmi často dochází ke směšování slovotvorby se stavbou slova, př́ípadně s lexikologií.

Poslední tvrzení, k němuž měli respondenti zaujmout postoj, bylo zaměřeno na rovinu morfologickou: „Ve spojeních tatínkovi bratři a dej to tatínkovi pišeme ve tvarech tatínkovi v koncovce -ovi vždy měkkéi.“

19 respondentů (26 \%) uvádí, že se s uvedeným tvrzením setkává.

„Mohou být také tatínkovy sestry, kde měkké i už nebude. Nebo dáme spojení tatínkovi bratři do 4. pádu, koncovka v prídavném jménu přivlastňovacím se změní."

„Nutné upozornit na rozdílné slovní druhy $v$ těchto př́padech. Toto považuji za velmi problematickou partii pro žáky. Zde používám drilová cvičení." 
„Ne. S tím se u dětí nesetkávám, nikdy jsem jim neříkal, že píšeme vždy-i. I šestáci u mě ví, že záleží, zda jde o při vlastňovací adjektivum nebo substantivum."

„Žádná koncovka -ovi!!! Musíš vědět, zda je to př́davné jméno přivlastňovací nebo podstatné jméno, pak si určíš pád a vzor."

„Pořád opakujeme podstatné vs. př́davné jméno. Stejně pořád dělají chyby."

V odpovědích sice zaznamenáváme správná vysvětlení různé slovnědruhové platnosti (podstatné jméno tatínek x přídavné jméno tatínkưv), ale problém je podle našeho názoru v tom, že $\mathrm{v}$ žádné $\mathrm{z}$ odpovědí nebylo naznačeno, že se jedná o různé koncovky (dej to tatínk-ovi x tatínkov-i bratři). Dokonce se v některých odpovědích explicitně mluví o různých koncovkách -ovi.

„Vysvětlíme si jasně rozdíly u koncovek podstatných a přídavných jmen, není ovi jako ovi... :)“

„Je třeba rozlišovat prídavné jméno přivlastňovací (možné dvě koncovky: -ovi/-ovy) a podstatné jméno (jen -ovi).“

Podobně problematické je vysvětlení „U spojení „tatínkovi bratři“ sdělim, aby si řekli: „ti bratři“. Zmínila bych $i$ variantu „tatínkovy sestry“. Zde je již viditelný rozdíl. "Tento postup podle našeho názoru žákům nepomůže (bez problémů si totiž řeknou ty bratři, ty ženy, ty děcka).

Za didakticky problematická pokládáme také navrhovaná drilová cvičení. Domníváme se, že metoda drilu v tomto př́padě není funkční, protože nevede žáky k pochopení rozdílů. Drilová cvičení 
je nutno v daném případě odmítnout, naopak řešení spočívá v pochopení stavby slova a ve vymezení koncovky.

Výsledky druhé části naší sondy věnované otázkám stylové př́znakovosti jazykových prostředků ukázaly, že problematice stylového příznaku je nejvíce pozornosti věnováno $\mathrm{v}$ hodinách komunikační a slohové výchovy - takto odpovědělo 65 dotazovaných, tj. $89 \%$. 37 učitelů $(50,7 \%)$ se stylově příznakovým jazykovým prostředkům věnuje v hodinách literatury a pouze 22 respondentů $(30,1 \%)$ uvedlo, že se této problematice věnuje také $\mathrm{v}$ a jazykové složce předmětu. Učivo o stylové prŕíznakovosti jazykových prostředků je zařazováno především do vyšších ročníků (podobně jako učivo o komplexních jazykových rozborech). Zároveň z odpovědí učitelů vyplynulo, že ne vždy se jim daří propojovat teoretické znalosti o stylové hodnotě jazykových prostředků v jednotlivých složkách předmětu český jazyk systematicky. 57,5 \% učitelů uvádí, že znalosti v jednotlivých složkách předmětu propojují spíše nahodile. Z komentářů učitelů uvádíme:

"Jak kdy, systém mám, ale občas se naskytne príležitost, kterou by bylo škoda nevyužit, četba žákovské práce, úryvek $v$ čítance."

„Snažím se toto téma připomínat pravidelnè, ale o propracovaném systému se asi mluvit nedá."

Za nejvhodnější jazykovou rovinu, v níž lze probírat problematiku stylové př́iznakovosti jazykových prostředků, považují učitelé rovinu lexikální - 55 respondentů (75,3\%). Naopak za nejméně vhodnou jazykovou rovinu je podle získaných odpovědí považována rovina foneticko-fonologická ${ }^{104}-9$ respondentů (12,3\%). 23 respondentů $(31,5 \%)$ uvádí, že tuto problematiku je vhodné

${ }^{104}$ Srov. zde výsledky dotazníkového šetření J. Málkové (s. 217). 
probírat v souvislosti s morfologickou rovinou, podle 18 respondentů $(24,7 \%)$ je vhodná rovina syntaktická. 13 respondentů svoji odpověd' rozvedlo $\mathrm{v}$ komentáři. Ve třech případech dotazovaní správně uvedli, že stylová příznakovost souvisí se všemi jazykovými rovinami, např.:

„Myslím, že je to tak vzájemně propojeno, že bych to takto jednoznačně neurčovala. Pokud musím odpovědèt, tak lexikální."

Přesto se ale objevily také odpovědi, které ukázaly na nepochopení problému: „Jazykové prostředky souvisí se slovní zásobou.“

Problematice stylové př́iznakovosti věnují učitelé českého jazyka pozornost v následujících aktivitách: ve slohových pracích - 65 učitelů $(89 \%)$, dále pak v rozboru literárních děl - 50 dotazovaných $(68,5 \%)$, v mluvních cvičeních - 29 respondentů $(39,7 \%)$ a v referátech - 15 respondentů $(20,5 \%)$.

Zajímalo nás také, jakým způsobem učitelé pracují s výsledky oprav slohových prací ve vztahu ke stylové hodnotě užitých jazykových prostředků (s ohledem na adekvátnost volby jazykových prostředků v daném komunikátu) ${ }^{105} .56$ dotazovaných $(76,7 \%)$ preferuje společnou analýzu ve třídě, 38 (52,1\% z celkového počtu dotazovaných) provádí následný individuální rozbor s jednotlivými žáky, př́padně vytváří cvičení zaměřená na problémové jevy - 24 (32,9 \%). Čtyři respondenti uvedli ještě jiný způsob, např.:

„Zejména prípravou pred tvorbou slohové práce, scaffoldingem zaměreným na adekvátní jazykové a stylové prostředky."

\footnotetext{
${ }^{105} \mathrm{~K}$ opravám slohových prací viz zde studie S. Štěpáníka (s. 104).
} 
Z pohledu vnímání stylového př́znaku jazykových prostředků jako učiva je velmi zajímavý výsledek úkolu zaměřeného na výběr jazykového materiálu, který se jeví jako nejvhodnější k pochopení uvedeného problému. Záměrně byly v dotazníku vybrány velmi průkazné jevy:

a) Podtrhněte slovo nespisovné: pořád, stále, soustavně, furt.

b) Najdète výraz, který je nositelem stylového príznaku hovorovosti: mohli bychom, mohli byste, nemužu si pomoct, děkuji.

c) Podtrhněte chybný (nekodifikovaný) tvar: hokejisté, husité, demonstranté.

V bodě a) a c) se jednalo o skupinu výrazů, mezi něž byly zařazeny nekodifikované prostředky - v bodě a) lexikální prostředek obecněčeský - výraz furt, v bodě c) hyperkorektní tvar demonstranté. Výrazy v bodě b) patří všechny mezi kodifikované jazykové prostředky odlišující se právě jen svým stylovým příznakem. V bodě a) i c) byl navíc zdůrazněn fakt nespisovnosti, nekodifikovanosti. 72,6 \% respondentů vybralo bod a) jako soubor výrazů nejvhodnějších pro výklad daného jevu, zatímco bod c) jen 6,8 \% respondentů. Variantu b) volilo 39,7 \% respondentů. $\mathrm{Z}$ výsledku zřetelně vyplývá směšování problémů spisovnosti a nespisovnosti s problematikou stylové hodnoty jazykového prostředku. Respondenti preferují výklad otázek stylového příznaku na nekodifikovaném výrazu roviny lexikální (furt) před rovinou morfologickou (demonstranté).

Tato tvrzení jsou podporována také výsledky dalšího úkolu. $\mathrm{V}$ něm byly představeny krátké textové ukázky různých funkčních stylů, a sice úryvky odborného textu a úryvek textu uměleckého. Nejčastěji (82\%) vybírali respondenti text uměleckého funkčního stylu, obsahující opět řadu nekodifikovaných výrazů. Je příznačné, že text odborného funkčního stylu nepokládají učitelé 
za vhodný pro výklad problematiky stylové hodnoty jazykových prostředků.

Viz př́íklady komentářů:

„Odborné texty, na kterých toho moc nevysvětlím z hlediska stylistického."

„Tento text (umělecký) obsahuje pestrou škálu jazykových prostředků, dobře se na něm problematika vysvětlí."

\section{Shrnutí}

Ze zjištěných výsledků dotazníkového šetření jednoznačně vyplývá, že metoda komplexních jazykových rozborů je učiteli ve výuce českého jazyka stále využívána jako jedna z frekventovaných výukových metod. Ukazuje se však, že stále není vnímána její komplexnost, jsou akcentovány jen některé jazykové roviny, a to zejména lexikální a morfologická, př́íp. syntaktická, i když o této rovině učitelé shodně uvádějí, že patři $\mathrm{k}$ nejobtížnějším. Jeden $\mathrm{z}$ hlavních cílů této metody, a sice komplexní pohled na jazyk v celé jeho struktuře, vymezení jazykových rovin, ale zároveň pochopení jejich vzájemné provázanosti a podmíněnosti, není podle našeho názoru zcela uspokojivě naplněn. Opakovaně se ukazuje nepochopení hranic mezi rovinou morfologickou a syntaktickou, mezi morfologickou a slovotvornou.

Ústrojnou součástí komplexních jazykových rozborů je práce $s$ textem a $s$ jeho jednotkami z pohledu jejich stylových příznaků, a to obecně pojatých a příznaků stylově kontextových, tedy těch, které jazykový prostředek nabývá až uvnitř celého komunikátu. Závěry zjištěné naším výzkumem ukazují na převahu vnímání 
stylového př́íznaku jazykového prostředku chápaného izolovaně. Jedno ze zásadních zjištění spočívá v tom, že respondenti směšují problém stylového příznaku pouze s otázkou spisovnosti či nespisovnosti jazykového prostředku. Stylový prríznak je chápán $\mathrm{v}$ mnohem větší míře na prostředcích roviny lexikální, příp. morfologické, naproti tomu prostřredky roviny hláskové a syntaktické respondenti často nevnímají.

\section{Použitá literatura}

ADAM, Robert. Gramatické rozbory češtiny: výklad a cvičení s řešeními. Praha: Univerzita Karlova, nakladatelství Karolinum, 2018. $240 \mathrm{~s}$.

ČECHOVÁ, Marie; STYBLÍK, Vlastimil. Čeština a její vyučování. Didaktika českého jazyka pro učitele základních středních škol a pro studenty učitelství. Praha: SPN, 1998. $264 \mathrm{~s}$.

ČECHOVÁ, Marie; aj. Komplexní jazykové rozbory. Praha: SPN pedagogické nakladatelství, 1996. $263 \mathrm{~s}$.

ČECHOVÁ, Marie; KRČMOVÁ, Marie; MINÁŘOVÁ, Eva. Současná stylistika. Praha: Nakladatelství Lidové noviny, 2008. $381 \mathrm{s.}$

NEKULA Marek in KARLÍK, Petr; NEKULA, Marek; PLESKALOVÁ, Jana (eds.). Encyklopedický slovník češtiny. Praha: Nakladatelství Lidové noviny, 2002. s. 380.

SPĚVÁČKOVÁ, Martina; VAŇKOVÁ, Jana. Dokáží studenti českého jazyka rozlišovat jazykové roviny a jim odpovídající jazykové prostředky? In ČECHOVÁ, Marie; SPĚVÁČKOVÁ, Martina (eds.). Od praxe $k$ teorii a zpět ve vyučování češtině. Plzeň: ZČU, 2019. s. 84-93. 


\section{Učitel jako vzor i arbitr kultivovanosti mluveného projevu ve výukové komunikaci}

Jitka Málková

Cílem následující kapitoly je zjistit na základě analýzy mluveného projevu, jak učitelé vnímají míru kultivovanosti svého vyjadřování ve výukové komunikaci (v rovině fonetické, morfologické a lexikální), zda jsou v tomto ohledu schopni sebereflexe. Na základě dotazníkového šetření rovněž posuzujeme, jak učitelé vedou ke kultivovanosti v mluveném projevu své žáky, jak jejich mluvený projev rozvíjejí a vyhodnocují, a to zejména pomocí mluvních cvičení.

Tento průzkum navazuje na naši výzkumnou sondu z roku 2019, která se zabývala postoji studentů učitelství 1. stupně základní školy a studentů bakalářského studia (nečeštinářů) ke spisovnému jazyku a jeho užívání (či schopnosti jej užívat a jeho prostředky diferencovat). Bylo v ní zjištěno, že většina studentů (budoucích pedagogů) uznává prestižní postavení spisovné češtiny i v mluvené podobě a uvědomuje si důležitou roli školy a učitele jakožto řečového vzoru v rozvíjení a kultivování mluveného projevu žáků. Řečovou kultivovanost vztahovali studenti především k užívání spisovných jazykových prostředků, ostatní kvality i spojitost s komunikační situací a komunikačním účelem většinou opomíjeli. Značné obtíže měli mj. s klasifikací jazykových prostředků jednotlivých jazykových rovin (zjištováno u roviny fonetické, morfologické a lexikální), což doložily i další, paralelně probíhající výzkumné sondy (Spěváčková, Vaňková 
2019, s. 91). Strukturální vnímání jazyka tedy nebylo u studentů prokázáno $\mathrm{v}$ dostatečné míre, studenti chápali jazyk spíše jako množinu jazykových prostředků bez vzájemných vztahů a hierarchického rozlišení. Zjištěná tendence tolerovat $\mathrm{v}$ mluveném projevu nespisovné jazykové prostředky tak souvisí s neschopností je identifikovat a diferencovat, což nesvědčí o uspokojivé znalosti jazyka a jeho užívání v řečové praxi. Ukázalo se tedy, že u budoucích pedagogů existuje na počátku jejich studia zřetelný protiklad mezi skutečným řečovým chováním (se zaměřením na mluvený projev) a představou o něm. Vyplývá to $\mathrm{z}$ nedostatečné znalosti systému jazykových prostředků a jejich funkce (viz zde M. Hrdlička, s. 184).

Aktuální výzkumná sonda se zaměřuje na učitele, kteří již ve školní praxi působí, a to jak na prvním stupni základní školy, tak i na stupni druhém (učitelé českého jazyka i ostatních předmětů). První část výzkumu proběhla formou analýzy zvukových nahrávek vlastního mluveného projevu ve výukové komunikaci s následnou sebeevaluací, v druhé části jsme použili formu dotazníkového šetření. Internetový odkaz na elektronický dotazník ${ }^{106}$ byl rozeslán učitelům základních škol převážně v Plzeňském kraji a zároveň byl sdílen na sociální síti Facebook, např. ve skupině Učitelé $+{ }^{107}$.

Obě části byly realizovány v období od února do června 2020. První části výzkumu se zúčastnilo 46 respondentů, dotazníkové šetření podstoupilo 50 respondentů. Délka jejich učitelské praxe se pohybovala $\mathrm{v}$ širokém rozmezí (1-35 let). Převažovala praxe v délce 10-35 let, jednalo se tedy ve většině prrípadů již o zkušenější a zkušené učitele.

\footnotetext{
${ }^{106}$ survio.com [cit. 1. 8. 2020]. Dostupné z: https://www.survio.com/survey/d/X7N 6G2B8M5V5Q3V5P

${ }^{107}$ Skupina sdružuje učitele a studenty učitelských fakult. Jejím cílem je předávání informací, výměna zkušeností a diskuse mezi učiteli.
} 
Analýza zvukové nahrávky zahrnovala provedení zjednodušeného fonetického přepisu 15-20 minut mluveného projevu respondentů v roli učitele ve vyučovací hodině. Dále se soustředila na následující úkoly vedoucí k sebehodnocení:

1. V textu prepisu nahrávky tučně vyznačte výslovnostní, tvaroslovné a lexikální nedostatky (nespisovné jazykové prostředky).

2. Vyznačte podtržením všechny naduživané (výplňkové) výrazy a $z v u k y .{ }^{108}$

3. Zhodnotte hlasitost svého projevu: a) vysoká b) přiměřná c) nedostatečná

Naprostá většina respondentů označila b) - 95,8 \%. Možnost a) zvolilo 4,2 \%.

4. Zhodnotte řčcové tempo svého projevu: a) poměrně rychlé b) přiměřené c) spíše pomalé

Většina respondentů označila b) - 74,9 \%. Možnost a) zvolilo $16,6 \%$ dotázaných, c) $8,5 \%$.

5. Zhodnotte pečlivost své artikulace: a) velmi dobrá b) místy horší c) špatná

Většina respondentů označila a) - 74,9 \%. Možnost b) zvolilo $25,1 \%$ dotázaných.

6. Svi̊j mluvený projev hodnotím z hlediska sledovaných jevi̊ jako: a) velmi kultivovaný b) převážně kultivovaný c) méně kultivovanýd) spiše nekultivovaný

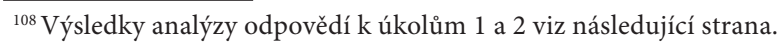


Většina respondentů označila b) - 64,1 \%. Možnost a) zvolilo 23,9 \% dotázaných, c) 4,1\%, d) 7,9\%.

Z porovnání nahrávek a přepisů a z vyhodnocení připojených úkolů a odpovědí vyplývá, že respondenti většinou nezachytí všechny své nedostatky, a to zejména $v$ rovině fonetické. $\mathrm{V}$ této rovině jsou schopni důsledně identifikovat (často ale až při opakovaném poslechu) většinou pouze markantní chyby typu vypouštění nebo změny konsonantů - eště, vem si, dyžtak, takle, kosky, menuje, pudeme, dyž, ňáký, todle...., dále hezitační zvuky a místy také porušování vokalické kvantity (prosim, myslim, tim...). Uvedené nedostatky se paradoxně v jejich projevech vyskytují poměrně hojně. $\mathrm{Na}$ druhé straně se však v několika př́padech setkáme i s tím, že za nedostatky jsou považovány náležité případy asimilace znělosti (názef, fšichni, koncofka, fšimneme si, prfky, aš, f pořátku, tagže, mnošství, skratka, něgdo, gdo, přetstafte si, butto, otásky, fodbalové...). Respondenti dále dovedou vcelku objektivně posoudit paralingvální prostředky, konkrétně tempo a hlasitost projevu. $\mathrm{V}$ naprosté většině je oprávněně hodnotí jako přiměřené, rovněž pečlivost artikulace jako velmi dobrou.

$\mathrm{V}$ rovině morfologické respondenti dobře identifikují porušení spisovné normy ve tvarech adjektiv (sešity jsou těžký, je to lehouč$k y ́ . .$.$) a sloves (kdyby si si, dělaj...). Za nespisovné ovšem nezřídka$ považují spisovné hovorové tvary některých sloves (děkuju, preju, potřebuju, použiju, zakazujou, jmenujou...), popř. tvary neutrální (zapíšu, napíšu). Části učitelů činí klasifikace jazykových prostředků této roviny značné obtíže - řadí sem totiž prostředky lexikální (tělocvik, prvňáčkové) nebo fonetické (sedum, eště, s tim, odněkud', preci, vopravdu, voni, na votočku...). Termín nespisovný tvar slova patrně ztotožňují s nespisovným výrazem nebo $s$ nespisovnou podobou výslovnosti. To opět dokládá problémy 
se znalostí lingvistické terminologie a přetrvávající neschopnost chápat jazyk jako systém (Málková 2019, s. 102).

V rovině lexikální není pro respondenty problém zachytit nadužívání některých výrazů, tzv. výplňkových slov (tak, takže, jo, že jo, ano, vlastně, prostě, jakoby....), často je však hodnotí mechanicky, nebot' neodlišují př́ípady, kdy je použití daného výrazu funkční. Nedostatky v podobě použití nespisovného lexika se jim daří vyhodnocovat pouze částečně (barák, furt, fabrika). K lexikálním nedostatkům přiřazují totiž i nedostatky jiných jazykových rovin (bysme, ty apoštolové, takle, čtyry), řadí sem mylně výrazy spisovné ( $v \check{z} d y c k y$, třeba, radši, trošku, desetiminutovka) a opět i výrazy s hovorovým př́znakem (tenhle, tyhlety, písemka).

Povědomí o výslovnostních stylech a jejich jazykových prostředcích má jen část respondentů. Zřejmě proto jsou $\mathrm{k}$ nedostatkům v mluveném projevu učitele, jak jsme uvedli výše, řazeny i spisovné hovorové jazykové prostředky. Ze stejného důvodu také učitelé označují jako chybu vypouštění počáteční hlásky $j$ v nepřízvučných tvarech slovesa být a vkládání vokálu $u$ do výslovnosti číslovek sedm a osm, což je však v základním (neutrálním) výslovnostním stylu ve školské komunikaci ortoepické. Lpění na explicitní (nezjednodušené) výslovnosti tvarů slovesa být řadíme k projevům hyperkorektnosti (podobně jako užívání tvaru číslovky dvěmi).

Z celkového pohledu považuje většina dotázaných svůj projev za převážně kultivovaný. Při porovnání zvukových záznamů a sebehodnoticí analýzy učitelských projevů však zjištujeme, že u některých respondentů není toto hodnocení objektivní (část záznamů vykazuje vzhledem k množství nedostatků spíše rysy méně kultivovaného projevu) a souvisí s problémy s vnímáním stylové hodnoty jazykových prostředků ( $v$ tomto případě ve 
fonetické, meeorfologické a lexikální jazykové rovině). Lze tedy konstatovat, že i u zkušených učitelů působících v praxi přetrvávají obtíže s vymezením spektra jazykových prostředků a jejich funkčně stylovým rozlišením (viz zde M. Spěváčková, J. Vaňková, s. 198).

Dotazníkovým šetřením jsme zjištovali, jak učitelé chápou pojem kultivovaný mluvený projev, jak hodnotí učitelův projev při výukové komunikaci z hlediska výslovnostního stylu a jak se žáky pracují na zlepšení úrovně jejich mluveného projevu, např. formou mluvních cvičení aj. Elektronický dotazník vyplnilo 32 učitelů 1. stupně ZŠ (64\%), dále 13 učitelů 2. stupně ZŠ, kteří vyučují češtinu i další předměty (26\%), a 5 učitelů nečeštinářů z 2. stupně ZŠ (10\%).

Úkol Vysvětlete pojem kultivovaný mluvený projev (které náležitosti by měl ve výukové komunikaci splňovat) vyžadoval tvořené odpovědi. Jejich kvalita se velmi lišila, některé odpovědi byly velmi stručné a svědčily o velmi zúženém chápání zadaného poj$\mathrm{mu}^{109}$ (Dobrá výslovnost; Srozumitelnost, spisovnost; Jasnost, spisovnost; Výslovnost, spisovnost, srozumitelnost; Nevím, ale mělo by se mluvit spisovně; Schopnost umět se vyjádřit; Spisovný, stručný, věcný; Připravenost, originalita, dioraz; Srozumitelnost; Spisovná reč, jasné instrukce). Část odpovědí obsahovala i podrobnější vymezení včetně paralingválních a extralingválních prostř̌edků (Srozumitelnost, stručnost, dostatečná stimulace, oční kontakt, nebát se připustit chybu, dostatečné použivání gest, přirozenost, střední hlasitost projevu, slovní zásoba; Spisovný český jazyk, bez parazitismů, dobrá výslovnost a artikulace, vhodné postavení těla a doprovodné pohyby, mimika a proxemika, jasný obsah

\footnotetext{
${ }^{109}$ Odpovědi respondentů uvádíme vždy v původní podobě a oddělujeme je pro přehlednost středníkem. Často byly heslovité, respondenti v nich k sobě přriřazovali různé kvality mnohdy nahodile.
} 
a formulace vět, podstatné vybrané informace; Znalost dostatečného množství výrazů a vhodné využití těchto výrazů v dané situaci, zretelné a správné vyslovování výrazن, vhodné tempo a hlasitost řeči, přiměrená gestikulace doprovázejicí mluvený projev, spisovnost a nevulgárnost, vhodná volba pomlky, nepoužívat parazitní slova). Pouze minimum odpovědí zahrnovalo kritérium adekvátnosti jazykových prostředků vzhledem ke komunikační situaci a účelu, zohledňující zejména věk žáků (Používat spisovný jazyk, hovořit výrazně a plynule, dbát na pečlivou výslovnost, využívat dalších prostředků mluveného projevu - síla, barva hlasu, pomlky $v$ řči... s cílem zaujmout žáky, mluvený projev přizpiosobit věku a znalostem žákư; Vhodná slovní zásoba, gramatická korektnost, srozumitelnost, využívání možností českého jazyka pro kultivované vyjadřování, volba jazykových prostředku odpovídajících složení a charakteristice posluchačù).

Hlubší povědomí o adekvátnosti jazykových prostředků a jejich využití v mluveném projevu učitele ve výukové komunikaci je patrné jen ze dvou odpovědí (Projev obsahující spisovné jazykové prostředky, bez jazykových prostředků obecněčeských ve všech jazykových rovinách, slangismů či vulgarismů, srozumitelný, slovní zásoba dle úrovně, věku žáki̊, prehledná větná stavba, bez rušivých zvuků nebo významově prázdných výplňkových slov, spisovná výslovnost; Spisovná čeština (hovorová), znalost problematiky, sdělení, výstižnost tématu, srozumitelnost, přiměřená rychlost mluvy, přiměřená hlasitost - přizpůsobení situaci, posluchačùm, zapojení neverbální komunikace). Požadavek užívání spisovných jazykových prostředků v souvislosti s nároky na kultivovaný projev učitele ve výukové komunikaci dominuje.

Na otázku Ke kterému výslovnostnímu stylu náleži mluvený projev učitele ve výukové komunikaci? neuvedli žádnou odpověd' 4 respondenti, nesprávně odpovědělo 17 respondentů (Neumím 
konkrétně zařadit, ale jsem zastánce naprosto přirozené komunikace, bez přetvářek; Spisovná výslovnost - 4x; Popisný jazyk; Spisovná mluva - 5x; Výklad; Výslovnost běžná; Pečlivý se všemi dobře volenými prostředky zvukové stránky jazyka; Manažerský a interakční styl učitele zahrnuje empatické vlastnosti). Z uvedených tvořených odpovědí je patrná neznalost odborné terminologie, z čehož vyplývá i neschopnost vymezit podstatu příslušného termínu, a dále opět výrazná vazba na spisovnost. Několik odpovědí (5) zařadilo mluvený projev učitele ve výuce k vysokému výslovnostnímu stylu (slavnostnímu), domníváme se však, že se částečně jedná bud' o nepochopení zadání, nebo o neznalost termínu-pojmu, někteří respondenti jej redukují pouze na pečlivou a zřetelnou výslovnost při výkladu učiva. Většina (24) respondentů uvedla správnou odpověd', a sice základní (neutrální) výslovnostní styl. Z výše uvedených výsledků sebeevaluace ovšem vyplývá, že ne vždy učitelé vědí, která výslovnostní pravidla pro tento styl konkrétně platí.

Další šetření dotazníku směřovalo k metodám a formám práce, jež učitelé ZŠ používají ke zlepšení úrovně žákovského mluveného projevu. Orientovalo se zejména na tzv. mluvní cvičení, která by měla při systematickém používání ve výuce „vypěstovat u žáků dovednost přirozeného souvislého plynulého projevu“ (Čechová 1998, s. 218). Učitelé si potřebnost jejich zařazování do vyučování uvědomují, v naší sondě je považuje za užitečné 86 \% respondentů, 14 \% je hodnotilo jako spíše užitečné, možnost spíše zbytečné a zbytečné neoznačil nikdo. Nadpoloviční většina učitelů chápe nutnost komplexního a systematického rozvíjení žákovského projevu, proto považuje za správné zařazovat mluvní cvičení do vyučování různých předmětů (58 \%), dalších $22 \%$ se domnívá, že by měla být součástí hodin pouze českého jazyka, $18 \%$ uvádí český jazyk v kombinaci s humanitně zaměřenými předměty. Stanoviska učitelů různých stupňů ZŠ se v tomto bodě 
poměrně rozcházejí - učitelé 1 . stupně preferují v naprosté většině zařazení mluvních cvičení do různých předmětů, pouze $14,5 \%$ by je začlenilo pouze do hodin českého jazyka. $\mathrm{Na} 2$. stupni je poměr mezi oběma skupinami téměř vyrovnaný. Všichni dotázaní učitelé se shodují v názoru, že by se mluvní cvičení měla zadávat co nejdřive, tedy na 1 . stupni od 1.-2. ročníku a na 2. stupni od 6. ročníku.

Frekvence konání připravených mluvních cvičení se poměrně různila, 1x týdně je zadává $32 \%, 1 x$ měsíčně $28 \%$ a $1 x$ čtvrtletně $18 \%$. Překvapivý je fakt, že týdenní a měsíční frekvence zadávání mluvních cvičení je nejvíce zastoupená a zároveň vzájemně téměř vyrovnaná na 1 . stupni ZŠ (týdenní - 49,9 \%, měsíční 43,3\%). Domníváme se, že tak nízká četnost nestačí k systematickému nácviku souvislého mluveného projevu a je v nerovnováze s možnostmi nácviku projevu psaného. Žáci nemají dostatek příležitostí mluvit před ostatními, zbavit se ostýchavosti a trémy, zvyknout si na pozornost posluchačů a získat potřebnou sebejistotu (Rysová 1999-2000, s. 27). Jejich vyjadřování ponese dlouho výrazné prvky neformální komunikace a neosvojí si dovednost respektovat spisovnou normu v mluveném projevu. Deficit prŕležitostí dále potvrzují i odpovědi učitelů 2. stupně ZŠ. Ukazují, že na tomto stupni vzdělávání je nejvíce zastoupená čtvrtletní frekvence zadávání mluvních cvičení (38,8\%), těsně za ní následuje týdenní $(33,3 \%)$ a s větším odstupem poté frekvence měsíční (11,1\%).

Logickým důsledkem výše zmíněných závěrů je zjištění, jak mluvní cvičení vnímají podle učitelů žáci (dotazovaní mohli uvést více odpovědí). 50 \% respondentů uvedlo, že žáci mají trému, 38 \% odpovědělo, že se stydí, 16 \% napsalo, že se žáci nechtějí zesměšnit. Zároveň učitelé uváděli i pozitivní fakta, kterých by bylo možné využít při motivaci - žáci to považují za zpestř̌ení hodiny (50 \%), 
chtějí ostatní zaujmout (42\%), získat dobrou známku (34\%), před ostatními se předvést (22\%). Pouze podle $4 \%$ učitelů žáky mluvní cvičení nezajímají.

Pozitivní motivací je i vhodná volba tématu. Na 1. stupni je jistě žádoucí vycházet ze skutečností, které jsou žákovi nejbližší, a postupně pak volit témata náročnější na zamyšlení a také témata odbornější (Čechová 1998, s. 218). V dotazníkovém šetření (nabízelo se více odpovědí) je jako téma mluvních cvičení nejvíce zastoupena přečtená kniha (64\%), dále následuje zážitek (54\%), koníčky a záliby (44\%), prázdniny (42\%), volné téma (40\%), zajímavý film (32), domácí mazlíček (28\%). Jiná témata uvedlo $32 \%$ učitelů a týkají se 2 . stupně ZŠ (např. aktuální události, významná osobnost, oblíbený recept, kapitola z učebnice, památky aj.).

Mluvní cvičení jsou dle shromážděných odpovědí v naprosté většině předem připravená, např. za domácí úkol (70 \%), někdy je žáci tvoří přímo v hodině (20\%), jiní učitelé obě varianty střídají. Trvají nejčastěji do 4 minut (32\%) nebo do 6 minut (20\%), u nižších ročníků do 2 minut (18\%). Časový rozsah neomezuje $16 \%$ učitelů - to sice dává žákovi relativní svobodu, ale neučí ho, jak svou řeč rozvrhnout, a může vést i k časovým ztrátám.

Pomocí mluvních cvičení se žáci podle respondentů zejména učí (nabízelo se více odpovědí) vystupovat před kolektivem (94\%) a vyjadřovat se plynule (92\%). Také si osvojují spisovný jazyk (78\%), rozšiřují slovní zásobu (68\%), učí se pracovat s hlasem (64 \%) a nastudují probírané učivo (38 \%). Řeč těla uvedlo $10 \%$ respondentů. Nikdo nezvolil variantu, že se žáci nic podstatného nenaučí.

Důležitým momentem je hodnocení mluvních cvičení. Znamená pro žáka jak motivaci prostřednictvím ocenění toho, co se 
mu v projevu podařilo, tak i zpětnou vazbu ve smyslu poučení, kterých nedostatků se dopustil a co prŕště zlepšit. V ideálním případě se na vyhodnocení podílí nejen učitel, ale i ostatní posluchači a rovněž žák sám. Hodnocení by mělo odrážet, jak žák zvládl základní prvky kultivovaného mluveného projevu; výběr a využití jazykových prostředků mluvené komunikace, tj. neutrálních a hovorových jazykových prostředků (samozřejmě s ohledem na věk žáka), práci s hlasem, řeč těla aj.

Dotazníkové šetření ukázalo, že 48 \% dotazovaných hodnotí mluvní cvičení slovně a spolu s ostatními žáky, 30 \% učitelů známkou (a to jedničkou, jiné klasifikační stupně se nevyužívají), 16 \% uvedlo kombinaci slovního hodnocení a známky, 2 \% hodnotí slovně bez účasti ostatních žáků. Žákovského sebehodnocení využívají pouhá $4 \%$ učitelů.

Kritéria hodnocení zahrnovala $\mathrm{v}$ dotazníkovém šetření pestrou škálu verbálních i neverbálních prostředků mluveného projevu, které respondenti mohli označit v libovolném množství i pořadí. Z výsledků vyplývá, že největší důraz kladou učitelé na plynulost a pohotovost vyjadřování (76 \%) a hlasitost (72\%), zda projev odpovídá tématu (60\%), na správnou výslovnost (50\%) a tempo řeči (50\%). Dodržování spisovného jazykového standardu hodnotí $46 \%$ respondentů, stejně jako oční kontakt (rovněž $46 \%$ ). Podobně je hodnocena šíře slovní zásoby $(44 \%)$ a gestikulace a postoj (44\%). Dále následuje stylizace vět (36\%), míra připravenosti (36\%), struktura projevu (34\%), projev spatra (30\%) a výplňková slova a zvuky $(24 \%)$. Deset procent respondentů uvádělo ještě další kritéria, nap̌r. umění zaujmout posluchače aj.

Procentuální hodnoty u prvních pěti kritérií napovídají, s kterými problémy se žáci při svých vystoupeních nejvíce potýkají. Souvisejí s již zmíněnou trémou, způsobenou většinou nedostatkem 
příležitostí mluvit před ostatními a formulovat souvislejší projev. Ten pak bývá často neucelený, málo hlasitý, nevýrazný, v rychlém tempu a s nedbalou artikulací. Za poměrně nízký považujeme údaj, že pouze pro $46 \%$ učitelů je kritériem hodnocení dodržování spisovného standardu češtiny a pro $44 \%$ šíře slovní zásoby. Vyplývá z toho, že jazykové prostředky hodnotí méně než polovina učitelů. Větší váhu při hodnocení by dále mělo mít i kritérium stylizačních dovedností a kritérium kompozice - v dotazníkovém šetření je uvedla pouze přribližně třetina učitelů (stylizační dovednosti $36 \%$, kompozici $34 \%$ ). Souhrnně lze tedy konstatovat, že verbální stránka mluvních cvičení není učiteli při hodnocení př́liš akcentována, a proto není se žáky při následném rozboru (pokud probíhá) ani dostatečně analyzována. Tím se tedy deficit dovednosti prakticky užívat náležitých jazykových prostředků v mluvené komunikaci prohlubuje.

Kromě mluvních cvičení používají učitelé ke zvýšení úrovně žákovského mluveného projevu i další formy práce, a to jak ve frontálním vyučování, tak při skupinové práci, při projektové výuce apod. Odpovědi respondentů deklarují snahu dát žákům během vyučování k mluvení maximum příležitostí, korigovat jejich vyjadřování, dialogizovat vyučování, posilovat komunikaci mezi žáky, podněcovat diskusi a prezentování vlastních názorů či výsledků práce žákovské skupiny. Učitelé dále zařazují dramatizační aktivity, recitaci, výrazné čtení, komunikační kruh, nejrůznější herní činnosti apod. Tyto formy práce však již nenabízejí tolik prostoru $\mathrm{k}$ vlastnímu nácviku mluveného projevu a důkladnější analýze použitých prostředků (zejména jazykových), jako je tomu u mluvních cvičení. Pouze šest učitelů uvedlo, že používají průpravné aktivity, např. dechová a artikulační cvičení včetně jazykolamů, s nimiž se ovšem pracuje někdy izolovaně, a tudíž samoúčelně (Rozcvička mluvidel - dechová cvičení, artikulace; Jazykolamy, nácvik správního dýchání; dechová cvičení - nacvičujeme se žáky správné 
nádechy a výdechy na uklidnění a upevnění hlasu; Jazykolamy, nácvik správného dýchání; Jazykolamy - baví žáky, chtějí se pred ostatními predvést, rozvijejí správnou artikulaci; Jazykolamy). ${ }^{110}$

Svůj vlastní mluvený projev jako řečový vzor pro žáky zmínili pouze dva respondenti (Snažím se dbát na kultivovaný mluvený projev - tedy dávám si pozor, abych používala spisovnou češtinu, abych hovořila plynule, srozumitelně, dbám na výslovnost; Vlastní př́klad). Z této skutečnosti jasně vyplývá, že učitelé roli řečového modelu chápou spíše jako teoretickou kvalitu a k míře kultivovanosti svého mluveného projevu jsou poměrně benevolentní, o čemž svědčí i zjištění v první části naší sondy. Těžiště práce se žáky vidí spíše ve vytváření příležitostí $\mathrm{k}$ mluvenému projevu, což je jistě chvályhodné. Otázkou však zůstává, jakým způsobem, jak často a zda vưbec je žákovský projev poté analyzován, aby tak žák dostal nejen príležitost promluvit, ale také poučení, jak by mohl svůj mluvený projev dále zlepšit.

\section{Shrnutí}

Na základě výsledků naší sondy lze konstatovat, že i zkušenější učitelé se ve svém vlastním mluveném projevu ve výukové komunikaci potýkají s vymezením spektra jazykových prostředků a jejich náležitým využitím. Zaznamenali jsme problémy s identifikací spisovných neutrálních, hovorových a obecněčeských jazykových prostředků a jejich klasifikací v rámci tř́ zkoumaných rovin (fonetické, morfologické a lexikální). Navzdory těmto zjištěním ukázala sebehodnoticí analýza, že učitelé považují svůj mluvený projev v naprosté většině za převážně kultivovaný. Při srovnání sebehodnocení se zvukovými nahrávkami ovšem zjištujeme,

\footnotetext{
${ }^{110}$ Pro větší názornost uvádíme všech šest autentických odpovědí, z toho důvodu se některé aktivity opakují.
} 
že výkon části respondentů takové úrovni neodpovídá. Kromě výše zmíněných skutečností to souvisí s vágním povědomím o výslovnostním stylu výukové komunikace.

Mluvený projev žáků se učitelé snaží rozvíjet v souladu s požadavky komunikačně orientovaného vyučování. Využívají k tomu nejrůznější aktivity napříč všemi formami výuky. Dotazníkové šetření ovšem ukázalo, že žáci sice dostávají prostor pro mluvený projev, ten ale nebývá dostatečně analyzován. Není tak vytvořena funkční zpětná vazba, a tedy ani podmínky pro systematické zdokonalování. Týká se to bohužel i tradiční formy nácviku mluveného projevu, tzv. mluvních cvičení, která jsou částí učitelů analyzována nedostatečně, zejména využití vhodných jazykových prostředků. Rovněž frekvence zařazování mluvních cvičení do výuky není často uspokojivá, a to na obou stupních ZŠ.

\section{Použitá literatura}

ČECHOVÁ, Marie; STYBLÍK, Vlastimil. Čeština a její vyučování. Didaktika českého jazyka pro učitele základních středních škol a pro studenty učitelství. Praha: SPN, 1998. $264 \mathrm{s.}$

MÁLKOVÁ, Jitka. Vnímání spisovnosti v mluveném projevu budoucími učiteli na počátku jejich studia. In ČECHOVÁ, Marie; SPĚVÁČKOVÁ, Martina (eds.). Od praxe $k$ teorii a $z$ pět ve vyučování češtině. Plzeň: ZČU, 2019. s. 94-103.

RYSOVÁ, Květa. K úrovni mluveného projevu žáků. Český jazyk a literatura, 1999-2000, roč. 50, č. 1-2, s. 27-32.

SPĚVÁČKOVÁ, Martina; VAŇKOVÁ, Jana. Dokáží studenti českého jazyka rozlišovat jazykové roviny a jim odpovídající jazykové prostř̌edky? In ČECHOVÁ, Marie; SPĚVÁČKOVÁ, Martina (eds.). Od praxe $k$ teorii a zpět ve vyučování češtině. Plzeň: ZČU, 2019. s. 84-93. 


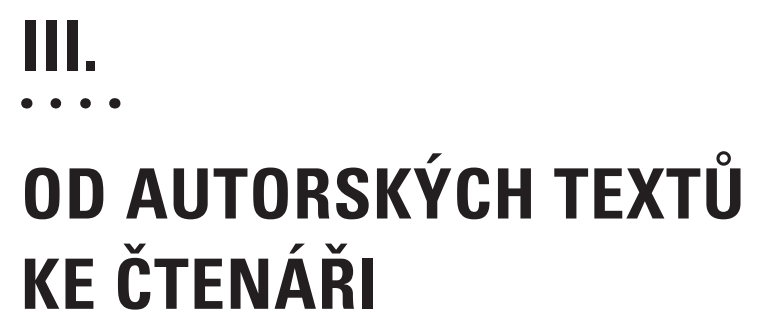




\title{
Literárněhistorické poznatky v literární výchově na 2. stupni ZŠ a v odpovídajících ročnících víceletých gymnázií
}

\author{
Ladislava Lederbuchová
}

Literárněhistorické poznatky o literatuře - problém v literární výchově na 2. stupni ZŠ (dále LV) permanentně přítomný. Přežil inovační didaktické snahy o změnu LV v 80. letech 20. století (srov. Chaloupka 1984), přežil i další koncepci LV (srov. RVP ZŠ 2017, s. 16-24). Dokázal se v nových podmínkách usadit jaksi v pozadí, nebot odbornou pozornost poutaly a dosud poutají především poznatky literárněteoretické, a modifikoval do podoby zdánlivě obhajitelné.

\section{Komunikační koncepce literární výchovy a poznatky o literatuře}

Je-li současná LV koncipována komunikačně, čtenářsky, ptáme se, jakou roli v obsahu jejího učiva vedle složky dovednostní či komunikační (tj. učit se dovednosti strukturního čtení) a vedle složky formativní či hodnotové (učit se esteticky prožívat obsahy artistních textů a rozvíjet své estetické a etické cítění a hodnocení, nejen ve vztahu $\mathrm{k}$ literatuře) má složka poznávací či vědomostní ve smyslu osvojování poznatků o literatuře. ${ }^{11}$

\footnotetext{
${ }^{111}$ Pod pojmem poznatek o literatuře rozumíme poznatek vědecký, resp. literárněvědecký, tzn. poznatek literární historie nebo literární teorie nebo literární kritiky.
} 
RVP ZŠ klade důraz na žákovu komunikační dovednost. Jejímu rozvoji mají prospívat vybrané poznatky o poetice textu, zvláště o literárních druzích. ${ }^{112}$ Program neuvádí, že k ovlivnění žákova „postoje a životní hodnotové orientace, k obohacení jeho duchovního života“ by měly přispět i poznatky literárněhistorické. Vyhýbá se jim i ve stanovení konkrétních cílů $L V .{ }^{113} \mathrm{~V}$ obsahu učiva se sice zřetel k literární historii deklaruje, ale uvedené položky výčtu odkazují jen k literární teorii. ${ }^{114}$ Bud’me spravedliví - v učivu o žánrech se uvádí zřetel k „vývojovým obdobím národní a světové literatury“ a jejich „představitelům“115 a konkrétní osobnostní rys „významných představitelü“ má také jeden z očekávaných výstupů. ${ }^{116}$

\footnotetext{
${ }^{112}, \ldots$..žáci poznávají prostřednictvím četby základní literární druhy, učí se vnímat jejich specifické znaky, postihovat umělecké záměry autora a formulovat vlastní názory o přečteném díle. Učí se také rozlišovat literární fikci od skutečnosti. Postupně získávají a rozvíjejí základní čtenářské návyky i schopnosti tvořivé recepce, interpretace a produkce literárního textu. Žáci dospívají k takovým poznatkům a prožitkům, které mohou pozitivně ovlivnit jejich postoje, životní hodnotové orientace a obohatit jejich duchovní život" (RVP ZŠ 2017, s. 16).

${ }^{113}$ Vzdělávání „směřuje k utváření a rozvíjení klíčových kompetencí tím, že vede žáka $\mathrm{k}$ [...] individuálnímu prožívání slovesného uměleckého díla, ke sdílení čtenářských zážitků, k rozvíjení pozitivního vztahu $\mathrm{k}$ literatuře i $\mathrm{k}$ dalším druhům umění založeným na uměleckém textu a k rozvíjení emocionálního a estetického vnímání" (ibid., s. 17).

${ }^{114}$ „Základy literární teorie a historie - struktura literárního díla (námět a téma díla, literární hrdina, kompozice literárního př́iběhu), jazyk literárního díla (obrazná pojmenování; zvukové prostředky poezie: rým, rytmus; volný verš), literatura umělecká a věcná (populárněnaučná, literatura faktu, publicistické žánry)“, ibid., s. 24.

115 „Literární druhy a žánry - poezie, próza, drama, žánry lyrické, epické, dramatické v proměnách času - hlavní vývojová období národní a světové literatury, typické žánry a jejich představitelé“ (ibid., s. 24). Z rámce našeho hodnocení nelze vyloučit korekci chyby - poezie a próza nejsou ani literární druhy ani žánry, ale výrazové formy sloužící literárním druhům - lyrika ze své druhové podstaty vyhledává poezii, ale může být psána i prózou, epika je většinou prozaická, ale básně přece známe i epické, že? Je s podivem, že tento lapsus nebyl odstraněn ani v poslední verzi RVP ZŠ z r. 2017.

${ }^{116}$ Žák „uvádí základní literární směry a jejich významné představitele v české a světové literatuře“ (ibid, s. 24).
} 
Ministerský vzdělávací program, aby zabránil přetěžování žáků nadměrným množstvím literárněhistorických poznatků, narýsoval ahistorickou koncepci LV, resp. vyloučil z ní literární historii, která by měla stejně jako literární kritika a teorie svými poznatky stát ve vědeckých základech učiva, a garantovat tak historický status textu. V souladu s programem a závěry nejen našich didaktických prací (např. Dítě a kniha 2004 ad.) jsme stále přesvědčeni, že pro rozvoj čtenářství pubescentního žáka je důležité poznávat literaturu prizmatem vlastní četby a nabývat poučení o literatuře na bázi vybraných poetických rysů textu. Ale také si uvědomujeme trvalou absenci historického faktoru $\mathrm{v}$ učivu LV a prohlubující se rozpor v prezentaci učiva LV ve školách: Někteří učitelé literárněhistorický pohled na literaturu ve své metodice zachovávají a žáka vyšších ročníků ZŠ (8. a 9.) nebo tercie a kvarty víceletého $G$ seznamují i s literárněhistorickým kontextem učiva. Jiní učitelé (třeba i v dobré snaze naplnit požadavky RVP) podceňují (často i vytěsňují) literárněhistorické poznatky o genezi textu - o autorovi, době a okolnostech vzniku textu, o jeho dobovém čtenářském (i literárněkritickém) přijetí - jako poznatky v učivu nedůležité či zbytečné, odvolávají se i na nezájem dětí o historická fakta, souvislosti, kontexty.

Že literární historie patři až do učiva školy střední, že věk žáků 12-15letých brání pochopení historických faktů a literárněhistorických kontextů, je teze chabě obhajující ahistorismus LV na ZŠ. Tento přístup $\mathrm{k}$ literárněhistorickým poznatkům (a často i metodická bezradnost jak literárněhistorický aspekt včlenit do učiva) je dán zkostnatělou představou o rozbujelém biografismu a literárněhistorickém pozitivistickém hromadění faktů, zvláště o okolnostech tvůrčího procesu, jako o trvalé metodě a výsledcích i současné literární historie. 
Snaha zabránit vlně faktografických dat a pamětnímu učení a také vyhovět zájmům žáka a jeho úrovni komunikace vedou kromě absence literárněhistorického poučení i $\mathrm{k}$ praktické redukci textové nabídky - sílí tendence češtinářů ZŠ vyhýbat se textům geneticky starším (tím i riziku žákova obtížnějšího porozumění uměleckému jazyku a obrazům tématu). ${ }^{117}$ Této tendenci nahrávají i některé teoretické závěry, které nepřímo odsuzují přítomnost klasických textů v čítankách, nebot’ ty jsou pro „samostatnou četbu“ žáka obtížné a neatraktivní, nejsou „dostatečně srozumitelné a sdělné“, a ve jménu snáze dosažitelného porozumění čítankovému textu rezignují na kultivační poslání LV (srov. Vala, Šmakalová, Válková 2019-2020 versus Lederbuchová 2019-2020). Tento způsob práce nemůže být obhajitelný ani tendenční interpretací RVP jako programu čtenářského, nebot’ $\mathrm{v}$ důsledku nevede ani ke zvýšení čtenářské kompetence žáka, na něhož není vyvíjen adekvátní didaktický tlak. V tomto smyslu „sklízíme ovoce“ didaktických dluhů.

Ahistorický přístup $\mathrm{k}$ literatuře (a k životu vůbec), jak ve škole, tak v laické veřejnosti, vyvolává diskusi, budí nesouhlas a postoje obranné, jejichž nositelé upozorňují na nebezpečí historického bezvědomí dětí a mládeže (srov. Poláček 2016-2017 ad.). Tento závěr dnes nelze chápat jako varování, ale už jako konstatování daného stavu. Bylo by nesmyslné z tohoto stavu vědomí mladých vinit jen školní $L V$, ale přiznejme si, že právě tato složka předmětu jako výchova estetická má př́ležitost přispět k proměně chápání historického statusu textu, resp. literárněhistorického aspektu ve čtenářských aktivitách žáka a ovlivnit tak jeho kulturní rozhled, a to i směrem $\mathrm{k}$ minulosti. Problém považujeme za zásadní a jeho

\footnotetext{
${ }^{117}$ Ve svém hodnocení se opíráme pouze o zprostředkovanou zkušenost $\mathrm{z}$ rozhovorů s učiteli ZŠ, ne o relevantní výzkum na dané téma. Přesto si troufáme tvrdit, že jde o rozmáhající se tendenci, přinášející dočasně uspokojivé, tj. bezproblémové řešení jak pro žáky, tak pro učitele, perspektivně však nepřijatelnou.
} 
řešení za klíčové pro pochopení struktury literárněvýchovného učiva na ZŠ a pro osvojování jeho obsahů, jak učitelem (z aspektu metodické prezentace učiva), tak žákem ( $\mathrm{z}$ aspektu konstruktivisticky pojatého učení).

Dříve než se budeme věnovat poznatkům ve struktuře učiva, zdůrazněme, že umělecká literatura, která vstupuje do vyučování, není jen učivem, ale zůstává přes didaktické zásahy (školní prostředí, prezentace celku vybraným čítankovým úryvkem, četba a její učitelem provokovaná reflexe...) stále uměním: Má schopnost působit na žáka i dalšími, učivem neakcentovanými a nezhodnocenými kvalitami, má sílu působit i přes školní omezení komplexně, pokud je didakticky kvalifikovaně představena (podrobněji Lederbuchová 2010, 32-48).

Učivo chápeme jako otevřenou dynamickou strukturu, v níž existuje stálý pohyb v účelné hierarchizaci složek. Klademe důraz na celistvost struktury, v níž každá složka ovlivňuje a spoluurčuje význam složek jiných i strukturu učiva jako celku: Poznatky ovlivňují mentální aktivity komunikace a jejich výsledek. V komunikační koncepci LV jsou složce poznatkové (poznatkům literárněteoretickým, literárněhistorickým, literárněkritickým) významem nadřazeny složky komunikační a hodnotová, formativní. Poznatky o literatuře (všeho druhu, získané různými cestami) jsou ve vztahu ke komunikaci s textem, ve všech fázích jeho recepce, $\mathrm{v}$ podřízeném postavení. Měly by fungovat jako prostředek zkvalitňování čtenářské konkretizace textu. Poznávání významů textu (specifičnosti jeho jazyka, kompozice, tématu) a jeho kontextů (specifičnosti žánrových a dobových charakteristik, reprezentativních významů autorského stylu) ovlivňuje hodnotu, kterou čtenář textu přikládá a též formuje jeho hodnotový systém vůbec. Právě v součinnosti s komunikační složkou učiva poznatky spoluutvářejí žákovo vědomí literatury jako hodnoty 
kulturní, integrační, přesahující okruh školního učiva. Hodnotu literatury v tomto smyslu RVP ZŠ nepřipomíná. ${ }^{118}$

Pro řešení našeho tématu bude užitečné srovnání s poznatky literárněteoretickými. K poznatkům o poetice textu, včetně druhových a žánrových specifik, se žák má dobrat reflexí vlastní četby, vlastního zážitku - nalézáním zdrojů čtenářského uspokojení v textu. Nezřídka se však z vybraných literárněteoretických pojmů (např. v podobě slovníčků v čítankách) stává ve vyučovací praxi samostatné učivo vytržené ze struktury dalších složek (jen výběr poznatků nezaručuje jejich plnohodnotnou didaktizaci), které si má žák racionálně osvojit a znalost pojmů prokázat bud' pamětní deklarací definice, nebo $\mathrm{v}$ lepším případě $\mathrm{v}$ písemném testu na textových př́kladech typu „najdi...“, „podtrhni...“ "119 Je evidentní, že privilegované postavení literárněteoretických poznatků (na úkor literárněhistorických), není ve vztahu k cílům LV samospasitelné, že i zde při volbě neadekvátní metody může dojít k hrubému didaktickému pochybení.

Pojmenovat poetický jev termínem je didakticky správné až po fázi žákova poznávání estetické funkce poetického jevu jako strukturní kvality textu. Následné užívání termínu a fixace jeho obsahu, resp. jeho významové potence by vždy měly být spjaty s četbou dalších textů, které daný jev obsahují, at jde o jevy jazykové (srov. Beránková 2002, s. 40-43, Lederbuchová 2017-2018), či tematické nebo komplexy druhové a žánrové. Jedině tak se

\footnotetext{
${ }^{118} \mathrm{~V}$ očekávaných výstupech ani $\mathrm{v}$ charakteristice učiva se o formativní účinnosti LV nemluví, žák sice „rozlišuje literaturu hodnotnou a konzumní, svůj názor doloží argumenty“ také se deklaruje, že „má pozitivní vztah k literatuře“ (RVP ZŠ, s. 24), a tím je zřetel k hodnotové potenci literární výchovy vyčerpán.

${ }^{119}$ Druhý z př́kladů jako kontrolní metodu nelze zavrhnout tehdy, jestliže kontrole předcházela žákovská reflexe, resp. interpretace daného poetického jevu př̀i opakované žákovské četbě textů, v nichž se sledovaný poetický jev nacházel a byl jako významově variabilní (díky různým kontextům), leč formálně relativně stálý žákům představen a pojmenován termínem.
} 
stane znalost žádoucím komunikačním nástrojem, nebot ve svých "genech" bude mít kód čtenářského zážitku - provokované obraznosti, citového vzrušení a racionální reflexe formálního tvaru daného jevu. V obsahu pojmu a jeho pamětní fixaci bude uložena i čtenářská cesta $\mathrm{k}$ jeho osvojení (komplexně o této problematice Lederbuchová 2010, s. 28-48).

\section{Didaktická transformace literárněhistorických poznatků}

Zatímco u vybraných poznatků literárněteoretických, resp. poetologických je pro jejich školní osvojování žákův bezprostřední čtenářský vztah $\mathrm{k}$ textu zřejmý a učitelova pomoc metodou didaktické interpretace též, u poznatků literárněhistorických je řešení jejich místa a funkce $\mathrm{v}$ rozvoji žákovy komunikace $s$ textem složitější.

Literární historie jako vědecká disciplína studuje dobovou genezi a recepci určitého autorského textu: Sleduje subjektivní motivace a determinace autorské i podmínky společenské, včetně existujících poetických a vůbec estetických norem a způsobu jejich inovativního porušení - hodnotí umělecký přínos díla. V neposlední řadě spolu s literární kritikou určuje texty literární klasiky jako díla s historicky prověřenou hodnotou. Ctižádostí literární historie je jednak zmapovat a vědecky zhodnotit všechny texty $\mathrm{v}$ procesu historického vývoje, jednak na tomto pozadí vytvořit kánon literární kultury - výběrem získat celek děl, jejichž umělecká hodnota zůstává z estetického i etického, resp. humánního hlediska trvalá, atraktivní i pro čtenáře dalších generací. Je pochopitelné (a právě historické), že měřítka výběru také podléhají proměnám dobových estetických i dalších norem života. Takový počin současné české literární historie představuje Česká 
knižnice. ${ }^{120}$ Co platí v kontextu literatury pro dospělé, světové i české, platí i pro literární klasiku v subsystému literatury pro děti a mládež. Je jasné, že vědomí o hodnotné literatuře je (mělo by být) utvářeno především ve škole všech stupňů. Učitelé češtináři (před nimiž i na 2. stupni ZŠ je úkol naučit žáka „rozlišovat literaturu hodnotnou a konzumní, RVP ZŠ, s. 24) by měli být literárněhistorickým vzděláním pro svou profesi připraveni - měli by zvládat velký objem literárněhistorických dat a souvislostí, měli by mít obsáhlou čtenářskou zkušenost a v tomto smyslu vědomí či povědomí o literárním kánonu jako kulturní hodnotě. A samozřejmě by si měli uvědomovat, že pro školní potřebu je nutné okruh kanonických děl vymezit didakticky.

O problému vztahu literárního kánonu a LV uvažoval O. Hník (2015-2016). Konstatuje hypotetičnost literárního kánonu a existenci řady kánonů pro školní užití - podle stupně školy, podle typu střední školy, až po kánony učitelské (podle češtináře), srov. ibid., s. 237. Negativně hodnotí naddimenzovanost těchto souborů, dále výběr sporný z aspektu umělecké hodnoty, výběr účelově redukovaný na určitý okruh významů - např. na funkci národně uvědomovací, historicky poučnou, ideologickou či zpolitizovanou, dále na funkci reprezentanta jen určité poetické

\footnotetext{
${ }^{120}$ „Česká knižnice je dlouhodobě koncipovaná ediční řada, která si klade za cíl představit $\mathrm{v}$ reprezentativní a textově spolehlivé podobě vrcholná literární díla vzniklá v českých zemích od počátků $\mathrm{k}$ dnešku. Za dvacet let existence České knižnice vyšlo $\mathrm{v}$ této řadě již devadesát titulů, což ji řadí $\mathrm{k}$ nejvýznačnějším edičním projektům české literární historie. Každý svazek, odborně posouzený vědeckou radou, je pečlivě edičně připraven, podílejí se na něm lektor a vědecký redaktor, kteří spolupracují s editorem na výsledném textu. Nedílnou součástí každého svazku je komentár, který seznamuje čtenáře z řad odborné i laické veřejnosti nejen se souvislostmi vzniku díla, jeho zapojením do celku autorovy tvorby a žánru, ale též s dobovým a pozdějším ohlasem. Od roku 2016 edici Česká knižnice společně vydávají Nadační fond České knižnice, Ústav pro českou literaturu AV ČR a nakladatelství Host. Na vydání jednotlivých svazků přispívá Ministerstvo kultury České republiky a Akademie věd ČR.“ Ediční text z titulu České knižnice Šrámek, Fráňa. Modrý a rudý, Stříbrný vitr, Léto, Splav. Praha: ÚČL AV ČR, 2000. Počet vydávaných děl kanonického kontextu se stále rozrůstá a má už téměř dvě stě titulů.
} 
funkce, určitého poetického jevu a v neposlední řadě na prezentaci neliterárního jevu, problému stojícího mimo text. V tomto ohledu autor hodnotí školní kánon jako nesourodý, z aspektu kritérií výběru textů jako nejednotný a hlavně - neodpovídající cílům komunikačního pojetí literární výchovy (srov. ibid., s. 240).

Kritika konkrétního textového obsahu LV souvisí přímo s naším problémem. Uváděnou naddimenzovanost školního kánonu, stejně i výběr umělecky méně hodnotných textů můžeme připsat autorům čítanek, ale je třeba mít na paměti, že čítanková nabídka textů, resp. jejich reprezentativních úryvků je materiálem pro didaktické užití učitelem a žákem. Pro další naše úvahy vyjdeme rovněž z Hníkova konstatování, s nímž se ztotožňujeme, že „povinná četba a kánon jsou [...] záležitostí široce kulturní (ibid., s. 236). A stejně jako autor jsme přesvědčeni o tom, že pro stanovení školního literárního kánonu jsou důležité „texty umělecké literatury (a jejich literární kontext)“, ibid., s. 236. Nezpochybňujeme ani pravdivé tvrzení o řadě školních kánonů, ale v souvislosti s didaktickou transformací literatury (výběr autora a textu v rámci jeho díla, výběr úryvku $\mathrm{z}$ daného textu a způsob jeho prezentace ve vyučování) budeme uvažovat o literárním kánonu didaktickém. S tím souvisí řešení otázky jak polysémii a multifunkčnost umělecké literatury strukturovat $\mathrm{z}$ aspektu polyfunkčnosti LV. Domníváme se, že vyloučíme-li ze souboru negativ Hníkem uváděných funkci ideologickou či politickou, lze všechny další, tj. funkci národně uvědomovací, historicky poučnou, reprezentativní pro určité poetické funkce, ale i pro prezentaci neliterárního jevu, přijmout jako žádoucí funkce LV. V textu didaktizovaném jako učivo jde vždy o účelnou redukci na okruh významů, jenž je interpretací zdůrazněn, ovšem nikoli bez ohledu na významovou strukturu textu jako celku (v tom se s O. Hníkem shodujeme). Už zde lze říci, že pro utváření didaktického kánonu jako žákova vědomí o literatuře je nezbytné angažovat $\mathrm{v}$ tomto procesu i literárněhistorické poznatky. 
Poznatkům ve vyučování se O. Hník věnuje také (2016-2017), mluví o poznatcích obecně, ale $\mathrm{z}$ textu vyplývá, že předmětem kritiky autora jsou poznatky literárněhistorické, zvláště pak jejich kvantita. Autor varuje před preferováním literární historie ve vyučování na úkor četby, před transmisí poznatků vedoucí $\mathrm{k}$ paradoxu: žák nedokáže oddělit podstatné od vedlejšího a pamětně fixované údaje brzy zapomíná. Kritika nesměřuje na oficiální koncepci LV (která naopak funkci literárněhistorických poznatků v učivu nedoceňuje, viz výše), ale na její pokřivení literárněhistorickými fakty v praxi. Autor připomíná didaktizaci poznatků, „učivo je otázkou výběru a zjednodušení, ale i dalších procesů didaktické transformace" (ibid., s. 84), a aniž se jí konkrétně věnuje, apeluje na učitele, aby si „míru sdělované faktografie a poznatků teprve odvozovaných $\mathrm{z}$ interpretace a jiných činností odvíjejících se od textu [...] stanovil sám“ (ibid., s. 87).

Mohli bychom s uspokojením konstatovat, že „méně znamená více" a že metoda didaktické interpretace textu (srov. Lederbuchová 1997, táž 2010) je i zde doporučována, kdyby nehrozilo, že „S vaničkou vylijeme i dítě“: Jak rozumět autorově „míře sdělované faktografie a poznatků“? Natož pak míře poznatků „teprve odvozovaných $\mathrm{z}$ interpretace"? Lze literárněhistorické poznatky odvozovat $\mathrm{z}$ interpretace? ${ }^{121}$ Nemělo by tomu být naopak, mají-li komunikaci a interpretaci, tedy kultivované konkretizaci textu sloužit? A co s odsuzovanou metodou transmise poznatků, když spolu s autorem víme, že „bez [...] faktografie, by se jakákoliv výuka [...] i v tak zvaných výchovách zhroutila“ (Hník 2016-2017, s. 87)?

\footnotetext{
${ }^{121}$ Je pravděpodobné, že i žák ZŠ podle knižního, zastaralého uměleckého jazyka textu může dílo nepřesně určit jako nesoučasné, vzniklé v minulosti, ale v tomto smyslu nejde o konkrétní, identifikační literárněhistorický poznatek. Zatímco jméno autora (či jeho umělecký pseudonym) a název díla (i literatury zcela současné) jsou poznatky literární historie nebo kritiky pro LV nezbytné, leč do vyučování vnesené. Určit dobovou historickou př́slušnost neznámého textu či dokonce identifikovat jeho autorství jen na základě interpretace je úkol vědecký, jehož řešení stojí mimo LV.
} 
Obsahy různých oblastí kultury, tj. vědy, umění a dalších sociálních hodnot, nevstupují do pedagogického pole bezprostředně, ale transformují se ve vztazích vyučovacího procesu. J. Skalková jako transformační faktory uvádí „kategorii cílů, hledisko subjektu žáka a roli učitele“ (Skalková 1999, s. 63). Učitel má být garantem, že kulturní obsahy (tedy i poznatky literární historie) „zprostředkuje žákům ve vlastním procesu vyučování“ (ibid., s. 64), nebot' ve vztahu $\mathrm{k}$ dalším faktorům reprezentuje, aktivizuje a konkretizuje vyučovací metodu respektující žákovy schopnosti a míru jejich rozvoje. Obsah učiva je tedy určen i metodicky. Nepochybujeme o kulturní nezbytnosti vést i žáka 2. st. ZŠ k poznávání historie vůbec a také k poznávání historie literární, tj. vést ho metodami adekvátními jeho věku, mentálním schopnostem, čtenářské a sociální zkušenosti k osvojování vybraných literárněhistorických poznatků. Čím se bude řídit jejich výběr a které metody zvolit, aby žáku 12-15letému pomáhaly v rozvoji jeho čtenářství a $\mathrm{v}$ kulturní orientaci?

S určitým kulturním obsahem je text spojen významovými charakteristikami, které jsou přítomny $\mathrm{v}$ řadě dalších textů vytvářejících daný kontext čili takovými hodnotami, jež se v řadě děl opakují. Jako učivo (i z literárněhistorického aspektu vzato) se text umělecké literatury ve škole prezentuje nejen jako neopakovatelný originální celek, ale především jako celek s takovými poetickými rysy, které ho přiřazují $\mathrm{k}$ dalším dílům stejných charakteristik. Učivem se stává umělecký text svou kontextovostí, svou schopností reprezentovat určitý kulturní celek, jenž může prostřednictvím komunikace s daným textem pubescentní žák při volbě optimální metody adekvátně svému věku poznávat. Literární text si i jako učivo zachovává estetickou funkci, ta je v LV potvrzena, anebo neadekvátní metodikou potlačena až znehodnocena (podrobněji Lederbuchová 2010, s. 41-48). 
Dříve než se budeme věnovat literárněhistorickému kontextu učiva, upozorněme na problém, jenž si žádá zvláštní pozornosti. Je známo, že pubescentní čtenář spontánně zaměňuje autorem zvolenou historickou látku epických nebo dramatických textů za obraz autorovy současnosti čili doby geneze textu, i v př́padě, že jde o rozdíl staletí. ${ }^{122}$ Pro dnešního žáka je vzdálenou historií i doba 20. století, obecně vzato doba předcházející jeho životní zkušenost. Látce je třeba věnovat didaktickou pozornost vždy, jako skutečnosti, k níž téma textu odkazuje.

\section{Literárněhistorický kontext jako předmět didaktické transformace}

Problém těsně souvisí s vymezením didaktického literárního kánonu pro žáka ZŠ. Jelikož se zabýváme LV v nejvyšších ročnících ZŠ, naše úvahy se budou převážně vztahovat ke klasické literatuře pro dospělé. Je jasné, že se budeme pohybovat v rovině zobecňující. Vycházíme z předpokladu, že učitelé užívají čítanky určené pro žáky 8. a 9. ročníku a že mají svobodnou možnost s jejich obsahem laborovat. ${ }^{123}$ Obsah čítanky tvořený konkrétními ukázkami epických a dramatických textů a výběrem básní z konkrétních

\footnotetext{
${ }^{122}$ To neznamená, že by se učitel neměl historickou látkou zabývat. Látka jako mimoliterární skutečnost sice není součástí umělecké struktury, ale téma textu k ní odkazuje, $\mathrm{v}$ tomto smyslu koresponduje s literárním kontextem a je třeba jí věnovat didaktickou pozornost. V 8. a 9. ročníku ZŠ se žák setkává (měl by se setkávat) i s texty dávné historie, především s těmi, jež reprezentují světovou klasiku - s úryvky textů biblických, s ukázkami antické, středověké, renesanční, klasicistní a barokní literatury v českých překladech nebo převyprávěních. A zde se problém historické látky a tématu didakticky aktualizuje jako literárněhistorický poznatek. Volba historické látky v 19. století a v literatuře moderní má různé důvody, jež může ožrejmit právě studium geneze textu (autor se jejím prostřednictvím může vyjadřovat ke společenským problémům své současnosti (alegoricky, symbolicky, narážkami apod.).

${ }^{123}$ Nemusejí probrat všechny texty, nemusejí využít všechny tam navrhované čtenářské aktivity, mohou čítanky doplnit o texty jiné, dle vlastního soudu vhodnější, stejně i zvolit po svém jiné interpretační aktivity pro své žáky.
} 
sbírek je komponován do žánrově tematických celků, i když právě $\mathrm{v}$ daných ročnících prristupuje historický zřetel pro výběr textů reprezentujících historické umělecké styly a směry (v obou případech jde především o kontexty literárněteoretické - tematické, žánrové, historickostylové). Většina čítanek obsahuje i oddíl textů vyhovujících spontánnímu čtenářskému zájmu žáka, je do něj zařazena i intencionální literatura pro mládež (pro náš záměr budou tyto texty vyhovovat jen výjimečně).

Z hlediska výběru textů i jejich řazení v čítankách se odvoláváme na literárněvědecké a didaktické vzdělání autorů čítanek a v tomto smyslu lze uvažovat o citovaných titulech v čítankách jako o didaktickém kánonu literatury pro nejvyšší ročníky ZŠ. Je jisté, že výběr klasických autorů jak literatury světové, tak české se bude víceméně shodovat, ale ve výběru jejich textů shoda být nemusí. Vedle textů anonymních (Bible) bude nepochybně zastoupen Ezop, Homér, Sofokles, Martialis, Petrarca, Chaucer, Villon, Shakespeare, Cervantes, Goethe (viz zde Franta, s. 296)... Z české literatury 19. století Mácha, Erben, Němcová, Havlíček (viz zde Pánková, s. 333), Neruda, Arbes..., z moderny Šrámek, Gellner, Hašek, Wolker, Nezval, Čapek..., z nedávné minulosti Seifert, Hrabal, Škvorecký, Skácel, Lustig, Fuks... Čím blíže současnosti, tím více bude rozdílů (nabídka textů autorů hodnotné literatury je poměrně velká, výběr obtížný), a to i v autorském zastoupení - někde bude chybět Michal, jinde Vaculík, jinde zas Havel, pravděpodobně však nikde nebude chybět $M$. Kundera. Lze tedy konstatovat, že základní kanonický okruh literatury přesahující třídu, ročník, školu není dán stejnými texty, ale výběrem stejných autorů literární klasiky.

Didaktický autorský kontext je premisa pro utváření žákova literárněhistorického vědomí o literatuře, o historickém statusu literatury, a to bez ohledu na literárněhistorickou periodizaci jejího 
vývoje od počátků $\mathrm{k}$ dnešku, nikoli však bez historických souřadnic - nikoli bez dobového zařazení autora a jeho tvorby. Žák by tedy měl pamětně ovládat jména autorů a názvy děl, z nichž četl úryvky (ne tedy čítankový název úryvku), nejen v souvislosti s druhovou a žánrovou příslušností díla (K. Čapek, R.U.R. - drama, žánr sci-fi, J. Škvorecký, Zbabělci - epika, román), ale měl by umět dané dílo také časově zařadit. $U$ děl starých uvést století, u děl 19. století konkrétní čtvrtinu či alespoň polovinu, u děl 20. století čtvrtinu, anebo desetiletí (např. K. Čapek, R.U.R. - dvacátá léta 20. století, Bílá nemoc - třicátá léta 20. století). Do takto průběžně autorsky obsazovaného historického literárního prostoru učitel bude vnášet další účelově vybrané informace $\mathrm{o}$ autorovi a jeho díle - především o žákem čteném díle $\mathrm{z}$ hlediska geneze a o dobové i následné recepci textu a také stručné informace o dalším význačném díle téhož autora. Jde o významové rozširrení autorského kontextu, u některých autorů o připomenutí jejich intencionální literatury pro děti (v dobré víree, že žáci mají obsah daných knih ještě v paměti), ne o vyčerpávající faktografický soupis tvorby!

$\mathrm{V}$ transformaci vědeckého poznání do učiva jde $\mathrm{z}$ hlediska metody o inverzní postup - poznatek, resp. usouvztažněná struktura poznatků získaná literárněhistorickou badatelskou prací s množstvím materiálu (studiem archivních pramenů, novinových kritik a recenzí, předchozích odborných studií a především studiem uměleckých textů a kontextů) je jako výsledek bádání užita ve vyučování jako prostředek pro žákovo poznávání kvalit textu a kontextu, které jsou vědě už známy, ale pro něho jsou objevem. ${ }^{124}$ Jde o obdobný proces, který známe ze školních chemických

\footnotetext{
${ }^{124}$ Je nepochybné, že žák jako kreativní čtenář v textu odhalí významy (individuálně, subjektivně asociované), o nichž se věda nezmiňuje, které mohou obsah textu originálně obohacovat, ale také to mohou být (a většinou jsou) významy, které ukazují na celkové neporozumění textu odporující záměrnosti jeho struktury, jak z aspektu genetického, tak dalších.
} 
laboratoří: žák pracuje s vědou ověřenými výsledky - užívá známých substancí ve známém poměru a pokusem dospívá ke známému výsledku, jenž je však pro něho novým poznáním. Této odbočky jsme užili proto, abychom obhájili tolik zatracovanou transmisi vědeckých faktů do vyučování. Literárněhistorická data nelze v LV dosahovat, s žákem primárně poznávat, ale lze je jako výsledky literární historie didakticky transformovat (vybírat a hierarchizovat dle didaktického záměru) a adekvátně žákovi nabízet jako oporu jeho četby.

Zde učitel z pozice čtenářského partnera a facilitátora procesu přestupuje do role autoritativního znalce. Transmise literárněhistorických poznatků může $\mathrm{v}$ učitelově výkladu četbě textu předcházet, nebo průběžně doplňovat reflexivní fázi žákovy četby (apercepční a interpretační). Literárněhistorické poznatky se tak stávají prímým pomocníkem interpretace a pomáhají žákovi textu porozumět. Poznatky o autorovi a době vzniku daného díla mají pro žáka stejnou efektivnost jako poznatky o poetice textu: Pomáhají plnohodnotnější komunikaci s textem.

Didaktický autorský kontext jako učivo prezentuje konkrétní umělecký text a základní informace o jeho vzniku především $\mathrm{z}$ aspektu kulturních podmínek doby, $\mathrm{v}$ níž autor žil a tvořil, popř. informace o dobovém a dalším ohlasu díla. Ve struktuře informací jsou nejdůležitější ty, které žáka vedou k pochopení takových významů textu, jež by nedocenil z hlediska jejich historické, ale ani současné hodnoty. Do didaktického autorského kontextu tak vstupuje i vysvětlení vybraných významů autorského jazyka textu, vedoucí k porozumění jazykové výstavbě na pozadí dobové jazykové normy, stejně i dobové konvence chování a jednání lidí v autorském obrazu postav a syžetových situací textu. Respekt $\mathrm{k}$ historickému statusu textu v procesu žákovské čtenářské konkretizace považujeme za nezbytný pro porozumění obsahu 
literárního sdělení jako dobově určitého, leč z aspektu estetického poslání historicky neomezeného. Vědomí autorského kontextu (informačně redukovaného, leč vědecky vzato správného) je pro žáka ZŠ „výstupem“ (řečeno jazykem RVP) reprezentujícím celou tvorbu daného autora a připraveným k aktualizaci, např. v LV na stř̌ední škole a četbou dalších autorových děl.

Vědomí didaktického autorského kontextu je pro -náctiletého žáka také jinak stěží dosažitelným (pro něho teoreticky obtížně uchopitelným) vědomím o konkrétním, historicky doloženém tvůrci textu. Znalost autorského kontextu tak transformuje jako poznání o konstrukci textu jako jazykové struktuře, o jeho literární umělosti a vstupuje i do struktury poznatků literárněteoretických. Didaktický autorský kontext je třeba utvářet a posilovat obezřetně, tak aby nedošlo k identifikaci autora a autorského subjektu textu, tak aby si žák uvědomoval rozdíl mezi osobností autora a stylizovanými významy textu a neztotožňoval lyrického mluvčího nebo epického vypravěče s autorem.

\section{Literněhistorický aspekt interpretační metodiky}

Učitelé v praxi získávají nejednu zkušenost s povrchní či přímo chybnou interpretací textu, jemuž žák spontánně neporozumí. Nezrrídka se tak děje na vrub neznalosti historického statusu textu. Někdy čtenáře svede $\mathrm{z}$ cesty neporozumění jedinému slovu: V Bezručově sociální baladě Kantor Halfar (Slezské písně) žák rozuměl slovu „mládenec“ jako pojmenování neženatého mladého muže, a ne už nemladého učitelského pomocníka s mizerným platem, který se jako člověk na hranici bídy v dobových sociálních podmínkách konce 19. století nemohl oženit a pod tlakem sociálních překážek nakonec skončil sebevraždou. Interpret viděl postavu jako sebevraha ze zklamané lásky, tedy zcela jinak než 
určovala záměrnost Bezručova textu. Žák by si pravděpodobně ve výkladu významové výstavby balady vedl jinak, správně, kdyby včas dostal nezbytné informace o historickém kontextu geneze balady a významu slova „mládenec“ jako dobového profesionalismu (o metodice poznávání uměleckého jazyka viz Lederbuchová 2015-2016, zde Franta, s. 296).

Čtenářsky relativně vyspělý a kulturně zdatný student gymnázia interpretoval Hrabětovu báseň Chvíle (Blues pro bláznivou holku) jako uměleckou reakci na okupaci republiky spojeneckými vojsky Varšavské smlouvy v srpnu 1968. Interpretace byla velmi sofistikovaná, s výkladem významů kulturních archetypů a metafor v duchu domýšleného tématu textu. Měla jedinou, avšak zásadní chybu - Václav Hrabě byl v době invaze vojsk více než tři roky po smrti (1965). Student báseň existenciální lyriky interpretoval chybně jako politický protestsong. Aby mohl uvažovat v jiných významových souvislostech, potřeboval znát konkrétní literárněhistorickou informaci o autorovi, o době jeho života. Tento „př́běh“ pozoruhodné interpretace vyvolal odbornou diskusi na stránkách Českého jazyka a literatury. ${ }^{125}$

Čtenářská kompetence nedospělého, historicky nepoučeného a celkově sociálně málo zkušeného žáka většinou nestačí $k$ uchopení významové potence literatury pro dospělé, navíc u textu historicky vzdáleného. Žák má právo nerozumět, učitel má povinnost pomoci s porozuměním: Poskytnout žáku nezbytné informace o době, v níž text vznikl, a také o autorovi - bud' autorský kontext představit před četbou textu, anebo s informacemi podle potřeby vstupovat do průběhu interpretace, a působit tak na žákovo hodnocení textu.

\footnotetext{
${ }^{125}$ Viz Kostečka 2011-2012, Hoffmann 2012-2013, Chaloupka 2012-2013, Lippmann 2012-2013, Lederbuchová 2013-2014. Vedle obhajoby interpretační kreativity autoři došli $\mathrm{k}$ závěru, že bez faktografické opory je tvořivost planá a výsledek chybný. K otázce procesu přijímání textu viz též Čechová 2017, s. 46-49.
} 
Eva Beránková na didaktické interpretaci básně F. Hrubína Tenkrát na Sázavě (Nesmírný krásný život), v níž metodicky angažovala literárněhistorický aspekt, ukazuje, jak žáci 8. ročníku ZŠ uměli zúročit kontextové informace o genezi textu (vznikl bezprostředně po 2. světové válce, básník se v obrazu milované řeky, $\mathrm{v}$ jejíž blízkosti byla střelnice vojsk SS, tématem k okupaci vrátil). Žáci s emočním nasazením a pochopením interpretovali obrazy vystihující okupační atmosféru: „osiky přesadili do lidí, „bodláčím navrch obrátili pole“, „A z řeky bezbranné na poplach duní krajem... zkamenělá salva balvanů“. Autorka popisuje průběh celé interpretační hodiny, včetně kontextu učiva, který umožnil srovnání s obrazem řeky v jiných Hrubínových textech (2002, s. $41-43)$.

V Čítance 8, učebnici pro 8. ročník ZŠ a odpovídající ročník víceletého gymnázia jsme do kapitoly Šoa (Lederbuchová, Stehlíková 2005, s. 160-174) zařadily báseň Jiř́ho Ortena O čem ví tesknota (Č́tanka jaro). ${ }^{126} \mathrm{Z}$ Ortenovy tvorby tam jsou citovány i Zákazy z jeho Žíhané knihy datované rokem 1940. Báseň v tomto kontextu jako učivo nepotřebovala informace o době vzniku (stručný historický a literárněhistorický úvod metodicky předcházel čtenářskému vstupu do kapitoly). Žáci tercie víceletého gymnázia dobře porozuměli obrazům textu $\mathrm{v}$ jejich metaforických významech, dokázali se identifikovat s autorským postojem a esteticky prožít a zhodnotit báseň jako výpověd’ o násilně umrtvovaném životě lidí se žlutou hvězdou.

\footnotetext{
${ }^{126}$ „V přestávce mezi životem a tamtím / kocourek s kamenem až na dně rybníka / pomalu vražedné andílky polyká / a tamto neprichází tamto má vždycky čas / Vidíte kocourka? Myslí si že se vrátí // Co privázali mu to tíha nazývá se [...] A pije zvolna jako by se kál / za všechny stehlíky které dř́v mordoval [...] v přestávce mezi životem a tamtím / co jde tak pomalu jako se chodí spát / když už noc minula a chtěl bys věčně spáti / bez pomyšlení na návrat", ibid., s. 161.
} 
Pak byli vyzváni, aby se vzdali své znalosti o době geneze básně a židovství autora. Poté shodně text hodnotili jako téma ekologické: Obraz kocourka s kamenem na krku odsouzeného k pomalému umírání se stal předmětem jejich soucitu, žalu, bolesti, smutku. Týrané zvíře krutě zabíjené zlovůlí člověka jako obraz násilné diskriminace lidí odsouzených norimberskými zákony k životu-neživotu zlovůlí nacistické ideologie. Návrat k prvnímu plánu textu, možnost znova hodnotit Ortenovy obrazy, žáci přijali vstřrícně jako způsob zmnožení estetického zážitku a posílení původního výsledku interpretace. Př́klad uvádíme, abychom zdo̊raznili, že literárněhistorický aspekt interpretace může přispět k relativně rychlému objasnění denotátu textu (hlavně básní), ale $\mathrm{v}$ didaktické interpretaci by neměl vést $\mathrm{k}$ podcenění estetického účinku konotační a asociační sféry významů. Pro utváření čtenářského obsahu textu jsou svou imaginací nezastupitelné, velmi důležité pro rozvoj emocionální a obrazotvorné sféry komunikace.

Didaktický autorský kontext je na fakta chudý. Přesto by se neměl jen proto samoúčelně doplňovat o informace biografické (až na zdůvodněné výjimky, viz výše lapsus v interpetaci Hrabětovy básně, nebo upozorňující na výjimečnou životní zkušenost motivující výběr látky textu). Informace o soukromém životě autora mohou být pro žáka atraktivní, ale v kontextu tvorby je nelze nadřazovat kulturním charakteristikám doby geneze textu. Např. pro porozumění Máchově poezii i próze je mnohem důležitější pochopení romantického postoje autora a stylizace témat než jeho sexuální život s Lori. V didaktické interpretaci Máje bude pro žáka významnější sdělení o poetice romantismu v první polovině 19. století (tragický střet individuality, konvence a práva, citu a rozumu) a konkrétně o básníkových př́iznačně romantických motivech (les, jezero, noc, loupežník, láska, smrt), než o jeho litoměřickém působení. 
Na rozdíl od Máchy je romantik K. J. Erben žákovi už znám jako sběratel lidové slovesnosti, zvláště jako adaptátor pohádek. Poučení o obdivu romantiků k lidové slovesnosti, ke zvykosloví a pověrečné kultuře $\mathrm{v}$ době geneze Erbenových textů by mělo žákovi pomoci $\mathrm{v}$ interpretaci balad Kytice z pověstí národních. V čítankách je častěji než jiné balady citována Polednice. Je ohlasem lidové baladiky, její mystičnosti a tragična, respektu k nadosobním démonickým silám. Dobový postoj autora a významy textového subjektu nemohou být v LV přehlíženy a baladě podsouvány významy v př́krém rozporu s jejím historickým statusem a romantickým obsahem. Didaktická interpretace stavící na materialistickém výkladu tragické situace, totiž že polednice je žebračka, kterou matka v rozčilení vidí jako nadpřirozenou bytost, a bráníc dítě nechtěně je zabije, ${ }^{127}$ neodpovídá záměrnosti textu. Takovýto výklad (polednice $=$ žebračka) degraduje romantický obsah balady, její mystičnost. Otec našel „dítě zalknuté“. Kdo zavinil jeho smrt? Polednice, zlá démonická síla, která si vzala jeho duši? Matka, která ho zadusila? Někdo třetí? ${ }^{128}$ Bude-li polednice žebračkou, kdo pak nahradí vodní příšeru v baladě Vodník? Kdo revenanta ve Svatebních košilích? Co s otevíráním hory v Pokladu? Poznatek o uměleckém hnutí v době geneze textu ${ }^{129}$ je zde

${ }^{127}$ Filmová adaptace balady (F.A. Brabec, Kytice) na tomto výkladu textu staví, významově baladu posouvá za hranice romantismu, neracionální romantické tajemno nahrazuje moderním hororem. Režisérskou interpretaci přejali i někteří učitelé (aniž by zhodnotili významový rozdíl mezi Erbenovou baladou a autorskou uměleckou parafrází Brabcovou) a pod jejich vlivem i žáci, jak dosvědčuje zkušenost vedoucí semináře Mgr. V. Pánkové ( $v$ rámci vzdělávací akce Rozvoj čtenářské gramotnosti žáků v 7. ročníku ZŠ v Libereckém kraji na přelomu let 2019-2020).

${ }^{128}$ Erben odkazuje i ke starozákonnímu podobenství o Abrahámu a Izáku. Abrahám v Hospodinově zkoušce obstál, a Jahve nedopustil, aby se otec stal vrahem svého syna, s posláním, že rodič nemá ohrožovat své dítě na životě. Této boží vůli a etickému zákonu se matka protivila a za svou vinu byla vyšší mocí potrestána smrtí dítěte (lidově řečeno - neměla se rouhat!). Připomeňme i pohádku B. Němcové Sedmero krkavců - zde děti nezemřely, ale jejich krkavčí podoba byla pro matku krutým trestem vedoucím k pokání.

${ }^{129}$ Roku vydání sbírky (1853) předcházela desetiletí Erbenova sběru a studia lidové slovesnosti a kultury vůbec. 
určujícím pro adekvátní proces i výsledek interpretace. Ahistorický materialistický výklad neodpovídá ani Erbenovu étosu balady: Propojení světa lidského a démonického je tragické. V Polednici čtenář pocituje hrůzu nejen ze smrti nevinného dítěte, ale i z tajemna její příčiny. Polednice (a Kytice vůbec) je dobrou př́ležitostí pro setkání žáka s fantaskní stránkou romantismu.

Literatura 1. poloviny 19. století je ve škole tradičně představována jako literatura „národního obrození. S respektem k výsledkům současné literární historie by se i v LV měla užívat terminologie, která lépe vystihuje duchovní klima doby a jeho literární výraz kontextuálně s uměleckým hnutím evropským. Pojem „národní obrozeni“ je historicky opodstatněný, ale z literárněhistorického aspektu málo specifický (vždyt’ Máchův Máj byl dobovou literární kritikou hodnocen jako nenárodní!). Na „nesoulad mezi aktuálním vědeckým pohledem na dějiny literatury a jeho prezentací ve školním prostředí [...] zejména v prrípadě literatury 19. století, s odkazem na „nejdůležitější inovaci v souboru monografií věnovaných literárnímu romantismu, parnasismu a klasicismu“ upozornil Martin Hrdina (2019-2020, s. 113). Nejde pouze o věc učiva SŠ (kam míŕila autorova kritika), ani jen o terminologii, ${ }^{130}$ ale o odborně adekvátní včlenění literárněhistorického aspektu do celkové koncepce učiva LV, a to i na ZŠ.

Na rozdílných interpretacích Polednice můžeme poukázat i na koncepční rozdíl užití literárněhistorického poznatku ve struktuře učiva o literatuře národního obrození a o světovém a českém romantismu v této době: Jako skladba národního obrození bude Polednice prezentována jako česky psaná literatura, zde navíc inspirovaná českou lidovou slovesností, bude chápána jako projev literatury národní v době bachovského absolutismu; interpretace bez zřetele $\mathrm{k}$ historicky danému uměleckému kontextu může

${ }^{130} \mathrm{~K}$ této problematice srov. také Čechová 2017, s. 194-201. 
vést $\mathrm{k}$ ahistorické, chybné aktualizaci obsahu textu. Ale jako dílo romantické $\mathrm{z}$ doby národního obrození bude interpretace vykazovat významy tragického střetu člověka a démonických sil, bude nabízet prožitek tajemna jako estetickou kvalitu, odkazující $\mathrm{k}$ lidové pověrečné kultuře a uměleckému kontextu dané doby. ${ }^{131}$ Respektovat historický status textu znamená i v učivu ZŠ uplatňovat zřetel $\mathrm{k}$ uměleckému kontextu doby geneze textu.

Že např. Čapkovu Bílou nemoc nebo Matku lze jen stěží interpretovat bez ohledu na dobu jejich geneze, je jasné, přestože kromě dobově aktuálních významů nabízejí obraz existenciálních problémů, jimiž svou dobu překračují. Při přípravě didaktické interpretace textu by učitel LV měl mít na paměti vždy, že autorský subjekt díla významově koresponduje se společenskou atmosférou, anebo prímo s konkrétními sociálními událostmi kulturními či politickými doby geneze textu, a to i v obrazech látky historické. V Knize apokryfů K. Čapka z konce 30. let 20. století je povídka Smrt Archimédova. Zobrazená situace vydírání a ohrožení věhlasného fyzika římským vojákem (končící Archimédovou smrtí) ukazuje $\mathrm{v}$ komorním prríběhu střet mocenské rozpínavosti Rímské říše a fyzického násilí s trvalostí duchovního odkazu, ale také pro dobu svého vzniku aktuálně (leč skrytě) střet politiky hitlerovského Německa s demokratickými státy Evropy, pro českého čtenáře především s Československem. Celková koncepce obrazu, včetně některých detailů (např. z kontextu vyplývá, že římský legionář zdraví historickým pozdravem pretoriánů, tj. zdviženou nataženou pravicí, tak jako v Čapkově době italští fašisté a němečtí nacisté), dává učiteli př́ležitost ukázat žákovi, jak se dobové determinanty geneze textu podílejí na tvorbě jeho obsahu (komentovanou modelovou didaktickou interpretaci

\footnotetext{
${ }^{131}$ Jako ukázku žádoucí koncepce učiva o české a světové romantické literatuře 19. století viz kapitolu Sen, láska a smrt v Čítance 8 (Lederbuchová, Stehlíková 2006, s. 114-155) a v Př́ručce učitele 8 (tytéž 2007, s. 70-85).
} 
apokryfu postihující všechny fáze žákovské recepce a upozorňující i na Čapkovu dobově modernistickou kompozici povídky viz Lederbuchová 1997, s. 86-104, táž 2010, s. 183-201).

\section{Shrnutí}

Literárněhistorické poznatky v učivu ZŠ (a odpovídajících ročníků víceletého gymnázia) jsou vymezeny didaktickými autorskými kontexty: Přimykají se $\mathrm{k}$ výběru textů v čítankách jako $\mathrm{k}$ didaktickému literárnímu kánonu a v tomto smyslu jsou jako nezbytné informace o autorovi a době geneze jeho textu ve významové symbióze se čtenářskou zkušeností žáka. Metodicky jsou do vyučování vnášeny transmisivně - v uceleném stručném výkladu učitel nastíní dobový kontext geneze textu před žákovskou četbou a ve fázi její reflexe pak poskytuje dílčí informace usměrňující, ovlivňující žákovskou interpretaci textu s respektem k textové záměrnosti.

Jako strukturovaná složka učiva mají literárněhistorické poznatky v zásadě dvě funkce: Stejně jako poznatky literárněteoretické jsou prostředkem zefektivňujícím proces a výsledek didaktické interpretace textu a tím žáka vedou $\mathrm{k}$ plnějšímu porozumění literatuře $\mathrm{v}$ daném kontextu literárního kánonu. Dále rozšiřují kulturní obzor žáka - ve funkci relativně pevných bodi̊ autorského kontextu (autor + konkrétní dílo, především text literární klasiky) přispívají $\mathrm{k}$ budování žákova historického vědomí o kultuře a zvláště literatuře (nejen) vlastního národa.

Pubescentní žák je bytostnou podstatou svého věku přirozeně zakotven $\mathrm{v}$ př́tomnosti a orientován $\mathrm{k}$ budoucnosti. Tak jako platí pro jiné přirozené entity, že jsou vstupem do kulturního kontextu ve své přirozenosti záměrně omezovány a vedeny k přijetí 
kulturních pravidel života, platí i pro žáka ve školní LV, že bude komunikovat i s texty, které nebudou momentálně vyhovovat jeho přirozeným zájmům a dosažené čtenářské kompetenci. Pro dnešního čtenáře není dána hodnota české literatury tím, že je psána česky. Ale žák může být esteticky a emočně zasažen uměleckým jazykem a tématy textu, jenž vstupuje do jeho vědomí poznamenán konkrétním, historicky určitým autorským postojem. Didaktický autorský kontext má potenci silného kultivačního momentu. Probíhá-li proces kultivace didakticky adekvátně, pak je žák schopen v procesu poznávání literatury v autorských kontextech její geneze komunikovat s významy, jež ho mohou zaujmout a duchovně obohatit. Literárněhistorické poznatky přispívají k nalézání jeho kulturní identity, k vědomí literatury jako odkazu minulosti, na nějž i on má duchovní dědičné právo.

\section{Použitá literatura}

BERÁNKOVÁ, Eva. Tvořivá hra jako cesta k pochopení literárního díla. Plzeň: Nakl. Fraus, 2002. 108 s.

ČECHOVÁ, Marie. Život s češtinou: Nomen omen: Češka - češtinářka - Čechová. Praha: Academia, 2017. 391 s.

HNÍK, Ondřej. K problému kvantity poznatků v literární výchově. Český jazyk a literatura, 2016-2017, roč. 67, č. 2, s. 83-87.

HNÍK, Ondřej. Školní literární kánon. Český jazyk a literatura, 2015-2016, roč. 66, č. 5, s. 234-241.

HOFFMANN, Bohuslav. O interpretaci literárního uměleckého textu. Český jazyk a literatura, 2012-2013, roč. 63, s. 12-19.

HRDINA, Martin. K otázce terminologie dějin literatury ve školní literární výchově. Český jazyk a literatura, 2019-2020, roč. 70, s. 112-115.

CHALOUPKA, Otakar. Systém literární výchovy a jeho perspektivy. Praha: Academia, 1984. 240 s. 
CHALOUPKA, Otakar. Interaktivita čtenářství. Český jazyk a literatura, 2012-2013, roč. 63, s. 57-61.

KOLEKTIV. Rámcový vzdělávací program pro základní vzdělávání. Praha: MŠMT, 2017. 165 s.

KOSTEČKA, Jiří. Interpreace a misinterpretace uměleckého textu. Český jazyk a literatura, 2011-2012, roč. 62, č. 5, s. 232-236. LEDERBUCHOVÁ, Ladislava. Didaktická interpretace uměleckého textu jako metoda literární výchovy na občanské a střední škole II. Plzeň: ZČU, 1997. 122 s.

LEDERBUCHOVÁ, Ladislava. Literatura ve škole: četba žáka a didaktická interpretace uměleckého textu v literární výchově na 2. stupni ZŠ a v odpovídajících ročnících víceletých G. Plzeň: ZČU, 2010. 266 s.

LEDERBUCHOVÁ, Ladislava. Právo na originalitu, na omyl, na kultivovanost. Český jazyk a literatura, 2013-2014, roč. 64, č. 4, s. 191-195.

LEDERBUCHOVÁ, Ladislava. O poznávání uměleckého jazyka. Český jazyk a literatura, 2015-2016, roč. 66, č. 4, s. 169-175.

LEDERBUCHOVÁ, Ladislava. Personifikace, apostrofa, metafora: poznatky o poetice jazyka v učivu literární výchovy na 2. stupni ZŠ. Český jazyk a literatura, 2017-2018, roč. 68, č. 3, s. $105-111$.

LEDERBUCHOVÁ, Ladislava. Jak čtou osmáci?: příspěvek do diskuse. Český jazyk a literatura, 2019-2020, roč. 70, č. 3, s. $123-125$.

LEDERBUCHOVÁ, Ladislava; STEHLÍKOVÁ, Monika. Čítanka 8: učebnice pro základní školy a víceletá gymnázia. Plzeň: Nakl. Fraus, 2006. $224 \mathrm{~s}$.

LEDERBUCHOVÁ, Ladislava; STEHLÍKOVÁ, Monika. Čítanka 8: příručka učitele. Plzeň: Nakl. Fraus, 2007. 104 s.

LIPPMANN, Karel. Lze se vyhnout „misinterpretaci“ uměleckého textu? Český jazyk a literatura, 2012-2013, roč. 63, s. 78-82. 
POLÁČEK, Jiří. Věc: výuka literatury. Český jazyk a literatura, 2016-2017, roč. 67, č. 4, s. 187-189.

SKALKOVÁ, Jarmila. Obecná didaktika. Praha: ISV nakladatelství, 1999. $312 \mathrm{~s}$.

VALA, Jaroslav; ŠMAKALOVÁ, Kristýna; VÁLKOVÁ, Kristina. Jak čtou osmáci? Český jazyk a literatura, 2019-2020, roč. 70, č. 2, s. 64-71. 


\title{
Současná česká próza ve vyučování: ukázky práce se studenty
}

\author{
Věra Zelenková
}

\section{Pojem postmoderna}

Úvodní část této kapitoly věnujeme termínu postmoderna, jeho bližšímu určení, charakteristice, možným úhlům pohledu. Zároveň bychom chtěli poukázat na ne zcela jednotné chápání či pojetí daného termínu. Navíc je třeba mít na paměti, že český kontext je specifický, zatímco v západních zemích probíhala diskuse o směřování literatury a kultury kontinuálně a postmoderna se rozvíjela minimálně od let těsně poválečných, u nás vzniklo čtyřicetileté manko. $\mathrm{V}$ uvolněných šedesátých letech se $\mathrm{k}$ nám některé myšlenky a texty dostaly, ale vše bylo přerušeno $\mathrm{v}$ roce 1968 . V samizdatu se v období normalizace dařilo šírit některé zahraniční literárněteoretické publikace formou opisů, okruh recipientů byl však značně omezen (Přibáň aj. 2018, s. 83-84). Probíhaly rovněž literárněhistorické a literárněvědné diskuse $\mathrm{v}$ bytových seminářích (vedli je např. J. Mukařovský, F. Vodička), zásadní publikace Miroslava Červenky s názvem Významová výstavba literárního díla mohla vyjít pouze v zahraničí (1978) a kniha Dílo jako dèní smyslu Milana Jankoviče byla vydána až v roce 1992, ačkoliv rukopis byl hotov již v roce 1968 (Haman 2006, s. 5).

Po roce 1989 bylo možné rozvinout hlubší diskusi, poznání, studium, ale tak výraznou mezeru se plně zacelit nedařilo a již 
nepodařilo. Celá řada literárněteoretických textů se dočkala překladů teprve v nedávné době (např. texty Fredrica Jamesona, Jeana Baudrillarda nebo Gérarda Genetta) a jejich recepce pochopitelně proběhla oproti zahraničí opožděně. Počátek 90. let představuje $\mathrm{z}$ literárněhistorického pohledu velmi specifické období a jeho ucelenější reflexe započala teprve v nedávné době (viz $V$ souřadnicích volnosti, $V$ souřadnicích mnohosti...). Jako kdyby $\mathrm{v}$ českém prostředí probíhal celý proces zrychleně. Mnohdy připomíná překotné vydávání děl autorů dříve zakázaných, žijících a publikujících v exilu, zahraničních autorů, i těch nově vstupujících na scénu, nepřehledný chaos. Velmi silně se začaly hlásit o slovo komerce a princip nabídky a poptávky. Texty autorů, jako byli Jiří Kolář, Zdeněk Rotrekl, Egon Hostovský, vycházely s mnohaletým odstupem, přicházely ke zcela jinému čtenáři, než kterému byly původně určeny, dostaly se do naprosto odlišné společenské situace a mnohé se tak nenávratně vytratilo.

Cílem této kapitoly není stanovit, co to postmoderna je, za což by byli mnozí studenti i učitelé jistě rádi. Ale ještě ani dnes není zcela ukončena debata o tom, co se skrývá pod tímto termínem, zda něco jako postmoderna vůbec existuje. Pojetí se mohou lišit i v jednotlivých národních literaturách.

Z hlediska literárněhistorického je vždy důležitá periodizace zkoumaného období. V souvislosti s postmodernou můžeme narazit na to, zda chápeme postmodernu jako historickou etapu, či jako termín používaný pouze pro uměleckou oblast, případně jako název pro umělecký směr. Snahy o periodizaci v sobě mohou nést nebezpečí zjednodušování či škatulkování, pro školskou praxi je však velmi potřebná, chápeme ji jako oporu, díky níž se studenti (i učitelé) mohou lépe zorientovat. Kultura, respektive literatura, nefunguje odděleně, naopak velmi výrazně reaguje na probíhající události a společenské procesy a nálady, proto je 
důležité brát v úvahu ekonomický, hospodářský a politický vývoj nejen v Evropě, ale i ve světě (viz zde L. Lederbuchová, s. 232).

Např. Frederic Jameson je toho názoru, že „ekonomicky se nástup postmodernismu či pozdního kapitalismu začal připravovat v 50. letech“, protože se podařilo vyrovnat válečné ztráty a uvést do praxe nové výrobní postupy. Za kulturní zlom považuje až léta šedesátá (Jameson 2016, s. 20-21). A dodává, že „mladší generace 60 . let se např́iště bude s někdejším opozičním moderním hnutím konfrontovat jako se souborem mrtvých klasikü“ (ibid., s. 28). Co bylo šokující pro společnost 20. a 30. let, bylo o třicet let později součástí kánonu.

Existují názory, že kořeny postmoderny sahají k průmyslové revoluci, tedy $\mathrm{k}$ počátkům společnosti zaměřené na spotřebu, výrobu, vlastnictví. Umění postupně ztrácelo na ceně, jak v přímém, tak i v přeneseném slova smyslu, protože bylo možné vyrobit stovky kopií originálního díla (obrazu, sochy, vázy), mohl si jej dovolit větší počet lidí. Často bylo těžké rozlišit originál od kopie. Umění přestávalo být výsadou vyšší společenské třídy.

Literatura není matematika a je třeba si zvyknout na určitou míru nejistoty, neexaktnosti, na mnoho proměnných, otazníků a zámlk. Zvlášt je to zřetelné u postmoderního textu. Ten vyžaduje čtenáře (odborníka i laika) otevřeného, schopného přijmout mnohovrstevnatost textu, vícero možností výkladu, ochotného uvažovat, přistupovat $\mathrm{k}$ daným textům s otevřeností. Interpretace by neměla sklouznout $\mathrm{k}$ tomu, že se recipient „honí za všemi možnými významy, aluzemi. Čtenář si postupně zvyká na to, že nemusí odhalit vše napoprvé. Umělecký text mu v určitých životních etapách bude poskytovat různé významy (s ohledem na rozvíjející se a měnící se životní i čtenářskou zkušenost). Učitel nemusí být ve stresu, že neodhalil všechny nástrahy autora, vždyt’ 
i umění je hra. Ovšem ne bezbřehá a rozhodně ne bez pravidel, jak si mnozí představují. (Časté reakce učitelů: „V tom si každý může vidět, co chce. Vždyt’ to nemá žádnou strukturu. Tyhle texty nedávají žádný smysl. Nerozumím tomu, proto se jim v praxi vyhýbám. Jak můžu žákưm ř́ct, že je to správně?")

Interpretace či analýza takového textu by neměla ani sklouznout k pouhému mechanickému vyhledávání jednotlivých aluzí, figur, tropů, druhů kompozičních postupů apod., ale měla by vést $\mathrm{k}$ hlubšímu porozumění textu. Měli bychom se ptát, jaká je funkce uměleckých prostředků ve vztahu $\mathrm{k}$ příběhu i ve vztahu ke čtenáři, jak na něho působí (viz zde V. Pánková, s. 333). Nezbavujme tyto texty jejich primární, a to estetické funkce (viz zde L. Lederbuchová, s. 232).

Jako příklad výše zmíněné mnohovsrtevnatosti textu často uvádíme román Umberta Eca Jméno růže (1980). Příběh františkána a bývalého inkvizitora Viléma $\mathrm{z}$ Baskervillu může posloužit coby př́ihodná ilustrace. Pokud si tento text přečte člověk méně zkušený životně i čtenářsky, popř. méně vzdělaný, bude pravděpodobně primárně vnímat detektivní příběh z období středověku. V případě, že stejný text bude číst člověk zkušenější životně i čtenářsky, vzdělanější, bude schopen odhalit i filozofickou, teologickou, historickou dimenzi, bude schopen dešifrovat množství aluzí. Stupeň odhalení se může měnit, čtenář odkrývá víc a víc, není vyloučeno, že časem začne text vnímat zcela odlišně.

Čtenář, pokud je aktivní, se stává tím, kdo text dotvárí. Umberto Eco tvrdí: „Když člověk píše, tak myslí na čtenáře. [...] Jakmile je dílo u konce, je nastolen dialog mezi textem a jeho čtenáŕi (autor je z něj vyloučen). Při vytváření díla je tu dialog dvojí. Jednak dialog mezi tímto textem a všemi ostatními texty napsanými předtím (knihy se píśi jenom o jiných knihách a o tom, s čím ty 
knihy souvisí) a pak je tu dialog mezi autorem a jeho čtenářem chápaný jako model.“ (Eco 2014, s. 234). Jan Balabán uvedl na toto téma $\mathrm{v}$ jednom rozhovoru ${ }^{132}$, že „čtenár je tak podstatný jako kniha. Text je naléhavé sdělení, bez adresáta by neměl smysl. [...] Rozhodně bych nebyl ke čtenáři moc laskavý nebo chápavý. V tomhle nechci mít se sebou ani s druhými žádné slitování: nepíšu pro blbce. Jde mi jen o to, být naprosto přesný. Psaní by mělo být to nejlepší, co jsem schopen tomu druhému říct." To je jeden z půvabů postmoderního textu (a nejen postmoderního). Někdo však může vnímat takovouto hru jako manipulaci či snad výsměch, někdy jimi pravděpodobně i je.

Jak jsme již uvedli, definovat v současné době pojem postmoderna není asi možné, za vhodnější považujeme stanovit kritéria pro její vymezení. Taková, která odpovídají zejména kontextu současné české literatury (i ta se však neustále mění) a která neplatí pouze v oblasti literatury, ale je možné je vztáhnout i k oblasti divadla, filmu, výtvarného umění, možná i ke změnám ve společnosti celkově. $F$. Jameson totiž upozorňuje na to, „že problém postmodernismu je zároveň problémem estetickým i politickým“" (Jameson 2015, s. 68).

Jedním ze základních rysů postmoderny je „pluralistické nazírání na svět i v procesu jeho poznávání, postmoderní člověk (nejen umělec) však často neusiluje o hierarchizaci jevů, protože pro postmodernu je hierarchizace znásilněním a mocenským zneužitím skutečnosti, důsledkem takového postoje je pak hodnotová vágnost, lhostejnost.“ (Haman 2003, s. 148). Tento pluralismus se projevuje ve všech oblastech života, „postmoderní společnosti už nemají nějaké řídící centrum, ale skládají se z řady, subsystémů; které jsou organizovány navýsost nezávisle“ (Welsch 1993, s. 23).

\footnotetext{
${ }^{132}$ Dostupné z https://www.lidovky.cz/kultura/mozna-nejsme-sami-rozhovor-s-janem -balabanem-z-roku-2004.A101217_130633_ln_kultura_glu
} 
Člověk je nucen „komunikovat s velmi rozdílnými světy práce a soukromého života [...] S rostoucím počtem systémů pravidel a smyslu se zvyšuje také orientační nejistota.“ (ibid., s. 24). „Došlo ke změně stanoviska, jímž se pokoušíme porozumět realitě, a to ze stanoviska jednoty ke stanovisku mnohosti.“ (ibid, s. 29).

K pluralitnímu přístupu je třeba mít odvahu, být otevřený vůči různým vlivům, ovšem takový přístup na nás klade velké nároky. Ne vždy se nám daří orientovat se v nepřeberném množství myšlenek, proudů, tendencí, zpráv; nedokážeme rozlišit, co je důležité, co podružné. Vytrácí se hierarchie společenská, postrádáme záchytné body, řád. A pokud se objeví jakýkoliv náznak uspořádanosti, je okamžitě destruován (Haman 2003, s. 151).

Na jedné straně můžeme být svědky dogmatického trvání na starých poetických konvencích, někdy až hysterického, na straně druhé naprosto anarchistického rozvolnění, kdy na ničem nezáleží (srov. zde V. Viktora, destrukce vztahu ke kritériím, s. 281). Opěrným bodem zachování starých konvencí může být historie, víra, vzdělání, ale i rodina či smysluplná práce. Tak například vztah k historii není pro postmoderního člověka jednoduchý, „minulost totiž nelze popřít, nebot popření vede $\mathrm{k}$ mlčení, musí být nazřena novým způsobem: ironicky, bez nevinnosti“ (Eco in Haman 2003, s. 151). Postmoderní společnost také postupně vytlačuje víru a na její místo staví konzum, jídlo, sex, ale zjištuje, že ji to neuspokojuje. A neví, jak a kam dál.

V souvislosti se situací u nás po roce 1989 a zejména na počátku 21. století je třeba si uvědomit, že spisovatel ztratil svoji výlučnou pozici mluvčího národa, typickou pro epochy předchozí. Paradoxně s touto ztrátou přišlo i jeho jisté osvobození, přestal být zodpovědným. Literatura byla zbavena služebné role, vymanila se $\mathrm{z}$ ideologické podřízenosti. Ztrátou vnějšího nepřítele ale také 
přišla o hnací motor, někoho či něco, vůči komu či čemu je možné se vymezit, proti komu psát (ztráta neprrítele jako by znamenala ztrátu důvodu existence). Hledání zásadního a nosného tématu stále pokračuje. Jednotliví autoři zřejmě nepocitují potřebu se sdružovat do úžeji a pevněji sepjatých literárních skupin, okruhů, vydávat manifesty, společné časopisy. Můžeme sledovat spíše solitéry, kteří o sobě vědí, pozorují se, čtou se navzájem, setkávají se, ale jedná se spíše o sympatie i antipatie v osobní rovině. Silné umělecké směry 20. a 30. let, jako např. poetismus a surrealismus, nevznikají, projevují se tendence, tematická blízkost (feminismus, ekologie).

Peter Zima vydělil v soudobé postmoderní literatuře (nejen české) čtyři základní modelové typy:

a) Text jako radikální řečový experiment, jenž je čtenáři nabízen jako kontingentní a partikulární konstrukt s hravě kritickým záměrem. U nás je možné za představitele tohoto modelu považovat např. J. Křesadla, Z. Brabcovou, V. Kremličku, J. A. Pitínského.

b) Čtivý, neorealistický, neoromantický či neomodernistický text $\mathrm{s}$ konvenčními vyprávěcími vzorci. Z českých autorů lze jmenovat M. Viewegha, J. Jandourka, B. Vaňka-Úvalského.

c) Ideologicko-utopistický text nových hnutí. V duchu feminismu se nesou texty A. Berkové, T. Boučkové, problematiky životního prostředí si všímá např. M. Urban.

d) Text destruktivní (subverzivní) revolty. Jedná se např. o J. Topola, V. Kahudu. Tím, co spojuje výše zmíněné autory a jejich tvorbu, je antimimetičnost (Haman 2003, s. 51-52).

Umělcova pozice je rovněž ztížena otupělým a mnohdy zhýčkaným recipientem, toho potřebuje zaujmout, vytrhnout $z$ letargie, chce jím zatřást a možná i otřást. Mnohdy mu nezbývá než šokovat, 
provokovat. Často jsme však místo toho svědky pouhého gesta, ironického šklebu, povrchnosti, pozérství, přebujelého umělcova ega. V tomto ohledu přestalo umění se svým recipientem komunikovat, nesnaží se o konstruktivní dialog, nepodněcuje diskusi.

Postupně se nejen z umění, ale i z médií, sociálních sítí, života, vytrácí autenticita. Otázkou zůstává, zda o ni vlastně stojíme. Nevyhovuje nám a není pro nás přijatelnější nakonec aranžovaná faleš víc než realita?

V literatuře se ztráta hierarchie, řádu, opěrných bodů projevuje mícháním, slučováním vysokého s nízkým v rovině stylů, žánrů, jazykových prostředků. Dochází k přechodům i destrukci $\mathrm{v}$ rovině časové i prostorové, někdy ostře a nečekaně, jindy zastřeně a neznatelně, podobně se prolínají roviny reflexivní a roviny promluv, což bývá podpořeno vymizením interpunkce, uvozovek, prolínáním pásma vypravěče a pásma postav (srov. např. Doležel 2014). Z prózy (ale i z divadelních her či přesněji z jejich inscenací) se mnohdy vytrácí príběh s výstavbou, na niž jsme si zvykli v románech realistických. Ačkoliv se nám může tato tendence jevit jako nová, nejedná se rozhodně o záležitost posledních pár let, ale jde o proces dlouhodobý (viz např. Petrohrad Andreje Bělého). Větší prostor je věnován vypravěči, míra subjektivity i subjektivizace stoupá a bývá zesílena užitím ich-formy. S ohledem na proces mizení příběhu a kladení důrazu na postavu vypravěče vymezil A. Haman v současné české próze dvě linie: linii autobiografickou - vypravěč se stává protagonistou vlastního prř́běhu a linii fantaskní - vypravěč se nechává unášet hrou představivosti $k$ tvorbě „nepravděpodobných“ fikcí (Haman 2003, s. 56-57).

Bylo by ovšem chybné si myslet, že se tradičního př́iběhu zřekli všichni čeští autoři. $Z$ autorů starší generace mu zůstávají věrní 
např. Ivan Klíma, Pavel Kohout, Jiří Stránský, z mladších spisovatelů např. Petr Šabach, Iva Pekárková, Filip Topol (Haman 2003, s. $56-57)$.

Jak jsme již naznačili, práce s postmoderními texty vyžaduje čtenáře, $\mathrm{v}$ našem prŕípadě učitele, poučeného, sečtělého, nepodcenuujícího př́ípravu (viz zde V. Pánková, s. 333 a D. Franta, s. 296). Tyto texty jsou zpravidla plny aluzí, hříček, náznaků (Lederbuchová 2002, s. 247), které jsou čtenáři při přijímání textu kladeny do cesty.

Můžeme namítnout, že již např. v Dostojevského Zločinu a trestu lze vidět propojení žánru detektivního a filozofické nadstavby, Don Quijote nese rysy dobrodružné literatury podobně jako Homérův Odysseus. Rozdíl mezi postmoderními texty a texty dnes již klasickými je však mimo jiné $\mathrm{v}$ tom, že postmodernímu autorovi slouží jako inspirační zdroj tzv. pokleslé žánry, např. detektivka, dobrodružný př́iběh, román pro ženy, horor (Pilař 2005, s. 59). V čem ještě tedy tkví novost postmoderny? J. Hoffmannová uvádí ve své studii $K$ charakteristice postmoderního textu množství základních rysů, jsou to např. (kromě výše uváděných) konfliktní ráz výstavby textu, intertextovost, metatextovost, autoreflexe, prolínání skutečnosti a fikce, nelineárnost, porušování kauzality, střetávání hledisek i perspektiv, návraty k mýtům a archetypům.

\section{Texty současné české prózy a literární výchova}

Texty současné české prózy by rozhodně neměly být $\mathrm{v}$ hodinách literární výchovy opomíjeny. Přesto se jim mnozí učitelé záměrně vyhýbají, obávají se jich, mají pocit, že jim nerozumějí, a tím je motivace zařazovat je do programu literární výchovy značně oslabena. Učitelé často argumentují tím, že nedokáží „dojít“ ve 
výkladu a četbě ani k roku 1989. Školní vzdělávací program však poskytuje poměrně dobrý manévrovací prostor a jistě je možné zařadit do programu i texty současné. Pokud se pro texty 21 . století rozhodnou, často se pak uchylují pouze k textům Vieweghovým (Báječná léta pod psa), Rudišovým (Nebe pod Berlínem) či Douskové (Hrdý Budžes). Z našeho pohledu tedy volí schůdnější cestu, protože se jedná o texty převážně dějové, neposkytující tak rozsáhlé možnosti ke kultivaci čtenářských kompetencí.

Pro školskou praxi je jistě užitečné vybírat texty reprezentující více tendencí a podob současné české tvorby: jak texty klasičtěji koncipované, tak texty experimentálněji laděné. Jen tak je možné poznávat tvorbu současných autorů komplexně, jejich poetiku i př́padný vývoj v rovině tematické či formální. Je třeba přistupovat $\mathrm{k}$ těmto textům otevřeně, nepodléhat prvnímu dojmu po první četbě, ale naopak nořit se do textu znovu a znovu, odlupovat jednotlivé vrstvy, vnímat motivy, přemýšlet o tématu, a to i přesto, že tyto texty nejsou mnohdy vůči čtenáři vstřícné, vyžadují jeho úsilí.

Mnohdy je nejen pro čtenáře laika, ale i pro učitele obtížné rozeznat kvalitní dílo od nekvalitního. Otázkou samozřejmě zůstává, která kritéria by mělo splnit dílo kvalitní. Lze spoléhat na faktor času, zda dílo obstojí v konkurenci. U současné tvorby nemusí ještě fungovat naplno. Mohou nám také pomoci recenze literárních kritiků či teoretiků v odborných periodikách, i jejich četba by měla být nedílnou součástí učitelské př́ípravy.

Součástí přípravy učitelů českého jazyka a literatury na katedře českého jazyka a literatury FPE ZČU je v prezenčním studiu a v celoživotním vzdělávání (dále CŽV) seminář zaměřený na současnou českou literaturu. Prozaické texty určené k interpretaci jsou např. Ajvazův soubor povídek Návrat starého varana, 
Topolova novela Anděl nebo Topolův román Kloktat dehet, Urbanův román Hastrman, Balabánův povídkový soubor Možná že odcházíme.

Pro účely této kapitoly budou použity: povídka Brouk z Ajvazova Návratu starého varana a Topolova novela Anděl.

Byly vybrány záměrně texty vzájemně odlišné, protože každý z nich reprezentuje jinou vývojovou tendenci polistopadové české prózy. Michal Ajvaz (nar. 30. 10. 1949) vstoupil do literatury teprve v roce 1989 básnickou sbírkou Vražda $v$ hotelu Continental. Je představitelem prózy experimentálně laděné, jeho texty vznikají na základě metody asociativní, automatického psaní, je výrazně ovlivněn fenomenologií. Často bývá označován za pokračovatele magického realismu, sám to však důrazně a důsledně odmítá. Pro účely semináře byl jako úvodní text zvolen soubor povídek Návrat starého varana z roku 1991. Přestože se jedná o Ajvazovu druhou publikaci, tvoří motivicky i tematicky ucelený útvar, autorův styl, poetika jsou již hotové, vykrystalizované, zůstává jim víceméně věren po celou svou spisovatelskou dráhu. V poslední době však jako kdyby se dostával do slepé uličky, a ukazuje se, že i takto zpočátku plodná metoda se jednou vyčerpá.

V osobnosti Jáchyma Topola (nar. 4. 8. 1962) se propojuje mnohé: umělecky založená rodina (literární i hudební větev), zákaz umělecké tvorby jeho otce, př́islušnost $\mathrm{k}$ undergroundové kultuře, účast v protirežimních akcích, zatčení, pobyty v psychiatrickém zařízení, psaní hudebních textů, alkohol, vstup do nové reality 90. let, hledání formy. Po vícežánrovém románu Sestra napsal Topol střídmější a čtenářsky přístupnější novelu Anděl (1995). I v ní pracuje s podobnými postupy, motivy, ale je umírněnější v kompozici i jazykové rovině. 
Oba autoři zastupují první polovinu 90. let. Jakkoliv jsem si vědoma zkratkovitosti a zjednodušenosti, v průběhu semináře CŽV, kdy máme vyhrazena dvě až tři setkání, jinak postupovat nelze. Vždy se zaměříme na dominantní rys dané prózy a analyzujeme jej; zpravidla se jedná o takový rys, který je pro poetiku autora či její vývojovou etapu zásadní a charakteristický.

\section{Povídka Brouk}

S ohledem na rozsah této kapitoly se budeme zabývat pouze Ajvazovou povídkou Brouk s přihlédnutím k Úvodu celé jeho knihy. V semináři (i vyučovací hodině) je možné věnovat se motivům a jejich funkci v př́běhu, všímat si aluzí, jež jsou v textu zakomponovány, a sledovat, jak se významy rozšiřují a prohlubují.

Při čtení Úvodu narazíme na motivy, se kterými Ajvaz pracuje opakovaně. Úvod sám připomíná výstavbou i zvolenými jazykovými prostředky odborný text a zároveň je naplněn motivy zvířat, jakousi magičností pražských ulic, navozuje surrealistický snový dojem. Lachtan v autobusu, tučňák stepující v kavárně Slavie, tučňák proplétající se davem na Národní třídě, tedy zvířata postavená do situací více či méně obvyklých pro člověka. A s těmito zvířaty se vypravěč setkává či spíše utkává; často nedokáže vyřešit naprosto banální situaci a dostává se do groteskních až trapných situací.

Často se opakuje motiv starých mrtvých jazyků (chetitština) či nečitelného písma. Místa, jako jsou např. noční autobus, kavárna, antikvariát, knihkupectví, pokoj, získávají magický rozměr, ukrývají tajemství, jsou labyrintem, odkrývají další a další prostory. V Úvodu je zmíněna korespondence Rainera Marii Rilkeho s Helenou von Nostitz-Wallwitz (v době, kdy Rilke psal Zápisky Malta 
Lauridse Brigga), traktát Pistis Sofia (v překladu Víra a moudrost, znovuobjevený gnostický text), filozof Maurice Merleau-Ponty. Tímto Úvodem jsou vytyčeny hranice, v nichž se budeme pohybovat $\mathrm{z}$ hlediska motivického, tematického i filozofického.

Čtenář by se neměl nechat zmást, po prvním čtení následují u studentů CŽV reakce typu: „Co to bylo?!, Absolutně nevím, co jsem četl/-a. Po druhém čtení: Ten text postrádá př́běh. Chybí mi dějovost. Po třetím čtení: Něco v tom ale je. Připomíná mi to Hrabala a jeho metodu psaní. Praha je tu hodně zvláštní. "Jedná se o autentické reakce. Bohužel jsem se setkala i s tím, že studentka CŽV (tedy již praktikující učitelka) odmítla číst opakovaně dané texty a demonstrativně se interpretace neúčastnila, to je postoj u stávajícího (CŽV) i budoucího učitele značně alarmující. Pokud se však čtenář rozhodne přistoupit na takto vytvořený svět, $v$ němž zvírata chodí, mluví, konají jako lidé (nebo jsou alegoriemi lidí či lidských typů?), v němž jedna věc či událost asociuje vždy další a dochází $\mathrm{k}$ jejich řetězení, $\mathrm{v}$ nichž hraje prim imaginace, hra, hravost, ale i filozofický přesah, pokusí se ponořit do chladných vod pod čarou, rozprostře se před ním magický fikční svět.

Povídka Brouk může sloužit jako svého druhu klíč k interpretaci všech povídek v souboru Návrat starého varana. Z interpretačního hlediska lze pracovat s vnímáním prostoru, at je to byt, labyrint, nebo voda, s motivem brouka, písma, dopisu, neporozumění.

Prostor: Smíchovský byt, v němž se nachází vchod do tajného podzemního malachitového paláce. Už tady můžeme zaznamenat kontrast mezi vysokým a nízkým, vznešeným a světským. Palác je tajemný, velký, rozsáhlý, byt je naopak malý a stísněný. Do paláce se vchází přecpaným šatníkem (hromadění věcí, chaos, nepřehlednost), kabáty a jejich vůně mohou vyvolávat halucinace, kapsy kabátů jsou dalším neznámým a tajemným prostorem, 
labyrintem, který skýtá mnohá překvapení, „naše ruce bloudí kapsami jako bezbranná slepá zvířata cizími norami“. Kapsy se podobají „třináctým komnatám, nejpozoruhodnějším archeologickým nalezištím“133 (s. 59), jež vydávají své zapomenuté poklady tomu, kdo chce hledat, kdo hledá, kdo se vydá na neznámou pout', kdo je odvážný... Mủže pak nalézt něco zapomenutého, důležitého, vzácného. Místa, věci, předměty zdánlivě obyčejné, všední, které již ani nevnímáme, mohou ukrývat nečekané, nekonečné prostory, čekající na své objevení.

Dalším prostorem je prostor knihovny. Je místem vzdělání, vědění, studia, ale v noci se mění v kluziště a za 258 let se z knihovny stane tržnice - tedy opět kontrast vznešeného a světského. Podobně jako sokolovna v Kunraticích, jež je místem zasvěcení. Vypravěč sedí v knihovně, studuje brožuru o chovu králíků, zmínku o tajemném vchodu do paláce objevil v poznámce pod čarou, $\mathrm{k}$ čemuž podotýká, že „poznámky pod čarou nikdo nečte, všichni spěchají, aby už byli na konci knihy, jako by byli za přečtené placeni od metru“ (s. 53). Čtení poznámek pod čarou přirovnává $\mathrm{k}$ „sestupování do temného suterénu stránky a zase se vracet“, na jiném místě je pak přirovnává $\mathrm{k}$ „ledovým vodám jezera, nebot poznámky byly hluboko pod hladinou. Jeho přítel byl nucen odstraňovat chaluhy, a přisáté mlže, pak znovu šplhal po strmé stěně zpátky, promáčený a ověšený chaluhami, které na něm vlály $\mathrm{v}$ chladném horském větru, pokousaný od dravých ryb, aby pokračoval ve čtení textu na místě, kde je přerušil, a aby za malou chvíli začal znovu sestupovat pod hladinu“" (s. 54). Ani on ani jeho prrítel nejsou líní, není jim zatěžko namáhat se, podstupovat obtížnou cestu za poznáním, věděním, objevy.

${ }^{133}$ Citujeme podle vydání z roku 1991. 
S tím je spojen motiv vody, jež zaplavila (ale nevyhladila!) tajemný nápis, ukrývá jej, často bývá studená, plavou v ní dravé ryby. Voda tedy není živlem př́iemným, nechtěli bychom se do ní nořit znovu a znovu, překonávat chlad i nebezpečí. Neslouží jako prostředek očisty, je plná chaluh, tedy není průzračná, nepřináší pocit úlevy. Diskomfort umocňují ostrý vítr a bolavé kousance od ryb. Další překážku představuje strmá stěna, ale ani ta nedokáže vypravěčova přítele odradit. Odhodlaně mírí za věděním a poznáním.

Brouk: Když vypravěč našel kýženou informaci o vchodu do paláce, nedaří se mu přečíst název ulice, $v$ níž se byt nachází. Na daném místě totiž sedí brouk, odmítá se hnout z místa, jako kdyby hlídal tajemství (motiv strážce). Vypravěč jej nedokáže jednoduše odstrčit, odfouknout, rozmáčknout. Zápasí s ním: „už mi zničil tužku, pero, hřeben a kartáček na zuby, nakonec se na něj vrhám holýma rukama, do kterých se s chutí zakusuje, ale za celou dobu se nepohne ani o píd ze svého místa, neodhalí ze jména ulice ani písmenko.“ (s. 55). Jsme svědky takřka archetypálního zápasu: „Brouk se však uvelebí na jediné místo na světě, $z$ něhož může zničit mé štěstí.“ (s. 56).

Podobnou neschopnost řešit naprosto banální situaci prokáže vypravěč v sokolovně, kde je svědkem eleusinských mystérií. Sedí před ním dáma s obřím kloboukem, a on tudíž nic nevidí, ostýchá se však a nedokáže ji požádat, aby si klobouk sundala. Nic sice neviděl, přesto se tváŕí, jako kdyby všemu rozuměl a vše mu bylo jasné, předstírá. Ostatní zasvěcenci se také tváří vědoucně, ovšem zda jsou opravdu zasvěcení, zůstává otázkou.

S prostorem, neschopností řešit banální situace, poznáním, souvisí také motiv psaní, písma, nečitelnosti. Vypravěč sedící $\mathrm{v}$ knihovně si dělá poznámky, postupně je nucen $\mathrm{z}$ nedostatku 
místa psát menší a menší písmena, dělat menší mezery: „snad by se to dalo vyřešit tak, že bych pokračoval pod dolním okrajem papíru a napsal konec vyprávění na desku stolu“ (s. 62). Písmo se stává skoro nečitelným, namačkaným. I podpis na nalezeném dopise je nečitelný, vypravěčův př́itel objevuje pod hladinou hieroglyfický text. Nerozluštitelnost představuje tajemství, záhadu, otazníky. $\mathrm{K}$ řešení je třeba překonat různé překážky. Text však může zůstat neproniknutelným, nepochopeným, protože právě to, co zůstává nerozluštěné a možná i nepochopitelné, nás pohání dál. Zcela odhalený svět by přestal být zajímavý, člověk by se uspokojil a dál se nerozvíjel.

Za velmi aktuální považujeme motivy přetvářky a snad i lenosti, $s$ níž přristupujeme ke vzdělání a $\mathrm{k}$ literatuře. Určitě je důležité zvažovat funkci zvolených prostředků ve vztahu k příběhu, $\mathrm{k}$ textu, jejich účinek na čtenáře.

Se studenty pravděpodobně nebudeme dopodrobna interpretovat aluze týkající se filozofie (eleusinská mystéria, fenomenologie, Hegelova Estetika, Kantovy kategorie, Aristoteles, Empedokles), týkající se literatury (André Breton, Marcel Proust, Elsinor), výtvarna či architektury (explosionalismus Vladimíra Boudníka, Výklenková pyramida v El Tajínu). Můžeme vybrat ty, na něž studenti intelektuálně stačí. Učitel by je však měl vnímat komplexně a v souvislostech, uvažovat o jejich funkci. Co by přejít neměl, je závěr povídky, jenž v podstatě tvoří její začátek. Představuje tak obraz Urobora požírajícího svůj vlastní ocas. Tento kruh lze chápat jako věčný koloběh života, jako symbol věčnosti a jednoty, duality a zároveň cykličnosti, bezkonečnost př́iběhu, procesu poznání i života samého. Autor vytvárí mýtus Prahy (vchod do paláce ve smíchovském bytě) i knihovny (pálení knih z hygienických důvodů, kluziště). 


\section{Novela Anděl}

Při celkové interpretaci Topolovy novely nelze pominout motivickou výstavbu, změny časových rovin, postavu vypravěče, fokalizaci, kompozici či užívané jazykové prostředky.

Tento text může posloužit jako ukázka míchání vysokého a nízkého v oblasti užitých jazykových prostředků v pásmu vypravěče i postav. Vševědoucí vypravěč pochází pravděpodobně ze stejného prostředí jako hlavní postava Jatek. V případě Jateka se jedná o nejednoznačnou postavu: nelze jej označit ani za kladného ani za záporného hrdinu, ne vždy vzbuzuje ve čtenáři sympatie a není jednoduché se s ním ztotožnit. Fokalizátorem je především Jatek. V pásmu vypravěče i postav můžeme vysledovat prostředky z oblasti spisovné i obecné češtiny („v jednolitý vrstvě“, „je mrtvej“, „svý prolhaný vyprávění“, „novej den“, „omotat svalama, šlachama, kostma, vlasama“, „mrk“, „hele“), často také silně expresivní i vulgární výrazy („vykašli se na to“, „vybodnout se na to“, „vypad“, „vole“, „píča“, „mizero“, „svině“, „neser“), objevuje se argot z prostředí drogově závislých („vstupenka“, „haš“, „vařeni"), velmi časté je užívání interjekcí („káp, káp, káp“, „ňu, ňu“, „ho, ho“, „he, he“, „šššs“, „křřr“, „uíí“, „uíííííííi“, „ugh“). Jazykové prostředky odpovídají prostředí, z něhož postavy pocházejí a v němž se pohybují.

Orientaci v textu může čtenáři ztěžovat absence uvozovek (o tom viz např. Adam 2006-7). Početné jsou rovněž zámlky (nedořečenost, zamyšlení, nedokončená výpověd') v pásmu postav, množství otazníků i vykřičníků, jež odkazují k expresivitě reálné mluvy, dokreslují psychické rozpoložení postav, jejich charakter. Z hlediska syntaktického lze vysledovat výčty, paralelismy, v pásmu postav kratší větné celky, jež dynamizují text. Celkově text plyne velmi svižně, místy jako kdyby byl chrlen. Všechny 
tyto prostředky odpovídají Topolovu názoru, že „mít svůj jazyk znamená zachovat si svou identitu“.

Porozumění textu může stěžovat i jistá fragmentárnost, místy snad až nepřehlednost, míchání žánrů i nelineární vyprávění událostí. Objevuje se také prolepse, tedy časový anachronismus, jehož podstatou je pohled do budoucnosti („Tohle všechno ho čekalo, nevěděl o tom. Nevěděl, že nakonec bude psát o ní.“). Funguje zpravidla jako ozvláštnění, jako vábnička pro čtenáře, má ho přimět nedočkavě číst dál, navíc tím vypravěč dokazuje svou důvěryhodnost a vševědoucnost. Ačkoliv se tedy vypravěč jeví jako vševědoucí, jeho pozice je shazována a znevěrohodňována autorem, jenž vstupuje do fiktivního př́iběhu (metalepse) a vměšuje se do něho („[...] z úst pomateného vypravěče, chorobného lháře tehdy v Nonstopu, vykládal i o Jatekovi [...], říkal [...] než skončil svý prolhaný vyprávění o Jatekovi, který věděl, že ten, co bere drogu, se sám stává drogou [...] a pak je mrtvej [...] pokroucený vyprávění z letopisů 5. čtvrti, báchorku, fantasmagorii, vyprávění o oční chorobě ve stadiu pokročilý psychopatie a o touze najít blaho ted' a tady [...] takovou moralitku se strašidlama, anekdotu pro sígry, než dou spát [...]“) Jedná se o jakési ironické štouchnutí, zpochybnění vypravěče i vyprávěného příběhu. Čtenář si tak nemůže být jist ničím.

\section{Srovnání}

Oba analyzované texty byly vybrány pro semináře záměrně jako ukázka české prózy první poloviny 90. let. Školské praxi mohou vyhovovat i s ohledem na rozsah, Ajvazovu metodu asociativního psaní je určitě vhodnější poznávat prostřednictvím jeho raných kratších textů. Podobně je tomu v případě Topolovy novely, protože román Sestra (podle vlastních učitelských zkušeností) činí 
studentům velké potíže vzhledem $\mathrm{k}$ formě i obsahu. Pokud budou tyto i jiné experimentálně laděné texty zařazeny do programu literární výchovy spolu s texty tradičněji vystavěnými, mohou pomoci ukázat rozmanité podoby současné české prózy. Prostřednictvím těchto krátkých próz se seznamujeme s tím, jak se postmoderní postupy a nástroje realizují v uměleckém díle.

V povídce Brouk sledujeme míchání vysokého a nízkého v rovině žánrové i motivické (filozoficky laděný text s prvky dobrodružné prózy, honosný palác a obyčejný smíchovský byt, tajemný obřad a sokolovna, knihovna a kluziště, nerozluštitelné záhadné písmo) V prríběhu je vytvářen obraz magické a také mytické Prahy, jakkoliv obyčejný prostor (knihovna, byt, skříň, kapsa) má tajemný rozměr, postupně odkrývá další a další zákoutí, podobný labyrintu, z něhož zpravidla není úniku, vrací nás zpět, na začátek, nebo nás posílá dál. $\mathrm{V}$ postavě brouka je zosobněn archetyp strážce, jenž urputně brání poklad či indicii. Strážcem by mohla být i žena $\mathrm{v}$ klobouku, přes niž vypravěč nevidí, a zůstává tak $\mathrm{v}$ nevědomosti. Zda tak ona dáma činí vědomě, zůstává otázkou. Zásadním rysem, jímž text naplňuje představu o postmoderní stylizaci, je pak rozpitá a nejasná hranice mezi fikcí a realitou. Vypravěčův přítel, potápějící se do studené vody, je spjat s realitou a poznámky pod hladinou (tedy pod čarou) naopak s fikcí.

V zásadě všechny Ajvazovy texty jsou výrazně intertextové, obsahují množství odkazů $\mathrm{k}$ dílům jiných autorů, ke skutečnostem $\mathrm{z}$ reálného i fiktivního světa, $\mathrm{k}$ osobnostem $\mathrm{z}$ oblasti literatury a filozofie. Postavy zvířat, bujná imaginace, magičnost, aluze, to vše dohromady tvoří hravý text, který čeká na čtenáře ochotného „nechat se v ledové vodě pokousat od dravých ryb“.

I v případě Anděla máme před sebou mnohovrstevnatý a strukturovaný postmoderní text, který obohatí čtenáře různého stupně 
rozvoje čtenářské zkušenosti. Nejvýraznější složkou Topolových textů je jejich jazyková rovina, pozorujeme mísení na ose spisovnost - nespisovnost, neutralita - expresivita, hojné užívání slangových výrazů, vulgarismů, germanismů, rusismů, proud řeči v pásmu vypravěče i v pásmu postav plyne rychle vpřed. Je možné, že pouze takto svižný a košatý jazyk bude v budoucnu schopen pojmenovávat podobně svižně pádící svět kolem nás. V časové rovině dochází k nelineárnímu vylíčení událostí a také $\mathrm{k}$ přechodům mezi časovými rovinami. Vypravěč vidí do budoucnosti, čtenáři to neskrývá a ještě mu naznačuje, co může očekávat. Vypravěčovu zdánlivě silnou pozici shazuje sám autor, když vstupuje do fikčního světa a znevěrohodňuje ho.

Společným bodem povídky Brouk a novely Anděl je tvořený mýtus spojený s pražskou čtvrtí Smíchov. V Andělovi se jedná o legendu vysvětlující vznik názvu Smíchov a také křižovatky Anděl. Zatímco u Ajvaze je ošuntělá čtvrt̉ využita k vytvoření kontrastu, u Topola naopak souzní s př́během i s postavami (respektive postavy souzní s prostředím) a podporuje dojem špinavosti.

V obou textech dochází k mísení žánrů (dobrodružný s prvky arbesovského sci-fi či s filozofickými a náboženskými motivy) a prostupování reality s fikcí. Nejednoznačnost hlavních postav a zároveň jejich výjimečnost plně odpovídají charakteristice postmoderního hrdiny.

\section{Shrnutí}

Postmoderní texty odkazují zpravidla k realitě zcela jinak, než je většina čtenářů, studentů i učitelů zvyklá. Podněcují tím čtenáře $\mathrm{k}$ novému pohledu na svět, snaží se ho přimět $\mathrm{k}$ tomu, aby vnímal svět v celé jeho barevnosti, což bývá namáhavé, leč potřebné. 
V prostředí jasně polarizovaném (černobílém) se jedinec nerozvíjí, nedostává se mu potřebných podnětů.

Nejednoznačnosti a nejistoty se není tř̌eba bát, ne všechno je možné beze zbytku vysvětlit, interpretovat, a i to je v naprostém pořádku. Postmoderní texty nás znejistují, snaží se zatřást našimi jistotami, respektive našimi představami o nich. Kdybychom dokázali vše vysvětlit, stal by se svět a život v něm nudným a nesnesitelným a člověk by ztratil motivaci k (sebe)rozvoji. V neposlední řadě tyto texty podněcují čtenářovu fantazii, což je v dnešní výrazně vizuálně zaměřené době hodně důležité. A všechny zmiňované umělecké prostředky tomuto cíli slouží nebo spíše napomáhají jeho naplnění.

Podobně jako jsou neukončené a otevřené konce mnohých současných prozaických textů, je otevřená i otázka směřování české prózy.

\section{Použitá literatura}

ADAM, Robert. Řeč postav ve vyprávění. In Český jazyk a literatura. 2006-2007, roč. 57, č. 4. s. 174-180.

AJVAZ, Michal. Návrat starého varana. Praha: Mladá fronta, $1991.81 \mathrm{~s}$.

DEMJANČUK, Nikolaj. Humanistická epistemologie Paula Feyerabenda a tvorba Bertolda Brechta. In NOVOTNÝ, Vladimír (ed.). Postmodernismus v umění a literatuře. Plzeň: Pro libris, 2003, s. 7-20.

DOLEŽEL, Lubomír. Narativní zpưsoby v české literatuře. Příbram: Pistorius \& Olšanská, 2014. 142 s. 
ECO, Umberto. Poznámky k Jménu růže. In Světová literatura, roč. 31 (1986), č. 2, s. 227-241.

FREEDMAN, Ralph. Life of a Poet: Rainer Maria Rilke. Illionis: Northwestern University Press, 1996. $640 \mathrm{s.}$

HAMAN, Aleš. Literatura v průsečíku pohledi̊: teorie - historie kritika. Praha: ARSCI, 2003. 173 s.

HAMAN, Aleš. Kritické úvahy o západní literární teorii. Praha: ARSCI, 2006. $204 \mathrm{~s}$.

HAMAN, Aleš. Postmoderna v české próze 90. let a nedůvěra k př́iběhu. In Novotný, Vladimír (ed.). Postmodernismus v umění a literatuře. Plzeň: Pro libris, 2003, s. 50-58.

HRABAL, Jiří. Fokalizace: analýza naratologické kategorie. Praha: Dauphin, 2011.221 s.

JAMESON, Frederic. Postmodernismus neboli kulturní logika pozdního kapitalismu. Praha: Rybka Publishers, 2016. 535 s.

LEDERBUCHOVÁ, Ladislava. Průvodce literárním dílem: Výkladový slovník základních pojmu literární teorie. Jinočany: Nakladatelství H \& H, 2002. 355 s.

LEDERBUCHOVÁ, Ladislava. O postavě postmoderní prózy. In Novotný, Vladimír (ed.). Postmodernismus v umění a literatuře. Plzeň: Pro libris, 2003, s. 119-145.

PILǍ̌, Martin. Vrabec v hrsti aneb Klišé v literatuře. Praha: Dokořán, 2005. $183 \mathrm{~s}$.

P̌̌IBÁŇ, Michal; aj. Český literární samizdat 1949-1989: edice, časopisy, sborníky. Praha: Academia, 2018. $612 \mathrm{~s}$.

TOPOL, Jáchym. Anděl. Praha: Hynek, 1995. 134 s.

WELSCH, Wolfgang. Postmoderna. Pluralita jako etická a politická hodnota. Praha: KLP, 1993. 57 s. 


\section{Internetové zdroje}

Deník N, 2019 [online]. Praha: N Media, a.s., [cit. 22.6.2020]. ISSN 2571-1717. Dostupné z:_https://denikn.cz/48740/celibat-je-rana-ze-ktere-kazdou-minutu-tece-krev-modlim-se-i-za-zemana-rika-knez-orko-vacha/

HOFFMANNOVÁ, Jana, 1992. K charakteristice postmoderního textu. Slovo a slovesnost [online]. 53(3) [cit. 11.8.2020]. ISSN 0037-7031. Dostupné z: http://sas.ujc.cas.cz/archiv.php ?art $=3470$

Lidovky.cz, 2010 [online]. Praha: MAFRA, a.s., [cit. 10.6.2020]. ISSN 1213-1385. Dostupné z: https://www.lidovky.cz/kultura/ mozna-nejsme-sami-rozhovor-s-janem-balabanem-z-roku-2004. A101217_130633_ln_kultura_glu

JAMESON, Frederic, 2009. Teorie postmoderny. Aluze: revue pro literaturu, filozofii a jiné. Olomouc: Katedra bohemistiky FF UP, [cit. 11.8.2020]. ISSN 1212-5547. Dostupné z: https://www. yumpu.com/xx/document/view/43839838/zde-aluze 


\title{
Arbesuiv Svatý Xaverius: Praktické uplatnění interpretace literárního díla
}

\author{
Viktor Viktora
}

Pro interpretaci prozaického textu je zásadní, aby text znali všichni účastníci výuky. Sama interpretace textu je náročná. Předpokládá znalost problematiky vzniku díla - tedy kontextu společenského, kulturního, literárního, literárněhistorického i literárněteoretického. Předpokládá dále schopnost výběru faktů souvisících s kontextem, nelze se domnívat, že budou všechna tato fakta uvedena. Konečně předpokládá sledování souvislostí působení konkrétního díla $\mathrm{v}$ čtenářské komunitě. Při interpretaci díla je třeba brát $\mathrm{v}$ úvahu jeho sémantickou víceznačnost i různou míru subjektivity interpretátora. Výraznou nevýhodou je soudobá rozvolněnost vztahů ke kritériím. Jejich absolutizace i absence znesnadňuje hodnocení i interpretaci. V každém př́padě je nebezpečná absolutizace jednoho metodologického př́stupu $\mathrm{k}$ interpretaci.

Arbesova romaneta představují přemostění mezi romantismem rehabilitovaným májovskou generací a počátky reálného vidění skutečnosti, u Arbesova pohledu podloženého racionálním př́stupem, logikou a sociálním cítěním. Svatý Xaverius podobně jako další romaneta byl zatím charakterizován tematicky a s Arbesovým kritickým vztahem $\mathrm{k}$ událostem sedmdesátých let 19. století. Arbes však věnoval pozornost i tvaru, formální podobě svých romanet. U Xaveria tak nalézáme prolínající se xaveriovské 
motivické linie - Balkův obraz umírajího sv. Xaveria, poslední chvíle Balkovy (jmenoval se rovněž Xaver) a jeho odkaz, osud vypravěčova přítele Xaveria. Prolínání lze interpretovat jako beznadějný zápas lidské existence o vlastní autenticitu. Epizody Arbesovy vypravěčské linie jsou sugestivně doprovázeny kontrastním nanášením barev.

1.

Značný počet statí uveřejněných v renomovaném časopisu Český jazyk a literatura, zabývajícím se didaktikou bohemistiky, sleduje práci s literárním dílem, otázky čtenářského zájmu, porozumění čtenému textu a jeho přiměřené interpretace. Do širšího prostoru zde vstupují úvahy o souvislostech textu s literárně historickým a širším uměleckým i společenským kontextem, stranou nezůstává ani problematika literárně teoretického pohledu na beletristické dílo. Zauvažujeme-li také o nových výsledcích literárněhistorického bádání i o nových postupech literárněteoretického uvažování (bohužel někdy př́liš konjunkturálního) a vezmeme-li v úvahu, že literární dílo nelze detailně interpretovat $s$ absolutní jednoznačností, pak lze pochopit spletitost uplatnění interpretačních postupů při výuce. Je zřejmé, jak závažný úkol tu musí řešit př́íslušný vyučující.

Podstatu tvoří komplex základních komponentů - znalost problematiky, výběr faktů, sledování souvislostí. Pochopitelně se bude rozsah tohoto komplexu lišit při výuce na základní a střední škole. Zaměřme se na středoškolskou problematiku, a to na analýzu prozaického díla. Vyvstává tu zásadní otázka. Základní soubor textů je dán čítankou. Celkem nespornou záležitostí je analýza básní. Složitěji se to jeví v próze. Při interpretaci by měl být $\mathrm{k}$ dispozici celý text. $\mathrm{S}$ ním by se měli seznámit všichni studenti. 
Tomuto požadavku ovšem nemůže vyhovět klasická vyučovací hodina. Při ní je možno postupovat jen nadhledově, souhrnně a sondážně. Pracovat $s$ textem celého prozaického díla lze pouze při menším počtu studentů, kteří celý text přečetli, a alespoň při dvouhodinové dotaci. To lze uskutečnit v zájmovém typu výuky, např́iklad v literárním semináři.

Za podpůrné východisko pro další úvahy považujeme názory vyslovené ve stati Ladislavy Lederbuchové Literárněhistorické poznatky v literární výchově na 2. stupni ZŠ a v odpovídajících ročnících víceletých gymnázií (viz zde s. 232). Autorka se kriticky vyrovnává s tendencemi ahistorické koncepce literární výchovy. Pregnantně formuluje: "Poznávací význam textu [...] a jeho kontextů [...] ovlivňuje hodnotu, kterou čtenář textu přikládá, a též formuje jeho hodnotový systém světa. Právě v součinnosti s komunikační složkou učiva poznatky spoluutvářejí žákovo vědomí literatury jako hodnoty kulturní, integrační, přesahující okruh školního učiva." (viz zde s. 236) Literární dílo má pak vedle základní funkce umělecké také funkce národně uvědomovací, etickou a v kontextu svého vzniku poznávací. K podobnému závěru o kontextu vzniku díla směřuje rovněž zde publikovaná stat’ Vladimíry Pánkové (s. 333).

Při interpretaci literárního díla musíme respektovat jeho sémantickou víceznačnost. Nesporným východiskem je sociální, umělecký a literární kontext, $v$ němž dílo vznikalo. Na tento kontext dílo reaguje. Dále je důležité si uvědomit, že mezi souhrnem mimoliterárních podnětů pro vznik díla a dílem samým se rozevírá interval, který je modifikován záměrem autorova pohledu. Realistický tvưrčí princip tedy bude ke kontextu vázán úže než princip realismus ignorující, polemizující s ním či jej deformující. 
Interpretace literárního díla a zvláště jeho posuzování literární historií či kritikou jsou problematizovány několika vlivy. Především tu působí současná destrukce vztahu ke kritériím. Jde přitom o širší spektrum kritérií estetických, ale i etických a těch, která regulují vztahy ve všech rovinách existence společnosti. Kritéria uplatňovaná závazně na jedné straně samu tvorbu podvazují. Bezbřehost či upouštění od kritérií na druhé straně vytvářejí z díla vágní konglomerát. Umění se ve svém celku nemůže vzdávat vztahu k základním hodnotám, jež se postupně konstituovaly s vývojem společnosti a tvoří její humánní soudržnost. Je tedy zřejmé, že míra respektování kritérií je další problém, s nímž se musí vyrovnávat každé posuzování literárního díla. Postmodernismus ${ }^{134}$ a "postpostmodernismus“ a jejich nevyhraněnost souvisí s trendy soudobého společenského vývoje, který přetíná historické kořeny i dědictví tradic humánních hodnot. Bez nich je každá společnost bezbranná tváří v tvář nečekaným sociálním i prŕrodním poryvům.

Vrátíme-li se k otázkám analýzy literárního díla, musíme překonat vznikající skepsi, která vychází z jeho mnohovýznamnosti, a tedy nemožnosti jednoznačné interpretace. Leckdy vzniká dojem, že analýza, kritika, výklad uměleckého díla je záležitostí posuzovatelů, kteří se úkorně snaží interpretovat, s čím autor žongluje, provokuje, čemu sám nevěří nebo co sám nezvládá. Odpovídá to tendenci dnešní doby, která ve všech oblastech života sebedestrukčně znejištuje lidskou existenci, lidské perspektivy i hodnoty. Je tak také pochopitelné, že na tuto atmosféru reaguje i umění.

Dále bude třeba respektovat i dvojí nepřekročitelnou hranici při úvahách o literární tvorbě. Jednu hranici tvoří vnější ideologický diktát, nikoliv vnitřní autorovo přesvědčení. Druhou hranici

$\overline{{ }^{134} \text { Viz zde V. Zelenková, s. } 258 .}$ 
stanovoval striktní strukturalismus, jehož podněty pro analýzu literárních děl jsou ovšem dodnes nedocenitelné. Byla to teze absolutní imanence literárního díla, podle níž neexistují jeho vazby ke skutečnosti a interpreta nemají zajímat. Od rigoróznosti této teze se naštěstí ustupuje.

K interpretaci literárního díla ještě poznamenejme, že by neměl být absolutizován jeden, obvykle nejnovější typ výkladu smyslu a působení uměleckého díla, s nímž se často setkáváme. Příkladem může být nedávné absolutní uplatňování teorie fikčních světů. A ještě jeden dodatek. Neexistuje univerzální metoda, kterou by bylo možno uplatnit při analýze literárního díla. Detaily interpretace téhož díla se nemusí vždy shodovat, mohou být ovlivněny subjektivním pohledem interpreta. Nemělo by být zpochybněno kotvení literárního díla v souvislostech jeho vzniku.

2.

Pokusme se uplatnit možnost interpretace na jednom $\mathrm{z}$ nejúspěšnějších a nejcitovanějších děl Jakuba Arbesa, na romanetu Svatý Xaverius. Detailní informace o J. Arbesovi, jeho tvorbě i jejím kontextu lze čerpat ze sedmi základních monografí́. Jde o následující - Karel Krejčí, Jakub Arbes: život a dílo (1946), týž, Kapitoly o Jakubu Arbesovi (1955), týž, Arbesovo romaneto (1975), Jaroslava Janáčková, Arbesovo romaneto (1978), táž, Jakub Arbes novinár (1987), Božena Plánská, Sociální romány Jakuba Arbesa (1987), František Všetička, Jakub Arbes (1993). Důležitý je i doprovodný komentář J. Janáčkové k vydání pěti Arbesových romanet v České knižnici (Jakub Arbes, Romaneta, 2006, zde Sivooký démon, Zázračná madona, Svatý Xaverius, Newtonův mozek, Ukřižovaná). 
Romaneto bylo naprosto novým žánrovým útvarem nerománové prózy. Svatý Xaverius, kterého autor dopsal koncem roku 1872, následoval po Ďáblovi na skřipci. Ten byl dopsán v roce 1867. Xaverius vyvolal značný čtenářský ohlas. Prózu ocenil především Jan Neruda a přisoudil jí žánrové označení romaneto. To jsou často citovaná fakta.

V sedmdesátých letech se odhodlala řada českých prozaiků vytvořit román. S ním zatím neměla česká literatura př́liš zkušeností. Národní obrození mohlo poskytnout jediný titul - Záři nad pohanstvem Josefa Lindy. Výrazně se rozrostly drobné prozaické útvary. Od dvacátých let 19. století po odkaz májovců se stala drobná prozaická tvorba souhrnem etud nebo skic, na něž mohly navázat úspěšné pokusy následné románové tvorby. $\mathrm{V}$ drobných prózách si mohli autoři ověřovat kompoziční a dějové postupy, modelování postav, spád dialogů, detaily popisů... Proto se objevilo od šedesátých let množství termínů pro označování drobných próz - povídka, novela, noveleta, črta, kresba, kř́ídová kresba, humoreska, kukátko, selanka, soudnička, fejeton, idyla... Jedinečné postavení v těchto souvislostech mělo romaneto.

J. Arbes sice nepatřil $\mathrm{k}$ přispěvatelům almanachu Máj, ale udržoval prrátelské vztahy s některými autory jeho okruhu. Měl k nim blízko zájmem o sociální otázky a k jejich současným problémům, ale také vztahem k romantismu, který májovci rehabilitovali. Arbes se stal nejvýznamnějším tvůrcem, jenž klenul spojující oblouk mezi romantismem a realismem. Přitom nešlo o realismus ve svých počátcích faktografický, popisný a citově traktovaný, ale o reálný pohled podložený racionální úvahou, racionální argumentací a reálně viděnou skutečností. Nejlépe se to Arbesovi dařilo $\mathrm{v}$ romanetech. Románové pokusy se rozmělňovaly právě $\mathrm{v}$ hromaděných detailech. 
Prolínání romantického a racionálního přístupu, někdy by se dalo uvažovat i o prolínání reality a groteskna, vytváří $\mathrm{v}$ atmosféře Arbesových romanet přídech nejistoty, očekávání čehosi nedefinovatelného. Nejde o samoúčelné vyvolávání hrůzy. Zamlžovaná tajuplnost vtahuje čtenáře do představ fantaskních či téměř hororových dějů, dovede toto napětí stupňovat až po představu hraničící s nevysvětlitelnou iracionalitou. Finální zlom nastolí logiku chladného racionálního výkladu. J. Arbes navíc rád využívá efekt náhody. Dále pracuje povětšinou s ohraničeným prostorem at interiéru, nebo exteriéru, který se může rozpínat i tísnivě úžit. S tím souvisí šerosvit a tma charakteristické pro noc, stmívání, či svítání. Prostor je dynamizován pohybem, úprkem postav, jejichž cesta je bud' bezcílná, mírú k zamlženému cíli nebo nabývá tvářnosti labyrintu. Atmosféru nejistoty zesilují také prř́rodní živly - bouře, déšt', vítr... Konflikt většinou navozuje v expozici událost zdánlivě se vymykající logice možné příhody nebo jejího vysvětlení. Důležitou funkci má i sen. Přitom usínání zůstává mimo autorovo vyprávění a čtenáře neupozorňuje na přechod do snové roviny, zato procitnutí vytváří zlomový návrat $\mathrm{k}$ logice príběhu.

Konfrontace subjektivního a objektivního probíhá v poměrně složitých liniích půdorysu dialogů, a to autorské narace, ale také $\mathrm{v}$ reprodukci nebo citaci dalších dialogických linií i písemných dokumentů. V pásmu autorského řečového projevu vystupuje sám autor-vypravěč. Není to osobnost vševědoucí, ale je omezena svým obzorem a úsudkem. Překvapení na něj čeká podobně jako na čtenáře.

Tematicky autor vychází ze své současnosti. Neopomíjí ani kontroverznost sociálních otázek a politické situace poslední třetiny 19. století. Na kritičnost postřehů poukazuje většina studií zabývajících se jeho dílem. Pouze F. Všetička (1993) upozornil také na 
Arbesovu poetiku, na tvarosloví. Všetičkovy závěry charakterizují Arbesa jako nejpodnětnějšího a nejlepšího představitele české prózy. Všetičkovy náhledy se pokusíme spolu s našimi poznámkami uplatnit při interpretačním pohledu na Arbesovo erbovní dílo, na romaneto Svatý Xaverius.

\section{3.}

Svatý Xaverius se z mimoliterárního hlediska představuje jedním omylem. Obraz Františka Xavera Balka v malostranském mikulášském chrámu zachycuje poslední okamžiky života svatého Františka Xaverského. Se životem se měl loučit v blízkosti Goy, portugalské indické enklávy. František Xaverský (1506-1552) však zemřel na čínském ostrově San Čoan pobliž Kantonu. Své misijní cesty podnikal po Indii, Malajsku, Japonsku, nebyl vpuštěn do Číny, na ostrově San Čoan očekával džunku, která ho měla tajně do Číny převézt. Onemocněl a zemřel. Ostatky byly převezeny do Goy, kde je pochován (Altwatter 1993, s. 145-146).

Ještě jedna faktografická poznámka. Svátek Františka Xaverského připadá na 3. prosinec. Třetího prosince 1877 dostal J. Arbes výpověd' z Národních listů (srov. Všetička 1993, s. 23). Nehodláme z tohoto faktu dělat závěry. Ale náhoda charakteristická pro Arbesovy vypravěčské postupy zde výrazně zasáhla do jeho osudu.

Osu romaneta tvoří vrstevnatý a prolínající motiv Xaveria vycházející ze tří linií - obrazu sv. Xaveria, závěru života jeho autora, a osudů Xaveria, prrítele autorova. Xaverius je původně neznámý muž, s nímž se vypravěč setkal u Balkova oltářního obrazu. Je několikrát připomenuta Xaveriova podoba se sv. Xaveriem z tohoto obrazu. Např́ílad v expozici: „Nápadná tato podobnost svatého Xaveria s neznámým mužem učinila na mne v pustém 
chrámě zvláštní dojem. “135 (s. 19). Volba adjektiv a př́íslovcí $s$ významem neurčitosti, tajemnosti nebo zamlženosti (v úryvku adjektiva neznámý, zvláštní) je pro autora charakteristická. Linie podoby Xaveriů zesiluje v závěru, kdy Xaverius umírá ve vídeňské věznici a do jeho podoby na dvoře věznice, kde se mohl procházet, se přímo promítá situování skonu sv. Xaveria na Balkově obraze. Xaveriovský motivický okruh se rozšiřuje na rekonstrukci posledních let života F. X. Balka. Balko sám měl jméno Xaver. Xaveriova babička jako děvče u Balka sloužila a z jejího vyprávění se Xaverius dozvídal detaily Balkova života i tvůrčího napětí. Sugestivní atmosféra jeho obrazu se promítá i do Balkových úvah a vzdechů: „Marnost, samá marnost!“, „K čemu to? Není to vše než pro oko; člověk se podívá a odvrátí a jde zas po svých!“ (s. 31). Před svým skonem babičce diktoval jakýsi odkaz upozorňující na „tajemství“ obrazu: „Kdo dovede třeba po léta dlíti před obrazem tím, kdo upne veškerou svou mysl na obraz, aby tajemství v obrazu skryté vypátral a komu se podaří tajemství to vypátrati, nemůže zůstati pro lidstvo bez ceny, nebot' duch jeho nabude oné síly a průpravy, jaké je potřebí k obrovskému dílu na prospěch veškerého lidstva. Jediné však věci je především třeba: Vytrvalosti a železné vưle. Kdo těmito bude obrněn před obrazem dlíti, by vypátral tajemství obrazu, tomu svatý Xaverius zjeví neocenitelný poklad.“ (s. 34). Balko umírá. „Venku bylo bouřlivo; nebe bylo skoro stále v plamenu a hřmění ani nepřestávalo. Vítr šuměl a hučel, časem zaskučel, jako když dítě pláče.“ (s. 32). Třikrát je citováno substantivum tajemství, bouře doprovázející Balkův skon vytvárí scéně dostatečnou expresivní atmosféru.

Podle Xaveria byl Balkovým odkazem a tajemstvím zašifrovaným do obrazu plán cesty k ukrytému pokladu. Zdánlivá logika Xaveriových úvah přesvědčila i autorského vypravěče. Ten se s Xaveriem vydal ve stopách plánku. Za jasné noci dorazili ke zdánlivému

${ }^{135}$ Citujeme podle vydání z roku 1963 v Praze. 
cíli. Zde se rozevírá jedna ze scenérií typické arbesovské noci. „Noc byla nadmíru klidná, teplá a jasná. Měsíc byl téměř v úplňku a jenom tu a tam na obloze stál zdánlivě nepohnutě bud' hustý osamělý mráček, nebo sněhobílý obláček, jehož okraje leskly se v stříbrném svitu luny jako drahocenný hermelín kolem labutí dívčí šíje.“ (s. 61). Při vykopávání „pokladu“ se od odhozené zápalky vzňala tráva, scénu osvětlil rudý plamen. „Rudá záře [...] počíná blednouti a mění se v záři př́íšerně bledě žlutou.“ (s. 67). Xaverius vidí v plameni postavu sv. Xaveria, „jak se vztyčuje, jak hrozivě zvedá ruku a jak [...] kyne [aby] prchl“. (s. 68). Xaverius se dal na útěk, pak se dlouhý čas s vypravěčem nesetkali.

V noci, kdy oba hledali „poklad“, byly v mikulášském chrámu vyloupány všechny drahokamy z monstrance na oltáŕi sv. Xaveria. Xaverius byl obviněn $z$ loupeže, zatčen a nemocen uvězněn ve Vídni. Vypravěč znající stav věci vyvinil Xaveria za pomoci svého vídeňského příbuzného. Pozdě. Choroba vykonala své a Xaverius, s nímž sice bylo ve věznici zacházeno slušně, zemřel. Stylizací jeho smrti vrcholí xaveriovská linie. Vypravěč se s Xaveriem loučí na dvoře věznice, kde se Xaverius mohl procházet. Zesláblý vězeň: „Pololeže a polosedě odpočíval [...] na hrubé houni na nosítkách. Byl oblečen v trestnický šat, jenž byl na prsou poněkud rozhalen. Dolejší část těla byla přikryta starým pláštěm, zpod kterého vyčnívaly obnažené nohy. Hlava př́telova byla poněkud nazad nachýlena; na smrt bledý, ba zsinalý obličej byl obrácen k modré obloze. Levá ruka př́telova spočívala na jeho prsou, pravice, v lokti ohnutá, visela k zemi.“" (s. 88). Lze připomenout, jak Arbes líćí v expozici umírajícího sv. Xaveria na Balkově obrazu. „Na pustém břehu mořském umírá o samotě muž v černém řeholním oděvu. Polo leže (sic!) odpočívá na improvizovaném loži, na hrubé rohožce, jsa zády opřen o skalisko, nad nímž je z hrubých kamenů, prken a jižních travin narychlo sdělán jakýsi druh střechy [...] Černé řeholní roucho je na prsou poněkud rozhaleno; 
dolení část těla je pokryta hrubou houní, zpod které je vidět jen obnažené kostnaté nohy zsinalé barvy. V levici drží umírající (sic!) dřevěný kř́iž s Kristem, pravice pak v lokti ohnutá visí bez vlády z lože.“ (s. 16). Dokonale propracovaná v detailech spěje sugestivní xaveriovská linie ke svému vyvrcholení - k prostoupení osudu světcova a prítelova. Je to jeden $\mathrm{z}$ arbesovských postupů, který nepočítá jen s paralelním řazením motivů, ale prolnutím sakrálního a profánního či oscilací mezi nimi vede k úvahám o nepostižitelných osudových a relativních životních jistotách. Arbes se tak dotýká neuchopitelnosti lidské existence a tužeb po jejích pevných obrysech.

Nemůžeme samozřejmě odmítat jiné typy interpretace, které směřovaly $\mathrm{k}$ výkladu Arbesova kritického vztahu vůči dobovým společenským poměrům. Např́klad J. Janáčková tak v České knižnici shrnuje zmíněné názory $\mathrm{v}$ upozornění na postupy rakouského soudnictví: „[...] orgán státní moci schopný obžalovat z krádeže v chrámu svatého Mikuláše na Malé Straně mladíka zcela nevinného, vystavit ho žalářování a umírání na dlažbě vídeňského vězení.“ (2006, s. 638). Přitom Arbes líčí jednání vězeňského personálu jako vstřícné, nepostrádající soucit. Snad by mohl být připomenut i rozdíl mezi jednáním justice v Praze a Vídni s politickými vězni. To Arbes ironicky v romanetu glosoval.

Motiv Xaveria má další důležitou funkci také v kompozičním rámování romaneta. Romaneto je rámováno několika závažnými motivy. Expozice se odehrává v Praze a v chrámu sv. Mikuláše. Vedle postavy Xaveria komunikuje vypravěč se svým vídeňským vzdáleným př́ibuzným, „malířem krajinářem zvučného jména“. Spolu procházejí pražskými kostely a host se v nich seznamuje $s$ nejlepšími pracemi českých malíruo Je natolik překvapen jejich počtem i kvalitou děl, že začal uvažovat o jejich souhrnné publikaci. Expozici uzavírá známá scéna ve svatomikulášském chrámu, 
kdy Balkův obraz si zevrubně prohlíží Xaverius, vyšvihne se na oltář a kružítkem něco vyměřuje. Zdáli to vypadá, jako kdyby se chystal obraz poškodit. Vypravěč pak doprovází Xaveria do jeho obydlí. To připomíná vězeňský interiér. „Dům byl starý, průjezd úzký a temný, schody dosti neschůdné. Přišedše na starodávnou dřevěnou pavlač, zahnuli jsme do temné, úzké chodbičky.“ (s. 25).

Závěr romaneta se odehrává ve vídeňském vězení, obdobě Xaveriova bytu. Zde je před amnestií vězněn za tiskový přečin vypravěč-redaktor. Setkává se zde s odsouzeným Xaveriem. Potvrdit Xaveriovu nevinu může také vypravěčův př́ibuzný - malíř, jemuž nevyšel plán s vydáním reprodukcí pražských oltářních obrazů. Xaverius umírá. Vypravěč se vrací do Prahy, navštěvuje mikulášský chrám a v pohnutí mysli, vzpomínaje na nedávno minuvší události, pln lítosti i hněvu se vrhá s otevřeným nožem na Balkův obraz. Zarazí ho špatně mířené bodnutí - nůž se zarazil do oltářního sloupu. Téměř zrcadlovitě komponované líčení řadí motivy $\mathrm{v}$ přesném pořadí. Současně dochází $\mathrm{k}$ augmentaci rámujících motivů - Xaverius zemřel, vypravěč se vrhl s nožem na Balkův obraz, interiér věznice je protějškem interiéru Xaveriova obydlí.

Zmíněná augmentace jistým způsobem dotváří myšlenkový vrchol romaneta. Xaverius se ve vězení kriticky vyjadřuje k současnému stavu společnosti: „[...] nynější stav nemůže potrvati [...] nynější osvěta, která neblaží, nesílí a neuspokojuje, musí zaniknouti, aby na jejích troskách vznikla osvěta nová, osvěta ryzé lidskosti.“ (s. 84). Bohatství měšce je tak přemáháno bohatstvím humanity. Snad zdáli by sem mohl zaznívat také hlas tradičnějšího výkladu, který v protikladu motivů souvisejících s Prahou a Vídní slyšel Arbesův kritický hlas vůči sedmdesátým letům, Arbesově současnosti. 
Jedna faktografická poznámka. V Arbesových romanetech se často objevuje obsáhlý výčet různých věcných informací. V Xaveriovi je například podán „seznam“ nejdůležitějších oltářních obrazů v Praze. Dozvídáme se, že Xaverius studoval díla francouzského matematika Josepha Louise Lagrange, švýcarského teoretika fyziognomie Johanna Kaspara Lavatera, zajímal se o debatu mezi Isaacem Newtonem a Gottfriedem Wilhelmem Leibnizem, týkající se diferenciálního počtu. J. Arbes se totiž zajímal o maximum informací z mnoha vědeckých oborů nejen z exaktní oblasti. Pořídil si rozsáhlé lístkové kartotéky, z nichž mohl čerpat poměrně přesnou faktografii a tu pak vkládal do výkladových partií svých romanet. Pracoval tedy nejen s logickou úvahou, ale také s přesným faktografickým zázemím.

Snad je zatím zřejmé, že Arbes není jen prozaik-epik, který dovedl reagovat na dobu a realitu, ale že věnoval pozornost i tvaru svého díla. $\mathrm{K}$ této problematice uved'me prozaikův postup při popisu epizod. Arbes pracuje s principem kontrastu, většinou barevného. Nejde o záběr malířského panoramatu ani o vějíře barev, ale o jejich kontrastní nanášení, jež podkresluje duševní rozpoložení postavy. Za „krásného letního odpoledne“ vstoupil vypravěč do mikulášského chrámu. Balkův obraz se nalézal „V nejlepším světle; sluneční paprsky vnikající oknem [...] padaly pak zase na oltářní obraz tak, že nemohl jsem si přáti lepšího osvětlení“ (s. 15). „Obraz má vcelku ráz pošmurný, jako by malíř světlejších barev užil pouze ku zvýšení dojmu barev temných [...] krátkým vousem zarostlý obličej [...] obrácen je k nebesům [...] jako by se zrak umírajícího stápěl v lesku slunce, jehož žlutavá záplava v pozadí obrazu nasvědčuje, že slunce bud’ teprve vyjde, anebo že bylo právě zapadlo [...]“ (s. 16). Pak autor pozoruje obraz a neznámého muže podobného umírajícímu světci: „[...] jako by obrovským prostranstvím chrámu míhaly se tajemné stíny, a přesto vše, že dobře jsem si přelud ten vykládal do chrámu vnikajícími 
paprsky slunce, křižujícími se s paprsky, vycházejícími z několika různobarevných věčných lamp, nebyl jsem přece s to, abych se ubránil neobyčejnému rozčilení [...] vzmáhající se úzkost má byla by znenáhla přešla v nejpodivnější druh bázně.“ (s. 19).

Z vyprávění Xaveriova o Balkově obrazu: „Obrovský chrám byl takřka kouzelně osvětlen. Několika okny padala dovnitř bledá zář měsíce [...] u protější stěny ve výši osvítila bílou sochu vážného starce; tam postříbřila temné řezbářské práce na portálu oltáře, přelétla jak charý stín oltář a vniknuvši hlouběji do chrámu zanikla v několika pramenech mezi lavicemi temné kaple [...] Zde paprsky měsíce krášlí a mírní, tam zase, zvláště kde tvoří s věčnými lampami dvojsvětlí, hyzdí až k děsnosti; jinde pak, kde temno paprsky přemáhá, anebo kam vưbec ani zář, ani reflex paprsků měsíčních nevniká, zírá hrozné, temné prázdno [...] Úzkost má nepochopitelným způsobem se vzmáhala." (s. 53-54). Kontrastní barevnost některých scén při líčení dynamického nebo dramatického děje nejen zesiluje jeho napětí, ale také sugestivně vyhraňuje líčení duševního napětí postav.

Světelná kontrastnost spolu s prolnutím Balkova umírajícího sv. Xaveria a Xaveriovým umíráním, s prolnutím osudu světce a člověka vrcholí v závěru romaneta. Když vypravěč dospěl k myšlence o vzniku nové osvěty ryzí lidskosti na troskách jejího nynějšího stavu, povzdechl si Xaverius, že Balkův obraz byl vlastně př́íčinou jeho uvěznění i choroby. Tak končí životní tragédie Xaveria absorbujícího osud svého jmenovce. Také scenérie vězeňského dvora prolnula scenérií prrístřešku, pod nímž světec umíral: „[...] rozhlédnul jsem se po dvoře, jenž byl v zlatých paprscích k západu se chýlícího jarního slunce zvláštního nabyl rázu, takže se zdálo, jako by pošmournost jeho aspoň na několik okamžiků byla $\mathrm{z}$ něho vypuzena [...] Poslední okamžiky, jež jsem strávil nablízku přítele, ztrpčila mi nevýslovná 
lítost...“ (s. 88). Onu lítost doplnily v odstupu času nevýslovný hněv a symptomy šílenství.

\section{Shrnutí}

Je zřejmé, že J. Arbes věnoval pozornost tvaru svého díla a že v souvislostech české prózy znamená výrazný specifický jev. Samo xaveriovské romaneto má zřejmě nadčasovější platnost než jen kritické svědectví podávané o době, kdy vzniklo. Zmíněná nadčasovost se týká životních hodnot i lidských osudů. Vzhledem $\mathrm{k}$ tomu, jak jsme $\mathrm{v}$ úvodu charakterizovali problematiku interpretace literárního díla, je nutno si stále uvědomovat, že i když jevy, které $\mathrm{v}$ díle nacházíme, objektivně existují, mohou být doplněny dalšími. Jako neexistuje závazný vzorec interpretace literárního díla, neexistují ani jeho definitivní interpretační závěry. Následující bádání může nalézt další závažné podněty. Pokud $\mathrm{k}$ tomu bude docházet, nezůstane dílo jen monumentem historie, ale bude moci svým poselstvím přispět dobám následujícím.

\section{Použitá literatura}

ALTWATTER, Donald. Slovník svatých. Přeložila a doplnila Jitka Matějů, Český národní kalendář sestavil Petr Svoboda. Vimperk: Papyrus, 1993. $436 \mathrm{~s}$.

ARBES, Jakub. Romaneta. Praha: Státní nakladatelství krásné literatury a umění, 1963. $313 \mathrm{~s}$.

JANÁČKOVÁ, Jaroslava. Komentář In Jakub Arbes, Romaneta. Praha: Lidové noviny, 2006. 676 s.

VŠETIČKA, František. Jakub Arbes / František Všetička. Praha:

Pražská imaginace, 1993. 97 s. 


\section{Model integrované výuky předmětu český jazyk a literatura: Praxe z klatovského gymnázia}

David Franta

„Pannou Orleánskou se třída zabývala již od velikonoc [!], tři čtvrtě roku. Těm, kteří zůstali sedět, byla důvěrně známa dokonce již z předešlého roku. Četli ji zepředu i zezadu, učili se nazpamět výjevům, vyráběli dějepisné vysvětlivky, cvičili na ní poetiku i gramatiku, převáděli její verše do prózy a prózu nazpět do veršů. Pro všechny, kdo při prvním pročítání cítili jejich svítivost a třpyt, tyto verše už zněly hluše. Nikdo již neslyšel tklivě měkký dívčí hlas, $\mathrm{v}$ němž se pozdvihují přízračné, přísné meče, $\mathrm{v}$ němž pancír již nekryje srdce a široce rozepjata mávají zářivá a krutá andělská kř́ídla. Nerozpoznávali již melodii v rozladěném kolovrátku, který den co den spouštěl znova. Koho z těchto mladých lidí byla by později rozechvívala téměř skličující nevinnost oné pastýřky, kdo by v ní byl miloval vítězství slabosti, kdo by byl plakal nad dětinskou výsostností, jež se opuštěna nebesy stává ubohou, bezmocně zamilovanou dívčinkou, ten to nyní všechno tak hned neprožije. Dvacet let bude možná potřebovat, než mu Johanka bude opět moci být něčím jiným než zaprášenou puntičkářkou.“ (Mann 1950, s. 12).

„V roce 1984 jsem věnoval Sylvii kurs postgraduálního studia, který vyústil v několik velmi pozoruhodných seminárních prací. Dnes znám každou čárku a každý skrytý mechanismus té novely. Zkušenost, kterou mám s opakovaným čtením textu v průběhu čtyřiceti let, mi ukázala, jak hloupí jsou ti, kteří tvrdí, že pitvání textu a pozorné čtení mu odebírají jeho kouzlo. Kdykoliv beru do 
ruky Sylvii, i když ji znám do nejmenších podrobností - a možná právě proto - vždy si ji znovu zamiluji, jako bych ji četl poprvé. [...] Zdánlivá nejistota, pokud jde o čas a místa, která činí ze Sylvie dílo tak fascinující (a způsobuje zděšení u prvoplánového čtenáře), je založena na narativní strategii a gramatické taktice, která je přesná jako hodinový strojek - což ovšem rozpozná jen čtenář vyšší úrovně." (Eco 1997, s. 21, 48).

Oba postoje, natolik vzájemně protikladné, reagují na společný problém, a sice na do̊kladné čtení textu, jeho analýzu, interpretaci, popř. další „nakládání“ s ním. Společná je jim také výrazná expresivita formy a axiologická extrémnost - fetišistické zaujetí jednou určitou knihou recipovanou bud' reálnou postavou Umberta Eca, nebo literární postavou gymnazijního profesora Raata, tj. z pozice profesionálního typu „čtenáře celoživotně soustavného a přemýšlivého“ či příslušníka „čtenářské šlechty“ (pojmy Jiřího Trávníčka 2007, s. 315; 2019). Výňatek z Ecovy eseje velebí „pitvání a v duchu hermeneutického kruhu neustálé čtení textu jako klíč k odkrytí v textu vloženého smyslu, zato Mannova literárně stylizovaná ukázka pedagogických metod, ne nepodobných současným „moderním“ př́ístupům ve vyučování češtině, pitvání“ textu a nakládání s ním groteskně shazuje. Ecův postoj ke knize je názorem literárního vědce, jemuž čtení knih a psaní o nich přináší nejen slast, ale také existenční zajištění; Mannův cynismus je sice uměleckým prostředkem literární fikce, ale vykresluje situaci známou i v současném školství. Ještě drobný detail v obou výňatcích, pro naše účely ovšem kardinální, zavdává i v bohemistice příčinu $\mathrm{k}$ diskusím, jež probíhají $\mathrm{v}$ různých vlnách a $\mathrm{v}$ různé míře od počátku moderní sémiotiky: podíl jazykové výstavby, včetně gramatických kategorií, na interpretaci textu.

Český jazyk a literatura (dále ČJL) má v soustavě učebních předmětů na základní i stř̌ední škole specifickou pozici: měl by pěstovat 
v žácích rozmanité komunikační dovednosti důležité pro další rozvíjení jejich osobnosti, ale ve školské praxi bývá většinou jen sumou (nikoliv strukturou!) složek jazykové, komunikačně-slohové a literární. Učivo se $\mathrm{v}$ jednotlivých složkách tohoto předmětu probírá lineárně a paralelně ve třech oddělených, málo prostupných řadách. Sice rámcové a školní vzdělávací programy (RVP, ŠVP) rozprostírají učivo předmětu ČJL do dvou složek (jazykově-komunikační a literární), ale tematické plány a vlastní edukační realita ani tuto míru integrace většinou nerespektují - chybějí totiž kvalitní didaktické materiály, zejména učebnice a pracovní sešity, jež tvoří $\mathrm{v}$ učitelské praxi stále asi nejčastěji reálné kurikulum. Ani vysokoškolská didaktika ČJL není unitární - vědecky se profilují didaktikové českého jazyka a didaktikové literární výchovy separátně. Chápeme-li ovšem vysokoškolskou didaktiku ČJL jako aplikovanou filologickou (v širokém slova smyslu) disciplínu, měla by vycházet $\mathrm{z}$ vědeckých základů a uznávaných a prověřených vědeckých metodologií i v rámci didaktických transformací vědecky podchycené reality (více Franta 2019).

Pro školskou praxi se nám jeví stále nejinspirativnější komplexní metodologií strukturalismus, ${ }^{136}$ sice téměř stoletý př́stup $\mathrm{k}$ „textovosti“ našeho světa, ovšem neustále inovovaný. Současný předseda Pražského lingvistického kroužku Tomáš Hoskovec hájí filologii jako komplexní, integrovaný vědecký obor, jenž se zabývá potencialitou jazyka v nejširším slova smyslu, včetně literární tvorby, jež je pouze aspektem jazykové komunikace, nikoliv jejím specifickým výsekem ${ }^{137}$. „Celý“ “138 text, „vyrobený“ z jazyka,

\footnotetext{
${ }^{136} \mathrm{~K}$ dějinám Pražského lingvistického kroužku (PKL) stručně a výstižně např. Šidák (2018).

${ }^{137}$ Tomu odpovídá i „učebnicové“ rozlišování funkčních stylů ve vyučování slohu: mezi nimi se vyjímá funkční styl umělecké literatury (umělecký funkční styl), a přesto se jinak pracuje v hodinách literární výchovy.

${ }^{138}$ Celistvost textu je problematická zejména ve vyučování - Jan Mukařovský kritizoval čítanky literární výchovy, protože vyjímají z celku jen fragmenty, a proto nelze
} 
je předmětem interpretace, jejímž výsledkem je smysl, který má závaznou nadosobní platnost, kterou garantují sociální normy řídící komunikaci, bez nichž by nedocházelo k porozumění. Text se skládá ze znaků různých úrovní (z výpovědi, verše, slova, gramatických a lexikálních vztahů, intonační kontury, fonému), jež nabývají ve vzájemných vztazích i s jinými texty určitých hodnot. Každý jazykový jev je potenciálně relevantní, ale úkolem interpretace textu však není všechny tyto vztahy a hodnoty postřehnout, protože i ten nejlepší čtenář má psycho-somatickou kapacitu omezenou, ale vnímat je v určitých dílčích systémech (definičních oborech) (Hoskovec 2018, 2012).

Styčné plochy s Hoskovcovým konceptem má „jiná“ filologická metoda, a sice lingvoliterární historie Alexandra Sticha. Ten příčinu neustále se snižující čtenářské schopnosti (gramotnosti) spatřoval v neporozumění gramatice a lexiku textu staršímu než současnému, jež brání čtenáři otevřít „svět vytvořený ze slov“. Nápravy lze dosáhnout vhodně zvoleným jazykově-slohovým detailem, aby „se zvýraznil a zjitřil jeho smysl pro to, jak estetické i myšlenkové poselství vychází z jazykového formování“ (Stich 1996, s. 10).

Jazykově-slohový detail však můžeme vztáhnout i na překlady do češtiny, protože podmínkou dobrého překladu je zachování vyváženého poměru mezi reprodukcí (původního obsahu i účinku na čtenáře) a tvůrčí činností (do struktury jazyka překladu) a iluze originálu (překladatel „nemá“ být viděn) (Levý 2012). Světová literatura sice i v hodinách češtiny může být recipována v původním jazyce (v současnosti však kvůli cizojazyčné

dojít k „odkrytí“ smyslu díla, viz -nk- 2001-2002. Domníváme se však, že jiné cesty než zvolením vhodných výňatků textů v souladu s vyučovacími cíli z praktických důvodů (šíře učiva při respektování základních hodnot euroamerické civilizace, vč. kanonické literatury) není. 
uniformitě jen v angličtině), ale vesměs je čtena v překladech do naší mateřštiny.

Didaktickou transformaci postulátů strukturalistů J. Levého, A. Sticha a T. Hoskovce si můžeme zkonkretizovat na učivu ČJL 2. ročníku čtyřletého studia a odpovídajících ročníků víceletého studia definovaném v aktuálním ŠVP Gymnázia Jaroslava Vrchlického v Klatovech. Při vnitřní integraci učiva jazykové, komunikačně-slohové a literární výchovy je nutné učivo restrukturalizovat při zachování poměru kvantity a kvality poznatků a přirozené celistvosti a při promyšlení struktury poznatků tak, aby byl svět tvořený $\mathrm{z}$ textů poznáván jako celek (Podroužek 2002, s. 8-10, 37-42).

Student druhého ročníku by si měl - stručně řečeno - osvojit morfologii, lexikologii a slovotvorbu českého jazyka, analyzovat normu odborného funkčního stylu a produkovat jeho útvary a „pročíst se“ českou a světovou literaturou 19. století. Zvolená témata se zdají být pro nenásilnou vnitřní integraci dobře zvolená. „Dlouhé“ 19. století, jak nazval historik Eric Hobsbawm období v letech 1789-1914, je zároveň věkem nacionalismu, kdy se utvářely („rodily“) moderní národy a s nimi celý, v různé míře nový sémiotický svět. Vladimír Macura plasticky vylíčil české národní hnutí 1 . poloviny 19. století ve svých odborných i uměleckých knihách jako sféru rozličných znaků (literárních, jazykových, historických, výtvarných, ekonomických ad.), již vytvářeli vlastenečtí intelektuálové s živelnou energií tvůrců. Moderní česká kultura tak má výrazný lingvocentrický základ s konstitutivní rolí (pseudo)etymologie, lexikologie, lexikografie a slovotvorby (Macura 2015, s. 47-68). Právě v 19. století se ustavovala zásahy teoretiků spisovná norma češtiny, jejíž některé jazykové oblasti, zejména pravopis (o vztahu ortografie a ideologie více Velčovský 2015) a morfologie, vyžadovaly od mluvčích 
kodifikované varianty jazykových prostředků nejpř́sněji v komunikačních situacích odborného života. Mluvu každodenního hovoru, jež obdržela od pozdějších bohemistů název obecná čeština, se národní „buditelée neodvážili vzít za spisovnou normu, a proto vznikla mírná diglosie, jež dodnes trápí většinu cizinců, kteří se učí češtině, i mnoho rodilých mluvčích (Sgall, Hronek 2014; Sgall, Panevová 2014).

Nacionalismus se v 19. století prolnul s romantismem, s nímž sdílel např. zálibu $\mathrm{v}$ národní minulosti či citovosti. Ústředním dílem evropského romantismu je druhý díl Goethova Fausta (Bloom 2000, s. 233). Student střední školy by se měl s oběma díly Fausta seznámit nejen pasivně, ale i aktivně, ač prý sám Goethe svému společníku Eckermannovi četbu Fausta nedoporučoval (Eckermann 1941, s. 147-148) ${ }^{139}$. Pesimisticky se k četbě Fausta na střední škole staví i J. Trávníček (2019), ale domníváme se, že lze zakoušet libost i $\mathbf{z}$ četby „nejgrotesknější a nejméně stravitelné ze všech velkých dramatických básní západního kánonu“ (Bloom 2000, s. 221), a sice vhledem do jednoho jazykově-slohového detailu, jenž ozřejmuje i tematickou rovinu celého díla. ${ }^{140}$

Již první interpreti Fausta si povšimli protagonistovy sázky s Mefistofelem jako „dramatického uzlu“, jenž rámuje Faustův př́běh (Brüning 2010, s. 31). Faust je nenasytný vědec, jenž ani $\mathrm{v}$ „minulých“ vědách (alchymii, tajných naukách) nenašel pravdu

\footnotetext{
${ }^{139}$ „,Ted’ čtu Fausta, ale shledávám, že je trochu těžký. 'Goethe si při těch posledních slovech zasmál. Řekl: ,Fausta bych vám byl ovšem ještě neradil. Je to šílená věc a překračuje všechny obyčejné pocity. [...] Faust je tak podivné individuum, že jen málo lidí dovede znovu prožívat jeho vnitřní stavy. Stejně charakter Mefistofelův je pro ironii a jako živoucí výsledek velikého pohledu na svět také něco velmi těžkého. Ale přihlédněte, jaká světla se vám při tom objeví. “ “

${ }^{140}$ Jsme si vědomi, že námi zvolené výňatky z Fausta jsou pro studenty gymnázia poměrně náročné, ale jsou voleny s ohledem na didaktický záměr, a domníváme se také, že dobře zvládnutou metodou práce $s$ textem se i sebeobtížnější výňatek může stát pro náctiletého čtenáře inspirativní.
} 
a chtěl by poznat veškeré vědění a prožít osudy všech lidí, a proto se čert domnívá, že ho lákavou nabídkou unaví a jeho duši strhne do pekla. Znění a podmínky sázky se staly předmětem i posudků dvou právníků, v nichž zazněly - jako ve známém rčení - tř̌i názory: Faust sázku prohrál právnicky, ale v básnicko-transcendentním smyslu vyhrál, nebo Faust sázku vyhrál absolutně, tj. i v mezích zákona (Fausts Pakt mit Mephistopheles in juristicher Beleuchtung 1903). J. Kohler, druhý z dotyčných právníků, správně zdůraznil, že Faust svoji imaginativní předtuchu manifestuje kondicionálem, ${ }^{141}$ čímž vyjadřuje pouze hypotézu, nikoliv právně napadnutelný akt (tamtéž, s. 128). Goethe se čtenářem vede právní hru, sám totiž vystudoval práva v Lipsku a ve Štrasburku (Hillebrand 2001, s. 43). V obou scénách jsou přímé i nepřímé prostředky přitahovány do sémantického pole času: verba trvat, dokonat, skončit a aaj. a substantiva hodiny, rafije, čas aj. (Grebeníčková, Köpplová a Pokorný 1982, s. 92-93). Každý jazykový znak, včetně morfologických jevů může ozřejmit smysl díla; gramatické kategorie způsobu a času, jak jsme se snažili dokázat, prostupují tematickou i kompoziční rovinou díla, čili: formu a obsah nelze od sebe oddělit. ${ }^{142}$

„Pitvání se“ v kondicionálech na Faustovi bystří chápání jazykových nuancí, zlepšuje úroveň čtenářské gramotnosti, a proto i taková práce s textem patři mezi tzv. soft skills (měkké dovednosti) (Hippel, Daubenfeld 2011, s. 50). Integrovaná a induktivně vedená práce $\mathrm{v}$ hodinách mateřského jazyka by měla u studentů vyvolat tzv. aha zážitek (Aha-Erlebnis), bez nějž by práce $s$ textem vedla $\mathrm{k}$ neporozumění restrukturalizovaného učiva jako v př́padě absolventky landshutského gymnázia: „Na vině je konjunktiv.

\footnotetext{
${ }^{141} \mathrm{~V}$ německém originále stojí konjunktiv. Konjunktiv má vedle jiných funkcí i funkci společnou s českým kondicionálem.

${ }^{142}$ J. Mukařovský (1948-1949, s. 101) objasňoval na eufonii uvolňující sémantické trsy v Máchově Máji cestu od „zevních složek ,formálních““ do „nejhlubších významových vrstev díla“.
} 
Určuje 20 minut školního světa. Würde. Tisíc myšlenek v hlavě. Proč konjunktiv? ${ }^{143}$ Přemýšleli jsme. [...] Nebyl nám předložen žádný výukový materiál. Nevěděli jsme, nad čím jsme přemýšleli. “" ${ }^{444}$ (Lang 2004, s. 35).

Výukový materiál si $\mathrm{v}$ našem př́padě dokáží pod učitelovou „sokratovskou metodou instruktivní“ vytvořit studenti sami, vyučující by měl vést své svěřence správně položenými otázkami týkajícími se pečlivé četby (close reading) k odvozování gramatického vědomí (již Chlup 1935, zejm. s. 169-207, 311-321). Jakékoliv dotazy učitele a následné odpovědi žáků se musejí týkat jasně textových struktur, bez nichž není možná diskuse (Zima 1998, s. 369-382). Sice se ř́ká, že text sám své čtenáře vede, ale čtenáři méně zkušení potřebují dobrého průvodce.

Vyučující by se mohl na námi zvolených výňatcích z Fausta dotazovat žáků na modalitu, tj. způsob platnosti obsahu určité výpovědi. Např. v 1700. verši slovesným tvarem jsi Faust skutečnost popisuje oproti jinému slovesnému tvaru trvej, kde si již takovou skutečnost žádá. Učitel by měl žáka navést na gramatiku čtverého (sic!) slovesného způsobu: způsob oznamovací (indikativ) + způsob rozkazovací (imperativ) + způsob podmiňovací „přítomný“ (kondicionál potenciální, hypotetický) + způsob podmiňovací „minulý“ (kondicionál nereálný). U kondicionálů jsme vložili jejich subhodnoty do uvozovek, protože si uvědomujeme problematičnost této terminologie: kondicionál totiž mluvnickou kategorii času k sobě neváže, takovou vlastnost má pouze indikativ (prézentu, préterita a futura). Tradičně se na základní i střední škole vyučuje jeden kondicionální způsob se dvěma subhodnotami, ale inovativní přístup vychází z logiky (ne)uskutečnitelnosti děje, již studenti mohou znát z vyučování angličtině. Modalita

\footnotetext{
${ }^{143}$ Viz poznámka č. 5 .

${ }^{144} \mathrm{Z}$ německého originálu přeložil do češtiny autor příspěvku.
} 
se nemusí vyjadřovat pouze morfologickými prostředky, např. částicí at' se vyjadřuje opisný imperativ, který do morfologického paradigmatu slovesa nepatří (Adam 2019, s. 33-34).

\section{Struktura slovesných kategorií způsobu a času v češtině}

\begin{tabular}{|l|c|c|c|}
\hline způsob & \multicolumn{3}{|c|}{ čas } \\
\hline indikativ & prézens & préteritum & futurum \\
\hline imperativ & \multicolumn{3}{|c|}{ (nevyjadřuje) } \\
\hline kondicionál potenciální & \multicolumn{3}{|c|}{ (nevyjadřuje) } \\
\hline kondicionál nereálný & \multicolumn{3}{|c|}{ (nevyjadřuje) } \\
\hline
\end{tabular}

Při pečlivém čtení si uvědomíme, jak odlišně je rámována sázka v 1699. a 11581. verši: (když) řeknu vs. chtěl bych (ř́ci), čili indikativem prézentu (vyjadřující budoucnost) (o tom Adam 2019, s. 37) vs. potenciálním kondicionálem. Hromadění nereálných kondicionálů, jež čas - jak bylo řečeno výše - nevyjadřují, v závěru ukázky podtrhují bezčasí, do něhož byl uvržen i Mefistofeles, který sázku prohrál, jak je vidno $\mathrm{z}$ dalšího děje díla. Faust vhodně zvoleným kondicionálem přelstil satana, který jeho slova špatně pochopil (Wierschin 2005, s. 326). Goethe se ostatně nechal slyšet, že Faust měl v úmyslu Mephistophela napálit již při uzavření sázky (Grebeníčková, Köpplová a Pokorný 1982, s. 93; originální znění Goethova výroku Grumach 1977, s. 50).

Poetika Fausta přitáhla Oswalda Spenglera v jeho filozofické úvaze Zániku Západu (1922) k prŕměru o euroatlantické civilizaci jako o kultuře faustovské. Je to totiž Faust, který prosadil pro své hospodářství (západní průmysl) vlastní právní systém, kvůli předtuše chystaného ráje na zemi (jejž nevidí, protože oslepl, ale 
jen si jej představuje) se neštítí zapálit chýšku Filemona a Baucidy, stařičkého páru, známého z Ovidiových Proměn.

Studentům může být nabídnut další úhel pohledu $\mathrm{k}$ interpretaci Fausta prostřednictvím opět dobře zvoleného výňatku $\mathrm{z}$ odborné úvahy, útvaru odborného funkčního stylu, a vést tak studenty k diskusi např. o charakteru Faustovy postavy, o právu a právním státu, vlivu nadnárodních korporací, ekologických problémech, tedy o aktuálních tématech.

\section{Shrnutí}

Poznali jsme, že určitý jazykově-slohový detail nám umožní funkčně skloubit jazykovou, literární a komunikačně-slohovou složku předmětu ČJL. Dalšími „dramatickými uzly“ mohou být slovotvorné mašíbly jungmannovské generace, „stylotvorné“ frazémy v Babičce B. Němcové, funkce slovesné osoby v Nerudově povídce Přivedla žebráka na mizinu (Franta 2018), přechodníky $\mathrm{v}$ Arbesových romanetech a jejich kondenzační funkce jako imitace technicko-vědeckého stylu, užití slovesného vidu v realistickém popisu např. v Raisových povídkách apod. Důraz na gramatické kategorie klade $\mathrm{v}$ tomto smyslu např. R. Adam v Interpretacích textů (nejen) ke státní maturitě (Vojtíšek 2019). Mnohé literární texty př́mo vybízejí k zaostření na jazykově-slohový detail, např. při odhalování podstaty jazykového humoru ve vyprávění o Enšpíglovi, jak o tom uvažuje Vladimíra Pánková (viz zde s. 333). Konstrukci textu jako jazykové struktury (na pozadí dobové jazykové normy u původní českojazyčné literatury) by měl podle Ladislavy Lederbuchové (viz zde s. 232) poznávat jako součást didaktického autorského kontextu, bez něhož může být interpretace (nejen) žákovská irelevantní, zavádějící, ba přímo chybná. 
Základní linie učiva je složena z kanonických uměleckých textů, jež k sobě přitahují témata jazyková a komunikačně-slohová, což je v souladu se strukturalistickými východisky. Bohužel návrhy na revidované RVP s touto integrací nepočítají, ba ji kvưli špatné praxi z centrálně zadávaných testových úkoli̊, jejichž tázání se po jazykových jevech na uměleckých textech jsou opravdu pouze mechanická či formalistní, nebo z neznalosti strukturalistických modelů podrobují kritice (Koubek 2019, s. 23, 62) ${ }^{145}$. Věříme však, že integrovaný př́stup ve vyučování češtině má smysl, jak jsme se pokusili dokázat na dílčí interpretaci Goethova Fausta.

\section{Př́loha 1}

\section{Rozložení učiva v ŠVP Gymnázia Jaroslava Vrchlického}

\begin{tabular}{|c|c|c|}
\hline \multicolumn{3}{|l|}{ 1. ročník } \\
\hline $\begin{array}{l}\text { obecné } \\
\text { poučení } \\
\text { o jazyku a řeči; } \\
\text { hláskosloví } \\
\text { - fonetika } \\
\text { a fonologie; } \\
\text { nauka o slovní } \\
\text { zásobě }\end{array}$ & $\begin{array}{l}\text { základní } \\
\text { poučení } \\
\text { o slohu; } \\
\text { prostěsdělovací } \\
\text { styl; } \\
\text { administrativní } \\
\text { styl }\end{array}$ & $\begin{array}{l}\text { podstata umělecké literatury; literární } \\
\text { druhy a žánry; struktura literárního } \\
\text { díla; literární interpretace a způsoby } \\
\text { vyjadřování zážitků z literárních děl; } \\
\text { počátky slovesného umění; } \\
\text { orientální literatura; } \\
\text { antická literatura; } \\
\text { středověké literatury; } \\
\text { humanismus a renesance; } \\
\text { baroko; } \\
\text { klasicismus a osvícenství }\end{array}$ \\
\hline
\end{tabular}

${ }^{145} \mathrm{~V}$ dotyčném dokumentu se vyskytují např. tyto formulace: „Z hlediska členění jazykové a literární obsahové domény patř́i ale utváření nástrojů na detailní práci s obsahem sdělení spíše do komunikační než do literární složky. Je úkolem pracovních skupin pro jazyk a literární výchovu, aby dokázaly tyto hranice nalézt a pojmenovat - nebo překonat.“; „Je nutno vyřešit umístění literární výchovy mezi kulturní povědomí a tvořivost a jazykovou a komunikační výchovu, zjasnit a dále hlídat vztahy, př̀kryvy a hranice oblastí.“ 


\begin{tabular}{|c|c|c|}
\hline \multicolumn{3}{|l|}{ 2. ročník } \\
\hline $\begin{array}{l}\text { nauka o slovní } \\
\text { zásobě; } \\
\text { nauka o tvoření } \\
\text { slov; } \\
\text { tvarosloví }\end{array}$ & odborný styl & $\begin{array}{l}\text { literární druhy a žánry související } \\
\text { s literaturou 19. století; struktura } \\
\text { literárního díla, text a intertextovost; } \\
\text { literární interpretace a způsoby } \\
\text { vyjadřování zážitků z literárních děl; } \\
\text { národní obrození; } \\
\text { romantismus; } \\
\text { česká literatura 60.-80. let } 19 \text {. století; } \\
\text { realismus a naturalismus; } \\
\text { moderní umělecké směry } 2 \text {. poloviny } \\
\text { 19. století ve světové literatuře }\end{array}$ \\
\hline \multicolumn{3}{|l|}{ 3. ročník } \\
\hline skladba & $\begin{array}{l}\text { publicistický } \\
\text { styl; } \\
\text { umělecký styl; } \\
\text { řečnický styl; } \\
\text { esejistický styl }\end{array}$ & $\begin{array}{l}\text { literární druhy a žánry související } \\
\text { s literaturou 1. poloviny 20. století; } \\
\text { struktura literárního díla, text } \\
\text { a intertextovost; literární interpretace } \\
\text { a způsoby vyjadřování zážitků } \\
\text { z literárních děl; } \\
\text { česká literatura na přelomu } \\
\text { 19. a 20. století; } \\
\text { světová literatura před 1. světovou } \\
\text { válkou; } \\
\text { odraz 1. světové války v literatuře; } \\
\text { světová literatura v letech } 1918-1939 ; \\
\text { česká literatura v letech } 1918-1939 ; \\
\text { druhá světová válka v literatuře }\end{array}$ \\
\hline \multicolumn{3}{|l|}{ 4. ročník } \\
\hline $\begin{array}{l}\text { obecné výklady } \\
\text { o jazyce; } \\
\text { vývoj } \\
\text { a současný stav } \\
\text { češtiny }\end{array}$ & $\begin{array}{l}\text { stylistika; } \\
\text { komunikace } \\
\text { a text }\end{array}$ & $\begin{array}{l}\text { základy literární vědy; } \\
\text { metody interpretace textu, text } \\
\text { a intertextovost; } \\
\text { zápas o charakter české literatury } \\
\text { v poválečném období; } \\
\text { světová literatura po } 2 \text {. světové válce; } \\
\text { česká literatura v letech } 1948-1989 ; \\
\text { náhled do současné české i světové } \\
\text { literatury }\end{array}$ \\
\hline
\end{tabular}




\section{Př́loha 2}

\section{Výňatky z 2. dílu Goethova Fausta}

Mefistofeles: Nechci si zahrávat s tvou nepřízní,

$(1688)^{146}$

každá tvá žádost bude vyplněna,

[...]

Faust: $\quad$ Když se mi zalíbí klid zápecníků,

potom at' nadejde můj čas!

Když uspokojen sebou samým,

lží hodnou sladkých lichotnic

i tvými požitky se zmámím,

pak půjdu klidně smrti vstř́ic.

Vsad'me se!

Mefistofeles: Platí!

Faust:

A co víc!

Když řeknu o některé chvíli:

„Jsi krásná, chvíle, trvej dál!“

pak užij svých pout, užij síly,

jak rád bych potom dokonal!

Potom at' umíráček zvoní!

Klid hodin, padne rafije,

tvá služba skončí, bude po ní,

čas pomine, zvon odbije.

[...

${ }^{146}$ Přeložil Jindřich Pokorný. 
Faust: $\quad$ Močál se šírí v přítmí hor

a hatí, co se dříve podařilo.

Vyhladit onen zhoubný mor, znamená dovršit mé velké dílo.

Pak milióny mohou na holině, ne bez jistot, zato volně, činně sít i žnout, lidská soubytí i stáda na nových lánech usadí se ráda. Za násypy, jež směle nakupí, najdou svá sídla pilné zástupy. Příboj vln bude bít až po okraj, nicméně za ním vytvoříme ráj, a kde by měl snad větší laskominy, lid navrší zas kvádry do trhliny. Jen jemu toužím věnovat své síly a všechnu moudrost končím tím, že ve svobodě mohu žít jen, chci-li a denně o ni zápasím. I tady bude dítě, muž i kmet žít střídou nebezpečí mnoho let. $\mathrm{V}$ tom hemžení bych se chtěl zastavit, na volné půdě vidět volný lid, a rríci o nestálém okamžiku: „Jsi krásná, chvíle, trvej dál!“ Tak doufám, že jsem v myslích smrtelníků trvalou stopu zanechal. A v předtuše té štastné chvíle chvil jsem právě vrcholnou slast okusil!<smiles>C1=CCCC1</smiles> 
Sbor: $\quad$ Je tich. Noc mlčí z orloje.

Rafije padá.

Mefistofeles: Padá! Dokonáno je.

Sbor: $\quad$ Čas minul. Minul čas.

Mefistofeles: Ten hloupý zvuk!

Cože to slovo značit má?

Čas minul - Ryzí nic - Ta nuda naprostá!

Co vůbec platno, věčně tvořit!

A stvořené zas do nicoty bořit!

Že minul čas? To značí věru málo.

Jak by to ani bylo nebývalo;

a štve se to přec v kruh, jak by to bylo.

Mně věčné prázdno spíš by bylo milo!

(11603)

\section{Použitá literatura}

ADAM, Robert. Př́ručka $k$ morfologii češtiny. Výklad a cvičení s řěseními. Praha: Karolinum, 2019. $94 \mathrm{~s}$.

BLOOM, Harold. Kánon západní literatury. Praha: Prostor, 2000. $640 \mathrm{~s}$.

BRÜNING, Gerrit. Die Wette in Goethes Faust. In PURDY, Daniel (ed.). Goethe Yearbook. Volume XVII. Rochester: Camden House, 2010, s. 31-54.

ECKERMANN, Johann Peter. Hovory s Goethem. Praha: Pavel Prokop, 1941. 211 s.

ECO, Umberto. Šest procházek literárními lesy: přednášky na Harvardově univerzitě. Olomouc: Votobia, 1997. 197 s.

\footnotetext{
${ }^{147}$ Přeložil Otokar Fischer.
} 
Fausts Pakt mit Mephistopheles in juristicher Beleuchtung. Goethes Jahrbuch, 1903, roč. 24, s. 113-131.

FRANTA, David. Modelování integrované výuky předmětu český jazyk a literatura (přednosti a limity). In ČECHOVÁ, Marie; SPĚVÁČKOVÁ, Martina (eds.). Od praxe $k$ teorii a zpět ve vyučování češtině. Plzeň: Západočeská univerzita, 2019, s. 116-133.

FRANTA, David. Transpozice slovesné osoby, zvl. onkání a onikání na př́kladu české literatury 19. století jako didaktický problém. Jazyk - literatura - komunikace, 2018, roč. 7, č. 2, s. 115-124.

GOETHE, Johann Wolfgang. Faust. Přeložil a poznámkami opatřil Otokar Fischer. Praha: SNKLU, 1965 (2. vydání). 579 s.

GREBENÍČKOVÁ, Růžena; KÖPPLOVÁ, Barbara; POKORNÝ, Jindřich. Kniha o Faustovi. Praha: Mladá fronta, 1982. $198 \mathrm{s.}$

GRUMACH, Renate (ed.). Goethe. Begegnungen und Gespräche. Band II (1786-1792). Berlin - New York: de Gruytes, 1977. $581 \mathrm{~s}$.

HILLEBRAND, Bruno. Was denn ist Kunst? Essays zur Dichtung im Zeitalter des Individualismus. Göttingen: Vandenhoeck \& Ruprecht, 2001. 430 s.

HIPPEL, Lukas von; DAUBENFELD, Thasten: Von der Uni ins wahre Leben. Zum Karrierestart Naturwissenschaftler und Ingenieure. Weinheim: Wiley-VCH, 2011. $239 \mathrm{~s}$.

HOSKOVEC, Tomáš. Jazyk. In SLÁDEK, Ondřej a kol. Slovník literárněvědného strukturalismu. Brno: Host, 2018, s. 330-341.

HOSKOVEC, Tomáš. Poetika a filologie (úvodní přednáška kolokvia Poetický Cikháj v Brně). In VERMIŘOVSKÝ, Adam (ed.). Poetický Cikháj v Brnè 2010. Brno: Tribun EU, 2012, s. 13-27.

CHLUP, Otokar. Středoškolská didaktika. Brno: Společnost nových škol v Brně, 1935. 356 s.

KOUBEK, Petr. Podkladová studie. Literární výchova a literární komunikace. Praha: NÚV, 2019. 115 s. 
LANG, Susanne. Erinnerungen an die Zeit vor Pisa. In Was bleibt? Ein Lesebuch zum 375-jährigen Schuljubiläum. München: Herbert Utz Verlag, 2004, s. 31-36.

LEVÝ, Jiří. Umění překladu. Praha: Miroslav Pošpa - Apostrof, 2012. $368 \mathrm{~s}$.

MACURA, Vladimír. Znamení zrodu a české sny. PIORECKÁ, Kateřina; VOJTKOVÁ, Milena (eds.). Praha: Academia, 2015. $658 \mathrm{s.}$

MANN, Heinrich. Profesor Neřád neboli Konec tyrana. Praha: SNKLU, 1964. $201 \mathrm{~s}$.

MUKAŘOVSKÝ, Jan. Poetika jako základ literární výchovy na střední škole (dnes gymnasiu). Štěpnice, 1948-1949, roč. 2, č. 1, s. 6-12, č. 6-7, s. 97-103.

-nk-. Nález dosud neznámého rukopisu přednášky prof. Jana Mukařovského pro posluchače Vysoké školy pedagogických studií. Český jazyk a literatura, 2001-2002, roč. 52, č. 7-8, s. $186-194$.

PODROUŽEK, Ladislav. Integrovaná výuka na základní škole. Plzeň: Fraus, 2002. 96 s.

SGALL, Petr; HRONEK, Jiří. Čeština bez príkras. Praha: Karolinum, 2014. $154 \mathrm{~s}$.

SGALL, Petr; PANEVOVÁ, Jarmila. Jak psát a jak nepsat česky. Praha: Karolinum, 2014. 198 s.

STICH, Alexandr. Vhlédnému čtenáři pozdravení. In týž. Od Karla Havlíčka k Františku Halasovi (lingvoliterární studie). Praha: Torst, 1996, s. 5-13.

Školní vzdělávací program pro čtyřleté gymnázium a vy̌̌ši stupeñ víceletého gymnázia (osmiletého, šestiletého) zpracovaný podle RVP G. Klatovy: Gymnázium Jaroslava Vrchlického, 2019. 458 s. ŠIDÁK, Pavel. Pražský lingvistický kroužek. In BARBOŘÍK, Vladimír; JANÁČEK, Pavel; PAVLÍČEK, Tomáš; ŠÁMAL, Petr; aj. Literární kronika první republiky. Praha: Academia, 2018, s. $176-180$. 
TRÁVNÍČEK, Jiří. Co s ní? Seminář k žákovské (povinné/doporučené) četbě. Praha: ZŠ Burešova, Praha 8, 9. 3. 2019.

TRÁVNÍČEK, Jiří. Česká čtenářská republika. Generace, fenomény, životopisy. Brno - Praha: Host, 2017. 446 s.

VELČOVSKÝ, Václav. Ideologie a pravopis. In: Moudři milují pověsti. Praha: PedF UK, 2015, s. 121-130.

VOJTÍŠEK, Ondřej. Metodologické vlivy v současných didaktických interpretacích na střední škole. Slovo a smysl, 2019, roč. 16, č. 31, s. 209-224.

WIERSCHIN, Martin W. Philologia. Würzburg: Königshausen \& Neumann, 2005. $400 \mathrm{~s}$.

ZIMA, Petr V. Literární estetika. Olomouc: Votobia, 1998. 447 s. 


\title{
Motivace nemotivovaných a česká středověká literatura
}

Jiří Novotný

\author{
Vy jděte příkladem, vy všichni, kdo učíte druhé: \\ jestliže pomijíte, co sami kážete - mlčte! \\ Čechy, latinská gnóma (14. století) ${ }^{148}$
}

\section{Prolog}

Mohu motivovat, jsem-li sám demotivován? Mohu motivovat někoho, kdo se doposud s motivačními podněty nesetkal? Mohu motivovat něčím, co vždycky čpělo pravým opakem a vzbuzovalo odpor? Složité otázky, na které je ale paradoxně možné jednoduše odpovědět. A odpovědí je třeba, zvláštł v současném prostředí nepřehledného a spoře koordinovaného českého školství. Odpovídat ovšem mohou jedině ti, kteří jen planě nedeklamují, nýbrž pracují se zaujetím, kteří neteoretizují, nýbrž jsou mocni praktických aplikací... ale především ti, kteří - triviálně řečeno - sami hoří s prastarou touhou neupalovat (jak bývalo v Čechách občas zvykem), nýbrž zapalovat...

Řada vysokoškolských pedagogů registruje u studentů (již během prvního semestru studia) řadu fatálních neznalostí. Taková zjištění se následně stávají stř̌edobodem pedagogického pohledu na další průběh studia. Hledáme příčiny (v systému vzdělávání), stěžujeme si (na stát, na kolegy) a často vypouštíme věty: „Že jste

${ }^{148}$ Spunar 1987, s. 76. 
nebrali? To už máte znát. Zopakujte si látku základní a střední školy. Není možné s vámi ztrácet čas. “Věty na první pohled sice logické, ovšem v samém důsledku povrchní, nezodpovědné a navýsost alibistické.

Jistě, za leccos může systém, za mnohé mohou vládní garnitury minulých desetiletí, jenomže - at' se již pohybujeme v jakémkoli společenském kontextu - pořád nám zůstávají na pomyslném startovním bloku výchovy a vzdělávání pouze učitelé a žáci. Právě učitelé jsou plně odpovědni za to, co učí a jak učí! Podívejme se tedy - my učitelé - kolem sebe a položme si několik (na první pohled) směšných otázek: „Je možné stavět dům bez základů? Je možné absolvovat špičkové automobilové závody na nenatlakovaných pneumatikách? Je možné vyrazit do sportovního utkání bez kondice, znalosti prostředí a pravidel?“

A s vědomím rozumu trrímaného $\mathrm{v}$ hrsti konečně dostatečně nahlas odpovězme sami sobě a všem kolem: „Ano, je to možné!“ Ovšem ty konce...

$\mathrm{K}$ dalšímu posouzení demotivačních mechanismů v českém školství využijeme výstupů z hodnocení kvality výuky studenty (interně dostupných v hodnoticích panelech Západočeské univerzity v Plzni) odrážejících spokojenost s oborem, s přístupy vyučujícího (včetně jeho serióznosti v hodnocení) i závěrečnou míru načerpaných a osvojených poznatků. Provedeme analýzu postřehů načerpaných během konzultací se studenty, přičemž nás především zajímají vědomostní data (výuková témata), o nichž si pedagogové myslí, že byla posluchači přijata, ale stav v osvojení poznatků je ve skutečnosti jiný.

A abychom dostatečně ilustrovali nedostatečnou míru soudnosti i pedagogické pokory, uvedeme několik gnómických dvojverší, 
moudrostí, ve středověku masivně frekventovaných a oblíbených. Stará moudrost nevyčpěla, ačkoli si to někteří myslí. Nehodláme ale jen kritizovat a stěžovat si, chceme-li jít dál a předat dalším generacím bohatý potenciál českého vzdělávání, který nám poskytlo minulé tisíciletí; ${ }^{149}$ jsme povinni hledat a tvořit. Doporučíme proto zodpovědným pedagogům několik zajímavých (a ještě nezarostlých) středověkých cest vedoucích od jara $\mathrm{k}$ podzimu, od porozumění $\mathrm{k}$ inspiraci, protože na počátku zrání a sklizně, bohatství celého roku, stojí právě jaro:

Máj dává třikrát: dá květ, květ plody, plod vưni.

I studium: porozumèt, mít nápad a na něm se slunit. ${ }^{150}$

\section{Podstata dialogického sporu}

Školské usilování je historií dvou diametrálně odlišných lidských typů - těch, kteří chtějí i mohou, a těch, kteří nemohou, protože nechtějí. Pak si ale položme několik dalších otázek. Kolik našich pedagogických předchůdců $\mathrm{v}$ minulosti pracovalo $\mathrm{v}$ tragických podmínkách, za hranicí bídy, v ohrožení vlastní rodiny, pod tíhou fatální sebedestrukce? A co my dnes?

Co (nebo snad „kdo“?) dnes devastuje nás... v době plošného blahobytu a lidmi snad již ani nevnímaného nadbytku sociálních jistot? Nejsme sami sobě - opět triviálně řečeno - žalobci, soudci i katy? Na počátku všeho musí totiž stát srdečný vztah $\mathbf{k}$ dítěti

\footnotetext{
${ }^{149}$ Literárně jsou zárodky vzdělávací činnosti v Čechách a na Moravě zachyceny již pro dobu 9. a 10. století (cyrilometodějská mise, vzdělávání sv. Václava a sv. Vojtěcha); podstatný je ale vznik nejstarší vzdělávací instituce, katedrální školy u sv. Víta na Pražském hradě, jejíž založení můžeme oprávněně klást již do sklonku 10. věku (Bláhová 1993, s. 27 a Novotný 1912, s. 712).

${ }^{150}$ Nepřehlédněme rafinovanou alegorii stř̌edověké moudrosti - nejprve načerpávat, následně využívat a posléze sklízet zasloužené plody práce (Spunar 1987, s. 77).
} 
(studentovi), ovšem nepostrádající důslednost a přesná pravidla respektovaná a dodržovaná oběma stranami. ${ }^{151}$ Řada učitelů totiž tř́má v ruce až trojí metr: jeden pro sebe, druhý pro své biologické děti a třetí pro ty ostatní. Ve vzdělávání tomu tak ale vždycky nebývalo:

Zoufaje nad strmou cestou jednou dvakrát utekl a spěchal $k$ milým rodičưm. Když se tak stalo, otec ho krutým bitím a pádnými ranami potrestal za útěk a v rozhořčení, ale k prospěchu věci, dal syna do blahodárných škol. ${ }^{152}$

Ve škole jako doma. Posíláme snad vlastní děti do školy bez bot; vyzýváme je k celodennímu mlčení; nevysvětlujeme, neptáme se, a tedy ani neodpovídáme? Proto se prrímo nabízí úvaha, proč nám útrapy, které bychom u vlastních dětí neakceptovali, u školní mládeže nevadí, ba dokonce, proč mnozí z nás (také rodičů) bývají nedílnou součástí kontraproduktivní pedagogické tortury. Na horizontu podobných úvah se vynořují pouze dvě možné prapríčiny: hloupost a lenivost.

Zjistíme-li doma, že dítě neobědvalo, zamítneme sladkost; vyběhne-li potomek ven bez řádného oblečení, zasáhneme; chce-li děcko samo poznávat, pomůžeme a srozumitelně zopakujeme vše potřebné, a to od začátku, nikoli zprostředka - prostě se snažíme vést dítě $\mathrm{k}$ tomu, že je potřeba nejprve absolvovat stupeň $\mathrm{A}$, abychom postoupili $\mathrm{k}$ metě $\mathrm{B}$, neřku-li $\mathrm{k}$ vrcholům $\mathrm{C}$ a $\mathrm{D}$...

${ }^{151}$ Povinnost velí, že by na počátku pedagogického usilování měla stát přirozená, nepředstíraná láska k dítěti. Kdo ji nemá, neměl by učit. I když - třeba uznat - existují různé podoby lásky, to věděli i naši středověcí předchůdci: Kdo nesahá $k$ rákosce, ten děti nemá moc v lásce (Spunar 1987, s. 79).

${ }^{152}$ Ukázka uvádí okolnosti vzdělávání sv. Vojtěcha na Libici, nekompromisní př́ístup rodiče - legenda Nascitur purpureus flos (rok 1004) Bruna z Querfurtu (Slavníkovci 1987, s. 153-154). 
Na druhém stupni základní školy - kam přicházejí děti z mnoha různých rodin (ale od jednoho, konkrétního učitele z prvního stupně) - se paradoxně dobře ví, co si dítě na prvním stupni neosvojilo. Vesele se ovšem jede dál; na střední škole se stará osvědčená humanistická a klasicistní zásada Ad fontes! ${ }^{153}$ také patrně moc neřeší, nebot’ se z časových (jenom?) důvodů musí jet dál - vždyt přicházejí různé děti z tolika škol, není v lidských silách individuálně zohlednit jejich dispozice a kompetence!

A vysoká škola už může klidně být tou pomyslnou špičkou ledovce, který nezrrídka potápí veškeré dobré úmysly. Co s tím, když se na obor hlásí tak málo studentů, ovšem z tolika různých středních škol? Musí „se“ jet dál...

Tolik o hlouposti.

Opravdu musíme jet dál? Nikdo nás přece nenutí neohlížet se za tím, co bylo na trati, co mají jezdci za sebou... co však mohlo trvale poškodit dopravní prostředek a ohrozit účastníka pomyslného závodu o čas. Opakovat tedy, ověřovat, suplovat, či nikoli? Repetitio est mater studiorum (sapientiae). ${ }^{154}$

Po více než pětadvacetileté praxi se studenty prvního semestru bakalářského studia lze zodpovědně prohlásit, že se bez již zmiňované „rekonstrukce základü“ neobejdeme, že se musíme pokorně ponižit, abychom byli posléze povýšeni - ponořit se až ad fontes a přitom neztratit důstojnost a autoritu. Člověk bezmála ani neuvěří, jaký motivační účinek takové dobrovolné a ochotné „potápění se“ může mít. Každý, kdo si dal práci s opakováním již dávno

\footnotetext{
${ }^{153}$ K pramenům! Kategorický imperativ vyzývající k hledání a poznávání podstat, bohatství minulosti, toho, co bylo a co musí být nejprve znovuobjeveno a připomenuto, aby mohlo být posléze smysluplně amplifikováno.

${ }^{154}$ Opakování je matkou učení (moudrosti).
} 
zapomenutého, s reflexí historického vývoje společnosti (viz zde L. Lederbuchová, s. 232) a s uchopením všeho interdisciplinárně uchopitelného, ${ }^{155}$ se patrně dočkal kýžených výsledků a může potvrdit, že se pohodlněji „cestuje s nahuštěnými pneumatikami“.

Tolik o lenivosti.

\section{Vstupní perikopy}

Hned v prvním semestru bakalářského studia se na katedře českého jazyka a literatury setkáváme $\mathrm{v}$ předmětu Úvod do studia literatury s nepochopitelnými nedostatky, které se týkají literárněhistorických a literárněteoretických znalostí studentů. O podrobnostech raději pomlčet. Připomeňme jen dominantní problémy s periodizací domácího literárního vývoje, kdy není valná část studentů schopna uvést ani tři základní periody (starší česká literatura - literatura 19. století - literatura 20. století). Podrobnější segmentace základních period a stěžejních subperiod rovná se nepřekonatelnému problému - totéž se (i po důkladném zopakování v prvním ročníku) objevuje v dalších semestrech studia, u dílčích zkoušek i během státních závěrečných zkoušek. ${ }^{156}$

\footnotetext{
${ }^{155}$ Máme přirozeně na mysli smysluplný (nikoli samoúčelně aplikovaný) interdisciplinární potenciál literárních textů. (viz zde V. Pánková, s. 344)

${ }^{156}$ Budeme-li parafrázovat (bez úmyslu urážet a skandalizovat) jeden z fakticky proběhlých dialogů, je rozměr celé tragédie na stole: Dotaz: Uvádíte Josefa Václava Sládka. Ve kterém století tvořil? Odpověd: V desátém. Dotaz: Byl tedy spolužákem sv. Václava? Odpověd: Ve čtrnáctém. Dotaz: Mohl být př́telem Karla IV.? Odpověd: Promiňte, v patnáctém. Dotaz: Znali se tedy s Janem Husem? Odpověd: V sedmnáctém. Dotaz: Takže se znali s Komenským? Odpověd: No tak to už vážně nevím, $k d y$ pan Sládek žil. Promiňte. Jedná-li se - jako v uvedeném případě - o rozhovor s vysokoškolským studentem a praktikujícím pedagogem v jedné osobě (student kombinovaného studia), který již cca dvacet let učí na základní škole, je nutné hledat prapř́íčiny takového neštěstí. Měli bychom pátrat (kromě arzenálu jeho nevědomostí) také po otisku neznámého pedagogického škůdce!
} 
Bezmála katastrofální je situace v uplatňování interdisciplinárních vztahů literární vědy, jelikož velmi často bezděčně vyplouvají na povrch další závažné problémy dotýkající se nejčastěji dějepisu a zeměpisu. Jistě, absolvent střední školy nepřichází studovat český jazyk a literaturu proto, aby byl detailně školen z historie či geografie, ale vzájemné vazby zmiňovaných oborů jsou tak pevné, že není zbytí, než usilovně dohánět dávno zameškané. Přichází-li maturant na vysokou školu (a má-li vážný zájem o pedagogickou profesi) s minimální znalostí historie vlastní země a s naprostou geografickou dezorientací, je třeba opět pátrat po tom, kdo je za stav zodpovědný, a v samém důsledku si dokázat vůbec představit, jaká míra znalostí odpovídá základnímu minimu pro složení maturitní zkoušky. ${ }^{157}$

Pokud vyučující (nejen na vysoké škole) nerezignují a nemají tendenci zlehčovat, protože nemají možnost ovlivnit systém, který dnes leccos dovolí, musí se alespoň pokusit s takovým stavem něco dělat, a tedy vyrazit směrem ad fontes, protože by nemělo platit, co tvrdili naši předkové (Spunar 1987, s. 78):

Kantor je veleben, když jeho žáček je hlava;

ale když pokulhává, pak vinen je jedině žák.

Studentů je možné se ptát na pocity z nového (vysokoškolského) prostředí, na plány do budoucna, na představy a přání, na inspirativní podněty, ale také na průběh dosavadní školní docházky. Dovíme se ledacos, protože se obvykle neostýchají mluvit o dosavadních zkušenostech plných neporozumění, přezírání

\footnotetext{
${ }^{157}$ Opět mohou promluvit letité zkušenosti, ale už raději bez historických konotací; za vše jen letmý vhled do geografických znalostí čerstvých maturantů, kteří v dnešní době (až na výjimky) nemají ani rámcovou představu o tom, co se odehrálo v Olomouci roku 1306: Bořivoj putoval z Prahy na Moravu - tedy na sever. Sever budu hledat dole na mapě. Pařiží protéká reka Volha... ne, ne - Dunaj! - Volha je v Polsku! Chudáci Poláci, chudáci Francouzi, chuděra matička Volha!
} 
i articistních ekvilibristik pedagogů. Uvádějí přirozeně také řadu nepřehlédnutelných pozitiv, která plnila, plní a budou plnit prostory rozličných školních budov.

Jenomže také narážejí na naprosté selhávání všeho, co ještě nedávno poměrně slušně fungovalo, ale dnes již nefunguje či funguje nedostatečně, a např́klad zmiňují, že je možné „dostat se kamkoli bez problému, být úspěšný bez jakékoli formy usilovnosti“, a nezřídka hovoří o „přednášení autorit bez zaujetí, převládajících výukových stereotypech i naprosto demotivujících návycích učitelů.

Studenti dále hovoří o jednotlivých oborech ve smyslu: „Mě by předmět jinak zajímal a bavil, ale kdo ho učil. Jenom jsme četli a mluvili o obsahu. Starou literaturu jsme neprobírali, to se dnes nemusí. Dějiny a letopočty jsme se neučili, škola byla zaměřena na ... Pořád jsme se biflovali, nic víc. S mapou jsme moc nepracovali. Na maturitu stačil jen seznam knih.“ Podobné reakce zoufalých vysokoškolských studentů se pomalu stávají dogmatem současné doby, jakýmsi „písmem svatým“ nechtěného. Také za tím stojí konkrétní lidé. ${ }^{158}$

\section{Nepředstíraná pokora}

Po tom všem, co bylo uvedeno, si nyní představme situaci, kdy začínáme s výukou předmětu Starší česká literatura - středověk, hned v prvním ročníku, ve druhém semestru vysokoškolského studia na pedagogické fakultě. Co si počít s budoucími (potenciálními) profesními kolegy, kteří měli k maturitě jen seznam několika knih, byli dosud „nějak“ zaměřeni, pořád se jen biflovali

\footnotetext{
${ }^{158}$ Dočkáme se stavu, kdy budou přijímáni ke studiu učitelské profese špičkoví jednotlivci prokazující dlouhodobý zájem o obor a letitou studijní průpravu?
} 
(ale bez znalosti roku 1306) a jsou připraveni vypravit se za věčně zmrzlou půdou pokrytou ledovci na naši Moravu?

Existují - jako téměř u všeho - dvě základní možnosti: nechat všeho a utéci, dokud je čas, nebo začít sám u sebe. A nyní zdůrazněme, že se ani zdaleka nejedná o otřepanou frázi, protože často slyšíme další studentský názor: „Kdyby na učitelích bylo vidět, jak je předmět baví, nás by to taky bavilo poslouchat." ${ }^{159}$ Tato důležitá informace dokumentuje vše, co již bylo výše uvedeno. Studenti ale především postrádají pedagogické hoření = zaujatost oborem; zaujatost podávající si ruku s tím, bez čeho se neobejdeme a co občas marně hledáme - s motivací. Opravdovost je žáky a studenty lehce rozpoznatelná, ale nestačí, není samospasitelná, třeba $\mathrm{k}$ ní doplnit ještě kolegiální a přátelský přístup související právě s láskou, o níž byla řeč. Pokud je opravdovost doprovázena seriózností a nezbytnou učitelskou pokorou, věříme, že není třeba utíkat. Pokorou je totiž v tomto konkrétním př́ípadě míněno opakování všeho podstatného, co měli jiní (na všech stupních škol) naučit, ale nenaučili, co měli jiní (na všech řídících a kontrolních stupních) zajistit, avšak nezajistili, protože jim právě ta profesní pokora jaksi chyběla.

Středověká literatura pracovala s topoi líčené (předstírané) pokory právě proto, že tehdy předstíraná nebyla. Ne jako dnes, kdy stále něco předstíráme, ale ve skutečnosti strádáme přemírou jistot a tupého sebevědomí. Víra se pak stává nevírou a zodpovědnost odchází neznámo kam - zodpovědnost za všechno a bohužel i za všechny - za žáky a studenty... a konec konců i za sebe.

Standardní populace dneška středověké literatuře již prakticky nerozumí a utápí se $\mathrm{v}$ interpretačních šumech a nedorozuměních

\footnotetext{
${ }^{159}$ Všimněme si - zatím jen „poslouchat“, nikoli „studovat“. Vědomí studia (a nejen naslouchání a učení se) přichází nepoměrně později. I za to ale někdo může!
} 
následně limitujících pohledy současníkủ na dávnou minulost. Ale i s tím se dá pracovat, pomalu, trpělivě a především... pokorně. Recipient není hloupý a dezorientovaný, když uvádí, že byla sv. Ludmila hodná žena, protože pomáhala vdovám a sirotkům, je pouze nezkušený a bloudí, protože mu dosud nikdo neukázal možnou (a neříkáme, že jedinou správnou, ale možnou) cestu. Již letmým poukazem na odpovídající pasáže Písma svatého sám zjistí, že v jeho dosavadním pevném názoru něco nehraje, a je-li pokorný, nastuduje si takřka sám, bez ukazovatele, nápovědy, průvodce či mentora vše potřebné. Nechá si poradit, ale nakonec se rozhodne sám a s plnou vahou osobní zodpovědnosti - v učitelství, ve vědě stejně tak jako v životě a ve víře platí stejná pravidla o osobní zodpovědnosti.

A nyní se ocitáme u posledního studentského vyjádření, které chceme prezentovat a které se dnes nezřídka objevuje. Řada absolventů základních a středních škol uvádí stále častější pedagogicko-výchovné manipulace všeho druhu. Někteří učitelé namísto uvěřitelného zaujetí oborem raději prezentují neuvěřitelné subjektivní pohledy politického a náboženského rázu, komentují globální hrozby celoplanetárního dosahu a hodnotí novověké migrace namísto toho, aby se věnovali práci, svému předmětu, a když už pocitují palčivou a neuhasitelnou touhu komentovat, aby hledali poučení v historických pramenech. Uvědomme si, že pedagogická autorita vede, ukazuje cestu... modeluje sice, ale nepokouší se vtěsnat duši mladého člověka do koridoru rozličných dogmatických bludů.

Tolik k manipulaci. 


\section{Postila žádostivých}

Studenti chtějí, jsou žádostiví, i když to na první pohled není vidět. Nesměřují-li někteří z nich k žádoucímu cíli požadovaným tempem, nastupují staletími osvědčené donucovací praktiky, bez kterých se zodpovědný učitel neobejde. Dnes už se ovšem nejedná o bití, jemuž v katedrální škole v Magdeburku čelil před více než tisíciletím sv. Vojtěch:

A tvrdí se o něm tahle podivuhodná věc: když náhodou učitel vytáhl paty, strávil jednou celý den hrou, jak je vlastní nestálým myslím chlapců. A když z čtené lekce neumèl ani slovo a právem rozhněvaný učitel ho začal bit, řekl: „Nech mne být, přčctu to. "Učitel ho tedy pustil a on velmi dobře četl, jako by věc již znal. Říkají také, že mluvil třemi jazyky misto jedním, že volal na učitele „Domine mi", $k d y z ̌ z$ metla rozdírala záda a pálící diotky se bolestně zatínaly do masa. Žáci totiž tehdy obvykle mluvili latinsky a nikdo se neodvážil před učitelem mluvit barbarskou řečí. (Slavníkovci 1987, s. 155)

Pedagog má preferovat spravedlivě tvrdou a zodpovědnou povinnost (podle předem stanovených pravidel) před plytkou zábavou a nezodpovědně líbivou, lenivou tolerancí. Na důslednost bychom neměli nikdy rezignovat.

Ptáme se, není-li na vysoké škole pozdě, zda nemáme usilovat o výuku starší literatury na základních a středních školách, přirozeně $\mathrm{v}$ mezích žákovských kompetencí a s ohledem na věk. Nepochybně, ale jak a s kým? Když přednesl autor této kapitoly na liberecké konferenci Současnost literatury pro děti a mládež (2014) př́spěvek Nejstarší česká tvorba na základní škole, setkal se s poměrně širokým zájmem. Na konci podnětné diskuse však 
bylo konstatováno, že se starší česká literatura do uvažovaného kánonu světových a českých děl pro děti a mládež prostě nevejde. Přednášející sice argumentoval tím, že rezignujeme-li na rámcovou znalost nejstarší české tvorby, pomalu dospíváme do pozice milovaného vnoučete, které s klidným svědomím prodá darovaný domeček i s prarodiči, přestože dosud nezemřeli. Avšak nic platné, zřejmě se navždy budeme muset obejít bez legend, Kosmovy kroniky, nejstarší česky psané tvorby, Karla IV., Husa, Komenského atp. Alarmující představa!

Tolik k rezignaci.

Vzdělávání je mimo jiné uměním výběru. Nedokáží-li autoři učebnic vybírat adekvátně $\mathrm{k}$ věku, kompetencím mládeže a potřebám doby vhodné texty nebo jsou-li učebnice předimenzované, je opět řada na učitelích. Ti stojí před zodpovědným rozhodnutím, jak zaujmout a naučit, aniž obejdou základní vzdělávací a oborové parametry, co vybrat a zdůraznit a co naopak potlačit, jak zohlednit potřeby a zájmy dnešních mladých lidí.

Využijeme-li nyní letitých zkušeností s interpretací nejstarších textů národní literatury, je možné kolegům na všech stupních škol a na školách různého zaměření nabídnout alespoň několik směrů, kterými mohou - mají-li zájem - postupovat. Doporučené texty se stanou vděčným prostředníkem výchovy a vzdělávání, protože nabízejí bohatou škálu možností a skrývá se v nich stará moudrost. Jejich aktualizační a interdisciplinární potenciál je značný, stačí jen hledat. Přistupme proto k jednotlivým tematickým blokům s předem stanoveným chronologických zřetelem. 


\section{Legenda zbožných přání}

Tvrdí-li kdokoli, že nejde, nebo se dokonce nemá pracovat na nižších stupních škol ${ }^{160} \mathrm{~s}$ domácí středověkou tvorbou, nepochybně bloudí. Není třeba pouštět se do bezvýchodných odborných debat, stačí v tichosti doporučit určité texty (tematické oblasti) nejstarší české literární tvorby a smyslupně s nimi pracovat. Postup je o to důležitější, že kráčíme prrímým směrem k motivaci posluchačů a disponujeme konkrétním silným fundamentem, protože byly navrhované kroky prakticky (a úspěšně) realizovány v posledních třiceti letech na všech stupních škol a dlouhodobě (a neméně úspěšně) se s nimi pracovalo během vysokoškolských projektů a přednášek (Novotný 2019, s. 149-159) i v oblasti celoživotního vzdělávání posluchačů, z nichž značná část disponovala pouze znalostmi české literatury nabytými během povinné školní docházky. ${ }^{161}$

Nepřistoupíme však $\mathrm{k}$ tomu, abychom prrímo doporučovali konkrétní části textů. V současné době všichni vyžadují přijít $\mathrm{k}$ hotovému, nejlépe dopravenému prrímo do místa bydliště, a to je základní chyba. Poznání národní minulosti vyžaduje upřímné úsilí motivované něčím více než je pouhé seznámení s textem, historickým pramenem. Je třeba trpělivě a se zájmem hledat.

V této kapitole se omezíme jen na nejstarší texty národní tvorby raného středověku, protože bychom jinak (při využití nabídky celé české stř̌edověké literatury) několikanásobně překročili možnosti jedné kolektivní monografie.

\footnotetext{
${ }^{160}$ Učitel musí být schopen sám vybrat pasáže odpovídající věku i odborné kompetenci žáků a studentů.

${ }^{161}$ Jedná se o vzdělávací programy Univerzity třetího věku i soukromé přednáškové aktivity, v posledních letech realizované např. v Plzni, Žatci, Klášterci nad Ohří, Podbořanech, Klatovech, Sušici, Plasích, Zbirohu, Spáleném Poříćí.
} 
První svazek textů nabízí staroslověnský penitenciál reprezentující velkomoravské období (2. polovina 9. století), nejstarší vývojovou periodu národní literatury (Vašica 2000, s. 218-226). Společensky silně exponované texty nabízejí řadu inspirací; zákonné předpisy sumarizují míru provinění a následného pokání $s$ nařízením odpovídajícího trestu, pracují s motivy sebepoškozování, zotročování lidí, opilství, smilstva; ilustrují rozličné právní postupy; mají silně etický podtext, ${ }^{162}$ který neztratil na aktuálnosti ani dnes, a... varují! Velkomoravská právní nařízení vycházela z původních byzantských vzorů, odrážela tedy prastarou zkušenost antického a raně středověkého světa.

Další významnou periodu starší literatury (tzv. epochu koexistence staroslověnštiny a latiny - 10. a 11. století) reprezentují nejstarší národní legendy i hagiografické texty sepsané v zahraničí a cílené na rané české dějiny. Pokud učitel nic z toho nečetl, nemůže vybírat a je věčně závislý pouze a jen na doporučení těch, kteří čtli.

Podívejme se proto např́klad na geografii středních Čech vyplouvající na povrch vyprávění o martyriu svatých Ludmily a Václava (Chaloupecký 1939, 1942; Ludvíkovský 1978; Staroslověnské legendy 1976), Vojtěcha (Krásl 1898; Kyralová 1996; Slavníkovci 1987) a přirozeně i Prokopa (Chaloupecký 1953), jehož vyhánění dáblů ze sázavské jeskyně stalo se proslulým a on sám - s duší poustevníka, démonobijce - vstoupil do panteonu svatých jako průkopník opravdovosti ve víře.

Nezapomeňme připomenout nejstarší zmínky legend o vzdělávání dětí v oblasti středních Čech; ukažme žákům, na kterém hradišti stál nejstarší český kostel; doložme jim, kde a jak umírali

\footnotetext{
${ }^{162}$ Zjistíme, že naši předkové před více než tisíci lety znali právní institut tzv. osoby blízké, že nepřipouštěli eticky neudržitelné výzvy k udavačství mezi rodinnými příslušníky atp. Porovnejme s některými ideologiemi 20. století.
} 
národní mučedníci a zemští patroni; dokažme jim, že kusé zmínky velkomoravských pramenů o středoevropském otrokářství raného středověku nejsou ojedinělé, vylhané ani přehnané (viz václavské a vojtěšské legendy); ${ }^{163}$ vyrazme s mládeží po stř̌edočeských hradištních lokalitách (Budeč, Levý Hradec, Libice nad Cidlinou, Libušín, Lštění, Mělník, Stará Boleslav, Tetín) známých z legend i z proslulé latinské kroniky děkana Kosmy; přečtěme jim kousek latinského textu, aby si uvědomili jazykovou podobu - pro obyčejné lidi nesrozumitelnou - nejstarší české literatury, protože teprve potom si uvědomí pravý dosah slov staroslověnského Proglasu (Vašica 1996, s. 141):

...abyste pro nerozum své mysli,

posloucháte-li slovo v cizím jazyku, neslyšeli je jako hlas zvonce mědèného. ${ }^{164}$

Inspirativní nabídku zakončíme zajímavostmi ze třetí vývojové periody starší české literatury, z období dominance latiny (12. století - polovina 13. věku). Základním žánrem tohoto časového úseku je nejstarší česká historiografie, na počátku stojí Kosmova Kronika Čechů a na ni navazují tzv. Kosmovi pokračovatelé Kanovník vyšehradský, Mnich sázavský, Vincencius, Jarloch, Anály hradištsko-opatovické, anonymní autoři letopisů ze 13. století. $\mathrm{V}$ př́padě historiografických děl ale nemůžeme komentovat konkrétní tematické celky, protože bychom se nedopsali. Je tedy opět třeba individuálně studovat a hledat kýžené inspirace.

${ }^{163}$ Všichni jsme se ve školách učili o společnosti prvobytně pospolné, starověké (otrokářské) a středověké (feudální); málokdy ale při výuce zazněla informace, že se právě raně středověká formace konstituovala na obchodu s lidmi a na rafinovaném zotročování lidí a na jejich přesidlování.

${ }^{164}$ Učitelé navedou žáky k souvislosti textu Konstantina-Cyrila (uvažovaný autor Proglasu) s 1. epištolou sv. Pavla Korintským (Nový zákon Písma svatého). Motiv se objevuje v celé středověké literatuře a akcentuje potřebu srozumitelného sdělování významů, tedy ne ve vytržení smyslů (ve složitých alegoriích), ani v cizím jazyku (pro nevzdělance neuchopitelném). 
Každého schopného pedagoga jistě hned napadne, s jak zajímavým interdisciplinárním potenciálem můžeme pracovat, uvedeme-li několik námětů z Kosmova díla a odkážeme-li na paralely u jeho pokračovatelů: informace týkající se nebeských úkazů i rozmarů počasí - in Kanovník vyšehradský; různé podoby násilného chování - in Jarloch, dokonce kanibalismu - in Vincencius; anonymní letopisy 13. století; přesidlování a zotročování lidí; popis Poohří coby luckého kraje; prríznačné popisy starých slovanských a předslovanských fortifikací; tendenční charakteristiky knížat; autorovy autobiografické aluze - včetně vzpomínek na studia - a jeho nesmírně zajímavý smysl pro humor, jako i úžasný dar empatie (vraždění Vršovců - popravy dětí).

Interdisciplinární výzvou je nepochybně Kosmovo líčení starých českých pověstí, které inspirovalo středověkou i novověkou kulturní frontu. $\mathrm{V}$ souvislosti s nimi je třeba speciálně upozornit na unikátní možnost multidisciplinárního využití přemyslovské pověsti, o které jsme již v minulosti opakovaně psali (Novotný 2019, s. 158-159) a opakovaně přednášeli. Nestává se př́liš často, že můžeme $\mathrm{k}$ interpretaci starého literárního textu využít mobilních telefonů, tabletů, počítačů apod., chceme-li výuku literatury prokombinovat s matematikou (výpočet slovní úlohy týkající se nočních přejezdů kněžny Libuše), geografií (poloha Libušína a Stadic), prŕrodopisem (rychlost jízdy na koni) a přirozeně dějepisem (bez komentáře). ${ }^{165}$

\footnotetext{
${ }^{165}$ Při této prríležitost opět připomínáme pohledy didaktiků (viz zde V. Pánková, s. 333), kteří akcentují smysluplnost interdisciplinarity (oproti samoúčelnosti), za jejich názory se přirozeně skrývá zdůraznění aktualizačních principů ve výuce. Proto v souvislosti s přemyslovskou pověstí doporučujeme pomocné informace a otázky: Představte si, že jedete v noci na kole - v úplné tmě, po nezpevněné lesní cestě - a musíte přebrodit řični tok. Všude kolem dravá zvěr - medvědi, vlci - a přirozeně také zlí lidé. Jedete sami, bez doprovodu - jako kněžna Libuše. Jakou rychlostí asi v noci jela? Mohl její kůn̆ jít, klusat, cválat, nebo po známé cestě uháněl tryskem? Proč Kosmas použil obratu „pověst širrí se lichá?"
} 
Naznačili jsme určité směry týkající se ale pouze nejstarší národní tvorby; pokud bychom postoupili do 14. a 15. století, rozevře se pomyslný vějír možností opravdu doširoka. Stranou zatím necháváme také vazby středověkých textů k výtvarnému umění. A protože není možné - přestože se to nezřídka děje - studovat a přednášet středověkou literaturu bez detailní znalosti historických dat, připomeneme v samém závěru alespoň dvě historické publikace, které pomohou rozkrýt počátky české státnosti i tajemná zákoutí stř̌edověké „duše“ (Spunar 1995; Třeštík 1997).

\section{Epilog}

Pozorný čtenář si jistě všiml, že kapitola byla strukturována do sedmi částí. Nejen to, byla př́ísně dodržena základní trichotomie kompozice celku. Při každém pročítání starých textů bytostně spjatých s křestanskou kulturou Evropy bychom si měli být vždy vědomi důsledné role číselné symboliky - reprezentované především biblickou novozákonní trojkou a starozákonní sedmičkou; ${ }^{166}$ totéž platí pro kombinace či kumulace těchto čísel.

Stará literatura umně pracovala také s barevnou symbolikou, bílá = nevinnost, čistota; červená = krev, umučení; žlutá (zlatá) = vláda, nebeské království Ježíše Krista; zelená = hanba, stud, pohanství. I v oblasti barevného spektra nalezneme inspirací - např́klad ve vazbě na výtvarné umění.

Středověk také dokázal programově pracovat $s$ alegorizací textu. Žáci a studenti alegorii rozumějí - pokud jí rozumí pedagog a umí ji vysvětlit a ilustrovat textem - a mnohdy dokáží učitelům otvírat při interpretaci textu nové významové obzory a nabízejí neotřelé souvislosti. Pro mnohé z nás je až nepochopitelné, jak

\footnotetext{
${ }^{166}$ Připomeňme základní číselné aspekty českých pohádek, resp. celé folklorní tvorby.
} 
názorně a s jakou lehkostí dokázali středověcí kantoři přednášet obecnou problematiku uměleckých jazykových prostředků či sémantiku latinského lexika. A ten pedagog současnosti, který opravdu chce a umí kráčet dopředu, si lehce poradí i s takovým specifikem středověké tvorby, ke kterému řadíme nesmírně zajímavé a umělecky neopakovatelné topoi ve všech podobách.

Jenom chtít...

O čem jsme vlastně uvažovali? O mnohém, ale hlavně o motivaci, především o motivaci, výhradně o motivaci, která má být hnacím motorem výchovy i vzdělávání v každém předmětu na každé české škole, aby se každému z nás učitelů splnilo přání profesora Viktora Viktory adresované v tomto roce studentům, kteří v univerzitním portálu hodnocení kvality výuky na Fakultě pedagogické ZČU upř́mně ocenili odbornou kvalitu přednášek páně profesora, jejich srozumitelnost, inspirativnost i zábavnost: Děkuji, přeji Vám, abyste si v budoucnu mohli o sobě přečíst něco podobného.

\section{Prameny a použitá literatura}

BLÁHOVÁ, Marie, 1993. Pražské školy předuniverzitního období. In PEŠEK, Jiř́í; SVATOŠ, Michal. Škola a město. Praha: Karolinum, Documenta Pragensia XI, 1993, s. 26-39.

CHALOUPECKÝ, Václav (ed.). Prameny X. století legendy Kristiánovy o Svatém Václavu a Svaté Ludmile. In Svatováclavský sborník. Praha: Národní výbor pro oslavu Svatováclavského tisíciletí, 1939. $630 \mathrm{~s}$.

CHALOUPECKÝ, Václav. Na úsvitu křestanství. Praha: Evropský literární klub, 1942. $292 \mathrm{~s}$. 
CHALOUPECKÝ, Václav; RYBA, Bohumil (eds.). Středověké legendy prokopské. Praha: Nakladatelství ČAV, 1953. 285 s.

KRÁSL, František; JEŽEK, Jan. Sv. Vojtěch, druhý biskup pražský, jeho klášter i úcta u lidu. Praha: Dědictví sv. Prokopa - číslo XXXIX, 1898. $795 \mathrm{~s}$.

KYRALOVÁ, Marie. Bruno z Querfurtu, Život svatého Vojtěcha, legenda Nascitur purpureus flos. Praha: Zvon, 1996. 125 s.

NOVOTNÝ, Jiří. Od centra k regionům. In ČECHOVÁ, Marie; SPĚVÁČKOVÁ, Martina (eds.). Od praxe $k$ teorii a zpět ve vyučování češtině. Plzeň: Západočeská univerzita, 2019, s. 148-159. NOVOTNÝ, Václav. České dějiny I. Praha: Jan Laichter, 1912. $782 \mathrm{~s}$.

Slavníkovci ve středověkém písemnictví. Úvodní studii, úvody a poznámky $\mathrm{k}$ textům napsal Rostislav Nový; texty přeložila Jana Zachová. Praha: Vyšehrad, 1987. 471 s.

SPUNAR, Pavel. Smích a pláč středověku. Praha: Odeon, 1987. $269 \mathrm{~s}$.

SPUNAR, Pavel. Kultura středověku. Praha: Academia, 1995 (2. vydání). $226 \mathrm{~s}$.

Staroslověnské legendy českého původu: Nejstarši kapitoly z dějin česko-ruských kulturních vztahů. Uspořádali Emilie Bláhová a Václav Konzal. Praha: Vyšehrad, 1976. 399 s.

TŘEŠTÍK, Dušan. Počátky Přemyslovců: Vstup Čechů do dějin (530-935). Praha: Nakladatelství Lidové noviny, 1997. 658 s.

VAŠICA, Josef. Literární památky epochy velkomoravské 863-885. Praha: Vyšehrad: 1996. 340 s. 


\section{Kam směřuje dnešní výuka literární výchovy?}

\section{Vladimíra Pánková}

Tato studie mapuje nepochopené inovační pojetí literární výchovy (dále jen LV), v níž dominují interpretačně nezacílené, mnohdy mechanicky uplatňované metody tvůrčího psaní, tvořivé dramatiky či kritického myšlení. Obsah kapitoly se opírá o postřehy $\mathrm{z}$ pedagogické praxe, tj. $\mathrm{z}$ hospitací $\mathrm{v}$ hodinách LV a z příležitostného lektorování praktikujících učitelů. Řada učitelů si stěžuje, že žákům činí potíže porozumět estetickému sdělení literárního díla. V té souvislosti volají po kreativních metodických postupech, které by žáka motivovaly k četbě a zároveň by pomohly prohloubit jeho čtenářskou gramotnost. Ve školním literárním vyučování, jež se postupně přeorientovává na čtenářské a komunikační aktivity žáka, se však stává, že učitelé (obzvláště ti, kteří sami nepronikli k podstatě díla, ale jsou vybaveni novým „metodickým balíčkem“) volí coby prostředek poznání uměleckého textu paradoxně ty metody, které žáka odvádějí od hlubšího porozumění textu. Tvořivé metody samy o sobě nejsou samospásné, a dokonce mohou být kontraproduktivní, není-li jejich volba kompatibilní s expresivní povahou textu. Pokud čtenářsky orientovaná výuka, byt postavená na přímé práci s textem, neskýtá žákům podněty $\mathrm{k}$ pochopení (otevření) uměleckého díla (k odkrytí jeho poetiky včetně žánrových a literárně druhových aspektů), pak LV (přestože kreativní) ztrácí svůj smysl. Cílem této kapitoly není kritika tvořivých metod, ale naopak snaha o obnovení jejich (mnohdy ztraceného) smyslu. 


\section{Literární výchova a literární komunikace v kurikulárních dokumentech}

Přímé (též ve smyslu zážitkové, tvořivé) poznávání uměleckého textu je deklarované rámcovými vzdělávacími programy (dále jen RVP). RVP pro základní vzdělávání (2017) akcentuje čtenářské, interpretační a produktivní činnosti, jejichž prostřednictvím mají být osvojeny především znalosti základů literární teorie, a to $\mathrm{s}$ cílem porozumět literárnímu dílu. $\mathrm{V}$ té souvislosti poukazuje Ladislava Lederbuchová (viz zde, s. 235) na ahistorickou koncepci inovativní LV, která ve snaze překonat faktograficky zaměřenou výuku (nadměrné množství výkladově zprostředkovaných informací o autorovi a jeho díle) se ubírá cestou druhého extrému, rezignuje na literárněhistorické poznatky o genezi textu. Autorka zde přesvědčivě demonstruje, že interpretační př́istup $\mathrm{k}$ dílu by se v komunikačně (konstruktivisticky) pojaté LV měl kombinovat $s$ př́stupem informačním, pokud je toho pro pochopení díla třeba, aniž by se těžiště práce přesunulo od recepce k literárnímu dějepisu.

Komunikační pojetí LV je zakotveno i v RVP pro gymnázia (2007), kde jsou literárněteoretické poznatky (prohloubené znalosti o struktuře literárního textu) usouvztažněny s poznatky literárněhistorickými (s podstatnými rysy základních period vývoje české i světové literatury, uměleckých směrů, se znalostí jejich představitelů, se specifickým postavením české literatury v kontextu literatury světové). K osvojení literárněvýchovného učiva (včetně toho formativního, tj. hodnotových orientací a postojů) jsou zde doporučovány metody četby, interpretace a tvůrčích aktivit. V souladu s důrazem na porozumění textu se v očekávaných výstupech literární komunikace vyžaduje posouzení funkce konkrétně realizovaných textových složek (vyprávěcích způsobů, typů promluv, básnických prostředků) a jejich estetického účinu 
na čtenáře. Přesto v pedagogické praxi stále dominuje formální rozbor textu ${ }^{167}$, tj. úkoly typu - najdi, vyhledej, označ, aniž by se sledoval smysl užití výrazových prostředků a tvůrčích (narativních, žánrových, kompozičních) postupů v textu.

Znalosti o poetice textu se přece neosvojují pro ně samé (aby se následně staly předmětem zkoušení), nýbrž pro zkvalitnění komunikace o literárním díle, $\mathrm{z}$ důvodu jeho hlubšího pochopení. V dobře a efektivně vedené LV jsou za tímto cílem vzájemně propojovány interpretační a tvořivé metody. Výstupy získané reflexí četby - řízeným čtením ${ }^{168}$ - představují (mohou představovat) východisko pro vstup do tvůrčích metod, kde se takto osvojené poznání interiorizuje, prohlubuje a propojuje s emocionálně-estetickým zážitkem. A obráceně. Z reflexe žákovy produktivní (kreativní) činnosti mohou být vyvozeny znalosti bud' o poetice uměleckého textu obecně, nebo o významové výstavbě a smyslu konkrétního díla. Při poznávání autorova díla na základě žákovy tvưrčí aktivity (tvưrčího psaní, tvořivé dramatiky) je žádoucnější, když žákova exprese není jen spontánní (intuitivní), ale když je

\footnotetext{
${ }^{167}$ Rozborem textu zde míníme formální pojmenovávání strukturních kvalit textu bez zhodnocení jejich významotvornosti či estetického účinu. Oproti tomu didaktická interpretace textu umožňuje reflektovat smysl užitých výrazových prostředků a tvůrčích postupů, navíc proces jejich poznávání propojuje se čtenářským zážitkem. ${ }^{168}$ Atribut ř́izenosti zde vychází z výzev uměleckého textu (z jeho strukturních dominant) a $\mathrm{v}$ souladu $\mathrm{s}$ tím pak $\mathrm{z}$ obsahu vytčeného učiva, nikoliv $\mathrm{z}$ jediného, předem daného (někdy dokonce nadiktovaného) obsahu textu. Rízené čtení by se tudíž nemělo zaměňovat $\mathrm{s}$ rozborem textu. Literární dílo se v řízeném čtení otevírá volnému, ale ne libovolnému přečtení. Není žádoucí, aby se jeden extrém (lpění na petrifikovaném výkladu textu) nahrazoval jiným extrémem (akceptací jakéhokoliv čtenářského názoru žáka). Řizené čtení umožňuje žákovi vyjádřit čtenářský názor na dílo, ale pokud se tento názor míjí s významovým koridorem textu, pak učitel má dát podněty $\mathrm{k}$ přehodnocení těchto prekonceptů. Jak podotýká Věra Zelenková (viz zde, s. 261), interpretace textu je hra, ale ne bezbřehá a rozhodně ne bez pravidel. Korekci čtenářských obsahů lze přesměrovat i na žáky - např́íklad prostřednictvím otázek: Souhlasíte s tímto přečtením díla? Proč ano? Proč ne? Jak byste z pozice literárních kritiků okomentovali tento výklad? Své připomínky argumentačně opřete o textové informace nebo o znalosti literárněhistorického, případně společensko-kulturního kontextu.
} 
žák seznámen s jejími pravidly, která vyrůstají z tvarových kvalit textu.

Následující podkapitola nabízí příklad z praxe, kde tvưrčí metoda (byt dobře zvolená) nepřispěla sama o sobě (bez předchozí reflexe četby a následující reflexe tvůrčích výstupů žáka) k pochopení literárního díla, ba naopak.

\section{Př́klad z praxe - Metoda tvưrčího psaní (domýšlení př́iběhu)}

Hospitace proběhla v 6. třídě plzeňské ZŠ při výuce LV. Předmětem četby byly kapitoly Enšpígl ve vlastní zemi a Enšpígl krejčím z knihy Enšpígl od Jiřího Koláře a Josefa Hiršala. Obě ukázky byly obsažené v Čítance pro 6. ročník základní školy a primu víceletého gymnázia od nakladatelství Fraus (Lederbuchová, Beránková 2003, s. 195-197). Nejprve nastíním obsah zvolených ukázek.

Enšpígl ve vlastní zemi: Enšpíglovi za jeho neplechy zakázal lüneberský vévoda vstup na své panství pod trestem oběšení. Enšpígl si ve snaze zachránit život koupí koně, vůz a od starého sedláka fưru ornice, kterou nahází na korbu. Poté se do hlíny zahrabe a doufá, že kolem vévodova paláce projede nepozorovaně. Náhoda však tomu chce, aby se vévoda a Enšpígl ještě jednou setkali. Mezi oběma proběhne následující rozhovor.

„Co tu ještě pohledáváš? Neřekl jsem ti, že tě dám pověsit, jakmile tě dopadnu ve své zemi?" pravil výhrůžně.

„Vaše jasnosti,“ odpověděl Enšpígl, „nejponiženěji vám oznamuji, že nejsem ve vaší zemi, ale ve své zemi. Koupil jsem ji za groš od jednoho sedláka, který mi svatosvatě 
přísahal, že je to jeho země, že ji zdědil po svém otci a ten zas po svém otci a tak dále až od Adama."

Mazaná odpověd' vévodu pobaví natolik, že Enšpíglovi dává milost, avšak pod podmínkou, že se v lüneburském panství již nikdy neobjeví.

Enšpígl krejčím: Enšpígl se v Berlíně učí krejčím. Mistr mu řekne: „pamatuj, dobrý krejčí musí šit tak, aby to nebylo vidět.“ Enšpígl tedy šije potmě, pod putnou. Jindy mistr řekne: „(...) tu máš kabát, nahod' na něj rukávy a pak můžeš jít taky na kutě. Ale pospěš si, at mi nespálíš všechny svíčky. "Enšpígl pověsí kabát na hřebík a celou noc na něj hází rukávy. Z levé strany levý, z pravé strany pravý. Ráno pak mezi mistrem a Enšpíglem dojde k roztržce.

„Copak jsem si pomyslil, žes takový nekňuba, a neviš, když řknu, abys nahodil rukávy na kabát, že to znamená, abys je př̀išil?"

„Aby vás čert vzal!“ řekl zlobně Enšpígl. „Něco jiného ríkáte a něco jiného myslíte."

Rozhněvaný Enšpígl odmítá mistrovi zaplatit propálené svíčky a odchází z učení, putuje do Brandenburgu.

Po hlasité četbě, aniž by proběhla její reflexe, byl zadán úkol pro tvưrčí psaní. Napište, jak by Enšpíglưv príběh mohl pokračovat. Koho dalšího by Enšpígl mohl potkat a jakou neplechu by mu mohl provést?

Nutno podotknout, že námět k tvưrčímu úkolu je dobře zadán, nebot' vyrůstá z výzev textu, avšak absence jednak literárněhistorických poznatků, které by dílo a jeho hrdinu zakotvily 
v čase, jednak reflektivního dialogu o díle zapř́íčinily, že žáci ve svém tvůrčím psaní nerespektovali strukturní kvality textu (paradoxně ty kvality, které by měly být kreativně poznány). Žáky domýšlený prŕběh se míjel s formou komiky užitou v rozprávkách o Enšpíglovi. Tvưrčí výstupy žáků se četly v poslední části hodiny. Všechny byly odměněny hromadným potleskem, aniž by se jejich obsah reflektoval se zřetelem $\mathrm{k}$ původnímu dílu. Součástí této kapitoly jsou parafráze těchto výstupů.

Žákovský výstup 1:

Enšpígl sedne na raketoplán a odletí do vesmíru, kde se seznámí s mimozemštany. Za pomoci zvláštního paprsku jim zneviditelní kosmickou lod'. Mimozemštané propadají panice, poněvadž si myslí, že se ocitli ve volném prostoru.

Vybraný výstup je extrémní v tom, že mění žánrový charakter původního díla, aniž by $\mathrm{k}$ této transformaci textu byl žák vyzván. ${ }^{169}$ Obsah tvůrčího výstupu vypovídá spíše o čtenářských preferencích žáka (v sci-fi má zřejmě oblibu) než o jeho porozumění dílu. Žákovský výstup je tak výsledkem mechanicky aplikované, interpretačně nezacílené metody tvưrčího psaní. Nejen zde, ale i v jiných výstupech žáků se objevovaly anachronické motivy překračující období středověku. Není se čemu divit, když poznávané dílo nebylo před tvưrčí činností historicky zakotveno.

Žákovský výstup 2:

Enšpígl doputoval do dalšiho města, kde se baví tím, že děsí „staré báby“. Čeká na ně „za rohem“, a když se k němu

\footnotetext{
${ }^{169}$ Jiná (mnohem smysluplnější) edukační situace by nastala v př́padě, že by učitel $\mathrm{v}$ zadání úkolu dal podnět $\mathrm{k}$ této inovaci, tj. k žánrové transformaci zábavné rozprávky do sci-fi. V reflexi žákovy exprese by se pak vyhodnocovaly změny textu na pozadí jednak jeho původního tvaru, jednak žánru, do kterého měl být přepsán.
} 
dostatečně približí, vyskočí ze svého úkrytu a bafne tak silně, že je z leknutí „trefí šlak“.

Druhý vybraný výstup reprezentuje všechny výsledky tvůrčího psaní, v jejichž obsazích se opakovaly motivy bafnutí, leknutí, šoku. I tyto výstupy narušují smysl původního textu, nebot̉ Enšpíglovo šibalství (i to, které není založeno na slovním humoru) je vždy promyšlené, propracované (zkrátka sofistikované) a primárně není namířené proti starým, bezbranným, slabým. Enšpígl si ve svém humoru bere na mušku lakotu, chamtivost, hloupost, nabubřelost či bezpráví. Avšak vzhledem $\mathrm{k}$ tomu, že interpretace textu ani reflexe tvůrčích výstupů neproběhly (jenom jejich četba), zůstalo dané dílo (co do porozumění) žákům uzavřeno. ${ }^{170}$ Význam tvůrčích metod se tak devalvuje, nebot’ se oproti původnímu záměru (pomoci s pochopením díla) posunuje k samoúčelné zábavnosti.

Žákovský výstup 3:

Enšpígl vykope velkou jámu, kterou zamaskuje větvemi a listím. Schová se za strom a čeká na svou obět. Když se lapenému dostatečně vysměje, pokračuje ve svém putování, aniž by mu pomohl z pasti ven.

Třetí vybraný výstup zastupuje obdobné výsledky tvůrčího psaní, $\mathrm{v}$ jejichž obsazích se opakoval motiv pasti, nástrahy. Ale ani takto laděné výstupy nekorespondují s intencí původního textu, poněvadž pasti, které Enšpígl líčí, nejsou pastmi v doslovném smyslu slova, nýbrž pastmi, které tkví v povaze konverzačních situací.

\footnotetext{
${ }^{170} \mathrm{~V}$ souvislosti $\mathrm{s}$ tím lze hovořit o „utajeném poznáváni“", které je v konkrétním případě zapříčiněné absencí reflektivní, resp. znalostní stránky učení. „Utajené poznávání", jehož záporným metodologickým důsledkem je „vyprazdňování obsahu“, sleduje napřič obory autorský kolektiv Jana Slavíka (2017, s. 386-397). Tento dysfunkční didaktický formalismus připomínají též Dominic Jačka a Petr Pánek (viz zde, s. 92).
} 
Zmíněné výstupy svědčí o nepochopení literárního díla a potvrzují výše řečené - to, že tvůrčí metody nejsou samospásné. Nejenže bez reflexe četby, nebo dokonce i bez reflexe žákovy exprese nemusí tyto metody přispět k porozumění díla, ale mohou dokonce od tohoto porozumění žáka vzdálit. A přitom by $\mathrm{k}$ smysluplnému užití vybrané metody stačilo tak málo. Zaprvé: Zasadit povídky (zábavné rozprávky) do dobového kontextu (př́iběhy o Enšpíglovi byly poprvé vytištěny v 15 . století, ale v ústním podání kolovaly již dříve) a spojit je s folklorním původem. Ani jedno, ani druhé se totiž z textu nevyčte. Zadruhé: Na pozadí těchto informací pak vést $s$ žáky rozhovor o díle.

Např́klad: Kdy se děj odehrává, už zhruba víme. Ted'k mistu. Kde (ve které zemi) se děj odehrává a podle čeho tak soudíte? (Při mapování Enšpíglovy cesty je sice možno využít mezipředmětové vazby na zeměpis, ale neměly by zastínit interpretační přístup k textu.) Co vás při četbě nejvíce zaujalo, pobavilo? A proč? Co je zdrojem těchto komických situací? (Při objevování principů jazykové a situační komiky lze do výuky začlenit vnitropředmětové vztahy s jazykovou výchovou, objevovat tak podstatu polysémie a frazémů, jejichž doslovné chápání se stává nástrojem protagonistovy hry.) ${ }^{171} \mathrm{Jak}$ byste na základě těchto situací charakterizovali Enšpígla? Proč Enšpígl chápe příkazy svých nadřizených doslova? Co ho $k$ tomu vede? (Zde je možné objevovat nejen protagonistův charakter a motivace jeho chování, ale také způsoby charakteristiky postavy, tj. situační charakteristiku jako typ charakteristiky nepřímé.) $)^{172}$

\footnotetext{
${ }^{171}$ Důležitost smysluplného (tedy ne mechanického) provázání jazykové, komunikačně-slohové a literární složky předmětu podtrhuje David Franta (viz zde, s. 296). V kontextu LV (při práci s uměleckým textem) vysvětluje potenciál vnitropředmětových vztahů na významotvornosti kondicionálu v Goethově dramatu Faust.

${ }^{172}$ Tyto a jiné otázky jsou zahrnuty do metodické př́ručky učitele, která nabízí náměty $\mathrm{k}$ řízenému čtení a $\mathrm{k}$ tvořivému uchopení vybraných textů z ročníkově korespondující čítanky. Srov. LEDERBUCHOVÁ, Ladislava; BERÁNKOVÁ Eva. Čítanka: př́ručka učitele pro 6. ročník základní školy a primu víceletého gymnázia. Plzeň: Nakladatelství Fraus, 2003, s. 77-78.
} 
Při vyvozování charakteru titulní postavy lze vyjít i z jejího jména. Jméno Enšpígl je počeštělou variantou německé složeniny Eulenspiegel. „Die Eule“ znamená sova, která svými významy odkazuje k moudrosti (zde k chytrému bláznovi). „Der Spiegel“ znamená zrcadlo. To, jak tento motiv v protagonistově jméně bude uchopen, záleží na čtenáři. Učitel se může ptát: Čemu Enšpígl svým humorem nastavuje zrcadlo? Nabízí se odpovědi typu lidským chybám, nešvarům, hlouposti. Pokud by žáci měli k dispozici více informací (učitel by jim převyprávěl např́klad ještě dva př́iběhy), mohli by z těchto obsahů vyvodit i to, že si Enšpígl tropí žerty vždy z těch, kteří disponují majetkem a společenským postavením (z vrchnosti, sedláků, mistrů-řemeslníků, hostinských), a svými uličnickými kousky jim způsobuje hmotné škody. Zrcadlo tak může ukazovat to, co lidový člověk chtěl vidět. Chudý člověk může svým selským rozumem přelstít boháče, a dokonce i z jeho ztrát těžit. ${ }^{173}$ Enšpígl de facto připomíná novelisticky koncipované hrdiny lidových pohádek. $\mathrm{K}$ tomuto rozhovoru by tak daly podnět mezipředmětové vztahy s německým jazykem, případně pak komparace s novelistickou lidovou pohádkou, pakliže byla v předchozích hodinách LV již poznána.

Až v tomto momentu - v konkretizační fázi recepce - se nabízí začlenění tvưrčího psaní na zadané téma. Teprve žák, který pochopil protagonistův charakter a podstatu zobrazené komiky, může ve svém vlastním textu rozvinout poetiku autorova textu. Pokud by se před tvůrčí činností realizovala reflexe četby, jejímž prostřednictvím by se usměrnilo a prohloubilo žákovo vnímání díla, nebo pokud by bylo alespoň vysvětleno, že v tvưrčím psaní se má navázat na povahu autorova textu, jistě by se žáci při domýšlení Enšpíglova př́iběhu vyvarovali výše zmíněných excesů.

\footnotetext{
${ }^{173}$ Lidovou tvorbu (pro mládež upravenou lidovou knížku) o Enšpíglovi komentuje a do historických souvislostí zasazuje Bohumila Grögerová. Srov. GRÖGEROVÁ, Bohumila. Slovo k čtenáři. In KOLÁŘ, Jiř́; HIRŠAL, Josef. Enšpígl. Praha: Albatros, 1992, s. 135-140.
} 
Někdo by mohl namítnout, že estetických obsahů textu se lze zmocňovat i intuitivně bez korigujících zásahů a podnětů učitele. Ano, ale ve třídě s cca 20 žáky se to povedlo jen jednomu z nich.

Žákovský výstup 4:

Fouká vichr a schyluje se k bouřce. Enšpígl na své cestě narazí na sedláka, který po rozlehlém dvoře hledá větrem odnesený doklad od právě koupeného konè. Sedlák na otázku, co dělá, si postěžuje: „Hledám jehlu v kupě sena.“ Enšpígl se ochotně nabidne, že mu s hledáním pomi̊že. Vyskočí na vi̊z, na němž je naloženo seno, které právě svezli z louky, a všechno ho vyhází. Potom ho začne prebírat a rozhazovat po dvoře. Na otázku, co dèlá, odpoví: „Hledám tu jehlu. "Než ho stihne sedlák vykázat, začne pršet a seno zmokne.

Tento mimořádně zdařilý žákovský výstup, který jde po významech původního textu, nebyl ze strany učitele ani žáků nijak komentován, de facto byl postaven na stejnou úroveň jako výstupy jiné. I talentovaným žákům tak zůstává utajeno historické pozadí textu, poněvadž to nelze odkrýt tvůrčí činností. Žák se tak nedozví, že př́iběhy o šprýmaři Enšpíglovi jsou dokladem folklorní tvorby (stejně jako pohádky nebo pověsti), tj. způsobu myšlení prostého středověkého člověka, který si jadrným humorem ulehčoval tvrdý život, jinými slovy že se nejedná o námětově původní dílo Koláře a Hiršala. Opravdu by šlo při zprostředkování této informace o přetěžování žáka literárněhistorickými poznatky?

To, co stojí v cestě efektivně a kreativně vedené LV, není nedostatek nebo neznalost tvůrčích metod, ale nezvládnutý způsob práce $s$ nimi. Uplatnění metod $\mathrm{v}$ čtenářsky orientované $\mathrm{LV}$ je vázáno na poetické zvláštnosti textu, de facto na učitelovo porozumění textu, 
a v souladu s nimi pak na obsah vytčeného učiva. Jinými slovy: dobrým učitelem-didaktikem není ten, kdo metody zná, ale ten, kdo s nimi umí zacházet. Navíc $\mathrm{v}$ expresivních předmětech, jako je LV, k tomu nestačí jen znalost vědních obsahů, ale i obsahů uměleckých, a těch není možné dosáhnout bez estetického cítění, všeobecného rozhledu a interpretačních schopností učitele. Přesto všechno tu vznikají tendence verbalizované Robertem Čapkem (propagátorem líného učitele), který ve svých přednáškách prosazuje provokativní názor, že není třeba aprobovaných učitelů, jen znalců metod. Názor je to sice líbivý (zřejmě i ekonomicky nosný), ale z didaktického aspektu neakceptovatelný, nebot pro komunikačně (konstruktivisticky) pojatou LV potřebujeme fundované učitele více než kdy dříve.

\section{Strategie líného učitele}

Jedním z didaktických trendů dnešní výuky je strategie líného učitele, který přesměrovává aktivitu $\mathrm{v}$ hodině na žáka. Jde-li o kompetentního učitele, děje se tak v duchu pedagogického konstruktivismu. Žáci se díky tomu podílejí na objevování svého poznání, angažují se při osvojování učiva - znalostí, dovedností, hodnotových orientací, postojů. Ve školní literární komunikaci se stávají spolutvůrci estetického obsahu uměleckých děl. Avšak aby učitel mohl být ve své pedagogické praxi „líný“, musí být nejprve velmi aktivní ve své prrípravě, nemluvě o jeho fundovanosti $\mathrm{v}$ oboru a jeho didaktice. Bez tohoto předpokladu edukace založená na principech líného učitele fungovat nebude.

Jiného názoru je Robert Čapek (srov. 2017, s. 41-43), podle kterého je prríprava líného učitele na výuku snadná a časově nenáročná, de facto se stává záležitostí několika vteřin, maximálně minut. Čapek podle délky učitelovy přípravy dělí metody na 
„schodové“ (jejich prríprava učiteli „trvá pouze cestu z kabinetu po schodech do třídy“) a na "dozorové“ (jejich promyšlení se odehrává „během dozoru o přestávce“). Tato forma učitelovy př́pravy přeorientovává pozornost od učiva $\mathrm{k}$ metodám. Byt obojí spolu úzce souvisí a tvoří kompaktní celek, metody ve výuce líného učitele (toho v podání Roberta Čapka) jednoznačně dominují a učivo je řešeno až druhotně. Metody jsou tak vybírány především pro ně samé - pro jejich zábavnost, kreativnost, hravost, aktivizační funkci.

Ovšem chce-li učitel připravit čtenářsky orientovanou hodinu LV, pak na začátku své př́ípravy nepřemýšlí o metodách, ale o textu, který má být čten. Poněvadž učitel, který chce žáky vést $\mathrm{k}$ četbě s porozuměním, musí textu nejprve porozumět sám. Učitelovo čtenářství by navíc mělo být poučené, tj. opřené o výsledky odborné interpretace (nebo s nimi komparované). Teprve poté co učitel zváží estetický a didaktický potenciál uměleckého textu, poměří ho s čtenářskými zájmy i dispozicemi svého žáka a na pozadí textové nabídky díla vyvodí obsah učiva, může k jeho osvojení promýšlet metodickou cestu (srov. Lederbuchová 2010, s. 135-139). Příprava učitele rozhodně není vteřinová nebo minutová, „schodová“ nebo „dozorová“, neodvíjí se od metod, nýbrž k nim směřuje. Znalost tvůrčích nebo jinak aktivizujících technik tedy sama o sobě ještě nezakládá didaktickou kompetenci učitele.

Podle Roberta Čapka (2017, s. 18-19) však líný učitel neučí dějepis, př́rodopis nebo jakýkoliv jiný předmět (a tudíž nemusí být $\mathrm{v}$ daném předmětu aprobovaný), nýbrž myšlenkové nástroje (a tudíž postačí, aby byl didaktikem znalým metod). Robert Čapek nebere $\mathrm{v}$ úvahu, že učitelova znalost obsahu se ve výuce mění v jeho zásadní nástroj a že teprve s ním přicházejí další nástroje (Hník 2014, s. 145). Propagátor líného učitele ve svých 
provokacích svévolně ignoruje nutnost provázanosti oborových obsahů a metodiky. Podle něj je jedno, jestli je text o Prokopu Holém nebo o žábě. Možná je to jedno u odborného textu, ale rozhodně ne u textu uměleckého. Zvolená forma uměleckého textu je totiž významotvorná a jako taková se podílí na utváření estetického sdělení. Zde není důležité jen to, co text (dílo) říká, ale také to, jak své obsahy utváŕí. Proto výběr metod musí vyrůstat $\mathrm{z}$ tvarových kvalit textu, kterých si je učitel vědom.

Dále je třeba mít na paměti, že inovační LV postavená na metodách tvůrčího myšlení (na tvořivé expresivitě žáka) nerezignuje na poznatky, jak se někdy mylně myslí a jak připomíná Ondřej Hník (srov. 2014, s. 41), jen se k nim dostává jinou cestou a v souladu s tím proměňuje jejich charakter, namísto literárněhistorických poznatků ( $v$ tradiční výuce výkladově zprostředkovaných) preferuje ty literárněteoretické či estetickovýchovné. Například připraví-li učitel do hodiny LV práci s metodou vypravěčské transformace, pak to musí být v prvé řadě on, kdo si uvědomuje, jakým způsobem je vybraný text narativně konstruován (kterým vypravěčem, $\mathrm{z}$ jaké perspektivy, zda $\mathrm{v}$ textu převažuje řeč postav nebo vypravěče a s jakým tvůrčím záměrem se tak děje), aby tyto odborné informace mohl transformovat do učiva. ${ }^{174}$ Avšak Robert Čapek ve svých přednáškách proklamuje, že učivo není důležité, podle něj je pouhou záminkou k práci žáků ve tř́ídě,

\footnotetext{
${ }^{174}$ Metodou vypravěčské transformace se v pedagogickém výzkumu zabývala Štěpánka Klumparová (srov. 2013, s. 321-344), která aplikaci metody ve vyučování LV podmiňuje literárněvědní a didaktickou odborností učitele (jeho znalostí poetiky textu, schopností analyzovat nejen autorovo dílo, ale i žákovy rekonstrukce tohoto fikčního světa a nakládat $\mathrm{s}$ nimi tak, aby byly přínosné pro výuku LV). Výsledky autorčina výzkumu prokázaly, že žáci sice intuitivně změny vypravěčské perspektivy provedou, ale pouze někteří jsou schopni si je také uvědomit a pojmenovat. Proto podle Klumparové by měla být velká pozornost zaměřena na reflexi, při níž učitel díky své fundovanosti pomáhá žákům porovnávat jednotlivé verze transformací, diskutovat nad nuancemi, které se v nich objevují, a vyhodnocovat jejich důsledky pro významovost díla (celkové vyznění fikčního světa).
} 
tj. k nácviku měkkých dovedností (soft skills). ${ }^{175} \mathrm{~K}$ tomu je potřeba podotknout následující.

Zaprvé: Učivo nelze oddělovat od měkkých dovedností žáka. Soft skills jsou nedílnou, velmi důležitou součástí učiva (toho nadoborového). Jejich obsah se de facto př̌krývá s obsahem klíčových (univerzálních) kompetencí, tj. s komunikačními dovednostmi, s kritickým a tvưrčím myšlením, se schopností kooperovat, respektovat názor druhého, vhodně argumentovat, být ochoten učit se novým věcem, podílet se na řešení problému.

Zadruhé: Způsob rozvíjení měkkých dovedností je (má být) ve výuce úzce svázán se specifickou povahou (i se specializovaným pojmovým aparátem) předmětu, tj. $s$ utvářením a rozvíjením oborových znalostí. ${ }^{176}$ Např́íklad při rozvíjení kompetence $\mathrm{k}$ řešení problémů si žák v konstruktivisticky pojaté LV osvojuje nebo upevňuje literárněteoretickou terminologii coby kognitivní nástroj myšlení (nástroj textových analýz), proniká $\mathrm{k}$ principům významové výstavby uměleckého textu, dobírá se smyslu konkrétního díla a zároveň zaujímá postoje např́ílad k etickým dilematům postav. $\mathrm{V}$ takto vedeném literárněvýchovném procesu žáci komunikují, verbalizují své názory, snaží se argumentovat, rozvíjejí své kritické nebo tvůrčí myšlení (podle povahy zařazených metod), ale nic $\mathrm{z}$ toho se neděje (nemá dít) samoúčelně (pouze pro hru samu nebo pro nácvik soft skills), vše je vázáno na literární nebo neliterární problém vyplývající z textové situace díla, tedy na poznatkové nebo na formativní učivo LV.

\footnotetext{
${ }^{175}$ Robert Čapek tento názor prezentoval na přednášce pořádané Západočeskou univerzitou v Plzni, kde promluvil na téma Líný učitel. Srov. https://czv.zcu.cz/linyucitel-robert-capek-na-zcu/

${ }^{176}$ Důležitost integrity kompetenční vrstvy (nácviku soft skills), tematické vrstvy (vstupní žákovské zkušenosti) a konceptové vrstvy výuky (oborové znalosti obsahu) objasňuje Slavíkův model hloubkové struktury výuky (srov. Slavík et al. 2017, s. $338-348)$.
} 
V opačném př́padě, nejsou-li měkké dovednosti propojené s oborovými znalostmi a dovednostmi, především tedy s pochopením literárního díla, se nácvik soft skills stává zástěrkou pro nekompetentní učitele, kteří se zaštitují kreativními metodami. Takoví učitelé korigují pouze komunikační pravidla určená metodou. Nezřídka se stává, že žáci celou hodinu pracují (hrají si) s textem, aniž by mu porozuměli. V té souvislosti se nabízí otázka: Kdo bude ve výuce líného učitele korigovat komunikační pravidla vycházející z uměleckého textu? Kdo pomůže žákům reflektovat a prohloubit jejich čtenářské i tvůrčí výstupy, když aprobovaných učitelů ani časově náročnější přípravy na výuku není třeba?

Další podkapitola nabízí vhled do hodiny líného učitele, v níž žáci po celou dobu samostatně pracovali s uměleckým textem. Ale bez podněcujících otázek učitele (bez frontálně vedeného reflektivního dialogu) a bez potřebných literárněhistorických informací dílo dezinterpretovali, aniž by na tuto skutečnost byli upozorněni.

\section{Př́klad z praxe - Trífázový výukový model E-U-R; metody RWCT (Čtením a psaním ke kritickému myšlení): brainstorming, podvojný deník, pětilístek}

Hospitace proběhla v 8. tř́dě plzeňské ZŠ při výuce LV. Předmětem četby a interpretace byla básnická skladba Karla Havlíčka Borovského Král Lávra. Její zkrácený text (zredukovaný o některé strofy) byl rozdělen na dvě části. První část končila omilostněním Kukulína, který díky matčině prosbě unikl oprátce, tragickému osudu svých předchůdců, a namísto toho se stal dvorním holičem. Druhá část zahrnovala motiv tajemství jednak šeptaného do vrby, jednak vyzrazeného na královském bálu. Oslí uši, které 
už není zapotřebí skrývat, se stávají všeobecně přijatým atributem královské moci. Vybraný text spolu s didaktickým aparátem (navrženými otázkami a úkoly) byl součástí dvou pracovních listů.

Vyučovací hodina byla realizována podle výukového modelu $\mathbf{E}-\mathbf{U}-\mathbf{R}^{177}$. Ve fázi evokace ${ }^{178}$ byla užita metoda brainstormingu, a to na téma pohádka. Učitelka položila otázky: Co všechno vás napadne, když se řekne pohádka? Které postavy v pohádce vystupují? Jak děj v pohádce končí? Pomocí brainstormingu byly sebrány tyto žákovské prekoncepty: příběh pro děti, zámek, princezny, králové, pohádkové bytosti (drak, vodník, čert, čarodějnice, víla), kouzla, boj mezi dobrem a zlem, zápletka, dobrodružství, láska, štastný konec.

Hned v úvodu je třeba poznamenat, že metoda brainstormingu včetně zadání (tématu a $\mathrm{k}$ němu kladených otázek) byla velmi dobře zvolena, nebot’ vyrůstá $\mathrm{z}$ tvarových kvalit textu. Havlíčkova báseň je totiž stylizována do pohádkového vyprávění. Učitel ve své přípravě na výuku si však musí být vědom také satirické povahy textu. Konec př́iběhu nenabízí štastné řešení situace jako v pohádkách, spíše kritizuje krutost samovládců, ale i pasivitu či odevzdanost národa, který trpně přežívá pod vládou těchto zdánlivě dobrotivých mocnářů. Smysluplnost brainstormingové

\footnotetext{
${ }^{177}$ Tř́fázový učební model E-U-R (evokace, uvědomění si významu, reflexe) pomáhá učiteli plánovat výuku tak, aby žák byl do procesu konstruování vlastního poznání zapojen co možná nejefektivněji.

${ }^{178}$ Ve fázi evokace (E) učitel sbírá žákovské prekoncepty - to, co žák o daném tématu ví, nebo co se domnívá, že ví, aniž by tyto výstupy byly korigovány. Evokace lze realizovat různými metodami - brainstormingem, myšlenkovou mapou, volným psaním (brainwritingem), předvídáním (podle titulu, ilustrace, obálky knihy nebo podle klíčových slov). Metodický postup se odvíjí od vytčených cílů, od učiva, kterého má být dosaženo. Takto mapované aktuální žákovy znalosti či zkušenosti se v dalších výukových fázích rekonstruují. Srov. Hausenblas, Koštálová 2006, s. 54-58. Učitelův zájem o dosavadní poznání žáka (zejména přechází-li žák z jednoho stupně školy na druhý) akcentuje s odkazem na humanistické heslo „ad fontes“ Jiří Novotný (viz zde, s. 320).
} 
evokace se projeví jen tehdy, budou-li v další fázi výuky estetické obsahy textu poznávány na pozadí autorovy doby a zpětně vztahovány $\mathrm{k}$ žákovským prekonceptům z úvodu hodiny. Žák si tak uvědomí, že nejde o klasickou pohádku, spíše o satiru převlečenou do pohádky. $\mathrm{V}$ opačném případě ( $\mathrm{v}$ případě nepropojených výukových fází, nadto ahistoricky vnímaného textu) se takto (byt dobře) připravená evokace stává samoúčelnou, jako tomu bylo $\mathrm{v}$ hospitované hodinè.

Fáze uvědomění si významu ${ }^{179}$ byla otevřena metodou podvojného deníku. Tato metoda žákům umožňuje nejprve písemně, poté verbálně reflektovat text. List nebo papír v sešitě si žáci rozdělí svislou čarou na polovinu. Do levého sloupce si poznamenávají ty pasáže, obrazy, výrazy, které je zaujaly. Do pravého sloupce pak píšou důvod, proč je vybrané úryvky zaujaly, komentují, jak jim rozumějí, jaké otázky v nich vyvolávají. ${ }^{180} \mathrm{~V}$ hospitované hodině byla tabulka o dvou sloupcích součástí pracovního listu, nebylo tedy třeba ji vytvářet. Žáci sdíleli své zápisky ve čtyřčlenných skupinách.

Na tomto místě je třeba podotknout, že podvojný deník je výbornou metodou pro otevření komunikace o literárním díle, nebơ ta je díky tomu odvíjena od pasáží, které si vyžádaly žákovu největší pozornost, tj. od prvotního čtenářského zážitku

\footnotetext{
${ }^{179}$ Ve fázi uvědomění si významu (U) se žáci vlastním úsilím dobírají k informacím, pracují s primárními prameny ( $\mathrm{v}$ LV především s uměleckými texty), které metodou didaktické interpretace (ideálně aktivizované metodami tvůrčího psaní, tvořivé dramatiky nebo RWCT) poznávají a na jejich pozadí pak posuzují obsahy svých prekonceptů z úvodní fáze vyučování. Nutno dodat, že tento interpretační přístup může být kombinován s př́stupem informačním a výkladovým, pokud informace potřebné $\mathrm{k}$ pochopení díla nelze $\mathrm{z}$ vybraného textu vyčíst. Avšak výklad by měl být pouze doplňkovou metodou, která ve vztahu k interpretaci plní služební funkci.

${ }^{180}$ POLÁKOVÁ, Irena: Podvojný deník - Popis metody. In Učení bez učebnic. Pro učitele [online]. Občanské sdružení Místo pro život HON [cit. 2020-06-25]. Dostupné z https://www.ucenibezucebnic.cz/index.php?id=516
} 
žáka. Je však vhodné tyto výstupy reflektovat též formou frontální výuky. Zaprvé proto, aby žáci mohli porovnávat své výstupy s názory spolužáků a přitom si uvědomili, že stejné pasáže mohou $\mathrm{v}$ různých čtenářích vyvolávat různé reakce. Zadruhé proto, že učitel vhodně volenými otázkami může korigovat a zároveň prohlubovat vhled do daného díla.

To se ovšem v hospitované hodině nedělo. Učitelka korigovala pouze pravidla daná metodou, nikoliv uměleckým textem. Navíc do zkrácené první části Havlíčkovy básně paradoxně nezahrnula její první strofu, kde se objevují stylistické figury typické pro pohádkovou naraci. ${ }^{181}$ Textová ukázka začala až strofou třetí. ${ }^{182}$ Předchozí brainstorming na téma pohádka tak do jisté míry pozbýval svého smyslu, poněvadž žáci pracovali s textem, v němž chyběly právě ty informace, které navozovaly vstupní pohádkovou atmosféru. Součástí pracovního listu k první části textu byly vysvětlivky $\mathrm{k}$ zastaralým nebo méně frekventovaným slovům (rekrutýrka, chasa, letnice, baldachýn), již zmíněná tabulka k podvojnému deníku a na ni navazující otázky: Jaké vlastnosti má král? Co asi skrývá pod vlasy? Myslišs, že Kukulín dokáže královo tajemství udržet? Jak se cítís, když znáš cizí tajemství? Máš potřebu se o něj podělit? Jak vidno, otázky jsou navrženy tak, že $\mathrm{v}$ rozporu s výzvami textu přesměrovávají čtenářovu pozornost od titulní postavy, příp. od poetiky žánru k psychologickému aspektu tajemství.

Z pozice hospitujícího jsem měla možnost naslouchat jedné skupině, tj. čtyřem žákům. Žákovské výstupy zde uváděné jsou výsledkem parafráze. Metodou podvojného deníku byly získané

\footnotetext{
${ }^{181}$ Byltě jednou jeden / starý dobrý král, / ale je to dávno, / taky od Čech dál, / troje moře, devatery hory / děli kraj ten od české komory, / kde on panoval.

${ }^{182}$ Posud krále Lávru / chválí irský lid, / nebyl ani tyran, / nebyl taky žid, / nenabijel cizím svoji kasu, / rekrutýrkou nesužoval chasu, /nedal chudé dřit.
} 
tyto žákovské výstupy: Zaujalo mě, že král dlouhé vlasy „nosil jak roj včel“. Je to hezké přirovnání. Král měl zřejmě hodně objemné vlasy. // Nejvíce mě zaujala sloka, která začíná slovy: „Padl los, ach, padl:", a to pro svou napínavost. Los rozhoduje o životě a smrti. // Mě upoutala sloka se šibenicí. Je dost strašidelná. Za službu se platí penězi, ale tento král dává trest smrti. // Mě nejvíce zaujala prosba vdovy, je velmi emocionální, dokáže v královi vzbudit lítost a soucit. A taky mi přijde zvláštní zápletka - holení krále. Je taková rutinní, fádní. Čekala jsem něco dobrodružného, třeba vysvobozování princezny.

Na připravené (výše zprostředkované) otázky žáci odpovídali následovně: Nevím, jestli byl král Lávra hodný, nebo zlý. Nebyl sice tyranem, ale pravidelně popravoval holiče. // Král Lávra byl spravedlivý $k$ lidu - neverboval mladé muže do války, ale byl krutý $k$ holičưm. // Lávra byl hodný, uctivý $k$ chudým lidem, netrápil je, byl to poctivý král, který nikoho neokrádal. Jen byl tajemný. Zabijel pro něco, co na sobě neměl rád, za co se styděl. A nechtěl, aby se o tom šiřily zprávy. // Král Lávra byl dobrosrdečný, hodný, milý, ke svému lidu spravedlivý. Ale dělal unáhlená rozhodnutí. Nepromýšlel následky nařizených poprav. Nedošlo mu, že poddaní ho nebudou mít po čase rádi. // Král pod vlasy skrývá šišatou hlavu nebo nějakou nepěknou vyrážku, špínu, která se nedá vymýt, nebo vši anebo růžky, třeba je to čert $v$ prevelečení, který se bojí prozrazení. Každopádně skrývá něco strašného, za co se stydí. // Nevím, jestli král udělal dobře, že nechal Kukulína naživu. Co když se někde podřekne? // Já si myslím, že tajemství udrží. Strach ze smrti ho přiměje mlčet. // Možná ze začátku ano, ale pak tajemství někomu řekne. // Když mám nějaké tajemství já, tak se svěřím kamarádovi a řeknu mu, at to nikomu neříká. Uleví se mi, ale zase mám strach, že kamarád to poví někomu dalšímu. // Krátkou dobu cizí tajemství udržím, ale pak ho potřebuji někomu říct. Chci se s ním pochlubit, abych vypadala di̊ležitě. 
Výstupy získané metodou podvojného deníku svědčí o vnímavosti žáků, kteří z básně vybrali esteticky zajímavá nebo dějově poutavá místa a kteří Havlíčkův text intuitivně (bez pobídky učitele) srovnávali s tím, co od pohádky očekávají. Ovšem není možné na tyto a další odpovědi, které víceméně mapují doslovnost textu, $\mathrm{v}$ jednom prrípadě dokonce straní nemorální brutalitě (nevím, jestli král udělal dobře, když nechal Kukulína naživu), zredukovat poznávání první části Havlíčkovy básně. Obzvláště ne, vyznačují-li se čtenářské prekoncepty žáků rozporuplností. Právě v ní lze najít motivační východisko pro poznávání díla, pro vypátrání příčin této protichůdnosti, a to na pozadí fikčního i reálného světa. Velmi podnětným výstupem je ten, $v$ němž se žákyně intuitivně dotýká hlouposti, lépe řečeno krátkozrakosti krále, který nedomýšlí následky svého krutého jednání. Učitel by měl tyto výstupy (pro jejich zajímavost, kognitivní potenciál, významovou protichůdnost) frontálně reflektovat, klást $\mathrm{k}$ nim otázky, tj. umět se doptávat tak, aby žáka vracel zpět k textu a nasvěcoval mu jeho hlubší patra.

Frontální výuka, která je líným učitelem upozad’ována, je však nenahraditelná zejména při reflexi výstupů získaných metodami tvưrčího nebo kritického myšlení. A právě $\mathrm{k}$ té reflexi je potřeba kompetentních učitelů, kteři rozumějí uměleckému textu a jeho kontextům.

Návrh na alteraci: V reflektivním dialogu se učitel může ptát (lépe by bylo, pokud by žák měl k dispozici první dvě strofy nebo alespoň tu první): Jaká atmosféra či nálada je vzbuzována $v$ úvodu básně? Jak je zde ličen král Lávra? Jak s tímto obrazem dobrého krále korespondují informace $z$ dalších slok? Může být ten, kdo pravidelně posílá nevinné na šibenici, dobrým králem? Proč se tedy o něm hovoři jako o dobrém králi? Proč se věci nepojmenují pravým jménem? Kdybyste vy vyprávěli tento př́běh, nazvali byste královu 
ukrutnost slabostí? Řekli byste jako vypravěč: „jenom jednu slabost / ten král dobrý mèl"? Slabostí se zde myslí nějaká slabá stránka člověka. Pro co máte slabost vy? Dá se slabost pro čokoládu srovnávat se slabostí pro šibenici? Proč tedy vypravěč užil právě tento výraz, a ne jiný? Jaký postoj skrze něj vyjadřuje k zobrazené situaci? Učitel tak konstruktivistickou cestou vede žáka k poznání ironického, až sarkastického (silně výsměšného) tónu básně, který v hospitované hodině nebyl žáky objeven (pocitován), ale který je důležitý pro pochopení díla. Čtenář totiž při jeho rozklíčování přestává věrit pozitivním atributům krále, uvědomuje si kritiku daných poměrů. Dále se učitel může ptát: Proč vypravěč v pohádkově laděné písni, jejiž dějiště je zasazeno za troje moře a devatery hory, zmiňuje Čechy? Jak Čechy souvisí se zemí krále Lávry? Pokud by si žáci nevěděli rady s těmito posledními otázkami, nevadí, je možné se $\mathrm{k}$ nim vrátit (nebo je položit) až po přečtení celého textu, v momentu, kdy budou objasněny historické souvislosti, za nichž dílo vznikalo.

Pracovní list č. 2 obsahoval zkrácenou verzi druhé části Havlíčkovy skladby. Žáci v týchž čtyřrčlenných skupinách opět pracovali metodou podvojného deníku a poté zodpovídali následující otázky zahrnuté do pracovního listu. Proč Kukulín svěřil tajemství staré vrbě? Jak byste vysvětlili rčení: „člověk se chodí vypovídat vrbě“? Co král skrýval pod vlasy? Jaké poučení z př́běhu plyne? Proč jde o pohádku? Žákovské výstupy zde uváděné jsou opět výsledkem parafráze.

Metodou podvojného deníku byly získané tyto žákovské výstupy: Nejvíce mě zaujal zázrak - způsob, kterým se tajemství rozšírilo mezi lidi. // Mile mě prekvapilo, že se král nemstil. Myslela jsem, že nechá popravit všechny, kdo byli na plese. // Mě nejvíce zaujalo, že se král za oslí uši už nestyděl. Myslel jsem, že bude zapírat, že pravdu na sobě nenechá znát. // Já jsem byla ráda, že se lidé králi nesmáli, že ho přijali i jako ušatce. 
Na otázky položené k textu žáci odpovídali následovně: Kukulín se vypovídá staré vrbě, poněvadž se potřebuje zbavit tíhy tajemství, ale zároveň chce mít jistotu, že se o tom nedozví ostatní. // Rčení o vrbě jsme nikdy předtím neslyšeli. Ale myslíme si, že vrbou je někdo, komu se můžeme vypovídat ze svých smutků, starostí. Nějaký důvěrný, blízký přitel. Někdo, komu věřme. // To je důvod, proč mi vrba prijide nemorální. Tajemství („a už vůbec ne taková“) by se neměla vykřikovat do světa. // Poučení 1: Nemá se vyzrazovat tajemství. Tady to náhodou dopadlo dobře, ale mohlo to dopadnout $i$ špatně. // Poučení 2: Nemáme se stydět za své vady. Kdyby Vávra i nadále nosil dlouhé vlasy, lidi by se mu smáli - ne pro oslí uši, ale pro přetvářku. Takhle jim oslí uši př̀išly po čase normální. Je dobré umèt se povznést nad vlastní nedokonalost. // Poučení 3: Když nás něco trápí, je dobré se někomu svěrit. Život bez tajemství je klidnější. Kukulínovi i králi Lávrovi se ulevilo, když už nemuseli nic skrývat. // Poučení 4: Lež má krátké nohy. Pravda vždycky vyjde najevo. // Jde o pohádku, protože v ní vystupuje král, ten má oslí uši, to je v životě nereálné, dále se zde objevuje kouzelná vrba, diky níz se dějí zázraky (basa vyřve tajemství), a príběh končí štastně. Král zmoudřel, prriznal sobě i ostatním nedostatky, stal se dobrým panovníkem. // Král mohl skončit hưr̆, lidé ho mohli vyhostit. Ale protože se tak nestalo, př́běh končí štastnè. // Přesto o klasickou pohádku pro malé děti nejde. Př́běh je temný. Král popravuje holiče. Děti by se mohly bát.

Žáci o textu vytrženém $\mathrm{z}$ historických souvislostí a bez podnětů ke strukturnímu čtení přemýšleli v logice jeho doslovnosti. Na této čtenářské úrovni dokázali, že jsou schopni analytického myšlení i následného zobecnění, že mají předpoklady $\mathrm{k}$ tomu, aby dílu př̀i správném didaktickém vedení porozuměli. $\mathrm{V}$ jejich výstupech je cítit velký kognitivní potenciál, který mohl být (ale nebyl) rozvinut. Ačkoliv jsou čtenářské názory žáků argumentačně (navíc i logicky) opřené o text a životní zkušenosti (o morální 
imperativy), v tom zásadním se zcela rozcházejí se záměrem textu. Tuto dezinterpretaci nejvýrazněji demonstruje odpověd: Král mohl skončit hưr̆, lidé ho mohli vyhostit. Ale protože se tak nestalo, př́iběh končí štastně. Žákovské výstupy (nereflektované a nekorigované učitelem) svědčí o nepochopení literárního díla.

Přestože žáci celou hodinu pracovali s textem, komunikovali o něm, argumentovali svými čtenářskými i životními zkušenostmi, navzájem se respektovali, jinými slovy posilovali tolik žádané soft skills, má zvolený edukační proces jednu slabinu (obdobně jako král Lávra u Havlíčka). Žáci Havlíčkovu satiru nepochopili (ostatně ji v básni ani neobjevili) a jejich interpretační úsilí paradoxně vedlo $\mathrm{k}$ „Zavádějícímu poznávání ${ }^{\text {“183 }}$.

Král byl ve čtenářských konkretizacích žáků vnímán jako hrdina, který se už nestydí za svůj vzhled, dokáže ho přijmout a své oslí uši ukázat celému světu. To, co v básni znamená pád královského majestátu, de facto jeho karikaturu, bylo žáky naopak vyloženo jako jeho vzestup. Od takto dezinterpretovaného (zdánlivě štastného) konce byl vyvozen žánrový aspekt pohádky, přestože právě závěr vyprávění ruší etický řád pohádek. V satirickém podtextu se totiž ukazuje faleš nastolené idyly - jednak samolibost vládců, kteří už nezastírají hloupost, ta se naopak stává veřejným atributem koruny (úřadu), jednak rezignaci národa, který přivykl na krutou směšnost panovníků. Paradoxně to jediné, v čem lze najít štastný konec (fakt, že pravda o samovládci vešla v širokou známost), bylo podle některých hodno morálního odsouzení (tajemství by se neměla vykřikovat do světa). Jiný žák $\mathrm{v}$ rozporu s tím došel k poznání, že pravda vždycky vyjde najevo.

\footnotetext{
${ }^{183}$ „Zavádějící poznáváni“ je autorským kolektivem Jana Slavíka (srov. 2017, s. 397) vykládáno jako zvláštní odnož „utajeného poznávání. Tímto termínem jsou označovány edukační situace, $\mathrm{v}$ nichž si žák osvojuje chybné koncepty rozcházející se s aktuálními vědeckými poznatky oboru.
} 
Avšak kognitivní konflikt v daných žákovských výstupech nebyl reflektován a nedal tak podnět $\mathrm{k}$ novému zamyšlení o díle, $\mathrm{k}$ přehodnocení čtenářských názorů nedošlo. Nikdo z žáků se z vlastní iniciativy nepozastavil nad symbolikou oslích uší, nad znakem hlouposti na korunované hlavě. Žáci při ahistoricky vnímaném textu víceméně ustrnuli na jeho denotativních významech a v př́íběhu krále s oslíma ušima spatřovali téma (sebe)přijetí člověka se všemi jeho nedostatky. Tomu přisoudili happyend, a bezděky tak přestrukturovali původní významovost díla.

V reflektivním dialogu je třeba žáky vést k poznání, že král Lávra není žádným hrdinou, lidumilem ani dobrákem, a kdyby mohl, oběsí i tu basu (bylo však již pozdě / basu oběsit). Žáky by mělo udivovat ne to, že král nikoho neposlal na šibenici, ale to, že poddaní se nepokusili svého panovníka svrhnout a nahradit ho jiným, lepším. Možná závěr skladby skýtá naději na absolutistickou vládu s lidskou tváŕí. Ale tato naděje je pouhou maskou pohodlného zvyku. Národ dlouho podřízený císařům a králům se bouřit nechce, je lepší trpně přežívat pod mocnáři, kteří jsou alespoň schopni soucitu (viz ušetřený Kukulín), než mít ambice tuto situaci změnit (velká věc je zvyk!).

Návrh na alteraci: V reflektivním dialogu se učitel může ptát: $K$ čemu odkazují oslí uši? Co znamená rčení „být oslem“? Znáte antický príběh o králi Midasovi? Co mají společného král Midas a král Lávra? Je tedy Havličkưv př́běh o králi Lávrovi námětově pưvodní? Proč se lidé s vládou ušatce smiŕili? Jak na vás pusobí verš: „velká věc je zvyk!"? V době, kdy Havlíček psal Krále Lávru, byly Čechy součástí mnohonárodnostní habsburské monarchie. Co vite o politické situaci českých zemí v polovinè 19. století? ${ }^{184}$

\footnotetext{
${ }^{184}$ Další (zase jiný, o tvořivou metodiku obohacený) návrh na interpretační prrístup k Havlíčkově básni (také akcentující reflexi politických okolností, za nichž báseň vznikala) prezentuje Ladislava Lederbuchová $(2004$, s. 68) v Čítance 7: prŕručce učitele pro základní školy a víceletá gymnázia.
} 
Při komunikaci s daným dílem jsou mezipředmětové vazby na dějepis nevyhnutelné. Učitel však posiluje žákovo historické povědomí jen do té míry, která je nutná k pochopení Havlíčkova odkazu. Z této exkurze do historie by měly vyplynout důvody Havlíčkova nedobrovolného pobytu v tyrolském Brixenu, kde také vznikla satirická báseň Král Lávra. Autor k ní našel inspiraci v irské lidové pohádce s midasovskou látkou. Nejde o to žáky zahlcovat literárněhistorickými informacemi o autorovi a jeho díle, ale je zapotřebí, aby žák chápal okolnosti vzniku díla, jehož autor byl za odbojovou činnost proti vládě a císaři (za politickou satiru) uklizen do vyhnanství. ${ }^{185}$

Povědomí o autorovi a jeho době lze posílit i atraktivně, tj. mezipředmětovou vazbou na hudební výchovu, a to písní Karel Havlíček Borovský od punk rockové kapely E!E. Samozřejmě nestačí pustit song, ale také je potřeba okomentovat jeho text. V první sloce se zpívá: Karla Borovskýho / chválil českýlid / protože se nedal nikým zastrašit / a že žádal na vrchnosti změnu / poslali ho šupem do Brixenu / aby měli klid, aby měli klid. Ve druhé sloce se pak objevují výstižné verše: nebaví ho mučednická role / radši by byl mezi lidmi dole. Havlíček netoužil po nálepce mučedníka, nýbrž po publiku, pro které by psal politickou satiru a od kterého byl odtržen Alexandrem Bachem, ministrem vnitra. Jak vidno, punk kapely E!E má s Havlíčkem mnoho společného. Prostým, ale silným (zde navíc i chytrým) textem a jednoduchou, chytlavou melodií tne do živého.

Fáze uvědomění si významu byla završena pětilístkem, další metodou kritického myšlení. Pětilístek připomíná báseň o pěti

\footnotetext{
${ }^{185}$ Podle Marie Řepkové (1971, s. 131) může (nemusí) postava krále Lávry odkazovat k rakouskému císaři a českému králi Ferdinandu I. Dobrotivému. Řepková (ibid., s. 132) ale také píše, že pohádkovost dodává satirickému vyobrazení obecné, nadčasové platnosti a dovoluje vždy nové konkretizace. Současní čtenáři si tak za krále Lávru mohou dosadit i jiné představitele státu než ty z Havlíčkovy doby.
} 
řádcích. Žáci podle předem daného schématu vyjadřují svůj postoj $\mathrm{k}$ tématu. První řádka nese jednoslovné téma (obvykle jméno postavy). Druhá řádka popisuje téma dvěma přídavnými jmény, vystihuje jeho podstatu. Třetí rádka rozvíjí dějovou složku tématu prostřednictvím tří sloves. Čtvrtá řádka je verš o čtyřech slovech, která se vztahují k tématu. Jde o významově nosnou, kondenzovanou myšlenku. Pátá řádka završuje podstatu tématu bud' jednoslovným výrazem, nebo pomocí přirovnání, metafory, sousloví či frazému (srov. Koštálová 2003, s. 6-7).

Pětilístek je výbornou metodou pro kultivaci závěrečné (konkretizační) fáze recepce. Žáci svým vlastním textem reagují na autorův text, vyjadřují svůj názor na něj. $Z$ předchozích čtenářských výstupů abstrahují závěry o titulní postavě. $\mathrm{V}$ tomto smyslu výstupy získané zmíněnou metodou poskytují učiteli zpětnou vazbu, říkají mu, jak a do jaké míry žák dílu porozuměl. Metoda pětilístku mapuje výsledky literární komunikace, učí žáka zobecňovat a jít $\mathrm{k}$ jádru věci, ale sama o sobě nenaviguje $\mathrm{k}$ hlubšímu vnímání díla (a pokud ano, jen ojediněle). Níže předkládané pětilístky jsou výrazem čtenářské konkretizace (zde dezinterpretace) díla, ilustrují to, čemu žák při četbě básně přisoudil největší význam.

\begin{tabular}{|c|c|}
\hline Král Lávra & Král Lávra \\
\hline spravedlivý krutý & hodný tajemný \\
\hline panuje stydí se soucítí & lže panuje rozhoduje \\
\hline $\begin{array}{l}\text { Byl to zvláštní panovník. } \\
\text { dobrota }\end{array}$ & $\begin{array}{l}\text { Lež má krátké nohy. } \\
\text { překvapení }\end{array}$ \\
\hline Král Lávra & Král Lávra \\
\hline $\begin{array}{l}\text { soucitný moudrý } \\
\text { stydí se zabíjí odpouští }\end{array}$ & $\begin{array}{l}\text { dobrosrdečný spravedlivý } \\
\text { vládne popravuje unáhluje se }\end{array}$ \\
\hline $\begin{array}{l}\text { Je důležité umět odpustit. } \\
\text { hurá! }\end{array}$ & $\begin{array}{c}\text { Neřeší, co způsobí popravami. } \\
\text { napětí }\end{array}$ \\
\hline
\end{tabular}


Ve fázi reflexe ${ }^{186}$ byly položeny tyto otázky: Co si $z$ dnešní hodiny odnášíte? Co jste se dozvěděli nového? Která metoda vás bavila? Žáci, kteří smyslu básně neporozuměli (ale to oni nevěděli), paradoxně odpovídali: Básničkám většinou nerozumím, ale tahle se mi líbila, byla jednoduchá na pochopení, měla prostý text. // Dozvěděla jsem se něco dalšího o pohádkách. Překvapilo mě, že nemusí mít jen „velké, dobrodružné zápletky“, ale i „zápletky $z$ obyčejného života“. // Žáky nejvíce bavila metoda pětilístku.

\section{Shrnutí}

Aby idea pedagogického konstruktivismu, podle níž se mají žáci aktivně angažovat ve vlastním procesu učení, byla ve výuce smysluplně realizována, potřebuje více než kdy dřive schopného, kompetentního učitele znalého svého oboru, nikoliv jen metod. Robert Čapek, propagátor líného učitele, se sice odvolává na principy pedagogického konstruktivismu, ale forma, kterou je prezentuje a převádí do výuky, je neakceptovatelná. Není možné jeden extrém - frontální, faktograficky zaměřenou výuku postavenou na výkladu mýtit druhým extrémem - adorací metod a upozad’ováním učiva.

To, co stojí v cestě dobře a efektivně vedené LV, není nedostatek nebo neznalost tvůrčích či jinak aktivizujících metod, ale jejich separace od oborového učiva ( $v$ LV zejména od estetického obsahu textu a jeho kontextů), tedy nefundovanost učitele, který sám $\mathrm{k}$ podstatě díla nepronikl. V konstruktivisticky pojaté LV jsou (by měly být) kreativní metody (tvůrčího psaní, tvořivé dramatiky) vybírány vždy s ohledem na záměr textu - jinými slovy tak, aby

${ }^{186} \mathrm{~V}$ reflexi (R), závěrečné fázi třífázového modelu učení, žák formuluje závěrečné pochopení vlastními slovy, nově získané poznatky propojuje s předchozími. Reflexe se netýká jen výsledků učení (o čem jsme se učili), ale též procesu učení (jak jsme se učili). Více Hausenblas, Koštálová 2006, s. 67-69. 
žákovi pomohly s pochopením literárního díla nebo s porozuměním principům významové výstavby textu. Tento primární důvod jejich zapojení do výuky (ukotven i v kurikulárních dokumentech) by neměl být zastíněn zábavností, na kterou se tyto metody někdy redukují (viz první př́klad z praxe).

Ale ani metody RWCT či pracovní listy vytěsňující frontální komunikaci o díle nejsou samospásné, jak ilustruje druhý př́klad z praxe, a bez erudovaného (korigujícího) vedení učitele nezaručí pochopení literárního díla, dokonce mohou přispět $\mathrm{k}$ jeho dezinterpretaci. Je tedy ironií, že Robert Čapek staví do kontrastu (namísto aby integroval) znalosti žáka získané frontální formou výuky (záměrně redukované na výklad) a dovednosti či postoje žáka získané ve výuce líného učitele, který „metodikaříc. Žáci $\mathrm{v}$ hospitované hodině líného učitele totiž nenabyli ani znalosti (literárněteoretické či literárněhistorické), ani interpretační dovednosti, navíc jejich morální postoje se míjely s estetickým záměrem textu. Není se čemu divit. Každý čtenář je dítětem své doby. Čtenářské konkretizace Havlíčkovy básně Král Lávra byly tudíž determinovány výchovou 21 . století. Žáci, kteří jsou vedeni k odvaze přijmout nedostatky (odlišnosti) své i svého okolí, vnesli tyto morální postoje do obsahu Havlíčkova díla, a bezděky tak přestrukturovali jeho původní významovost. Konkrétní příklad z praxe ukazuje důsledek nezvládnuté metodiky, její nepropojenosti s didaktickou znalostí obsahu.

Nemá-li toto být směr, kudy se ubírá (bude ubírat) výuka LV, pak je zapotřebí kombinovat jednak kreativní výuku s výukou frontální, $\mathrm{v}$ níž jsou poučeně reflektovány čtenářské i tvůrčí výstupy žáků, jednak interpretační prrístup $\mathrm{k}$ dílu s přístupem informačním a výkladovým, vyžaduje-li to povaha textu. 


\section{Použitá literatura}

ČAPEK, Robert. Líný učitel: Jak učit dobře a efektivně. Praha: Raabe, 2017. $140 \mathrm{s.}$

GRÖGEROVÁ, Bohumila. Slovo k čtenáři. In KOLÁŘ, Jiří a Josef HIRŠAL. Enšpígl. Praha: Albatros, 1992, s. 135-140.

HAUSENBLAS, Ondřej; KOŠŤÁlOVÁ, Hana. Co je E-U-R? Podrobněji k evokaci. Kritické listy: občasník pro kritické myšlení, 2006, roč. 6, č. 22, s. 54-58.

HAUSENBLAS, Ondřej; KOŠŤÁlOVÁ, Hana. Co je E-U-R? Podrobněji k fázi Uvědomění si významu informací. Kritické listy: občasník pro kritické myšlení, 2006, roč. 6, č. 23, s. 57-59.

HAUSENBLAS, Ondřej; KOŠŤÁLOVÁ, Hana. Co je E-U-R? Podrobněji k fázi reflexe. Kritické listy: občasník pro kritické myšlení, 2006, roč. 6, č. 24, s. 67-69.

HNÍK, Ondřej. Didaktika literatury: Od textů umělecké povahy k didaktice estetickovýchovného oboru. Praha: Karolinum, 2014. $179 \mathrm{~s}$.

KLUMPAROVÁ, Štěpánka. Tvořivé přístupy k narativu v didaktice literatury: Narativní transformace a její didaktický potenciál. In SLAVÍK, Jan; aj. Tvorba jako zpưsob poznávání. Praha: Karolinum, 2013, s. 321-344.

KOŠŤÁLOVÁ, Hana. Brainstorming aneb Dovedeme rozpoutat bouři nápadů $\mathrm{v}$ mozcích našich žáků? Kritické listy: občasník pro kritické myšlení, 2003, roč. 3, č. 12, s. 5-7.

LEDERBUCHOVÁ, Ladislava; BERÁNKOVÁ, Eva. Čítanka pro 6. ročník základni školy a primu víceletého gymnázia. Plzeň: Nakladatelství Fraus, 2003.

LEDERBUCHOVÁ, Ladislava; BERÁNKOVÁ, Eva. Čítanka: príručka učitele pro 6. ročník základní školy a primu víceletého gymnázia. Plzeň: Nakladatelství Fraus, 2003. LEDERBUCHOVÁ, Ladislava. Č́tanka 7: př́ručka učitele pro základní školy a víceletá gymnázia. Plzeň: Nakladatelství Fraus, 2004. 
LEDERBUCHOVÁ, Ladislava. Literatura ve škole: Četba žáka a didaktická interpretace uměleckého textu v literární výchově na 2. stupni základní školy a $v$ odpovídajících ročnících víceletého gymnázia. Plzeň: Západočeská univerzita v Plzni, 2010.

Rámcový vzdělávací program pro gymnázia: RVP G. Praha: Výzkumný ústav pedagogický v Praze, 2007.

Rámcový vzdělávací program pro základní vzdělávání. Praha: MŠMT, 2017.

ŘEPKOVÁ, Marie. Satira Karla Havlička. Praha: Academia, 1971. $194 \mathrm{~s}$.

SLAVÍK, Jan; JANÍK, Tomáš; NAJVAR, Petr; KNECHT, Petr. Transdisciplinární didaktika: o učitelském sdílení znalostí a zvyšování kvality výuky např́ič obory. Brno: Masarykova univerzita, 2017. $455 \mathrm{~s}$.

\section{Internetové zdroje}

Líný učitel Robert Čapek na ZČU. [online]. ZČU v Plzni: Celoživotní a distanční vzdělávání, 2019. [cit. 30.6.2020]. Dostupné z www: https://czv.zcu.cz/liny-ucitel-robert-capek-na-zcu/

POLÁKOVÁ, Irena: Podvojný deník - Popis metody. In Učení bez učebnic. Pro učitele [online]. Občanské sdružení Místo pro život HON [cit. 25.6.2020]. Dostupné z https://www.uceni bezucebnic.cz/index.php?id $=516$ 


\section{Resumé}

Resumé shrnuje výsledky bádání, $\mathrm{k}$ nimž dospěli autoři jednotlivých kapitol monografie. $\mathrm{V}$ preambuli je vyložen postup a metodologie při výzkumu, je naznačeno tematické rozvrstvení a užší zaměření zpracovaných statí.

V prvním tematickém oddílu přináši studie Jany Vejvodové analýzu nového modelu výuky na FPE ZČU v Plzni přispívajícího k překonání „propasti“ oddělující vzdělávací teorii od praxe. Autorka ukazuje, jak disciplíny Základy reflexe a hodnocení výuky v bakalářském studiu a Reflexe a hodnocení výuky v navazujícím magisterském studiu vedou studenty i vyučující k transdisciplinární didaktické součinnosti, $\mathrm{k}$ součinnosti mezi oborovými didaktikami a obecnou didaktikou i pedagogikou.

Růžena Písková představuje ve své kapitole poznatky z pedagogické praxe realizované tzv. „na dálku“. Překvapivým pozitivem se stalo rozšíření sociálního kontaktu žáků i studentů v době celostátní karantény. Žáci oceňovali zájem studentů učitelství i to, že mohou komunikovat $s$ dalším učitelem. Studenti učitelství za největší př́nos považovali svou účast na reálné výuce s prvky distančního vzdělávání, byli svědky toho, jak problematické může spojení na dálku být.

Dominic Jačka a Petr Pánek ve své analýze kvalifikačních prací ukázali, že závěrečné práce studentů obsahují celou řadu obecných, formálních i jazykových nedostatků. Poukázali na to, že jazykové nedostatky mají původ už na základní a stř̌ední škole a nepodařilo se je eliminovat ani na vysoké škole. Postihli, že vysokoškolská príprava studentů učitelství není soustavná a systematická, proto navrhují zavést promyšlený systém zadávání 
a tvorby kvalifikačních prací, který bude vycházet z konsenzu katedry o její vědecko-výzkumné činnosti a zároveň povede k lepšímu propojení pedagogické praxe s teorií.

Studie Stanislava Štěpáníka ukazuje, že př́lišné zaměření na formu může podstatně zkreslit hodnocení žákovských prací. Vždy je třeba hledět k funkci textu a funkci jazykových prostředků $\mathrm{v}$ něm, tzn. $\mathrm{k}$ adekvátnosti a vhodnosti jejich užití v daném textu. Přitom je nezbytné upřednostnit kvality tematicko-obsahové a slohové. Hlavním cílem výuky češtiny totiž není jazyková správnost, ale rozvinutá komunikační kompetence.

Druhý tematický blok je věnován vybraným aspektům zvládání jazykového učiva od nejnižších úrovní a jazykových rovin směrem ke komplexnímu pohledu na jazyk a řeč. Výzkumné šetření Jaroslavy Novákové prokázalo, že přestože je u dětí v mateřských i základních školách intenzivně stimulována oblast grafomotoriky, ve značné míře nedosahují děti a žáci velkých či rychlých pokroků. Přričina spočívá v nesystematičnosti a chaotičnosti při zadávání grafomotorických cviků, a zejména v nerespektování vývoje grafomotoriky v daném období. Přitom kvalitní rozvoj grafomotoriky usnadňuje nácvik techniky psaní, následně také psaní zrychluje a umožňuje snazší a přesnější písemné vyjadřování; v konečném důsledku pak podporuje celkový plynulý rozvoj gramotnosti i myšlení.

Komparačně pojatá sonda Heleny Chýlové orientovaná na ověřování znalostí pravopisu u budoucích bohemistů přinesla zjištění, která je možno přímo užít v praxi. Důležitým aspektem výuky na vysoké škole by mělo být odstraňování různých mylných výkladů a vysvětlení, které si studenti přinášejí z nižších stupňů škol a z mediálního prostoru, např. záměna pravopisu a gramatiky. Potvrdilo se, že stále existují dva základní okruhy pravopisných 
jevů vnímané jako problematické: užívání velkých písmen a užívání interpunkčních znamének, $\mathrm{k}$ nimž se $\mathrm{v}$ současnosti přidává i zápis přejatých slov.

Milan Hrdlička potvrzuje nezastupitelnou roli prestižní variety českého národního jazyka, spisovné češtiny, v oficiální komunikaci. Poukazuje na nedostatečnou znalost formálního tvarosloví a na nepochopení podstaty mluvnických kategorií. Představuje základní klasifikaci chyb a nejčastější příčiny, které vedou k porušování kodifikované normy.

Studie Jany Vaňkové a Martiny Spěváčkové ukazuje, že ve výuce českého jazyka je stále využívána jako jedna z frekventovaných výukových metod metoda komplexních jazykových rozborů. Jako zásadní přednost je vnímána její komplexnost, i když je doložitelné, že stále přetrvává nepochopení hranic mezi jednotlivými jazykovými rovinami (zejména morfologickou a syntaktickou). Výsledky sondy dále ukázaly, že stylová hodnota jazykového prostředku je často vnímána izolovaně, tedy bez ohledu na jeho kontextové zařazení. Rovněž dochází ke směšování stylových příznaků se spisovností a nespisovností jazykových prostředků. Stylový prríznak je nejvýrazněji vnímán u jazykových prostředků lexikálních.

Jitka Málková shrnuje výsledky výzkumné sondy zaměřené na mluvený projev učitelů ZŠ a na metody rozvíjení mluveného projevu žáků. Ze sebehodnocení učitelů vyplynulo, že považují svůj mluvený projev ve výuce převážně za kultivovaný. Analýza audionahrávek ukázala, že sebehodnocení respondentů je zkresleno jejich problémy s orientací ve spektru spisovných a nespisovných jazykových prostředků. Dotazníkové šetření doložilo, že učitelé využívají k rozvíjení mluveného projevu žáků různé metody, zejména mluvní cvičení. Frekvence zařazování těchto aktivit je však nízká a nejsou často ani vhodným způsobem vyhodnocovány. 
Třetí oddíl představuje práci učitele a žáků s autorskými texty ve smyslu možných interpretací.

Ladislava Lederbuchová přesvědčivě dokazuje, že literárněhistorické poznatky jako strukturovaná složka učiva v literární výchově na základní škole a odpovídajících ročnících víceletého gymnázia tvoří v didaktické interpretaci významovou symbiózu se čtenářskou zkušeností žáka. Rozvíjí jeho komunikaci s dobově determinovaným uměleckým textem, rozšiřují jeho kulturní obzor, přispívají k nalézání jeho kulturní identity - k budování historického vědomí o kultuře a zvláště literatuře (nejen) vlastního národa.

Věra Zelenková zdůrazňuje potřebu zařazovat do výuky texty současných autorů a potřebu komplexního přístupu $\mathrm{k}$ nim. Ve školské praxi je vhodné vybírat texty reprezentující různé tendence. Autorka považuje za významné, že současné texty svými užitými uměleckými postupy a prostředky podněcují čtenářovu fantazii.

Viktor Viktora dokládá, že pro interpretaci prozaického textu je zásadní, aby text znali všichni účastníci výuky, předpokládá se znalost kontextu společenského, kulturního, literárního, literárněteoretického. Při interpretaci díla je třeba brát $\mathrm{v}$ úvahu jeho sémantickou mnohoznačnost i různou míru subjektivity interpretátora. Výraznou nevýhodou je soudobá rozvolněnost vztahů ke kritériím. Jejich absolutizace i absence znesnadňuje hodnocení i interpretaci. V každém prŕípadě je nebezpečná absolutizace jednoho metodologického prŕstupu k interpretaci. To předvádí na Arbesových romanetech, představujících přemostění mezi romantismem rehabilitovaným májovskou generací a počátky reálného vidění skutečnosti, u Arbesova pohledu podloženého racionálním přístupem, logikou a sociálním cítěním. 
Př́nosem studie Davida Franty je navržení takového modelu výuky, který by skloubil čili integroval výchovu jazykovou, slohovou a literární v komplexní výchovu komunikační. Autorova práce s textem, jak je demonstrována na př́kladu Goethova Fausta jako průsečíku morfologické kategorie způsobu a času, romantické poetiky a odborné úvahy, je kompromisem mezi současnými jazykově- a literárněvědnými metodami na jedné straně a pedagogicko-didaktickými trendy na straně druhé.

Jiří Novotný na základě informací z dostupných univerzitních zdrojů dochází k přesvědčení, že značná část studentů bohemistiky projevuje zájem o národní dějiny a starší českou literaturu, přestože tvrdí, že je studium starší literatury a dějepisu obecně nikdy předtím nezajímalo, ba jim bylo vyučujícími zoškliveno. Příčinou mohou být některé zažité stereotypy: malý (nebo žádný prostor) věnovaný starší literární tvorbě, izolovaná výuka bez uplatnění interdisciplinárních vazeb, nedostatečný pedagogický příklad atp. Starší českou literaturu je třeba studovat a znát, nejen pro poučení, nýbrž především z důvodu poznání kontinuity společenského (literárního) vývoje naší země.

Vladimíra Pánková v závěrečné studii analýzou hospitovaných vyučovacích hodin ukázala, že mechanické (interpretačně nezacílené) uplatnění tvořivých metod nebo metod kritického myšlení při práci s uměleckým textem není samospásné. Nejenže bez vedení fundovaného učitele tyto metody nepodporují čtenářskou gramotnost žáka, ale dokonce mohou být i kontraproduktivní, tj. vést $\mathrm{k}$ dezinterpretacím daného textu. Její analýza ukázala, že četbě s porozuměním v cestě stojí funkční nepropojenost metod s oborovým poznáním, nefundovanost učitele, který sám ke smyslu díla nepronikl. 


\section{Summary}

The present abstract summarizes the results delivered by the authors of the individual chapters in the monograph. The preamble presents research procedures and methodology, outlines layers of the topics and specific focus of the presented texts.

In the first thematic section, Jana Vejvodovás paper brings an analysis of a new teaching model at FPE ZCU (Pedagogical Faculty of the University of West Bohemia) contributing towards bridging the gap between educational theory and practice. The author demonstrates how the subjects 'Foundations of reflexion and evaluation of teaching' in the Bachelor's programme and 'Reflexion and evaluation of teaching' in the follow-up Master's programme lead students and instructors towards interdisciplinary didactic collaboration, towards collaboration among subject-specific didactics, and general didactics and pedagogy.

Růžena Písková presents findings from her so-called 'distant' teaching practice in her chapter. Widening of social contacts of pupils and students during the nationwide quarantine turned out to be an unexpected benefit. The pupils appreciated the teacher-trainees' enthusiasm as well as the fact that they were able to communicate with another instructor. The teacher-trainee students saw their participation in real teaching with distant learning features as the biggest asset and they could witness how daunting distant learning can be.

Dominic Jačka and Petr Pánek found in their analysis of degree qualification works that students' graduation papers contain a wide range of general, formal and language deficiencies. They pointed out the fact these mistakes originate as early as elementary 
or secondary schools and they haven't been eliminated even at university either. They argued that higher education-level preparation of future teachers is not continual or systematic and they propose introducing a sophisticated plan of assignment and writing qualification papers based on the consensus of the respective department and its scientific and research activities and will lead to better connection of pedagogic theory and practice.

Stanislav Štěpáník’s paper shows how overemphasizing the form may significantly distort evaluation of pupils' writing assignments. It is always important to take into view the function of the text and the function of linguistic means in it, which is adequacy and appropriateness of their use in a given text, while it is essential to give preference to the topic, content and stylistic qualities since the primary goal of teaching Czech is developing communicative competence, rather than language correctness.

Second thematic section is dedicated to selected aspects of competence in language arts from the lowest levels and language layers towards a more complex view of language and speech. Jaroslava Novákovás research project confirmed that despite the intensive stimulation of graphomotorics at pre-school and elementary schools, pupils do not achieve progress significant or rapid enough. This is caused by the unsystematic and chaotic assigning of graphomotorics activities and especially by failing to respect the development of graphomotics during the early stages in spite of the fact that its proper development enhances the practice of writing technique and subsequently accelerates writing and enables easier and more accurate self-expression in writing. Moreover, it facilitates complete and smooth development of literacy and thinking. 
A comparative survey by Helena Chýlová focused on assessing spelling and orthography skills in future Czech major graduates brought findings applicable in practice. Uprooting various misteachings and misinterpretations students bring from their pre-college schooling and the media, such as mistaking spelling and grammar issues, should constitute an important element of university instruction. It has been established that there are still two basic areas of spelling issues seen as difficult: capitalization and punctuation, recently joined by spelling of borrowed words.

Milan Hrdlička affirms the irreplaceable role of the prestigious variety of the Czech language - Standard Czech in formal communication. He points out insufficient command of formal morphology and the failure to understand the essence of grammar categories. He presents a basic classification of errors and common causes leading to diverting from codified norms.

The study by Jana Vaňková and Martina Spěváčková demonstrates that complex sentence analysis as a frequently used method remains to be applied in teaching Czech language. Its comprehensiveness is seen as the primary advantage while it can be proved that the boundaries between the individual language layers (especially morphological and syntactical) often keep being misunderstood. The findings of their survey further showed that stylistic value of a linguistic means is often perceived in isolation, i.e. regardless of its contextual classification. Yet another phenomenon is mistaking stylistic features and formality vs. colloquiality of linguistic means. Stylistic features are most distinctive in lexical linguistic means.

Jitka Málková summarizes results of her research survey focused on speaking performance of elementary school teachers and methods of developing speaking performance in pupils. It was 
found from the teachers' self-reflection that they assess their speaking performance in class as 'cultivated'. However, the analysis of audio recordings revealed that the respondents' self-evaluation was distorted due to their issues with understanding the spectrum of standard and non-standard linguistic means. The questionnaire-based research showed that teachers use a variety of methods to develop pupils' speaking performance, mainly speaking practice. The frequency of using these activities is rather low and they often tend to be poorly assessed.

The third section presents the teacher's and students' work with original texts in the sense of possible interpretations.

Ladislava Lederbuchová convincingly proves that literary-historical knowledge as a structured part of literature education curriculum at elementary schools and corresponding grades of junior comprehensive schools form, in didactic interpretation, a meaning-creating symbiosis with the pupil's reading experience. It develops the pupil's communication with period-determined literary text, broadens their cultural horizons and contributes to discovering their cultural identity - to building historical awareness of culture and especially literature of (not only) their country.

Věra Zelenková stresses the need to include contemporary authors' texts into the curriculum and the necessity of approaching them in a complex manner. In school education, it is appropriate to select texts representing various tendencies. The author sees as significant the fact that contemporary texts stimulate readers' imagination by their applied artistic methods.

Viktor Viktora presents evidence that while interpreting a prosaic text, it is fundamental for all participants of the class to be familiar with the text. The knowledge of social, cultural, literary and 
theoretical contexts is expected. It is important to take into consideration the interpreted text's semantic multi-layered character as well as varying levels of the interpreter's subjectivity. A clear disadvantage is today's loose attitude towards criteria. Their absolutisation or absence makes text evaluation and interpretation more challenging. In any case, it is dangerous to single out only a sole methodological approach to interpretation. This is demonstrated at Arbes's romanettos bridging romanticism rehabilitated by the Maj generation poets and beginnings of realistic views of reality, supported by Arbes's rational approach, logical thinking and social conscience.

The contribution of David Franta's paper is the design of such a teaching model that would be able to integrate language, composition and literature education into a complex communication education. The author's work with a text, as demonstrated on Goethe's Faust, as a junction of morphological category of mood and tense, romantic poetics and expert essay is a compromise between current linguistic and literary theory methods on one side and pedagogical and didactic trends on the other.

Based on facts obtained from available university sources, Jiří Novotný argues that a considerable part of Czech studies students shows interest in national history and older Czech literature despite claiming that studying older literature and history in general never really interested them or even that they were put off by their teachers. Possible causes may be some deep-rutted stereotypes: little or no space given to older literary works, learning in isolation - without applying interdisciplinary links, insufficient pedagogical examples etc. Older Czech literature is well worth studying and knowing, not only for the factual knowledge itself but especially in order to understand the continuity of our country's social and literary development. 
In the closing paper, Vladimíra Pánková analysed observed lessons to show that mechanical (devoid of any interpretative focus) application of creative teaching methods or critical thinking methods in working with literary text is not self-saving. Not only without erudite teacher's guidance these methods do not develop the pupil's reading skills, but they can even be counterproductive and result in misinterpretation of a given text. Her analysis proves that reading comprehension is hindered by the lack of functional connection of methods and subject knowledge, and incompetence of the teacher themselves failing to grasp the work's true meaning. 


\section{Použitá literatura}

ADAM, Robert. Gramatické rozbory češtiny: výklad a cvičení s řešeními. Praha: Univerzita Karlova, nakladatelství Karolinum, 2018. 240 s.

ADAM, Robert. Př́ručka k morfologii češtiny: výklad a cvičení $s$ řešeními. Praha: Karolinum, 2019. $94 \mathrm{~s}$.

ADAM, Robert. Co neumějí studenti bohemistiky. Český jazyk a literatura, 2010-2011, roč. 61, č. 1, s. 8-14.

ADAM, Robert. Postup při morfologickém rozboru jmenných tvarů. Český jazyk a literatura, 2017-2018, roč. 68, č. 5, s. 222-229.

ADAM, Robert. Řeč postav ve vyprávění. In Český jazyk a literatura. 2006-2007, roč. 57, č. 4. s. 174-180.

ADAM, Robert. Určování morfologických kategorií jmen: sonda do praktik začínajících studentů bohemistiky. Didaktické studie, 2018, roč. 10, č. 1, s. 13-30.

ALTWATTER, Donald. Slovník svatých. Přeložila a doplnila Jitka Matějů, Český národní kalendář sestavil Petr Svoboda. Vimperk: Papyrus, 1993. 436 s.

ARGYRIS, Chris; SCHÖN, Donald A. The theory of practice. Increasing professional effectiveness. Reprint. San Francisco: Wiley \& Sons, Incorporated, John, 1992. $264 \mathrm{s.}$

BEDNÁŘOVÁ, Jiřina; ŠMARDOVÁ, Vlasta. Diagnostika ditěte předškolního věku. Brno: Edika, 2015 (2. vydání). 217 s.

BENDL, Stanislav; aj. Klinická škola: misto pro výzkum a praktickou př́pravu budoucích učitelů. Praha: Univerzita Karlova v Praze, Pedagogická fakulta, 2011 (1. vydání). 554 s.

BENEŠ, Martin, aj. Studie k Moderní mluvnici češtiny 5. K české fonetice a pravopisu. Olomouc: FF UPOL, 2013. $208 \mathrm{s.}$

BERÁNKOVÁ, Eva. Tvořivá hra jako cesta k pochopení literárního díla. Plzeň: Nakl. Fraus, 2002. 108 s. 
BERMEL, Neil. Pravidla jako cukr a bič? Pravopis v českém národním korpusu (1. část). Naše řeč, 2008, ročník 91, č. 1, s. 1-12. BLÁHOVÁ, Marie. Pražské školy předuniverzitního období. In PEŠEK, Jiř́í; SVATOŠ, Michal. Škola a město. Praha: Karolinum, Documenta Pragensia XI, 1993, s. 26-39.

BLOOM, Harold. Kánon západní literatury. Praha: Prostor, 2000. $640 \mathrm{~s}$.

BOSCOLO, Pietro. Engaging and motivating children to write. In BEARD, Roger; MYHILL, Debra; RILEY, Jeni; NYSTRAND, Martin (eds.). The SAGE handbook of writing development. London: SAGE, 2009, s. 300-312.

BRÜNING, Gerrit. Die Wette in Goethes Faust. In PURDY, Daniel (ed.). Goethe Yearbook. Volume XVII. Rochester: Camden House, 2010, s. 31-54.

CVRČEK, Václav. Teorie jazykové kultury po roce 1945. Praha: Karolinum, 2006. 123 s.

CVRČEK, Václav. Regulace jazyka a Koncept minimální intervence. Praha: Karolinum, 2008. 232 s.

CVRČEK, Václav; aj. Mluvnice současné češtiny 1. Jak se píše a jak se mluví. Praha: Karolinum, 2010. 354 s.

ČAPEK, Robert. Liný učitel: Jak učit dobře a efektivně. Praha: Raabe, 2017. $140 \mathrm{~s}$.

ČÁP, Jan. Psychologie výchovy a vyučování. Praha: Univerzita Karlova, 1993.

ČECHOVÁ, Marie. Mluvnické kategorie podstatných jmen ve vyučování českému jazyku. Praha: Státní pedagogické nakladatelství, 1976. $154 \mathrm{~s}$.

ČECHOVÁ, Marie. Vyučování slohu. Praha: SPN, 1985. $260 \mathrm{~s}$.

ČECHOVÁ, Marie. Vztah spisovnosti a nespisovnosti v pedagogické komunikaci. Pedagogika, 1995, roč. 45, č. 1, s. 38-42.

ČECHOVÁ, Marie; aj. Komplexní jazykové rozbory. Praha: SPN pedagogické nakladatelství, 1996. 263 s. 
ČECHOVÁ, Marie; STYBLÍK, Vlastimil. Čeština a její vyučování. Didaktika českého jazyka pro učitele základních středních škol a pro studenty učitelství. Praha: SPN, 1998 (2., upravené vydání). $264 \mathrm{~s}$.

ČECHOVÁ, Marie. Komunikační a slohová výchova. Praha: ISV nakladatelství, 1998. $226 \mathrm{~s}$.

ČECHOVÁ, Marie; aj. Současná stylistika. Praha: Nakladatelství Lidové noviny, 2008. $381 \mathrm{~s}$.

ČECHOVÁ, Marie; aj. Čeština - řeč a jazyk. Praha: Státní pedagogické nakladatelství, 2011 (3. upravené, rozšířené vydání). $442 \mathrm{~s}$.

ČECHOVÁ, Marie. Řeč o ř reči. Praha: Academia, 2012. $311 \mathrm{~s}$.

ČECHOVÁ, Marie. Variantní kodifikace, nebo kodifikace variet? Český jazyk a literatura, 2012-2013, roč. 63, č. 1, s. 19-25.

ČECHOVÁ, Marie. Život s češtinou: Nomen omen: Češka - češtinářka - Čechová. Praha: Academia, 2017. 391 s.

ČECHOVÁ, Marie. Srovnání nesrovnatelného? Znalosti funkční morfologie u žáků před 50 lety a dnešních bohemistů. Český jazyk a literatura, 2018-2019, roč. 69, č. 1, s. 24-32.

ČERMÁK, František. Obecná a spisovná čeština: poměr, funkce a metodologie. In ŠRÁMEK, Rudolf (ed.). Spisovnost a nespisovnost dnes. Brno: Pedagogická fakulta Masarykovy univerzity, 1996, s. 14-18.

DANEŠ, František. Situace a celkový stav češtiny. In DANEŠ František; aj. (eds.). Český jazyk na přelomu tisíciletí. Praha: Academia, 1997, s. 12-24.

DEMJANČUK, Nikolaj. Humanistická epistemologie Paula Feyerabenda a tvorba Bertolda Brechta. In NOVOTNÝ, Vladimír (ed.). Postmodernismus v umění a literatuře. Plzeň: Pro libris, 2003, s. 7-20.

DOLEŽEL, Lubomír. Narativní zpưsoby v české literatuře. Příbram: Pistorius \& Olšanská, 2014. 142 s. 
DUFFEK, Václav; aj. Pre-service teacher training in the virtual classroom: pilot study. In BESEDA, Jan; ROHLÍKOVÁ, Lucie (eds.) DisCo 6 2019: E-learning - Unlocking the Gate to Education around the Globe - 14th conference reader. Prague: Center for Higher Education Studies, 2019, s. 201-210.

DVOŘÁK, Josef. Vývojová verbální dyspraxie. Ždár nad Sázavou: Logopedické centrum, 2003. 144 s.

DYLEVSKÝ, Ivan. Anatomie dítěte. Nipioanatomie. 2. díl. Praha: ČVUT, 2017. $646 \mathrm{~s}$.

ECKERMANN, Johann Peter. Hovory s Goethem. Praha: Pavel Prokop, 1941. $211 \mathrm{~s}$.

ECO, Umberto. Poznámky k Jménu růže. In Světová literatura, roč. 31 (1986), č. 2, s. 227-241.

ECO, Umberto. Šest procházek literárními lesy: přednášky na Harvardově univerzitě. Olomouc: Votobia, 1997. 197 s.

FÁBIANOVÁ, Adelaida. Orofaciálna a bazálna stimulácia u detí $s$ psychomotorickým oneskorením $v$ ranom veku. Havlíčkův Brod: Tobiáš, 2014. $160 \mathrm{~s}$.

Fausts Pakt mit Mephistopheles in juristicher Beleuchtung. Goethes Jahrbuch, 1903, roč. 24, s. 113-131.

FLOWER, Linda; HAYES, John. A cognitive proces theory of writing. College Composition and Communication, 1981, roč. 32, č. 4, s. 365-387.

FRANTA, David. Transpozice slovesné osoby, zvl. onkání a onikání na př́kladu české literatury 19. století jako didaktický problém. Jazyk - literatura - komunikace, 2018, roč. 7, č. 2, s. 115-124.

FRANTA, David. Modelování integrované výuky předmětu český jazyk a literatura (přednosti a limity). In ČECHOVÁ, Marie; SPĚVÁČKOVÁ, Martina (eds.). Od praxe $k$ teorii a zpět ve vyučování češtině. Plzeň: Západočeská univerzita, 2019, s. $116-133$. 
FREEDMAN, Ralph. Life of a Poet: Rainer Maria Rilke. Illionis: Northwestern University Press, 1996. 640 s.

FRIEDERICI, Angela D. Language in Our Brain: The Origins of a Uniquely Human Capacity. Cambridge, Massachusetts: The MIT Press, 2017. $284 \mathrm{s.}$

GANGALE, Debra C. Rehabilitace orofaciální oblasti. Praha: Grada, 2004. 232 s.

GREBENÍČKOVÁ, Růžena; KÖPPLOVÁ, Barbara; POKORNÝ, Jindřich. Kniha o Faustovi. Praha: Mladá fronta, 1982. $198 \mathrm{s.}$

GREGG, Noel; COLEMAN, Chris; DAVIS, Mark; CHALK, J. C. Times essay writing: Implications for high-stakes tests. Journal of Learning Disabilities, 2007, roč. 40, č. 4, s. 306-318.

GRÖGEROVÁ, Bohumila. Slovo k čtenáři. In KOLÁŘ, Jiří a HIRŠAL, Josef. Enšpígl. Praha: Albatros, 1992, s. 135-140.

GRUMACH, Renate (ed.). Goethe. Begegnungen und Gespräche. Band II (1786-1792). Berlin - New York: de Gruytes, 1977. 581 s. HAMAN, Aleš. Literatura v průsečíku pohledi̊: teorie - historie kritika. Praha: ARSCI, 2003. 173 s.

HAMAN, Aleš. Kritické úvahy o západní literární teorii. Praha: ARSCI, 2006. $204 \mathrm{~s}$.

HAMAN, Aleš. Postmoderna v české próze 90. let a nedůvěra $\mathrm{k}$ př́iběhu. In NOVOTNÝ, Vladimír (ed.). Postmodernismus v umění a literatuře. Plzeň: Pro libris, 2003, s. 50-58.

HAUSENBLAS, Ondřej; KOŠŤÁLOVÁ, Hana. Co je E-U-R? Podrobněji k evokaci. Kritické listy: občasník pro kritické myšlení, 2006, roč. 6, č. 22, s. 54-58.

HAUSENBLAS, Ondřej; KOŠŤÁlOVÁ, Hana. Co je E-U-R? Podrobněji k fázi Uvědomění si významu informací. Kritické listy: občasník pro kritické myšlení, 2006, roč. 6, č. 23, s. 57-59.

HAUSENBLAS, Ondřej; KOŠŤÁLOVÁ, Hana. Co je E-U-R? Podrobněji k fázi reflexe. Kritické listy: občasník pro kritické myšlení, 2006, roč. 6, č. 24, s. 67-69. 
HAUSENBLAS, Karel; KUCHǍ̌, Jaroslav; aj. Čeština za školou. Praha: Orbis, 1974. 486 s.

HAVRÁNEK, Bohuslav. Úkoly spisovného jazyka a jeho kultura. In HAVRÁNEK, Bohuslav; WEINGART, Miloš (eds.). Spisovná čeština a jazyková kultura. Praha: Melantrich, 1932, s. 32-84.

HENDRICK, Carl; MACPHERSON, Robin. Co funguje ve třídě? Most mezi výzkumem a praxí. Praha: Euromedia Group, 2019. $230 \mathrm{~s}$.

HENDRICH, Josef; aj. Didaktika cizích jazyků. Praha: Státní pedagogické nakladatelství, 1988. $498 \mathrm{~s}$.

HILLEBRAND, Bruno. Was denn ist Kunst? Essays zur Dichtung im Zeitalter des Individualismus. Göttingen: Vandenhoeck \& Ruprecht, 2001. 430 s.

HIPPEL, Lukas von; DAUBENFELD, Thasten: Von der Uni ins wahre Leben. Zum Karrierestart Naturwissenschaftler und Ingenieure. Weinheim: Wiley-VCH, 2011. 239 s.

HNÍK, Ondřej. Didaktika literatury: Od textů umělecké povahy $k$ didaktice estetickovýchovného oboru. Praha: Karolinum, 2014. $179 \mathrm{~s}$.

HNÍK, Ondřej. Školní literární kánon. Český jazyk a literatura, 2015-2016, roč. 66, č. 5, s. 234-241.

HNÍK, Ondřej. K problému kvantity poznatků v literární výchově. Český jazyk a literatura, 2016-2017, roč. 67, č. 2, s. 83-87.

HOFFMANN, Bohuslav. O interpretaci literárního uměleckého textu. Český jazyk a literatura, 2012-2013, roč. 63, s. 12-19.

HOSKOVEC, Tomáš. Jazyk. In SLÁDEK, Ondřej a kol. Slovník literárněvědného strukturalismu. Brno: Host, 2018, s. 330-341.

HOSKOVEC, Tomáš. Poetika a filologie (úvodní přednáška kolokvia Poetický Cikháj v Brně). In VERMIŘOVSKÝ, Adam (ed.). Poetický Cikháj v Brně 2010. Brno: Tribun EU, 2012, s. 13-27. HRABAL, Jiř́. Fokalizace: analýza naratologické kategorie. Praha: Dauphin, 2011. $221 \mathrm{~s}$. 
HRABAL, Vladimír; PAVELKOVÁ, Isabella; MAN, František. Psychologické otázky motivace ve škole. Praha: SPN, 1984. $254 \mathrm{~s}$.

HRDINA, Martin. K otázce terminologie dějin literatury ve školní literární výchově. Český jazyk a literatura, 2019-2020, roč. 70, s. 112-115.

HRDLIČKA, Milan. Jazyková chyba a práce s ní v jazykovém vyučování. In ŠEBESTA, Karel; ŠKODOVÁ, Svatava (eds.). Čeština - cílový jazyk a korpusy. Liberec: Technická univerzita v Liberci, 2012, s. 89-108.

HRDLIČKA, Milan. Vo vobecný češtině a jiné př́běhy. Praha: Karolinum, 2015. 266 s.

HRDLIČKA, Milan. Spisovná a obecná čeština ve výuce cizinců. In NEKULA, Marek; ŠICHOVÁ, Kateřina (eds.). Variety češtiny a čeština jako cizí jazyk. Praha: Akropolis, 2017, s. 85-106.

HRDLIČKA, Milan. Variantností k chaosu? Český jazyk a literatura, 2017-2018, roč. 68, č. 4, s. 174-180.

HRDLIČKA, Milan. Kapitoly o češtině jako jazyku nemateřském. Praha: Karolinum, 2019. 166 s.

CHALOUPECKÝ, Václav (ed.). Prameny X. století legendy Kristiánovy o Svatém Václavu a Svaté Ludmile. In Svatováclavský sborník. Praha: Národní výbor pro oslavu Svatováclavského tisíciletí, 1939. $630 \mathrm{~s}$.

CHALOUPECKÝ, Václav. Na úsvitu křestanství. Praha: Evropský literární klub, 1942. $292 \mathrm{s.}$

CHALOUPECKÝ, Václav; RYBA, Bohumil (eds.). Středověké legendy prokopské. Praha: Nakladatelství ČAV, 1953. 285 s.

CHALOUPKA, Otakar. Systém literární výchovy a jeho perspektivy. Praha: Academia, 1984. 240 s.

CHALOUPKA, Otakar. Interaktivita čtenářství. Český jazyk a literatura, 2012-2013, roč. 63, s. 57-61.

CHLUP, Otokar. Středoškolská didaktika. Brno: Společnost nových škol v Brně, 1935. 356 s. 
CHOCHOLOUŠKOVÁ, Zdeňka; SLAVÍK, Jan; SOUKUPOVÁ, Pavla. Nové poznatky z transdisciplinární didaktiky. In SANDANUSOVÁ Anna (ed.). Educo. Príprava učitelov prírodovedných, polnohospodárskych a príbuzných odborov $v$ meniacich sa požadavkách. Nitra: FPV UKF v Nitre, 2019, s. 5-29.

JAMESON, Frederic. Postmodernismus neboli kulturní logika pozdního kapitalismu. Praha: Rybka Publishers, 2016. 535 s.

JANÁČKOVÁ, Jaroslava. Komentář In Jakub Arbes, Romaneta. Praha: Lidové noviny, 2006. 676 s.

JANÍK, Tomáš. Didaktické znalosti obsahu a jejich význam pro oborové didaktiky, tvorbu kurikula a učitelské vzdělávání. Brno: Paido, 2009. 120 s.

JANÍK, Tomáš. Kvalita (ve) vzdělávání: obsahově zaměřený př́stup ke zkoumání a zlepšování výuky. Brno: Masarykova univerzita, 2013. $434 \mathrm{~s}$.

JELÍNEK, Milan. Co je to jazyková chyba? In KNESSELOVÁ, Helena; KLÍMOVÁ, Květoslava; HAUSER, Přemysl (eds.). Profesor Hauser jubilující. Brno: Pedagogická fakulta Masarykovy univerzity, 2001, s. 75-85.

KEJKLÍČKOVÁ, Ilona. Vady řeči u dětí. Praha: Grada, 2018. $224 \mathrm{~s}$.

KELLOGG, Ronald T. The psychology of writing. Oxford: Oxford University Press, 1999.

KLIMOVIČ, Martin. Detský pisatel' v procese tvorby textu. Prešov: Prešovská univerzita v Prešově, 2016. 164 s.

KLUMPAROVÁ, Štěpánka. Tvořivé př́stupy $\mathrm{k}$ narativu v didaktice literatury: Narativní transformace a její didaktický potenciál. In SLAVÍK, Jan aj. Tvorba jako zpưsob poznávání. Praha: Karolinum, 2013, s. 321-344.

KOLÁ̌̌, Zdeněk a kol. Výkladový slovník z pedagogiky. Praha: GRADA, 2012. 192 s.

KORČÁKOVÁ, Jana. Chyba a učení cizím jazykưm. Hradec Králové: Gaudeamus, 2004. 134 s. 
KORTHAGEN, Fred; aj. Jak spojit praxi s teorii: didaktika realistického vzdělávání učitelů. Brno: PAIDO, 2011. 293 s.

KOSTEČKA, Jiří. Interpretace a misinterpretace uměleckého textu. Český jazyk a literatura, 2011-2012, roč. 62, č. 5, s. 232-236. KOŠŤÁLOVÁ, Hana. Brainstorming aneb Dovedeme rozpoutat bouři nápadů $\mathrm{v}$ mozcích našich žáků? Kritické listy: občasník pro kritické myšlení, 2003, roč. 3, č. 12, s. 5-7.

KOUBEK, Petr. Podkladová studie. Literární výchova a literární komunikace. Praha: NÚV, 2019. 115 s.

KRÁSL, František; JEŽEK, Jan. Sv. Vojtěch, druhý biskup pražský, jeho klášter i úcta u lidu. Praha: Dědictví sv. Prokopa - číslo XXXIX, 1898. $795 \mathrm{~s}$.

KYRALOVÁ, Marie. Bruno z Querfurtu, Život svatého Vojtěcha, legenda Nascitur purpureus flos. Praha: Zvon, 1996. 125 s.

LANG, Susanne. Erinnerungen an die Zeit vor Pisa. In Was bleibt? Ein Lesebuch zum 375-jährigen Schuljubiläum. München: Herbert Utz Verlag, 2004, s. 31-36.

LEDERBUCHOVÁ, Ladislava. Didaktická interpretace uměleckého textu jako metoda literární výchovy na občanské a střední škole II. Plzeň: ZČU, 1997. 122 s.

LEDERBUCHOVÁ, Ladislava. Průvodce literárním dílem: Výkladový slovník základních pojmů literární teorie. Jinočany: Nakladatelství H \& H. 2002. 355 s.

LEDERBUCHOVÁ, Ladislava; BERÁNKOVÁ, Eva. Čítanka pro 6. ročník základní školy a primu víceletého gymnázia. Plzeň: Nakladatelství Fraus, 2003.

LEDERBUCHOVÁ, Ladislava; BERÁNKOVÁ, Eva. Čítanka: príručka učitele pro 6. ročník základní školy a primu víceletého gymnázia. Plzeň: Nakladatelství Fraus, 2003.

LEDERBUCHOVÁ, Ladislava. O postavě postmoderní prózy. In NOVOTNÝ, Vladimír (ed.). Postmodernismus v umění a literatuře. Plzeň: Pro libris, 2003, s. 119-145. 
LEDERBUCHOVÁ, Ladislava. Čítanka 7: příručka učitele pro základní školy a víceletá gymnázia. Plzeň: Nakladatelství Fraus, 2004.

LEDERBUCHOVÁ, Ladislava; STEHLÍKOVÁ, Monika. Čítanka 8: učebnice pro základní školy a víceletá gymnázia. Plzeň: Nakl. Fraus, 2006. 224 s.

LEDERBUCHOVÁ, Ladislava; STEHLÍKOVÁ, Monika. Čítanka 8: příručka učitele. Plzeň: Nakl. Fraus, 2007. 104 s.

LEDERBUCHOVÁ, Ladislava. Literatura ve škole: Četba žáka a didaktická interpretace uměleckého textu v literární výchově na 2. stupni základní školy a v odpovídajících ročnících víceletého gymnázia. Plzeň: Západočeská univerzita v Plzni, 2010. 266 s.

LEDERBUCHOVÁ, Ladislava. Právo na originalitu, na omyl, na kultivovanost. Český jazyk a literatura, 2013-2014, roč. 64, č. 4, s. 191-195.

LEDERBUCHOVÁ, Ladislava. O poznávání uměleckého jazyka. Český jazyk a literatura, 2015-2016, roč. 66, č. 4, s. 169-175.

LEDERBUCHOVÁ, Ladislava. Personifikace, apostrofa, metafora: poznatky o poetice jazyka v učivu literární výchovy na 2 . stupni ZŠ. Český jazyk a literatura, 2017-2018, roč. 68, č. 3, s. 105-111.

LEDERBUCHOVÁ, Ladislava. Jak čtou osmáci?: př́spěvek do diskuse. Český jazyk a literatura, 2019-2020, roč. 70, č. 3, s. $123-125$.

LEVÝ, Jiří. Umění překladu. Praha: Miroslav Pošpa - Apostrof, 2012. $368 \mathrm{~s}$.

LIPPMANN, Karel. Lze se vyhnout „misinterpretaci“ uměleckého textu? Český jazyk a literatura, 2012-2013, roč. 63, s. 78-82.

LIPTÁKOVÁ, Ludmila, aj. Integrovaná didaktika slovenského jazyka a literatúry pre primárne vzdelávanie. Prešov: Pedagogická fakulta Prešovské univerzity, 2011. 579 s.

MACURA, Vladimír. Znamení zrodu a české sny. PIORECKÁ, Kateřina; VOJTKOVÁ, Milena (eds.). Praha: Academia, 2015. $658 \mathrm{s.}$ 
MÁLKOVÁ, Jitka. Vnímání spisovnosti v mluveném projevu budoucími učiteli na počátku jejich studia. In ČECHOVÁ, Marie; SPĚVÁČKOVÁ, Martina (eds.). Od praxe $k$ teorii a zpět ve vyučování češtině. Plzeň: ZČU, 2019. s. 94-103.

MAREŠ, Jiří. Osobní reflexe událostí při zavádění strukturovaného studia učitelství. Pedagogika, 2013, roč. 4, s. 460-484.

MARTINCOVÁ, Olga (ed.). Co přinášejí nová Pravidla českého pravopisu? Praha: Ústav pro jazyk český, 1991. 51 s.

MATHESIUS, Vilém. O požadavku stability ve spisovném jazyce. In HAVRÁNEK, Bohuslav; WEINGART, Miloš (eds.). Spisovná čeština a jazyková kultura. Praha: Melantrich, 1932, s. 14-31.

MATHESIUS, Vilém. K výslovnosti cizích slov v češtině. In Čeština a obecný jazykozpyt. Praha: Melantrich, 1947, s. 110-129.

Mluvnice češtiny 2. Věd. red. Jan Petr. Praha: Academia, 1986. 536 s. MORALES, Rodolfo Castillo. Orofaciální regulační terapie. Praha: Portál, 2006. 184 s.

MUKAŘOVSKÝ, Jan. Poetika jako základ literární výchovy na střední škole. Štěpnice, 1948-1949, roč. 2, č. 1, s. 6-12, č. 6-7, s. 97-103.

-nk-. Nález dosud neznámého rukopisu přednášky prof. Jana Mukařovského pro posluchače Vysoké školy pedagogických studií. Český jazyk a literatura, 2001-2002, roč. 52, č. 7-8, s. 186-194.

MYHILL, Debra, aj. Re-thinking grammar: The impact of embedded grammar teaching on students' writing and students' metalinguistic understanding. Research Papers in Education, 2012, roč. 27, č. 2, s. 1-28.

NEKULA Marek in KARLÍK, Petr; NEKULA, Marek; PLESKALOVÁ, Jana (eds.). Encyklopedický slovník češtiny. Praha: Nakladatelství Lidové noviny, 2002. s. 380.

NOCOŃ, Jolanta. Kształcenie umiejętności pisania w języku ojczystym w perspektywie lingwistycznej i lingwodydaktycznej. Didaktické studie, rukopis. 
NOCOŃ, Jolanta. Styl(e) wypowiedzi pisemnej licealistów. Studia Pragmalingwistyczne, 2010, roč. 2, s. 66-78.

NOVÁKOVÁ, Jaroslava. Prvopočáteční čtení a psaní u žáka se speciálními vzdělávacími potřebami. In ČECHOVÁ, Marie; SPĚVÁČKOVÁ, Martina (eds.). Od praxe $k$ teorii a zpět ve vyučování češtině. ZČU v Plzni: Plzeň, 2019, s. 169-177.

NOVOTNÝ, Jiří. Od centra k regionům. In ČECHOVÁ, Marie; SPĚVÁČKOVÁ, Martina (eds.). Od praxe $k$ teorii a zpět ve vyučování češtině. Plzeň: Západočeská univerzita, 2019, s. $148-159$.

NOVOTNÝ, Václav. České dějiny I. Praha: Jan Laichter, 1912. $782 \mathrm{~s}$.

PILǍ̌, Martin. Vrabec $v$ hrsti aneb Klišé v literatuře. Praha: Dokořán, 2005. $183 \mathrm{~s}$.

PODROUŽEK, Ladislav. Integrovaná výuka na základní škole. Plzeň: Fraus, 2002. 96 s.

POLÁČEK, Jiří. Věc: výuka literatury. Český jazyk a literatura, 2016-2017, roč. 67, č. 4, s. 187-189.

PORUBSKÁ, Gabriela. Vzţah všeobecnej didaktiky a pedagogickej praxe. In Význam pedagogickej praxe $v$ profesijnom raste učitel'ov, Zborník príspevkov z vedeckej konferencie s medzinárodnou účastou. Nitra: Pedagogická fakulta UKF v Nitre, 2001, s. $43-48$.

PRAVDOVÁ, Markéta; SVOBODOVÁ, Ivana (eds.). Akademická príručka českého jazyka. Praha: Academia, 2014. 536 s.

Pravidla českého pravopisu (S Dodatkem Ministerstva školství, mládeže a tělovýchovy). Praha: Academia, 1993. 389 s.

Pravidla českého pravopisu. Praha: SPN, 1958. $391 \mathrm{s.}$

PRŮCHA, Jan; WALTEROVÁ, Eliška; MAREŠ, Jiří. Pedagogický slovník. 6. vydání. Praha: Portál, 2009. 395 s.

P̌̌IBÁŇ, Michal; aj. Český literární samizdat 1949-1989: edice, časopisy, sborníky. Praha: Academia, 2018. 612 s. 
Př́ruční mluvnice češtiny. KARLÍK, Petr; NEKULA, Marek; RUSÍNOVÁ, Zdenka (eds.). Praha: Nakladatelství Lidové noviny, 1995. $800 \mathrm{~s}$.

Rámcový vzdělávací program pro gymnázia: RVP G. Praha: Výzkumný ústav pedagogický v Praze, 2007.

Rámcový vzdělávací program pro základní vzdělávání. Praha: MŠMT, 2017. 165 s.

RUSEK, Martin; SLAVÍK, Jan; NAJVAR, Petr. Vyjádření autorů. ORBIS SCHOLAE, 2016, roč. 10, č. 2, s. 161-171.

RYSOVÁ, Květa. K úrovni mluveného projevu žáků. Český jazyk a literatura, 1999-2000, roč. 50, č. 1-2, s. 27-32.

ǨEPKOVÁ, Marie. Satira Karla Havlíčka. Praha: Academia, 1971. $134 \mathrm{~s}$.

SGALL, Petr; HRONEK, Jiří. Čeština bez příkras. Praha: Karolinum, 2014. $154 \mathrm{~s}$.

SGALL, Petr; PANEVOVÁ, Jarmila. Jak psát a jak nepsat česky. Praha: Karolinum, 2014. 198 s.

SCHÖN, Donald A. The reflective practitioner, how practitionals think in action. New York: Basic Books 1983. $384 \mathrm{~s}$.

SKALKOVÁ, Jarmila. Obecná didaktika. Praha: ISV nakladatelství, 1999. $292 \mathrm{~s}$.

SLANČOVÁ, Daniela. Východiská interaktívnej štylistiky (Od eklektizmu k integrácii). Slovenská reč, 2003, roč. 68, č. 4, s. 207-223.

SLAVÍK, Jan; CHRZ, Vladimír; ŠTECH, Stanislav; aj. Tvorba jako způsob poznávání. Praha: Karolinum, 2013. 538 s.

SLAVÍK, Jan; JANÍK, Tomáš; NAJVAR, Petr; KNECHT, Petr. Transdisciplinární didaktika: o učitelském sdílení znalostí a zvyšování kvality výuky např́ič obory. Brno: Masarykova univerzita, 2017. $455 \mathrm{~s}$.

Slavníkovci ve stredověkém písemnictví. Úvodní studii, úvody a poznámky $\mathrm{k}$ textům napsal Rostislav Nový; texty přeložila Jana Zachová. Praha: Vyšehrad, 1987. 471 s. 
SOLMS, Mark; TURNBULL, Oliver. Mozek a vnitřní svět. Praha: Portál, 2014. 309 s.

SPUNAR, Pavel. Smích a pláč středověku. Praha: Odeon, 1987. $269 \mathrm{~s}$.

SPUNAR, Pavel. Kultura středověku. Praha: Academia, 1995 (2. vydání). $226 \mathrm{~s}$.

STICH, Alexandr. Vhlédnému čtenáři pozdravení. In Od Karla Havlička k Františku Halasovi (lingvoliterární studie). Praha: Torst, 1996, s. 5-13.

SPĚVÁČKOVÁ, Martina; VAŇKOVÁ, Jana. Dokáží studenti českého jazyka rozlišovat jazykové roviny a jim odpovídající jazykové prostředky? In ČECHOVÁ, Marie; SPĚVÁČKOVÁ, Martina (eds.). Od praxe $k$ teorii a zpět ve vyučování češtině. Plzeň: ZČU, 2019. s. 84-93.

SPILKOVÁ, Vladimíra. Gradace praktické přípravy, „reflektivní praxe" v novém modelu prípravy na PedF UK. In JŮVA, Vladimír (ed.). Teorie v pedagogické praxi, praxe v pedagogické teorii $v$ učitelském studiu. Sborník př́ispèvki̊ z celostátního semináre, Šlapanice u Brna, 7. a 8. února 1995. Brno: Paido, 1995, s. 62-65. Staroslověnské legendy českého pưvodu: Nejstarší kapitoly z dějin česko-ruských kulturních vztahů. Uspořádali Emilie Bláhová a Václav Konzal. Praha: Vyšehrad, 1976. 399 s.

STROUHAL, Martin; ŠTECH, Stanislav (eds.). Vzdělání a dnešek: pedagogické, filosofické, historické a sociální perspektivy. Univerzita Karlova: Karolinum, 2016. 226 s.

STYBLÍK, Vlastimil. Problém reformy českého pravopisu z hlediska školy. Praha: SPN, 1966. 98 s.

SVOBODOVÁ, Ivana; aj. Psaní velkých písmen v češtině. Praha: Academia, 2015. $350 \mathrm{~s}$.

SVOBODOVÁ, Jana. Čeština na rozcestí. Ostrava: Ostravská univerzita, 2014. $136 \mathrm{~s}$.

SVOBODOVÁ, Jana; aj. Fenomén spisovnosti v současné české jazykové situaci. Ostrava: Ostravská univerzita, 2011. 233 s. 
SVOBODOVÁ, Jana. Jazyková specifika školské komunikace a výuka mateřštiny. Ostrava: Ostravská univerzita, 2003. 148 s. ŠIDÁK, Pavel. Pražský lingvistický kroužek. In BARBOŘíK, Vladimír; JANÁČEK, Pavel; PAVLÍČEK, Tomáš; aj. Literární kronika první republiky. Praha: Academia, 2018, s. 176-180.

ŠIMANDL, Josef. Jaké úpravy pravopisu a kdy? (Na okraj Pravidel českého pravopisu 1993). Čeština doma a ve světě, 1993, ročník 1, č. 2, s. 62-73.

ŠIMÍČKOVÁ ČİŽKOVÁ, Jitka; aj. Přehled vývojové psychologie. Olomouc: UPOL, 2005. $176 \mathrm{s.}$

Školní vzdělávací program pro čtyřleté gymnázium a vyšši stupeň víceletého gymnázia (osmiletého, šestiletého) zpracovaný podle RVP G. Klatovy: Gymnázium Jaroslava Vrchlického, 2019. $458 \mathrm{~s}$.

ŠMILAUER, Vladimír. Nauka o českém jazyku. Praha: Státní pedagogické nakladatelství, 1972 (1. vydání). 334 s.

ŠMILAUER, Vladimír. Profil češtináře. Český jazyk a literatura, 1969, roč. 19, s. 241.

ŠTĚPÁNÍK, Stanislav. Konstruktivistické a kognitivně-komunikační paradigma jako východisko koncepce výuky českého jazyka. Pedagogika, 2020, roč. 70, č. 1, s. 5-28.

ŠTĚPÁNÍK, Stanislav. Vliv nové podoby maturitní zkoušky z českého jazyka a literatury na vyučování ve výpovědích učitelů. Pedagogická orientace, 2018, roč. 28, č. 3, s. 435-471.

ŠTĚPÁNÍK, Stanislav. Výuka češtiny mezi tradicí a inovací. Praha: Academia, 2020. $328 \mathrm{~s}$.

ŠTĚPÁNÍK, Stanislav; aj. Školní výpravy do krajiny češtiny: didaktika českého jazyka pro základní školy. Plzeň: Fraus, 2020. $312 \mathrm{~s}$.

TEJNOR, Antonín. Český pravopis a veřejné mínění. Naše řeč, 1969, ročník 52, č. 5, s. 265-285.

TRÁVNÍČEK, Jiří. Česká čtenářská republika. Generace, fenomény, životopisy. Brno - Praha: Host, 2017. 446 s. 
TŘEŠTíK, Dušan. Počátky Přemyslovců: Vstup Čechů do dějin (530-935). Praha: Nakladatelství Lidové noviny, 1997. 658 s.

ULIČNÝ, Oldřich. Čeština devadesátých let dvacátého století. In ŠRÁMEK, Rudolf (ed.). Spisovnost a nespisovnost dnes. Brno: Pedagogická fakulta Masarykovy univerzity, 1996, s. 59-63.

URBÁNEK, Petr. Vybrané problémy učitelské profese. Aktuální analýza. Liberec: TU, 2005. 229 s.

VACHEK, Josef. Český pravopis a struktura češtiny. Listy filologické, 1933, ročník 60, č. neuvedeno, s. 278-319.

VALA, Jaroslav; ŠMAKALOVÁ, Kristýna; VÁLKOVÁ, Kristina. Jak čtou osmáci? Český jazyk a literatura, 2019-2020, roč. 70, č. 2, s. 64-71.

VAŠICA, Josef. Literární památky epochy velkomoravské 863-885. Praha: Vyšehrad: 1996. 340 s.

VÁGNEROVÁ, Marie. Vývojová psychologie I. Praha: Karolinum, 2005. $468 \mathrm{~s}$.

VEJVODOVÁ, Jana. Konstruktivistické přístupy v prrípravě studentů na pedagogickou praxi. In ČECHOVÁ, Marie; SPĚVÁČKOVÁ, Martina (eds.). Od praxe $k$ teorii a zpět ve vyučování češtině. Plzeň: Západočeská univerzita v Plzni, 2019, s. $16-31$.

VELČOVSKÝ, Václav. Ideologie a pravopis. In Moudři milují pověsti. Praha: PedF UK, 2015, s. 121-130.

VOJTÍŠEK, Ondřej. Metodologické vlivy v současných didaktických interpretacích na střední škole. Slovo a smysl, 2019, roč. 16, č. 31, s. 209-224.

VŠETIČKA, František. Jakub Arbes / František Všetička. Praha: Pražská imaginace, 1993. 97 s.

WELSCH, Wolfgang. Postmoderna. Pluralita jako etická a politická hodnota. Praha: KLP, 1993. 57 s.

WIERSCHIN, Martin W. Philologia. Würzburg: Königshausen \& Neumann, 2005. $400 \mathrm{~s}$. 
WIŚNIEWSKA, Halina; KARWATOWSKA, Małgorzata. O typowości tekstów uczniowskich. In BARTMIŃSKI, Jerzy; BONIECKA, Barbara (eds.). Tekst: analizy i interpretacje. Lublin: Wydawnictwo UMCS, 1998, s. 255-266.

ZIMA, Petr V. Literární estetika. Olomouc: Votobia, 1998. 447 s.

\section{Internetové zdroje}

Deník N, 2019 [online]. Praha: N Media, a.s., [cit. 22.6.2020]. ISSN 2571-1717. Dostupné z: https://denikn.cz/48740/celibat -je-rana-ze-ktere-kazdou-minutu-tece-krev-modlim-se-i-za -zemana-rika-knez-orko-vacha/

HOFFMANNOVÁ, Jana, 1992. K charakteristice postmoderního textu. Slovo a slovesnost [online]. 53(3) [cit. 11.8.2020]. ISSN 0037-7031. Dostupné z: http://sas.ujc.cas.cz/archiv.php? art $=3470$

JAMESON, Frederic, 2009. Teorie postmoderny. Aluze: revue pro literaturu, filozofii a jiné. Olomouc: Katedra bohemistiky FF UP, [cit. 11.8.2020]. ISSN 1212-5547. Dostupné z: https://www. yumpu.com/xx/document/view/43839838/zde-aluze

Lidovky.cz, 2010 [online]. Praha: MAFRA, a.s., [cit. 10.6.2020]. ISSN 1213-1385. Dostupné z: https://www.lidovky.cz/kultura/ mozna-nejsme-sami-rozhovor-s-janem-balabanem-z-roku -2004.A101217_130633_ln_kultura_glu

Líný učitel Robert Čapek na ZČU. [online]. ZČU v Plzni: Celoživotní a distanční vzdělávání, 2019. [cit. 2020-30-06]. Dostupné z www: https://czv.zcu.cz/liny-ucitel-robert-capek-na-zcu/

LOUDOVÁ, Irena, SIMONOVÁ, Carmen, TříSKALOVÁ, Libuše. Rukovět k pedagogické praxi. [online] [cit. 28.7.2020]. Dostupné z: http://inpdf.uhk.cz/wp-content/uploads/2014/03/Skripta_ Rukovet_k_pedagogicke_praxi.pdfu 
MYHILL, Debra, aj. Grammar for writing? The impact of contextualised grammar teaching on pupil's writing and pupils' metalinguistic understanding: ESRC End of Award report, RES-06223-0775. Swindon: ESRC, 2011. [cit. 14.6.2020]. Dostupné z: https://www.researchcatalogue.esrc.ac.uk/grants/RES-062-23 -0775/outputs/read/c5bff83b-28d3-4945-8b8c-eb4b4c8406ae

POLÁKOVÁ, Irena: Podvojný deník - Popis metody. In Učení bez učebnic. Pro učitele [online]. Občanské sdružení Místo pro život HON [cit. 25.6.2020]. Dostupné z https://www.uceni bezucebnic.cz/index.php?id=516

Rámcové požadavky na studijní programy, jejichž absolvováním se ziskává odborná kvalifikace $k$ výkonu regulovaných povolání pedagogických pracovníkü. [online]: MŠMT, 2017. [cit. 24.9.2020]. Dostupné z: https://www.msmt.cz/vzdelavani/dalsi -vzdelavani/ramcove-pozadavky-na-studijni-programy-jejichz -absolvovanim

SLAVÍK, Jan; aj. Profesní soud o kvalitě výuky: předem a následně strukturovaná reflexe. In Pedagogika, 65(1), s. 5-33. [cit. 20.6.2020] Dostupné z: http://pages.pedf.cuni.cz/pedagogika/ $? \mathrm{p}=11138$ \&lang $=\mathrm{cs}$

Vzdělávání na dálku v základních a středních školách: Tematická zpráva. Česká školní inspekce [online]. 2020, 7. 5. 2020 [cit. 6.5.2020]. Dostupné z: https://www.csicr.cz/Csicr/media/Prilohy/ PDF_el._publikace/Tematick \%c3 \%a9 \%20zpr \%c3 \%a1vy/ Vzdelavani-na-dalku-v-ZS-a-SS-Tematicka-zprava.pdf www.msmt.cz

\section{Použité zdroje z umělecké literatury}

AJVAZ, Michal. Návrat starého varana. Praha: Mladá fronta, $1991.81 \mathrm{~s}$. 
ARBES, Jakub. Romaneta. Praha: Státní nakladatelství krásné literatury a umění, 1963. 313 s.

GOETHE, Johann Wolfgang. Faust. Přeložil a poznámkami opatřil Otokar Fischer. 2. Praha: SNKLU, 1965 (2. vydání). 579 s.

MANN, Heinrich. Profesor Neřád neboli Konec tyrana. Praha: SNKLU, 1964. $201 \mathrm{~s}$.

TOPOL, Jáchym. Anděl. Praha: Hynek, 1995. 134 s. 


\section{Věcný rejstřík}

A

aha zážitek 302

aktivita

- učitele $68,73,213,228$

- žáka 4, 8, 16, 37, 39, 42, $48,55,57,104,105,122$,

$235,243,333,335,343$

alegorie 243, 270, 316, 328, 330

alterace $24,52,60,352,356$

aluze 14, 260, 261, 266, 269,

273, 276, 329

analýza/rozbor

- komplexní jazykový 10, 86, 198-206, 212, 215,

365

- kritická 2,7

- literárního díla 14, 281, 283-285, 295

- textu 13, 47, 109, 121, 202, 241, 245-247, 251, 253, 254, 261, 281, 297, 299, 307, 329, 330, 335, 339, 366

- učiva (konceptová) 23, 28

- vědecká 13

C

centrální nervová soustava

(CNS) 130, 131, 134

cyklus vzdělávání 4,9
$\check{C}$

čtenár $9,10,14,15,236,239$, $243,245,247,252,253,255$, 259, 260-262, 264, 266, 267, 270, 273-278, 283, 287, 297, 299, 301-303, 330, 335, 341, $350,353,357,360$

čtenářský

- prekoncept 335, 348, 349

- zážitek 233, 237, 238, 335, 349

čtení

- řízené 78, 335, 340

- strukturní 232, 354

D

data korpusová 159, 163, 164-167, 169, 173 dezinterpretace 355,358 , 360, 367 diagnostika

- pedagogická 22, 131, 148 dialog, viz i rozhovor - reflektivní 338, 347, 352, 358

didaktika

- českého jazyka 6, 25, 58, 109, 298

- literatury 24, 32, 49

- obecná 21,27,28, 363 
- oborová 1, 2, 4, 21,27, 28,363

dílo

- umělecké 233, 284, 285, 333,343

- časová rovina

u. d.-a 265, 274, 277

- prostorová rovina

u. d.-a 265

- pochopení u. d.-a 333, $334,339,353$

E

edukace, edukační 92, 97-102, 298, 338, 343, 355 evaluace $11,32,55,99,218$, 224

F

facilitátor 246

fáze

- recepce 236, 254, 341, 358

- uvědomění 349,357

formalismus 122, 124, 339

funkce

- estetická 113, 120, 237, 242, 261

- motivační 22, 29, 40

- umělecká 283

G

grafomotorika 9, 105, 130,

$134,136,137,142-149,364$
$\mathbf{H}$

historiografie 328

hodnocení

- slohových prací 106, 108, $109,111,119,122,123$

- výuky $6,15,21,23,27$, $28,33,37,55,59,60,95$, $315,331,363$

\section{$\mathrm{CH}$}

chyba/nedostatek

- formální 96, 120, 121, 363

I

ilokuce 107

interdiciplinární vztahy 55, $100,320,341,357$

interpretace

- didaktická 13, 47, 55, 100, $238,241,249,250,251$, $253,254,335,349,366$

- textu, viz analýza textu interpretátor 281, 366

J

jazyková rovina

- foneticko-fonologická 87, 205, 212

- lexikální 200, 204, 205, 212-217, 221, 222, 229

- morfologická 157, 170, 204, 205, 207, 209, 210, 213-217, 220, 229, 365 
- syntaktická 204, 205, 207, 209, 213, 215, 216, 365 jazykově-slohový detail 15 , 299, 301, 305 jazykový projev, viz i text 13 , $152,177,178$ jazykový prostředek

- stylová hodnota $\mathrm{j}$.

p.-u 198-201, 212-215, 221, 365

- umělecký 261, 278, 297, 331

jazykový systém $1,10,124$, $175,203,221$

K

kodifikace, kodifikovaný 10 , $12,119,133,151-153,156$, 157, 159-167, 169-172, 174, 177, 178, 181, 183, 189, 190, 191, 193, 200, 214, 301, 365

kognitivní proces 105 kompetence

- čtenářská 235, 248, 255, 267

- didaktická 108, 344

- komunikační 13, 54, 105, 123, 124, 181, 190, 364 - reflektivní $6,23,25,28$, 59,60

komplexní jazykový rozbor, viz analýza/rozbor komunikace

- elektronická 7, 64, 89

- online 64

komunikační

- dovednost 119, 125, 133, 298, 346

- situace 2, 107, 200, 203, 217, 233, 301

- záměr 107

komunikát 100, 107, 113, $119,121,124,203,213,215$ koncepce

- literární výchovy 13, 232, 234, 236, 241, 252, 283, 334

- výuky 2

konstruktivismus, konstruktivistický 36, 236, 334, 343, 346, 353, 359

kontaminační proces 192 kontext

- didaktický autorský 244, 246, 247, 250, 254, 255, 305

- společenský 281, 282, 315, 366

- umělecký 14, 245, 252, 253, 282, 283

kresba

- rozvoj k. 136, 168

kultivovanost vyjadřování

- učitele 11, 12, 178, 217, 222, 223, 229, 365 
L

latina $154,324,327,328,331$

legenda $277,317,325-328$

literárněhistorický

- aspekt 234, 235, 242, 249, 250, 252

- poznatek, viz i transmise

1. p.-ů 13, 232-234,

236-238, 240-243, 246,

252, 254, 255, 283, 334,

$342,345,366$

literatura

- klasická 13, 14, 243

- současná $14,241,258$, 262, 265-267, 276, 278, 307,324

- starší česká 15, 319, 321, 325, 326-328, 367

literární kánon

- didaktický 240, 243, 244, 254

lokuce 107

M

manipulace

- pedagogicko-výchovná 323

materiál

- didaktický 68, 86, 88, 90, 298

metoda

- analytické m.-y 3, 14

- brainstormingu 3,15 , $347,348,350$
- didaktické interpretace textu 13, 47, 241, 254

- dotazníková 3, 13

- experimentální 3, 13

- interpretační 247, 335

- konfrontační 3

- kritického myšlení 35

- líného učitele 4, 343, 344, $347,359,360$

- pětilístek 15, 49, 347, 357, 358, 359

- podvojného deníku 15 , $347,349,350,352,353$

- simulační m.-y 6, 26, 59

- tvořivé m.-y $15,333,335$, 356, 367

- výuková 25, 130, 131, 215,365

metodická př́ručka 5, 340 metodika

- metodika 3A 23, 24, 28, 37 metodologie 2, 23, 281, 298, $339,363,366$

mezipředmětové vztahy, viz interdisciplinární v. mikrovyučování $6,25,26,59$ mluvní cvičení $10,11,213$, 217, 222, 224-228, 230, 365 modalita 303 model

- E-U-R 35, 49, 347, 348

- hloubkové struktury výuky 28, 346 
- integrované výuky 14, 296 motiv (literárního díla) 112, 250, 267-270, 272, 273, 280, 289, 291, 292, 328, 338, 339, 341,347

motivace/motivování 8,15 , $30,31,48,49,54,57,59,60$, $76,77,105,119,122,125$, 151, 181, 209, 225, 226, 238, $266,278,314,322,326,331$, 340

motorika

- hrubá 134, 136-138, 149

- jemná 9, 134, 136, 149 myšlení

- analytické 354

- kritické 15, 32, 35, 333, 346, 347, 352, 357, 367

- tvůrčí 345, 346, 352

- vývoj. m.-í 131, 135

$\mathbf{N}$

nedostatek/chyba 3-5, 10, $14,69,85,95-97,110,116$, $118-121,123,124,133,138$, $139,144,146,159,162,181$, $182,189,190,193,194,211$, 220-222, 227, 233, 248, 272, $319,326,341,342,354,356$, 359, 360, 363, 365 nespisovnost/nespisovný 109, $110,113,116,118,162,163$, $168,171-173,185,187,188$,
192, 200, 214, 216, 218-221, 277,365

norma

- spisovné češtiny 181, 300

- spisovné výslovnosti 12

O

období

- prenatální 130

- předškolní 142

obecná čeština 183, 187-189,

191, 274, 301

obsah

- sdělení 87, 120, 121, 306

- učiva 232, 233, 242, 335, 343, 344

oprava slohových prací 108 , 124, 125, 213

oromotorika $130,134-136$

$\mathbf{P}$

pedagogická praxe

- bloková výstupová 25 , $26,44,60,64-68,70,88$, 89,91

- náslechová (bakalářská a navazující) 7, 23-25, $28-31,34,37,39,40,59$

- souvislá 5-7, 27-29, 41-44, 46, 52, 56-58, 60, 148

penitenciál 327

periodizace $244,259,319$ 
perlokuce 107

poezie $86,233,250$

postava

- pásmo p. 265, 274, 277

postmoderna $14,258-260$,

262-264, 266, 276-278, 284

postoj

- studenta 22, 42, 133, 153, $182,217,360$

- učitele 10, 22, 42, 270

postup kompoziční 261, 286, 335

pověst $86,251,329,342$

poznání

- komplexní 2

- odcizené 24, 122

- osvojené 335

- utajované 24

práce

- bakalářská 95, 97, 99

- diplomová 8,58

- kvalifikační 8, 92, 93, 95, 97-102, 363, 364

- s chybou 69

pravopisná reforma 151, 158 praxe

- pedagogická, viz pedagogická p.

- reflektivní 22, 23

prekoncept čtenářský, viz

čtenářský p.

proces učení 130, 359 produkce

- textu 105, 119, 233, 234, 243, 249, 251, 253, 254, 334

- žákovských prací 8

projev

- mluvený 1, 11, 12, 85, 100, 163, 217-219, 221-225, 227-230, 365

- psaný 10, 12, 120, 133, 134, 136, 144, 191 propriorecepce 130 próza, prozaický 86,250 , 258, 265-269, 275, 276, 278, 281-283, 286, 288, 295, 366 př́prava učitelů $4,6-8,11$, 20, 21, 92-95, 99, 101, 102, $148,149,153,175,177,167$, 344

přístup

- integrovaný 306

- pluralitní 263

- praktický 1

- teoretický 1 psaní přejatých slov 154, 157, $167-169,174,175,178,365$ psychomotorický vývoj 9, 130, 131, 133, 149

$\mathbf{R}$

recepce žákovských textů 107, 121, 233 
reflexe výuky $6,20,21,23$, $27,28,33,37,57-60,95$, 363

rozhovor, viz i dialog - o díle 338, 340, 360

rozvoj řeči $130,134,136$

$\check{\mathbf{R}}$

řečový vzor 217, 229

S

sebeevaluace $11,32,218$, 224

sebereflexe $11,22,26,55$, 102, 217

slohová práce, viz i text žákovský 8, 54, 75, 104-106, 108-111, 119, $120,122-125,213$

složka

- jazyková 13, 31, 34, 109, $116,118-120,155,156$, 212, 298, 305, 340

- komunikačně-slohová 298, 305,340

- literární 13, 32, 298, 305, 306, 340

smysl textu/díla 15, 285, 299, $302,335,339,346,367$

soft skills $302,346,347,355$ sonda

- výzkumná, viz i šetření 2, $5,6,8,11,95,153,156$,
159, 200-202, 217, 218,

365

spisovný jazyk / spisovnost 1 , $118,119,172,174,176,178$, $182,199,200,214,216,217$, 222-224, 226, 277, 365 staroslověnština 327,328 struktura, strukturovat 28 , 93, 95, 99-101, 133, 134, $182,187,189,202,218,227$, $232,233,236,237,240,243$, 247, 254, 261, 276, 298, 299, 303, 305-307, 335, 346, 366 studijní program $21,23,59$, $94,95,98,101,109,154,156$ styl

- autorský 113, 116, 236 stylová hodnota, viz s. h. jazykového prostředku symbolika

- barevná 330

- číselná 330

syntéza $3,21,22,134,135$

$\check{\mathbf{S}}$

šetření

- dotazníkové 7, 10, 11, 29, $41,60,67,71,133,153$, 154, 156, 183, 200, 203, $212,215,217,218,222$, 226-228, 230, 365

- výzkumné, viz i sonda 136,364 
škola

- cvičná/fakultní $8,64,90$, 148

- střední $2,9,10,24,25$, 27-29, 31, 34, 39, 43, 46-49, 51, 52, 58, 60, 64, $65,71,72,75,81,97,110$, $151,153,154,156,181$, 193, 194, 234, 239, 247, $301,303,315,318,320$, $323,324,363$

- vysoká 22, 65, 93, 97, 147, $148,153,154,318,320$, $324,363,364$

- výzkumná 4

- základní 9, 25, 27-29, 39, $46,48,52,60,64,65,68$, $69,71,74,81,97,104$, $108,133,136,137,139$, 142, 144-146, 148, 149, 154, 156, 181, 182, 194, 198, 200, 202, 217, 218, 303, 315, $318,319,323,324,336,340$, 356, 363, 364, 366

\section{T}

technika psaní 9, 122, 135, 136, 364

téma

- literárního díla 233

- volba t.-u 68, 98, 226 text, viz i jazykový projev - literárněteoretický 259
- výstavba t.-u 248, 258, 265, 266, 269, 274, 297, $335,346,360$

- žákovský, viz i recepce ž. t.-ů 104, 106-109, 111, $114,119,122-124$

transformace

- didaktická 33, 53, 59, 199, 238, 240, 241, 243, 246, 298,300

transmise

- literárněhistorických poznatků 246

tvůrčí

- psaní 55, 130, 136, 333, 335-339, 341, 349, 359

- úkol 54, 337

U

učebnice $2,5,8,75,76,100$, 171, 185, 205, 226, 249, 298, 325

učitel

- jako experimentátor 2

- jako facilitátor, viz facilitátor

učivo

- jazykové 6, 49, 105, 199, 364

- pravopisné 153, 177

- struktura u.-a 100, 236, 254, 366

- vnitřní integrace u.-a 300 
uptake 55

úzus 12

V

velkomoravské období 327

víceznačnost $14,281,283$

virtuální třída $6,26,59,72$

vizuomotorika $142,144,145$

výchova

- jazyková 45, 47, 48, 60, 300, 306, 340, 367

- komunikačně-slohová 25 , $27,32,45,47,48,54-56$, $86,212,300$

- literární 13-15, 45, $47-49,54,55,60,232$, $237,240,266,276,283$, $298,300,306,333,334$, 366

vypravěč

- pásmo v.-e 265, 274, 277 vypravování $75,108,109$,

116,120

výstavba textu, viz i text

- uměleckého 346
- významová 248, 258, 335, 346,360

výuka

- distanční 26, 66, 81, 363

- experimentální 4

- frontální 43, 228, 350, 352,360

- integrita v.-y 23

- na dálku 64, 66-72, 74-76, 79, 81-84, 88, 89, 90

- tandemová 36, 58

W

webinář $7,68,78-81,84,85$, 88,90

$\mathbf{Z}$

zpětná vazba $53,55,57,69$, $72,76,82,83,85,86,88,89$, $120,227,230,358$ zraková pamět 133 


\section{Výběrový jmenný rejstř́ík ${ }^{187}$}

A

Adam, Robert 5, 158, 199, 305

B

Beránková, Eva 249

C

Cvrček, Václav 12, 191

$\check{C}$

Čapek, Robert 343-346, 359, 360

Čechová, Marie 1-18, 119, 154, 155, 161-164, 175, 192, 199

D

Dokulil, Miloš 199

E

Eco, Umberto 261, 297

F

Franta, David 14, 296-313, 340,367
G

Gebauer, Jan 199

$\mathrm{H}$

Haman, Aleš 265

Hausenblas, Karel 190, 199

Hobsbawm, Eric 300

Hoffmannová, Jana 12, 266

Hoskovec, Tomáš 298-300

Hrbáček, Josef 199

Hrdina, Martin 252

Hrdlička, Milan 5, 10,

181-197, 165

$\mathrm{CH}$

Chýlová, Helena 9, 133,

151-180, 165

J

Jačka, Dominic 8, 92-103, 363

Jelínek, Jaroslav 1, 199

K

Kostečka, Jiří 8

Kučera, Václav 8

\footnotetext{
${ }^{187}$ Jedná se o rejstř́ík jmen autorů odborných a vědeckých textů, s nimiž se pracuje $\mathrm{v}$ jednotlivých kapitolách monografie.
} 
L

Lederbuchová, Ladislava 13, 14, 232-257, 283, 305, 334, 356,366

Levý, Jiří 300

M

Macura, Vladimír 300

Macháčková, Ivanka 153

Málková, Jitka 11, 217-230, 365

Mathesius, Vilém 11, 12, 152

Mukařovský, Jan 258, 298, 302

$\mathbf{N}$

Nezkusil, Vladimír 8

Nováková, Jaroslava 9,

130-150, 364

Novotná Hůrková, Jiřina 12

Novotný, Jiř́i 15, 314-332, 367

$\mathbf{P}$

Palková, Zdena 12

Pánek, Petr 8, 92-103, 363

Pánková, Vladimíra 15, 251, 283, 305, 333-362, 367

Písková, Růžena 7, 64-91, 363

$\mathbf{R}$

Romportl, Milan 12
S

Skalková, Jarmila 242 Spengler, Oswald 304 Spěváčková, Martina 10, 198-216, 365

Stich, Alexandr 12, 299, 300

Styblík, Vlastimil 199

Svoboda, Karel 1, 10

Svobodová, Ivana 159, 183

$\check{S}$

Šmilauer, Vladimír 102, 192, 199

Štěpáník, Stanislav 8,

104-128, 364

V

Vachek, Josef 12

Vaňková, Jana 10, 198-216, 365

Vejvodová, Jana 5, 6, 17, 20-63, 66, 79, 363

Viktora, Viktor 14, 281-295, 331, 366

Všetička, František 285, 287, 288

Z

Zelenková, Věra 14, 258-279, 335, 366 


\section{Od praxe $k$ teorii a zpět ve vyučování češtině II}

\section{Autorský kolektiv}

Editorky:

prof. PhDr. Marie Čechová, DrSc.

Mgr. Martina Spěváčková, Ph.D.

Vydání publikace bylo schváleno Vědeckou redakcí

Západočeské univerzity v Plzni.

Recenzenti:

doc. PhDr. Ondřej Hník, Ph.D.

doc. Mgr. Patrik Mitter, Ph.D.

Překlad anglického resumé:

Mgr. Jaroslav Kubalík

Typografická úprava:

Jakub Pokorný

Grafický návrh obálky:

Anastasia Vrublevská

Vydala:

Západočeská univerzita v Plzni

Univerzitní 2732/8, 30100 Plzeň

První vydání, 404 stran

Pořadové číslo: 2348, ediční číslo: 55-030-21

Plzeň 2021

ISBN 978-80-261-1011-8

ISBN 978-80-261-0982-2 (brožovaná vazba)

DOI https://doi.org/10.24132/ZCU.2021.10118 